UNIVERSIDAD DE SALAMANCA

FACULTAD DE FILOLOGÍA

DEPARTAMENTO DE LITERATURA ESPAÑOLA E HISPANOAMERICANA

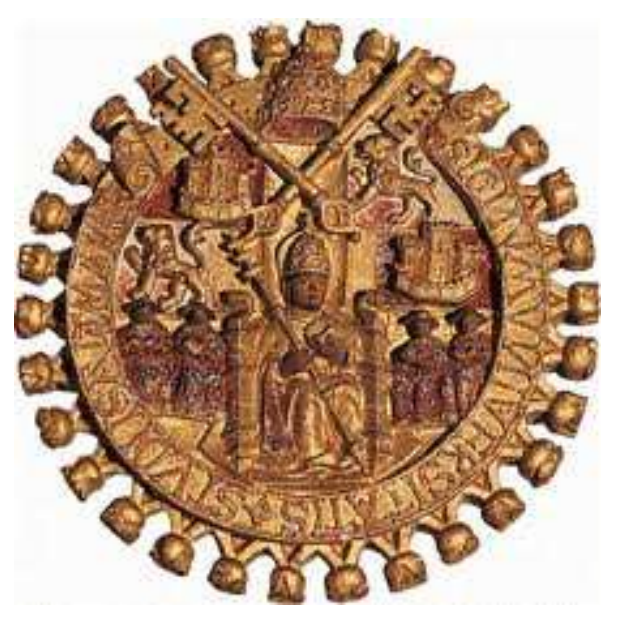

Programa de Doctorado

Vanguardia y posvanguardia en España e

Hispanoamérica. Tradición y rupturas en la literatura hispánica.

\title{
LA ÚLTIMA CLARIDAD. EL PENSAMIENTO LITERARIO DE GUILLERMO SUCRE
}

Autor: IOANNIS ANTZUS RAMOS

Directora: DRA. CARMEN RUIZ BARRIONUEVO

\section{4}

Tesis doctoral 



\section{UNIVERSIDAD DE SALAMANCA \\ FACULTAD DE FILOLOGÍA}

DEPARTAMENTO DE LITERATURA ESPAÑOLA E HISPANOAMERICANA

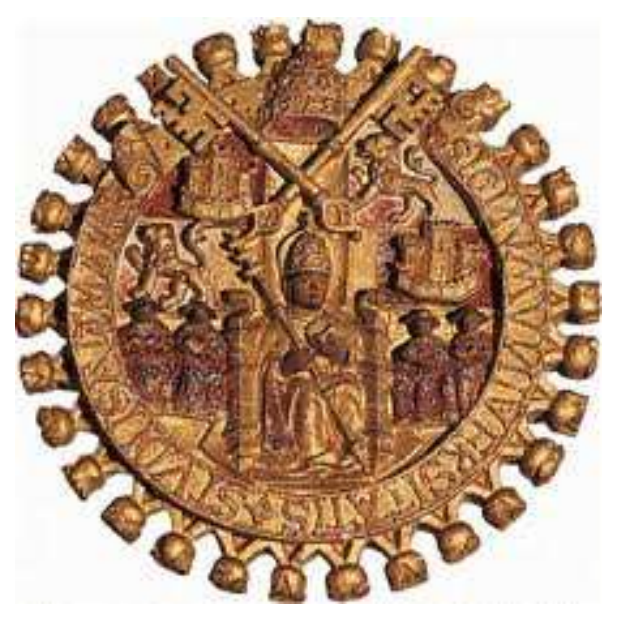

\section{LA ÚLTIMA CLARIDAD. EL PENSAMIENTO LITERARIO DE GUILLERMO SUCRE}

Tesis doctoral dirigida por la Dra. Carmen Ruiz Barrionuevo, presentada en el Departamento de Literatura Española e Hispanoamericana, Facultad de Filología, Universidad de Salamanca.

$\mathrm{V}^{\mathrm{o}} \mathrm{B}^{\mathrm{o}}$

La Directora del Trabajo

Fdo.: Carmen Ruiz Barrionuevo
El autor

Fdo.: Ioannis Antzus Ramos 

CUALQUIER DÍA PUEDE SER TODO EL TIEMPO Y ARROJARNOS a la última claridad.

O cualquier claridad nos arrojará al tiempo del primer día.

Y ya no habrá ninguna revelación.

Guillermo Sucre. La vastedad (1988) 

¿Cómo obtener placer en un placer relatado (aburrimiento de los relatos de sueños, de los relatos parcelados)? ¿Cómo leer la crítica? Una sola posibilidad: puesto que en este caso soy un lector en segundo grado es necesario desplazar mi posición: en lugar de aceptar ser el confidente de ese placer crítico -medio seguro para no lograrlo- puedo, por el contrario, volverme su "voyeur", observo clandestinamente el placer del otro, entro en la perversión; ante mis ojos el comentario se vuelve entonces un texto, una ficción, una envoltura fisurada. Perversidad del escritor (su placer de escribir no tiene función); doble y triple perversidad del crítico y de su lector y así al infinito.

Roland Barthes. El placer del texto (1973) 



\section{AGRADECIMIENTOS}

Este trabajo habría sido imposible sin la ayuda de algunas personas.

A la Dra. Carmen Ruiz Barrionuevo, directora de esta investigación, le debo mucho más de lo que puedo consignar en estas líneas. De su buen hacer he aprendido muchas de esas cosas que no se enseñan, y trabajar con ella ha sido muy enriquecedor. Además, le doy las gracias por la orientación, la motivación y el apoyo recibidos a lo largo de estos años.

Un reconocimiento especial merece Estela Aganchul, que me acogió durante meses en su casa de Caracas mientras realizaba esta investigación. A su conversación crítica e inteligente le debo, en buena medida, el cariño que siento por Venezuela.

A Carlos Sandoval, profesor de la Universidad Central de Venezuela, le agradezco la ayuda y la atención durante mis estancias en Caracas.

También quiero dar las gracias al propio Guillermo Sucre, Ítaca que me brindó el hermoso viaje. La enorme generosidad que ha mostrado en sus entrevistas y cartas ha mejorado notablemente el resultado de esta investigación.

Agradezco de todo corazón las correcciones y las sugerencias de mi madre, Carmen, primera lectora de este trabajo, y la comprensión y la paciencia de mi mujer, Lucía. Ellas han sido un apoyo tan importante que no es exagerado decir que este trabajo es también un poco suyo.

Por último, estoy muy agradecido a las autoridades educativas españolas porque este trabajo no habría podido escribirse sin la beca FPU que me concedió el Ministerio de Educación entre los años 2008 y 2012. 

A mi abuela Carmen, por sus rezos a Santa Gema.

A Lucía y a mi pequeño Yannis, en camino. 



\section{ÍNDICE}

Introducción p. 1

Capítulo I. El contexto biográfico e histórico-político. .p. 11

Capítulo II. Contexto cultural de Guillermo Sucre (1958-1968)...............p. 43

II. 1. Guillermo Sucre en el campo literario venezolano (1958-1968)........p. 48

II. 1.1. Cantaclaro (1950)....................................... 52

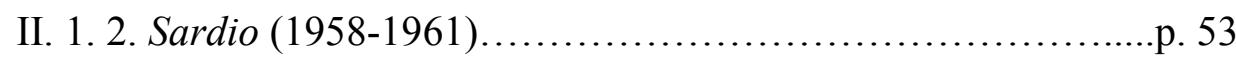

II.2. "El Techo de la Ballena" (1961-1969).............................p. 57

II.3. La cultura del oficialismo (1962-1968)............................p. 69

II.3.1. "Letras y artes”, la página literaria de La República (62-64)...p. 77

II.3.2. Zona Franca. Revista de literatura e ideas (1964-1966)........p. 89

II.3.3. Imagen. Quincenario de arte, literatura e información cultural

(1967-1968)

.p. 96

Capítulo III. El pensamiento literario de Guillermo Sucre (1958-1963)..........p. 113

III.1. El reclamo de autenticidad......................................p. 127

III.2. El rechazo de los excesos expresivos............................p. 138

III.3. Saturación, fabulación, universalidad............................p. 144

Capítulo IV. El pensamiento literario de Guillermo Sucre (1964-1968)...........p. 153

IV.1. Reintegrar el absoluto.........................................p. 154

IV.2. Álgebra y fuego............................................... 158

IV.3. La plenitud del mundo infantil..................................p. 168

IV.4. Guillermo Sucre y la estética de modernidad.......................p. 176

IV.5. Hacia una crítica poética....................................... 191

Capítulo V. La política estética de Guillermo Sucre (1958-1968)...............p. 205

Capítulo VI. El pensamiento literario de Guillermo Sucre desde 1969...........p. 223

VI. 1. La conciencia del lenguaje....................................p. 235 
VI. 2. La invención de lo real......................................p. 240

VI. 3. En la órbita estructuralista y cubista............................. 254

VI. 4. La búsqueda de un lenguaje diáfano..............................p. 265

VI. 5. Moralidad, impersonalidad, universalidad..........................p. 285

VI. 6. Guillermo Sucre y la literatura hispanoamericana..................p. 306

VI. 7. Guillermo Sucre y la crítica literaria................................p. 329

Capítulo VII. La escritura crítica de Guillermo Sucre........................p. 351

VII. 1. La crítica como sistema........................................p. 353

VII. 2. Una matemática expresiva......................................p. 368

VII. 3. El tono dubitativo y la búsqueda de la precisión crítica..............p. 373

VII. 4. El lector modelo..........................................p. 385

Capítulo VIII. La política estética de Guillermo Sucre desde 1969.............p. 397

Conclusiones........................................................p. 413

Bibliografía..................................................... 427

Apéndice I. Entrevistas y cartas....................................... 457

Apéndice II. Contribución para una bibliografía de Guillermo Sucre...........p. 489

Summary \& Conclusions in English.................................p. 517

Conclusions in English........................................... 547

Relación de Imágenes...................................................p. 561 


\section{INTRODUCCIÓN}

El objetivo de esta tesis es el estudio del pensamiento literario de Guillermo Sucre (Venezuela, 1933), que es considerado uno de los exegetas más importantes de la poesía hispanoamericana del siglo XX. Pretendemos así llenar un vacío en los estudios literarios que ya resulta inaceptable teniendo en cuenta el reconocimiento unánime de que ha sido objeto su trabajo. En efecto, son muchos los intelectuales que han destacado la valía de la obra de Sucre en las últimas décadas. En el texto titulado "El espacio del reconocimiento" (1967), Octavio Paz citaba a nuestro autor entre los críticos más relevantes del continente y señalaba que a él le "debemos algunos de los más intensos poemas de la joven poesía hispanoamericana y, simultáneamente, los ensayos más lúcidos sobre los movimientos poéticos contemporáneos"1. Treinta años después, en una carta enviada al embajador venezolano ante el Reino Unido con motivo de la postulación de Guillermo Sucre para la Cátedra Simón Bolívar de la Universidad de Cambridge, el mismo escritor mexicano se refería a Sucre como "uno de los mejores ensayistas y críticos literarios hispanoamericanos" y señalaba que

sus ensayos, artículos y antologías son modelos en su género y han sido y siguen siendo contribuciones fundamentales en el dominio de la crítica literaria contemporánea en nuestra lengua. En esos textos y estudios encuentro una rara alianza entre la penetración intelectual y la erudición, la sensibilidad y la elegancia del estilo. Sucre es, sin duda, uno de nuestros mejores ensayistas. $^{2}$

Asimismo, Emir Rodríguez Monegal, en una ponencia leída en la Universidad de Toronto en 1970 decía que "en el campo de la poesía, a las luminosas exploraciones de Octavio Paz han sucedido, por un lado, los trabajos de un crítico y poeta tan

${ }^{1}$ Octavio Paz: "El espacio del reconocimiento", en OOCC, Vol. II. Excursiones/Incursiones. Dominio extranjero, Barcelona, Galaxia Gutenberg/Círculo de Lectores, $2^{\text {a }}$ ed., 2000, p. 1146. (El texto fue publicado originalmente en Corriente alterna (1967)) La cita sigue: "Sucre es un ejemplo más, como Roberto Juarroz, de que el rigor no está reñido con la inspiración."

${ }_{2}^{2}$ Octavio Paz, citado en el artículo anónimo: "Guillermo Sucre. Profesor titular de Cambridge", en El Nacional, Caracas, 13-06-1997, p. C-14. 
especialmente dotado como Guillermo Sucre"3. Y en una de las primeras reseñas aparecidas sobre La máscara, la transparencia (1975) llamaba a nuestro autor "poeta distinguido, crítico de primer orden"4 y le reconocía como uno de los grandes estudiosos de la poesía del continente junto a Saúl Yurkievich, Julio Ortega y Ramón Xirau. Por su parte, Roberto González Echevarría iba incluso más allá y opinaba, en $L a$ voz de los maestros (2001), que Guillermo Sucre era "tal vez el crítico más avanzado de poesía en nuestra lengua"

El reconocimiento a la labor de Sucre ha sido tan general que también aquellos críticos que marcaban diferencias con respecto a sus planteamientos no dejaban de alabar la calidad de su trabajo y sobre todo de su obra fundamental, La máscara, la transparencia. Así, por ejemplo, David Medina Portillo, en una reseña de 1994 sobre la Antología de la poesía hispanoamericana moderna (1993), a pesar de los defectos que veía en ella no dejaba de señalar que Sucre "es uno de los mejores críticos con que cuenta la poesía latinoamericana. En este sentido, hasta hoy no existe ningún otro ejemplo comparable a La máscara, la transparencia, ventura de la sensibilidad, el dato y la reflexión, capaces de penetrar y entregarnos una lectura ordenadora, apartada de generalizaciones pero también excluyente de atenciones forzadas" ${ }^{\text {, }}$. En un artículo sobre esta misma obra, Adolfo Castañón reprobaba un supuesto exceso de subjetividad en la crítica de Sucre, pero reconocía sin embargo que "se trata del ensayo más importante y más completo, pese a sus omisiones, escrito sobre la poesía hispanoamericana en los

${ }^{3}$ Emir Rodríguez Monegal: "El ensayo y la crítica en la América Hispánica” en Obra selecta, Caracas, Biblioteca Ayacucho, 2003, pp. 359-364, p. 364. (Este texto se editó por vez primera en El ensayo y la crítica en Iberoamérica, Actas del XIV Congreso de Literatura Iberoamericana, Toronto, Toronto University, 1970, pp. 221-227)

${ }^{4}$ Emir Rodríguez Monegal: “Un lector de poesía”, en Plural, México, núm. 54, vol. V, nº, marzo de 1976, p. 58.

5 Roberto González Echevarría: "Doña Bárbara escribe la ley del llano", en La voz de los maestros, Madrid, Verbum, 2001, p. 73. Esta obra de González Echevarría apareció por primera vez en inglés: The Voice of the Masters. Writing and Authority in Modern Latin American Literature, Austin, University of Texas Press, 1985.

6 David Medina Portillo: “Antología de la poesía hispanoamericana moderna”, en Vuelta, México, núm. 214, sep. 1994, p. 36. 
últimos años". Y en una nota añadía aún más: "Ni Figuración de la persona de Julio Ortega, ni Fundadores de la nueva poesía latinoamericana de Saúl Yurkievich, ni Poesía Iberoamericana contemporánea de Ramón Xirau son tan exhaustivos o tan complejos literariamente como el libro de Sucre"7.

También los críticos venezolanos han respaldado la excelente labor de nuestro autor en este campo. En un estudio dedicado a La máscara, la transparencia, Francisco Rivera afirmaba que en este trabajo Guillermo Sucre "pone en evidencia una curiosidad intelectual tan grande y una capacidad crítica tan poco común que está destinado a convertirse en texto de consulta obligatoria para todos los que se interesen en la evolución de nuestra poesía desde los ya lejanos años del modernismo hasta el momento presente" puede ser el más importante (por su idioma: organización sensorial de la crítica; por su desarrollo, una mirada variable sobre la misma/múltiple letra; por la fidelidad intelectiva ante la poesía) de la crítica venezolana"9 . Y Alfredo Chacón indicaba, por su parte, que es “el libro más abarcante [sic] y penetrante que se conoce sobre la poesía hispanoamericana del siglo"10.

7 Adolfo Castañón: "Guillermo Sucre: silencio, historia y persona en la poesía hispanoamericana”, en Venezuela entrevista. Crónicas, ensayos, narraciones, Mérida, El otro, el mismo, 2009, p. 114; p. 122. El artículo se publicó por primera vez en la revista Siempre, México, 1976.

${ }^{8}$ Francisco Rivera: "Guillermo Sucre y la poesía latinoamericana", en Inscripciones, Caracas, Fundarte, 1981, p. 11.

9 María Fernanda Palacios y José Balza: "Conversación con Guillermo Sucre", en Falso Cuaderno (Literatura, arte, crítica, ciencia y otras cosas), Caracas, núm. 2, octubre de 1976, p. 3.

10 Alfredo Chacón: "Guillermo Sucre en la vastedad", en Cuadernos Hispanoamericanos, Madrid, núm. 528, junio 1998, pp. 111-114, p. 111. Muchos otros autores han reconocido la labor de Sucre. Juan Liscano, en un artículo de 1965 sobre la joven poesía en Venezuela, destacaba que Sucre era un "excelente crítico", una "inteligencia formada en disciplinas universitarias", y que tenía "un sentido riguroso, digno y exigente de la creación poética." (Juan Liscano: "Cinco poetas jóvenes venezolanos", en Sur, Buenos Aires, núm. 293, mar.-abr. 65, pp. 79-91, p. 80). Asimismo, Ramón Xirau, en una crítica aparecida en Vuelta sobre el poemario En el verano cada palabra respira en el verano (1976) destacaba a Sucre como un gran poeta y afirmaba que también "son de primera los libros de crítica" publicados por él. (Ramón Xirau: "En el verano cada palabra respira en el verano", en Vuelta, México, enero 77, p. 40). Enrique Krauze afirmaba por su parte que Guillermo "no sólo es un poeta de la luz sino uno de los ensayistas más finos del idioma. La máscara, la transparencia es el punto culminante de una indagación intelectual de verdad extraordinaria." (Enrique Krauze: El poder y el delirio, Caracas, Alfa, 2008, p. 118). Un capítulo aparte merecería el aprecio y la admiración que le profesaron siempre sus alumnos. Un testimonio sobre esta faceta de Guillermo se puede apreciar en sendos ensayos de Gustavo Valle y Boris 
Pero todo este reconocimiento general al trabajo de Sucre no se ha traducido, como decimos, en una atención crítica equivalente. Las investigaciones que se han dedicado a su obra han sido pocas, parciales, de escasa repercusión para la comprensión cabal de la misma, y raramente han superado la extensión del artículo periodístico o del capítulo de libro $^{11}$. La única excepción a este respecto es la tesis de Jorge Romero León titulada La critique littéraire vénézuélienne des années 1960-1970 12 (1988), que dedica a Guillermo Sucre un espacio amplio dentro del capítulo "La crítica inmanente". Este trabajo toca todos los puntos esenciales del pensamiento de Sucre pero lo enmarca dentro de una visión de conjunto de la crítica en Venezuela. Ello le impide, por una parte, centrarse exclusivamente en nuestro autor $y$, por otra, atender de manera diacrónica al proceso de formación de sus ideas.

Cuando intento explicarme la falta de atención de que ha sido objeto la obra de Guillermo Sucre puedo encontrar varios motivos. En primer lugar, si excluimos las obras Borges, el poeta (1967; 1974), La máscara, la transparencia, la Antología de la poesía hispanoamericana moderna, y sus libros de poesía, el resto de su producción se encuentra dispersa en periódicos y revistas de Venezuela, México y EEUU, entre otros países, y esta es una circunstancia que puede haber determinado que la mayor parte de su producción haya pasado inadvertida para el investigador. En segundo lugar, la crítica literaria es un género que ha recibido, equivocadamente a mi juicio, poca atención de

Muñoz. (Vid. Gustavo Valle: "Guillermo Sucre: la libertad y la cordura", en "El Papel Literario" de El Nacional, Caracas, 13-06-2009, pp. 7-8. El artículo está editado también en Cuadernos Hispanoamericanos, Madrid, núm. 713, nov. 2009, pp. 39-44) y Boris Muñoz: "Saludo mínimo a Guillermo Sucre", en "El Papel Literario" de El Nacional, Caracas, 20-04-1997, p. G-1. Aquí afirma que "la historia de la literatura venezolana alcanza con Sucre la síntesis más difícil: lo reflexivo y lo poético. Su obra es una llave. No leerla equivale a mantener cerradas muchas puertas."

${ }^{11}$ Vid. al final de este trabajo el Apéndice II, "Bibliografía sobre Guillermo Sucre”, pp. 508 y ss.

12 Jorge Romero León: La critique littéraire vénézuélienne des années 1960-1970, Paris, Université de la Sorbonne Nouvelle, Paris III, Institut d'études Ibéro-américaines, 2. vols., 1988. En el artículo citado más arriba, Alfredo Chacón llamaba la atención sobre el injusto olvido de que había sido objeto la poesía de nuestro autor. A este respecto ha sido Gustavo Guerrero quien más ha contribuido a reivindicar la obra de Sucre. (Vid. Gustavo Guerrero (ed.): Conversación con la intemperie. Seis poetas venezolanos. Barcelona, Galaxia Gutenberg, 2008) 
los estudiosos de la literatura hispanoamericana, a lo que hay que añadir quizá el carácter exigente del pensamiento y de la escritura de nuestro autor, que podría haber actuado como un elemento disuasorio. En tercer lugar, Guillermo Sucre ha profesado siempre "una ética de escritor", es decir, una actitud que él considera propia de los grandes autores de la tradición occidental y que implica el desdén "por el prestigio superficial o por una gloria aldeana"13. En vez de buscar la autopromoción y de jugarse su destino con "los brazos tendidos hacia la eternidad"14, nuestro autor prefirió el arduo camino del esfuerzo solitario y esta conducta ha mermado sin duda la repercusión de su obra en un tiempo como el nuestro acostumbrado a la espectacularidad del intelectual.

En cualquier caso, al dedicar este trabajo íntegramente al pensamiento literario de Guillermo Sucre pretendemos llenar (así sea parcialmente) un hueco en los estudios literarios que ya nos parece inadmisible. Más concretamente, el objetivo de esta tesis será hacer un estudio de conjunto (pero sin pretensiones totalizadoras) de las ideas estéticas de nuestro autor, que permita apreciar sus constantes y sacar conclusiones a partir de ellas. Para ello tendremos en cuenta la práctica totalidad de los escritos publicados por Sucre desde finales de los años cincuenta hasta el momento actual y, en cuanto a sus obras fundamentales (Borges, el poeta y La máscara, la transparencia), tomaremos en consideración las diversas ediciones, que presentan entre sí diferencias significativas. Así podremos apreciar el trabajo de Sucre en toda su extensión y más allá de la perspectiva reducida con que se le ha tratado convencionalmente. Además, nuestra aproximación no tendrá una voluntad exclusivamente descriptiva sino que trataremos de relacionar su pensamiento con el de aquellos escritores que son referencia permanente de su trabajo e intentaremos extraer las implicaciones políticas y culturales de su concepción de la literatura.

\footnotetext{
${ }^{13}$ Guillermo Sucre: "Testimonio: Las constantes de nuestra generación”, en Sardio, Caracas, núm. 3-4, pp. 277-282, p. 279.

${ }^{14}$ Guillermo Sucre: "Los inmortales", en El Papel Literario de El Nacional, 30-10-58.
} 
Al emprender este trabajo nos estamos situando plenamente en la tradición de "la crítica de la crítica", pero nos gustaría ofrecer dentro de este ámbito una perspectiva original. Como lo ha señalado memorablemente Octavio Paz, "la crítica tiene una función creadora: inventa una literatura (una perspectiva, un orden) a partir de las obras"15. En la medida en que instaura un orden, la crítica tiene implicaciones políticas, es decir, que supone un determinado "reparto de lo sensible" e interviene "en la distribución general de las maneras de hacer y en sus relaciones con maneras de ser y formas de visibilidad"16. Por eso, al sistematizar el pensamiento literario de Sucre trataremos de determinar de qué manera su estética, en tanto que estética, contribuye a configurar una "mirada de lo común"17 que es, en sí misma, y en sentido estricto, política. Con ello no pretendemos revelar la adscripción de Sucre a un partido ni estudiar ideológicamente su discurso. De lo que se trata es de arrojar luz sobre la dimensión política que está implícita en la propia estética, sin la cual el estudio de la misma resultaría necesariamente incompleto e insustancial. Para ello será imprescindible, por supuesto, tener en cuenta el contexto político y cultural en que se inscribe la obra de nuestro autor.

En cuanto a la estructuración del trabajo nos decantamos por una perspectiva diacrónica. Pensamos que esta es la mejor manera de abordar sus ideas estéticas y su crítica literaria, pues por motivos biográficos se aprecia una división relevante entre su obra anterior y posterior al año 1968. Además de ser un momento clave de la historia contemporánea, en el verano de ese año nuestro autor marchó a los Estados Unidos donde permanecería hasta 1975. Ese periodo de siete años en la Academia norteamericana cambió radicalmente el contexto de repercusión de sus ensayos, lo que

\footnotetext{
${ }^{15}$ Octavio Paz: "El espacio del reconocimiento", en OOCC, Vol. II, op.cit., pp. 1147-1148.

${ }^{16}$ Jacques Ranciére: El reparto de lo sensible. Estética y política, Santiago, LOM, 2009, pp. 10-
}

${ }^{17}$ Ibid., p. 10. 
impuso diferencias con su producción previa y resultó determinante para el desarrollo de su obra ulterior. Atendiendo a este hecho dividiremos el trabajo en dos partes diferenciadas que presentan, por supuesto, muchos puntos en común: en la primera abordaremos el periodo "venezolano" de Sucre, es decir, su producción anterior a su partida a los EEUU (1958-1968) y en la segunda sus escritos publicados desde su llegada a los EEUU hasta el presente (1968-2013). Si bien esta división pudiera parecer descompensada en cuanto al número de años, no lo es en cuanto al corpus de los textos que abarca cada periodo, pues el número de los trabajos de Sucre, sobre todo de los aparecidos en prensa, se ha ido reduciendo con el paso del tiempo.

Una vez establecida esta partición fundamental, estudiaremos el lapso 19581968 desde dos perspectivas diversas. En primer lugar expondremos el contexto cultural en que se desarrolla la obra de Sucre, es decir, que nos ocuparemos de lo que concierne a la posición de nuestro autor en el abanico de políticas culturales que se abrió como resultado de la Guerra Fría. En segundo lugar, entraremos plenamente en el estudio de su obra y trataremos de establecer los puntos fundamentales de su pensamiento literario durante este periodo. Para ello distinguiremos de nuevo dos etapas, en la primera abordaremos los escritos publicados entre 1958 y 1963 y en la segunda los editados entre el 64 y el 68. Esta división nos permitirá apreciar mejor el proceso de formación intelectual de nuestro autor, que tuvo lugar principalmente durante estos años, y ver con detalle cómo van apareciendo sus ideas, de dónde proceden y los cambios que sufren. Trataremos de estudiar entonces el pensamiento de Sucre en estrecha relación con aquellos autores con los que mantiene un vínculo más estrecho y para ello seguiremos un criterio estrictamente cronológico. Además, a partir de la sistematización de sus ideas, intentaremos establecer el "reparto de lo sensible" que implica la obra de Sucre, para lo cual nos apoyaremos en la teoría de Jacques Ranciére. Esta doble perspectiva 
con la que enfocaremos el estudio de su primera época (1958-1968) tiene que ver con dos maneras de indagar las implicaciones políticas de la estética. En la primera nos centraremos en describir la posición de nuestro crítico en la distribución polémica de lugares y de funciones que tuvo lugar, también en el ámbito de la cultura, con la institución de la IV República venezolana (1958-1998). En la segunda trataremos de ordenar su pensamiento estético y las constantes de su crítica literaria atendiendo a sus implicaciones políticas, a las que dedicaremos íntegramente, a modo de conclusión parcial, el último capítulo de la primera parte.

En lo que concierne al segundo periodo de su obra hay que decir que tras la llegada de Sucre a los EEUU en 1968, su proyecto estético sufrió un cambio notable, motivado sobre todo por su inserción en un nuevo contexto. El enfoque latinoamericanista del nuevo medio universitario y la proyección continental de las revistas en las que participó determinaron que su interés se centrara en el estudio de la poesía continental. Esto tuvo al menos dos consecuencias complementarias: por un lado, sus escritos perdieron el compromiso con la cultura nacional que se aprecia en los publicados durante el periodo venezolano (1958-1968); por otro, su obra ganó en proyección continental y, marcada por los cambios de la teoría cultural, adquirió un carácter definitivamente creativo.

Estas modificaciones imponen cambios en nuestra manera de aproximarnos críticamente a su obra. En primer lugar, y aunque es evidente que el pensamiento de Sucre se siguió enriqueciendo a lo largo del tiempo, consideramos que en el nuevo período su proceso de formación intelectual ya está completado y por lo tanto el acercamiento que emprendemos será sincrónico. Después de 1968 la concepción estética de nuestro autor se puede dar por consolidada y ello determina que los cambios que tienen lugar en su pensamiento sean menores y que no sea tan necesario un estudio 
diacrónico como lo era en la etapa previa. Hecha esta salvedad, nuestra aproximación a su obra seguirá los mismos pasos: trataremos de sistematizar las constantes de su pensamiento atendiendo también a la obra de aquellos escritores que resultaron decisivos para nuestro autor. A partir de ellas, intentaremos definir el reparto de lo sensible que está en juego en su estética y ello nos permitirá apreciar las diferencias, si es que las hay, con el que había propuesto en el periodo anterior. Además, el carácter esencialmente creativo que Sucre asigna a su crítica a partir de 1968 nos obliga a tener en cuenta ahora el estudio de la forma literaria. A este respecto trataremos de establecer paralelos, como él mismo haría, entre su pensamiento y su actitud ante el lenguaje, pues sólo a partir de este vínculo la literariedad resulta significativa.

En suma, al sistematizar la visión sucreana de la literatura atendiendo al contexto intelectual en que esta se forja y a sus implicaciones políticas y culturales, nos gustaría que esta tesis sirviera como estímulo para posteriores acercamientos a la obra de Sucre y que fuera tenida en cuenta para estudiar su magnífica poesía, que en cierto modo complementa el corpus que aquí tomamos en consideración. Con esta intención incorporamos dos apéndices al final de este trabajo, el primero incluye entrevistas y cartas originales e inéditas de Guillermo Sucre, y el segundo es una bibliografía directa e indirecta del autor, que se compila por primera vez aquí. Esta investigación aspira asimismo a contribuir, así sea modestamente, al proceso de las ideas literarias en Venezuela y en Hispanoamérica que, aunque es un aspecto esencial para comprender la creación propiamente dicha, es curiosamente una de las facetas más descuidadas de los estudios literarios del continente. 


\title{
CAPÍTULO I
}

\section{CONTEXTO BIOGRÁFICO E HISTÓRICO-POLÍTICO}

\author{
Guillermo Sucre Figarella nació en Tumeremo ${ }^{18}$, Estado Bolívar, Venezuela, el
}

14 de mayo de 1933. Fue el menor de los cinco hijos de Juan Manuel Sucre, comerciante de la casa Bolhm, y de Inés Figarella Cordoliani, descendiente de una familia corsa ${ }^{19}$. Cuando Guillermo contaba apenas con un año y medio de vida, el 28 de octubre de 1934, falleció su padre a causa de la fiebre amarilla y la familia se vio obligada a emigrar a Ciudad Bolívar. Allí, a orillas del Orinoco, Sucre cursó los estudios primarios y se inició en la literatura gracias a los libros de su abuelo, Juan Manuel Sucre Ruiz, miembro de la Academia Nacional de la Historia. En su primera juventud leyó la biografía de un ilustre antepasado suyo, Antonio José de Sucre ${ }^{20}$, así como crónicas y textos de historia; también algunas novelas de Dumas y las Rimas de Bécquer. En esa época solía visitar con su abuelo la granja "Las acacias” en el Manacal,

${ }^{18}$ Parte de la información biográfica de Guillermo Sucre la tomo de José Balza: "Guillermo Sucre: la felicidad y el árbol de la tormenta”, publicado en Obras selectas. Ensayos. Fulgor de Venezuela, Caracas, Fondo Editorial de Humanidades y Educación, Departamento de Publicaciones de la UCV, 2001, pp. 333-354. Me apoyo también en cartas, entrevistas y en artículos del propio Sucre, que iré citando a lo largo de este trabajo.

$19 \mathrm{Su}$ hermano mayor Juan Manuel Sucre Figarella (1925-1996) intervino en la conspiración militar contra Pérez Jiménez en 1957 y fue comandante general del ejército durante los años 1973-1974, al final de la primera presidencia de Rafael Caldera. Su hermano Leopoldo Sucre Figarella (1926-1996) fue nombrado gobernador de Bolívar por el presidente Rómulo Betancourt en 1959. Durante el gobierno de Raúl Leoni (1964-1969) sirvió como Ministro de Obras Públicas, y en el mandato de Jaime Lusinchi fue nombrado presidente de la Corporación Venezuela de Guayana (CVG), cargo que mantuvo hasta 1993. En 1965 publica Las obras públicas y el desarrollo integral. José Francisco Sucre Figarella (19322007), por su parte, sirvió en el servicio exterior de Venezuela, y fue embajador en Rusia y en Austria. Participó con su hermano Guillermo en revistas literarias y publicó en 1966 el libro El marxismo en la actualidad. Completa la nómina de hermanos Antonio Guillermo Sucre Figarella (1930-1981).

${ }^{20}$ Antonio José de Sucre (Cumaná, 1795- Nariño, 1830) fue un estadista y militar venezolano, prócer de la Independencia americana, que llegó a ser presidente de Bolivia, gobernador del Perú, General en Jefe del Ejército de la Gran Colombia y Comandante del Ejército del Sur. Preguntado por su parentesco con el poeta Ramos Sucre, el propio Guillermo ahondaba así en sus orígenes familiares: "El apellido Sucre en Venezuela es un solo tronco y viene desde la época de la Colonia y de la Capitanía General de Venezuela. Ramos Sucre desciende del primer matrimonio del padre del Mariscal Sucre, es decir, de los Sucre Alcalá; mi abuelo paterno era descendiente del segundo matrimonio del padre del Mariscal, es decir, de los Sucre Márquez, uno de los cuales, Juan Manuel Sucre Márquez, se estableció en Angostura (Ciudad Bolívar) después de las Guerras de Independencia. En pocas palabras, Ramos Sucre era sobrino biznieto del Mariscal, lo mismo que mi abuelo Juan Manuel Sucre Samarra. C'est tout." (Guillermo Sucre: “Carta I, octubre de 2012”, transcrita en el Apéndice I de este mismo trabajo, p. 473) 
a la que se referirá en sus primeros libros de poesía. En Ciudad Bolívar permaneció hasta agosto de 1945, cuando se trasladó a Caracas para iniciar el Bachillerato en el Liceo de Aplicación. Ese año, cuando Guillermo tenía apenas doce, murió su madre durante una operación quirúrgica. Marcada por la pérdida temprana de sus padres y por el sentimiento de la ausencia, la infancia ha tenido para Sucre una importancia fundamental y ha sido determinante en su obra. Por ello, en una entrevista reciente, refiriéndose al papel de la ironía en su literatura señalaba:

la ironía es una manera de no ser aseverativo (ni totalitario). Tampoco es un juego, sino una última sagesse. Es una pasión en la medida en que no nace de un cálculo. Y quizá surja de una experiencia: la de tantos paraísos perdidos. En mi caso, la muerte de mi padre cuando apenas era un infante o la de mi madre cuando era un adolescente impúber. Un amigo solía decir: "es que Guillermo no ha tenido infancia." Es y no es cierto. Conservo un amor por el amor o por la felicidad que sólo se tiene en la infancia. Y, claro, por eso el pasado y la memoria son tan intensos en mí. ${ }^{21}$

A su llegada a la capital en 1945 Guillermo Sucre vivió con sus hermanos en un apartamento de El Silencio, un barrio céntrico de la ciudad que había sido recientemente reformado y que en los años siguientes, a medida que el país avanzaba hacia la democracia, "se convertirá en ágora"22. Después de pasar por el Liceo de Aplicación, Guillermo se matriculó del quinto curso de bachillerato en el Liceo "Andrés Bello",23 _ era el curso académico 1949-1950. Allí colaboró en la dirección del periódico Espiral, donde apareció un texto suyo titulado "Soledad invertebrada". Comprometido desde muy joven con la democracia venezolana y en particular con el partido Acción Democrática, el golpe militar que derrocó al gobierno de Gallegos en 1948 llevó a que el joven Guillermo participase en protestas que le acarrearían serios problemas. En 1949, junto a un grupo de anarquistas españoles, boicoteó una lectura de poetas

${ }^{21}$ Guillermo Sucre: "Entrevista por escrito. Octubre de 2011”, infra en Apéndice I, pp. 468-469.

${ }^{22}$ Ramón J. Velásquez: “Aspectos de la evolución política de Venezuela en el último medio siglo”, en VVAA: Venezuela moderna (1926-1976), Medio siglo de historia, Caracas, Fundación Eugenio Mendoza y Ariel, $2^{a}$ ed., 1979, pp. 13-433, p. 61. Se refiere a que durante el Trienio (1945-1948) tuvieron lugar allí multitud de mítines políticos.

${ }^{23}$ En el Liceo "Andrés Bello" Sucre tuvo como compañero a Antonio Pasquali (1929), que en 1960 publicó el influyente libro Comunicación y cultura de masas. Además fue alumno de Eduardo Crema (1892-1974), crítico literario venezolano. Otros profesores ilustres del colegio fueron Mayz Vallenilla y Dionisio López Orihuela. 
próximos al régimen de Franco (Agustín de Foxá y Leopoldo Panero, entre otros), y ello le costó quince días en la Cárcel Modelo. Un año más tarde, participó junto a otros intelectuales civilistas y demócratas ${ }^{24}$ en el primer y único número de la revista Cantaclaro (1950), que fue decomisado por la policía de la Junta Militar por las evidentes referencias de la publicación al derrocado presidente Gallegos.

En el curso 1950-1951, Guillermo Sucre ingresó en la Universidad Central de Venezuela para cursar Filosofía y Letras, pero sus estudios se vieron interrumpidos por la agitación política en contra de la dictadura. En octubre de 1951, como consecuencia de las protestas, la Universidad perdió su autonomía y la autoridad universitaria fue sustituida por un Consejo de Reforma. Como respuesta a la creciente presión del régimen sobre la institución, a comienzos de 1952 tuvieron lugar toda clase de incidentes: "toma de la universidad por los estudiantes, mítines en la Ciudad Universitaria, prisión de las comisiones estudiantiles, medidas contra los profesores, peleas en las aulas" 25 . Junto a otros compañeros (entre los que se encontraban también Rafael Cadenas $^{26}$ y Manuel Caballero ${ }^{27}$ ) Guillermo Sucre participó en la toma de las instalaciones de San Francisco, antigua sede de la Universidad Central, con el objeto de defender la autonomía de la institución. Como consecuencia de ese suceso fue detenido y encarcelado durante tres meses y medio, y en julio de ese mismo año, con tan solo diecinueve años, la situación política le forzó a un largo exilio, que pasará primero en Chile y después en París.

24 Jesús Sanoja Hernández, Miguel García Mackle, Rafael José Muñoz, Jesús R. Zambrano, Juan Liscano, y un hermano de Guillermo, José Francisco Sucre.

${ }^{25}$ Ramón J. Velásquez: “Aspectos de la evolución política...”, en VVAA: Venezuela moderna (1926-1976)...op.cit., p. 159.

${ }^{26}$ Rafael Cadenas (Barquisimeto, 1930), poeta venezolano, autor, entre otros, de estos libros fundamentales: Los cuadernos del destierro (1960), Memorial (1977), Amante (1983) y Gestiones (1992).

27 Manuel Caballero (Barquisimeto, 1931-Caracas, 2010), historiador y periodista venezolano, autor de varios libros entre los que destacan Gómez, el tirano liberal: vida y muerte del siglo XIX (1993) y La gestación de Hugo Chávez: 40 años de luces y sombras en la democracia venezolana (2000). 
Guillermo vivió en Santiago de Chile entre 1952 y 1955, y allí estudió

Castellano y Literatura en el Instituto Pedagógico. Uno de sus profesores fue Ricardo

Latcham $^{28}$, que a su vez era amigo de Picón-Salas y que, al saber que Sucre era

venezolano, le "distinguió con su protección y amistad"29. En el Pedagógico, el joven

Sucre conoció a Jorge Teiller ${ }^{30}$ que estudiaba Historia y Geografía, y a otros jóvenes

como Jaime Valdivieso, Antonio Avalón, Mónica Imbert, Ángela Jiménez ${ }^{31}$, etc. Con

ellos Guillermo creó una tertulia literaria en la que leían y comentaban sus respectivos

poemas, ensayos y relatos. Durante su estancia chilena, Sucre conoció también a los

poetas Nicanor Parra ${ }^{32}$, Braulio Arenas y Gonzalo Rojas y, entre los políticos, a Rómulo

${ }^{28}$ Ricardo Latcham (Chile, 1903-La Habana, 1965), fue crítico literario y profesor universitario chileno. Sus obras más importantes son: 12 ensayos: antología de Santiago (1944), Blest Gana y la novela realista (1959), Carnet crítico: ensayos (1962).

${ }^{29}$ Guillermo Sucre: “Carta I, octubre de 2012”, infra en Apéndice I, p. 473.

30 Sobre Jorge Teiller, Guillermo afirmaba en una carta lo siguiente: "Jorge Teiller era ya [entonces] un poeta con mucho dominio expresivo y originalidad, lo que se nota en su primer libro Para ángeles y gorriones (1956). Jorge, hacia esta fecha, estaba por casarse con una muchacha preciosa, que era muy amiga de todos nosotros Matilde Guevara. Cuando yo vivía en Caracas, me enviaba sus libros que yo reseñaba en Zona Franca. Cuando elaboramos la Antología de la USB incluí a Jorge y creo que fue uno de los éxitos de esta Antología, al menos le abrió un público lector venezolano. Creo que el tono nostálgico de su poesía, su sentido de lo irreparable y el sentido misterioso de la Frontera (del Sur), la fascinación por la aventura como el Grand Meaulnes de Fournier o el Rimbaud de las Iluminaciones, son rasgos notables de su poesía. Y nadie más inocente que él. En un capitulo que ideo para La máscara -El Reino- le reservo un buen espacio." (Guillermo Sucre: “Carta I, octubre de 2012”, infra en Apéndice I, p. 474)

${ }^{31}$ Guillermo conoció a Ángela Jiménez "tomando el troleybus en Vicuña Macquena, que nos dejaba a varias cuadras del Instituto al que llegábamos caminando. El Instituto era un conjunto de hermosos y sencillos edificios cubiertos de hiedra, y con un inmenso jardín (campus) sembrado de álamos. En el trayecto hablaba mucho con Ángela y casi iniciamos un romance. Dejé de verla por un tiempo y cuando la encontré de nuevo en el centro de Santiago me presentó a un profesor de matemáticas, con el que iba a casarse. Disimulé mi indignación y no nos volvimos a ver. Sin embargo, le dedico un breve poema de mi tercer libro [En el verano cada palabra respira en el verano (1976)], al cual añado unos versos de Neruda, titulado "Ángela Adónica”, que con frecuencia le memorizaba a ella, y era como nuestra contraseña." (Guillermo Sucre: "Carta I, octubre de 2012", infra en Apéndice I, p. 474)

32 "A Nicanor me lo presentaron en la Biblioteca y cuando supo que yo era venezolano inmediatamente me preguntó por su amigo Juan Sánchez Peláez, quien había vivido años antes en Santiago. Éramos más o menos vecinos (él vivía en La Alameda y yo en Vicuña Macquena) y con frecuencia me invitaba a ver las piezas que montaba el Teatro Universitario en la Plaza de la Moneda. A veces él no iba y me acompañaba su hija. Yo admiraba a Nicanor por su poesía (era la época de Poemas y anti-poemas) y por su ingenio un poco mordaz. En los veranos nos encontrábamos en el Sur, ya fuese en Valdivia, ya fuese en Concepción. Años después, en 1967, vino a Caracas, invitado a un Encuentro de Escritores norteamericanos y latinoamericanos, que celebró sus reuniones en un Club del Litoral, y al cual yo también asistí. Recuerdo una sesión nocturna que fue de diálogo abierto y en la que Robert Lowell y Nicanor leyeron sus poemas y, además, Lowell leyó un poema de Nicanor, y éste un poema de Lowell traducido por él. En ese Encuentro Nicanor me decía: «en estas reuniones no hay que hablar mucho porque después no nos invitan más». Terminado el Encuentro, nos vinimos a Caracas, y fui un poco su cicerone en la ciudad, junto con Sánchez Peláez. Lo llevé a la Ciudad Universitaria y cuando le mostré el Aula Magna, le dije: «aquí Neruda en 1959 leyó sus poemas». Noté que a Nicanor no le cayó muy bien la 
Betancourt, líder de Acción Democrática en el exilio, y al dirigente socialista Salvador Allende. Durante esta época, participó en las manifestaciones organizadas por el Partido Socialista de Chile -como la que se celebró contra la intervención de la CIA en Guatemala- e, invitado por el propio Allende, asistió con otros venezolanos a escuchar un discurso en el que él pedía a los representantes de su país que no asistieran a la $\mathrm{X}$ Conferencia Interamericana, que se iba a celebrar en Caracas en ese año de 1954. Además, fue en Chile donde Guillermo leyó la primera edición de Libertad bajo palabra (1949) de Octavio Paz y donde compró las ediciones originales de Las formas del fuego y El cielo de esmalte (1929), del venezolano Ramos Sucre. Tras permanecer tres años en el país sureño, nuestro autor marchó a París en 1955 becado por la Alianza Francesa, y allí asistió a varios cursos en La Sorbonne.

En 1956, tras cuatro años en el exilio, Guillermo Sucre regresó a su país, aprovechando que la dictadura de Pérez Jiménez, a raíz de una protesta ante la ONU, había comenzado a dar visas a los exiliados políticos ${ }^{33}$. Al regreso, Sucre se volvió a matricular en la Escuela de Letras de la Universidad Central para terminar sus estudios, tantas veces interrumpidos, y tuvo la suerte de conocer a dos profesores que resultarán decisivos para su formación: Ángel Rosenblat ${ }^{34}$ y Mariano Picón Salas ${ }^{35}$. Con el noticia. Poco después me preguntó por qué a él no lo invitaban al Aula Magna en vez de la pequeña sala del Ateneo de Caracas. Al día siguiente había tomado el avión y sin avisar se marchó; apenas me dejó una esquela con el adiós. Por suerte, le había pedido permiso para publicar en Imagen los "Artefactos" que había leído en las reuniones del Litoral, a lo cual accedió no sin antes protestar por los honorarios. Así era Nicanor, siempre inconforme. Imagen era una revista tamaño tabloide, quinquenal, que se vendía en los kioscos, recién creada por el INCIBA y la cual yo dirigí hasta 1968. Para una futura edición de La máscara, pienso dedicarle a Nicanor un espacio más amplio." (Guillermo Sucre: "Carta I, octubre de 2012”, infra en Apéndice I, p. 475)

33 En este momento regresaron también a Venezuela José Francisco Sucre -hermano de Guillermo-, Jesús Sanoja Hernández, Alberto Aranguren, Porfirio Gómez, etc.

${ }^{34}$ Ángel Rosenblat (Wengrow, Polonia, 1902-Caracas, Venezuela, 1984), destacado filólogo y profesor universitario. En los años 30 se formó en el Centro de Estudios Históricos de Madrid junto a maestros como Américo Castro y Navarro Tomás. Más tarde fue discípulo de Amado Alonso y de Pedro Henríquez Ureña en el Instituto de Filología de Buenos Aires, donde conoció también a Raimundo y María Rosa Lida. Con la llegada de Perón al poder se exilió a Caracas, en 1946, donde un año después fundó la Cátedra de Filología de la Universidad Central. Fue un gran estudioso del español de América y en particular del habla popular venezolana. En "El Papel Literario" de El Nacional publicó regularmente sus "Buenas y malas palabras". Algunas de sus obras más importantes son: Lengua y cultura de 
primero Guillermo estudió dos materias de Filología y también Literatura Española, y con el segundo la parte de Literatura Hispanoamericana que le faltaba para completar su currículo $^{36}$. Con ambos maestros Guillermo estableció una relación intelectual y de amistad que le marcará decisivamente y que resulta determinante para comprender su obra. "Desde estos años - dice el propio Sucre- mi vida se cruzó, de alguna manera, con la de Picón-Salas y la de Ángel Rosenblat"37.
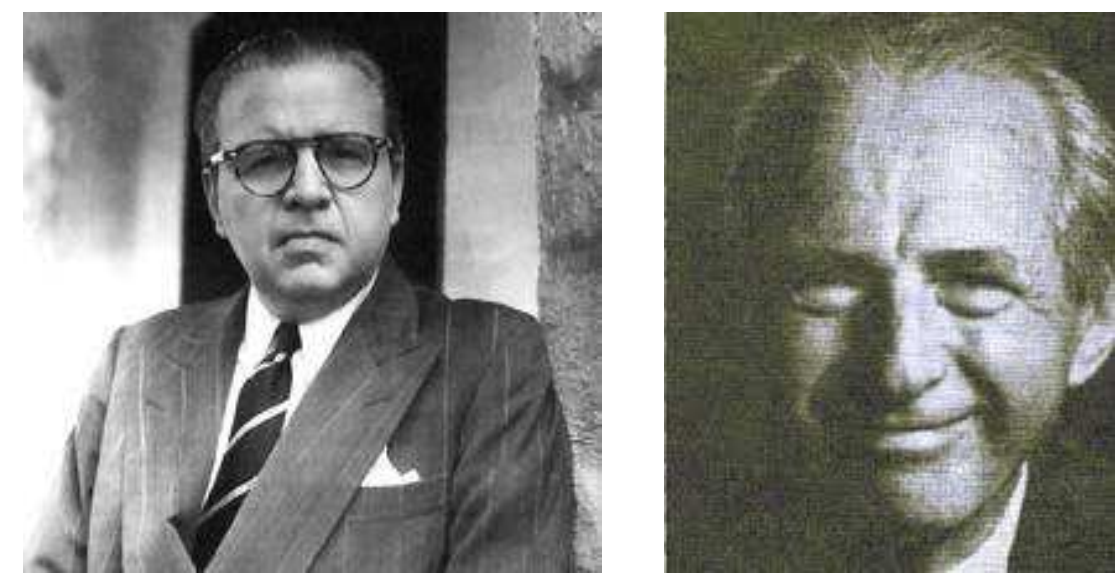

Imágenes 1 y 2. Mariano Picón Salas (1901-1965) y Ángel Rosenblat (1902-1984).

Hispanoamérica: Tendencias actuales, (1933), Buenas y malas palabras (1960), La educación en Venezuela (1964), La primera visión de América y otros estudios (1965), y La lengua del "Quijote", (1971). Para una descripción más detallada de su participación en el Instituto de Filología de Buenos Aires vid. Ángel Rosenblat: "Amado Alonso" en La primera visión de América y otros estudios, Caracas, Ministerio de Educación, 2a ed., 1969, pp. 211-222.

${ }^{35}$ Mariano Picón Salas (Mérida, 1901-Caracas, 1965), escritor y diplomático venezolano. En su obra destacan los ensayos históricos, los de crítica literaria y los dedicados a la historia cultural de América Latina. Exiliado en Chile durante la dictadura de Gómez, Picón Salas regresó al país tras la caída del dictador en 1936, donde trató de impulsar el desarrollo educativo y cultural de la nación. En 1940 fundó la Revista Nacional de Cultura, y la Facultad de Filosofía y Letras de la UCV en 1946. Más tarde, a petición del presidente Raúl Leoni diseñó y organizó el Instituto Nacional de Cultura y Bellas Artes (1965). Fue embajador de Venezuela en Colombia (1947-1948), Brasil (1958-1959), ante la UNESCO en París (1959-1962) y en México (1962). De entre su amplia bibliografía podemos citar: Formación y proceso de la literatura venezolana (1940), De la Conquista a la Independencia; tres siglos de historia cultural latinoamericana (1944), Biografía de Francisco de Miranda (1946), Comprensión de Venezuela (1949) y la autobiografía Regreso de tres mundos: un hombre en su generación (1959).

${ }^{36}$ En esa época, Sucre asistió además a un seminario sobre la Estética de Heidegger impartido por el filósofo hispano-venezolano Federico Riu. Este profesor y filósofo publicó después en la revista Imagen, dirigida por nuestro autor. (Guillermo Sucre: “Carta I, octubre de 2012", infra en Apéndice I, p. 477)

37 Guillermo Sucre: "Carta I, octubre de 2012”, infra en Apéndice I, p. 471. Un recuento detallado de la relación personal de Guillermo Sucre con ambos maestros puede verse en la misma carta. 
En el verano de 1957, después de graduarse por fin, Guillermo Sucre fue de nuevo encarcelado por motivos políticos y permaneció en la prisión de Ciudad Bolívar los últimos siete meses antes de la caída del régimen. En esa que sería su última estancia en la cárcel coincidió, entre otros, con el poeta Rafael José Muñoz, con el novelista José Vicente Abreu, y con el historiador Ramón J. Velásquez, que sería secretario de Betancourt entre los años 1959 y 1963 y Presidente de la República por un breve período en 1993. El descontento social generalizado explotó el 23 de enero de 1958, fecha en que se produjo un levantamiento civil y militar que acabó finalmente con el régimen de Pérez Jiménez. Ese mismo día, que se convertiría en los años por venir en el símbolo de la unidad nacional contra la dictadura ${ }^{38}$, Guillermo Sucre recuperó la libertad. A partir de su salida de prisión, nuestro autor comenzó a intervenir con continuidad en el campo cultural venezolano, y como ya hiciera antes de la dictadura militar (1948-1958), apoyó al partido Acción Democrática y a su líder Rómulo Betancourt $^{39}$, que fue el encargado de liderar la transición hacia la democracia que

38 “Lo que diferencia al 23 de enero de los episodios similares de nuestra historia es su carácter de jornada colectiva, tanto en lo militar como en lo civil. Pues hasta 1948, la caída de todo Gobierno representaba en Venezuela, el triunfo y consolidación en el poder del caudillo vencedor en la jornada." (Ramón J. Velásquez: "Aspectos de la evolución política..." en VVAA: Venezuela moderna (19261976)...op.cit., p. 198). Como afirma al respecto Coronil: "Once again civil resistance developed into a military conspiracy. Without the insurgence of the military, the civilian opposition would have been unable to topple Perez Jimenez. Yet without the ever-increasing, broadbased civilian opposition to the regime, the military would not have turned against its leader. The 1958 revolution was neither a traditional military coup nor a mass uprising from below. Rather it was, in a peculiar but real way, the crystallization of collective discontent -from different classes, sectors, and bulwarks of power, including the military- against the increasingly arbitrary and personal rule of Perez Jimenez. Peculiar, because these groups had not participated in common struggles and were not linked by interdependent sectoral interests. Real, because they were nevertheless united in their opposition to an unresponsive government and shared an interest in a state that would use the nation's fiscal resources on their behalf." (Fernando Coronil: The Magical State: Nature, Money, and Modernity in Venezuela, Chicago \& London, The University of Chicago Press, 1997, p.212)

39 Guillermo Sucre ha señalado en una entrevista reciente: “Apoyé la candidatura de Rómulo Betancourt, quien fue electo Presidente ese mismo año." (Guillermo Sucre: "Entrevista por escrito, octubre de 2012", infra en Apéndice I, p. 466). En otro lugar ha afirmado lo mismo: "A lo largo de la llamada IV República (1958-1998) viví momentos de mucha tensión emocional e intelectual. A poco de instalarse el gobierno de Rómulo Betancourt, que yo apoyaba, se produjo la división de su partido Acción Democrática y la formación del Movimiento de Izquierda Revolucionaria con la mayoría de la juventud adeca [...]" (Guillermo Sucre: "Carta I, octubre de 2012", infra en Apéndice I, p. 477. Cursiva nuestra). Alexis Márquez, en un ensayo sobre la revista Zona Franca, señalaba que durante esta época tanto Guillermo Sucre como Luis García Morales eran militantes activos de Acción Democrática: "Liscano había sido un consecuente luchador contra la dictadura perezjimenista, y había vivido muchos años en el 
iniciaba el país. Llegados a este punto, me parece que es fundamental que expliquemos someramente el ideario de este partido, pues conocerlo es imprescindible para entender mejor las aspiraciones políticas que configuran el contexto en que se desarrolla la obra de Sucre.

El partido Acción Democrática -fundado por Rómulo Betancourt en 1941, pero cuyos orígenes se remontan a 1928- nació con la intención de dar representatividad política a los nuevos sectores sociales ${ }^{40}$ surgidos como consecuencia de la reanudación del "proceso de implantación"41. En el nuevo contexto surgido como consecuencia de la exportación de petróleo, Acción Democrática se definió políticamente por oposición a

exilio, y aunque nunca fue militante, estaba en aquella época muy vinculado con el partido Acción Democrática, de orientación social-demócrata, si bien para entonces esa alineación ideológica era más inferible que explícita. En la fundación de la revista lo acompañaron dos jóvenes escritores muy conocidos, militantes activos, ellos sí, del mencionado partido, aunque más identificables como intelectuales que como políticos: Guillermo Sucre, poeta, crítico literario y profesor universitario de prestigio, y Luis García Morales, poeta igualmente conocido en el medio venezolano. Desde el primer número apareció Juan Liscano como director, mientras Sucre y García Morales figuraban como integrantes del equipo de trabajo, bajo la escueta mención de Redacción." (Alexis Márquez Rodríguez: "La revista Zona Franca (1964-1984)", en VVAA: Le discours culturel dans les revues latinoaméricaines de 1970 à 1990, Cahiers du CRICCAL, 3ème Série, París, Presses de la Sorbonne Nouvelle, s/a, pp. 237-245, p. 239. Cursiva nuestra). Por otra parte, como se aprecia en la nota 2, sus hermanos mayores, sobre todo Juan Manuel, militar, y Leopoldo, político, estuvieron también vinculados en diverso grado a Acción Democrática.

${ }^{40}$ Acción Democrática quiso ser un partido "en el que cupieran como en un gran frente nacional todas las clases sociales y todos los sectores que estaban empeñados en la liquidación del gomecismo y que deseaban transformar a Venezuela en un país moderno y sustituir las tradicionales tiranías por un gobierno democrático." (Betancourt afirmó eso en su exilio de las Juntas de Abangares, Costa Rica, 1931. Citado por Ramón J. Velásquez, "Aspectos de la evolución política..." en VVAA: Venezuela moderna (1926-1976)...op.cit., p. 77). En el acto de fundación de AD, en 1941, Betancourt señaló algo similar: "Acción Democrática aspira a ser [...] el cemento que amalgame a todos los venezolanos que amen su nacionalidad". (Citado por Diego Bautista Urbaneja: "La nación, Estado, petróleo y democracia en la historia de Venezuela", en Carrera Damas, Germán et al.: Comprensión de nuestra democracia, Caracas, Fondo Editorial 60 años de la Contraloría General de la República, 1998, pp. 135-162, p. 153)

${ }^{41}$ Ofrezco a continuación algunas citas para facilitar la comprensión del concepto "proceso de implantación” que emplea Carrera Damas: "El proceso sociohistórico de las sociedades latinoamericanas puede ser concebido como un proceso de implantación de sociedades" (Germán Carrera Damas: Una nación llamada Venezuela, Caracas, Monte Ávila, 1980, p. 21). "El proceso de implantación es básicamente el resultado del correlacionamiento entre la base europea y la base indígena, en función de la ocupación del territorio. Este correlacionamiento se expresa en un proceso de estructuración social y en su correspondiente estructura económica." [...] "El carácter abierto del proceso de implantación implica la inserción en el mismo de nuevos factores, generados tanto en la base europea como en la base indígena." (Ibíd., p. 22). [...] "La primera fase [...] recoge el momento a partir del primer contacto entre los europeos y los indígenas" (Ibíd., p. 26). [...] "La segunda fase [...] es el lapso durante el cual aquellos núcleos que apenas habían alcanzado una existencia todavía precaria [...] llegan a constituirse como sociedades." [...] "La tercera fase es la que llamo de articulación plena con el sistema capitalista mundial o [...] de desarrollo dependiente de la implantación.” (Ibíd., p. 27). Más adelante Carrera Damas añade: "el proceso de implantación se da en dos direcciones, es decir, en un sentido horizontal o espacial de ocupación del territorio, y en un sentido vertical o social de conformación de la sociedad." (Ibíd., p. 40). Por lo tanto, el momento que aquí se describe forma parte de la tercera fase de este proceso. 
los gobiernos militares: primero frente al de Juan Vicente Gómez (1909-1935) y después frente al de Marcos Pérez Jiménez (1948-1958). Mientras que estos regímenes se habían apropiado para su propio beneficio del poder político y del patrimonio natural de la nación, Acción Democrática quería ser la encarnación política del pueblo y, al mismo tiempo, el distribuidor ecuánime de la riqueza nacional ${ }^{42}$. Además, como durante las autocracias de Gómez y de Pérez Jiménez, el Estado de derecho y las libertades públicas habían brillado por su ausencia, Acción Democrática reivindicó la agenda política del liberalismo, que incluía el principio de la soberanía popular, la división de poderes, la configuración de un sistema plural de partidos, y el respeto a los derechos y las garantías individuales y sociales.
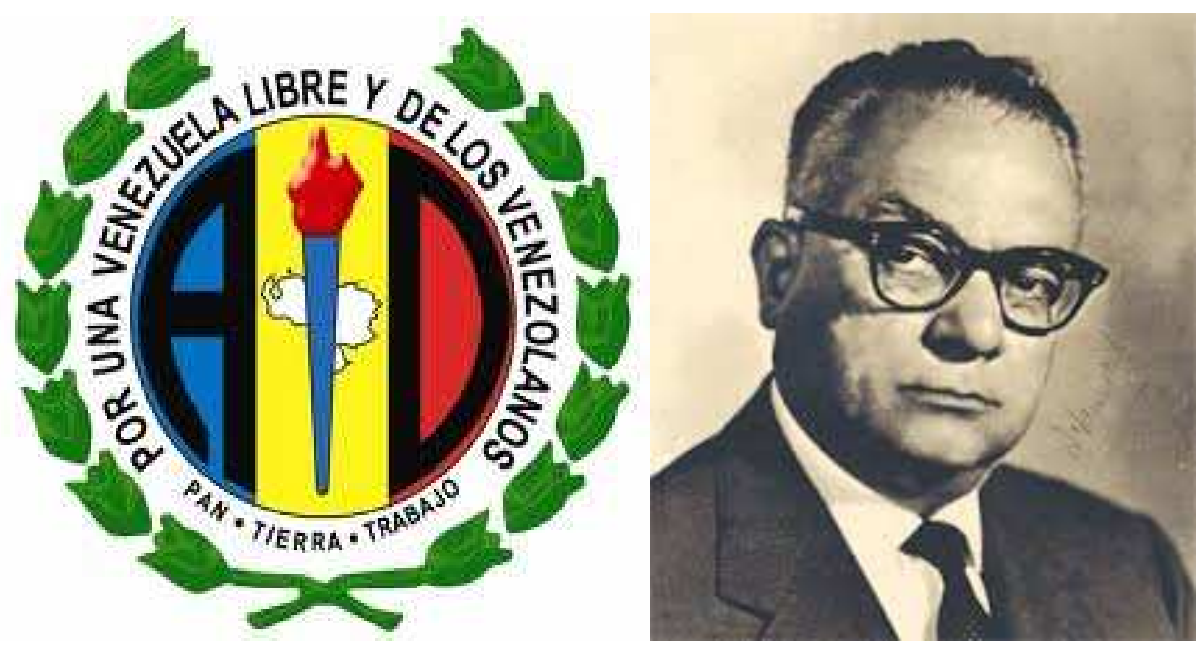

Imágenes 3 y 4. El escudo de Acción Democrática y su líder Rómulo Betancourt (1908-1981).

En el terreno económico, el partido de Betancourt adoptó la idea de Uslar Pietri de "sembrar el petróleo"43 y quiso que el ingreso proveniente de esta materia prima

${ }^{42}$ Así, la democracia pasó a significar "un sistema de participación popular no sólo en la vida política nacional, sino también en la riqueza natural de la nación." (Fernando Coronil: The Magical State...op. cit., p. 96. Traducción mía)

${ }^{43}$ La expresión "sembrar el petróleo" apareció por primera vez en el editorial del diario Ahora el 14 de julio de 1936 y se advierte asimismo en los artículos incluidos en el volumen Arturo Uslar Pietri: De una a otra Venezuela, Caracas, Monte Avila Editores, 1973, passim. Coronil define así la idea de Uslar de "sembrar el petróleo": "Uslar Pietri claimed that it was urgent to use the "transitory wealth" of 
redundase en el desarrollo económico y social de todos los venezolanos. De este modo, tanto Rómulo Betancourt como los intelectuales ideológicamente afines (pertenecientes en su mayoría a la llamada "generación del 28”) actualizaron la oposición decimonónica entre civilización y barbarie en la pugna democracia versus dictadura $^{44}$ y convirtieron a aquel sistema político en una suerte de fetiche que acabaría con todos los males del país. Esta oposición ha constituido un verdadero leitmotiv de gran parte de la literatura venezolana del siglo $\mathrm{XX}$, y es particularmente visible en la obra de dos autores fundamentales vinculados a Acción Democrática como son Rómulo Gallegos y Mariano

\section{Picón Salas. Como ha indicado Carrera Damas}

La alternativa frente al Proyecto Nacional de la clase dominante es la del desenfreno caudillista y la guerra civil, ideologizados profundamente a través de la educación y de la literatura, a través de todo medio posible: caudillismo y guerra civil que repugnaban a las conciencias civiles y civilizadoras; caudillismo igual barbarie, es el pensamiento que se fragua en Doña Bárbara y en toda la literatura venezolana, en contrapartida de un anhelo constante de mantener el hilo de la constitucionalidad. ${ }^{45}$

the present "destructive economy" to create the healthy and broad foundations of a "progressive economy that will be our true declaration of independence." If political independence had been Simon Bolivar's heroic achievement, full independence would now be the task of those capable of transforming ephemeral wealth into permanent productive capacity." (Fernando Coronil: The Magical State...op.cit., p. 105). Según Coronil, "This phrase ["sembrar el petróleo"] became the central slogan in the political discourse of democratic development." (Ibid., p. 105)

${ }^{44}$ Ya en un memorandum publicado por Organización Venezolana (ORVE), futura AD, en 1936, "Corruption was identified with autocratic rule; democracy was presented as providing a check against the possibility of corruption in a vastly expanded state possessing growing financial resources." (Ibíd., p. 101.) Esta corriente de opinión está motivada por la "trampa ideológica" del Proyecto Nacional y por su marcado occidentalismo, que determina que en Venezuela (como en Latinoamérica en general), "the contest between democracy and dictatorship has been cast as part of this nightmarish colonial struggle between civilization and barbarism." (Ibíd., p. 229)

45 Germán Carrera Damas: Una nación...op.cit., p. 138. Lo que estaba en juego en el proyecto de Acción Democrática no era solo la democratización de la vida política y el reparto igualitario de la riqueza nacional sino también la adaptación del Proyecto Nacional liberal instituido en la Constitución de 1864 a las nuevas condiciones económicas y sociales del siglo XX. Carrera Damas define el Proyecto Nacional como "un complejo ideológico, formulado por la clase dominante como expresión y como factor de su dominación, en tanto opera como modelo para la organización y funcionamiento de la sociedad. Pero un modelo cuyo objetivo es justamente mantener, consolidar y ampliar la posición preeminente que en la sociedad ocupa la clase dominante." (Germán Carrera Damas: Una nación...op.cit., p. 83). "Los textos constitucionales y la actividad ideológica que ellos generan, tienden a hacer aparecer el Estado Liberal, en su estructura constitucional, como la única forma de organización política de la sociedad capaz de responder a las expectativas y aspiraciones de todos los sectores de esa sociedad." (Ibíd, p. 86). Y más adelante: "si algún pensamiento tiene continuidad y coherencia en la historia de Venezuela es justamente el pensamiento liberal, que cuaja en la Constitución de 1864.” (Ibíd, p. 108). También Fernando Coronil comparte la concepción de Carrera Damas: "Ever since the struggle for independence, liberalism had been the public language of the Venezuelan political elite; identified with the very origins of the nation, this language seemed untouchable." (Fernando Coronil: The Magical State...op.cit., pp. 85-86) 
Esta constante se aprecia también en la obra de Picón Salas, que siempre defendió la tradición civilista y democrática frente a las dictaduras militares. Por eso, en su interpretación de la historia venezolana el ensayista merideño situaba, de un lado, a la barbarie anárquica de la Federación y a los regímenes dictatoriales, y, de otro, a la civilización representada por el liberalismo democrático. Así afirmaba, por ejemplo, que después de la guerra de la Federación, Caracas, "una ciudad crisol", "trata de civilizar y dar forma a esas gentes que galopando en su instinto, salieron de la comarca más lejana a fijar su nombre e imponerse. $\mathrm{Y}$ es comprensible que roto el marco jurídico y la jerarquía de la vieja sociedad fundada en la tradición y la sangre, sea el militarismo la única fuerza coordinadora, la disciplina instintiva de un pueblo en ebullición, en trance de fundirse ${ }^{\natural 4}$. Entonces, recuperar la senda democrática implicaba derrocar de una vez por todas las montoneras anárquicas y el caudillismo. Ello permitiría implantar por fin un sistema político justo que además de repartir de manera ecuánime el poder político y económico, implementaría un Estado de derecho, respetuoso de las libertades públicas, y convertiría a Venezuela en un país a la altura de los centros metropolitanos ${ }^{47}$. Las esperanzas depositadas en esta forma de gobierno dieron lugar a lo que el historiador Bautista Urbaneja ha llamado la "mística democrática"48. En efecto, se pensaba que con la llegada de la democracia acabarían todos los males del país, que se vinculaban a la

46 Mariano Picón Salas: "Antítesis y tesis de nuestra historia”, en Viejos y nuevos mundos, Caracas, Biblioteca Ayacucho, 1983, pp. 56-57. Es conocida también la apreciación de Picón de que Venezuela entra al siglo XX en 1935, tras la caída de la dictadura de Gómez.

${ }^{47}$ El marcado carácter occidentalista del Proyecto Nacional provocó contradicciones constantes entre los principios teóricos y la práctica política, y además determinó que la "búsqueda de la modernidad en Venezuela, proyectada por el discurso oficial como la voluntad de parecerse a los centros metropolitanos, [se convirtiese] en el objetivo legitimador de la política nacional." (Fernando Coronil: The Magical State...op.cit., p. 367. Traducción mía). Según la definición de Coronil, el "occidentalismo" es "the implicit conception of the West animating its representation of non-Western societies." (Ibíd, p. 14)

48 Tomo la expresión de Bautista Urbaneja, que a propósito de las esperanzas democráticas suscitadas en 1958, definía así la "mística democrática": "La reinstauración de la democracia en 1958 vino acompañada de una gran esperanza colectiva en la creación de un régimen político de alta calidad ética, por contraste con la dictadura que se acababa de derrocar, y uno de cuyos vicios más denunciados era la corrupción." (Diego Bautista Urbaneja: La política venezolana desde 1958 hasta nuestros días, Caracas, Fundación Centro Gumilla, Universidad Católica Andrés Bello, 2007, p. 30) 
pervivencia de los regímenes autoritarios. En la valoración que Ramón J. Velásquez hizo del clima político de 1945 (y que es extensible igualmente a 1958) se aprecia bien lo que esta expresión significa:

todos los venezolanos de 1945 creíamos en el voto universal como en el milagro de la purificación nacional. Y pensábamos que respetado el voto de las mayorías, en Venezuela se liquidarían todos los males tradicionales del nepotismo, del amiguismo, del peculado, del tráfico de influencias, del engaño y de la farsa que atribuíamos exclusivamente al origen oligárquico de los sucesivos regímenes que habían ejercido el poder. ${ }^{49}$

Una vez alcanzado el poder en los comicios de diciembre de 1958, el gobierno de Betancourt se impuso como "objetivo rector" consolidar la democracia representativa de partidos en los términos establecidos por el Pacto de Punto Fijo (1958). Para ello era imprescindible -ya aprendida la lección del Trienio (1945-1948)- establecer un sistema que hiciera posible el reparto del poder entre los principales partidos políticos y en el que se sintieran representadas todas las fuerzas políticamente significativas del país. Como el Estado se convirtió en el gerente del poder político y económico de la nación, ambos poderes deberían distribuirse lo más ampliamente posible, de manera que no hubiera ningún grupo descontento con la democracia o, en todo caso, que los grupos descontentos fueran los menos posibles. La búsqueda del consenso en los términos indicados significó la exclusión de los extremismos políticos que se oponían a la consolidación institucional: el golpismo militar, nostálgico del orden anterior a 1958, y el terrorismo de la izquierda revolucionaria que, siguiendo el ejemplo cubano y amparado por el régimen de Fidel Castro, formó a partir de 1960 una guerrilla que trató de desestabilizar al gobierno. En ese contexto, la democracia se definió por ser el término medio entre dos excesos (y dos amenazas): la dictadura militar por un lado y el

${ }^{49}$ Ramón J. Velásquez, “Aspectos de la evolución política...”, en VVAA: Venezuela moderna (1926-1976)...op.cit., p. 76. 
comunismo revolucionario por otro ${ }^{50}$. Frente a las posturas radicales, la democracia venezolana se convirtió en la expresión política de la mesura y del consenso.

Cuando Guillermo Sucre salió de la cárcel en enero de 1958 se posicionó a favor de la Junta de Gobierno y en las elecciones de diciembre de ese mismo año apoyó la candidatura de Rómulo Betancourt. Como hemos visto, Guillermo había estado vinculado a Acción Democrática ya en la resistencia y había sufrido la represión y el exilio durante la década dictatorial (1948-1958). Al situarse a favor del gobierno y del consenso institucional, Sucre estaba apoyando el retorno de la democracia social y de la tradición liberal frente al caudillismo personalista; y al mismo tiempo se distanciaba de los extremismos políticos que amenazaban la construcción del nuevo orden. Como veremos más adelante, esta identidad política resulta fundamental para comprender "el reparto de lo sensible" ${ }^{51}$ que implica su concepción estética y que está detrás del linaje intelectual que nuestro autor reivindicará en los años por venir.

Al salir de prisión, nuestro autor se incorporó al grupo Sardio, que venía reuniéndose en Caracas desde 1956. En mayo-junio de 1958 salió el primer número de la revista homónima, en la que Sucre jugó un papel fundamental ${ }^{52}$. Aunque a partir de

50 "In Venezuela, the struggle for democracy developed as a struggle against gomecismo and against communism.” (Fernando Coronil: The Magical State...op. cit., p. 133)

${ }^{51}$ La expresión, que explicaremos más adelante, pertenece a Jacques Ranciére: El reparto de lo sensible...op.cit., pp. 10-11.

${ }^{52}$ En la Carta que me envió personalmente, el propio Sucre señalaba que él mismo había escrito los "Testimonios" (especie de manifiestos de la revista): "Sí, muchos de los Testimonios de Sardio son míos." (Guillermo Sucre: "Carta I, octubre de 2012", infra en Apéndice I, p. 477). Los "Testimonios" aparecían sin firma pues se suponía que su autoría era colectiva y que las opiniones pertenecían al grupo establecido alrededor de la revista. Sin embargo, esta ausencia de firma revela una constante del propio Sucre, que siempre trató (y esto es parte de su ética de escritor) de alejarse de la fama y de las pretensiones de figurar que tenían muchos intelectuales. Esta voluntad de quedar siempre en un segundo plano le llevó a no aparecer como director de la revista Imagen hasta el número 8 de la publicación, a no firmar muchos de los editoriales de esta revista, y a escribir algunos artículos de ese quincenario bajo el pseudónimo de Rodrigo Antúnez. (Vgr. Rodrigo Antúnez: "Una revista en la tradición moderna. Revista Nacional de Cultura", en Imagen, Caracas, núm. 20, 1/15 mar. 68, p. 22; "Mariño Palacio: la inmadurez creadora” en Imagen, Caracas, núm. 21, 15/30 mar. 68, p. 4; “Hacia dónde van las artes plásticas?” en Imagen, Caracas, núm. 21, 15/30 mar. 68, p. 22; "La poesía de los muros", en Imagen, Caracas, núm. 22, 1/15 abr. 68, p. 22; "Literatura y sociedad: una relación problemática”, en Imagen, Caracas, núm. 24, 1/15 may. 68, p. 6; "Literatura crítica", en Imagen, Caracas, núm. 27, 15/30 jun. 68, p. 2). Además, como hemos dicho en la Introducción, pensamos que esta voluntad expresa de no figurar puede ser una de las causas de la poca atención crítica que ha recibido su obra literaria. 
1960 -coincidiendo con la radicalización de los jóvenes de AD- el grupo se dividió en dos sectores opuestos políticamente, inicialmente todos los miembros de Sardio se declararon "afiliados [...] de un humanismo político de izquierda",53 y su ideología revelaba una afinidad evidente con la del partido Acción Democrática. Extendiendo la "mística democrática" a su propio ámbito, los jóvenes agrupados en torno a la revista consideraban que la cultura era inseparable de la democracia y reclamaron un compromiso ético de los intelectuales:

Ser político equivale a tanto como ser hombre. Toda indolencia es propicia a la esclavitud y a la humillación del espíritu. Quienes soslayan esta verdad olvidan que ciertas fuerzas oscuras, desencadenadas un momento dado sobre la historia, quebrantan siempre la dignidad de toda creación. Por ello es que cultura y tiranía son radicalmente incompatibles. Las dictaduras son algo más que la ciega imposición del instinto o de la codicia. Ellas surgen como la fundamental negación de la esencialidad humana y de la inteligencia. ${ }^{54}$

Es así que la democracia (y en este caso su "sinónimo", la libertad) era para

ellos, como para Acción Democrática, un régimen político que debía garantizar la dignidad del hombre en un aspecto tanto político como económico:

La libertad no puede ser [...] engañosa entelequia a la cual vayan a sacrificarse imperativos más urgentes y concretos. Si ella debe ser concepto dinámico que habitúe al hombre al reino de su potencia interior y de su dignidad de ser sobre la tierra, no puede eludir la felicidad material y social de los pueblos. Conjugar en un armonioso sistema de coordenadas todos estos planos es el objetivo determinante de la Democracia. La libertad no se justifica sino en la medida en que hace realidad esa conjunción. ${ }^{55}$

En los números posteriores a enero de 1959, los miembros de Sardio saludaron con optimismo "la liberación de Cuba", y expresaron su esperanza en que el Gobierno Provisional, "tal como ocurriera en nuestro país, pueda llevar a los cubanos a un proceso

\footnotetext{
${ }^{53}$ Guillermo Sucre: “Testimonio”, en Sardio, Caracas, núm. 1, mayo-junio 1958, p. 2. Como ya se ha advertido los "Testimonios" aparecían sin firma, pero su autoría es de Sucre.

${ }^{54}$ Ibíd., p. 1. Para establecer este vínculo entre cultura y democracia seguramente influyeron en Sucre las ideas al respecto de Mariano Picón Salas. Como el propio Guillermo dice en una carta: "Picón Salas murió el 1 de enero de 1965. El año anterior, encargado por el presidente electo Raúl Leoni, preparó lo que iba a ser el Instituto de Cultura y Bellas Artes (INCIBA), que se iba a instalar el 18 de enero de 1965. Poco antes de morir, había escrito «Prólogo del Instituto Nacional de Cultura», discurso inaugural que, como el que había pronunciado 30 años antes al inaugurar las actividades de la Facultad de Filosofía y Letras, constituyen la verdadera doctrina del pensamiento democrático frente a la cultura. En ninguna otra época se ha hablado de la relación de Estado y Cultura con tanta inteligencia, ecuanimidad, y sin ningún paternalismo. La cultura venezolana ha tenido otros logros después, pero no ha superado ese momento de cotidiano dominio y de generosa empresa colectiva que iba a tener con Picón-Salas." (Guillermo Sucre: “Carta I, octubre de 2012”, infra en Apéndice I, p. 471)

${ }^{55}$ Guillermo Sucre: "Testimonio", loc.cit., p. 2.
} 
electoral y encaminar a la República hacia sus fundamentos democráticos, tanto tiempo extraviados" ${ }^{, 56}$. Por supuesto se mostraron satisfechos con la victoria de Betancourt en los comicios electorales de diciembre de 1958, valoraron positivamente "su inquebrantable decisión de hacer viva la letra de los Pactos [de Punto Fijo] y Programas Mínimos de Gobierno" y apelaron a la ciudadanía para que colaborase en la tarea de consolidación de la democracia, y para ello proponían

iniciar la formación de un vasto frente contra cualquier posible y descabellado golpismo; robustecer y agigantar la acción conjunta de obreros, campesinos, estudiantes, profesionales, sindicatos petroleros del Zulia, Falcón, Anzoátegui y Monagas y sindicatos del hierro de Guayana, todos dispuestos a respaldar no incondicionalmente, sino lúcida y conscientemente, la estabilidad del gobierno electo en los comicios de diciembre. ${ }^{57}$

Asimismo, los jóvenes agrupados en torno a la revista reclamaron "con plena

conciencia, una política económica más audaz y nacionalista que salve para la patria los grandes recursos de nuestro patrimonio material" ${ }^{, 58}$, lo que coincidía con la propuesta económica de Acción Democrática, que condujo a la creación de la OPEP (1961) y más

56 s/f: "La liberación de Cuba”, en Sardio, Caracas, núm. 3-4, sep.-dic. 1958, p. 274. Este documento, que apareció sin firma, fue escrito probablemente por Guillermo Sucre. "Para el venezolano de 1959, Fidel Castro no era liberal, ni ortodoxo, ni socialista, ni comunista y representaba únicamente la lucha por la libertad y por el rescate de la dignidad del pueblo cubano." (Ramón J. Velásquez: “Aspectos de la evolución política...", en VVAA: Venezuela moderna (1926-1976)...op.cit., p. 229)

${ }^{57}$ s/f: “¿Una posible conjura contra la constitucionalidad?, en Sardio, Caracas, núm. 3-4, sept.dic. 1958 , p. 276. Este documento que aparece también sin firma fue posiblemente escrito por Sucre. Era frecuente en esta época que los sindicatos y la patronal respondieran con huelgas a los intentos de golpe de Estado contra la naciente democracia. Por ejemplo, en septiembre de 1958, se decretó una huelga ante el intento de alzamiento militar de Juan de Dios Moncada y de José Hely Mendoza. (Sobre este incidente Vid. Ramón J. Velásquez: “Aspectos de la evolución política...”, en VVAA: Venezuela moderna (19261976)...op.cit., pp. 217-218)

${ }^{58}$ Guillermo Sucre: “Testimonio", loc.cit., p. 2. El nacionalismo económico era parte del ideario accióndemocratista, que planteaba que la riqueza nacional debía repartirse entre todos los venezolanos. Además, en 1958 el antiimperialismo en Venezuela era un sentimiento generalizado, porque se sabía del apoyo explícito que los EEUU habían brindado a Pérez Jiménez, al que llegaron a condecorar, en octubre de 1953, con la "Legión del Mérito, el máximo galardón de la nación norteamericana." (Ramón J. Velásquez: “Aspectos de la evolución política...", en VVAA: Venezuela moderna (1926-1976)...op.cit., p. 177). A este respecto en la propia revista Sardio se decía: "Prevemos y exigiremos siempre de los Estados Unidos de Norteamérica, una total revisión de su política con los países latinoamericanos, por cuanto se ha revelado desacertada e inconsecuente, contraria a la auténtica aspiración democrática de nuestros pueblos y, muchas veces, divorciada de las elementales normas del Derecho de Gentes." (s/f: "La liberación de Cuba", loc.cit., p. 274). Una muestra del clima anti-norteamericano de la población venezolana en este momento se puede apreciar en los sucesos que tuvieron lugar con la visita de Nixon a Caracas en mayo de 1958. El entonces Vicepresidente tuvo que refugiarse en la Embajada de su país por la intensidad de las protestas y no pudo cumplir con su agenda. (Para un recuento más detallado del incidente Vid. Ramón J. Velásquez: “Aspectos de la evolución política...”, en VVAA: Venezuela moderna (1926-1976)...op.cit., p. 208 y ss.) En esta época, un marcado sentimiento anti-norteamericano se había extendido por todo el continente lo que, unido al triunfo de la Revolución cubana, motivó el cambio de política hemisférica de los EEUU durante los años sesenta. 
tarde a las nacionalizaciones del hierro (1975) y del petróleo (1976). En cuanto a la formación del pueblo, los sardianos reclamaron la extensión "a los vastos sectores desasistidos del país una educación racional y democrática que incorpore a nuestro

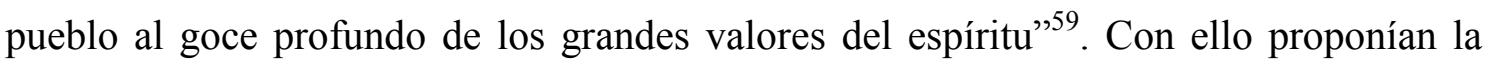
generalización de una educación humanista y democrática que hiciera al pueblo capaz de disfrutar de esa cultura liberal y occidentalista que ellos defendían desde la revista. La homogeneidad ideológica del grupo "Sardio" y, en general, la del campo cultural venezolano, perduró mientras se mantuvo vigente la unidad de los diferentes sectores de la sociedad venezolana que siguió al 23 de enero de 1958. Pero a partir de 1960 surgió una guerrilla de izquierda que, apoyada por el régimen de Castro, trató de desestabilizar la transición a la democracia emprendida por el gobierno de Rómulo Betancourt. El último número de Sardio, publicado en 1961, incluía el artículo titulado "Testimonio sobre Cuba" ${ }^{\circ 0}$. Este texto ya revelaba el apoyo de un sector de la revista a la política del régimen de Castro, lo que selló definitivamente la división del grupo.

La participación de Sucre en Sardio se había interrumpido con la publicación del séptimo número de la revista en abril-mayo de 1959, de manera que cuando el grupo se dividió nuestro autor se encontraba ya en París, adonde había marchado en el verano de 1959, becado por la Embajada de Francia y por la Universidad Central, y ya casado con Julieta Fombona ${ }^{61}$.

${ }^{59}$ Guillermo Sucre: "Testimonio", loc. cit., p. 2. La cita continúa: "La cultura no puede seguir siendo privilegio de élites ni de clases. Para asumir la gravedad de nuestro destino histórico requerimos la presencia de un pueblo luminoso y creador, sensible al imperio de las ideas y de la verdad."

${ }^{60}$ s/f.: "Testimonio sobre Cuba", en Sardio, Caracas, núm. 8, 1961, pp. 3-19. Cuando este "Testimonio" se publicó hacía tiempo que Sucre se encontraba en París, circunstancia que añadida al contenido y al estilo del artículo nos hace pensar que no es de su autoría.

${ }_{61}$ Julieta Fombona Zuloaga fue una destacada traductora y ensayista venezolana. Vertió al español una infinidad de libros del francés y del inglés, muchos de los cuales fueron publicados en Monte Ávila y en las ediciones de la Universidad Central de Venezuela. Entre los autores que tradujo se encuentran Roland Barthes, Herbert Marcuse, Raymond Aron, Gertrude Stein, Sylvia Plath, Edith Warton, W. B. Yeats, Ana Balakian, Lucien Goldmann, y un largo etcétera. Como ensayista, además de algunos artículos sobre Nathalie Sarraute y Julio Cortázar en los años 60, escribió "Teresa de la Parra: las voces de la palabra", que se publicó como introducción al volumen Teresa de la Parra: Obra. Narrativa, ensayos, cartas, Caracas, Biblioteca Ayacucho, núm. 95, 1983, pp. IX-XXVI. Un emotivo homenaje de 


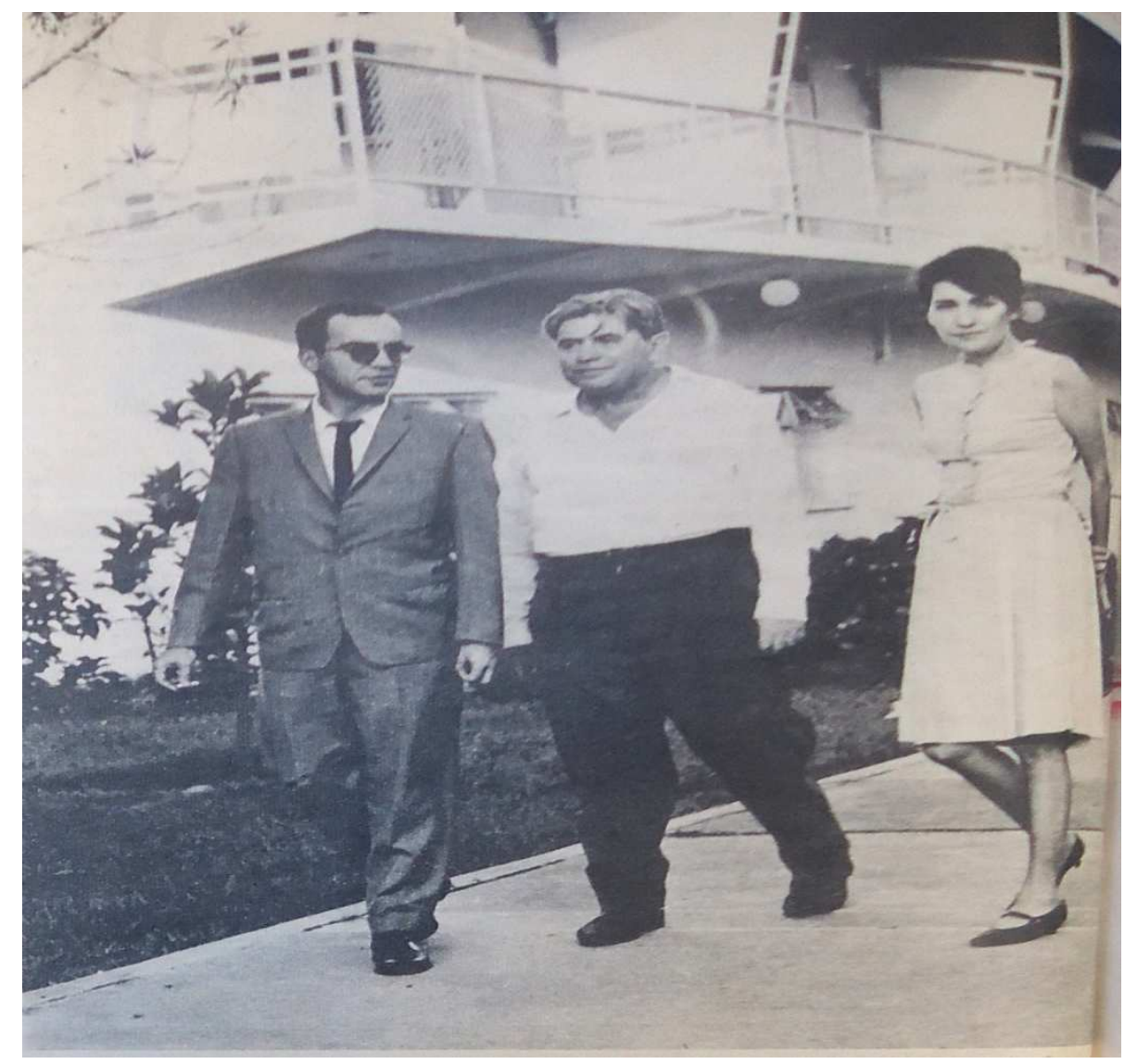

Imagen 5. Guillermo Sucre (izq.) con Julieta Fombona (dcha.) y Lucien Goldmann en la Ciudad Universitaria de Caracas. (La foto acompañaba al artículo de Sucre titulado "Entrevista con Lucien Goldmann”, en Zona Franca, Caracas, año I, núm. 5, 1/15 nov. 1964, pp. 6-7).

En la Ciudad de la Luz Guillermo estudió literatura francesa y emprendió una tesis que nunca terminaría sobre César Vallejo, quien sin embargo resultaría ser un autor decisivo para su formación intelectual. En esta segunda etapa en París se iba a producir otro hecho determinante para nuestro autor: el encuentro y el comienzo de una amistad duradera con Octavio $\mathrm{Paz}^{62}$. Se encontraron primero en el apartamento en que vivía el

Guillermo Sucre a la que fuera su mujer se puede leer en Guillermo Sucre: "Ahora reposa en Greenwood", en "El papel literario" de El Nacional, Caracas, 10 de diciembre de 2005, p. 1. Fruto de su matrimonio con Julieta Fombona son sus hijos Guillermo, Inés y Natalia.

${ }^{62}$ Esta afinidad con Paz implica la asunción de una cierta política estética y cultural, pues como lo ha señalado Rubén Medina, "por lo común, las ideas, los gustos literarios y las perspectivas de Paz se imponen sobre sus colaboradores. Paz, al parecer, escoge como colaboradores a aquellos que se someten a sus designios personales o comparten plenamente su visión de la literatura." (Rubén Medina: "El poder 
poeta mexicano, que había pertenecido a Paul Eluárd; y después en casa de Picón Salas, que por aquel entonces era embajador de Venezuela ante la UNESCO. Posteriormente se vieron en la Embajada de México y en 1961 conversaron sobre el Premio Formentor, del que Paz era jurado. Se separaron cuando Paz marchó como embajador a la India, pero a partir de ese momento mantendrían el contacto por correspondencia. En los años siguientes el futuro Nobel le envió a Guillermo numerosos textos inéditos que nuestro autor publicó en las revistas Zona Franca e Imagen. En la capital francesa Sucre estableció también amistad con otro intelectual destacado de su misma generación, Alejandro Rossi ${ }^{63}$. Además, durante la estancia de Guillermo en París, vio la luz en Venezuela su primer poemario, Mientras suceden los días, con textos escritos entre 1955 y 1957, es decir, durante el exilio y en la cárcel.

En enero de 1962, después de tres años en París, Sucre regresó a Venezuela y comenzó a impartir clases en la Universidad Central de las asignaturas Teoría Literaria, Corrientes Literarias Contemporáneas y Literatura Francesa. En ese momento, el país se encontraba "enguerrillado" y Guillermo se posicionó en contra de los grupos armados:

Cuando regresé, a comienzos de 1962, el país no sólo estaba polarizado políticamente sino enguerrillado: los jóvenes de Acción Democrática y todo el Partido Comunista -muchos de ellos compañeros de cárcel- habían creado un maquis y un terrorismo en ciertas ciudades. Eso después de dos intentos de insurrección militar en Carúpano y en Puerto Cabello. Y, además contaban con el apoyo de Fidel Castro. Nunca apoyé estos movimientos y, personalmente, se lo decía a muchos de sus activistas. ${ }^{64}$

de la escritura y la escritura del poder: los ensayos de Octavio Paz”, en Héctor Jaimes (coord.): Octavio Paz: la dimensión estética del ensayo, México, Siglo XXI, 2004, pp. 101-130, p. 109)

${ }^{63}$ Alejandro Rossi (Florencia, 1932-México D.F. 2009), filósofo y ensayista mexicano de origen italiano y venezolano. Entre sus obras fundamentales se cuentan Lenguaje y significado (1968) y Manual del distraído (1978). Fue miembro del Consejo de Redacción de las revistas Plural y Vuelta, ambas dirigidas por Octavio Paz, y miembro del Colegio de México desde 1996. Sucre habla de su relación con Rossi en el artículo "Recuerdos personales", en Letras libres, México, núm. 130, oct. 2009, pp. 44-48.

${ }^{64}$ Guillermo Sucre: "Entrevista por escrito, octubre de 2012”, infra en Apéndice I, p. 466. Esta postura en contra de la guerrilla se mantuvo hasta la desaparición de la misma. En 1964 Sucre censuró el apoyo de Sartre a la guerrilla venezolana en "Las buenas y las malas razones de Sartre", en Zona Franca, Caracas, año I, núm. 4, 15/30 oct. 1964, p. 4. 
Desde el mes de julio de ese año, Guillermo Sucre asumió la dirección, junto al chileno Martín Cerda ${ }^{65}$ y al venezolano Luis García Morales ${ }^{66}$, de la página literaria dominical "Letras y Artes", en el diario oficialista La República, y en ella participó regularmente hasta febrero de 1964. En esta época colaboró además en la Dirección General de Cultura de la Universidad Central, gestionada entonces por Pedro Duno y Rodolfo Izaguirre ${ }^{67}$. En esa editorial apareció en 1963 su traducción de la obra de René Girard, Mentira romántica y verdad novelesca ${ }^{68}$. Un año después, publicó en ese mismo sello una "Introducción" a las Poesías ${ }^{69}$ de Jacinto Fombona, poeta venezolano de la Generación del 18, que era además el padre de su mujer. En 1965, Sucre concluyó su trabajo de ascenso Borges, el poeta, el primer estudio dedicado exclusivamente a la poesía del autor argentino, que apareció editado por la UNAM en 1967.

65 Martín Cerda (1930-1991), ensayista chileno que residió durante largos períodos en Venezuela. Después de participar en esta página literaria, regresó a Chile, donde formó parte, desde 1966, del Instituto Latinoamericano de Relaciones Internacionales (ILARI). Desde su país participó con Zona Franca. En los años 70 volvió a Caracas y colaboró en la Junta directiva de Monte Ávila, donde coincidió de nuevo con Sucre en el período 1975-1977. Entre sus obras más destacadas están La palabra quebrada: ensayo sobre el ensayo (1982) y Escritorio (1987). Guillermo Sucre le dedicó el emotivo artículo "Homenaje a Martín Cerda", en Vuelta, México, núm. 182, enero 1992, donde se puede leer un relato de su amistad.

${ }^{66}$ Luis García Morales (1929), poeta venezolano. Su libro más importante es Lo real y la memoria (1962). Además de participar en esta página literaria, dirigió por un tiempo la Revista Nacional de Cultura.

${ }^{67}$ Rodolfo Izaguirre (Caracas, 1931), ensayista y crítico cinematográfico venezolano. Colaboró con Sucre en la revista Imagen.

${ }^{68}$ René Girard: Mentira romántica y verdad novelesca, Caracas, Ediciones de la Biblioteca de la UCV, 1963 [1961]. En años anteriores se había publicado una traducción suya de Saint-John Perse: Estrechos son los navios (fragmentos), Caracas, Ediciones Sardio, 1957.

${ }^{69}$ Jacinto Fombona Pachano: Poesías, Caracas, Universidad Central de Venezuela, 1964. 

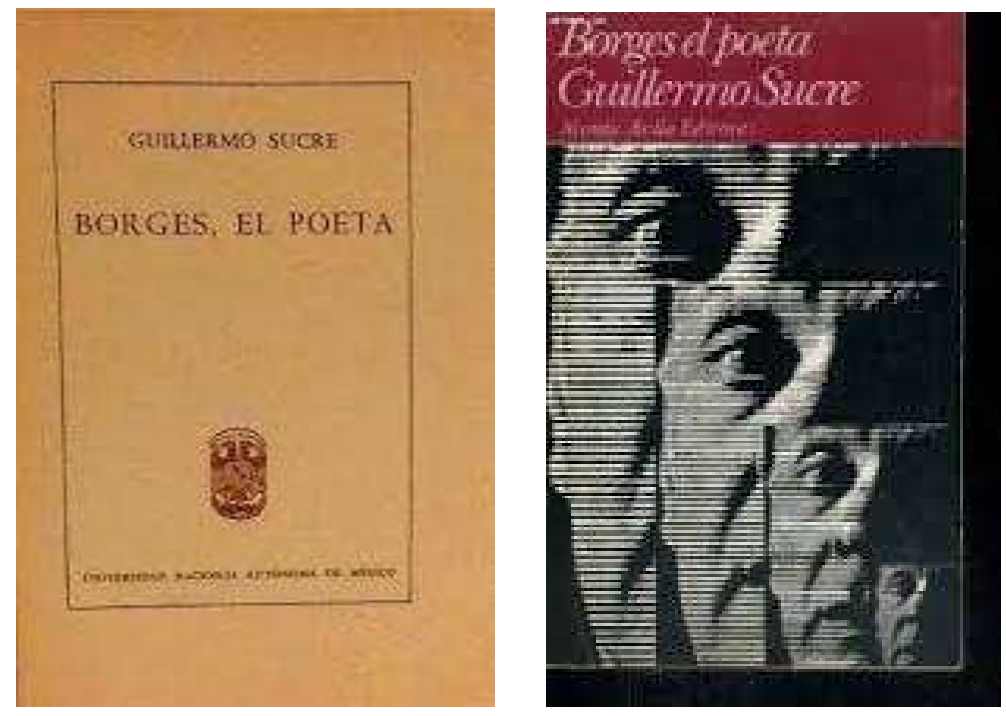

Imágenes 6 y 7. Primera y segunda ediciones de la obra de Sucre Borges, el poeta $(1967 ; 1974)$.

Desde julio de 1964, Sucre se embarcó en la aventura de la revista Zona Franca, dirigida por Juan Liscano, con el que ya había colaborado en Cantaclaro (1950) y también en "El Papel Literario" de El Nacional, en 1958. El autor de Nuevo Mundo Orinoco (1959) era, al menos entonces ${ }^{70}$, un intelectual civilista y demócrata que durante este período se enfrentó duramente con los jóvenes que apoyaban a la guerrilla izquierdista $^{71}$. Por lo tanto, la participación de Sucre al frente del Consejo de Redacción en la revista que Liscano dirigía implicaba una toma de posición explícita a favor del oficialismo. Sin embargo la colaboración de Guillermo en Zona Franca no duró mucho, pues las desavenencias entre él y Liscano dieron lugar a que dejase de trabajar en la revista a la altura del número 39, editado en noviembre de 1966, y a que con el paso de

${ }^{70}$ Juan Liscano fue demócrata al menos durante este período. Más tarde apoyó, junto a otros intelectuales como Uslar Pietri o Mayz Vallenilla, los golpes perpetrados por Hugo Chávez en 1992, lo que provocó una polémica entre estos intelectuales y Guillermo Sucre, que se mantuvo siempre firme en la defensa de la democracia.

${ }^{71}$ Entre muchos ejemplos de la polémica que sostuvo con los jóvenes, se puede citar un artículo en que Acosta Bello acusaba a Juan Liscano de atender sobre todo a los intereses políticos a la hora de valorar las obras literarias. Según Acosta, Liscano "acomete a campo traviesa con una tropa de esquemas, contra todos los que no sean de su secta, yendo más allá en estos «deberes» de partido, empujado por los intelectuales burócratas y por los fáciles compromisos con el oficialismo." (Arnaldo Acosta Bello: "La táctica literaria y la estrategia política”, en Tabla redonda, Caracas, núm. 7, mar.-abr. 1961, p. 7) 
los años nuestro autor llegase incluso a considerar una equivocación su participación en la misma ${ }^{72}$.

En 1967 Sucre viajó brevemente a París, ciudad que visitaba por tercera vez ${ }^{73}$. En el mes de mayo de ese mismo año, ya en Caracas y a instancias del Instituto Nacional de Cultura (INCIBA), Guillermo fundó y asumió la dirección de la revista Imagen y colaboró, asimismo, junto a Simón Alberto Consalvi y Benito Milla en la fundación de la editorial Monte Ávila. Ese año se celebró en Caracas el XIII Congreso de Instituto Internacional de Literatura Iberoamericana, que sufrió algunos problemas de organización debido al terremoto que asoló la ciudad justo antes de su comienzo. Con ocasión de ese Congreso, Guillermo Sucre recibió a Emir Rodríguez Monegal, con el que se carteaba desde hacía tiempo, y que ya entonces era director de la polémica revista Mundo Nuevo ${ }^{74}$.

En el mes de julio de 1968, tras 29 números publicados, nuestro autor dejó la dirección de la revista Imagen a cargo de Edras Parra y marchó a los EEUU, donde

72 Sucre también lamentó después su colaboración en Sardio: "fuera del entusiasmo juvenil y ciertas amistades, tampoco Sardio representó mucho para mí, quizá porque no estuve a la altura de ella. Así que puedo hablar, como Borges de la secta ultraísta, de la equivocada secta sardiana. Lo mismo puedo decir de Zona Franca." (Guillermo Sucre: “Carta I, octubre de 2012”, infra en Apéndice I, p. 477). El arrepentimiento por su participación en Zona Franca se debió quizás a que la distancia ideológica con Juan Liscano fue aumentando con el tiempo, sobre todo a partir de la reincorporación de Sucre a Monte Ávila entre 1975 y 1977 y de la polémica surgida a raíz de los artículos publicados en Vuelta en 1993.

73 Durante esa visita, Lucien Goldmann, al que Guillermo y Julieta habían conocido y entrevistado cuando el filósofo visitó brevemente Venezuela en 1964 (Guillermo Sucre: "Entrevista con Lucien Goldmann", en Zona Franca, Caracas, año I, núm. 5, 1/15 nov. 1964, pp. 6-7), le entregó a Julieta Fombona una copia manuscrita de su obra recién terminada Filosofía de la Ilustración que Julieta traduciría y publicaría en Venezuela. Al año siguiente de ese viaje, Guillermo Sucre tradujo la obra de Lucien Goldmann: El teatro de Jean Genet. Ensayo de estudio sociológico, Caracas, Monte Ávila, 1968, y además publicó un suplemento en Imagen sobre el mismo tema. (Imagen, Caracas, Supl. núm. 21, 15/30 mar. 1968). Además, en este viaje a París de 1967, Guillermo trató de contactar con Alejo Carpentier, al que había conocido en Caracas durante los años de exilio del narrador cubano, pero finalmente sólo pudo mantener con él una conversación telefónica.

${ }^{74}$ Estos datos aparecen en Emir Rodríguez Monegal: "Diario de Caracas”, en Obra selecta, op.cit., pp. 241-276. (El artículo se publicó originalmente en Mundo Nuevo, París, núm. 17, nov. 1967, pp. 4-24). Mundo Nuevo se fundó en París, financiada por el ILARI [Instituto Latinoamericano de Relaciones Internacionales] con el propósito de contrarrestar la influencia de Cuba como foco de atracción de la intelectualidad latinoamericana. Al poco tiempo de su fundación se destapó el vínculo de la CIA con el Congreso por la Libertad de la Cultura y con el ILARI, por lo que Mundo Nuevo fue inmediatamente acusada por la izquierda latinoamericana de colaborar con los EEUU. (Para revisar esto en profundidad, vid. María Eugenia Mudrovcic: Mundo Nuevo. Cultura y Guerra Fría en la década del 60, Rosario, Beatriz Viterbo Editora, 1997) 
permanecería hasta 1975. Su primer destino en Norteamérica fue la Universidad de Pittsburgh, donde enseñó literatura hispanoamericana entre 1968 y 1970. Allí tuvo la oportunidad de conocer la Academia norteamericana y de relacionarse con destacados intelectuales que trabajaban en ella, como por ejemplo con Raimundo Lida $^{75}$-al que le unía una amistad común con Ángel Rosenblat. En Pittsburgh, Guillermo coincidió de nuevo con Octavio Paz cuando el poeta mexicano fue invitado para dictar la Cátedra Mellon Chair, y retomó además el vínculo con Rodríguez Monegal, que le invitó a Yale con motivo de un Congreso sobre Lezama Lima. En 1970, Guillermo Sucre fue el primer venezolano al que se le concedió una beca Guggenheim, que disfrutó en Silver Spring, Maryland. Ese mismo año, nuestro autor editó su segundo poemario, La mirada, con textos escritos a lo largo de los años sesenta (1962-1969). Entre 1972 y 1975 Guillermo volvió a impartir clases en Pittsburgh y escribió los ensayos que componen su obra fundamental La máscara, la transparencia (1975). La estancia en Norteamérica brindó a Sucre el acceso a publicaciones especializadas que tenían una repercusión continental como la Revista Iberoamericana ${ }^{76}$ o Review. En esta época participó además en Plural, la revista de Octavio Paz. El nuevo contexto cultural determinó que Guillermo abandonara la preocupación que a lo largo de los años sesenta había

\footnotetext{
75 Según lo explica Guillermo: "Conocí en Pittsburg [en 1972] al profesor Raimundo Lida que iba a dirigir la Cátedra Mellon en Literatura Española. Lida era de la misma generación de Rosenblat, amigo de él y lector de sus libros; ya me conocía de nombre, pues había leído mi libro sobre Borges, y por él supe que a Borges le había gustado mucho también y se lo dijo cuando [Borges] había dado clases en Harvard. Cuando regresé a Caracas, en 1975, recibí una carta de él [de Lida] proponiéndome, autorizado por los demás profesores del Departamento Hispánico, la Cátedra de Literatura Hispanoamericana en reemplazo de Anderson Imbert, quien se iba a jubilar. Pero -hélas!- yo no podía aceptar por muchas razones. Las personales: tanto Julieta como yo creíamos que nuestros hijos debían terminar su formación en nuestro país; lo que en ese momento fue acertado pero a la larga un error: mis hijos, aun en Caracas, tuvieron una educación más norteamericana que hispánica; actualmente los tres viven y trabajan en Nueva York, y Julieta misma -para quien los States era su segunda patria- murió en NY, Brooklyn, en 2005. Luego, porque yo mismo pensaba que tenía y tengo un espíritu poco académico y una formación intelectual nada apta para pasar mi vida en una Universidad tan exigente como Harvard." (Guillermo Sucre: "Carta I, octubre de 2012", infra en Apéndice I, pp. 475-476). (Para más datos sobre su relación con este profesor Vid. Guillermo Sucre: "Recuerdo de Raimundo Lida", en Raimundo Lida: Rubén Darío: Modernismo, Caracas, Monte Ávila Editores, 1984, pp. 9-17)

${ }^{76}$ Sucre formó parte de la Comisión Editorial de esta revista junto a Fred. P. Ellison, Seymour Menton, Emir Rodríguez Monegal y Gonzalo Sobejano, entre 1971 y 1973. Durante esta etapa Guillermo conoció a Roberto González Echeverría, con quien estudiará más tarde su hija Inés Sucre Fombona.
} 
mostrado por la cultura venezolana y que adoptara una visión más amplia, más latinoamericanista. Como él mismo ha afirmado: "Mi estancia en los States fue muy estimulante en lo personal y en lo intelectual, a pesar de los malos ratos que se pasaban en esos departamentos hispánicos. Como tuve que concentrarme en el campo hispanoamericano, esos años me sirvieron para ampliar mis lecturas y para tener una visión más amplia de nuestra literatura"77. Además, el nuevo contexto cultural le permitió establecer un contacto más estrecho con la teoría y la poesía escritas en lengua inglesa y en particular con autores como John Cage, T. S. Eliot, Ezra Pound, Susan Sontag, Gertrude Stein, George Steiner, Wallace Stevens ${ }^{78}$ y William Carlos Williams $^{79}$.
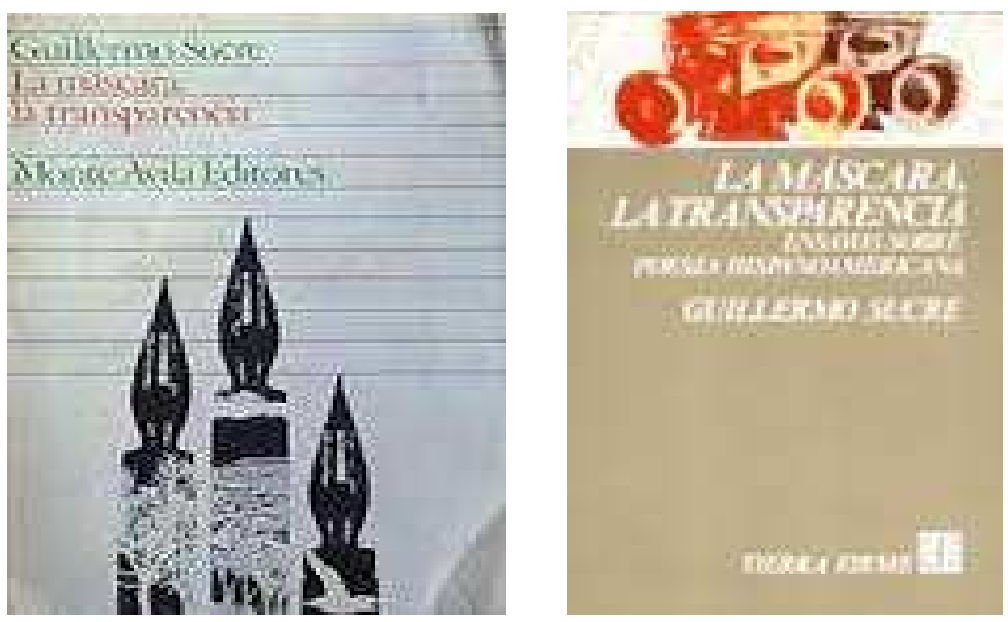

Imágenes 8 y 9. Primera y segunda ediciones de La máscara, la transparencia (1975; 1985).

Cuando Guillermo Sucre regresó a Venezuela en 1975, tras siete años en los Estados Unidos, pasó a ocupar el puesto de Director Literario de la editorial Monte Ávila. Allí coincidió de nuevo con Martín Cerda, con quien había colaborado

\footnotetext{
${ }^{77}$ Guillermo Sucre: “Carta I, octubre de 2012”, infra en Apéndice I, p. 475.

78 En esta época Sucre tradujo a Stevens y a Williams. (Wallace Stevens: Adagia, Caracas, Fundarte y Dirección de Cultura de la G.D.F., Colección "Breves” núm. 6, Caracas, 1977)

79 William Carlos Williams: La primavera y todo, Caracas, Monte Ávila, 1980. Este último volumen lo tradujo en colaboración con su mujer Julieta Fombona.
} 
anteriormente en el diario La República entre 1962 y 1964. Sin embargo, en 1977, las

desavenencias con Juan Liscano, entonces vicepresidente de la empresa, se hicieron insostenibles y le llevaron a dejar su puesto en la editorial:

En verdad, en 1967, junto con Simón Alberto Consalvi y Benito Milla fui uno de los fundadores de Monte Ávila. A mi me había gustado mucho trabajar en Monte Ávila, en los años iniciales. Pero [en 1975] había cambiado enormemente. Curioso: la Editorial, como tal, se había consolidado y tenía cierto prestigio, pero humanamente no era la misma. El Sr. Juan Liscano, íntimo amigo del nuevo Presidente de la República, Carlos Andrés Pérez, se hizo nombrar VicePresidente de la empresa, y había introducido en ella "l’ère du soupçon", estimulando en empleados subalternos y hasta en el propio Don Benito Milla un espíritu de intriga y de recelos. Lentamente se había ido apoderando de Monte Ávila [...] vivía con una escritora argentina, a la cual publicaba sus libros, así como todos los de él. Lo decisivo para mí fue que un sr. Ególatra [Liscano], que hacía su politiquería literaria, había puesto a Monte Ávila a su servicio y obstaculizaba mi trabajo. Así que no me quedó otro camino que renunciar. ${ }^{80}$

Además de participar en Monte Ávila, a su vuelta de los EEUU Sucre retomó su puesto como profesor del Postgrado de Literatura en el Instituto Pedagógico de Caracas. En 1976, recibió el Premio Nacional de Literatura por su ensayo La máscara, la transparencia, que había editado Monte Ávila un año antes, y publicó su tercer poemario, En el verano cada palabra respira en el verano (1976), escrito en los EEUU entre 1969 y 1974. Un año después apareció otro poemario, Serpiente breve (1977), también producido durante su estancia en Norteamérica. Entre 1977 y 1981 Guillermo impartió cursos de literatura en la Universidad Simón Bolívar de Caracas, donde organizó y fundó la Maestría en Literatura Hispanoamericana. Con un equipo de esa Universidad, que contaba en sus filas con el destacado poeta chileno Gonzalo Rojas ${ }^{81}$, Sucre elaboró la Antología de la poesía hispanoamericana moderna, en dos tomos. En 1980, organizó en esa Universidad el Simposio "Perspectivas sobre la Literatura

${ }^{80}$ Guillermo Sucre: “Carta I, octubre de 2012”, infra en Apéndice I, p. 476.

${ }^{81}$ En la edición del primer volumen de esta Antología (1982) participó el poeta chileno Gonzalo Rojas (1917-2011), que vivió en Venezuela entre 1975 y 1980. Como ya sabemos, Sucre había conocido a Rojas durante su estancia en Chile. En Caracas, Rojas fue miembro del Departamento de Literatura de la Universidad Simón Bolívar, donde coincidió con Guillermo Sucre. Fruto de esa etapa son dos poemas que el vate chileno le dedicó a su amigo venezolano: "Advertencia al poeta Guillermo Sucre cuando quiso dejar la poesía" y "Oficio de Guillermo". Ambos se encuentran en su libro Concierto, Gonzalo Rojas: Contra la muerte y otras visiones, La Habana, Casa de Las Américas, 2007, pp. 92-94. Otros profesores que colaboraron en la elaboración de la Antología son Ana María del Re, Sonia García García, Alba Rosa Hernández Bossio, Luis Miguel Isava y Violeta Urbina Tosta. La Antología se publicó en dos volúmenes, el primero en 1982 y el segundo en 1994. (Guillermo Sucre (coord.): Antología de la poesía hispanoamericana moderna, Monte Ávila y Editorial Equinoccio, Caracas, 1982 y 1994) 
Latinoamericana" ${ }^{\natural 2}$, que reunió a intelectuales como Roberto González Echeverría, Rafael Cadenas o Pablo Antonio Cuadra, entre otros.

A principios de la década de los ochenta, entre finales de 1981 y principios de 1983, Guillermo Sucre residió en Madrid. En la Biblioteca Nacional de esa ciudad, nuestro autor elaboró la edición de Viejos y nuevos mundos de Picón Salas para la Biblioteca Ayacucho ${ }^{83}$ y escribió sendos ensayos sobre Ángel Rosenblat ${ }^{84}$ y Raimundo Lida $^{85}$. Mientras Guillermo estaba en Madrid, le concedieron el Premio Cervantes (1981) a Octavio Paz, y esa circunstancia permitió que los viejos amigos se volvieran a encontrar. El escritor mexicano le mostró a nuestro autor el manuscrito, todavía inédito, de Sor Juana Inés de la Cruz o las trampas de la fe (1982). A su vuelta a Venezuela en 1983, Guillermo formó parte de la Junta Directiva de Monte Ávila, que ahora dirigía el notable poeta Eugenio Montejo ${ }^{86}$, a quien le unía una estrecha amistad. En esta época, Sucre preparó en esa editorial caraqueña la "Biblioteca" de Mariano Picón Salas, e impulsó la de Ángel Rosenblat. Entre 1983 y 1985 siguió impartiendo clases en la Universidad Simón Bolívar y modificó la primera edición de La máscara, la transparencia, que fue reeditada por el Fondo de Cultura Económica en 1985. En ese año Guillermo se separó de su mujer, Julieta Fombona, y regresó como profesor a la

\footnotetext{
${ }^{82}$ Las Actas de este Simposio están editadas: Guillermo Sucre (coord.): Simposia. Perspectivas sobre la literatura latinoamericana, Caracas, Editorial Equinoccio, 1980.

${ }^{83}$ Mariano Picón Salas: Viejos y nuevos mundos, Caracas, Biblioteca Ayacucho, núm. 101, 1983.

${ }^{84}$ En Madrid, Guillermo Sucre escribió el ensayo "Rosenblat: la generosidad del lenguaje", que él concibió como un homenaje al $80^{\circ}$ aniversario del filólogo argentino-venezolano y que se publicó en "El Papel Literario" de El Nacional, Caracas, 5 y 9 de diciembre de 1982. Sobre La primera visión de América y otros estudios de Rosenblat, Sucre ya había publicado: "En la magia del lenguaje", en Zona Franca, Caracas, año II, núm. 30, febrero de 1966, pp. 16-18. Por último, en 2003, Sucre participó en un homenaje organizado por la UCV para conmemorar el centenario del nacimiento de Rosenblat y leyó un texto titulado “Ángel Rosenblat: la palabra y la ilusión”, que se publicó posteriormente en Principia, Revista de Cultura de la Universidad Centrooccidental Lisandro Alvarado, Barquisimeto, enero de 2005, núm. 24, pp. 54-64. Dario...op.cit.

${ }^{85}$ Me refiero al ya mencionado "Recuerdo de Raimundo Lida", en Raimundo Lida: Rubén

${ }^{86}$ Eugenio Montejo (1938-2008) ha sido uno de los poetas venezolanos más destacados de la segunda mitad del siglo XX. Sus libros más importantes de poesía son: Terredad (1978), Alfabeto del mundo (1986) y Adiós al Siglo XX (1992). En su obra ensayística destacan La ventana oblicua (1974), El taller blanco (1983) y El cuaderno de Blas Coll (1981). Mantuvo una relación de amistad con Guillermo Sucre, como él mismo indica en su artículo "Recuerdos personales", loc.cit. En La máscara, la transparencia, Sucre le dedica un apartado a su obra en la sección "La metáfora del silencio".
} 
Escuela de Letras de la Universidad Central, a la que se refiere como su "verdadera casa ${ }^{87}$, pues allí se había graduado a finales de los años cincuenta. En 1988 apareció en la editorial Era de México su poemario La vastedad (1988), libro que cierra el ciclo poético que se había iniciado con En el verano cada palabra respira en el verano (1976).

En 1989 Sucre ocupó la jefatura del Departamento de Literaturas Clásicas y Occidentales en la Universidad Central de Venezuela. Allí, en los años siguientes, impartió un Taller de ensayo y seminarios sobre El Quijote, Montaigne, Borges, Camus, etc. ${ }^{88}$ En 1989 retomó la dirección de la revista Imagen que había fundado en 1967 y en 1990 la dejó, como ya sucediera entonces, en manos de Edras Parra. En 1992 publicó en Sevilla su último poemario editado hasta la fecha, La segunda versión, que recoge textos escritos entre 1987 y 1992. Un año más tarde publicó unos controvertidos artículos en "Los cuadernos de la cordura", la sección que desde $1990^{89}$ tenía en la revista mexicana Vuelta. Defensor a ultranza de la democracia, en esos artículos Sucre criticaba a los intelectuales que habían respaldado los golpes de Estado que Venezuela sufriera en febrero y noviembre de 1992. Como el propio Guillermo ha afirmado: "Muy pocas veces escribí sobre política, pero sí lo hice cuando el golpe de Chávez contra Carlos Andrés Pérez, que no era especialmente de mi admiración, pero yo creía que derrocar a Carlos Andrés Pérez iba a traer muchas consecuencias, y por eso me opuse"90. En esos artículos Guillermo acusaba de "stalinismo cultural" a ciertos intelectuales venezolanos que, aunque habían medrado a la sombra del Estado, fueron capaces de apoyar los golpes militares y de llamarse a sí mismos "disidentes":

\footnotetext{
${ }^{87}$ Guillermo Sucre: “Carta I, octubre de 2012”, infra en Apéndice I, p. 476.

${ }^{88}$ Para la labor de Sucre como profesor se pueden consultar los ensayos de Gustavo Valle y Boris Muñoz. (Vid. supra nota 10, p. 3)

${ }^{89}$ El primero de los artículos publicados en esta sección de Sucre es "La virtud antropófaga", en Vuelta, México, sep. 1990. Durante esta misma época, Guillermo participó en la sección literaria del diario El Universal, dirigida entonces por Patricia Guzmán.

${ }^{90}$ Guillermo Sucre: "Entrevista oral, octubre de 2011", infra en Apéndice I, p. 463. El texto está ligeramente modificado.
} 
Desde que en febrero de 1992 se produjo el primero de los dos golpes de Estado que ha sufrido el país, nuestros más conspicuos intelectuales han hecho lo posible y lo imposible por abrirle camino a la conspiración militar, adoptando sus mismos argumentos, sustentando sus mismos objetivos y, por tanto, justificándola, o atenuando su horror o su alevosía para quizá propiciar otra. Si hasta ahora no han llegado a legitimarla públicamente del todo, es por la sencilla razón de que no ha triunfado. Pero para hacerla triunfar se han valido impunemente de cuanto una democracia les ofrece, y aun con privilegios. Han recurrido a todos los medios salvo el asumir una responsabilidad o un mínimo de arrojo ¿o riesgo? La megalomanía los preservó, eso sí, de incurrir en tales excesos. Y, tal como los militares que se alzaron sólo fueron valientes después de rendirse casi sin combatir y de haber sacrificado a sus subalternos o a civiles indefensos, ellos apenas han resultado ser unos maestros de la intriga y del chantaje. ${ }^{91}$

Sucre retomaba así el vínculo entre intelectualidad y ética democrática que ya

había defendido desde las páginas de Sardio en 1958. Unos meses más tarde, nuestro autor emitió un juicio sobre la recepción de sus artículos e hizo un balance de la polémica que suscitaron:

Creo que fueron leídos como la réplica necesaria (¿esperada?) a quienes, diciéndose intelectuales, renunciaron a las ideas democráticas para sumarse a la conjura armada, y aun alentarla, sin importarles mucho las terribles consecuencias que esto podía y puede acarrearle al país: la cadena de golpes, la violencia crónica, la devastadora agitación social. [/] Pero creo que fueron leídos sobre todo como la crítica intrínseca a una clase intelectual cuya imagen no nace profundamente de una obra que conmueva, válida por sí misma, sino que nace de la infatuación más desmedida, así como del abuso del tráfico de influencias a la sombra de una burocracia cultural del mismo Estado tan dispendiosa como cortesana (mientras se ha empobrecido a nuestra Educación), y del bombo que le presta cierta prensa amarillista, a la que sirve con esmero cómplice. $^{92}$

La relación que Guillermo establecía entre intelectualidad y democracia le llevó

a contraponer la conducta de estos intelectuales o bien con los escritores auténticos, o

bien con los verdaderos disidentes, aquellos que oponiéndose al totalitarismo comunista

eran capaces de arriesgar su vida por la verdad:

Al leer la literatura disidente que se escribió en los países hasta ayer comunistas, sentimos inmediatamente lo que es de verdad una intelliguentsia. Reconocemos en ella la conciencia herida, la pasión de las ideas y, en medio de la rabia o el desamparo, la serena dignidad de la palabra -que nunca se rebajó al odio, al retorcimiento o al desplante. No sólo se jugó la vida contra un poder omnímodo y una sociedad totalitaria; también supo dar claridad a la

${ }^{91}$ Guillermo Sucre: "Los cuadernos de la cordura. La indefensión de las palabras", en Vuelta, México, núm. 199, jun. 1993, pp. 57-58, p. 58. La cita continúa: "Huérfanos ahora de militares que les sirvan a sus intereses (y, cuidado, éstas son gentes de grandes intereses, constantes y sonantes), se autoproclaman disidentes. En última instancia, no hay mejor salida que el lamentable patetismo: hacer ver que son unos perseguidos por el Poder o que luchan, solitaria y denodadamente, contra su hidra despiadada. [/] Estos son, pues, los disidentes venezolanos: unos conspiradores privilegiados y vergonzantes. O para decirlo con mayor justeza y justicia: forman parte de lo que Julien Benda, en un libro memorable, llamó "la traición de los intelectuales". Aun lo que escriben parece estar marcado por ese sello indeleble que Ana Ajmatova descubrió en cierta clase intelectual rusa: son inmorales hasta por el estilo."

92 Guillermo Sucre: "Los cuadernos de la cordura. La polvareda y la falacia”, en Vuelta, México, núm. 202, sep. 93, pp. 54-55, p. 54. 
desolación espiritual de su tiempo, encarnar un destino. [...] Entonces, a la pomposidad, a la megalomanía, al oportunismo, al resentimiento y al chantaje; a los seres que han vivido sin probar la hora ineludible o nunca han sentido lo que hay de desgarrador, íntimo e íngrimo en toda moral; a todo eso reunido bajo el signo de la más deplorable retórica, cuando no del charloteo, a eso ¿es a lo que vamos a llamar intelligentsia venezolana? ${ }^{93}$

Aunque Guillermo no mencionó abiertamente a los intelectuales cuyo comportamiento censuraba, en esos artículos se refería veladamente a Juan Liscano, Uslar Pietri, Mayz Vallenilla, etc. ${ }^{94}$ En el mes de julio de 1993, Liscano y otros muchos escritores, auspiciados por la dirección de El Nacional, mantuvieron una verdadera cruzada contra las opiniones de nuestro autor ${ }^{95}$. La polémica suscitada no amedrentó a Guillermo Sucre, quien, al hacer un balance de lo acontecido, unos meses después reafirmó su confianza en las instituciones democráticas: "Luego que escribí mis dos artículos, han ocurrido cambios radicales pero fluidos y pacíficos en el gobierno y, por

\footnotetext{
${ }^{93}$ Guillermo Sucre: “Los cuadernos de la cordura”, en Vuelta, México, núm. 197, abr. 93, pp. 1618 , p. 17.

94 En una entrevista que mantuvimos en Caracas en octubre de 2011 Guillermo Sucre afirmaba
} en referencia a este episodio: "Cuando la insurrección fallida del actual Comandante-Presidente [Chávez] en 1992, publiqué dos o tres artículos en Vuelta. Sin nombrarlos, aludía a ciertos intelectuales que luego apoyaron al Comandante cuando ganó las elecciones en 1998. Eso me parecía un bochorno. Gente amiga, que yo apreciaba y creo que aún aprecio, que fueron intelectuales civilistas y hasta rectores de Universidades, se sumaron a esta desgracia. Y también ataqué al periódico El Nacional, chavista desde el comienzo y hoy decepcionados. Pero todo esto me reveló la crisis moral de nuestro país. La muerte de Paz, la de mis hermanos mayores, la de mi esposa -aunque ya nos habíamos divorciado- fue todavía un motivo de crisis personal." (Guillermo Sucre: "Entrevista por escrito, octubre de 2011", infra en Apéndice I, p. 467)

95 Algunos de los artículos suscitados por esta polémica fueron: Juan Liscano: "De escritores" en El Nacional, Caracas, sección Cartas a El Nacional, 27 de junio de 1993, p. A-5; Eloi Yagüe Jarque: "Muchos de nuestros intelectuales son comadronas de la conspiración militar", y "Disparos contra el Innombrable", en El Nacional, Caracas, 2 de julio de 1993, p. C-18; Equipo de Arte de El Nacional: "Toda generalización es arbitraria y hay que evitar el personalismo", en El Nacional, 3 de julio de 1993, p. C-12. (En él participaron Salvador Garmendia, Denzil Romero, Eduardo Casanova, Armando José Sequera, Rafael Arráiz Lucca); Luis Barrera Linares: "El regreso del Mariscal Sucre" en El Nacional, Caracas, 8 de julio de 1993, p. A-5; Hugo Colmenares: "La lucha es entre cogollos culturales", en El Nacional, Caracas, 8 de julio de 1993, p. C-14. (En esta encuesta participaron Óscar Rodríguez Ortiz, Eduardo Liendo, Manuel Bermúdez, Earle Herrera, Tarek Williams Saab). Juan Carlos Santaella: "Dentro del cristal", en El Nacional, Caracas, 8 de julio de 1993, p. C-14; Juan Nuño: "Poetas a la greña", en El Nacional, Caracas, 10 de julio de 1993, p. C-16.; Chefi Borzacchini: "Juan Liscano por Juan Liscano", en El Nacional, Caracas, 18 de julio de 1993, p. C-2. (Entrevista a Juan Liscano centrada en la polémica suscitada por los artículos de Sucre). Alexis Rodríguez Gómez: "Guillermo Sucre: ¿un metaintelectual?", en El Nacional, Caracas, sección Cartas al director de El Nacional, 18 de julio de 1993, p. A-5.; Juan Nuño: "Mala mezcla y peor puntería", en Revista Criterion, Caracas, núm. 7, agosto de 1993, pp. 8-10; José Balza: "Márgenes en la locura”, en Revista Criterion, Caracas, núm. 7, agosto de 1993, pp. 11-13. En la revista Vuelta se publicaron asimismo los siguientes artículos en respuesta a Guillermo Sucre, Juan Liscano: "Polémica venezolana en México", Vuelta, México, núm. 203, oct. 1993, pp. 53-55, y Juan Nuño: “¿Qué pasa en Venezuela?, en Vuelta, México, núm. 203, oct. 1993, pp. 55-57. 
tanto, en la política del país; la mejor prueba de que vivíamos y vivimos -aun con todos sus vicios y defectos- en un sistema democrático legítimo" ${ }^{96}$.

El mismo año de esta polémica, en 1993, apareció en Monte Ávila la edición definitiva de la Antología de la poesía hispanoamericana moderna, que Sucre había elaborado con un grupo de profesores de la Universidad Simón Bolívar. En 1996 nuestro autor recibió el "Premio Francisco de Venanzi", otorgado por la Universidad Central a investigadores de destacada trayectoria. En 1997 fue el elegido para dictar en la Universidad de Cambridge la Cátedra "Simón Bolívar". Un año después, cuando falleció Octavio Paz, Guillermo Sucre escribió en Vuelta un ensayo en el que hacía un recorrido por la relación biográfica y literaria que mantuvo con el gran poeta mexicano ${ }^{97}$. En 2005 pereció Julieta Fombona, la madre de sus hijos, de la que se había divorciado años atrás y Guillermo, a modo de homenaje, escribió el emotivo artículo "Ahora reposa en Greenwood"98.

A día de hoy, Guillermo Sucre reside en Caracas, aunque la situación política que vive el país desde 1998 le mantiene al margen de las instituciones culturales del Estado. A propósito de la cultura venezolana bajo el régimen de Chávez, Guillermo Sucre y su actual pareja, María Fernanda Palacios, destacaban en un encuentro con Enrique Krauze en el año 2008 que "la autonomía ha desaparecido y el Estado se ha vuelto cada vez más intervencionista y excluyente. Para publicar hoy en Monte Ávila antes un ejemplo de pluralidad y rigor- sirven más las lealtades al régimen que el verdadero talento, y los rechazos por razones ideológicas se incrementan" $" 99$. En este clima de pérdida de la autonomía cultural que había existido durante los cuarenta años

${ }^{96}$ Guillermo Sucre: "Los cuadernos de la cordura. La polvareda...", loc.cit., pp. 54-55.

${ }^{97}$ Guillermo Sucre: “Mi itinerario con Octavio Paz”, en Vuelta, México, núm. 259, jun. 98, pp. 24-25.

${ }^{98}$ Sobre Julieta Fombona, vid. supra nota 61, p. 27.

99 Enrique Krauze: El poder y el delirio...op.cit., pp. 118-119. La paráfrasis de la entrevista a Sucre y Palacios se encuentra en las pp. 118-121. 
anteriores, no es extraño que la cultura se enfrente (y cito las propias palabras de Sucre) al "exilio voluntario de sus mejores representantes" y también al problema "de la autoexclusión”, pues “muchos artistas e intelectuales críticos del régimen o ajenos a él han decidido dejar de participar en las instituciones culturales del Estado venezolano, por miedo a que el poder los use como instrumentos o a que la oposición más radical los califique de traidores o de cómplices" ${ }^{, 100}$. Esta es, en resumen, la penosa situación política y cultural que hoy deben afrontar Guillermo Sucre y otros miembros de su generación, y es tanto más lamentable en la medida en que estos intelectuales se habían comprometido desde su primera juventud y de una manera personal con la defensa de la democracia representativa y el respeto de las libertades públicas. De este modo, los acontecimientos políticos que se han sucedido en el país desde 1998 suponen el fracaso político de toda una generación que se comprometió emocional e intelectualmente con la institucionalidad democrática y con todo lo que ella implicaba. Aunque ahora nuestro autor está jubilado, sigue impartiendo regularmente seminarios en organismos privados sobre temas literarios que han sido siempre de su interés, como la poesía moderna, Borges, Camus, etc.

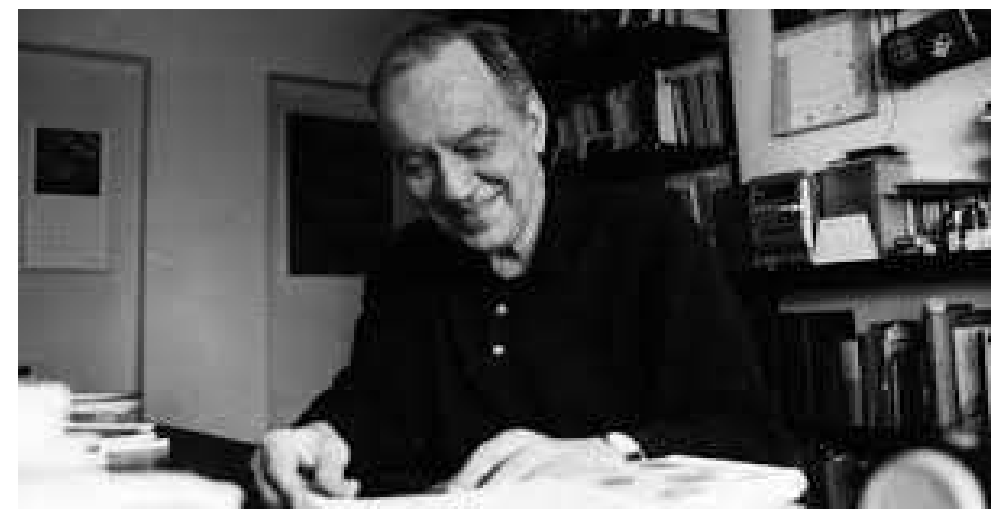

Imagen 10. Guillermo Sucre en su despacho.

100 Ibid., p. 121. Para profundizar en las opiniones de Guillermo Sucre sobre el régimen de Chávez se puede consultar su reciente artículo, Guillermo Sucre: "Democratura", en Letras Libres, México, núm. 165, sep. 2012, pp. 14-17. 
En el 2009 recibió el Doctorado Honoris Causa por la Universidad Central de Venezuela, pues las universidades siguen gozando de una cierta autonomía con respecto a la gestión del gobierno. Tiene un libro de poesía prácticamente terminado, que ha titulado Los regresos, con poemas escritos entre 1993 y 2011, y que previsiblemente aparecerá en este año 2013. Prepara también para su publicación dos colecciones de ensayos, El lenguaje del alma, donde trata cuestiones relacionadas con la literatura, y Poesía y ensayo, que contiene sendos estudios sobre Ramos Sucre y Picón Salas. 


\section{CAPÍTULO II}

\section{EL CONTEXTO CULTURAL DE GUILLERMO SUCRE (1958-1968)}

El proyecto estético y cultural que Guillermo Sucre emprendió durante los años sesenta $^{101}$ se enmarca en el pensamiento de la generación que accedió al campo literario a partir de 1958. A pesar de que a lo largo de esta década los jóvenes artistas e intelectuales venezolanos se fueron polarizando en dos sectores con diferentes concepciones políticas y estéticas, todos ellos compartieron al principio una misma posición ideológica y unos puntos de vista similares. La mayoría de los integrantes de esta generación habían nacido en el interior del país y cuando llegaron a Caracas hacia 1950 para cursar sus estudios medios y superiores se sumaron a la resistencia contra la dictadura y sufrieron la represión y el exilio. La situación política que vivía Venezuela les obligó a residir durante largas temporadas en otros países de Europa y de América Latina, y ello les permitió pensar su propio país desde fuera. Además, el enfrentamiento con la dictadura reforzó en muchos de ellos la concepción liberal y occidentalista propia de las élites letradas del continente. Imbuidos de la "mística democrática" que envolvía ese momento histórico, los intelectuales de la nueva generación pusieron todas sus esperanzas en el regreso de ese sistema político, pues además de ver en él la virtud económica y social, lo concebían como una esperanza para el desarrollo nacional, tantas veces pospuesto, y para que Venezuela se abriese definitivamente al mundo. En este sentido, los jóvenes intelectuales no tomaban en cuenta el contexto particular de

${ }^{101}$ Isava ha propuesto una periodización alternativa para esta década, que nosotros compartimos. De acuerdo a este crítico venezolano para periodizar los años 60 en la cultura venezolana, "[t]al vez sea más adecuado establecer como fechas de referencia los años de 1958, con la caída de Marcos Pérez Jiménez y la consolidación del grupo Sardio, y de 1968, con el inicio de la pacificación y el cierre del ciclo de El Techo de la Ballena." (Luis Miguel Isava: "Los sesenta: seis poetas hacia la conciencia de las palabras", en Carlos Pacheco et al. (coord.): Nación y literatura. Itinerarios de la palabra escrita en la cultura venezolana, Caracas, Fundación Bigott y Editorial Equinoccio, 2006, pp. 641-652, p. 641) 
Venezuela sino que concebían la democracia en términos esenciales y creían que, al instaurarse en el país, traería consigo el progreso y la modernidad.

Con relación a la cuestión nacional, los escritores que accedieron al campo literario a partir de 1958 tuvieron una concepción diferente a la de generaciones anteriores. Los intelectuales del 18, del 28 y del 36 habían vivido íntegramente "el proceso transformador" de Venezuela, que fue consecuencia de la abrupta modernización que siguió a la aparición del petróleo. Por eso, muchos de ellos buscaron proveer "de memoria nacional al nuevo crisol social" y a la vez "darle pautas para su evolución”. En cambio, "los escritores jóvenes surgi[eron] desconectados de la entraña histórica del país" ${ }^{102}$ y ello dio lugar a que asumieran una responsabilidad con la nación diferente a la de sus mayores. Para la joven generación, que no había conocido la Venezuela anterior al petróleo, el país era una "dimensión excéntrica de Occidente"103 y por tanto la cultura venezolana debía enmarcarse, sin perder su particularidad, en los patrones definidos por la cultura occidental ${ }^{104}$.

En cuanto a la literatura nacional, estos jóvenes consideraban que era necesario actualizarla históricamente, es decir, que era preciso adecuar la expresión literaria a su propia cosmovisión y a la nueva realidad política del país. Para el momento en que esta generación accedió al campo literario (1958) era evidente que se había producido una desconexión entre la estructura social y la expresión literaria. Ángel Rama llamaba la atención sobre este hecho cuando indicaba que para ese año "las remanencias folklóricas resultaban agobiantes, así como la literatura moralizadora a la que [seguía] adherida una clase burguesa cuando ya de facto la ha[bía] invalidado en la estructura

\footnotetext{
102 Ángel Rama: "Miguel Otero Silva de una a otra Venezuela", en Ensayos sobre literatura venezolana, Caracas, Monte Ávila, 1991, pp. 83-91, p. 88.

${ }^{103}$ Octavio Paz: La llama doble. Amor y erotismo, en OOCC, Vol. VI, Ideas y costumbres II. Usos y símbolos, Barcelona, Galaxia Gutenberg, 2aed., 2003, p. 978.

104 Ángel Rama: "Salvador Garmendia y la narrativa informalista", en Ensayos sobre literatura...op.cit., pp. 123-124. En este sentido, los jóvenes se distinguían de las generaciones anteriores pero también del Nuevo Ideal Nacional, que durante la dictadura de Pérez Jiménez "había comprimido la cultura nacional dentro de formas arcaicas y provincianas." (Ibid.)
} 
económica y social que consigue crear" ${ }^{\natural 05}$. Por lo tanto, la modernización de la literatura nacional emprendida por la generación del 58 respondía “a una exigencia real y auténtica del momento", pues el "agobiante modelo de Rómulo Gallegos o Andrés Eloy Blanco", aunque "válidos en su tiempo y respetables en su honrada invención artística, ya no servían a los jóvenes creadores" ${ }^{\text {"106 }}$.

Como consecuencia cultural de la reanudación del "proceso de implantación", en la literatura venezolana de la primera mitad del siglo XX habían coexistido un gran número de propuestas estéticas ${ }^{107}$. Sin embargo, institucionalmente se había privilegiado una literatura que tenía como objetivo "construir el "mapa" narrativo de la nación" y cuyo mayor exponente era Rómulo Gallegos ${ }^{108}$. Aunque los intelectuales jóvenes reconocían la obra de este novelista, su propia cosmovisión les impedía seguir tratando de crear "una atmósfera identitaria entre patria y relato"109. Menos ingenuos, los nuevos intelectuales no trataron de construir textualmente la nación ni quisieron ser los custodios de su memoria, sino que se marcaron el objetivo de adecuar definitivamente la literatura venezolana a los cambios históricos que el país estaba

${ }^{105}$ Ibíd., p. 104.

${ }^{106}$ Ibid., p. 104.

${ }^{107}$ Pausides González ha advertido que en las revistas literarias venezolanas de la primera mitad del siglo XX "las estéticas del siglo XIX mueren [...] como en un proceso de degradación y sublimación donde se podrá tropezar con todo a la vez." El mismo crítico señala que a lo largo de ese período se vivió un proceso de "transfiguración" cultural, que determinó que hasta los años 60 se viviera en "una época de verdaderos cambios donde todas las estéticas se cruzaron." (Pausides González Silva: "De La Alborada a Cantaclaro: literatura y compromiso en cinco revistas", en Carlos Pacheco et al. (coord.): Nación y literatura, op.cit, pp. 415-430, pp. 418-419). El "proceso de implantación" habría dado lugar en Venezuela a una aceleración de la superposición cultural típica de América Latina. Para una explicación de la noción de proceso de implantación, vid. supra nota 41, p. 18.

108 "Desde el imaginario del relato, [...] la obra de Gallegos se propone ser la cartografía misma de la nación que aspira a alcanzar su figura: a la par de la organización sociopolítica, Gallegos agrega el imaginario constructivo de la novela. [...] Su obra [...] es el más alto imaginario constructivo de nuestra tradición literaria y cultural. Gallegos [en los cuarenta] seguirá publicando [y] [...] creando una atmósfera identitaria entre patria y relato, atmósfera de la cual participan otros narradores como Ramón Díaz Sánchez o Arturo Uslar Pietri" (Víctor Bravo: "Transición y expectativas del medio siglo", en Carlos Pacheco et al. (coord.): Nación y Literatura, op.cit., pp. 583- 590, p. 587). De la misma opinión es Ángel Rama: "Venezuela, [...] se mantuvo apegad[a] más que otras áreas culturales latinoamericanas, al concepto de que la narrativa duplicaba especularmente la realidad, tal como lo hicieron creer los maestros regionalistas (Pocaterra, Gallegos)." (Ángel Rama: "Salvador Garmendia y la narrativa informalista", en Ensayos sobre...op.cit., p. 150)

${ }^{109}$ Víctor Bravo: "Transición y expectativas del medio siglo", en Carlos Pacheco et al. (coord.): Nación y Literatura, op.cit., p. 587. 
viviendo. Para lograr esto era preciso adoptar, de una vez por todas, las corrientes estéticas que marcaba el reloj de la literatura mundial, lo que permitiría que el arte venezolano adquiriese repercusión más allá de las propias fronteras. Al dar la espalda a la tradición "constructiva", los jóvenes recuperaron toda esa literatura que Víctor Bravo llama "reconstructiva" y que se caracteriza por ser autorreflexiva y crítica "de valores presupuestos y absolutos"110. Los mejores ejemplos de esta tradición especular que habían quedado fuera del canon y que la nueva generación reivindicaría son La tienda de muñecos (1927) de Julio Garmendia, Cubagua (1931) de Enrique Bernardo Núñez, Ifigenia (1924) de Teresa de la Parra y la obra poética (publicada íntegramente para 1929) de José Antonio Ramos Sucre.

Es decir que con el cambio generacional se produjo una modificación abrupta de la concepción de la literatura que había estado dominando hasta ese momento en Venezuela. La ética democrática de la nueva generación, unida al temor de caer en el anacronismo, les hizo relegar todas las concepciones telúricas o nacionalistas de la literatura así como aquellas que concedían a la escritura literaria una dimensión ancilar, ya consistiera ésta en la sumisión al mercado o a una determinada ideología política. En este sentido, pensamos que la generación del 58 en Venezuela fue la primera en abandonar "la fase de la conciencia amena de retraso, correspondiente a la ideología de «país nuevo»" y en acceder a "la fase de la conciencia catastrófica de retraso, correspondiente a la noción de «país subdesarrollado»" "111. A decir de Antonio Cândido, "la conciencia del subdesarrollo" (que se empezó a manifestar en el continente a partir de 1950) provocó que la literatura dejase de lado "su amenidad y su curiosidad, presintiendo o percibiendo lo que había de enmascaramiento en el encantamiento pintoresco o en la caballerosidad ornamental con que antes se trataba al hombre

\footnotetext{
${ }^{110}$ Ibid., p. 585.

${ }^{111}$ Antonio Cândido: "Literatura y subdesarrollo" en César Fernández Moreno (coord.): América Latina en su literatura, México, Siglo XXI, 1972, pp. 335-353, p. 337.
} 
rústico" ${ }^{112}$. Esta nueva mentalidad supuso que los intelectuales empezaran a aceptar con naturalidad su vinculación cultural y social con Occidente, y que lo que "era imitación" se fuera cambiando "cada vez más en asimilación recíproca" "113. De este modo, la conciencia de subdesarrollo transformó lo que era una relación de dependencia cultural con los países centrales en una relación de interdependencia, y ese cambio permitió a la literatura latinoamericana superar los dos excesos en que incurrían las obras que expresaban la ideología de "país nuevo": la imitación de los modelos foráneos y, su contraparte, el telurismo y el nacionalismo exacerbados ${ }^{114}$. Al trascender estas desmesuras, la conciencia de "país subdesarrollado" suscitó una literatura que, sin dejar de ser nacional, asimilaba los valores artísticos y las corrientes literarias universales.

Esta crítica del telurismo y del nacionalismo estrecho emprendida por la generación del 58 en Venezuela tuvo que ver además con un cambio que aconteció a nivel filosófico y que tambaleó los cimientos epistemológicos de este período. Por esta época se produjo una "disolución” de los códigos simbólicos de lectura aceptados hasta entonces, lo que implicó una modificación en los procesos de escritura.

De los narradores regionalistas a los vanguardistas de los años cincuenta, se fue desintegrando ese código que unificaba las dos lecturas paralelas: la de los datos realistas (imágenes, fenómenos, objetos) y la simbólica (estableciendo significaciones). Al desaparecer el código, esta última se esfumó, no dejando más que la nostalgia del apetecido orden mágico que concitan siempre las estructuras simbólicas y la primera se trasmutó en simple enumeración caótica [...]. La disolución del código fue inicialmente producto de la corrosión del agnosticismo sobre la cosmovisión religiosa, pero en la medida en que ésta, antes de morir, se trasladó a la cosmovisión humanística a la que decretó su solapada heredera, la corrosión agnóstica volvió a ejercerse sobre este ersatz [sustituto], obviamente menos justificado y legítimo, paralizando toda posibilidad de que engendrara un nuevo sucedáneo. ${ }^{115}$

112 Ibid., p. 337.

${ }^{113}$ Ibid., 347.

114 En ese sentido Cândido advierte que mientras la literatura permanecía en la "conciencia amena de retraso" "por un lado las élites imitaban lo bueno y lo malo de las sugestiones europeas, pero, por otro, a veces simultáneamente, afirmaban la más intransigente independencia espiritual, en un movimiento pendular entre la realidad y la utopía de carácter ideológico. Y así vemos que analfabetismo y refinamiento, cosmopolitismo y regionalismo, pueden tener raíces mezcladas en el suelo de la incultura y del esfuerzo para superarla." (Ibid., p. 343). Sartre denuncia esta misma equivalencia entre realismo y artepurismo al principio de la "Presentación" de Les Temps Modernes (Jean Paul Sartre: "Presentation des Temps Modernes", en Situations II, París, Gallimard, 1948, pp. 9-30, p. 10). Como veremos, el propio Guillermo Sucre reitera la crítica de ambos excesos en muchas ocasiones a lo largo de este período.

115 Ángel Rama: "Salvador Garmendia y la narrativa informalista", en Ensayos sobre...op.cit., pp. $150-151$. 
La generación venezolana del 58 fue entonces y por tanto la primera que se enfrentó en el país a la crisis de la metafísica tradicional. Esta ruptura conllevaba la puesta en duda de todas las teorías tradicionales sobre la representación: de acuerdo al nuevo paradigma el lenguaje dejaba de considerarse un espejo fiel de la realidad y se volvía una entidad autónoma, imagen o simulacro. A pesar de estas constantes comunes, la nueva generación se fue dividiendo a partir de 1961 en dos sectores que defendieron políticas estéticas diferentes. Uno de ellos, el más moderado, defendió el paradigma modernista de las artes y se vinculó con los medios culturales del Estado. El otro, crítico y contestatario, tuvo su máxima expresión en el grupo vanguardista "El Techo de la Ballena" (1961-1969).

\section{1. GUILLERMO SUCRE EN EL CAMPO LITERARIO VENEZOLANO (1958-1968)}

El proyecto estético y cultural que Guillermo Sucre desarrolló a lo largo de los años sesenta consistió en una "invención" de la modernidad estética con el objetivo de que este paradigma artístico fuera asimilado por la literatura y el arte venezolanos. Para decirlo de otra manera, a partir de 1958 Sucre emprendió una actualización histórica de la literatura y del campo literario venezolanos para adecuarlos a las bases estéticas y funcionales del arte moderno occidental. Para lograr esta actualización, a lo largo de la década Guillermo trató de fundar una estética literaria firme sobre dos pilares básicos, la autonomía y el universalismo, y, como consecuencia necesaria, propuso la profesionalización del escritor y del crítico. Al ampararse en la estética de modernidad $^{116}$ para establecer pautas que permitieran la valoración objetiva de las

${ }^{116}$ De acuerdo a la definición de Ranciére, la estética de modernidad (o "modernismo", como él lo llama) es "la visión del arte moderno como arte de la autonomía" y eso, según él, es algo que sólo se puede establecer a posteriori. Los grandes proyectos estéticos de la modernidad, como las obras de Mallarmé, de Mondrian o de Schoenberg, surgieron estrechamente relacionadas "con todo tipo de preocupaciones de tipo arquitectural, de tipo social, eventualmente de tipo religioso, político y otros". Por 
obras, Sucre estaba ayudando a construir las bases de una institución arte que sería el homólogo estructural de la democracia naciente. De este modo, a través de su crítica literaria y de su participación en revistas y suplementos culturales, Guillermo aportó su granito de arena a la modernización estructural en la que el país estaba inmerso.

La continuidad del proyecto estético que Sucre emprendió durante los años sesenta nos permite avanzar una nueva interpretación de este período de la cultura venezolana. La solidez del propósito de Guillermo y el hecho de que participase en muchas de las revistas que se editaron durante este lapso, nos ha llevado a establecer un vínculo entre todas ellas y a trascender su comprensión como eventos aislados. En efecto, tanto en Sardio (1958-1959), como en "Letras y Artes" (1962-1964), Zona Franca (1964-1966) e Imagen (1967-1968) es patente la personalidad y el proyecto estético de nuestro autor, por lo que se advierte una misma intención entre todas ellas. La coherencia programática de estas publicaciones tiene, por supuesto, diversos matices en la medida en que los planteamientos de nuestro autor se fueron enriqueciendo a lo largo de la década. Sin embargo, en ningún momento Sucre perdió de vista el objetivo fundamental, que era introducir la literatura venezolana en el paradigma artístico de la modernidad.

A partir de esta secuencia que hemos establecido, se aprecia mejor la polarización que el campo cultural venezolano sufrió a partir de 1961. Las

\footnotetext{
lo tanto, "la doxa moderna" establece la autonomía radical de estos proyectos una vez que desanuda la mezcla entre las razones artísticas y las razones políticas (o de otra índole) que se encuentra en su origen. (Jacques Ranciére: El tiempo de la igualdad. Diálogos sobre política y estética, Barcelona, Herder, 2011, p. 204). Mientras que el sistema representativo separaba lo que era arte de lo que no lo era, con la llegada de la revolución estética el arte se reconoce por su carácter de indistinción, lo que da lugar a una proliferación de desórdenes en la identificación del arte. Contra este desorden moderno se ha inventado un bastión, que se conoce como modernismo: "Le modernisme est la pensée de l'art qui veut l'identification esthétique de l'art mais refuse les formes de désidentification dans lesquelles celle-ci s'effectue, qui veut l'autonomie de l'art mais refuse l'hétéronomie qui en est l'autre nom." Esta fábula identifica simplemente la revolución moderna del arte al descubrimiento de una esencia pura del mismo, con lo que se consigue asegurar una "distinción global entre el arte y el no-arte" que en verdad es inexistente en el régimen estético. (Jacques Ranciére: "Les antinomies du modernisme", en Malaise dans l'esthéthique, Paris, Galilée, 2004, pp. 93-94. Traducción mía)
} 
publicaciones en las que participó Guillermo Sucre constituyen el núcleo del proyecto estético y cultural del "oficialismo", que contó con intelectuales moderados que se opusieron tanto a la guerrilla como a la vanguardia estética a ella vinculada. A pesar de que, mediada la década, este sector fue respaldado por el aparato cultural del Estado, nosotros pensamos, y aquí vamos a defender, que los planteamientos de nuestro autor en ningún momento se sometieron a un pensamiento oficial sobre literatura o sobre estética. Lo que se produjo más bien fue una coincidencia entre el ideario de Sucre (que éste venía defendiendo ya desde 1958, cuando las instituciones culturales del nuevo Estado ni siquiera existían) y la cultura promovida más adelante por el Estado venezolano, cuya intervención en este ámbito cobró peso sobre todo a partir de la fundación del INCIBA (Instituto Nacional de Cultura y Bellas en Artes) en 1965.

En el polo del campo cultural opuesto al oficialismo se encuentran los movimientos estéticos contestatarios que surgieron a partir de 1961 como consecuencia de la radicalización política de un sector de la izquierda y cuyo mejor exponente fue "El Techo de la Ballena”. Estos grupos vanguardistas pusieron en juego un arte crítico, es decir, una política estética diferente al paradigma de modernidad que Sucre y otros intelectuales trataban de impulsar entre los creadores venezolanos. De este modo, mientras que el proyecto de nuestro autor y, más tarde, del oficialismo, se fundó en las nociones de autonomía y universalismo, "El Techo" y los movimientos afines trataron de recomponer "de diversas maneras" "las políticas alternativas del devenir-mundo del arte y de la retirada de la forma artística rebelde" "para construir las formas y las metamorfosis del arte crítico",117.

117 Jacques Ranciére: "Estado de la política, estado del arte", en Sobre politicas estéticas, Barcelona, MACBA, 2005, p. 55. La polarización cultural que tuvo lugar en Venezuela durante esta década es una contraposición entre dos visiones opuestas de la modernidad: modernismo versus arte crítico, en la concepción que da Ranciére a ambos términos. 
Una vez dicho esto, podemos establecer tres momentos diferenciados en el contexto cultural venezolano de los años sesenta, en estrecha vinculación con el acontecer de la política nacional. En un primer momento, tras la caída de la dictadura, la unidad mitológica que siguió al 23 de enero tuvo su correlato cultural en el proyecto de Sardio, cuyos miembros se comprometieron con la transición a la democracia que vivía el país. A partir de 1961, y como consecuencia del proceso de radicalización de la izquierda, el grupo "Sardio" se dividió en dos sectores. Uno de ellos se opuso a la violencia guerrillera y a los excesos vanguardistas, siguió promoviendo la estética de modernidad que había venido defendiendo hasta este momento, y colaboró más tarde en los medios financiados por el Estado. En este grupo, que era minoría en un primer momento, se situaron entre otros Guillermo Sucre, Luis García Morales y Elisa Lerner $^{118}$. El otro defendió la insurrección armada y creó una vanguardia que se enfrentó al gobierno e impugnó tanto la cultura venezolana tradicional, de corte realista y costumbrista, como el proyecto que el oficialismo estaba tratando de implementar. En esta facción contestataria se enmarcaron los grupos vanguardistas que fueron surgiendo a partir de 1961, el más importante de los cuales fue "El Techo de la Ballena". Por último, un tercer período de la historia cultural de la década tuvo lugar entre 1964 y 1968, cuando el sector vanguardista fue perdiendo fuerza y sus mejores exponentes cedieron paulatinamente a la institucionalización, con lo que se iban introduciendo al sistema que tan duramente habían atacado durante los años de mayor radicalización política.

Para abordar de la manera más clara posible la participación de Guillermo Sucre en el campo cultural venezolano seguiremos un orden cronológico, lo que nos permitirá además apreciar la continuidad de su proyecto cultural. Así pues, comenzaremos por

\footnotetext{
${ }^{118}$ Elisa Lerner (1932), narradora, ensayista y dramaturga venezolana, que en el año 2000 obtuvo el Premio Nacional de Literatura. Algunas de sus obras fundamentales son Vida con mamá (1976, teatro), Yo amo a Columbo (1979, ensayo) y Crónicas ginecológicas (1984, ensayo).
} 
Cantaclaro y Sardio; después trataremos del sector vanguardista y, dentro de él, señaladamente de "El Techo de la Ballena"; finalmente, presentaremos la labor de nuestro autor en los medios culturales patrocinados por el Estado venezolano (o afines a él): "Letras y Artes”, Zona Franca e Imagen.

\section{1. 1. Cantaclaro (1950)}

La participación de Guillermo Sucre en el campo literario venezolano se remonta a 1950, año en que salió a la luz el único número de la revista Cantaclaro. Aunque nuestro autor sólo contribuyó en esa publicación con un poema, en ella se advierten ya algunas constantes - como el respaldo a la democracia y el universalismoque Guillermo defenderá a partir de 1958. En Cantaclaro participaron, entre otros, Jesús Sanoja Hernández, Miguel García Mackle, Rafael José Muñoz, Jesús R. Zambrano, Juan Liscano, Guillermo Sucre, y su hermano, José Francisco Sucre. La edición fue decomisada por la policía de la Junta Militar que en ese momento ocupaba el poder, pues aparte de la referencia del título, “en la portada aparecía una foto del derrocado presidente constitucional, Rómulo Gallegos, y una nota de solidaridad para con el mismo"119. En "Los tres puntos de Cantaclaro", especie de manifiesto que encabezaba la publicación, sus integrantes se declaraban "de una orientación izquierdista democrática militante" ${ }^{120}$ y partidarios del compromiso sociopolítico del intelectual:

Concebimos la obra de un artista, de un escritor, de un intelectual cualquiera, como la realización integral del hombre en una expresión total de su inteligencia y los hechos prácticos con sus relaciones con la sociedad, de tal suerte que el pensamiento y la acción son para nosotros un solo hecho continuo. Como consecuencia de lo anterior, la revista Cantaclaro reconoce el mérito de aquellos intelectuales que responsables ante su obra y consecuentes con su pensamiento, tienen una trayectoria vertical como hombres de ideas y una actitud ejemplar como ciudadanos. $^{121}$

${ }^{119}$ Carmen Virginia Carrillo: De la belleza y el furor. Propuestas poéticas renovadoras en la década de los sesenta en Venezuela, Mérida, El otro el mismo, 2007, p. 68.

${ }^{120}$ Citado por Pausides González: "De La Alborada a Cantaclaro: literatura y compromiso en cinco revistas.", en Nación y literatura, op.cit., p. 428.

${ }^{121}$ Citado por Ángel Gustavo Infante: "Estética de la rebelión: los manifiestos literarios", en Nación y literatura, op.cit., pp. 407-413, pp. 410-411. 
Además de solicitar el compromiso de los escritores y de "pregonar un profundo aliento cívico" $" 122$, en lo que atañe a la discusión cultural los miembros de Cantaclaro "propusieron un universalismo «de adentro hacia fuera, universalismo de revelación y justificación americanas»" "123 que debemos considerar sintomático de esa "conciencia de subdesarrollo" estudiada por Cândido, que empezó a aparecer en el continente hacia mediados del siglo XX. El grupo adoptó el universalismo por contagio de "Contrapunto" $" 124$, colectivo que para 1950 todavía se encontraba activo y en vísperas de publicar el sexto y último número de la publicación homónima. Después de la aparición del único número de Cantaclaro, en el que se advertía "una actitud claramente beligerante" ${ }^{, 125}$ en contra de la dictadura que se encontraba en el poder desde 1948, los jóvenes intelectuales que habían participado en su publicación sufrieron la cárcel y el exilio, lo que retrasó su presencia en el campo cultural hasta la reanudación de la democracia en 1958.

\section{1. 2. Sardio (1958-1961)}

Ocho años después de la aparición de Cantaclaro, y tras pasar tres temporadas en la cárcel y cuatro años en el exilio, Guillermo Sucre fundó junto a Luis García Morales, Adriano González León ${ }^{126}$ y Rómulo Arangibel la revista Sardio (1958-1961),

122 Pausides González: "De La Alborada a Cantaclaro: literatura y compromiso en cinco revistas.”, en Nación y literatura, op.cit., p. 429-430.

${ }_{123}$ Carmen Virginia Carrillo: De la belleza y el furor...op.cit., p. 69. La cita pertenece al manifiesto "Los tres puntos de Cantaclaro".

${ }^{124}$ El grupo Contrapunto surgió en 1946 y el primer número de su revista en 1948. A decir de Víctor Bravo, en la revista Contrapunto "se plantea un rasgo que ya no abandonará nuestra cultura: el universalismo." (Víctor Bravo: "Transición y expectativas del medio siglo", en Carlos Pacheco et al. (coord.): Nación y Literatura, op.cit., p. 586). Como se indica en la propia revista Contrapunto, "Por el espíritu abierto a todas las señales con que se expresa el mundo desde la intimidad y no por una respuesta común, hemos cerrado filas en esta revista. Nuestro único sectarismo será el de permanecer fiel a la realidad espiritual del presente." (Citado por Ibíd., p. 586.) Según González, el grupo Cantaclaro había surgido "bajo el influjo ideológico del grupo Contrapunto" (Pausides González: "De La Alborada a Cantaclaro: literatura y compromiso en cinco revistas.”, en Nación y literatura, op.cit., p. 427)

125 Ibid., p. 429.

${ }^{126}$ Adriano González León (Valera, 1931-Caracas, 2008), escritor venezolano conocido por sus cuentos y por la novela País portátil (Premio Biblioteca Breve, 1968). 
cuyo primer número salió en mayo-junio de 1958. A partir del tercer número, la nómina de los miembros del Comité de Redacción aumentó con la presencia de Elisa Lerner, Gonzalo Castellanos, Salvador Garmendia ${ }^{127}$, Rodolfo Izaguirre y Ramón Palomares ${ }^{128}$.

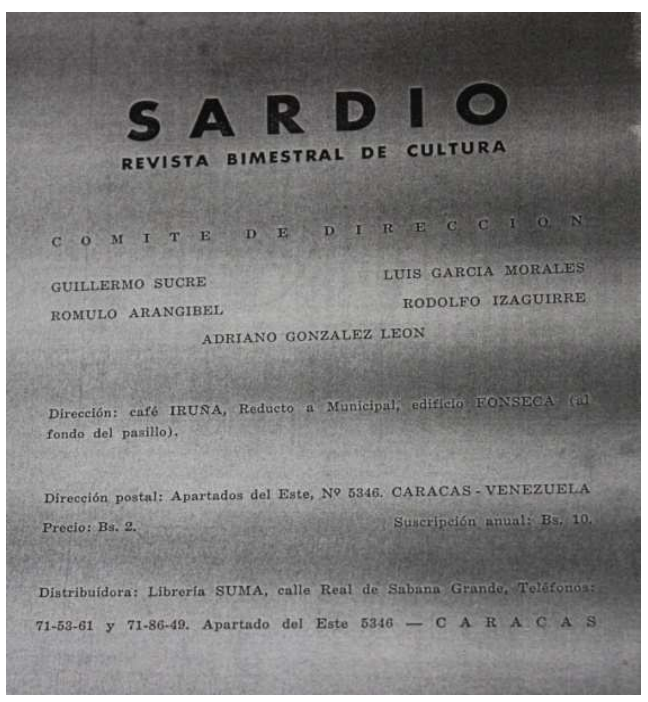

Imagen 11. Portada fotocopiada del primer número de la revista Sardio.

Como ya hemos señalado, todos los participantes en la revista, al menos en un primer momento, se comprometieron con el camino a la democracia que iniciaba el país y en particular con el partido Acción Democrática ${ }^{129}$. Inspirados por una voluntad que muchos de ellos, como el propio Sucre, no abandonarían en toda la década, desde la revista se trató de que la literatura venezolana asimilara la estética de modernidad $^{130}$. Dicho de otra manera, desde las páginas de Sardio se intentó construir una institución arte y una literatura en los términos que imponía la cosmovisión liberal y occidentalista

${ }^{127}$ Salvador Garmendia (Barquisimeto, 1928-Caracas, 2001), narrador y periodista venezolano. Entre sus obras más importantes destacan Los pequeños seres (1958), Los habitantes (1961), Día de ceniza (1963) y Memorias de Altagracia (1973). Fue condecorado con el Premio Nacional de Literatura en 1973.

128 Ramón Palomares (Escuque, Venezuela, 1935), poeta venezolano cuyas obras más importantes son El Reino (1935), Paisano (1964), Honras fúnebres (1965) y Adiós a Escuque (1974). Recibió el Premio Nacional de Literatura en 1975.

${ }^{129}$ Como hemos visto antes, en muchos textos de Sardio se filtra la ideología del partido Acción Democrática. (Vid. supra pp. 23 y ss.)

${ }^{130}$ Hemos explicado este concepto supra. Vid. nota 116, p. 47. 
de los miembros del grupo. Para lograr la actualización histórica del campo cultural sintieron que su principal enemigo era esa intelectualidad corrupta e insincera (es decir, antiliberal) que había hecho "política literaria" de sus intereses particulares:

Antes que seres requeridos por una vocación o por las determinantes de la inteligencia, hemos tenido a todo lo largo de nuestra cultura pequeños aprendices de "mandarines", extenuados aspirantes de una fama o una fortuna que paradójicamente siempre se les ha negado. Con una irresistible seducción por el prestigio superficial o por una gloria aldeana, se embriagaron con elogios mutuos y acomodativos [sic], hasta el punto de que hicieron arte e institución de esa despreciable y ya proverbial "política literaria". 131

Los jóvenes intelectuales propusieron acabar con la corrupción imperante en el campo literario mediante la introducción de una nueva conducta profesional que desdeñaba el conformismo característico de la intelectualidad nacional y ponía en valor actitudes como la exigencia, el esfuerzo y la necesidad de ponerse al día:

Debemos alimentar una firme voluntad de estilo, una vigilante dedicación al estudio y una ideología más original y moderna. Nuestra cultura aparece ayuna de ideas y problemas, como si aún viviéramos en una Arcadia de imperturbables regocijos. Hay que poner de relieve una conciencia más dramática de la realidad y del hombre. Pero una conciencia rigurosa, estremecida de lucidez y de exigencias. La ingenuidad y la improvisación deben estar distantes de nuestros propósitos. ${ }^{132}$

Además, frente al amiguismo y la corruptela cultural, los intelectuales de Sardio buscaron imponer criterios profesionales y objetivos (es decir, legales, liberales) para valorar las obras literarias: "El inconformismo y la exigencia han comenzado por nosotros mismos y jamás hemos claudicado con el intercambio de halagos y requiebros entre los de nuestra generación. [...] Una creciente e insobornable sinceridad ha sellado

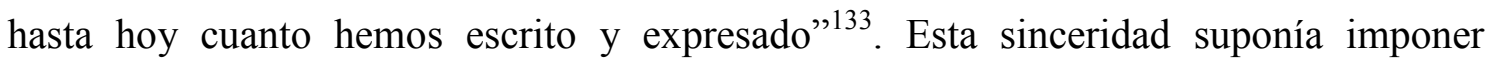
límites "al arribismo y al fraude intelectual" $" 134$, para lo que era necesario asumir una conciencia estética definida que sirviera para combatir los mitos y las arbitrariedades que una intelectualidad complacida y complaciente había introducido en la literatura nacional. Es decir, que además de cambiar las actitudes era necesario introducir valores

\footnotetext{
${ }^{131}$ Guillermo Sucre: “Testimonio. Las constantes...”, loc.cit., p. 279.

132 Guillermo Sucre: "Testimonio" loc. cit., p. 3.

133 Guillermo Sucre: "Testimonio. Las constantes...", loc. cit. p. 280.

${ }^{134}$ Ibid. p. 281.
} 
estéticos objetivos y acordes con los nuevos tiempos. Por eso, los sardianos rompieron “con el pasado insertando corrientes universalistas que lo cancelaran bruscamente, y como al mismo tiempo su formación cultural todavía se hizo en la órbita de la influencia francesa $[\ldots]$, se remontaron a las vanguardias de la primera postguerra en París"135. Para lograr la ansiada actualización histórica de una cultura -la venezolana- que percibían "provinciana, aislada y atrasada"136, en las páginas de la revista se reunieron,

en una suerte de compilación antológica dirigida a un lector poco informado o escasamente conocedor de las tendencias literarias mundiales desde comienzos de siglo, textos de y sobre las vanguardias literarias europeas, relatos de autores norteamericanos y europeos de la posguerra, así como reseñas sobre cine y música que comentan propuestas consideradas novedosas para el ambiente cultural venezolano. ${ }^{137}$

Este carácter antológico de Sardio se aprecia también, como veremos, en los demás proyectos culturales que Guillermo Sucre emprendió a lo largo de la década. El objetivo fundamental que con esto se perseguía era familiarizar al lector con la estética de modernidad que la revista trataba de promocionar.

El apoyo unánime a la democracia venezolana (el período de "unidad mitológica") entró en crisis hacia 1960, año en que a decir de Chacón se produjeron "las grandes rupturas de convenios aparentes y el comienzo de los enfrentamientos reales" ${ }^{\prime 38}$. La revista Sardio no permaneció insensible a la creciente polarización política del país, y el número 7 de la publicación, que vio la luz en abril-mayo de 1959, es el último en que se puede apreciar la afinidad ideológica entre los miembros del

135 Ángel Rama: "Salvador Garmendia y la narrativa informalista", en Ensayos sobre literatura...op.cit., p. 105. El universalismo (o, más bien, occidentalismo) presente en Sardio se advierte, por ejemplo, en esta afirmación contenida en su primer "Testimonio": "El hombre de hoy está volcado hacia una experiencia más vasta y compleja, que sería inútil simplificar con limitaciones regionales o partidistas, y está urgido por anhelos profundos de universalidad. Orientados hacia esa gran experiencia es como debemos tratar los problemas nacionales. Es imperioso elevar a perspectivas más universales los alucinantes temas de nuestra tierra." (Guillermo Sucre: "Testimonio", loc. cit., p. 3)

136 Ibid., p. 628. En uno de los Testimonios señalan: "No confundimos universalidad con cosmopolitismo, pero se nos hace evidente que el exceso de color local, con todas sus derivantes, ha viciado de raíz gran parte de nuestras manifestaciones artísticas". (Guillermo Sucre: "Testimonio", loc.cit., p. 3)

${ }^{137}$ María del Carmen Porras: "Tres revistas literarias de los años sesenta y el problema de la cultura nacional”, en Carlos Pacheco et al. (coord.): Nación y literatura ...op.cit., p. 628.

138 Alfredo Chacón: "Trayectoria ideológica de la izquierda cultural venezolana 1958-1968", "Prólogo" a La izquierda cultural venezolana 1958-1968, Caracas, Editorial Domingo Fuentes, 1970, pp. 9-57, p. 37. 
grupo. También fue el último en que participó Guillermo Sucre, que en el verano de 1959 había marchado a París, donde permanecería hasta 1962. En el primer trimestre de 1961 apareció el octavo número de la publicación, en el que ya se hace evidente el desvío ideológico de algunos de los miembros de Sardio con respecto al compromiso adoptado inicialmente a favor del gobierno democrático. La divergencia política motivó la división del grupo y el final del proyecto iniciado en 1958. En ese número final apareció sin firma el "Testimonio sobre Cuba", que mostraba un apoyo explícito a la política del régimen de Castro, el cual a partir de ese año se adhirió al marxismoleninismo. En ese ejemplar se editaron además varios documentos de "El Techo de la Ballena", grupo vanguardista que surgió precisamente del sector de Sardio que se había radicalizado políticamente. El importante papel ideológico que Guillermo Sucre jugó en Sardio nos lleva a interpretar esta revista (al menos en sus siete primeros números) como un primer estadio del proyecto cultural que nuestro autor desarrollaría a lo largo de la década, y a descartar por tanto las interpretaciones aisladas que se han hecho de la publicación. En efecto, Sardio recupera todo su sentido si la entendemos como parte de esa intervención cultural que Sucre desarrolló a lo largo de los años sesenta. Al tiempo que participaba en esta revista (es decir, entre mayo de 1958 y junio de 1959) Guillermo Sucre publicó críticas y reseñas sobre literatura venezolana y latinoamericana en "El Papel Literario" del diario El Nacional, suplemento que durante el año 1958 dirigió Juan Liscano.

\section{2. EL TECHO DE LA BALLENA (1961-1969)}

Cuando Guillermo Sucre regresó a Venezuela en 1962, tras haber permanecido tres años en París, la situación política del país era muy diferente de la que había dejado al marchar en 1959, cuando la joven intelectualidad mantenía todavía un apoyo unánime 
a la transición a la democracia que iniciaba el país. En el año 1960 un sector del partido Acción Democrática fundó el Movimiento de Izquierda Revolucionaria (MIR) y dio inicio a la lucha guerrillera, con lo que el panorama político y cultural cambió completamente. A la vez que se rompió el consenso político en torno a la democracia, los artistas e intelectuales se dividieron en dos sectores, que defendían diferentes posiciones políticas y estéticas. El más moderado siguió siendo partidario del gobierno de Betancourt y se opuso a la violencia guerrillera que trataba de desestabilizarlo; al mismo tiempo, promovió una estética modernista que se fundaba en los pilares de la autonomía y el universalismo. En cambio, el grupo más radical se mostró partidario de la guerrilla y asumió un enfoque estético vanguardista y crítico que tenía la intención de provocar, explícita e implícitamente, tanto a la sociedad venezolana como a su cultura oficial. Si bien, como ya sabemos, el proyecto de Sucre se enmarca en el sector "oficialista", para entender bien su posición es preciso explicar la trayectoria y el carácter de la vanguardia cultural que se formó durante estos años.

El grupo vanguardista "El Techo de la Ballena" estuvo formado por escritores y artistas, entre los cuales se contaban antiguos miembros de "Sardio" como Adriano González León y Salvador Garmendia así como otros jóvenes, muchos de ellos dedicados tanto a la literatura como a las artes plásticas: Carlos Contramaestre, Edmundo Aray, Caupolicán Ovalles, Dámaso Ogaz y Juan Calzadilla, entre otros. “E1 Techo" inició su andadura en marzo de 1961, con una exposición titulada "Para restituir el magma" y con la publicación de su primer manifiesto-revista, Rayado sobre el Techo, del que aparecieron tres entregas entre 1961 y 1964. 


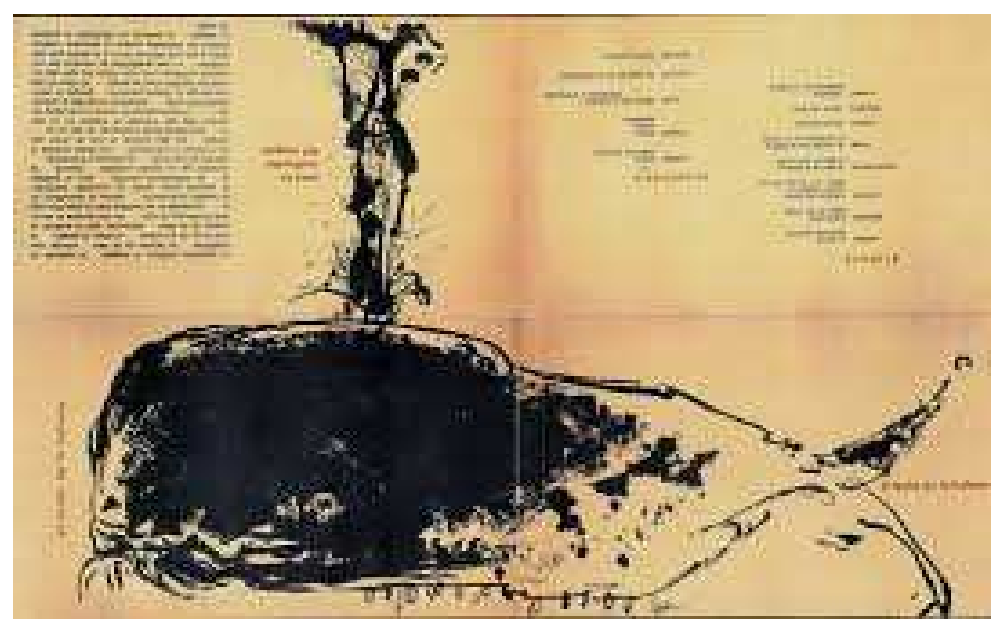

Imagen 12. Primer manifiesto-revista de "El Techo de la Ballena".

Como ya se ha dicho anteriormente, "El Techo" nació de una escisión del grupo "Sardio", pues en el octavo número de esta publicación, además del mencionado “Testimonio sobre Cuba", que era claramente favorable al gobierno revolucionario de la isla, aparecieron tres textos donde "se definían los intereses y las aspiraciones" del nuevo movimiento vanguardista. Esos escritos eran "un pre-manifiesto y las introducciones a los catálogos de las dos exposiciones que [los integrantes del nuevo grupo vanguardista] habían realizado en los meses de marzo y junio de ese mismo año"139. La exposición de junio se tituló "Homenaje a la cursilería" y "constituyó el primer intento de demolición de la concepción pequeñoburguesa que dominaba a la cultura venezolana" $" 140$. En la reseña escrita a propósito de este "Homenaje", aparecida en Sardio, la constitución del nuevo grupo vanguardista se justificaba en estos términos:

No como producto del azar, ni como ocio o actividad de un grupo de intelectuales evadidos o presuntamente inadaptados en el actual engranaje social, sino más bien como un gesto de franca protesta ante la permanente e indeclinable farsa cultural del país y el continuado desacierto político y económico que registra la democracia venezolana, el Techo de la Ballena ha comenzado a poner en evidencia la inveterada mediocridad de nuestro ambiente cultural. ${ }^{141}$

${ }^{139}$ Carmen Virginia Carrillo: De la belleza y el furor...op.cit., pp. 96-97.

140 Ángel Rama: "Salvador Garmendia y la narrativa informalista", en Ensayos sobre literatura ...op.cit., p. 119.

141 La cita procede de Sardio, Caracas, núm. 8, marzo 1961, p. 136. (Citado por María del Carmen Porras: "Tres revistas literarias de los años sesenta y el problema de la cultura nacional", en Carlos Pacheco et al. (coord.): Nación y literatura...op.cit., p. 634) 
A ese primer "Homenaje" siguió en noviembre de 1962 el "Homenaje a la necrofilia", organizado por Carlos Contramaestre, que "marcó el ápice del movimiento, su más pleno ejercicio de la provocación" ${ }^{\text {142 }}$, pues la agresividad de la exposición conmocionó a la opinión pública hasta el punto de que intervino la Iglesia Católica excomulgando a los organizadores de la muestra. Un poco antes, ese mismo año, había aparecido el libro de Caupolicán Ovalles ¿Duerme usted, señor Presidente?, cuya publicación provocó las iras del presidente Betancourt, dio lugar a la detención del prologuista de la obra, Adriano González León, y obligó al autor del poemario a exiliarse del país. En 1964, "El Techo de la Ballena" realizó "una exposición de testimonios de su trayectoria que fue presentada como un balance y resultó ser la despedida"143. Con motivo de esa exposición, que marcó el principio del final del grupo, se publicó el tercer y último número de Rayado sobre el Techo ${ }^{144}$.

El hecho de que el grupo perdiera fuerza a partir de 1964 es un síntoma más del vínculo simbólico que "El Techo de la Ballena" había establecido con la insurgencia revolucionaria. A finales de 1963 se celebraron en el país unas elecciones presidenciales que contaron con una masiva participación popular, lo que supuso un golpe importante para la guerrilla, que había llamado a la abstención. A partir de 1964 el nuevo gobierno

142 Ángel Rama: "Salvador Garmendia y la narrativa informalista", en Ensayos sobre literatura...op.cit., p. 119.

143 Alfredo Chacón: "Trayectoria ideológica de la izquierda cultural venezolana 1958-1968", "Prólogo" a La izquierda cultural...op.cit., p. 47.

${ }^{144}$ Chacón hizo este balance de la trayectoria del grupo: "Atrás quedaban los actos y obras del apogeo: la exposición "Para restituir el Magma", marzo 61; la revista-plaquette Rayado sobre El Techo, $\mathrm{N}^{\mathrm{o}}$ 1, marzo 61, № 2 mayo 63; la exposición "Homenaje a la Cursilería", junio 61; la exposición de pinturas de Gabriel Morera Cabezas Filosóficas, noviembre 61; el libro de poesía de Caopolicán Ovalles ¿Duerme Usted, Señor Presidente?, mayo 62; la plaquette de poesía del chileno Dámaso Ogaz Espada de doble filo, agosto 62; la exposición-publicación de Carlos Contramaestre "Homenaje a la Necrofilia", noviembre 62; el libro de poesía de Juan Calzadilla Dictado por la Jauría, noviembre 62; el libro de textos de Adriano González León y fotos de Daniel González Asfalto-Infierno, enero 63; la exposición colectiva Sujetos plásticos, mayo 63; la exposición de Juan Calzadilla "Dibujos Coloidales", abril 63; la edición tubular del poema de Caopolicán Ovalles En uso de razón, julio 63; la Exposición Tubular, julio 63; el libro de minimodramas de Edmundo Aray Twist presidencial, agosto 63; el libro de poesía de Francisco Pérez Perdomo Los Venenos Fieles, noviembre 63; la revista-libro Rayado sobre El Techo, $\mathrm{N}^{\mathrm{o}}$ 3, agosto 64; y el libro de poemas de Juan Calzadilla Malos Modales, septiembre 65." (Ibíd., pp. 48-49). Algunas de las cursivas corresponden a la negrita del original. 
de Leoni cambió de estrategia con respecto a la insurrección armada, concediendo amnistías a presos políticos y tratando de reintegrar a los miembros más radicales de la izquierda al proceso democrático que se iba consolidando. Desde 1965 (sobre todo a partir de la llegada de Simón Alberto Consalvi a la Presidencia del INCIBA) se produjo un proceso paralelo de integración de los antiguos vanguardistas a las instituciones culturales del Estado, "primero a través de la revista Zona Franca, luego de la Oficina Central de Información y la Revista Nacional de Cultura, hasta llegar a la culminación que representan el quincenario Imagen, la editorial Monte Ávila y las exposiciones de propaganda gubernamental"145. Sin embargo, aunque hacia 1964 "El Techo" comenzó a perder fuerza, los "más tesoneros animadores" de esta vanguardia, Carlos Contramaestre y Edmundo Aray

le proporcionaron una irregular supervivencia que cubrió casi toda la década del sesenta, apelando al funcionamiento de galerías de arte, exposiciones de pintura informal, publicaciones literarias signadas por una tónica surrealista que comenzó a devenir anacrónica a medida que se disolvía el complejo político-cultural que había prohijado el movimiento, pero que aseguró la difusión de sus principios generadores junto con una previsible retorización. ${ }^{146}$

El grupo desapareció definitivamente en 1968 tras la publicación del volumen Salve, amigo, salve y adiós, que incluía colaboraciones de Edmundo Aray, Efraín Hurtado, Juan Calzadilla, Dámaso Ogaz y Carlos Contramaestre, entre otros. Ya desde 1964, pero más aún a partir de este momento se produjo,

como antes en el surrealismo francés, el reconocimiento tardío de su naturaleza de literatos que hacen los integrantes del movimiento, decidiéndose a acometer esas obras ambiciosas y realizadas que antes aborrecieron. Por lo mismo, la dominante grupal de la primera época, dej[ó] paso a la inclinación individual hacia el reconocimiento de la especificidad literaria de cada uno y a la búsqueda de la creación propia. Así es que ingresa[ron] a la literatura, aunque ella ya no [fuera] igual a la que atacaron en sus comienzos. ${ }^{147}$

145 Ibid., pp. 49-50. Los nombres en cursiva corresponden a la negrita del original. En esta afirmación se aprecia bien el vínculo de los proyectos en los que participó Sucre con el oficialismo.

146 Ángel Rama: "Salvador Garmendia y la narrativa informalista", en Ensayos sobre literatura ...op.cit., pp. 118-119.

${ }^{147}$ Ibid., p. 143. 
Después de la furia insurreccional, los antiguos vanguardistas tuvieron que "vivir en la sociedad y en la cultura que intentaron derribar"148 y publicaron obras como País portátil (1968) de González León, Premio Biblioteca Breve de ese año, o La mala vida (1968) de Salvador Garmendia -quien, sin embargo, no había dejado de publicar durante los años de mayor agitación política. Ya avanzada la década y mermadas las esperanzas revolucionarias,

la colaboración con la cultura oficial no aparec[ía] abiertamente como una traición a la izquierda cultural, de ésas que se denunciaban duramente cuando dicha izquierda vivía su fase de mayor cohesión y actividad: en primer lugar, porque este punto de referencia casi había desaparecido; luego, porque esta vez no se trataba de casos aislados, sino de una tendencia practicada por una buena parte de los antiguos miembros de los grupos. ${ }^{149}$

A partir de 1968 surgió en Venezuela toda una narrativa cercana a la novela testimonio, que se dedicó a referir la experiencia de la lucha armada y que ya nada tenía que ver con la producida durante el período insurreccional.

Analicemos ahora, más de cerca, en qué consistió el empeño de "El Techo de la Ballena". Como se ha repetido muchas veces, este grupo de vanguardia quiso ser "el equivalente literario y artístico de la violencia armada venezolana de la época betancourista" ${ }^{\prime 50}$, y así parecían reconocerlo los propios miembros del colectivo en su "Segundo manifiesto", donde fijaban su posición con respecto a la violencia guerrillera:

Nuestras respuestas y nuestras acciones surgen de la misma naturaleza de las cosas y de los acontecimientos, como claro ejercicio de la libertad, clave para la transformación de la vida y la sociedad [...] Como los hombres que a esta hora se juegan a fusilazo limpio su destino en la Sierra, nosotros insistimos en jugarnos nuestra existencia de escritores y artistas a coletazos y mordiscos. ${ }^{151}$

${ }^{148}$ Ibid., p. 143.

149 Alfredo Chacón: "Trayectoria ideológica de la izquierda cultural venezolana 1958-1968”, "Prólogo" a La izquierda cultural...op.cit., p. 55.

150 Ángel Rama: "Salvador Garmendia y la narrativa informalista", en Ensayos sobre literatura...op.cit., p. 123. Cursiva nuestra. Sin descartar la relación evidente del grupo vanguardista con la radicalización política de la izquierda, Héctor Brioso ha afirmado adecuadamente que "la cohesión de los artistas balleneros surge primariamente de un debate cultural y estético, y secundariamente de una ambición política que todos ellos poseen en una Venezuela que atraviesa notables convulsiones y luchas por el poder." (Héctor Brioso Santos: Estridencia e ironía. El Techo de la Ballena. Un grupo de vanguardia venezolano (1961-1969), Sevilla, Universidad de Sevilla, 2002, p. 129)

151 Anónimo: "Segundo manifiesto" en Rayado sobre el techo $n^{\circ} 2$, 1963. (Citado por María del Carmen Porras: "Tres revistas literarias de los años sesenta y el problema de la cultura nacional", en Carlos Pacheco et al. (coord.): Nación y literatura ...op.cit., p. 634) 
En efecto, "El Techo" tendió a imitar en el campo cultural las acciones terroristas de los grupos armados, y ello implicaba enfrentarse, a través de sus acciones y propuestas estéticas, a la cultura promovida institucionalmente. Oponiéndose al realismo tradicional, que ya resultaba anacrónico, y a la estética de modernidad fundada en el valor de la autonomía, los jóvenes vanguardistas se adhirieron a una propuesta "crítica", es decir, a un arte que resultaba de la interacción entre los dos polos fundamentales del régimen estético del arte. Como lo ha explicado Ranciére:

La estética tiene su política o mejor su tensión entre dos políticas opuestas: entre la lógica del arte que se convierte en vida al precio de suprimirse como arte [el modernitarismo] y la lógica del arte que hace política con la condición expresa de no hacerla en absoluto [el modernismo]. El arte crítico es entonces un arte que negocia la relación entre las dos lógicas estéticas: entre la tensión que empuja el arte hacia la "vida" y la que separa la sensorialidad estética de las otras formas de experiencia sensible. Debe tomar prestado a las zonas de indistinción entre el arte y las otras esferas [la vida] las conexiones que provocan la inteligibilidad política. Y debe tomar prestado al aislamiento de la obra el sentido de heterogeneidad sensible que alimenta las energías políticas de rechazo. ${ }^{152}$

Para analizar la estética crítica de "El Techo de la Ballena" nos centraremos en

dos aspectos básicos: 1) la búsqueda obsesiva de lo nuevo y 2) la indistinción igualitaria

entre lo artístico y lo no-artístico. Como es propio de los movimientos vanguardistas, también el grupo que nos ocupa trató de "renovarlo todo a su alrededor inmediata y radicalmente"153. A este respecto, en el "Segundo manifiesto", ya citado más arriba, "se explicaba que «la necesidad de investigación y la experimentación» son el «único camino que puede mantener en una permanente vitalidad nuestro provinciano universo plástico»y se describía a los que se someten a los cánones establecidos como un

152 Jacques Ranciére: "Problemas y transformaciones del arte crítico", en Sobre políticas estéticas...op.cit., p. 39. La cita sigue: “[...] La combinación de estas dos fuerzas adquiere necesariamente la forma de un ajuste de lógicas heterogéneas. Si el collage ha sido uno de los grandes procedimientos del arte moderno, es porque sus formas técnicas obedecen a una lógica estético-política más fundamental. El collage, en el sentido más general del término, es el principio de un "tercio" político estético. Antes de mezclar pintura, periódicos, tela encerada o mecanismos de relojería, mezcla la singularidad de la experiencia estética con el devenir-vida del arte y el devenir-arte de la vida cotidiana." Además afirma Ranciére: "Si existe una cuestión política del arte contemporáneo, no es en la clave de la oposición modernidad/posmodernidad donde podemos encontrarla. Es en el análisis de las metamorfosis que afectan al "tercio" político, a la política fundada sobre el juego de los intercambios y de los desplazamientos entre el mundo del arte y el del no-arte.” (Ibíd., p. 43)

${ }^{153}$ Héctor Brioso Santos: Estridencia e ironía...op.cit., p. 96. 
«trágico desfile de cadáveres vivientes»" $" 154$. La "modernolatría" $" 155$ característica del grupo les llevó a rechazar todo lo aceptado estética, moral y socialmente, incluida la tradición artística y el arte oficial. Así, en el manifiesto citado más arriba se impugnaba el arte convencional, cuyas manifestaciones más difundidas eran el paisajismo tradicional, el realismo socialista ${ }^{156}$ y el movimiento abstracto y cinetista ${ }^{157}$ que se empezaba a consolidar en el país. En lo concerniente a la literatura el grupo se distanció de las diversas corrientes que se venían sucediendo desde la caída de Gómez, impugnó el "oficialismo", y se opuso sistemáticamente a cualquier atisbo de institucionalización cultural. Según afirmaban en ese mismo "Segundo manifiesto":

Sentirse satisfecho por un premio oficial o por lograr la concurrencia a representaciones internacionales es un pobre alimento que aniquila la tarea del artista, cuando no la vida. Es ingresar en ese trágico desfile de cadáveres vivientes que ya han formado nuestros escritores, desquiciados en su mayor parte por la burocracia como en el caso de "Viernes", aletargados por las relaciones públicas como en el caso de "Contrapunto", domesticados por un compromiso absurdo como en el caso de los escritores oficialistas. ${ }^{158}$

Enfrentados como lo estaban a la sacralización del arte, los balleneros se adhirieron en un primer momento al informalismo plástico, tendencia que representaba una alternativa al racionalismo abstracto del arte geométrico y les permitía "internarse

${ }^{154}$ Ibid., p. 165. Para los balleneros, "la novedad artística es la vida artística, luego arte viejo es igual a arte muerto." (Ibid.)

155 Ibid., p. 182.

${ }^{156}$ En el "Segundo Manifiesto", aparecido en Rayado Sobre el Techo, no 2 (1963), los balleneros se oponían al arte convencional: "Comenzando por todo el paisajismo tradicional con el que señores gotosos paseaban desde sus habitaciones del Country o Valle Arriba por el cerro del Ávila. [/] Los otros bandos están demasiado señalados, adornados con flores como el señor López Méndez, atestados de demagogia como el Taller de Arte Realista..." (Citado por Héctor Brioso Santos: Estridencia e ironía...op.cit., p. 100)

157 "Nosotros encontramos que esa suerte de neoplasticismo que hacían los geométricos se había transformado en academia, que sus búsquedas no conducirían a nada, excepto a su absorción por el capitalismo y su posterior conversión en mercancía. Contra esto, propusimos un arte destructivo. Ése fue el sentido de la "Necrofilia"." ("Entrevista a Carlos Contramaestre", en Carmen Zarita Díaz Orozco: El mediodía de la modernidad en Venezuela (Arte y literatura en el Techo de la Ballena)", Mérida, CDCHTULA, 1997, pp. 141-142. Citado por Héctor Brioso: Estridencia e ironía ...op.cit., p. 155)

${ }^{158}$ Ibíd., p. 100. Como afirmó el propio Brioso, "el Techo" es "un grupo de artistas polémicos en todos los terrenos y deseosos de alterar un medio ambiente cultural que consideraban viciado e inducido deliberadamente por el poder político.” (Ibíd., p. 131). En “¿Por qué la Ballena?”, Adriano González León se opuso al entorno de la cultura nacional, que según él constituía "un medio beato y conformista". (Citado por Ibíd., p. 143). Una muestra de esta oposición a la institucionalización del arte es su rechazo del informalismo mediada la década del 60 . 
instintivamente en la autenticidad de la materia"159. De hecho, como lo ha señalado Rama, esta tendencia tuvo un peso fundamental en la consolidación del grupo, cuya primera exposición -“Los espacios vivientes” (Maracaibo, 1960)- fue un rechazo explícito al abstraccionismo en boga. A decir del crítico uruguayo-venezolano:

puede estimarse que el informalismo, más que una afiliación estética definitiva, fue una toma de posición rebelde contra el medio [...] Mientras el geométrico habría de continuar su desarrolló triunfal hasta lograr la aceptación y consagración oficial, el informalismo de la hora se adheriría a una posición opositora y protestataria -confusa, ardiente, vulgar, caótica- y buscaría enfrentar los valores que sostenían a la nueva sociedad burguesa venezolana, transformándose en un instrumento de choque y provocación. ${ }^{160}$

Sin embargo, los balleneros se distanciaron de este movimiento cuando percibieron "su progresivo aburguesamiento y su insuficiencia estética"161 para llevar a cabo la renovación radical en la que ellos estaban empeñados. "El Techo" fue, en efecto, mucho más lejos que el informalismo, pues su objetivo fundamental era "generar una fuerte convulsión social y alterar el orden estético" ${ }^{\# 2}$. Por eso en las propuestas del grupo "la expresión y la acción” suplantaron “a la preocupación por la forma”, el objeto artístico se sustituyó "por la acción de crearlo", y "el producto -la obra- por el proceso" ${ }^{163}$. Ejerciendo una violencia paralela a la de los grupos armados, los balleneros llevaron a cabo "un arte de guerrillas, de atentados, una auténtica rociada de

159 Ibid., p. 151.

160 Ángel Rama: "Salvador Garmendia y la narrativa informalista", en Ensayos sobre literatura...op.cit., p. 126.

161 "los balleneros se aferrarán provisionalmente al nuevo credo informalista, para alejarse después de él, entre ironías y burlas, a causa de su progresivo aburguesamiento y su insuficiencia estética para unos artistas empeñados en una renovación mucho más radical. En el intervalo, los miembros del grupo venezolano harán suya una reivindicación informalista tan esencial como el retorno a la materia primera, al caos." (Héctor Brioso: Estridencia e ironía...op.cit., p. 151) "Cuando el informalismo dejó de ser todo lo azaroso y natural que decía ser, dejó de interesar a los artistas balleneros. Entonces los del Techo emprenden una campaña contra el arte informal." (Ibíd., p. 158) "Renuncian los balleneros a ser informalistas como si renegasen de un premio, un salón oficial o una galería, sin advertir que la esencia del movimiento ya los había invadido profundamente." (Ibíd., p. 159)

${ }^{162}$ Ibid., p. 49. "los ismos tienden a justificarse, con razón, por su mismo papel de revulsivos sociales y estéticos, de ejercicios, no sólo de terrorismo artístico, sino de "propaganda por el hecho" (el viejo slogan anarquista), capaces de conmover hasta los cimientos del edificio del arte, la institución crítica, la recepción de los productos de la creación, los gustos del público, etc." (Ibíd., p. 85)

${ }^{163}$ Ibíd., p. 232. Héctor Brioso reconoce con Rama, que "el Techo" fue el "equivalente literario y artístico" de la lucha armada y que los balleneros "imitaron las tácticas de la lucha guerrillera". (Ibíd., pp. 132-133. Las cursivas sobre el texto de Rama pertenecen al propio Brioso). Sin embargo afirma que "este deslizamiento no nos permite, por sí mismo, asegurar que el nacimiento del grupo obedezca a una propuesta de tipo político". (Ibid.) 
explosiones estéticas"164 de modo que no les preocupaba "la exigencia historicista ni la permanencia de las creaciones, sino su efectividad del momento"165. Como la intención del grupo era "agredir y [...] soliviantar la estructura cultural vigente" "166, sus integrantes llevaron a cabo una inversión de los valores estéticos establecidos. Marcados por la exigencia informalista de retornar "a la materia primera" $" 167$, los integrantes de "El Techo" cuestionaron permanentemente las distinciones estéticas entre materiales artísticos y no-artísticos, y reivindicaron la belleza en lo más insólito y vulgar, confiriendo así un estatuto artístico provocador a los desechos y a las miserias que la cultura vigente rechazaba. En esta oposición al arte institucionalizado se acercaron al "arte bruta" de Dubuffet, que proponía un retorno a la creación instintiva o primaria, más allá de cualquier "jerarquía de prestigio o calidad"168, y defendieron "la capacidad de la ballena para vivir por sí misma, es decir, para sobrevivir a los inconvenientes de la estética y la cultura: «La ballena para vivir no necesita saber de zoología»"169. En este sentido, "El Techo" se hacía eco de la tradición anti-intelectual que había inaugurado el futurismo italiano con su "viejo argumento vanguardista de demoler museos y bibliotecas" $" 170$. Por otra parte, la oposición del grupo a las convenciones estéticas determinó que se relegase la noción de autor ${ }^{171}$ y que la mayoría de los textos del grupo fueran "colectivos" y aparecieran "fragmentados en partes, unidos bajo una rúbrica común que no necesariamente los torna[ba] unitarios ni coherentes". De modo que entre

${ }^{164}$ Ibid., p. 235. Este arte de guerrillas surge, al igual que la violencia guerrillera, por oposición a la violencia del gobierno. (Ibíd., p. 235)

165 Ángel Rama: "Salvador Garmendia y la narrativa informalista", en Ensayos sobre literatura...op.cit., p. 121. "aun podría agregarse que sus acciones imitaron las tácticas de una lucha guerrillera, con sus bruscas acometidas, su repentinismo, el manejo de una exacerbada y combativa imaginación." (Ibíd., p. 120)

166 Ibid., p. 121.

167 Héctor Brioso: Estridencia e ironía...op.cit., p. 151.

${ }^{168}$ Ibid., p. 121.

${ }^{169}$ Ibid., p. 55.

${ }^{170}$ Ibid., p. 102.

171 Como lo ha señalado Carmen Virginia Carrillo, los miembros del grupo rechazaron "la noción de autor" a través de la creación de "falsarios." (Carmen Virginia Carrillo: De la belleza y el furor...op.cit., 110) 
las creaciones del grupo fueron habituales ejercicios colectivos como el "collage, el cadáver exquisito, la amalgama plástica y el manifiesto escrito al alimón”"172.

Esta libertad se extendió al empleo del lenguaje, pues la Ballena buscó desde sus inicios un "exceso de expresión"173 y censuró cualquier "contención expresiva, especialmente si ésta lleva[ba] el sello del buen gusto clásico y la educación burguesa"174. En sus textos promovieron una suerte de "promiscuidad verbal""175 e incluyeron lo malsonante y lo escatológico con la intención de provocar a la sociedad y de suspender los cánones establecidos. En relación con esto hay que señalar, además, que en las creaciones del grupo hubo un recurso incansable al azar ${ }^{176}$ y al humor ${ }^{177}$ que, consecuentes con sus postulados, los balleneros emplearon incluso contra sus propias producciones. El objetivo final de todo este radicalismo que los miembros de "El Techo" ejercieron contra la estructura social y cultural vigente consistía en "restituir el magma la materia en ebullición la prótesis de adán"178, es decir, en recuperar una suerte de caos material originario, anterior incluso al hombre mismo. Este anhelo enlazaba con las pretensiones del Romanticismo y de la Vanguardia histórica de retornar a la Edad de Oro del principio de los tiempos, pero en el caso del grupo venezolano hay que ver en

${ }^{172}$ Héctor Brioso: Estridencia e ironía ...op.cit., p. 202.

${ }^{173}$ Ibid., p. 40.

${ }^{174}$ Ibid., p. 249. Como afirma el propio Brioso, en los textos de "El Techo" se da una "tendencia a ofender verbalmente a la sociedad" (Ibíd., p. 249) que enlaza con una tendencia vanguardista a "la escatología verbal" (Ibíd., p. 248). En los textos de "El Techo" "El lenguaje adquiere la facultad verdaderamente vanguardista de crear y destruir el mundo, al ser llevado al colmo de sus facultades combinatorias y expresivas" (Ibíd., p. 257).

175 Ibid., p. 238.

176 Carlos Contramaestre señaló que "lo que realmente nos diferencia de los movimientos políticos tradicionales marxistas es que no había ningún dogma que nos aprisionara, sino que había una profunda libertad, y es esto lo que vamos a proclamar desde nuestras primeras actuaciones en el plano estético, cuando empezamos a crear objetos, a hacer esculturas sin ningún tipo de dogma, ni ataduras políticas o estéticas. Se trataba de entender que había un camino por delante sin límite, abierto, y que la libertad es una arremetida indetenible e imparable." (Citado por Ibíd., p. 134)

177 Ibid., p. 172. Esto conlleva que el propio grupo incorpore "la crítica de sus principios fundamentales dentro de su mismo credo estético: la Ballena es atacada despiadadamente por los balleneros; el Techo es rayado en primer lugar por sus propios constructores." (Ibid., p. 172) (Para la función que cumplió el humor en el grupo vid.ibíd., pp. 165 y ss.)

${ }^{178}$ Carmen Virginia Carrillo: De la belleza y el furor...op.cit., p. 98. 
esta propuesta una voluntad "de destruir las estructuras culturales y sociales alienadas y alienantes"179, es decir, una propuesta esencialmente negativa.

Como es evidente por lo que acabamos de afirmar, "El Techo de la Ballena" presenta una ética opuesta al talante demócrata y moderado de Guillermo Sucre y del sector "oficialista". Las vanguardias suelen ser agrupaciones colectivas minoritarias, condición que les impone la necesidad de hacer proselitismo y de aglutinar a sus miembros ante la sociedad a la que se enfrentan. Esto determina que presenten un carácter violento más o menos pronunciado que asigna un tono asertivo a sus manifestaciones, las cuales pretenden imponer la estética propia y anular las propuestas ajenas. Es evidente además que las vanguardias en general y en particular "El Techo" están enfrentados a cualquier concepción clásica de la sociedad y de la estética, lo que les llevaba a caer en excesos que eran impugnados por quienes, como Guillermo, creían en la esencialidad del arte y del hombre.

A pesar de la radicalidad de la Ballena y de todas las implicaciones que hemos destacado, el grupo se enmarca en el proceso modernizador que caracteriza a la cultura venezolana de esta década, sólo que su puesta al día se inserta en un marco diferente al del oficialismo. También "El Techo" constituye una toma de posición rebelde contra un medio cultural y estéticamente anacrónico, sólo que en su caso el rechazo se cumplió con la virulencia propia de una tradición intelectual vanguardista que en este momento contaba con reflejos similares en Europa y en los EEUU. El ambiente de efervescencia cultural que vivía el país en los primeros años sesenta dio origen a otros grupos con caracteres y pretensiones similares a los de "El Techo", de los que destacaremos tres. “Trópico Uno" se fundó en la ciudad de Puerto La Cruz, al occidente del país, en 1964, y en él participaron, entre otros, Gustavo Pereira, José Lira Sosa y Rita Valdivia. Este

$$
{ }^{179} \text { Ibid., p. } 98 .
$$


grupo siguió "la línea estético-ideológica" de "El Techo" y planteó que "la estética de la subversión [era] la única para alcanzar la libertad creadora"180. El colectivo "Cuarenta grados a la sombra", también de carácter contestatario, nació en Maracaibo en 1964 y en él participaron algunos escritores y pintores que habían pertenecido a "Apocalipsis" (1955-1958) como Miyó Vestrini, Enrique León y Alberto Urdaneta. Por último, en el momento en que empezaron a dispersarse definitivamente los movimientos guerrilleros, se empezó a editar la revista Rocinante (1968-1978), de tendencia socialista, y que actuó de bisagra entre las dos décadas.

\section{3. LA CULTURA DEL “OFICIALISMO” (1962-1968)}

Como hemos visto en el segundo capítulo, después de 1958 la democracia venezolana hubo de combatir a los extremismos políticos que se oponían a su estabilidad (la revolución comunista por un lado y el golpismo militar por otro) y se convirtió en la expresión política de la mesura y del consenso. La problemática que Venezuela vivía a nivel nacional era inseparable de la situación internacional, pues sus enemigos en política interior eran secundados por países vecinos como Cuba o la Republica Dominicana. De este modo, también en política exterior, el Estado venezolano se convirtió en un defensor a ultranza de la democracia y, al menos durante la presidencia de Rómulo Betancourt (1959-1963), no reconoció a ningún gobierno que no hubiera sido elegido mediante procedimientos democráticos. Esta defensa incondicional de la "libertad" frente a la amenaza del totalitarismo convirtió a Venezuela durante este período en un aliado fundamental de los EEUU, que como consecuencia del triunfo de la Revolución cubana (1959) se había visto forzado a cambiar su estrategia continental. Entre el final de la Segunda Guerra Mundial y la

\footnotetext{
${ }^{180}$ Ibid., p. 122.
} 
llegada al poder de Fidel Castro, la política exterior de los EEUU hacia el continente había sido más bien pasiva. En esos años, a través de instituciones interestatales como la Organización de Estados Americanos (OEA), fundada en 1948, y de inversiones privadas, impulsadas con fuerza durante el gobierno de Dwight Eisenhower (19531961), EEUU había conseguido mantener sin problemas el control de los asuntos continentales. Pero el triunfo de la Revolución en Cuba y, sobre todo, el temor a su expansión, hizo imprescindible la adopción de una nueva política hemisférica, que se centró en impulsar el desarrollo económico de América Latina. Esta nueva estrategia se basó en la obra Las etapas del desarrollo económico ${ }^{181}$ (1960) de W. W. Rostow, donde se afirmaba que "el desarrollo autosostenido alcanzado por las sociedades industriales maduras" era "el punto de llegada de todo el proceso histórico". "La moraleja latinoamericana de esa visión de la historia universal era que el riesgo de revolución cesaría cuando el subcontinente alcanzara por fin ese desarrollo autosostenido, y que era por lo tanto urgente impulsarlo en ese sentido" $" 182$. El programa "Alliance for the Americas" puesto en marcha por el gobierno de Kennedy a partir de 1961 es en este sentido emblemático, pues con él los EEUU pretendían invertir en América Latina la suma de 20.000 millones de dólares durante diez años con el objetivo de promover la mejora económica de la región y frenar el auge de los movimientos revolucionarios. De este modo, mientras que en los años cincuenta EEUU había dado su apoyo a regímenes dictatoriales como los de Pérez Jiménez o Batista (por citar sólo dos), a partir de los sesenta se empezó a interesar por gobiernos reformistas y moderados, es decir, por aquellos que, como era el caso de la Venezuela democrática, "buscasen reformar, pero

${ }^{181}$ W. W. Rostow: The Stages of Economic Growth: A Non-Communist Manifesto, Cambridge, Cambridge University Press, 1960.

182 Tulio Halperin Donghi: Historia contemporánea de América Latina, Madrid, Alianza, 1994, p. 539. Es evidente el marcado carácter occidentalista del libro de Rostow y, en general, de todas las políticas desarrollistas que se implementaron durante esta etapa en América Latina. 
también preservar, la estructura de relaciones económicas y sociales existente"183. El carácter centrista y consensual de la democracia venezolana, su inspiración liberal, el apoyo decidido al empresariado y a los intereses norteamericanos y sus avances en políticas sociales, la convirtieron a ojos de los EEUU en el modelo político perfecto que oponer a la Revolución cubana.

La cercanía entre las posiciones políticas de Venezuela y de los EEUU durante este período de máximo apogeo de la Guerra Fría dio lugar a una coincidencia en las estrategias ideológicas de ambos países ${ }^{184}$. Ello motivó que el Estado venezolano favoreciera el mismo concepto de la cultura y de las artes que durante este período el Congreso por la Libertad de la Cultura (organismo cultural fundado por la CIA en 1953 cuyo objetivo era contrarrestar la influencia comunista durante la Guerra Fría) estaba promocionando a nivel internacional. Ya desde finales de los años 50, el Congreso venía suavizando la imagen anticomunista que había asumido en los comienzos de esa década ${ }^{185}$ y "destinó todos los recursos disponibles" a impulsar la "desmilitarización de la cultura"186. El objetivo fundamental (como en el caso de la "Alianza para el progreso") era lograr el "apaciguamiento ideológico" e impedir que se produjeran nuevos alzamientos revolucionarios. Para ello, el Congreso adoptó la consigna del "fin de las ideologías", con la que pretendía "generar la desilusión con respecto al socialismo [...], demostrar lo innecesario de la revolución, probar que se puede llegar a los mismos fines sin pasar por ninguna ruptura violenta, desalentar de este modo todo impulso

${ }^{183}$ Fernando Coronil: The Magical State...op. cit., p. 229. Traducción mía.

${ }^{184}$ Esto no era producto de la casualidad, pues en los años 40 Rómulo Betancourt se había inspirado políticamente en el Discurso de las cuatro libertades, pronunciado por Roosevelt en 1941 y en la Carta del Atlántico, suscrita en agosto de 1941 entre Roosevelt y Churchill. (Vid. Naudy Suárez Figueroa: "Pensar, plantar, curar la democracia en Rómulo Betancourt", prólogo a Rómulo Betancourt: Selección de escritos políticos (1929-1981), Caracas, Fundación Rómulo Betancourt, 2006, p. 13)

${ }^{185}$ Durante los años 50, este organismo intervino en esa batalla de ideas que fue la Guerra Fría lanzando una "ofensiva liberal a escala internacional" y tratando "por todos los medios de contrarrestar los mitos pro-soviéticos." (María Eugenia Mudrovcic: Mundo Nuevo. Cultura y Guerra Fría ...op.cit., p. 14)

$$
{ }^{186} \text { Ibid., p. } 18 .
$$


revolucionario $\mathrm{y}$, subrepticiamente, convalidar el statu quo" ${ }^{\text {187 }}$. Además, para que cundiera esta desideologización era necesario que el enfoque ideológico asumido por el poder se presentara como la norma, esto es, que ocultara o diera por hecha su propia posición.

En el caso de la Venezuela de los años sesenta, lograr el "apaciguamiento ideológico" y generar el máximo consenso posible en torno a la democracia se convirtió, como hemos visto, en uno de los objetivos fundamentales de la política interior. En el Pacto de Punto Fijo (1958) la democracia venezolana se conformó a sí misma como un régimen político que, al mantener satisfechos a todos los grupos políticamente significativos del país, resumiría las aspiraciones políticas del pueblo venezolano. Ello implicaba una igualación entre el fin de la política y el sistema democrático que, al presentarse a sí mismo como la norma consensual, se erigía en el estandarte de la moderación y la cordura ante los extremismos de derecha y de izquierda. Por homología estructural, en el contexto de radicalización política, pero también cultural y estética de los años sesenta, el Estado venezolano impulsó una cultura liberal y occidentalista que se presentaba a sí misma como la norma, con lo que denunciaba implícitamente cualquier orientación que se alejase de sus postulados. Para lograr la desmilitarización cultural de los bandos contrarios al consenso, los medios culturales del Estado se ocuparon de exaltar "las bondades prácticas del diálogo" y "la tolerancia"188, y establecieron una separación radical entre la cultura y la política que les llevó a impulsar la estética de modernidad ${ }^{189}$, fundada en los conceptos de la autonomía y del universalismo.

187 Ángel Rama: "Los intelectuales en la época desarrollista", en Marcha, Montevideo, 27 de mayo de 1966, p. 31.

${ }^{188}$ María Eugenia Mudrovcic: Mundo Nuevo...op.cit., p. 19.

${ }^{189}$ Para la explicación de este concepto vid. supra nota. 116, p. 47. 
La intervención del Estado venezolano en la cultura alcanzó una dimensión verdaderamente importante a partir del momento en que Simón Alberto Consalvi ${ }^{190}$ asumió la presidencia del INCIBA en 1965. Así como el gobierno de Raúl Leoni (19641968) había cambiado de estrategia con respecto a la guerrilla tratando de reintegrar a los antiguos combatientes a la política parlamentaria, el INCIBA intentó desmilitarizar la cultura y lograr la progresiva unificación del campo literario en torno al sector oficialista, tarea que para 1968 se podía considerar concluida. Para alcanzar la unanimidad en torno a la posición consensual, los organismos culturales del Estado "hicieron esfuerzos por tender el puente roto entre la izquierda cultural y el resto del mundo venezolano" ${ }^{, 191}$. Adoptaron para ello una actitud inclusiva y dialogante que, bajo la bandera de la tolerancia y de la solidaridad, implicaba en realidad el apoyo a una idea esencialista y desideologizada de la cultura ${ }^{192}$. Al mismo tiempo, el vínculo del INCIBA con las posiciones artísticas más avanzadas de Occidente, cuyas características eran el internacionalismo cultural, el vanguardismo estético, la autonomía literaria y el componente crítico, fue un gancho atractivo para la izquierda cultural ${ }^{193}$.

${ }^{190}$ A la muerte de Consalvi, Guillermo Sucre publicó un artículo donde repasaba su trayectoria y su legado para la cultura venezolana. (Vid. Guillermo Sucre: "Consalvi, la diplomacia inteligente", en Letras Libres, México, núm. 175, jul. 2013, pp. 38-40)

${ }^{191}$ Rafael Arráiz Lucca: "Las tareas de la imaginación. (La cultura en el siglo XX venezolano)", en Germán Carrera Damas et al.: Comprensión...op.cit., p. 190.

${ }^{192}$ La estrategia adoptada por el INCIBA levantaba sospechas ya en 1970. Como afirmó Chacón en ese año: "La «amplitud» con que la nueva administración del INCIBA resuelve su problema político de limar las antiguas asperezas con la izquierda para dotar al Gobierno de un parapeto cultural que hasta entonces le había sido negado, le permite dar la impresión de que esta organización es la gran auspiciadora de lo nuevo en la cultura y que no hay contradicción entre las expectativas de los intelectuales y los favores del Gobierno, o como muchos sin duda preferirán, el Estado venezolano. La culminación de este proceso ocurre con la fundación de la Editorial Monte Ávila, una empresa que se declara abierta a todas las corrientes." (Alfredo Chacón: "Trayectoria ideológica de la izquierda cultural venezolana 1958-1968", "Prólogo" a La izquierda cultural...op.cit., p. 18. La cursiva corresponde a la negrita del original)

${ }^{193}$ Como afirma Ranciére, la concepción del arte moderno como arte de la autonomía fue establecida por teóricos marxistas porque "se trataba de demostrar que, si la revolución social había sido confiscada, en el arte se había mantenido en cualquier caso la pureza de la ruptura con lo que ella comportaba de promesa de emancipación." Sin embargo, "más tarde esta complicada dialéctica se borró en un dogma simple sobre el arte moderno como arte de la autonomía." (Jacques Ranciére: El tiempo de la igualdad...op.cit., p. 204) 


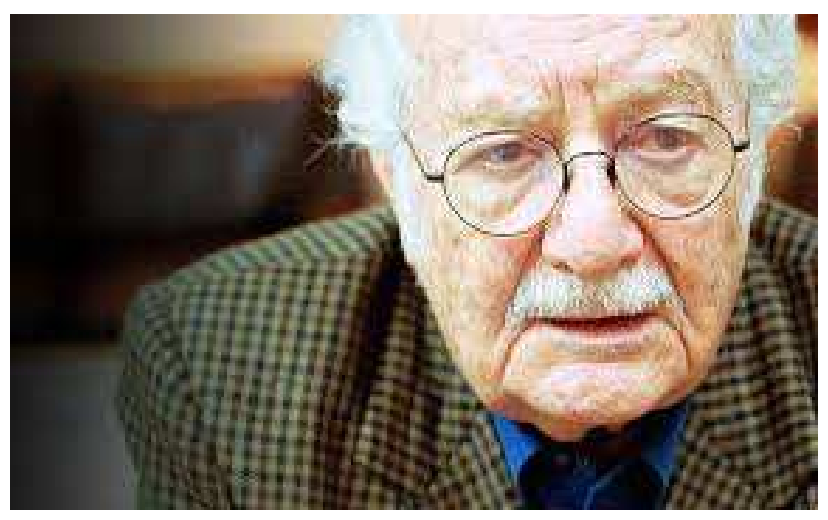

Imagen 13. Simón Alberto Consalvi (1927-2013), director del INCIBA durante este periodo.

Un ejemplo de la manera de proceder del Estado venezolano con respecto a la cultura se puede apreciar si nos acercamos críticamente a la premiación de que fue objeto La casa verde (1966) de Vargas Llosa, en la primera edición del Premio Internacional de Novela Rómulo Gallegos, de ese mismo año. Aunque se repitió hasta la saciedad que el Premio se concedía únicamente por criterios estéticos (que era, por tanto, "una demostración, en fin y por circunstancias obvias, de que en este Concurso sólo ha privado la razón cultural, el más absoluto respeto a la inteligencia, fueren cuales fueren los riesgos que comporte"194), lo cierto es que "el público latinoamericano no pudo dejar pasar por alto que la entrega se producía en momentos en que Venezuela elevaba una queja contra Cuba en la OEA"195. Como Vargas Llosa se contaba entonces entre los escritores partidarios del régimen cubano, premiarle resultaba simbólicamente muy rentable, pues se conseguía a un tiempo probar la independencia de juicio del Estado venezolano, defender una actitud inclusiva que suponía una concepción esencial y despolitizada de la literatura, apropiarse simbólicamente de un autor afecto a la

\footnotetext{
${ }^{194}$ Simón Alberto Consalvi: "Un premio inobjetable", discurso de concesión del Premio Rómulo Gallegos, en Mundo Nuevo, París, núm. 17, nov. 1967, pp. 92-93.

${ }^{195}$ María Eugenia Mudrovcic: Mundo Nuevo...op.cit., pp. 162-163.
} 
Revolución y quizás, obligar al gobierno cubano a tomar partido, como pensaba Monegal que sucedería ${ }^{196}$.

En el contexto de los años sesenta, al apoyar a la literatura internacionalista y vanguardista propia del canon liberal defendido también por el Congreso por la Libertad de la Cultura, el Estado venezolano representaba un tercer estilo de acción cultural, que le distinguía de la estrategia adoptada por otros Estados latinoamericanos:

Frente al intervencionismo cultural y al estrangulamiento económico que propició el Estado autoritario argentino, o frente al agresivo disciplinamiento encarado por el estado nacionalista mexicano, la política oficial que adoptó el Estado venezolano en los 60 representa, sin duda, un tercer estilo de acción cultural. A mediados de la segunda mitad de la década, cuando el resto de los oficialismos latinoamericanos asistían perplejos a los procesos de politización de la vanguardia artística y se resistían a seguir patrocinándola, el Estado venezolano no sólo premia (liberal y ostentosamente) al boom de novela latinoamericana, sino que encara también un explosivo proyecto de modernización y expansión de toda su industria cultural. $^{197}$

La promoción estatal de la cultura tuvo un primer espacio en la página literaria

"Letras y Artes", dirigida por Guillermo Sucre, Luis García Morales y Martín Cerda, que apareció en el diario oficialista La República entre 1962 y 1964. En el año en que desapareció este suplemento inició su andadura la revista Zona Franca, dirigida por Juan Liscano y con Guillermo Sucre y Luis García Morales como únicos miembros del Consejo de Redacción. Si bien esta última publicación no fue financiada directamente por el Estado venezolano, se situó ideológicamente en la órbita oficialista, como lo demuestran sus vínculos con el ILARI ${ }^{198}$ y con la gran familia de revistas liberales del

196 "En una carta a Jorge Luis Recavarren, miembro del ILARI peruano, Rodríguez Monegal escribió lo siguiente: [/] "Con respecto a Vargas Llosa, te ruego que no escribas nada en contra de él. Mario está haciendo un esfuerzo muy grande por conservar la amistad con los cubanos y no perderla del todo conmigo. Yo tengo esperanza de que él finalmente rompa con los cubanos. Estos se están poniendo cada vez más energuménicos [sic] y resulta bastante difícil seguirlos. Por otra parte, como es casi seguro que le den el premio Rómulo Gallegos a Mario, él va a ir a Venezuela al Congreso de Caracas que se reúne a principios de agosto y al cual yo voy a ir también. Estoy casi seguro que si le dan el premio R.G. y si Mario acepta, los cubanos le van a escribir una de esas famosas cartas abiertas como la que le escribieron a Neruda. Este es mi cálculo y por eso te pido que no provoques ninguna colisión entre Mario y nosotros. En este juego en que estamos metidos, querido Jorge Luis, no hay más remedio que tener paciencia." (Rodríguez Monegal 1967c) [/] La ruptura que Rodríguez Monegal deseó en 1967, ocurrió sí, pero cuatro años después, en 1971, cuando el caso Padilla.” (Citado en Ibíd., p. 163)

${ }^{197}$ Ibid., pp. 161-162.

198 Estas siglas corresponden al Instituto Latinoamericano de Relaciones Internacionales, organismo creado por el Congreso por la Libertad de la Cultura: "La etapa de revitalización [de la imagen del Congreso] comenzó en 1962 con el nombramiento de Keith Botsford y Luis Mercier Vega como 
continente. A partir de 1965 (con la llegada de Consalvi a la presidencia del INCIBA) se organizó el Premio Internacional de Novela Rómulo Gallegos (1967), Guillermo Sucre creó la revista Imagen (1967) y nació la editorial Monte Ávila (1968), en cuya fundación participó nuestro autor junto a Consalvi y Benito Milla. Este último fue el primer director de la empresa y para ello vino expresamente del Uruguay donde había sido director de la editorial Alfa y de la revista Temas, y corresponsal de Mundo Nuevo $^{199}$. Durante estos años, el INCIBA auspició además la celebración del XIII Congreso del Instituto Internacional de Literatura Iberoamericana (IILI), celebrado en Caracas en agosto de 1967, y un simposio convocado por la "Fundación Interamericana para las Artes" 200 a principios de noviembre del mismo año.

Al regresar a Venezuela en 1962, Guillermo Sucre se encontró con que el Estado comenzaba a ceder espacios y recursos para promocionar una concepción cultural y estética que él mismo compartía. Su estancia de tres años en París le había familiarizado

«representantes itinerantes permanentes del Congreso» en América Latina [...] y culminó a principios de 1966 cuando Josselson fundó el Instituto Latinoamericano de Relaciones Internacionales (ILARI). Con la creación del ILARI como órgano legalmente independiente, el Comité Ejecutivo lograba así reemplazar al desacreditado Departamento Latinoamericano del Congreso por la Libertad de la Cultura sin necesidad de renunciar a sus aspiraciones sobre la región. [...] Reflejando preocupaciones familiares al Congreso, el ILARI se interesó por la formación de las élites liberales en América Latina y manifestó especial inclinación hacia las ciencias políticas y sociales. [...] el ILARI figuró desde el primer número como «organismo asociado» a Mundo Nuevo; es decir que fue -de entrada- la «cara pública» y la fachada financiera de la revista que dirigía Emir Rodríguez Monegal." (Las citas están tomadas de Ibíd., pp. 2526)

199 Ibíd., p. 45. Seguramente Milla llegó a la dirección de Monte Ávila recomendado por Emir Rodríguez Monegal, que en esta época mantenía una correspondencia con Simón Alberto Consalvi. Benito Milla también había publicado en Zona Franca y en la propia revista Mundo Nuevo y se trataba de un intelectual claramente vinculado con "la gran familia liberal" del continente. En la serie de artículos que Ángel Rama publicó en Marcha sobre las relaciones de los intelectuales latinoamericanos con el Congreso por la Libertad de la Cultura decía tener "tímidas sospechas" de la vinculación de Benito Milla con el citado organismo: "Qué cosa sea en verdad ese tan mentado "Congreso por la Libertad de la Cultura", nadie mejor para decirlo en nuestro medio que el Dr. Aldo Solari [...] o el Sr. Benito Milla, librero-editor director de una revista de orientación similar al Congreso, y de una sala de arte y cultura que paga dicho Congreso. Mientras ambos guarden silencio, se podrán barajar respecto a ese organismo, las prevenciones que formulara hace unos meses Carlos Real de Azúa en estas páginas." (Ángel Rama: “Tímidas sospechas", en Marcha, Montevideo, 6 de mayo de 1966, p. 29. El artículo fue respondido por sendas cartas de Solari y Milla, publicadas bajo el título de "Réplicas" en Marcha, Montevideo, 13 de mayo de 1966, pp. 28-29)

${ }^{200}$ A este Simposio Guillermo le dedica un editorial en Imagen (Guillermo Sucre: "El intelectual y nuestro tiempo", en Imagen, Caracas, núm. 13, 15/30 nov. 67, p. 2) y se refiere a ese evento al hablar de su relación con Nicanor Parra. (Vid. supra nota 32, p. 14). Como lo explica el propio Sucre, este Simposio trataba de favorecer la relación entre los escritores norte y suramericanos, con lo que contribuía a la concordia y a la desideologización de la cultura. 
con las revistas de corte liberal que se editaban en Francia y le había permitido además adentrarse con profundidad en la tradición de la poesía moderna que, desde Baudelaire a Valéry, se fundaba en el valor de la autonomía y que proponía una separación radical entre la literatura y la vida. Por eso, en las revistas que editó o en las que colaboró entre 1962 y 1968, Sucre adoptó muchos de los “ideologemas” de la prensa "libre” y defendió un canon estético de modernidad, en que "la promesa de emancipación" no se sostiene más que al precio de "mantener la distancia entre la forma disensual de la obra y las formas de la experiencia ordinaria” ${ }^{, 201}$. Esto confirma que Guillermo tomó partido en esa "guerra"202 surgida en los años sesenta y que en ella promovió explícitamente la cultura liberal y "despolitizada" que en ese momento le interesaba defender al Estado venezolano. Con ello no queremos decir que nuestro autor se sometiera a una estrategia ajena: lo que sucedió más bien fue que Sucre concebía el arte y la literatura en términos semejantes a los que a las instituciones estatales les interesaba en ese momento impulsar o favorecer.

\section{3. 1. “LETRAS Y ARTES”, LA PÁGINA LITERARIA DE LA REPÚBLICA (1962-1964)}

El regreso de Guillermo Sucre a Venezuela se produjo en el momento en que la guerrilla y la vanguardia cultural estaban en su período de mayor actividad, pero nuestro autor respaldó firmemente la gestión gubernamental y se posicionó en contra de los insurgentes. En julio de ese mismo año $1962^{203}$ fundó junto al chileno Martín Cerda y al venezolano Luis García Morales una página literaria dominical, "Letras y Artes", que se publicó en el diario oficialista La República hasta los primeros meses de 1964. La

${ }^{201}$ Jacques Ranciére: "Políticas estéticas”, en Sobre politicas estéticas...op.cit., p. 34.

${ }^{202}$ En una entrevista, Juan Liscano afirmó a propósito del primer quinquenio de los sesenta: "Se trataba de una guerra, y hay que tener eso muy claro. Y en esa guerra todos tomamos partido." (Entrevista hecha por Tomás Eloy Martínez: "Un hombre nunca se despierta de la misma manera", en "El Papel Literario" de El Nacional, Caracas, 4 de abril de 1976)

${ }^{203}$ El primer número de la página "Letras y Artes” apareció el 22 de julio de 1962. El título alternó hacia el final de la publicación con el de "Letras y Arte" que me parece más fiel al contenido de la revista, en cuanto que trató sobre todo de literatura y artes plásticas. 
estancia de Sucre en París durante los tres años anteriores, además de permitirle estrechar o establecer lazos con intelectuales como Picón Salas, Octavio Paz o Alejandro Rossi, le valió para entrar en contacto con la teoría literaria francesa más actual (el estructuralismo y la nueva crítica) y con revistas de corte liberal como Les Lettres Nouvelles, France-Observateur o L`Express, que en los años por venir serán para nuestro autor una referencia y una fuente de material. Además de los directores de la página citada, en ella participaron con asiduidad Elisa Lerner, Juan Sánchez Peláez ${ }^{204}$, César Dávila Andrade ${ }^{205}$, Manuel Quintana Castillo, y Pierre de Place, los cuales a lo largo de la década intervendrán también en otros medios oficialistas.

La página literaria estuvo dividida en tres secciones, "Las literaturas. Los libros. Los autores" -firmada por Martín Cerda-, "Crónica literaria" -donde publicaba preferentemente Guillermo Sucre-, y otra, de contenido variable, que se dedicaba a un autor o una obra que se quería reivindicar o a las artes plásticas, que tuvieron mucha presencia en la publicación.

${ }^{204}$ Juan Sánchez Peláez (1922-2003), poeta venezolano de gran influencia en el siglo XX. En su juventud vivió en Chile donde se relacionó con los poetas surrealistas del grupo "Mandrágora". Al volver a Venezuela publicó Elena y los elementos (1950) libro que transformó el panorama poético del país. Otras obras suyas son Animal de costumbre (1959), Filiación oscura (1966) y Rasgos comunes (1975). Guillermo Sucre analiza su obra en el capítulo "La metáfora del silencio" de La máscara, la transparencia.

${ }^{205}$ César Dávila Andrade (Cuenca, Ecuador, 1918-Caracas, 1967), escritor ecuatoriano que vivió y trabajó en Venezuela. Su obra está compuesta por poesía y narrativa breve. Entre sus libros más importantes están Catedral salvaje (1951) y Arco de instantes (1959). 

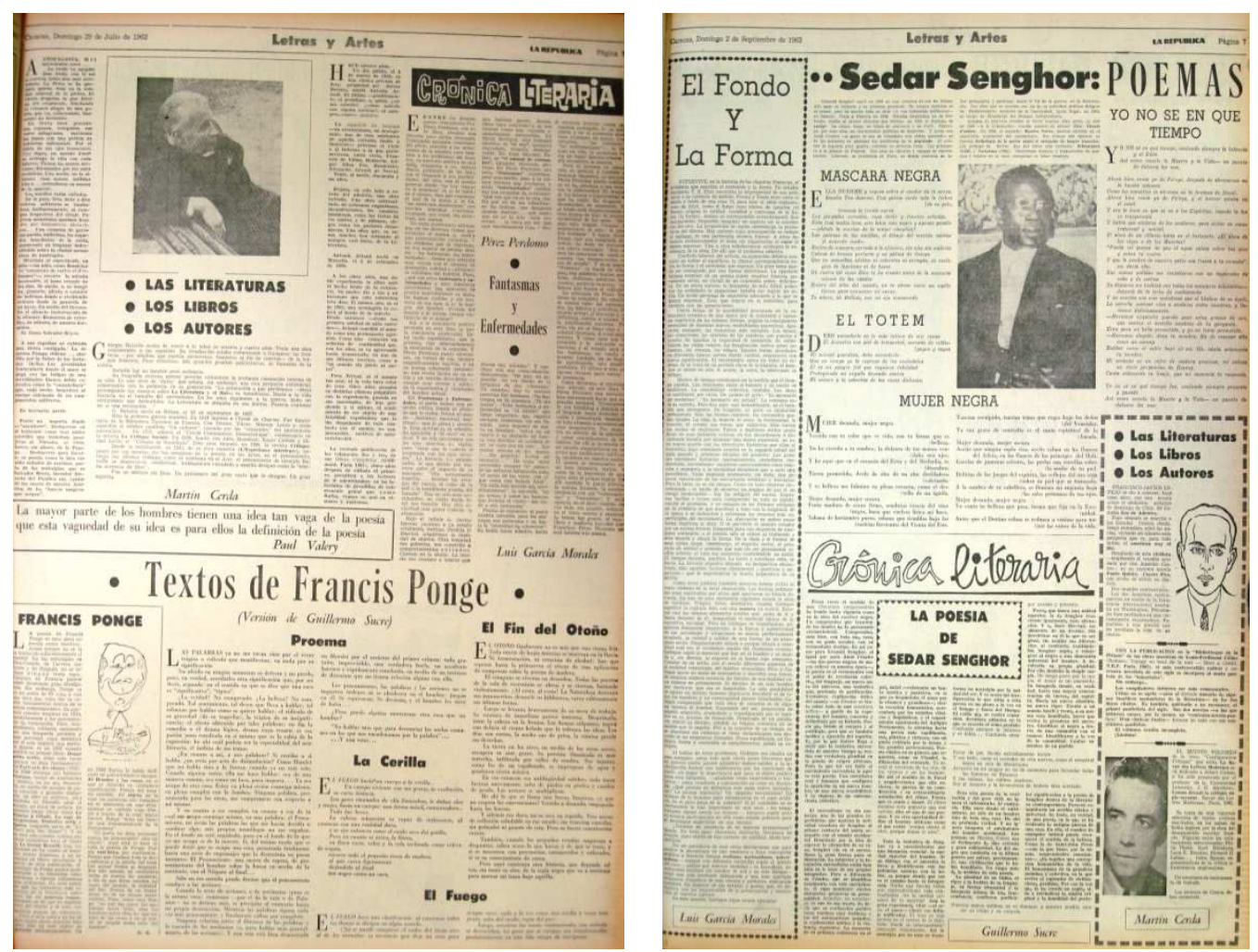

Imágenes 14 y 15. Dos números de la página literaria “Letras y Artes”.

El espacio de Martín Cerda funcionó como una ventana abierta a la actualidad editorial francesa $\mathrm{y}$, en menor medida, a las novedades publicadas en Italia, Chile, España y Venezuela. El objetivo era tender puentes con la cultura francesa, que conformaba el centro del canon liberal y occidentalista que desde la página se quería promocionar. En su bloque, el crítico chileno comenzaba por mencionar la edición de una obra o una efeméride particular (un aniversario o una publicación) para, a partir de allí, trazar una reseña biográfico-literaria del autor que se pretendía introducir al público venezolano. Atenta sobre todo al catálogo de Gallimard y Pierre Seghers, esta sección dio cuenta de la publicación de la Correspondencia de Flaubert, de las Obras Completas de Artaud, del Gilles de Drieu La Rochelle, de las Obras maestras de Céline, de una selección de Restif de la Bretonne, etc. Y además reivindicó, entre otros, a Tristan Tzara, Jean Cocteau, Samuel Beckett, Valery Larbaud, Ortega y Gasset, e. e. 
cummings, Robert Frost, Alfonso Reyes, Vicente Huidobro, Joaquín Edwards Bello, Benjamín Subercasseaux, y Luis Cernuda.

La sección "Crónica literaria” -en la que además de Guillermo Sucre escribieron regularmente Elisa Lerner y Luis García Morales- se ocupó sobre todo de reseñar obras de autores venezolanos. Estas se leían a partir un sistema de valores "objetivo": la estética de modernidad, que se sustentaba en las nociones de autonomía y universalidad, y que desde la página se ofrecía como el modelo para el desarrollo de la literatura nacional. Algunas de las críticas publicadas en este bloque fueron positivas, como las dedicadas a Antonio Arráiz y Enriqueta Arvelo Larriva ${ }^{206}$, pero también hubo valoraciones negativas como las que recibieron Uslar Pietri, Guillermo Meneses y Miguel Otero Silva ${ }^{207}$. Al enfrentarse a grandes personalidades de la cultura nacional, "Letras y Artes" evidenciaba que su único compromiso lo establecía con la propia literatura y que se mantenía al margen de vicios como el arribismo y la corruptela cultural que ya se habían denunciado desde las páginas de Sardio. En este bloque se escribió también sobre Francisco Pérez Perdomo, Juan Calzadilla, Manuel Pedro González, Antonio Stempel París, Pascual Venegas Filardo, Serrano Poncela, Oswaldo Trejo, y tuvieron cabida autores extranjeros como Jorge Gaitán Durán, Anne Langfus (Premio Goncourt 1962), Vicente Aleixandre, Witold Gombrowicz y Octavio Paz.

Además de estas dos secciones, el espacio principal de la publicación presentaba un carácter de antología, cosa que la crítica ha destacado también a propósito de Sardio $^{208}$. Este apartado central se dedicó a familiarizar al lector con la obra de autores que formaban parte del canon de la modernidad que en la página literaria devino un

\footnotetext{
${ }^{206}$ Guillermo Sucre: "La poesía de Antonio Arráiz", en La República, Caracas, 23-09-62, p. 7 y Guillermo Sucre: "Enriqueta Arvelo Larriva", en La República, Caracas, 16-12-62, p. 7.

${ }^{207}$ Guillermo Sucre: "Uslar Pietri. Un retrato en la geografía", en La República, Caracas, 22 de julio de 1962, p. 7. Guillermo Sucre: "Guillermo Meneses. La misa de Arlequín”, en La República, Caracas, 14 de octubre de 1962, p. 7. Guillermo Sucre: "La muerte de Honorio: un buen testimonio, no una novela", en La República, Caracas, 12 de enero de 1964, p. 7.

${ }^{208}$ Vid. supra el fragmento que remite a la nota 137, en p. 54.
} 
sinónimo de la idea misma de literatura. El procedimiento consistía, normalmente, en publicar una introducción a la obra del autor, acompañada de una mínima selección de su obra y de fragmentos en prosa donde el propio autor resumía su poética. De esta manera, la página literaria ofrecía a sus lectores las herramientas para hacerse una idea (aparentemente objetiva) de la poética del escritor. Sin embargo, como los fragmentos procedían de una selección previa, eran en realidad los directores de "Letras y Artes" quienes definían de qué manera los autores publicados debían ser leídos. En este apartado principal aparecieron textos (muchas veces traducidos por el propio Sucre o por su mujer, Julieta Fombona) de y sobre Francis Ponge, Lawrence Durrell, Paul Eluard, Vicente Huidobro, Octavio Paz, Pierre Reverdy, Gonzalo Rojas, Cesare Pavese, Vicente Gerbasi, César Vallejo, Robbe-Grillet, Fernando Pessoa, Jorge Luis Borges, Andrés Voznessenski, Alejandra Pizarnik, Blas de Otero, Maurice Blanchot ${ }^{209}$, Yorgos Seferis, Alain Fournier, Sedar Senghor, Saint-John Perse, Jacinto Fombona Pachano, etc. En esta sección central también se publicaron entrevistas a Jorge Luis Borges, Marguerite Duras y Julio Cortázar -estas dos últimas realizadas por Alejandra Pizarnik quien, desde París, colaboraba habitualmente con la página literaria. Otras veces el espacio central se dedicaba a ensayos sobre artes plásticas, como "Presencia de Georges Braque" y "La intuición en arte" de Manuel Quintana Castillo, "Trascendencia plástica de la escultura africana" de Pedro Briceño o "Encuentro con Oswaldo Vigas" de José Mascarell, entre muchos otros. En "Letras y Artes" se publicaron además poemas de Octavio Paz ${ }^{210}$, Dylan Thomas, Alejandra Pizarnik, Guillermo Sucre, Luis García Morales y César Dávila Andrade, así como un cuento de Baica Dávalos.

\footnotetext{
${ }^{209}$ El texto de Blanchot está traducido por Guillermo Sucre: "Sobre la crítica literaria", en $L a$ República, Caracas, 5 de enero de 1964, p. 7.

${ }^{210}$ De Octavio Paz se publicó un poema inédito que el escritor mexicano le envió a Sucre desde Nueva Delhi. (Octavio Paz: “Un día en Udaipur”, en La República, Caracas, 08-12-63, p. 7)
} 
Si bien "Letras y Artes" careció de un manifiesto o de un editorial donde se formularan explícitamente las intenciones de la publicación, eso no le impidió tener una discursividad claramente definida. Una de las constantes del suplemento fue su voluntad de introducir al lector venezolano en una concepción liberal de la cultura e impulsar la tradición modernista que para los redactores de la página constituía la definición misma de la literatura. Con el fin de lograr estos objetivos se ampararon en el concepto de autenticidad, que será fundamental en la teoría literaria que nuestro autor formuló a lo largo de toda la década. Un escritor es auténtico cuando su escritura responde exclusivamente a un requerimiento íntimo, vital; es decir, si establece una necesidad entre su carácter o su destino y su creación artística. Cuando se cumple esta coincidencia, la obra escapa de todos los excesos que convierten a la literatura en una expresión falsa. La escritura auténtica trasciende entonces todas las desmesuras éticas y estéticas con que se puede encontrar la literatura: no cae en el formalismo ni en el “contenidismo", no se somete a modelos foráneos sin haberlos asimilado previamente y rechaza cualquier nacionalismo o pintoresquismo artístico. Por lo tanto, el concepto de autenticidad resume los dos pilares básicos sobre los que se asienta la estética literaria de Sucre que es, por extensión, la de la página literaria: la autonomía y el universalismo.

Los tres directores de "Letras y Artes" defendieron esta noción de la autenticidad, aunque cada uno a su manera. Como de la concepción literaria de Sucre nos ocuparemos más adelante, pasamos ahora a referir de qué manera Cerda y Morales trataron esta idea. El crítico chileno reclamó la autenticidad literaria pero definiéndola al contrario, es decir, indicando en qué situaciones un escritor resulta inauténtico o "tramposo":

Escribir es, en sí mismo, un acto destinado al prójimo. Un esbozo (cuando no una súplica) de convivencia. Pero es aquí, en el umbral de esta cuestión disputada, donde suele irrumpir la trampa en la Literatura. Donde se presencia el escritor tramposo. Porque, crease o no, también en la literatura trabaja la trampa. Se la descubre en la zapa de los maestri d'inganni. Pero ¿cuándo trampea un escritor? Por ahora, diremos que lo hace: 1.- Cuando altera el sentido 
de lo real. (Supóngase una novela donde se intente mostrar la "humanidad" de la esclavitud). 2.Cuando adultera el desenvolvimiento factual de lo real. (Supóngase una obra donde Polonia figure invadiendo, en 1939, al Reich de Hitler). 3.- Cuando silencia o encubre las situaciones límite de su mundo. (Supóngase un escritor de la Independencia "absolutamente" extraño a ese proceso). 4.- Cuando embarga su obra al dictado. Es decir, cuando se alínea en una propaganda. (¿Será necesario invocar un caso posible?). ${ }^{211}$

Para el ensayista chileno, como vemos, el escritor está siempre comprometido, sólo que su compromiso lo debe establecer dentro del lenguaje y no con imposiciones que relegarían la literatura a una simple función ancilar.

El escritor es su palabra. Palabra es la urdimbre de su obra. [...] La Literatura supone siempre un mínimo de consciencia reflexiva. No se escribe sin más. Es preciso tener conciencia del oficio de escribir. No basta adelantar una obra hacia el público, si previamente dicha obra no adelanta lo que Roland Barthes denomina la moral del lenguaje. (Es sobre este plano de consideraciones que debe, plantearse a mi entender, la cuestión de la "literatura comprometida." Cuestión espinuda en buena medida por culpa de sus corifeos que no siempre deslindan el orden de la literatura del de la propaganda. La escritura, del dictado). ${ }^{212}$

Por su parte, Luis García Morales, en su artículo "El Fondo y la Forma", rechazaba tanto a aquellos escritores que anteponían el significado al significante como a aquellos que caían en el error opuesto ${ }^{213}$. Ambos excesos suponían que el autor no estaba siendo fiel a sí mismo, pues en el primer caso sometía la escritura a fines extraliterarios y en el segundo convertía la literatura en una simple mímesis de lo extranjero. Ante estas desproporciones, García Morales proponía un término medio, es decir, la fiel correspondencia entre fondo y forma:

Hay autores cuya preocupación se reduce al hallazgo de una perfección técnica, formal. A otros les seduce exclusivamente el tema sin importarle el cómo lo deben expresar. Una u otra exuberancia arriesgan la excelencia de la obra. De allí que el problema subsista. Conflicto interior del artista, su aspiración debiera consistir en hallar el equilibrio, la clásica correspondencia entre la forma y el contenido que expresa. ${ }^{214}$

García Morales señalaba además que el mismo desajuste que advertía a nivel individual se producía cada vez que las nuevas generaciones ascendían al campo

${ }^{211}$ Martín Cerda: s/t, en la sección "Las literaturas. Los libros. Los autores", La República, Caracas, 7 de abril de 1963, p. 7.

${ }^{212}$ Ibíd. En este párrafo es evidente la lectura de la obra Le dégré zéro de l'écriture, de Barthes. Este teórico fue fundamental también para el pensamiento del propio Guillermo Sucre.

${ }^{213}$ García Morales rechazaba así la caída en los excesos expresivos, que será una constante de la crítica de Guillermo Sucre durante este período.

${ }^{214}$ Luis García Morales: "El Fondo y la Forma" en La República, Caracas, 02-09-1962, p. 7. En este texto se aprecia una cierta influencia de Borges y de su concepción de la literatura como repetición. 
literario, como era el caso del momento en que escribía. Siempre que tiene lugar un cambio histórico y se impone la necesidad de ser actual o moderno,

[f]alsos y legítimos estilos proliferan en esos instantes críticos, en esa desordenada o disciplinada batalla por alcanzar una nueva expresión, un tono nuevo acorde con las directrices históricas que rijan el momento. [...] Tales impulsos promueven, sin duda, una general renovación de las estructuras estéticas y literarias. Pero la tarea no es sin riesgos. Como toda empresa desmesurada -el hecho de inventar ya implica de por sí un riesgo incalculable- hay los peligros del exceso. Espíritus tardíos o torpes para comprender en toda su significación el problema, o se rezagan en las formas antiguas en la creencia de que marchan a tono con la exigencia de la época o se desbordan y extreman los recursos más superficiales del movimiento. $\mathrm{La}$ aberración en ambos casos torna ilegítima la obra. $\mathrm{O}$ se pervierte el sentido creador por un exceso formal, búsqueda pura con desprecio de cualquier contenido; o el interés sólo se atiene al contenido y éste inunda y ahoga la forma. De la duda y el frenesí de esos ciclos surge, sin embargo, el espíritu rector, el principio de unidad y armonía que aun sin ser plenamente visible orienta al cabo ese momento confiriéndole un estilo. ${ }^{215}$

El autor del artículo que citamos encontraba el mejor ejemplo de "espíritu rector" en la figura de Rómulo Gallegos, que como novelista "captó lo esencial que hay en el hombre y su mundo y, sin desvíos, lo expresó en la forma más adecuada”. Por eso, ante los desvíos que advertía en algunos sectores de la generación joven, lo proponía como modelo:

Al hablar de estos problemas, Gallegos nos resulta un caso ejemplar, sobre todo ante cierta joven literatura que, en nuestro medio parece adjudicar mayor validez a la investigación formal con indiferencia por las cuestiones fondo, sin negar la importancia que para el objeto poético tiene esta búsqueda -saludable como experimento o tentativa- como resultado o culminación su valor es discutible. ¿Qué postula en definitiva este nada nuevo formalismo? La pureza expresiva? Un singular hermetismo? Un rechazo de lo humano para embelesarse en el puro artificio, en el puro juego de la palabra? Si el contenido no es ciertamente lo más importante de una obra -los temas humanos siguen siendo los mismos-, tampoco puede serlo su mínima participación en ella como simple pretexto para el despliegue superficial de una técnica. [...] Sin ser partidario de esas otras desviaciones que para ocultar la desventura de una mediocre o falsa concepción estética o literaria llaman realismo, nacionalismo o universalismo -aunque con diferente intención según el caso-, pienso que nuestra realidad -la dramática, insoslayable realidad del hombre de acá y de este tiempo- exige una más profunda indagación y una más acertada respuesta. Exigencia de más sincera y auténtica dedicación creadora. En especial de sus artistas y poetas que, en definitiva, son los responsables de la preservación y renovación de nuestra cultura. ${ }^{216}$

De este modo, los miembros de la publicación se ampararon en el valor de la autenticidad para hacer pasar por la norma el canon liberal y occidentalista que defendían y, correlativamente, para desterrar los excesos expresivos del convulso campo cultural venezolano de los años sesenta. Sin embargo, a diferencia de lo que había

\footnotetext{
${ }^{215}$ Ibid., cursiva nuestra.

${ }^{216}$ Ibid.
} 
acontecido en Sardio, en esta página literaria no se trató de política abiertamente. Como era propio de las revistas liberales de este período, el tema se abordó sobre todo a través de referencias al mundo soviético que tendían a inducir un estado de opinión favorable al consenso, es decir, al ideario liberal. Cuatro artículos de "Letras y Artes" trataron directamente el tema de la cultura en los países comunistas: "La actual poesía soviética", "La vida intelectual en Budapest", "Krushev y la libertad de creación” y "Un comunista aristócrata (I) y (II)". Tomados en su mayoría de revistas liberales francesas, estos artículos revelan el vínculo de "Letras y Artes" con estas publicaciones y muestran la labor de "caja de resonancia"217 que ejercía esta página literaria. Los ensayos ponían de relieve la dicotomía entre, por un lado, el mundo socialista, la censura y la represión y, por otro, el "mundo libre" y la libertad de creación. El primero de estos artículos, "La actual poesía soviética”, es una traducción de Guillermo Sucre de un artículo de Pierre Forgues aparecido en el número 25 de Les Lettres Nouvelles, dedicado a la literatura rusa. En él se ponía el acento en la poesía soviética que se desmarcaba del oficialismo y trascendía cualquier dimensión ideológica. El siguiente ensayo de tema similar aparecido en "Letras y Artes" es uno de René Etiemble, editado originalmente en France-Observateur y traducido también por Guillermo Sucre. En él se trataba sobre "La vida intelectual en Budapest", es decir, sobre la apertura cultural que Hungría estaba viviendo después de las revueltas de 1956. En este trabajo, Etiemble se mostraba satisfecho por los cambios políticos logrados en el país centroeuropeo y se alegraba por la celebración de un congreso de literatura comparada, disciplina hasta entonces vedada por motivos políticos:

Y sobre todo es en Hungría, en Budapest, donde se realizó [...] un congreso internacional de literatura comparada -el primero organizado en el mundo socialista desde la muerte de Stalin. Que una disciplina sospechosa de liberalismo, de "cosmopolitismo" y aun de "formalismo", se vea ahora reconocida, estimulada, brillantemente representada en Budapest por sabios de los cuales algunos habían padecido el jdanovismo, es algo que da ánimo; que los

${ }^{217}$ La expresión es de María Eugenia Mudrovcic: Mundo Nuevo...op.cit., p. 45. 
yugoslavos estuviesen presentes y no los albaneses, era buen signo. Que una verdadera discusión se haya entablado entre polacos y rusos, entre húngaros y rusos, entre franceses y rusos, era enormemente placentero. La Asociación verdaderamente internacional de literatura comparada es desde ahora posible. ¿Quién lo hubiese imaginado hace seis años [en 1956] ${ }^{218}$

El ensayo de García Morales "Kruschev y la libertad de creación” es el único con este tema escrito por un miembro de la página literaria ya que los otros proceden de versiones francesas. En él, el crítico y poeta venezolano denunciaba que la supuesta libertad que el mandatario soviético había prometido para los artistas en 1956 no se estaba cumpliendo y que, pese al anuncio de apertura ideológica, el partido seguía prohibiendo ciertas manifestaciones estéticas ${ }^{219}$. Además, en la página literaria apareció un fragmento del libro La Rebelión del Espíritu, de los húngaros Tamás Aczél y Tibor Méray $^{220}$, publicado en Francia. En esta obra, sus escritores -que habían sido "stalinianos, distinguidos con premios literarios y halagados por los jerarcas oficiales"se veían "retrospectivamente a sí mismos con admirable y dramática lucidez: como

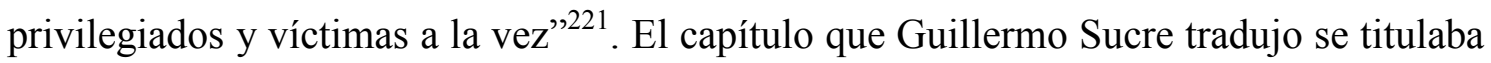

\footnotetext{
${ }^{218}$ René Etiemble: "La vida intelectual en Budapest”, en La República, Caracas, 16-12-62 y 23$12-62$, p. 7.

${ }^{219}$ Luis García Morales: "Kruschev y la libertad de creación”, en La República, Caracas, 17-03-
} 1963, p. 7. Con la llegada de Kruschev y del período del "deshielo", nos dice García Morales, "Luego de tantos años oprimidos, el arte y la literatura estallan. El creador socialista reivindica el poder de la palabra. Acoge con entusiasmo la rebelión estética. Estancado, degradado, a la zaga de la revolución económica, el mundo artístico de la Unión Soviética va a hacerse, por primera vez!, revolucionario. [/] Pero ¿qué ocurre? Esta perspectiva de pronto resulta intolerable. La revolución no permite la libertad de creación. Y el juez supremo de la inteligencia soviética [Kruschev] condena por traidores a quienes pretenden revelar sin coacciones el estado de espíritu de un pueblo y de una época. ¿Qué persiguen estas medidas? El retorno a la era del silencio? [...] La rebeldía estética y literaria, es decir: la libertad, es entonces incompatible con el sistema comunista? Es, entonces, tan frágil "la sólida" estructura soviética que a los pocos meses de conceder el permiso para expresarse libremente urge la intervención oficial para poner cese a lo que el Kremlin considera "traición". Y esa "traición" no es el esfuerzo del hombre soviético por reivindicar su derecho a decir la verdad? [/] Desgraciadamente, imagino, quienes viven directamente el problema, ya no podrán responder. Y veremos todavía al poeta de la U.R.S.S., frente al dilema, ahora renovado, que mencionaba Pierre Forgues [en el artículo traducido por Sucre:]: «después de la muerte de Stalin, los poetas han tenido que conquistar para la poesía el derecho de existir, es decir, de ser otra cosa que la ejecutante de las simples consignas del Bureau Político»."

${ }^{220}$ Tamás Aczél (1921-1994), escritor húngaro ganador de los premios Kossuth (1949) y Stalin (1952) de literatura. Desencantado con el comunismo durante este periodo, apoyó al Primer Ministro Imre Nagy durante la rebelión de 1956. Al caer Nagy, se exilió a los EEUU, donde fue profesor de literatura. Tibor Méray (1924), intelectual húngaro, ganador del premio Kossuth (1953). Desafecto con el sistema comunista, apoyó también a Imre Nagy, para después exiliarse en Londres y París. En 1992 ganó el premio Pulitzer. Algunas obras suyas traducidas a otros idiomas son The Enemy (1958), Thirteen Days That Shook the Kremlin (1959), The Revolt of the Mind (1959) y On Burchett (2007).

221 Este comentario sobre los autores aparece sin firma en la sección "En Síntesis", en $L a$ República, Caracas, 22-9-62, donde se informa sobre la publicación en Francia de La Rebelión del 
"Un comunista aristócrata"222 y estaba dedicado al filósofo Gyorgy Lukács. En él se

hablaba de un Lukács ajeno a la disciplina totalitaria del partido, lo que, sin dejar de ser

cierto, suponía insistir en la idea de una cultura y de un intelectual despolitizados.

Cuando el autor de El alma y las formas (1911) regresó a su país procedente de Moscú

en 1945, nos dicen los autores, "existía un partido notablemente jerarquizado, regido

por una disciplina de hierro, emprendedor y audaz, irresistiblemente lanzado en el

camino hacia el poder, mientras que en el dominio de la cultura estaba Gyorgy Lukács y

sus pacientes explicaciones, su indulgencia para con las debilidades humanas, sus

distracciones profesorales, su invalorable experiencia y su cigarro entre los labios"223.

Paralelamente a la denuncia del oprobio comunista, en "Letras y Artes" se valoró muy positivamente a los escritores "libres", es decir, a aquellos que habían conseguido mantener su independencia intelectual y literaria, como Vallejo ${ }^{224}$,

Espíritu, de los húngaros Tamas Aczel y Tibor Meray. Presumo que el comentario es de Guillermo Sucre, quien luego traduce el artículo para la página literaria. Una estrategia característica del bando liberal de la Guerra Fría era promocionar defecciones de escritores y sobre todo apoyarse en intelectuales desencantados. Eso se advierte, por ejemplo, con el caso de Dumont, tratado en el ensayo de Mundo Nuevo "Notas sobre Cuba", de Fejtö. Dumont era un agrónomo francés que había colaborado con Castro pero que había roto con el régimen. Como nos dice Mudrovcic, "Para la revista [Mundo Nuevo], Dumont tiene valor por haber sido, antes que nada, una figura cercana a la revolución cubana. El éxito o la garantía del proceso de polarización que venimos describiendo depende, en gran medida, de la puesta en marcha de mecanismos de expropiación simbólica a través de los cuales Mundo Nuevo convierte en propios los valores de su otro-ideológico. Esto quiere decir que a la revista no le importa tanto el disenso per se sino explotar el plus ideológico que al acto de disentir adjunta el hecho de haber consentido antes." (María Eugenia Mudrovcic: Mundo Nuevo...op.cit., p. 87)

${ }^{222}$ Tamas Aczel y Tibor Meray: "Un comunista aristócrata", I y II, en La República, Caracas, $13-10-63$ y $20-10-63$, p. 7.

${ }^{223}$ Ibíd., 13-10-63, p. 7. Un poco antes se había señalado, en el mismo sentido, que Lukács: "Difería de los demás "moscovitas" [húngaros que se habían exiliado en Rusia, stalinistas en su mayoría] en que nunca trataba de imponer sus opiniones a la fuerza." Más adelante, Aczel y Meray indicaban que Lukács estuvo "dominado por un perpetuo desgarramiento entre los imperativos del Partido y los de su conciencia." De lo que se trataba era de establecer una relación entre el intelectual y la ética democrática.

224 En el número que la página literaria dedicó a la figura de Vallejo se destacaba la independencia que el poeta peruano supo mantener frente a las imposiciones doctrinarias: "Vallejo es hoy el poeta por excelencia: en su poesía desnuda, sin halagos ni mistificaciones, encarna la conciencia del hombre contemporáneo. Mientras la poesía de otros -regocijados "mandarines" de la Revolución- ha servido para cantar crueles y pequeños fetiches que la historia se ha encargado de derrumbar, la de Vallejo aún conserva toda su heroica y admirable autenticidad." (Nota de la redacción, en La República, Caracas, 14-04-63, p. 7). Se establecía así una oposición entre Vallejo y Neruda que Sucre ya había planteado en su artículo "Sobre Pablo Neruda”, en Sardio, Caracas, núm. 3-4, sept.-dic. 58, pp. 254-256. 
Reverdy $^{225}$, Paul Éluard, etc. Así, lo que Martín Cerda valoraba a propósito de Jean

Cocteau era precisamente su compromiso con la libertad, que lo era también con la autonomía literaria:

«Les habla -leíamos en su célebre 'Lettre aux Américains'- uno de los últimos hombres libres, con todo lo que encierra de soledad y de falta de electores el hecho de ser libre. No puedo pretender ser apoyado por ningún grupo, por ninguna escuela, por ninguna iglesia, por ningún partido...» [/] Era la voz que precisábamos. Una voz irreductible, consciente de los riesgos que pesan, en nuestro mundo, sobre aquellos que, desafiando las censuras de diestra o de siniestra, toman la palabra en su debida magnitud autónoma, poniéndola al servicio de la libertad humana. De una libertad en acto, que se prueba a sí misma, como un discurso rebelde, disconforme. De una libertad que comienza siendo la propia voz, como lo fue la propia obra [...] de Jean Cocteau [...]. Nadie podrá extrañarse que, tarde o temprano, los historiadores coincidan en hablar del tiempo de Cocteau, como, en nuestros días, se habla del tiempo de Apollinaire. Estaremos orgullosos, sin duda alguna, de haber vivido la larga aventura de este tiempo. ${ }^{226}$

El 16 de febrero de 1964 se editó el último número de la página literaria con participación de Guillermo Sucre y Martín Cerda, con lo que se daba por finalizado un proyecto iniciado en julio de 1962. Luis García Morales había abandonado antes "Letras y Artes" para asumir la dirección de la Revista Nacional de Cultura desde su número 158-159, correspondiente a la edición de mayo-agosto de 1963. Durante este período nuestro autor publicó en ella varias reseñas, y también participó con algunos ensayos en Sur, la revista bonaerense que en ese momento dirigía el escritor Héctor A. Murena ${ }^{227}$, amigo personal de Juan Liscano.

${ }^{225}$ Martín Cerda: s/t, en la sección "Las literaturas. Los libros. Los autores", en La República, Caracas, 7-4-63, p. 7.

${ }^{226}$ Martín Cerda: s/t, en la sección "Las literaturas. Los libros. Los autores", en La República, Caracas, 13-10-63, p. 7. Cerda reivindicó asimismo el universalismo de Valéry Larbaud, que fue "uno de los escritores franceses más abiertos, más francos al rumor del gran mundo, reivindicando, en forma ejemplar, el concepto de cosmopolitismo literario. [/] Larbaud fue el gran cosmopolita. [/] El gran cosmopolita que, por encima de los malentendidos, por encima de la perfidia de los diccionarios, supo hacer no sólo de las letras, sino, en verdad de la Tierra, el horizonte de su actividad literaria, del mismo modo como, en nuestras tierras, lo ha hecho Jorge Luis Borges, este argentino que ha rescatado para América su originaria función universal. [...] Larbaud hizo, con los medios espectrales de la poesía, aquello que no pudieron hacer la Sociedad de Naciones, ni que, al parecer, ha podido hacer las Naciones Unidas. Hizo que el espíritu, la hominidad trascendiera, superara las limitaciones que, por un azar de la razón, los hombres habían establecido en la tierra." (Martín Cerda, en "Las literaturas. Los libros. Los autores", en La República, Caracas, el 12-1-64, p. 7)

${ }^{227}$ Héctor A. Murena (Buenos Aires, 1923-1975) fue un escritor argentino de ensayo, narrativa y poesía. Entre sus obras fundamentales podemos citar: El pecado original de América (1954), Homo atomicus (1962), y La metáfora y lo sagrado (1973). Después de dirigir la revista Sur fue corresponsal de Mundo Nuevo en Buenos Aires (Vid. María Eugenia Mudrovcic: Mundo Nuevo...op.cit., p. 45) y dirigió la Colección de Estudios Alemanes de Monte Ávila, posiblemente cuando el director de esa editorial era Juan Liscano. 


\section{3. 2. ZONA FRANCA. REVISTA DE LITERATURA E IDEAS (1964-1966)}

En septiembre de 1964, tan solo unos meses después del final de "Letras y Artes", Juan Liscano fundó la revista Zona Franca, que nació con Guillermo Sucre y Luis García Morales al frente del Consejo de Redacción. Si bien no recibió financiación directa del Estado, esta revista ha sido considerada por la crítica la publicación pionera del oficialismo ${ }^{228}$. Nosotros pensamos que su discursividad entronca en parte con la línea iniciada en Sardio y continuada en "Letras y Artes". Y decimos “en parte” porque mientras Sucre participó en Zona Franca su proyecto cultural no tuvo vía libre, sino que tuvo que coexistir con el de Liscano.
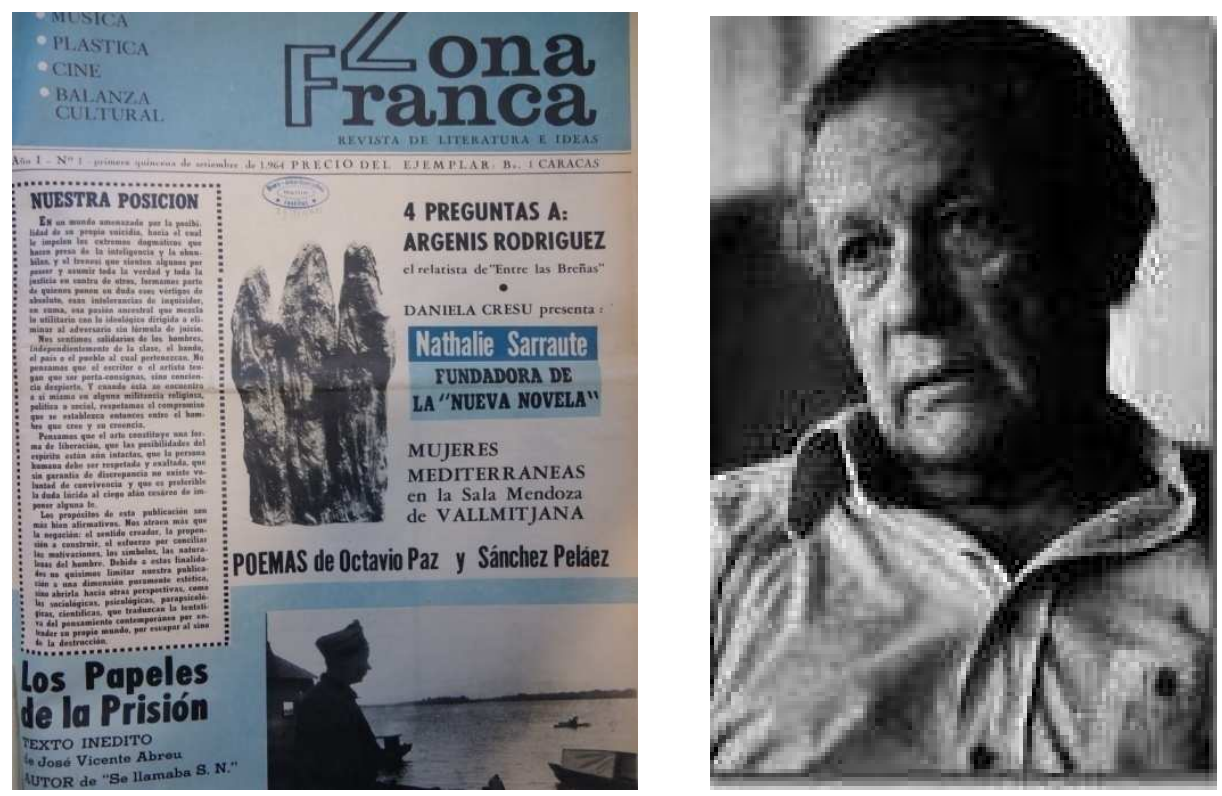

Imágenes 16 y 17. El primer número de Zona Franca y Juan Liscano (1915-2001), director de la publicación.

La revista Zona Franca se creó por la necesidad que tenían, tanto el Estado venezolano como los intelectuales demócratas, de ejercer una influencia en el ámbito de la cultura, que en este momento (tanto a nivel nacional como continental) estaba

228 Ángel Rama: "Salvador Garmendia y la narrativa informalista", en Ensayos sobre literatura...op.cit., p. 106. 
dominado por sectores de la izquierda revolucionaria ${ }^{229}$. Como indicó el propio

\section{Liscano:}

La revista nació por razones ideológicas. Esa fue la razón inicial. En esa etapa, de ascenso del castrismo, había en Venezuela una serie de revistas de orientación muy decidida, guerrillera y pro-castrista. Algunos intelectuales nos sentimos un poco perdidos en esa situación, y decidimos fundar una revista, Guillermo Sucre, Luis García Morales y yo. Desde un principio se planteó que no iba a ser una revista de combate, que no iba a caer en la polémica, sino que simplemente iba a abrir un espacio para poderse expresar uno con toda la libertad que quería. Así nació y así fue. A medida que se fue atenuando la pugna política y fueron desapareciendo las revistas de izquierda, alineadas con el castrismo y guerrilleros, también Zona Franca fue cambiando, hasta convertirse, de manera clara, sobre todo al final de la primera etapa, en una revista abierta a todos los jóvenes de América Latina, cualquiera que fuese su posición ideológica o política. Ese fue uno de los factores que más contribuyeron a darla a conocer y a ganar prestigio dentro y fuera del país. ${ }^{230}$

Por ello, como era característico de la prensa liberal en esta época, desde el principio Zona Franca planteó "la necesidad de «coexistencia» y «convivencia civilizada» entre los intelectuales" y "la urgencia de un «diálogo no-ideológico»"231.

Así, en su primer editorial, "Nuestro propósito", podemos leer:

En un mundo amenazado por la posibilidad de su propio suicidio, hacia el cual le impelen los extremos dogmáticos que hacen presa de la inteligencia y la obnubilan y el frenesí que sienten algunos por poseer y asumir toda la verdad y toda la justicia en contra de otros, formamos parte de quienes ponen en duda esos vértigos de absoluto, esas intolerancias de inquisidor, en suma, esa pasión ancestral que mezcla lo utilitario con lo ideológico dirigida a eliminar al adversario sin fórmula de juicio. [/] Nos sentimos solidarios de los hombres, independientemente de la clase, el bando, el país o el pueblo al cual pertenezcan. No pensamos que el escritor o el artista tengan que ser porta-consignas, sino conciencia despierta. Y cuando ésta se encuentra a sí misma en alguna militancia religiosa, política o social, respetamos el compromiso que se establezca entonces entre el hombre que cree y su creencia. [/] Pensamos que el arte constituye una forma de liberación, que las posibilidades del espíritu están aún intactas, que la persona humana debe ser respetada y exaltada, que sin garantía de discrepancia no existe voluntad de convivencia y que es preferible la duda lúcida al ciego afán cesáreo de imponer alguna fe. ${ }^{232}$

${ }^{229}$ Como ha señalado un crítico venezolano, “en esa etapa se dio en Venezuela la paradójica circunstancia de que los gobiernos de turno y los sectores ideológicamente identificados con ellos tenían el poder político, el militar, el religioso y el económico, pero no ejercían ningún dominio, ni siquiera un influencia medianamente poderosa, sobre la actividad intelectual, especialmente en el ámbito de los escritores y de los artistas." (Alexis Márquez Rodríguez: "La revista Zona Franca (1964-1984)", en VVAA: Le discours culturel...op.cit., p. 238)

${ }^{230}$ Juan Liscano afirma esto en una entrevista que le concedió a Alexis Márquez Rodríguez. (Ibid., p. 240)

${ }^{231}$ María Eugenia Mudrovcic: Mundo Nuevo...op.cit., pp. 16-17. La intención de esto, como sabemos, era lograr la desmilitarización de la cultura.

${ }^{232}$ S/f: "Nuestra posición", en Zona Franca, Caracas, año I, núm. 1, 1/15 sep. 1964, portada. Aunque el texto aparece sin firma, se supone que fue escrito por Juan Liscano, el director de la publicación. Este editorial continúa: "Los propósitos son más bien afirmativos. Nos atraen más que la negación: el sentido creador, la propensión a construir, el esfuerzo por conciliar las motivaciones, los símbolos, las naturalezas del hombre. Debido a estas finalidades no quisimos limitar nuestra publicación a una dimensión puramente estética, sino abrirla hacia otras perspectivas, como las sociológicas, psicológicas, parapsicológicas, científicas, que traduzcan la tentativa del pensamiento contemporáneo por entender su propio mundo, por escapar al sino de la destrucción." 
Aparte de esta voluntad de establecer un diálogo conciliador de las diferencias ideológicas, en la revista se defendió un "modelo liberal-humanista"233 de cultura, es decir, una cultura autónoma y universalista cuyo valor fundamental era la autenticidad. En un texto escrito a propósito del segundo aniversario de la publicación, después de agradecer su apoyo a los patrocinadores, anunciantes y suscriptores, Juan Liscano señalaba a modo de balance:

Hemos tratado de superar cualquier nacionalismo y regionalismo, en aras de un sentir continental y planetario. En una época puesta bajo los signos contradictorios de la destrucción nuclear y psicológica, de la conquista espacial y de la mutación humana, nos hemos trazado un propósito: afirmar un humanismo sin limitación de modas y lugares, y cuidarnos de esa rebeldía y de ese nihilismo cotizados a buen precio en los mercados del arte y de la literatura, y los cuales, por lo tanto, constituyen una nueva retórica y una actitud sin autenticidad. ${ }^{234}$

El posicionamiento político y el modelo de cultura de Zona Franca coincidían en buena medida con lo que había venido proponiendo Guillermo Sucre. Sin embargo, nuestro autor no pudo desarrollar aquí su proyecto con la misma libertad con que lo había hecho en las publicaciones que hemos tratado anteriormente. Si bien la revista de Liscano dio mucha importancia a la literatura e incorporó textos de creación ${ }^{235}$, se preocupó también, como lo indica el subtítulo de la publicación, por las “ideas” y dio cabida a temas mitológicos y religiosos del gusto del director. Además, en una decisión que seguramente no gustó a Sucre, el director de Zona Franca rechazó expresamente dar cabida al boom de la literatura latinoamericana que se iniciaba por esos años ${ }^{236}$, con lo que se distanciaba del vanguardismo estético y del internacionalismo cultural, que eran valores fundamentales de la estética que Sucre quería introducir en Venezuela. Así,

${ }^{233}$ María Eugenia Mudrovcic: Mundo Nuevo...op.cit., p. 58.

${ }^{234}$ S/f: “Segundo aniversario", en Zona Franca, Caracas, año II, núm. 36, ago. 1966, p. 2. Se supone que el texto fue escrito por Juan Liscano, el director de la publicación. La cursiva es nuestra. Como se ve claramente en la cita, la autenticidad era una manera de establecer una concepción "normal" o "natural" de la literatura frente a los excesos nihilistas y rebeldes.

${ }^{235}$ En la revista se publicaron poemas de Sánchez Peláez, Octavio Paz, Homero Aridjis, Montes de Oca, Severo Sarduy, André Breton, René Char, Luis García Morales, Juan Liscano, Guillermo Sucre, etc.

${ }^{236}$ A decir de Arráiz Lucca, esta decisión se debió a que Liscano consideraba que el boom era "una operación comercial editorial." (Rafael Arráiz Lucca: Juan Liscano, Caracas, El Nacional, Biblioteca biográfica venezolana, núm. 74, 2008, p. 53) 
en cuanto a la literatura hispanoamericana Zona Franca reivindicó casi exclusivamente a Borges y a Octavio Paz, que editó en la revista muchos de los artículos que luego integrarían el volumen Corriente alterna (1967). En la publicación de Liscano participaron, además de los miembros del Consejo de Redacción (que a partir del número 25 se amplió con Elisa Lerner, Pedro Briceño, Pierre de Place, César Dávila Andrade, Alfredo Gerbes y Baica Dávalos) autores y críticos como H. A. Murena, Alejandra Pizarnik, Gutiérrez Girardot, Julio Ortega, Martín Cerda, Alain Bosquet, Rafael José Muñoz, Antonio Márquez Salas, Gonzalo Arango, David Alizo, Rafael Grau, Isaac Chocrón, Jorge Medina, Eugenio Montejo, Federico Riu, etc.

El propósito abiertamente ideológico de Zona Franca determinó que su estrategia coincidiera con la que había propuesto el Congreso por la Libertad de la Cultura (y más tarde el ILARI) para América Latina. El vínculo de la publicación con este organismo es evidente por varios motivos. En primer lugar, porque en la revista de Liscano apareció propaganda del ILARI y de las publicaciones financiadas por esta institución como Mundo Nuevo (París), Eco (Colombia), Sur (Buenos Aires), Diálogos (México) etc., y a su vez en ellas se editaron anuncios de la revista venezolana ${ }^{237}$. En segundo lugar, porque participó del "sistema de préstamos internos" que se estableció entre estas revistas (y otras de la gran familia liberal), el cual tenía como objetivo "unificar y estrechar las bases tópicas de la comunidad internacional"238 en torno al ideario compartido. Este sistema se estableció a través de colaboraciones ${ }^{239}$ y corresponsalías. Baica Dávalos, miembro del Consejo de Redacción de Zona Franca,

${ }^{237}$ Por ejemplo, hay propaganda de Zona Franca en Mundo Nuevo, núm. 2 y en el núm. 17.

${ }^{238}$ María Eugenia Mudrovcic: Mundo Nuevo...op.cit., pp. 47-48. Un ejemplo típico de este procedimiento se puede apreciar con la inclusión en Zona Franca del tema de la censura soviética ejercida contra Siniavski y Daniel.

${ }^{239}$ El primer artículo publicado en Zona Franca es uno de Ignazio Silone, miembro destacado de la sección italiana del Congreso por la Libertad de la Cultura, con el título de "El compromiso del intelectual". Homero Aridjis, jefe de redacción de la revista mexicana Diálogos publicó poemas en Zona Franca ("Antes del reino", en Zona Franca, Caracas, núm. 34, junio de 1966, p. 41). H. A. Murena, director de Sur, colaboró también en la revista de Liscano. Guillermo Sucre, por su parte, participó en los números 5 y 19 de Mundo Nuevo, etc. 
era al mismo tiempo delegado en Venezuela de Mundo Nuevo, la revista editada en París por Rodríguez Monegal ${ }^{240}$. Como ha señalado Mudrovcic, gracias a estas corresponsalías "Mundo Nuevo supo despertar adhesión en una minoría letrada que actuó -conscientemente o no- como caja de resonancia a gran escala"241. Estos vínculos entre las diferentes revistas liberales facilitaron, como decimos, que Zona Franca participara del préstamo de información que se estableció entre ellas. Así la publicación dedicó un número prácticamente monográfico (el 34, correspondiente a junio de 1966) a la represión sufrida por los escritores soviéticos Andrés Siniavski y Yuli Daniel. Con ello la revista de Liscano, que evitó tratar de política abiertamente, recuperaba la oposición "censura versus libertad de expresión”, que validaba automáticamente la postura liberal $^{242}$. Zona Franca tomó este tema de la revista Encounter del Reino Unido, que lo había tratado en su edición de abril de 1966. Un mes más tarde que en la revista de Liscano, en julio de ese mismo año, el tema sería abordado en el número inaugural de Mundo Nuevo ${ }^{243}$. El monográfico que Zona Franca le dedicó a esta cuestión se abría con un artículo de Guillermo Sucre titulado "El poder de la literatura". En ese ensayo nuestro autor indicaba que lo que caracterizaba a la literatura era "su espíritu crítico y

${ }^{240}$ Vid. supra nota 74, p. 31.

${ }^{241}$ María Eugenia Mudrovcic: Mundo Nuevo...op.cit., p. 45. "por medio de este dispositivo, conocido en la jerga periodística como «teoría de la mancha de aceite», la revista buscó sensibilizar los centros de decisión intelectual porque eran éstos, en última instancia, los encargados de proyectar sobre el resto de la sociedad determinados códigos, determinados lenguajes y, también, determinadas ideologías. En todo caso, el éxito que los corresponsales de Mundo Nuevo tuvieron en las tareas de promoción y adhesión compensó con creces los déficits que el sistema demostró como productor de actualidad." (Ibíd., p. 46)

${ }^{242}$ Un tratamiento similar de lo político hemos advertido a propósito de "Letras y Artes". En este sentido, la estrategia de estas revistas consistía en "imponer sus propias reglas de juego validando ideologemas que el público tuvo que consumir sin ningún tipo de explicación previa.” (Ibíd., p. 171)

${ }^{243}$ Encounter era una de las revistas financiadas directamente por el Congreso por la Libertad de la Cultura. El vínculo de Zona Franca con la publicación londinense es patente porque toma de ella las ilustraciones de los escritores. El mismo tema es tratado en el número 1 de Mundo Nuevo, en la sección "Documentos". Allí se reproduce el texto de Leopold Labedz: "El proceso de Moscú", sobre la represión sufrida en la URSS por estos escritores, que había sido publicado originalmente en Encounter. En la publicación parisina aparecen además dos artículos sobre el mismo tema de Vargas Llosa y Carlos Fuentes. 
reflexivo" y que, por lo tanto, cualquier atentado contra la libertad y la potencialidad crítica del escritor debía ser denunciado:

Si por algo se ha caracterizado la literatura soviética ha sido por su conformismo, por su alarmante capacidad para aceptar dócilmente las consignas impuestas desde el poder. Sólo una exigua corriente heterodoxa ha tenido el coraje no sólo de poner en cuestión los dogmas del régimen, sino también de salvar el honor mismo de la literatura: su espíritu crítico y reflexivo. ¿Qué sería de una literatura satisfecha o temerosa de ejercer eso que sin duda es su rasgo más inherente? Un gran poeta contemporáneo ha dicho que el escritor es siempre la "mala conciencia" de su tiempo. Y ello es válido tanto para el escritor del mundo occidental como del mundo comunista. De otro modo sería reducir la creación literaria a un puro ejercicio verbal, a una actividad intrascendente. A Andrés Siniavski y Yuli Daniel, sin embargo, se les ha condenado recientemente en Moscú por ejercer el deber de crítica de todo escritor lúcido. ${ }^{244}$

Así Guillermo se hacía eco de la idea de que la literatura, desde su autonomía, era una "insurrección permanente" ${ }^{245}$. Al ensayo de Guillermo le seguían los "Retratos de Siniavski y Daniel”, unas "Notas al margen del proceso de Moscú", y varios relatos de los propios escritores.

${ }^{244}$ Guillermo Sucre: "El poder de la literatura", en Zona Franca, Caracas, año II, núm. 34, jun. 66, pp. 2-3. La cita sigue así: "Tal aberración podría sorprender si no se conociera de antemano el pensamiento oficial soviético frente a la literatura misma. ¿No lo expresó ya un escritor de tanta jerarquía como Cholojov, al afirmar que no se puede escribir en Rusia nada que atente contra los sagrados principios del régimen? Pareciera la otra cara de la tradicional mentalidad burguesa: una suerte de idealismo edificante y optimista que sirva para vivir dentro de los valores ya constituidos." En esta crítica es patente la huella de Barthes, que había señalado que la literatura del realismo socialista copiaba los esquemas de la literatura burguesa clásica: "El realismo socialista francés retomó [...] la escritura del realismo burgués, mecanizando desenfadadamente todos los signos intencionales del arte." (Vid. Roland Barthes: El grado cero de la escritura, Madrid, Siglo XXI, 2005, especialmente el capítulo III: "Escritura y revolución"). De acuerdo al teórico francés, la verdadera literatura era aquella que se situaba más allá de los dogmas, fueran estos burgueses, marxistas o religiosos, y que era, por tanto, capaz de criticarlos.

${ }^{245}$ Vid. infra el apartado IV. 4. "Guillermo Sucre y la estética de modernidad", en pp. 174 y ss. 

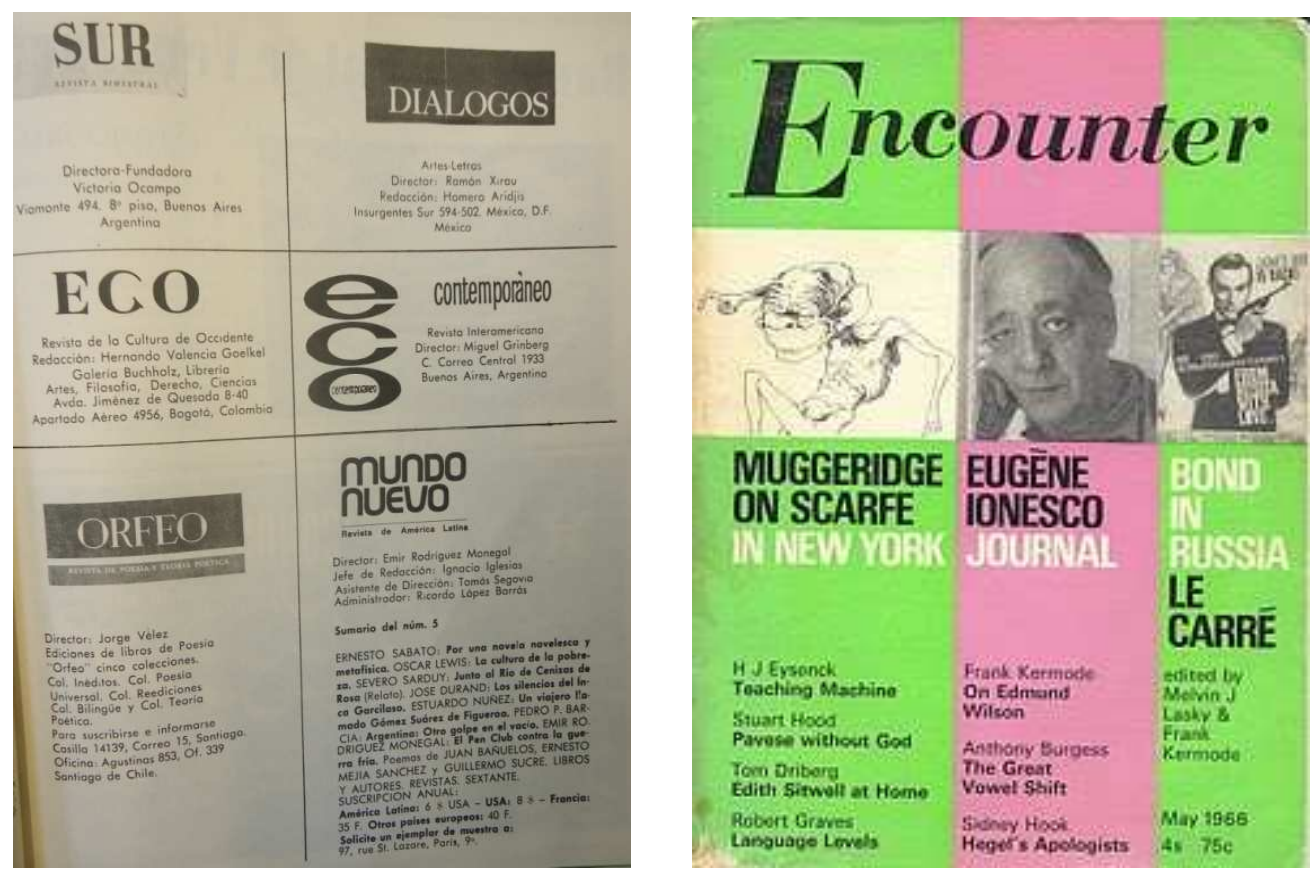

Imágenes 18 y 19. Propaganda de otras publicaciones del ILARI aparecida en Zona Franca y número de la revista Encounter, financiada por el Congreso por la Libertad de la Cultura.

A partir del número 39, correspondiente a noviembre de 1966, Guillermo Sucre se desmarcó del Consejo de Redacción de la revista por "desavenencias intelectuales"246 con su director. Dos años y medio después de eso, en el primer trimestre de 1969, la dificultad de la revista para encontrar financiación hizo que dejara de publicarse temporalmente ${ }^{247}$. Sin embargo, Zona Franca renació, ya sin la colaboración de nuestro autor, en dos ocasiones: vivió una segunda etapa entre 1970 y 1973 y una última y definitiva entre 1977 y $1983^{248}$.

${ }^{246}$ Guillermo Sucre: "Entrevista por escrito, octubre de 2011", infra en Apéndice I, p. 467. Aunque Sucre no especifica el motivo de estas desavenencias, Arráiz Lucca deja entrever que se debieron a diferencias en cuanto a la dirección de la revista. "Mientras convivieron en la publicación Liscano y Sucre, se veía una tensión entre temas literarios (Sucre) y extraliterarios (Liscano). Esta tensión, con la salida de Sucre se resolvió a favor de temas universales que tenían, entre otras, expresión literaria." (Rafael Arráiz Lucca: Juan Liscano, op.cit., p. 53)

${ }^{247}$ El final de la primera etapa se produjo en febrero-marzo de 1969, a la altura del número 66.

248 Después del final de la primera etapa en 1969, Zona Franca resurgió “de nuevo en mayojunio de 1970 con el poeta Rafael José Muñoz en la Jefatura de Redacción y perduró hasta diciembre de 1973, saliendo bimestralmente, cumpliéndose así una segunda etapa en la que se publicaron 22 números. La tercera y última etapa será de mayo-junio de 1977 hasta diciembre de 1983; en ella acompañaron al Director los escritores Alejandro Oliveros, por un lapso breve en la co-dirección, Julio E. Miranda y Oscar Rodriguez Ortiz en las Jefaturas de Redacción [...]. Se hicieron 36 entregas.” (Ibid., p. 52) 
II. 3. 3. IMAGEN. QUINCENARIO DE ARTE, LITERATURA E INFORMACIÓN CULTURAL (19671968)

Al poco tiempo de abandonar la redacción de Zona Franca, Guillermo Sucre fundó la revista Imagen, cuyo primer número salió en mayo de 1967. Esta publicación nació enteramente financiada por el Instituto Nacional de Cultura y Bellas Artes (INCIBA), lo que le concedió una estabilidad económica que le permitió prescindir de la publicidad privada. Durante el año largo en que se mantuvo al frente de la publicación, Guillermo Sucre consiguió conferirle su propio carácter $^{249}$, y eso la aproxima a "Letras y Artes" más que a Zona Franca.
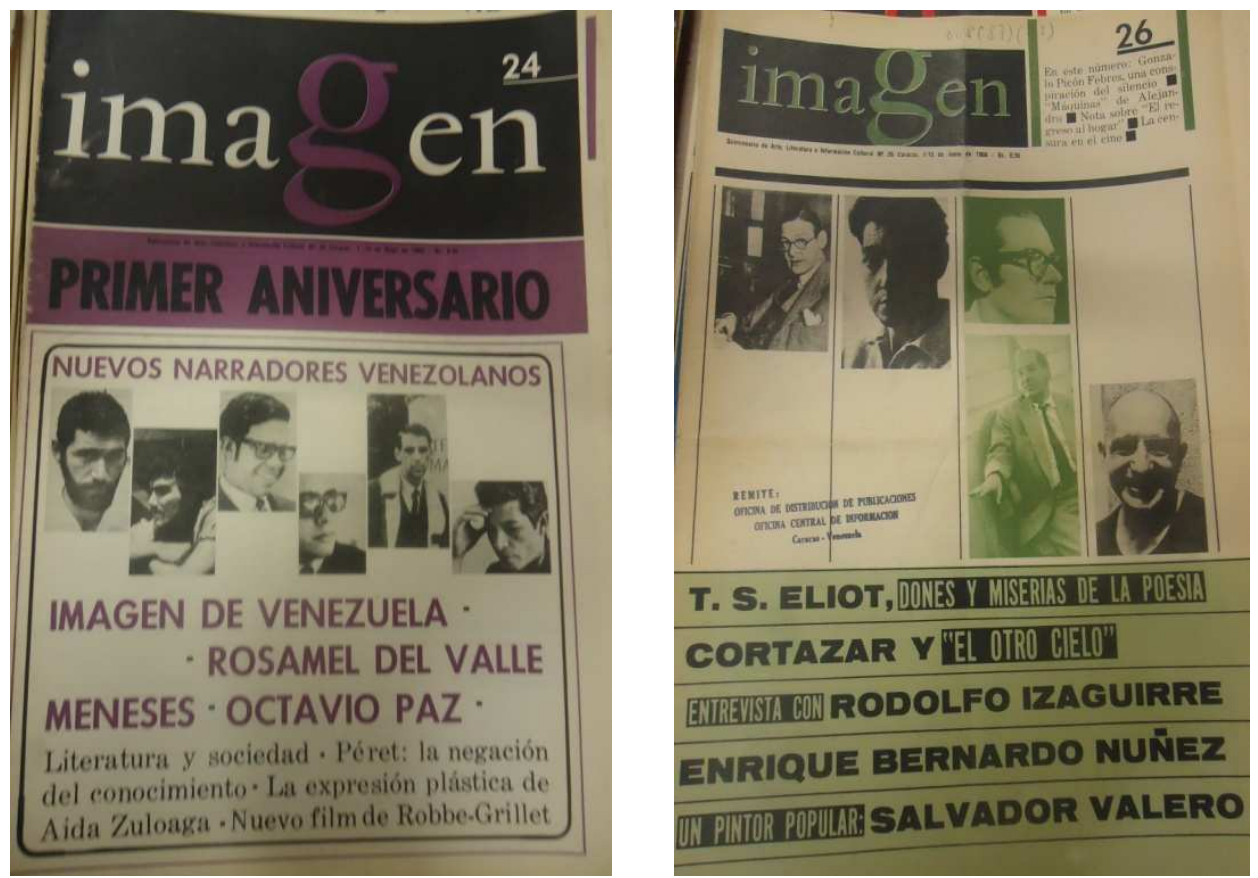

Imágenes 20 y 21. Dos números de la revista Imagen editados durante la dirección de Guillermo Sucre.

Aunque el Comité de Redacción (sobre todo tras su ampliación en el número 7) estuvo formado esencialmente por escritores como Juan Sánchez Peláez, Oswaldo

${ }^{249}$ A decir de François Delprat, la personalidad de Sucre "es una de las que han dejado en Imagen la huella más duradera." (François Delprat: "Un magazine de grande diffusion Imagen", en VVAA: Le discours culturel...op.cit., p. 248. Traducción mía) 
Trejo $^{250}$, Isaac Chocrón ${ }^{251}$, Francisco Pérez Perdomo ${ }^{252}$, Antonia Palacios ${ }^{253}$, etc. la literatura compartió espacio con otras expresiones artísticas. La revista fue fiel al subtítulo y concedió mucha importancia a las artes plásticas -contando con críticos como Manuel Quintana Castillo y Clara Diament de Sujo- al teatro -tratado por Rubén Monasterios- y al cine -tema predilecto de Rodolfo Izaguirre. Como se indicaba en el primer editorial de la publicación, titulado "Presentación. Nuestro propósito", el propósito fundamental de Imagen fue cumplir una labor

de diálogo y de comunicación de ideas; de expresión, de información crítica vivaz, de ponernos al día en todo cuanto al dominio de la Cultura ocurre o acontece en el mundo, no sólo en Venezuela, sino en toda América Latina donde hoy se experimenta una actividad artística extraordinaria, hasta el punto de que ya estamos llegando a mostrar mayoría de edad. ${ }^{254}$

El objetivo, como en "Letras y Artes”, era poner a la cultura venezolana al día de lo que acontecía en "el mundo" y, para lograrlo, la revista trató de "suscitar un diálogo entre lo venezolano, lo latinoamericano y lo europeo, estableciendo verdaderos vasos comunicantes entre la inteligencia creadora de todos los países"255. La cultura venezolana, se pensaba desde Imagen, alcanzaría su "mayoría de edad" cuando lograra entroncar desde sus presupuestos particulares con el discurso estético de la modernidad $^{256}$. Por eso, la revista presentó esta tendencia como la única forma válida de

250 Oswaldo Trejo (1924-1996), cuentista y narrador venezolano. Entre sus obras más importantes se hallan También los hombres son ciudades (1962), Andén lejano (1967) y Textos de un texto con Teresas (1975).

${ }^{251}$ Isaac Chocrón (Maracay, 1930-Caracas, 2011), destacado dramaturgo, narrador y ensayista venezolano. Entre sus obras teatrales podemos citar Animales feroces (1963), Tric Trac (1967), El acompañante (1978). Fue fundador de la Compañía Nacional de Teatro y director de la Escuela de Artes de la UCV.

${ }^{252}$ Francisco Pérez Perdomo (1930), poeta y crítico literario venezolano. Entre sus obras más destacadas se encuentran Fantasmas y enfermedades (1961), Los venenos fieles (1963), Depravación de los astros (1966) y Ceremonias (1975). Recibió el Premio Nacional de Literatura en 1980.

253 Antonia Palacios (Caracas, 1904-2001), escritora venezolana. Entre sus obras más importantes podemos citar Ana Isabel, una niña decente (1949), Viaje al frailejón (1955) y Los insulares (1972). Obtuvo el Premio Nacional de Literatura en 1976 y el Premio Municipal en 1982.

${ }^{254}$ Guillermo Sucre: "Presentación. Nuestro propósito", en Imagen, Caracas, núm. 1, 15/30 mayo 67 , p. 2. Aunque algunos editoriales aparecen sin firma se los atribuimos a Guillermo Sucre por ser el director de la publicación.

2-3.

${ }^{255}$ Guillermo Sucre: "Primer aniversario", Imagen, Caracas, editorial núm. 24, 1/15 mayo 68, pp.

${ }^{256}$ Vid. Guillermo Sucre: "La prueba de fuego", en Imagen, Caracas, editorial núm. 8, 1/15 de septiembre de 1967, p. 2. Y también Guillermo Sucre: "En el umbral de una nueva literatura", en Imagen, Caracas, núm. 20, 1/15 de marzo de 1968, p. 2. 
expresión cultural y la estableció como modelo para el lector nacional al que la publicación iba dirigida. En la concepción de Sucre, la estética de modernidad sustentada en los principios básicos de la autonomía y el universalismo- se fue enriqueciendo paulatinamente a lo largo de la década ${ }^{257}$. La noción de la literatura que planteó Imagen se basó en dos puntos fundamentales: 1) La reivindicación de la crítica como actividad imprescindible para crear una conciencia estética y construir una literatura sobre bases fundadas ${ }^{258}$. 2) La creencia de que la literatura es sobre todo y ante todo lenguaje ${ }^{259}$, y que esa autonomía con respecto a lo real le confiere "una dimensión de gratuidad que, por sí misma, encierra un carácter crítico y aun explosivo, ${ }^{\text {260 }}$. La política cultural de Imagen debe leerse en relación a sus referentes perdidos, es decir, a

${ }^{257}$ Como el modelo de Sucre era la literatura occidental, su concepción sobre la literatura se fue enriqueciendo a medida que ese modelo iba evolucionando.

${ }^{258}$ Vid. Guillermo Sucre: "Presencia de la crítica", en Imagen, Caracas, núm. 7, 15/31 de agosto de 1967, p. 2. Para Julio Miranda este editorial es más definitorio que el propuesto en el primer número. A este respecto señala el crítico venezolano: "De hecho, ese editorial del número 7 es una presentación de la revista más resuelta que la de su salida, «Nuestro propósito», desangelada e insípida, que quizá por cautelosa, se limitaba a insistir en el «diálogo» y la «comunicación de ideas». Como si se definiera ahora realmente, el séptimo editorial habla de la inexistencia de la crítica en Venezuela, de su necesidad y del papel que Imagen aspira a jugar en tal sentido." (Julio Miranda: "Lucha armada, lucha escrita: Zona Franca e Imagen en la Venezuela de los '60" en Saúl Sosnowski et al.: La cultura de un siglo: América Latina en sus revistas, Buenos Aires, Alianza, 1999, pp. 409-419, p. 415)

259 Esta idea, que es un verdadero lugar común de la revista, aparece por primera vez en el editorial del núm. 3, que viene encabezado por un epígrafe de Carlos Fuentes. En ese editorial se lee que "la voluntad de lenguaje" es lo que unifica el discurso de la actual novelística hispanoamericana. (Guillermo Sucre: editorial del núm. 3, en Imagen, Caracas, núm. 3, $15 / 30$ de junio de 1967, p. 2). La misma idea aparece en la introducción al Suplemento dedicado a la joven narrativa venezolana, que para Sucre "No es una narrativa que se defina por una temática sorprendente [...], sino por la conciencia del lenguaje. Queremos decir, simplemente, que no es el tema concebido como "historia" o "argumento" lo que importa en estos relatos. Su validez les viene sobre todo de la perspectiva que asume el narrador: la libertad con que se mueve su mirada, la capacidad de conferir a lo significante un halo de resonancia más profunda, el don de descubrir en la realidad otros hilos más sutiles que no están en la simple apariencia de las cosas." (Guillermo Sucre: "En la línea más cercana”, Imagen, Caracas, núm. 24, 1/15 mayo 1968, p. 9). Esta concepción se convirtió en un verdadero lugar común en este período (Vid. infra el apartado IV. 4. "Guillermo Sucre y la estética de modernidad", pp. 174 y ss.)

${ }^{260}$ Guillermo Sucre: "La nueva literatura", en Imagen, Caracas, núm. 27, 15/30 junio de 1968, p. 2. En otro editorial Sucre indicaba: "Toda obra literaria auténtica encierra una crítica social, propone incluso una requisitoria más profunda de la condición humana. [...] La literatura es revolucionaria a partir de sus propios valores y no de aditamentos que le son ajenos. Cambiar la vida, proponía Rimbaud, y éste ha sido uno de los impulsos de toda la poesía moderna. Pero para ello no ha tenido que caer en una patética angustia social, más demagógica y a veces interesada que realmente inconformista. No hay que llorar en público, afirmaba Lautréamont, y acaso esto pueda servir de ejemplo para ciertos falsos apóstoles que entre nosotros proclaman un drama que ellos mismos no asumen vitalmente. Nuestra literatura no tiene por qué negarse ningún tema -el de la violencia, por ejemplo, que justamente ha dado unidad temática a un libro recién publicado. Pero lo que si no puede hacer es renunciar a la convicción y a la autenticidad estética. Esta es su verdadera opción, so pena de pasar por falsaria." (Guillermo Sucre: "La opción de la literatura", en Imagen, Caracas, núm. 9, 15/30 de septiembre de 1967, p. 2) 
ese tipo de literatura que la publicación explícitamente rechazaba. La estética

promocionada por Imagen excluía a todas aquellas obras que no reconocían la radical

autonomía del lenguaje, es decir, a aquellas que se esforzaban por representar

ingenuamente la realidad empírica o que ponían la literatura al servicio de propósitos

que excedían lo artístico. Así, la revista marcó una distancia tanto con los nacionalismos

o los pintoresquismos literarios, que tanta fuerza tenían todavía en Venezuela, como con

el arte utilitario, que perdía su carácter crítico en favor de la recompensa o del éxito ${ }^{261}$.

Guillermo Sucre consideraba que Borges y la literatura que de él procedía eran el

ejemplo a seguir:

el hecho concreto y significativo es que lo mejor de la literatura latinoamericana ha dado el salto: ni realismo superficial, ni modelos o cánones del pasado, ni mala conciencia de preocupación social. No por azar la obra de Jorge Luis Borges [...] es la que mayor influencia ejerce en los escritores de este continente. Dominada por un sentido lúdico, esa obra es también la que ha expresado más profundamente nuestro mundo espiritual. Conciencia de esa influencia la tienen el propio Fuentes, Cortázar, Lezama Lima, Carpentier, Vargas Llosa, Cabrera Infante, Sarduy, es decir, todo lo que actualmente es más creador entre nosotros. El último libro de Cortázar [...] es una clara de demostración de ello: lo impregna ese espíritu borgiano que ve en la literatura una pura creación del lenguaje donde, sin embargo, se dilucida la propia realidad. Y es que ya el nuevo escritor latinoamericano no se deja chantajear por dudosas pretensiones ideológicas. Su obra sí expresa nuestra realidad, pero en una dimensión estética y no vagamente sociológica. La expresa, pero no la refleja simplemente. ${ }^{262}$

La concepción de la literatura que aparece en Imagen presenta un vínculo

evidente con la que en ese mismo momento estaba siendo promocionada por la revista

Mundo Nuevo de París, dirigida por Emir Rodríguez Monegal ${ }^{263}$. Guillermo conoció

${ }^{261}$ De esta manera Sucre se distanciaba tanto del realismo socialista como de la cultura de masas. Vid. Guillermo Sucre: "El arte y la moda", Imagen, Caracas, editorial núm. 25, 15/30 mayo 68, p. 2.

${ }^{262}$ Guillermo Sucre: "El arte y la realidad", en Imagen, Caracas, núm. 21, 15/30 marzo de 1968, p. 2. Nótese que los novelistas que menciona, excepto Carpentier, pertenecen al "canon" de Mundo Nuevo. La cita sigue: "La constituye: revela sus significados más secretos, traduce sus claves, que no están dadas tan sólo en la apariencia de los conflictos sociales, sino en todo el comportamiento del hombre. Justamente, es una literatura revolucionaria porque tiene conciencia de la palabra, de su autonomía y de su validez. Y no deja de ser importante que esa conciencia estética traduzca paralelamente una conciencia social, incluso más despierta e incisiva. [...] El arte como reflejo de la realidad o de la sociedad es una teoría de perezosos, esto es, de conservadores."

${ }^{263}$ En Imagen nuestro autor editó varios artículos de Rodríguez Monegal. En colaboración con Vargas Llosa: "Paradiso", en Imagen, Caracas, núm. 11, 15/30 oct. 1967, p. 21. En solitario: "Borges: el tiempo y el yo individual", en Imagen, Caracas, núm. 12, 1/15 nov. 1967; "Horacio Quiroga, el horror de París", en Imagen, Caracas, núm. 22, $1 / 15$ abril de 1968; "El mundo mágico de Carlos Fuentes", en Imagen, Caracas, núm. 16, 1/15 de enero de 1968; "Paradiso en su contexto", en Imagen, Caracas, núm. 25, 15/30 mayo de 1968, pp. 4-5. Además, Sucre publicó una reseña del libro de Monegal El viajero inmóvil. (Guillermo Sucre: "Neruda y el tiempo recobrado", en Imagen, Caracas, núm. 12, 1/15 de 
personalmente al director de esa publicación en agosto de 1967, con motivo de la celebración en Caracas del XIII Congreso del Instituto Internacional de Literatura Iberoamericana (IILI). Para aquel entonces ya habían mantenido un contacto por carta y Monegal había leído el ensayo de nuestro autor sobre Borges así como el único libro de poesía que había publicado ${ }^{264}$. Cuando ambos directores se encontraron ya había saltado el escándalo sobre la financiación de Mundo Nuevo por el ILARI (es decir, por la CIA) por lo que el vínculo de Imagen con la revista parisina suponía una nueva toma de partido en el polarizado contexto cultural de los años sesenta.
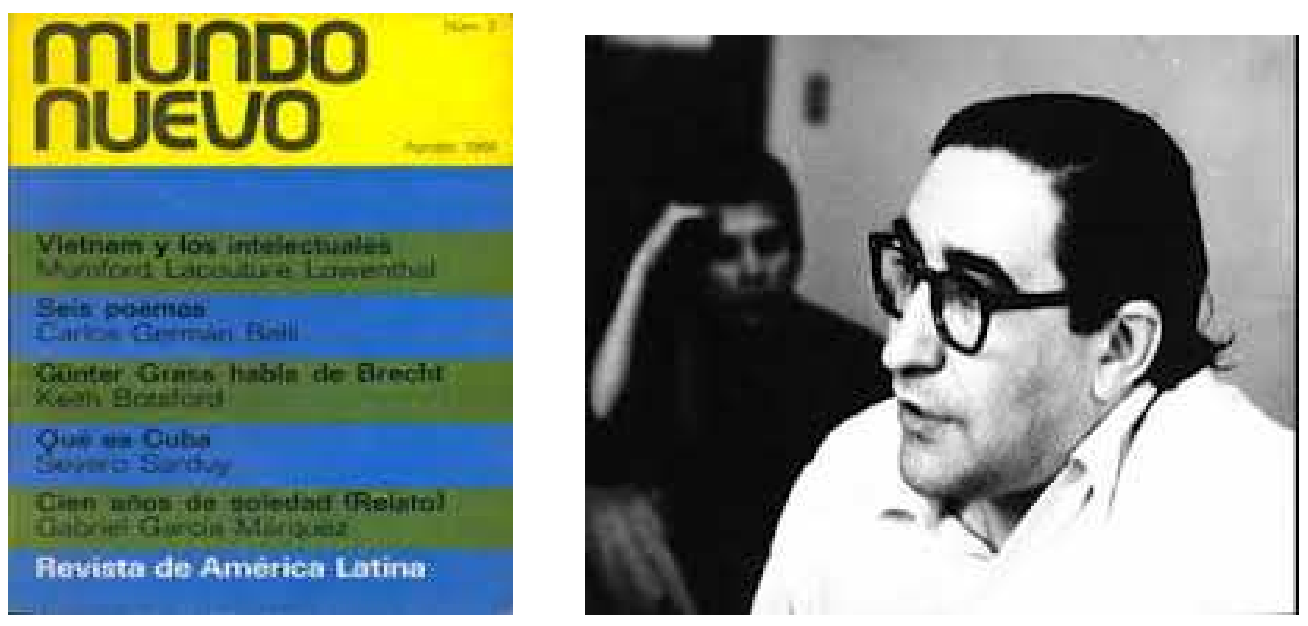

Imágenes 22 y 23. Ejemplar de Mundo Nuevo y fotografía de su director, Emir Rodríguez Monegal (1921-1985).

De todos los mitos que circularon en la publicación de Monegal, Mudrovcic señala tres que "lograron proyectar cierta organicidad a su programa editorial: la imagen espectacular de escritor latinoamericano, la independencia ideológica del discurso

noviembre de 1967, pp. 4-5). Nuestro autor escribió sobre Tomás Segovia, que fue asistente de dirección de Mundo Nuevo durante los primeros números de la revista. (Guillermo Sucre: "La poesía como reconocimiento", en Imagen, Caracas, núm. 28, 1/15 de julio de 1968, p. 24.) En Mundo Nuevo se editaron poemas de Guillermo Sucre: "Mutaciones", en Mundo Nuevo, París, núm. 5, nov. 1966, y una selección de la joven poesía venezolana. Guillermo Sucre: "Nuevos poetas venezolanos", en Mundo Nuevo, París, núm. 19, ene. 68, pp. 21-54. Tomás Segovia, publicó en la revista parisina una reseña sobre Zona Franca e Imagen. (Tomás Segovia: "Una red de agujeros", en Mundo Nuevo, París, núm. 4, oct. 1966, pp. 88-89). Asimismo, la sección "Sextante" de la revista parisina correspondiente a agosto del 66, núm. 2, concedió mucha importancia a la cultura venezolana.

${ }^{264}$ Estos datos aparecen referidos en Emir Rodríguez Monegal: "Diario de Caracas", en Obra selecta, op.cit., pp. 241-276. 
literario y la fe en el lenguaje como estructura universal de sentido"265. Precisamente estas tres características se filtraron en la publicación de Sucre, pues además de la autonomía literaria y de la fe en el lenguaje -y contrariamente a lo que había hecho Zona Franca-Imagen dio cabida en sus páginas a los autores del boom, sobre todo a Carlos Fuentes y Vargas Llosa. Estos autores encarnaban esa “imagen espectacular"266 del escritor latinoamericano que promovía la revista parisina, como se aprecia, por ejemplo, en estas afirmaciones del creador de La ciudad y los perros (1962) sobre su amigo mexicano:

Hay en Fuentes, siempre, una especie de irremediable optimismo que resulta contagioso. Cuando habla de lo que está escribiendo, o de lo que acaba de leer, o de lo que hará mañana, parece que estuviera diciendo me saqué la lotería." Y más adelante: "Él se las arregla para leer todo lo que importa -libros, revistas y artículos de periódicos- para ver todos los espectáculos de interés, viaja constantemente y mantiene una correspondencia amazónica, y nada de esto lo aparta de su trabajo de escritor, al que dedica cuatro o cinco horas diarias ¿Cómo hace? Él claro, se ríe: es un secreto profesional, dice. ${ }^{267}$

Como se advierte ya por la presencia de estos autores, el quincenario dirigido por Guillermo actuó como "caja de resonancia” del canon de Mundo Nuevo y reivindicó a aquellos autores que habían sido respaldados por la publicación de Rodríguez Monegal. Esta labor de altavoz que cumplió Imagen se aprecia en el caso de los novísimos -Severo Sarduy, Gustavo Sáinz ${ }^{268}$, Manuel Puig y Néstor Sánchez-, que habían sido “inventados” por Mundo Nuevo.

${ }^{265}$ María Eugenia Mudrovcic: Mundo Nuevo...op.cit., p 171.

${ }^{266}$ Ibíd., p. 61. "el carácter homogéneo del boom no está dado por el modelo de escritura que el boom postula sino por el modelo de escritor que Mundo Nuevo institucionaliza." (Ibid., p. 65)

${ }^{267}$ Vargas Llosa: "Carlos Fuentes en Londres", en Imagen, Caracas, núm. 12, 1/15 de nov. 1967, p. 3. El escritor peruano publicó también un texto sobre Asturias ("Un hechicero maya en Londres", en Imagen, Caracas, núm. 3, p. 3) y un ensayo sobre los cuentos de González León ("7 relatos de cataclismo y poesía", en Imagen, Caracas, núm. 14-15, 15/30 de dic. 1967, p. 32). Especial atención recibió el "Premio Rómulo Gallegos" de 1967, concedido al propio Vargas Llosa, al que se dedicó el suplemento del núm. 7. Sobre Fuentes se publicaron en Imagen: Jaime López Sanz: "Carlos Fuente: Zona Sagrada", núm. 9, 15/30 sep. 67, supl., s/p. S/f: “Carlos Fuentes y la censura española”, núm. 11, 15/30 oct. 1967, p. 21; Edras Parra: "Fuentes y la pasión por la palabra", núm. 19, 15/28 feb. 1968, p. 24. Además, el suplemento del núm. 16 fue dedicado enteramente a la obra de Fuentes, con un texto de Rodríguez Monegal: "El mundo mágico de Carlos Fuentes", en Imagen, Caracas, núm. 16, 1/15 de enero de 1968. También se dio cabida en la revista de Sucre a Juan Carlos Onetti y a Julio Cortázar.

${ }^{268}$ Sobre Gustavo Sáinz en Imagen se publicó un artículo de Edras Parra: "Un paraíso perdido: la adolescencia”, en Imagen, Caracas, núm. 14-15, 15/30 dic. 67, p. 4. 

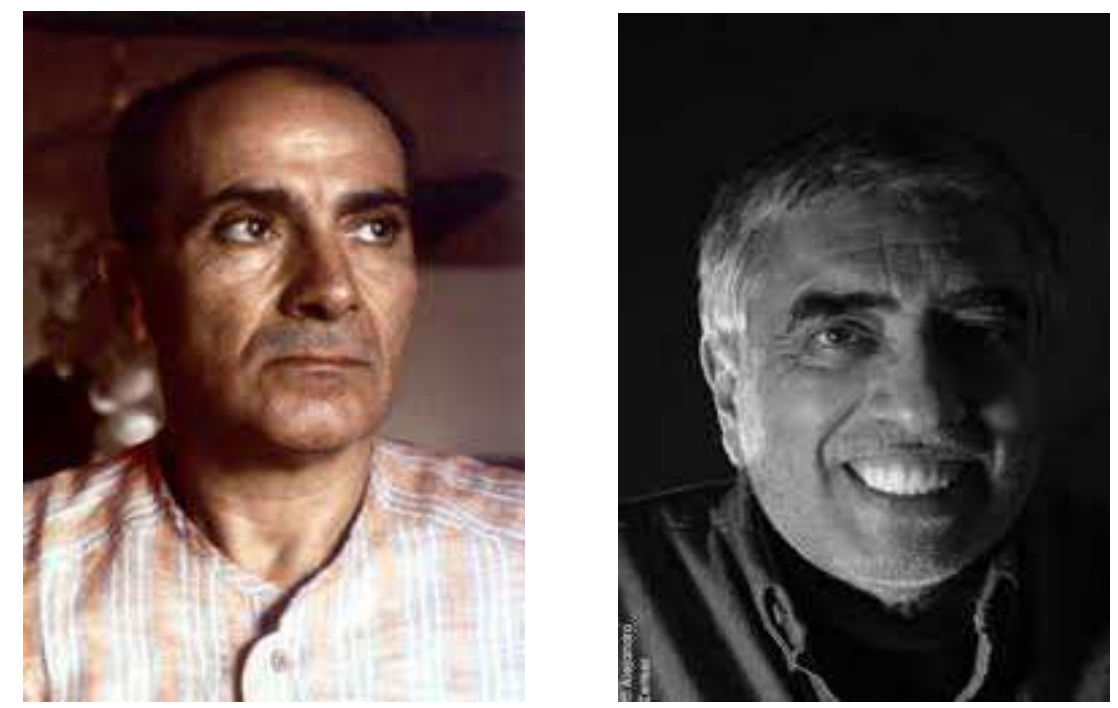

Imágenes 24 y 25. Manuel Puig (1932-1990) y Gustavo Sáinz (1940), dos de los "novísimos" que fueron impulsados por la publicación Mundo Nuevo.

Es evidente además que al hablar sobre estos autores, en Imagen se colaron las interpretaciones de sus obras que habían sido establecidas por el crítico uruguayo. Así, en el artículo que Héctor A. Carricart escribió sobre Manuel Puig y Néstor Sánchez se aludía a la revista de Monegal y se destacaba que el elemento fundamental en sus novelas era la voluntad de lenguaje. Por eso, a propósito de Sánchez se afirmaba lo siguiente: “Tiene una rebelión, una rebelión en la literatura. ¿Cuál es la rebelión o la revolución de Néstor Sánchez? Una conciencia, una idea persecutoria: que el lenguaje es la «textura íntima de la narración». El lenguaje transforma toda narrativa, para superarla en una realidad pura, universalista y quitarla del esquematismo tradicional de la narrativa externa". Y algo similar se indicaba a propósito de Puig: “«La traición de Rita Hayworth» es otro de los grandes libros en que el medio es el lenguaje, donde la palabra no es para decir algo, sino para reelaborar la realidad de la narrativa"269. Del mismo modo, en la Nota introductoria al suplemento del número 25, que consistió en un capítulo de la novela de Puig que se acaba de citar, Sucre destacaba que "lo que interesa a Puig, y lo que sin duda es su aporte más sorprendente, es el tratamiento del lenguaje.

${ }^{269}$ Héctor A. Carricart: "Puig y Sánchez en el boom literario", en Imagen, Caracas, núm. 8, 1/15 sep. 1967, p. 4. 
En este sentido La traición de Rita Hayworth lleva a cabo una suerte de exploración hacia dentro, hacia la esfera misma de la forma narrativa en donde el lenguaje se ha despojado de cualquier conformidad retórica y aborda la palabra en un desplazamiento más dinámico, esto es, coloquial” ${ }^{, 70}$. La afinidad entre el criterio de Imagen y el de Mundo Nuevo se advierte además en el hecho de que los únicos autores cubanos que tuvieron repercusión en la revista caraqueña fueron Lezama Lima, Cabrera Infante ${ }^{271}$ y Severo Sarduy, precisamente los mismos que estaban siendo promocionados por Monegal.
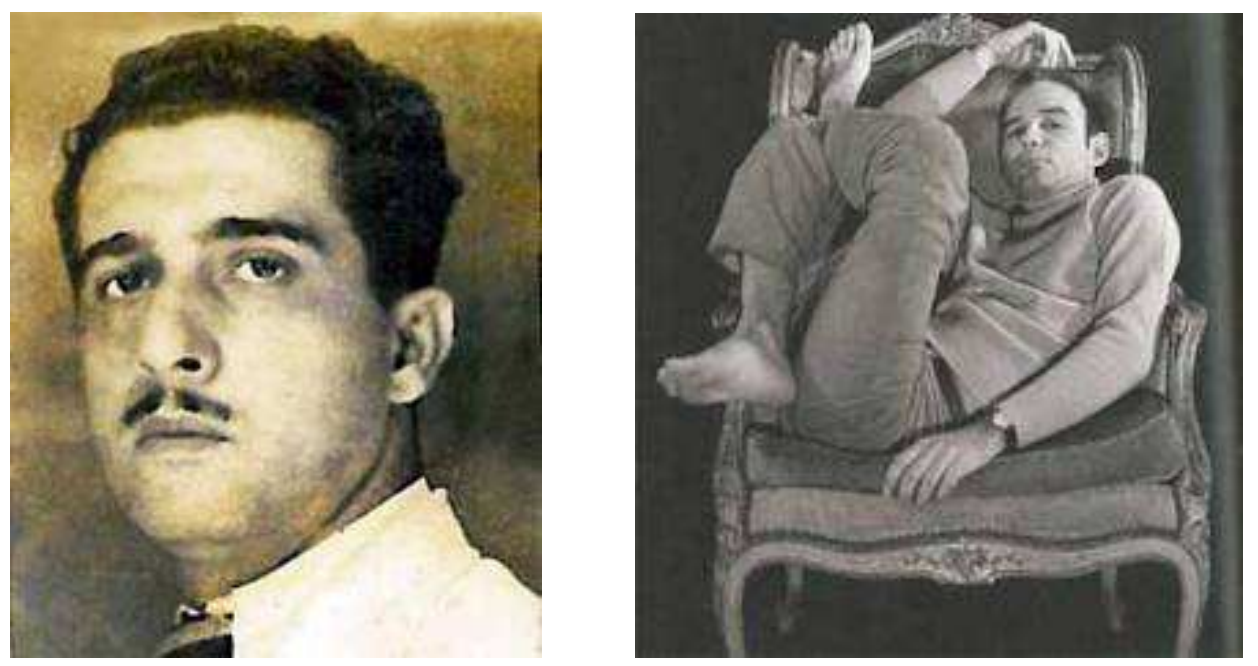

Imágenes 26 y 27. José Lezama Lima (1910-1976) y Severo Sarduy (1937-1993).

En lo que respecta a Sarduy, Mudrovcic ha señalado que la revista parisina "jugó un rol fundamental en los procesos de constitución y consolidación autorial", y que “apadrinó" su "fundación mitológica" inscribiéndolo "dentro de cierto linaje prestigioso

${ }^{270}$ s/f: "Nota introductoria al Supl. núm. 25", en Imagen, Caracas, 15/30 mayo 1968. Aunque apareció sin firma, la nota pertenece a Sucre. Una consecuencia del acercamiento a las formas de leer de Mundo Nuevo fue la reproducción de los errores que había cometido la revista parisina. Al imitar a la publicación de Monegal, Imagen cayó en el mismo error que la crítica ha señalado a propósito de la lectura de los novísimos emprendida por la publicación parisina. A decir de Mudrovcic, la generación de los novísimos "fue mal leída por la revista parisina porque Rodríguez Monegal evaluó el post-boom con los mismos paradigmas que había usado para medir al boom." (María Eugenia Mudrovcic: Mundo Nuevo...op.cit., p. 76).

${ }^{271}$ Sobre Cabrera Infante se publicó el artículo Edras Parra: "Cabrera Infante. Tres tristes tigres", en Imagen, Caracas, núm. 5, 15/30 de jul. 67, p. 14. 
que permite, por último, su incorporación consagratoria al flujo de las letras

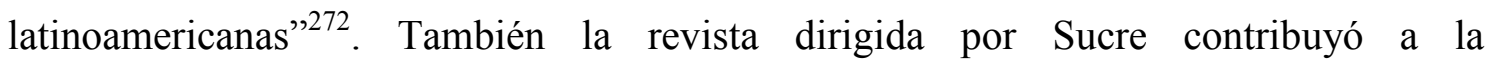
consolidación de este autor novel, que para este momento sólo había publicado Gestos (1963) y De donde son los cantantes (1967). En Imagen apareció una entrevista sobre él realizada por Basilia Papastamatíu: "Severo Sarduy: una nueva interpretación del Barroco"273, y se publicó un texto breve del propio Severo sobre el artista cubano José Ramón Díaz Alejandro ${ }^{274}$. Además, Sucre escribió sobre su segunda novela el ensayo "Sarduy: los plenos poderes de la retórica" e insistió en la centralidad concedida al "poder del lenguaje":

Trama, desarrollo, desenlace, contenido ideológico, coherencia significativa, análisis psicológico, reconstrucción realista: todo ello está lejos de ser lo esencial de su obra. [/] De donde son los cantantes es la novela que primero se asume como retórica, como poder del lenguaje. El lenguaje no cumple en ella tan solo, como sería lo normal, una función expresiva; no es un simple vehículo, sino que es su tema central, su ámbito de irradiación, su verdadero personaje y hasta su única aventura. ${ }^{275}$

A propósito de Lezama Lima, la publicación dirigida por Guillermo tomó prestados artículos que ya habían aparecido en $M u n d o$ Nuevo $^{276}$, por lo que la revista caraqueña reprodujo la interpretación de Paradiso (1966) establecida por Rodríguez Monegal. El crítico uruguayo había insistido en el componente homosexual de la novela y en la oposición que ello suponía a la política emprendida en ese ámbito por el régimen cubano $^{277}$. Otros autores que Imagen tomó directamente del canon de Mundo Nuevo

${ }^{272}$ María Eugenia Mudrovcic: Mundo Nuevo...op.cit., pp. 95 y 97. "La marca internacionalista que Fuentes asegura al modelo a través de su relación gozosa con la cultura de masas, se superpone ahora al componente-Sarduy que incorpora, por su lado, el prestigio y el control del lenguaje codificado del grupo Tel Quel, foco representativo de la élite cultural más selecta de la época" (Ibíd., pp. 62-63)

${ }^{273}$ Basilia Papastamatíu: "Severo Sarduy: una nueva interpretación del Barroco", en Imagen, Caracas, núm. 14-15, p. 3

${ }_{274}$ Severo Sarduy: "Máquinas”, en Imagen, Caracas, núm. 26, 1/ 15 de junio de 1968, p. 19

275 Guillermo Sucre: "Sarduy: los plenos poderes de la retórica", en Imagen, Caracas, núm. 20, 1/15 de marzo de 1968, p. 24.

${ }^{276}$ Mario Vargas Llosa y Rodríguez Monegal: "Paradiso”, en Imagen, Caracas, núm. 11, p. 21. Emir Rodríguez Monegal: "Paradiso en su contexto", en Imagen, Caracas, núm. 25, 15/30 mayo de 1968, pp. 4-5.

277 “Según Emir Rodríguez Monegal, la obra de Lezama era «un libro maldito» para la revolución porque, como dirá más tarde, «[e]n momentos en que el Gobierno cubano había decidido la persecución de los homosexuales, su concentración en campos de trabajo y reeducación de la UMAP, Lezama Lima entrega una novela que presenta en forma directa y a la vez metafórica las actividades 
fueron José Donoso ${ }^{278}$ y Guimaraes Rosa ${ }^{279}$, prácticamente el único brasileño del que se trató en la publicación venezolana. Aparte de estos escritores, algunos críticos que habían participado en Mundo Nuevo, como Julio Ortega, Saúl Yurkievich, César Fernández Moreno y José Miguel Oviedo, lo hicieron también en la revista caraqueña dirigida por Guillermo Sucre. Por otro lado, la afinidad que Imagen estableció con Mundo Nuevo y con otras publicaciones liberales hace que las exclusiones sean igualmente previsibles. Como ha señalado Julio Miranda, en el quincenario hubo “descuidos” -“Arreola, Bioy Casares, Monterroso, la literatura del Brasil, la del Caribe anglo o francoparlante"- y también "omisiones", como

Adoum, Antonio Cisneros, Roque Dalton, Juan Gelman, Enrique Lihn, Ángel Rama que coinciden con la de casi todos los escritores cubanos aún por entonces en la Isla, de Desnoes a Vitier, de Guillén a Retamar, de Barnet a Padilla, de Jesús Díaz a Virgilio Piñera. En lo que concierne a los poetas, y salvo Guillén, Lihn, Padilla y Vitier, las exclusiones son las mismas de La máscara, la transparencia [...], el brillante libro de ensayos de Sucre, y de la Antología de la poesía hispanoamericana moderna [...], coordinada por él. No podrían encontrarse omisiones tan sistemáticas entre los narradores y poetas venezolanos publicados o comentados en Imagen, notamos, sí, la ausencia de la gente de Tabla Redonda, Trópico Uno, En letra roja, sin poder precisar el grado de autoexclusión. ${ }^{280}$

Además del vínculo literario, la relación entre Imagen y Mundo Nuevo se estableció asimismo en cuanto al tema "político". Como era la norma en los medios liberales, la revista dirigida por Sucre trató este tema tangencialmente, sobre todo a través de denuncias a la censura. En este sentido, el quincenario denunció el veto de libros llevado a cabo por algunos Estados latinoamericanos como Perú o Argentina.

homosexuales de algunos de sus protagonistas» [...]. Tratando justamente de hacer explícita esta contradicción, Mundo Nuevo leyó Paradiso enfatizando casi exclusivamente el componente homosexual que actúa en la base de la obra de Lezama." (María Eugenia Mudrovcic: Mundo Nuevo...op.cit., pp. 105106) 1967 , p. 24.

${ }^{278}$ Marta Mosquera: “Dos novelas de José Donoso”, en Imagen, Caracas, núm. 8, 1/15 de sep.

${ }^{279}$ Sobre Guimaraes Rosa, Imagen publicó dos artículos: Rodolfo Izaguirre: “Guimaraes Rosa: Gran sertón: Veredas" en Imagen, Caracas, núm. 5, 15/30 ago. 67, supl. pp. 10-11, y Otoniel Santos Pérez: “Guimaraes Rosa visto por terceros", en Imagen, Caracas, núm. 13, 15/30 nov. 67, pp. 8 y 17.

${ }^{280}$ Julio Miranda: "Lucha armada, lucha escrita: Zona Franca e Imagen en la Venezuela de los '60", en Saúl Sosnowski et al.: La cultura de un siglo...op.cit., pp. 417-418. Sobre la literatura brasileña ya hemos indicado que la excepción fue Guimaraes Rosa, precisamente un autor reivindicado por Monegal. 
Esta cuestión, que nuestro autor tomaba directamente de Mundo Nuevo ${ }^{281}$, sirvió para establecer una oposición entre la libertad de expresión y la intervención estatal en la cultura, que era rechazada por las publicaciones liberales, partidarias más bien de un "pasaje paulatino de las industrias culturales a manos privadas" y de la "transnacionalización de la literatura latinoamericana"282. Asimismo Imagen llamó la atención sobre la censura del régimen franquista a Cambio de piel (1967), la novela de Carlos Fuentes premiada por Seix Barral ${ }^{283}$, asunto que apareció en Mundo Nuevo un mes más tarde. En general, Imagen se opuso sistemáticamente "a cualquier forma de intervención destinada a silenciar el mensaje de las manifestaciones artísticas"284. Por ello, ya en un plano puramente nacional, intentó combatir la censura cinematográfica que se había extendido en Venezuela y propuso la creación de un Comité que permitiera aunar esfuerzos en su contra. La crítica de nuestro autor no se refería al gobierno venezolano en su conjunto (pues parece que la censura se ejercía a nivel estatal o municipal) sino a ciertos sectores reaccionarios, a los que asociaba con la pasada dictadura:

En Venezuela está planteada a diario la lucha contra fuerzas tradicionalmente reaccionarias que no aceptan vivir en libertad. Con todo su poder y la experiencia de largos años sometiendo las conciencias, tienen en sus manos los instrumentos más variados, sutiles y efectivos para mantener su influencia. La lucha por un cine sin censura es, en la Venezuela de

${ }^{281}$ El editorial al que nos referimos es "El destino del libro en América Latina", correspondiente al núm. 19, 15/30 feb. 68. En Mundo Nuevo el tema había sido tratado en el núm. 20, de febrero de 1968. El editorial del núm. 21, "El arte y la realidad", también se citaba explícitamente a la revista de Monegal.

${ }^{282}$ Ibid., p. 150. Estos medios rechazaron cualquier intervención estatal en la cultura siempre que ésta no favoreciera sus intereses, como sucedió en el caso de Venezuela.

${ }^{283}$ S/f: "Carlos Fuentes y la censura española", en Imagen, núm. 11, 15/30 octubre de 1967, p. 21. El mismo asunto apareció en la revista de Monegal un mes más tarde (Mundo Nuevo, núm. 17, nov. 1967, pp. 90-91)

${ }^{284}$ Guillermo Sucre: “Un comité contra la censura”, núm. 26, 1/15 de junio 1968, p. 2. En cuanto al tema de la URSS, en Imagen se publicó la entrevista "Un día con Solzhenitsin", tomada de $L a$ Quinzaine Littéraire. En ella el escritor ruso hacía hincapié en los años de privación de libertad que había sufrido por expresar en una carta sus puntos de vista sobre el régimen de Stalin, y se insistía en la esencia crítica del escritor y de la literatura. ("Un día con Solzhenitsin”, en Imagen, Caracas, núm. 10, 1/15 oct. 67, p. 3). Además se incluyó un artículo sobre la "Novela joven en la URSS" y una reseña titulada "Cuba y los premios de Casa de las Américas". 
hoy, apenas un capítulo de una actitud más amplia, una actitud de alerta y de indeclinable combatividad. $^{285}$

Por otra parte, quizás porque la agresividad de la guerrilla en este momento ya era menor, la revista de Sucre no insistió tanto como Zona Franca en la necesidad de potenciar un "diálogo no-ideológico". Aparte de una vaga mención en el primer editorial, el tema del diálogo y del entendimiento mutuo más allá de las diferencias ideológicas apareció en el resumen que Guillermo ofreció del simposio de la "Fundación Latinoamericana para las Artes", celebrado en Caracas en noviembre de 1967. En su recuento, nuestro autor se esforzaba por establecer, allí donde no existió, una conciliación entre grupos ideológicamente enfrentados:

Entre gentes con diferencias ideológicas profundas y con distintas posiciones ante la vida y la cultura, parecía imposible el acuerdo. Sin embargo, lo hubo: el acuerdo fue el diálogo abierto y aun la más radical controversia. Esta última, que fue, sobre todo, de carácter ideológico, no dejó de ser saludable. Aunque todos los participantes en el simposio asistían a él en representación de sí mismos, y no en representación de países, credos o tendencias, no faltó, por decirlo así, la polarización geopolítica. [...] No es fácil que en reuniones como éstas, donde se encuentran intelectuales norteamericanos y latinoamericanos, no se produzca una suerte de enfrentamiento. [...] De manera que la relación entre Latinoamérica y los Estados Unidos, sobre todo en el plano político y económico, se convirtió en tema de constante deliberación. Ello fue útil en más de un sentido. Por una parte, sirvió a los latinoamericanos para plantear y criticar la situación de dependencia de nuestros países respecto a los Estados Unidos. Por la otra, permitió no tanto que los norteamericanos tomaran conciencia de esa situación [...], como que se definieran frente al poder absorbente de su propio país. Así, esta doble vertiente -y es lo importante- tuvo su punto de convergencia: cada uno de los participantes en el simposio supo asumir una actitud crítica ante la realidad que le concernía. ${ }^{286}$

Una estrategia similar a la empleada aquí por Guillermo Sucre la ha advertido Mudrovcic en el "Diario del P.E.N.” de Emir Rodríguez Monegal. Pese a la conocida disputa que se había producido en dicho Congreso entre Neruda y Silone, el director de Mundo Nuevo indicaba en su extracto que "sobre la oposición triunfó en este Congreso

${ }^{285}$ Guillermo Sucre: “Un comité contra la censura”, loc.cit. Vid. también Guillermo Sucre: "Una política cultural", en Imagen, Caracas, núm. 14-15, 15/30 dic. 1967. Rodolfo Izaguirre abordó este tema en "La censura en el cine", en Imagen, Caracas, núm. 26, 1/15 jun. 68, p. 2.

${ }^{286}$ Guillermo Sucre: "El intelectual y nuestro tiempo", en Imagen, Caracas, núm. 13, 15/30 nov. 1967, p. 2. 
la concordia. Sobre los extremos de la ideología o de la política, la necesidad del diálogo, 287.

Además de esta relación con Mundo Nuevo, a través de la corresponsalía en París de Alfredo Silva Estrada, Imagen retomó el vínculo con la actualidad cultural francesa que vimos a propósito de "Letras y Artes", y las publicaciones galas volvieron a ser una referencia y una fuente de material. Así, entre Imagen y las revistas liberales francesas se puso en funcionamiento ese "sistema de préstamos internos" que sirvió para "unificar y estrechar las bases tópicas de la comunidad internacional" en torno al ideario liberal $^{288}$.

Pese al nexo evidente que Imagen estableció con Mundo Nuevo (y en general con la prensa liberal editada en Francia) no hay que pensar que esta relación agota la dimensión de la revista caraqueña. El quincenario dirigido por Sucre actuó como un amplificador de ciertos aspectos de la publicación parisina para el público venezolano, pero su trascendencia fue sin duda mucho más allá. En líneas generales, durante la dirección de Guillermo la revista cumplió con el objetivo inicial de establecer "vasos

${ }^{287}$ Emir Rodríguez Monegal: “Diario del P.E.N.”, en Mundo Nuevo, París, núm. 4, oct. 66. (La cita la tomamos de María Eugenia Mudrovcic: Mundo Nuevo...op.cit., p. 68). A decir de Mudrovcic, "frente a la variable denuncialista que encarnó Casa de las Américas", el discurso liberal prefería "representarse en un discurso integracionista de tono moderado y ecléctico que evadió sistemáticamente la polémica verbal." (Ibíd., p. 71)

288 María Eugenia Mudrovcic: Mundo Nuevo...op.cit., pp. 47-48. De revistas francesas se tomaron varios artículos. Podemos citar: "Un día con Solzhenitsin”, en Imagen, Caracas, núm. 10, 1/15 oct. 67, p. 3., que se tomó de La Quinzaine Litteraire, y el artículo de Jean Dubuffet: "Cultura y subversión”, en Imagen, Caracas, núm. 29, 15/30 de julio de 1968, cuya versión original había aparecido en la revista L'Arc, núm. 35. De La Quinzaine Littéraire se tomó el artículo de Carlos Fuentes sobre Juan Goytisolo (Carlos Fuentes: “Aprender una nueva rebelión”, en Imagen, Caracas, núm. 25, 15/30 mayo de 1968, p. 24). Los materiales publicados en el suplemento dedicado a Baudelaire procedían de un Coloquio organizado en Francia por la “Asociación por la Libertad de la Cultura” en enero de 1968. De él se publicaron el artículo de Jean Starobinski: "Baudelaire, de la crítica a la poesía" y otro de Gilles Hennault: "Modernidad y tecnología". Ambos aparecieron en Imagen, Caracas, Supl. 19, 15/29 de febrero de 1968. El suplemento del núm. 28, de José María Castellet: "Tiempo de destrucción para la literatura española", apareció inicialmente en Les Lettres Nouvelles. Además, desde Imagen se prestó especial atención a los artistas latinoamericanos reconocidos en París, como Julio Le Parc, Matta, Lam, etc. En el quincenario de Sucre apareció una traducción de Silva Estrada del catálogo de la exposición parisina dedicada a Matta y Lam ("Lam, Matta, Penalba, en el Museo de Arte Moderno de París", en Imagen, Caracas, núm. 27) 
comunicantes" "entre lo venezolano, lo latinoamericano y lo europeo"289. Para tender estos puentes entre la cultura venezolana y la occidental, reivindicó a artistas venezolanos o extranjeros cuya concepción estética coincidía con la que la revista quería promocionar. Ya que uno de los objetivos de la publicación era mantener informado al lector sobre la actualidad cultural, a partir del número tres apareció en las páginas centrales un suplemento que consistía en un monográfico sobre un tema particular -normalmente un autor o una obra que se quería reivindicar. Estos anexos fueron "una apertura directa para la presentación de nuevos talentos" y también un espacio para "poner en contacto a los artistas con el gran público",290.

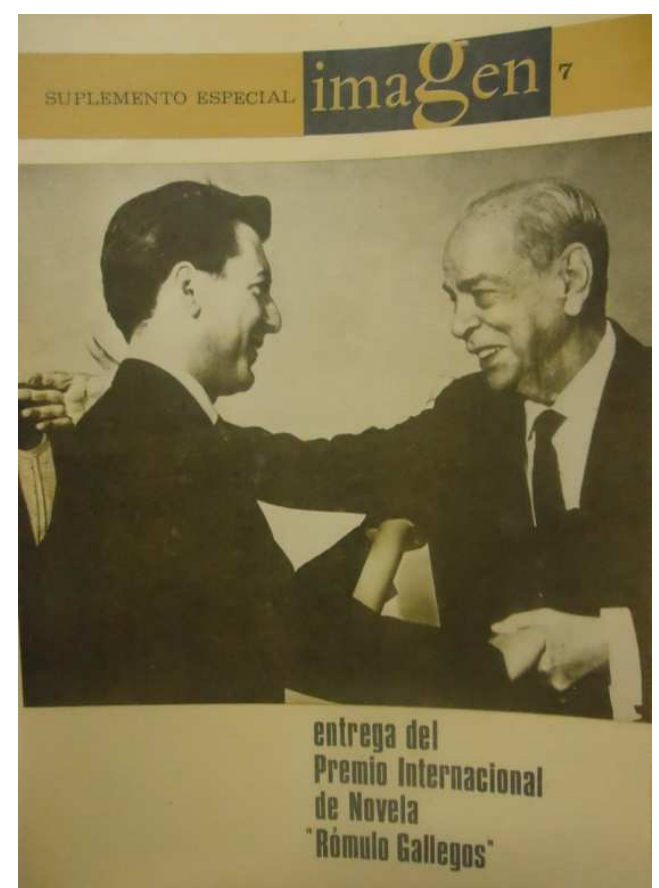

Imagen 28. Suplemento núm. 7 de la revista Imagen, dedicado a la entrega del Premio Internacional de Novela "Rómulo Gallegos". En la portada se aprecia a Vargas Llosa saludando al mismo R. Gallegos.

Los suplementos se dedicaron tanto a cuestiones de literatura como de artes plásticas y en ellos se trató sobre temas o autores como Julio Le Parc, la novela

${ }^{289}$ Guillermo Sucre: "Primer aniversario", loc.cit.

290 François Delprat: "Un magazine de grande diffusion Imagen", en VVAA: Le discours culturel...op.cit., p. 248. Traducción mía. 
latinoamericana actual, Alejandro Otero, el Premio Rómulo Gallegos, Mario Abreu, El teatro de Jean Genet de Lucien Goldmann, Pájaros de Saint John Perse ${ }^{291}$, "Sartre escritor", Carlos Fuentes, Armando Reverón, la joven narrativa venezolana, La traición de Rita Hayworth de Manuel Puig, Charles Baudelaire, César Vallejo, Julio Cortázar, la poesía de Fernández Moreno, los nuevos poetas venezolanos, etc. Muchas veces, como ya vimos que sucedía en "Letras y Artes", "en vez de imponer una apreciación de la obra de arte, el lector era incitado a saborear él mismo y, por tanto, a formarse su propio juicio" ${ }^{292}$. Sin embargo, como la revista ejercía sobre los autores una apropiación y una selección, este juicio aparentemente incondicionado dependía en realidad de la interpretación previa llevada a cabo por los editores. Además de estos monográficos, en Imagen se publicaron artículos de y sobre grandes escritores de dimensión universal ${ }^{293}$ y en ella participaron además muchos escritores venezolanos de la nueva generación, sobre todo aquellos que compartían la concepción estética propuesta por la revista como José Balza ${ }^{294}$, Elisa Lerner, Rafael Cadenas, Francisco Massiani ${ }^{295}$, David Alizo, y un largo etcétera. ${ }^{296}$

${ }^{291}$ A veces estos suplementos coinciden con las traducciones que Sucre había emprendido por la misma época. Sucre tradujo la obra de Lucien Goldmann: El teatro de Jean Genet, Caracas, Monte Ávila, 1968. Los pájaros, de Saint-John Perse fue también vertida al español por él y se editó más tarde en Caracas, Fundarte, 1977.

${ }^{292}$ François Delprat: "Un magazine de grande diffusion Imagen”, en VVAA: Le discours culturel...op.cit., p. 248. Traducción mía.

${ }^{293}$ Entre los autores publicados se encontraban, además de los ya mencionados, Jorge Luis Borges, Ernesto Sábato, André Malraux, García Márquez, Octavio Paz, Alejo Carpentier, Simone de Beuvoir, H. A. Murena, Serrano Poncela, Juan Bosch, Miguel Ángel Asturias, Michel Butor, Horacio Quiroga, André Breton, Mallarmé, Henri Michaux, Juan Carlos Onetti, Blaise Cendrars, Fernando Arrabal, Jorge Semprún, Robbe-Grillet, Apollinaire, Juan Gil Albert, Nicanor Parra, y un largo etcétera.

294 José Balza (1939) es uno de los narradores venezolanos más importantes de la segunda mitad del siglo XX. Entre sus novelas están Marzo anterior (1965), D (1977), Percusión (1982), Medianoche en video: 1/5 (1988). Ha publicado también libros de cuentos y ensayos.

${ }^{295}$ Francisco Massiani (1944) es un escritor y pintor venezolano. Su obra más conocida y editada es Piedra de mar (1968). En 2012 recibió el Premio Nacional de Literatura.

${ }^{296}$ Otras autores venezolanos que publicaron o sobre los que se escribió en Imagen son Luis García Morales, Juan Calzadilla, Ida Gramcko, Alfredo Silva Estrada, Guillermo Meneses, Carlos Noguera, Jesús Alberto León, Mariño Palacio, Pedro Grases, Antonia Palacios, Oscar Sambrano Urdaneta, Arnaldo Acosta Bello, José Francisco Sucre, Eduardo Crema, Julieta Fombona, Ludovico Silva, Eugenio Montejo, Armas Alfonzo, Adriano González León, Juan Liscano, Ramón Palomares, Aquiles Nazoa, Yepes Boscán, Rafael Pineda, Hernando Track, etc. 
Si bien en este recuento hemos incidido sobre todo en el aspecto literario de la revista, hay que destacar que Imagen concedió a las artes plásticas, al cine y al teatro tanto espacio como a la literatura, y que se ocupó además de la filosofía y el pensamiento contemporáneos. En la publicación se escribió en varias ocasiones sobre Marcuse, así como sobre Marshall McLuhan ${ }^{297}$, Althusser, Sartre y Roland Barthes ${ }^{298}$, entre otros. Para ello, el quincenario contó con la participación de destacados profesores como Federico Ríu, Antonio Pasquali o Eduardo Vásquez, los cuales habían colaborado antes en la revista Crítica contemporánea ${ }^{299}$. En su despedida de la dirección de Imagen, a la altura del número 29, en julio de 1968, Guillermo Sucre hizo este balance de la publicación:

Creo que, en cierto modo, Imagen es la revista no tanto de una nueva generación como de una nueva actitud venezolana, y me atrevería a decir latinoamericana, frente a la cultura y a la responsabilidad de la inteligencia. Es posible que represente, más allá de diferencias de edad o de diferencias ideológicas y aún estéticas, a quienes entre nosotros propician una nueva confrontación con la creación intelectual. Esta nueva perspectiva tiene, además de otros, dos rasgos esenciales que la definen. Por una parte, una actitud crítica que permita ir más allá de las jerarquías establecidas y crear un estado de conciencia menos deferente [...]. Pero, además, a este espíritu crítico va asociada una voluntad solidaria, por encima de mezquindades regionalistas, con todo lo que en nuestro país y fuera de él constituye un riesgo creador y una nueva formulación de la cultura. Claro que no han faltado quienes hayan puesto reparos a esta solidaridad, invocando como siempre esos vagos sentimientos patrióticos muy propios del "espíritu de seriedad" (J. P. Sartre) que estimula tanta falsificación en todas las actividades del hombre. Pero creo que ésta ha sido la mejor línea de Imagen, lo que ha hecho de ella una revista en ruptura con la idolatría vernácula y con la pereza mental tan extendida entre nosotros. Y, lo más importante, es que tengo la convicción de que no se interrumpirá esa línea. ${ }^{300}$

297 Sobre Marcuse aparecieron en la revista los siguientes artículos: Eduardo Vázquez: "La filosofía como subversión”, en Imagen, Caracas, núm. 9, p. 24. Eduardo Vázquez: "4 ensayos de Herbert Marcuse", en Imagen, Caracas, núm. 17, pp. 6-7. Antonio Pasquali: "Por Marcuse y por la utopía", en Imagen, Caracas, núm. 29, 15/31 jul. 69, pp. 6-7. Sobre McLuhan se publicó: Antonio Pasquali: "Marshall McLuhan o la ideología represiva", en Imagen, Caracas, núm. 27, 15/30 jun. 68, p. 8.

${ }^{298}$ Federico Riu: “Actualidad de Althusser”, en Imagen, Caracas, núm. 20, p. 4. A Sartre se le dedicó un suplemento completo: Federico Riu: "Sartre escritor", en Imagen, Caracas, núm. 10, 1/15 oct. 67. José Balza: "La operación estructuralista en Roland Barthes", en Imagen, Caracas, núm. 23, 15/30 abr. 68, pp. 6-7.

${ }^{299}$ Esta revista, que se publicó entre 1960 y 1966, fue una de las manifestaciones visibles que adoptó en Venezuela la profesionalización de las ciencias sociales que desde mediados de siglo tuvo lugar en todo el continente. En ella "las obras consideradas recibían un tratamiento diferente a la convencional atribución de elogios o improperios, y eran analizadas en función de sus objetivos declarados o implícitos, de su consistencia metodológica y expositiva, de sus implicaciones técnicas o ideológicas." (Alfredo Chacón: "Trayectoria ideológica de la izquierda cultural venezolana 1958-1968", "Prólogo" a $L a$ izquierda cultural...op.cit., p. 34)

${ }^{300}$ Guillermo Sucre: “Con la misma adhesión”, en Imagen, Caracas, núm. 29, 15/30 jul. 68, p. 2. 
Guillermo dejó su cargo en la revista a Edras Parra -que hasta ese momento había estado al frente de la redacción- y marchó a los EEUU, concretamente a la Universidad de Pittsburgh, para enseñar Literatura hispanoamericana. En 1989 nuestro autor retomó la dirección de la revista, pero un año más tarde la cedería de nuevo a Edras Parra. A día de hoy, aunque con muchos cambios, Imagen aún se sigue publicando. 


\section{CAPÍTULO III}

\section{EL PENSAMIENTO LITERARIO DE GUILLERMO SUCRE (1958-1963)}

Cuando Guillermo Sucre accedió al campo literario tras la caída de la dictadura

de Pérez Jiménez se encontró con un problema grave para el desarrollo de la literatura nacional: la ausencia de valores estéticos. Esta falta de criterios era la consecuencia de que el campo literario estuviera dominado por una intelectualidad deshonesta e insincera, que anteponía sus intereses personales a los valores estéticos. Ya en el primer "Testimonio" de Sardio, además de reclamar de los escritores venezolanos más lucidez y dedicación al oficio, nuestro autor había señalado que

Si algo es alarmante entre nosotros es la ausencia de debates sobre los problemas y motivaciones de la creación, la ausencia de análisis objetivos al juzgar la obra del artista. Vivimos en medio de prejuicios y cofradías. Nos falta meditación, trascendencia. Nuestra escala de valores está regida por la timidez y la complacencia. Pero la cultura es algo más que un juego deleitoso de gentes que se rinden mutua pleitesía. Ella es la expresión de la historia, espejo de los júbilos y de las tribulaciones del hombre. El reino inquebrantable de la verdad. ${ }^{301}$

Guillermo denunciaba así que el "arribismo" y el "fraude intelectual” se habían adueñado de la cultura venezolana y que ésta, por lo tanto, había olvidado su verdadero cometido: "la mayoría de nuestros escritores y artistas han rendido fiel tributo a la cortesanía intelectual o a ese otro devorante minotauro del oportunismo político o del bienestar egoísta, olvidando lo que debe ser único imperativo del espíritu: una vasta y penetrante comunicación con el universo, los sueños, la grandeza y aun la miseria del hombre" 302 .

${ }^{301}$ Guillermo Sucre: "Testimonio", loc.cit., p. 3. En un texto publicado en 1962 Sucre seguía insistiendo en el mismo problema: "El hecho esencial que debemos señalar es la falta de una conciencia estética aun en las mejores o en las más sanas expresiones de nuestra crítica literaria. Es decir, la ausencia de un sistema de valores sobre los cuales fundar, a partir de la intuición personal que todo crítico tiene de una obra, juicios que tengan un cierto desarrollo objetivo, una cierta realidad en la obra que se analiza. Lo cual permitiría reemplazar las simples impresiones o las opiniones demasiado generales y vagas por referencias a "hechos estéticos" concretos a través de los cuales se individualice la obra misma. (Guillermo Sucre: "La crítica literaria”, en La República, Caracas, 09-12-62, p. 7)

302 Guillermo Sucre: “Testimonio. Las constantes...", loc.cit., p. 279. En un texto de la misma época Sucre señalaba lo siguiente: "Las complacencias y prejuicios en que ha languidecido gran parte de la vida espiritual venezolana han creado mitos y fetiches por largo tiempo inquebrantables. Así, un equívoco tráfico de mutuas reverencias y de idolatrías ha tenido vasto y acogedor escenario en toda la 
La deshonestidad intelectualidad y la consiguiente ausencia de valores críticos habían tenido consecuencias negativas para el desarrollo de la literatura nacional. En primer lugar, habían impedido conformar una "literatura propiamente dicha", es decir, un "sistema de obras ligadas por denominadores comunes"303. En respuesta a un cuestionario de 1958, nuestro autor señalaba que "ni siquiera" se podía "hablar de «crisis» para la novela venezolana", pues hacerlo

implicaría el reconocimiento de una plenitud estética anterior, de una suerte de "cuerpo novelesco" homogéneo y consagrado, hasta de una visión singular del mundo. Nada de ello ha logrado, precisamente, nuestra novela en general, como expresión de un espíritu y de una cultura. Acaso la misma inmadurez de nuestras tradiciones haya impedido la cristalización de esas virtudes que, en definitiva, son las que comunican validez a la novelística de cualquier país. $^{304}$

Para Sucre, la narrativa nacional se había renovado en la primera mitad del siglo

XX gracias a la obra de Gallegos, pero después de él "sobrevino un sensible descenso en relación con ese impulso inicial, sin que hoy podamos vislumbrar una voluntad creadora capaz de abrir nuevas perspectivas ${ }^{\text {305 }}$. En segundo lugar, la carencia de una crítica autorizada había impedido a la literatura venezolana entroncar con la estética de la tradición moderna, y esa situación determinaba el aislamiento de la cultura nacional. Como la intelectualidad no se guiaba por valores estéticos sino por la búsqueda del

historia de la literatura venezolana. La ausencia de un definido sistema de valores y un no siempre disimulado desdén por lo objetivo y analítico así como un apego negligente a lo convencional y consagrado y ese penoso aire de provincialismo que suele regir nuestro destino, acaso hayan propiciado ese falso y regocijante clima de plenitud y neutralizado también cierto espíritu crítico indispensable a la autenticidad y proyección de toda cultura." (Guillermo Sucre: "Balance de una encuesta. Sobre novela venezolana", en El Papel Literario de El Nacional, 09-10-58)

303 "Antonio Candido ha distinguido entre "manifestaciones literarias" y una "literatura propiamente dicha" a la que considera un "sistema de obras ligadas por denominadores comunes", precisando que "estos denominadores son, además de las características internas [...] ciertos elementos de naturaleza social y psíquica, aunque literalmente organizados, que se manifiestan históricamente y hacen de la literatura un aspecto orgánico de la civilización." (La cita, que procede de Antonio Cândido: Formaçao da literatura brasileira (Momentos decisivos), Livraria Martins Editora, Sao Paulo, 1959, t. 1, p. 17, está tomada de Ángel Rama: "La modernización literaria latinoamericana (1870-1910)", en La crítica de la cultura en América Latina, Caracas, Biblioteca Ayacucho, № 119, 1985, p. 87)

304 Guillermo Sucre: "Nuestra novela no ha culminado", respuesta a la encuesta de Carlos Dorante: "La novelística en manos de una juventud desinteresada", El Papel Literario de El Nacional, Caracas, 14-08-58.

${ }^{305}$ Ibíd. Otros escritores que la nueva generación exaltaba "sin mezquindad, pero también sin complacencia" fueron Alejo Carpentier, Vicente Gerbasi, Mariano Picón Salas, Juan Liscano, Miguel Ángel Asturias y Gonzalo Rojas. (Guillermo Sucre: “Testimonio. Las constantes...”, loc.cit., pp. 280281) 
favor personal, la literatura había quedado relegada respecto a las tendencias literarias universales y carecía de repercusión más allá de las propias fronteras:

nuestra técnica narrativa aún parece insegura y la creación de los grandes temas en nuestro mundo se mantienen en un tratamiento anecdótico e insustancial, porque nuestras mismas criaturas novelescas no aciertan a superar ese vago pero ya rígido sistema de relaciones entre el hombre y la naturaleza y no parecen vivir con plena lucidez la poderosa aventura del espíritu contemporáneo. [...] hasta los mismos autores que una crítica complaciente ha pretendido consagrar, no representan, en relación con los grandes nombres americanos y universales, sino una visión anacrónica e intrascendente dentro del ejercicio creador. ${ }^{306}$

El aislamiento de la literatura venezolana sólo era positivo para esos escritores mediocres que, adulados por una crítica deshonesta, y ajenos a lo que sucedía fuera del territorio nacional, creían "haber conquistado la eternidad con unos libritos de poemas, con una «plaquette», con una novela" ${ }^{307}$. Estos mismos autores eran los que creaban esas obras que para Guillermo resultaban inactuales e impostadas, pues al carecer de un criterio estético apropiado, incurrían en excesos formales y expresivos que eran a un tiempo la causa y el síntoma de la crisis cultural que vivía Venezuela:

Hay en cierta literatura del país toda una legión de grandes elefantes o de medrosos roedores del espíritu, eternos frustrados de un mundo que siempre les enrostra sus fugas, sus éxtasis pusilánimes, que, muy asépticos y pudorosos, incapaces de sentir los portentosos y no siempre confortables desencadenamientos de la historia o del destino del hombre, parecen cultivar vagas y gratuitas pretensiones de inmortalidad. Son los pájaros carpinteros de la creación, los híbridos estetas, los tardíos alquimistas del lenguaje, pequeños seres funerarios que inciensan su propia y arrogante banalidad. ${ }^{308}$

Ante este sombrío panorama, la generación de Sucre, con él a la cabeza, trató de modernizar y profesionalizar la literatura nacional. En un ensayo publicado en Sardio Guillermo ponía de manifiesto la labor que los jóvenes agrupados en torno a la revista pretendían cumplir:

constituimos una generación consciente de su destino, poseída por una voluntad de trascendencia, fiel a las verdaderas y dramáticas constantes del tiempo que le ha tocado vivir y en él enraizada y comprometida, dispuesta a redimir por ejercicio del espíritu y de la verdad lo que otras generaciones parecen haber sacrificado por la negligencia y las pequeñas ambiciones; [...] somos un grupo de escritores y artistas para quienes la creación es combate con el destino o con la historia y no esa farsa creciente que es la cultura en nuestro país. ${ }^{309}$

\footnotetext{
${ }^{306}$ Guillermo Sucre: "Nuestra novela no ha culminado", loc.cit.

${ }^{307}$ Guillermo Sucre: "Los inmortales", loc.cit.

308 Ibid.

${ }^{309}$ Guillermo Sucre: "Testimonio. Las constantes...", loc.cit., p. 277.
} 
El objetivo de Sucre era introducir jerarquías e imponer límites a la complacencia indiscriminada y al libertinaje que advertía en el campo literario venezolano, para lo cual era necesario promover nuevas actitudes intelectuales e introducir una conciencia estética fundada en criterios objetivos. Algunos años antes que Guillermo otros autores de dimensión internacional habían insistido en la necesidad de enjuiciar las obras atendiendo únicamente a valores artísticos. Jean Paul Sartre, un pensador muy leído por nuestro autor en esta época, había propuesto en su artículo "La nationalisation de la littérature" que la crítica debía recuperar su función. Durante los años de la Resistencia a la ocupación nazi, los intelectuales franceses se habían dedicado a estimar a los escritores por criterios extraliterarios como su pertenencia al maquis, su condición de prisionero de guerra o su pertenencia a un determinado partido político. Frente a esta sobrevaloración, que nada tenía que ver con el talento literario de los autores, el pensador francés proponía lo siguiente:

Peut-être la critique pourrait-elle contribuer á sauver les lettres si elle se souciait de comprendre les oeuvres plutôt que de les consacrer. En tout cas nous avons ici le ferme propos d'aider á la déflation littéraire. Il est probable que nous ne nous ferons pas beaucoup d'amis. Mais la littérature s'endort; une bonne passion, fût-ce la colère, aura chance, peut-être de la réveiller. $^{310}$

En el ámbito hispanoamericano esta misma actitud se advierte en los artículos que Emir Rodríguez Monegal publicó en Marcha a lo largo de los años 50. Desde las páginas del semanario uruguayo, el intelectual denunciaba la carencia de criterios estéticos en la generación inmediatamente anterior a la suya y la señalaba como responsable de la corrupción del ambiente cultural. En contraste con estos intelectuales, Monegal destacaba que los escritores de su propia generación -que habían empezado a destacar en el campo literario hacia 1940- restauraron "los fueros de la crítica" introduciendo "un nuevo sistema de valores literarios" que incluía "la utilización de un 53.

${ }^{310}$ Jean Paul Sartre: "La nationalisation de la littérature”, en Situations II, op.cit., pp. 33-53, p. 
mismo patrón crítico para la literatura nacional que para la extranjera, aboliendo las complacencias nacionalistas y el fomento a la industria local; [...] la edificación de la crítica sobre el análisis minucioso y objetivo de cada obra y no sobre la opinión talentosa del momento; [... y] el reconocimiento de la función social del crítico"311.

Ante una degradación semejante de la crítica y de la intelectualidad en Venezuela, Guillermo Sucre quiso acabar con el arribismo y la falta de exigencia de los escritores venezolanos -vicios que habían dado lugar a una literatura informe y azarosay comenzó a reclamar a la literatura un carácter necesario. El crítico pensaba que si las obras respondían a motivaciones forzosas e ineludibles se podrían liberar de los fines extraliterarios que tanto daño habían hecho a la cultura nacional. Esta exigencia se estableció de la siguiente manera: las obras debían presentar una relación necesaria con su creador y con el contexto histórico de producción pues sólo así podrían entroncar con los valores estéticos universales. En uno de los "Testimonios" de Sardio, nuestro autor propuso este condicionante para acabar con la deshonestidad que imperaba en el campo literario:

el acto de elegir, desgarradamente lúcido e impersonal y cuando es más convincente y verídico, debe surgir de la coincidencia con anhelos y realidades ineludibles de la historia y debe posesionarse de su destino integral como inteligencia creadora. Cuando no ocurre tal coincidencia o tal posesión, cuando la decisión de crear un mundo no nace de necesidades de vida, de requerimientos impostergables, el acto de escoger corre el riesgo de volverse no sólo ya gratuito e inexpresivo, sino también arribista y acomodaticio. ${ }^{312}$

En el mismo texto Guillermo insistía en la importancia de que la obra arraigara en la historia pues en esa coincidencia veía un posible escape a los intereses menores que ocupaban a la intelectualidad nacional:

El que se establezca entre las circunstancias históricas dadas y la voluntad creadora del hombre verdaderas coordenadas susceptibles de ser realizadas a través de muchos caminos y que uno de ellos sea el del arte, creemos que ha de ser una de las aspiraciones más nobles del escritor. Es en tal dimensión donde su compromiso se hace viviente y fecundo, y aun

311 Emir Rodríguez Monegal: "La nueva literatura nacional”, en Obra selecta, op.cit., pp. 25-35, p. 29. (El artículo se publicó originalmente en Marcha, Montevideo, núm. 653, 26 de diciembre de 1952, pp. 25-27)

312 Guillermo Sucre: "Testimonio. El intelectual de izquierda y cierta estética revolucionaria", en Sardio, Caracas, núm. 7, abril-mayo de 1959, p. 431. Cursiva nuestra. 
despersonalizado. Fuera de ella, y a pesar de que aparentemente se elija una causa renovadora, todo puede verse sometido a la contingencia de pequeñas ambiciones e intereses más o menos transitorios. ${ }^{313}$

Ahora bien, al proponer esta correspondencia precisa entre el creador, el contexto y la obra, Sucre estaba proponiendo un ideal de orden y saturación que está vinculado a una política estética y cultural muy concreta. Al reclamar una coincidencia clásica entre la expresión y lo expresado o, lo que es lo mismo, entre el autor, el mundo y la escritura, Guillermo estaba rechazando los excesos expresivos y convirtiendo a la literatura en un cuerpo armónico y bien compensado en el que no sobra nada. Para entender bien la política estética que nuestro autor defenderá a lo largo de esta etapa es imprescindible remontarse a las fuentes de su concepción estética y cultural.

En consonancia con su maestro Picón Salas, Guillermo pensaba que tanto la cultura como los valores estéticos tenían una dimensión ecuménica. El ensayista merideño consideraba que la cultura occidental defendía principios humanos esenciales e insobornables y se oponía, en consecuencia, al relativismo y a la verdad deformada por criterios ideológicos: "La fe en los valores que están más allá de la secta o de la propaganda del instante, la consideración o -si se quiere- el sueño de un Arte, una Ciencia y una Filosofía que desde lo meramente temporal se proyecte hacia más fijos valores humanos, continúa siendo, a pesar de las guerras, las crisis y los odios de nuestra edad, el supuesto de toda idea de Cultura"314. Para Picón, la cultura debía “encontrar otra vez los arquetipos: los cánones que desde nuestra discordia y conflicto particular nos eleven a aquella esfera superior -esfera platónica de las ideas- inalterable

${ }^{313}$ Ibíd. p. 431. Por esta necesidad de actualización histórica de la literatura, Sucre rechazaba la postura crítica del cubano Manuel Pedro González. "Así como algunos críticos europeos -Wladimir Waidlé, entre ellos- intentan estudiar la novela contemporánea rigiéndose por la novela del siglo XIX, él pretende igualmente que la nueva narrativa hispanoamericana se rija por modelos tipo Azuela, Gallegos, Güiraldes, etc. Es inobjetable que asigne a estos escritores calidad de maestros [...] pero no deja de ser impropio querer que los nuevos novelistas marquen el mismo paso. Actitud que desvirtúa todo sentido creador dentro de la literatura." (Guillermo Sucre: "Manuel Pedro González: Ensayos críticos", en La República, Caracas, 03-11-63. Se puede ver también la crítica de Sucre a Waidlé en Guillermo Sucre: "Perspectivas sobre la novela", en La República, Caracas, 28-07-63)

${ }^{314}$ Mariano Picón Salas: “Alegato de Europa. Prólogo de 1946”, en Viejos y nuevos...op.cit., p. 333. 
de todo accidente; forma de las formas, estrella polar del espíritu"315. En consecuencia, los creadores venezolanos debían ser capaces de hallar, a partir de su condición particular, "lo Universal humano" pues "una Cultura es verdaderamente grande cuando, remontándose sobre las imágenes particulares, llega como los griegos, los franceses, los italianos del Renacimiento, la edad de oro de la Filosofía alemana, a descubrir las normas universales"316. Haciéndose eco de esta concepción, Sucre pensaba que era imprescindible que las obras nacionales convinieran con los valores universales del alma humana. Ahora bien, estos principios supuestamente universales se correspondían con una política estética y cultural que consistía en la defensa de una suerte de clasicismo moderno, es decir, de un paradigma de orden y saturación ante la amenaza de la literariedad democrática ${ }^{317}$. Al fundar su estética de acuerdo a este modelo, Guillermo se sumaba a un "linaje" intelectual que había nacido con la recepción de Poe por los poetas simbolistas franceses, se había prolongado a lo largo del siglo XX en múltiples direcciones, y se aprecia con diferentes matices en los grandes autores que marcaron la visión sucreana de la literatura y del lenguaje como Vallejo, Borges, Picón Salas, Camus, Rosenblat, Barthes, Paz, etc. Si bien todos estos intelectuales defendieron de distinta manera, como veremos a lo largo de este trabajo, este paradigma "clásico", en la concepción de nuestro autor la estética propuesta por los poetas simbolistas y por Mariano Picón Salas tuvo un peso fundamental. El modelo planteado por ambos (simbolistas y Picón) fue asumido de tal manera por Sucre que para él la literatura misma se confundía con él.

En un texto escrito en 1958 y titulado muy acertadamente "Los inmortales", Guillermo cuestionaba la actitud de ciertos creadores venezolanos que hacían

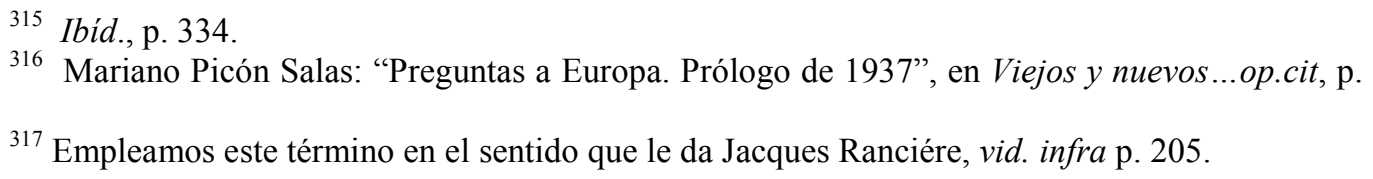


una literatura ajena a la verdadera y exigente lucidez, a la disciplina creadora, a ese milagroso y cotidiano ejercicio del espíritu. Ninguna problemática los mueve a dudas y nada en sus obras parece inquietarlos o perturbarlos. [...] Son los imperturbables y regocijados que viven de los halagos de una crítica insincera. Son los tediosos inmortales. Esta es actitud que define a más de un escritor en nuestro país y a todos, en cierto modo, nos compromete. ${ }^{318}$

A continuación señalaba la causa de esta conducta impropia: "Acaso -decía

Sucre- hemos olvidado la lección de los grandes creadores de todas las épocas"319.

Como ejemplo de esa actitud universal que él era incapaz de hallar entre los escritores nacionales Guillermo mencionaba a Valéry, a quien "no le preocupaba la eternidad, pero buscaba, sí, un absoluto a través de un rigor permanente del intelecto y a través de una tensa iluminación del espíritu" ${ }^{, 320}$. Es evidente, por lo tanto, que la propuesta estética de los simbolistas fue una referencia fundamental para nuestro autor.
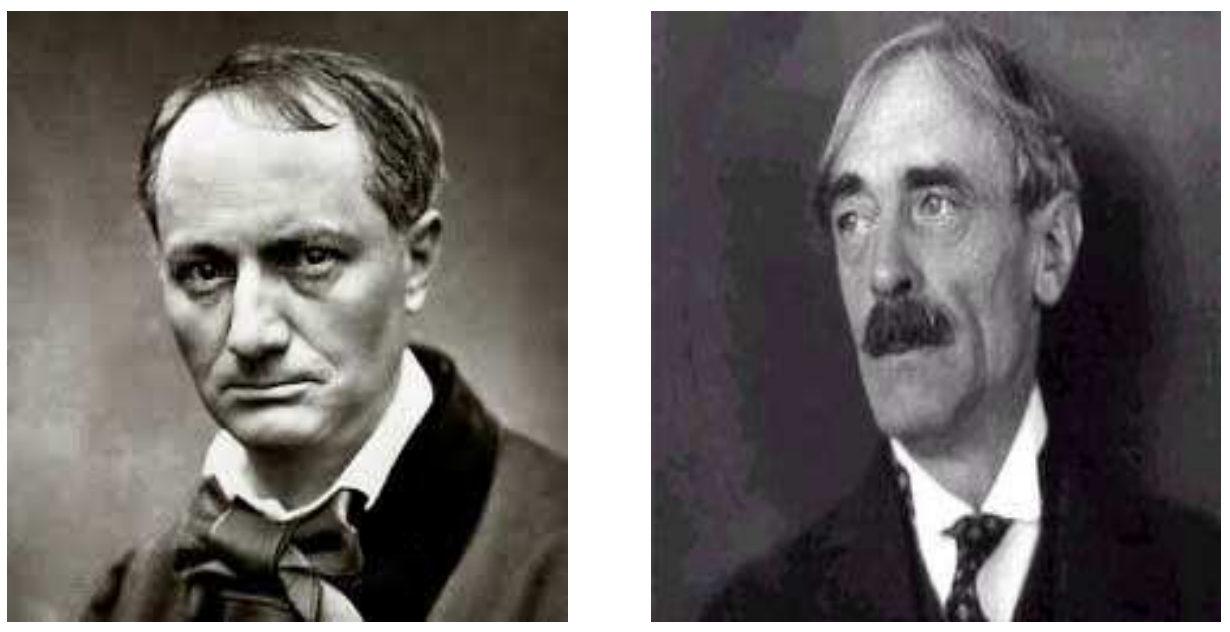

Imágenes 29 y 30. Charles Baudelaire (1821-1867) y Paul Valéry (1871-1945), dos de los grandes poetas simbolistas.

El punto básico de la estética de estos poetas era la oposición "al sistema, o a la ausencia de sistema, que se llama romanticismo"321. En contraste con este movimiento,

${ }^{318}$ Guillermo Sucre: "Los inmortales", loc. cit.

${ }^{319}$ Ibid.

${ }^{320}$ Ibíd. Nuestro autor indicaba que era preciso retomar el testigo de esos grandes creadores entre los que citaba también a Malraux y a Perse- que "se jugaron su destino [...] con un esfuerzo reiterado e implacable en sus vidas y sus obras" y que, si bien no pretendieron alcanzar la inmortalidad "fueron los victoriosos habitantes de su tiempo, los inquebrantables y tenaces creadores de un mundo." (Ibid.)

321 Paul Valéry: "Situación de Baudelaire”, en VVAA: Matemática tiniebla. Genealogía de la poesía moderna, Barcelona, Galaxia Gutenberg, 2011, p. 262. 
los simbolistas definieron una actitud propia del escritor y establecieron estrictas limitaciones a la creación literaria lo que dio lugar a la fundación de una suerte de clasicismo moderno, es decir, de un paradigma de orden y de saturación que opusieron al azar y a la desmesura. Siguiendo la doctrina de Poe -que había propuesto renunciar a la utilidad directa del poema y "gozar de un estado de ánimo que se contraponga tanto como sea posible al estado de ánimo poético"322- los simbolistas se opusieron a los abandonos y las arbitrariedades en que había incurrido el movimiento romántico:

Los románticos habían descuidado todo, o casi todo lo que pide al pensamiento una atención y una continuidad dificultosas. Buscaban los efectos de choque, de arrastre y de contraste. Ni la medida ni el rigor ni la profundidad les atormentaban demasiado. Rechazaban la reflexión abstracta y el razonamiento y no sólo en sus obras, sino incluso en la preparación de sus obras, lo que es infinitamente más grave. ${ }^{323}$

La escuela romántica en sus peores manifestaciones se había caracterizado por "la facilidad apasionada", "la inconsistencia del estilo" y "los desbordamientos de la necedad y extravagancia"324. Incluso la obra de un poeta como Víctor Hugo, pese a sus innegables virtudes, "rendía culto a lo vulgar, se perdía en la elocuencia profética y los inacabables apóstrofes" ${ }^{325}$. Esta tendencia a la desmesura les llevó a favorecer "un inmenso desarrollo de literatura descriptiva", que "dispensa de cualquier encadenamiento, admite todo lo que admiten los ojos, permite introducir nuevos términos a cada instante. Resulta de ello que el esfuerzo del escritor, reducido y concentrado en ese instante, se aplicó a los epítetos, a los contrastes de detalle, a los «efectos» fácilmente separables. Fue el tiempo de las joyas" ${ }^{\text {326 }}$. Como resultado de una confianza colosal en ellos mismos, los poetas románticos habían caído en excesos de objetividad y de subjetividad, que estaban estrechamente vinculados. Al dar cabida en la creación literaria a la elocuencia y a lo narrativo esos vates incurrieron en un

${ }^{322}$ Edgar A. Poe: "El principio poético”, en VVAA: Matemática tiniebla ...op.cit., p. 32.

323 Paul Valéry: "Situación de Baudelaire”, en VVAA: Matemática tiniebla ...op.cit., p. 263.

324 Ibid., p. 263.

325 Ibid., p. 264.

326 Paul Valéry: "Le decía yo a veces a Stéphane Mallarmé", en VVAA: Matemática tiniebla...op.cit., p. 312. 
formalismo superficial que quería ser una compensación ante la proliferación de detalles vanos e insustanciales. Además, los poetas de este movimiento incidieron en eso que Baudelaire había llamado "la poesía del corazón"327, es decir, en un exceso de pasión que resultaba de la falta de control intelectual. Ante el descuido y la falta de lógica que advertían en la poesía romántica, los simbolistas se impusieron el rigor y la exigencia más severos. Por eso Valéry afirmaba que la afinidad entre estos últimos poetas no era estética sino ética: más que unos principios artísticos similares todos tuvieron en común una "renuncia" parecida, un mismo rechazo a lo fácil y a lo instintivo. El valor de una obra se establecía entonces a partir de los límites que se imponía a sí misma ${ }^{328}$ y el nivel de exigencia de esos poetas era tan severo que tan sólo les quedaba estar resueltos

a no admitir nada por lo que no sienta real necesidad interior, nada que no sea la existencia esperada por su ser más profundo; a no consentir nada que se resuelva en palabras cuya significación no le suponga una experiencia inmediata y un valor incluido en el tesoro de sus afectos. Ídolos por ídolos, prefiere los que están hechos sólo de su propia sustancia antes que los propuestos por otros. ${ }^{329}$

Este ideal implicaba el establecimiento de un vínculo necesario entre la mirada y la escritura o, lo que es lo mismo, entre el temperamento del artista y su expresión literaria. En suma, la política estética de los simbolistas consistió en la asunción de una ética determinada ante la creación literaria. En oposición a los excesos de contenido y

${ }^{327}$ Charles Baudelaire: “Théophile Gautier”, en Obras, México, Aguilar, 2a ed., 1963, p. 718. Allí señalaba: "Durante la época desordenada del romanticismo, época de ardiente efusión, se usaba a menudo de la siguiente fórmula: ;La poesía del corazón! Se otorgaba así a la pasión derechos absolutos; se le atribuía una especie de infalibilidad. [...] El corazón es fuente de pasión, el corazón es fuente de abnegación, de crimen; sólo la imaginación es fuente de poesía." (Ibíd.) En el mismo texto el vate proponía lo siguiente: "La sensibilidad del corazón no es favorable en absoluto al trabajo poético. Una extrema sensibilidad de corazón hasta puede perjudicar, en ese caso. La sensibilidad de la imaginación es de otra naturaleza; sabe elegir, juzgar, comparar, huir de esto, buscar aquello, rápidamente, espontáneamente. De esta sensibilidad, a la que se llama generalmente el Gusto, obtenemos poder para evitar el mal y buscar el bien en materia poética. (Ibíd., p. 719)

${ }^{328}$ Como dice Valéry: "El rigor de los rechazos, la cantidad de soluciones que se desdeñan, de posibilidades que uno se prohíbe, revelan la naturaleza de los escrúpulos, el grado de conciencia, la cualidad del orgullo e, incluso, los pudores y temores diversos que se pueden sentir en relación con los juicios futuros del público. En este punto la literatura alcanza el ámbito de lo ético: es en este orden de cosas donde puede introducirse el conflicto entre lo natural y el esfuerzo; donde la literatura obtiene de la resistencia a lo fácil sus héroes y sus mártires; donde se manifiesta su valor, y también, alguna vez, su hipocresía." (Paul Valéry: "Carta sobre Mallarmé a Jean Royère", en VVAA: Matemática tiniebla...op.cit., p. 306)

${ }^{329}$ Paul Valéry: "Existencia del simbolismo", en VVAA: Matemática tiniebla...op.cit., p. 289. Primera cursiva nuestra. 
expresión propios del romanticismo, estos poetas se impusieron el cálculo y la exigencia más extremas y buscaron una síntesis armónica entre el sujeto y el objeto, la pasión y la inteligencia y la forma y la significación, con la intención de lograr una expresión saturada y perfecta.

La política estética de los simbolistas fue aplicada al ámbito cultural venezolano en la obra ensayística de Mariano Picón Salas. El humanista merideño llegó a ella tanto a través de la lectura directa de estos poetas como a través de los pensadores del Romanticismo alemán, fuente que ambos compartían. El maestro de Sucre trató de ordenar la cultura nacional con arreglo a un modelo de saturación que la hiciera semejante a las culturas metropolitanas, y apta, en consecuencia, para expresar desde su condición particular los valores universales del espíritu ${ }^{330}$. Picón pensaba que las civilizaciones europeas, "ya ordenadas y sistematizadas"331, eran auténticas porque presentaban un acuerdo total entre la identidad y la expresión cultural que cancelaba la posibilidad del suplemento. Por lo tanto, para lograr un desarrollo semejante de la cultura venezolana era imprescindible que los hechos culturales gozaran de un arraigo similar. El ideal de orden y saturación cultural que Picón anhelaba para Venezuela (es decir, la coincidencia entre la mirada y la expresión que diera lugar a una cultura auténtica) no se había cumplido porque, como herencia de la educación colonial, la cultura se había mantenido ajena al contexto y había permanecido como algo abstracto, superpuesto a la propia circunstancia: "Nuestra cultura superior ha sido -como en todos los países suramericanos-, algo extraño al medio; flotante sobre nuestra realidad, ajeno al misterio propio que se llama el país. Glosa, repetición, traducción, fue la forma de nuestras universidades anquilosadas" ${ }^{332}$. La desconexión entre las ideas y el medio de

${ }^{330}$ Sobre la concepción cultural de Picón Salas vid. supra pp. 1116-117.

${ }^{331}$ Mariano Picón Salas: "Pequeña confesión a la sordina”, en Viejos y nuevos...op.cit,. p. 4.

${ }^{332}$ Mariano Picón Salas: "Proceso del pensamiento venezolano", en Viejos y nuevos...op.cit., p. 70. La cita sigue: "El sabio solía ser el abogado instruido en los códigos de los más lejanos países [...]. 
aplicación había dado lugar a que la cultura venezolana fuese algo distanciado de la propia realidad: "Lo que entre nosotros se llama la cultura -decía Picón Salas- no es propiamente la identificación o comprensión con la tierra, sino la fuga, la evasión”333.

Ante la superficialidad de la cultura venezolana, el ensayista insistió a lo largo de toda su obra en la necesidad de dar un fundamento propio a la cultura nacional, es decir, en el requerimiento de que las ideas arraigaran en "lo concreto" 334 . A este respecto, en el artículo titulado "Una voluntad nacional" señalaba que "toda auténtica Educación como toda auténtica Cultura sólo tiene valor en cuanto se elabora en las profundidades del ser; en cuanto surge como voluntad y necesidad interna más que como mecánica imitación de lo que viene de fuera. Su carácter foráneo, inadaptado, es el mayor obstáculo que pesa sobre nuestro régimen educativo",335. Y en otro texto reclamaba que la inteligencia no debía ser "adorno y objeto inútil", "evasión y nostalgia", sino "comprensión y revelación de la tierra"336.

Por ello existe tan profundo abismo entre las leyes fabricadas en Caracas y la oscura circunstancia autóctona. Por ello, lo que tiene más valor en la producción cultural venezolana, son algunas obras de imaginación donde el instinto del artista -como en ciertas páginas de poesía o de novela- tropezó más inconsciente que conscientemente, con el secreto o el enigma nativo." (Ibíd.) En su obra De la Conquista a la Independencia el ensayista afirmaba igualmente: "Las formas pomposas de la iglesia, el estado y la enseñanza velan al espíritu criollo, aún informe, la visión de la realidad próxima y concreta." ("El Barroco de Indias" en Viejos y nuevos...op.cit., p. 169).Y añadía más adelante: "La cultura es un fenómeno de superposición de noticias, más que de síntesis. El método rigurosamente deductivo de la escolástica no les provee de espíritu histórico para comprender el caso particular o distinguir lo concreto más allá del muro de fórmulas e ídolos verbales que lo esconde.” (Ibíd., p. 173) Además, para Picón esta condición desarraigada de la cultura venezolana estaba vinculada con los órdenes políticos de la Colonia y del caudillismo -"bajo el reinado de los «césares» los intelectuales venezolanos solieron llamarse «orfebres», coleccionistas de adjetivos, optimistas y alabadores profesionales." (Mariano Picón Salas: "Proceso del pensamiento venezolano", en Viejos y nuevos...op.cit., p. 60) e implicaba un empleo particular del lenguaje, que imponía una distancia entre la forma y la significación: "La herencia de la educación colonial y española, educación de palabras más que de cosas, educación que tras de los claustros del siglo XVII parecía amurallarse contra la Naturaleza [...] vino a complicarse con la retórica delirante que nos cerraba un contacto más directo con nuestro medio físico y moral. Nuestro atrasado sistema educativo prolongó hasta hoy lo que llamaríamos el período fraseológico de la cultura venezolana: la palabra divorciada del hecho, suelta y autónoma en su vaga sonoridad." (Mariano Picón Salas: "Notas sobre el problema de nuestra cultura", en Viejos y nuevos...op.cit., p. 74)

66.

${ }^{333}$ Mariano Picón Salas: "Proceso del pensamiento venezolano", en Viejos y nuevos...op.cit., p. nuevos...op.cit., p. 74.

${ }^{335}$ Mariano Picón Salas: "Una voluntad nacional”, en Viejos y nuevos ...op.cit., p. 83.

${ }^{336}$ Mariano Picón Salas: "Proceso del pensamiento venezolano", en Viejos y nuevos...op.cit., p. 71. 
Además, así como los simbolistas habían propuesto una síntesis armónica del sujeto y del objeto y de la pasión y la inteligencia, Picón reclamaba que la cultura venezolana, para ser auténtica, debía conciliar las desmesuras culturales representadas por el nacionalismo y el cosmopolitismo y los defectos estéticos a ellas vinculados: el realismo y el esteticismo. Por eso proponía -adaptando las ideas de Schiller a la problemática de la cultura hispanoamericana- la necesidad de hallar una unidad adecuada entre la cultura europea y la naturaleza americana:

Desde Rousseau y Goethe muchos grandes europeos viven en nostalgia de Naturaleza como los suramericanos queremos aplacar el instinto y la pasión ciega en el orden de la Cultura. Cuando la Cultura pierde el contacto de la Naturaleza, se convierte en intelectualismo frío, en el cálculo abstracto e inhumano. La Naturaleza sin la Cultura es el reino sombrío y casual del instinto, la sorpresa hecha terror, la crueldad sedienta, el pánico del que no sabe. "Hay una barbarie de la reflexión como hay una barbarie del instinto", decía Schiller. Los grandes momentos de la Humanidad son aquellos que -como en la clara mañana del clasicismo griego- la inteligencia y la vida pueden marchar juntas; el espíritu no niega al cuerpo, sino lo comprende y lo integra. [/] La Cultura de Europa y la Naturaleza de América se desean, pues, y se buscan, como en un vasto sueño de humanidad total. ${ }^{337}$

En línea con esta búsqueda de armonía, el maestro de Sucre anhelaba una conciliación entre las posturas nacionalistas y las extranjerizantes que, por separado, representaban dos formas del desarraigo y, por lo tanto, de la inautenticidad cultural:

Ni la vana soberbia por la tradición autóctona, sin someterla a ningún análisis, ni la otra vanidad de muchos nuevos pobladores de que sus estilos de vida son los civilizados y ejemplares, han de servirnos para esta etapa tan apasionadamente movida que emerge en la Historia nacional. [...] La mejor venezolanización [...] será la que armonice adecuadamente como síntesis y no como discordia o simple superposición, este juego de influencias recíprocas. $^{338}$

Esta concepción cultural está presente también, como es lógico, en la concepción estética del ensayista. En lo que atañe al arte y a la literatura venezolanas, Picón 336.

${ }^{337}$ Mariano Picón Salas: “Preguntas a Europa. Prólogo de 1937”, en Viejos y nuevos...op.cit., p.

${ }^{338}$ Mariano Picón Salas: "Pequeño tratado de la tradición”, en Viejos y nuevos...op.cit., p. 90. También en el marco de las ideas proponía una unión del idealismo y del materialismo, las dos filosofías más importantes de la tradición occidental: "Hasta ahora la cultura europea se realizó como choque de dos filosofías, de dos maneras de concebir el mundo. Hubo las épocas del idealismo subjetivo en que [...] se negó lo material y terrestre para comunicarse con el alma descarnada y desasida en su profunda espelunca; en su sonora soledad. Y hubo las otras, del naturalismo y el materialismo sin dioses y sin misterio, en que el hombre solo estuvo como a la orilla de la vida, en aquella frontera en que su epidermis rozaba las cosas. Una cultura que armonice esos dos mundos, que nos dé al mismo tiempo la conciencia de nuestro poder y nuestras limitaciones pudiera lograr -después de estos días de angustia- la nueva "sofrosine" que pareció evaporarse con la lejana vida griega." (Mariano Picón Salas: "Profecía de la palabra”, en Viejos y nuevos...op.cit., p. 459) 
defendía el mismo acuerdo entre las posturas nacionalistas y las cosmopolitas, pues lo que él anhelaba era un ideal de orden y saturación entre el ser y la expresión que fuera capaz de trascender los excesos inarmónicos que distanciaban a la cultura venezolana de la ordenación que él advertía en las culturas de otras latitudes:

Acaso a fundir esas corrientes opuestas de lo puramente popular y localista, de lo altamente culto y europeizante, que han parecido marchar sin soldarse en nuestra Literatura, se dirija el esfuerzo de las generaciones próximas; y ya hay una serie de síntomas que lo anuncian. Todo gran arte ha resultado de esa confluencia necesaria entre lo nacional y lo universal. Sólo de estas síntesis que supera el folklore, pero que no es tampoco el cerrado invernadero para que lo disfruten escasos iniciados, surgirá la expresión del suramericano integral. ${ }^{339}$

Vemos, por lo tanto, que el maestro de Sucre trató de ordenar la cultura venezolana de acuerdo al modelo de completitud que advertía en las viejas civilizaciones europeas. Para ello era imprescindible que las ideas tuvieran un arraigo en la propia tierra, es decir, que no hubiera una distancia entre la expresión cultural y el medio. Sólo entonces la cultura venezolana podría conciliar los excesos culturales y estéticos entre los que se había debatido históricamente (el nacionalismo y el cosmopolitismo, el realismo y el formalismo) y expresar ese "otro matiz diferenciado" “en la clave común de la cultura occidental" "340.

Siguiendo la política estética y cultural propuesta por Picón Salas y por los poetas simbolistas, Guillermo leyó las obras literarias venezolanas en este período a partir de un ideal de orden que implicaba la correspondencia entre la expresión y lo expresado. Por una parte cuestionó a aquellas que incurrían en excesos porque no habían sido capaces de establecer una relación necesaria entre la mirada del autor, el

${ }^{339}$ Mariano Picón Salas: "Lo hispanoamericano desde los EEUU”, en Viejos y nuevos...op.cit., p. 432. La novela Doña Bárbara (1929) de Rómulo Gallegos era precisamente la obra donde esta unión cultural y estética se cumplía de la manera más eficaz: "En pocos libros literarios como éste las dos corrientes en que se debatiera la literatura venezolana -como las otras regiones de América- hallaban su síntesis y conciliación. De una parte, había comenzado con los costumbristas del siglo XIX el intento de describir la vida rural, pero como captada desde fuera, en holganza, caricatura o recreo de hombre urbano que se apiada y sonríe de lo pintoresco o arcaico que observa en el campesino: por otra, hubo la literatura de los demasiados [sic] cultos que apenas tejieron sobre el modelo de las formas importadas -temiéndole a una auténtica expresión nacional- el tímido testimonio de su presencia y angustia. (Mariano Picón Salas: "A veinte años de Doña Bárbara", en Viejos y nuevos...op.cit., p. 130)

${ }^{340}$ Mariano Picón Salas: "Alegato de Europa. Prólogo de 1946”, en Viejos y nuevos...op.cit., p. 333. 
contexto histórico y la escritura. Por otra destacó las virtudes de las obras saturadas, es decir, de aquellas en las que se apreciaba una correspondencia armónica entre la vivencia, el entorno y la expresión literaria, pues ellas concedían a la literatura venezolana una dimensión universal.

\section{1. EL RECLAMO DE LA AUTENTICIDAD}

Guillermo Sucre se sirvió del concepto de autenticidad para acabar con los excesos vinculados al arribismo y a la insinceridad intelectual que campeaban a sus anchas en el campo literario venezolano. Esta noción implicaba establecer, por una parte, un vínculo ineludible entre la experiencia vital de los creadores y su expresión literaria de manera que ésta superara los excesos perniciosos en los que estaba incurriendo y dejara de servir para referir motivos ajenos a la literatura; por otra parte, suponía que las obras entroncarían con la política estética que Sucre consideraba esencial a la literatura.

La autenticidad había sido un punto fundamental de la teoría poética de los simbolistas que, a decir de Paul Valéry, habían resuelto "no rendir culto a otras verdades que las deliberadamente elegidas o edificadas por ellos mismos" ${ }^{\text {341 }}$. El propio Baudelaire había repetido que la visión subjetiva del artista era un elemento básico de la literatura y del arte: "El artista, el verdadero artista, el verdadero poeta, -decía el autor de Las flores del mal- no debe pintar sino de acuerdo a lo que ve y lo que siente. Debe ser realmente fiel a su propia naturaleza. Debe evitar como la muerte el hacer uso de los ojos y de los sentimientos de otro hombre, por grande que sea; pues, entonces, las producciones que nos ofreciera, serían, a su respecto, mentiras y no realidades" ${ }^{\text {} 342}$. De

\footnotetext{
${ }^{341}$ Paul Valéry: "Existencia del simbolismo", en VVAA: Matemática tiniebla ...op.cit., p. 284.

${ }^{342}$ Charles Baudelaire: "Salón de 1859", en Obras, op.cit., p. 554. En otro ensayo señalaba: “Qué es el arte puro, según la concepción moderna? Es la creación de una magia sugestiva que contenga
} 
acuerdo a este criterio el gran vate francés valoraba negativamente al pintor M. Ingres, que tenía "la admiración bastante fácil, de carácter bastante ecléctico, como todos los hombres desprovistos de fatalidad"343 y ensalzaba en cambio a Balzac que, a pesar de haberse dedicado al "género plebeyo" de la novela de costumbres, logró en ella "cosas admirables, siempre curiosas y a menudo sublimes [...] porque ha volcado en ellas todo su ser" ${ }^{344}$.

También Picón Salas había sido un firme defensor del valor de la autenticidad, pues en él advertía la posibilidad de conciliar la expresión y lo expresado ante los excesos representados por la espontaneidad y el hermetismo:

el significado humano de la obra literaria depende de su autenticidad, y [...] ésta es, asimismo un valor estético. El conflicto entre la obra de arte autónoma y la "comprometida" en que tanto se insiste ahora, pudiera derivarse más claramente a la oposición entre veracidad y falsedad artística. [...] Así como nos fatiga la espontaneidad informe de los malos románticos, también puede disgustarnos el helado hermetismo, sin posibilidad de comunicación, de muchas obras del día. El tipo "pompier" que sólo copia mecánicamente las formas generales de la época y no agrega nada personal al legado del arte, se produce en todas las escuelas y estilos; pudo ser alternativamente, figurativo o abstracto. Y en la imitación, puramente externa, de una "manera", sin contenido vivencial propio, consiste lo "inauténtico",345

En línea con esta concepción, el humanista merideño establecía una división entre el escritor valeroso, que nos habla siempre "con palabras que brotaron calientes de la fragua del alma", y el pusilánime, que "se escuda en su follaje retórico, en el adjetivo cómplice y encubridor" y sacrifica "la autenticidad a las convenciones de los otros" ${ }^{, 346}$.

Al emplear el concepto de la autenticidad Guillermo no se limitó a repetir las ideas al respecto de los simbolistas y de Picón Salas, sino que complementó y

a la vez al objeto y al sujeto, el mundo exterior al artista y el artista mismo." (Charles Baudelaire: "El arte filosófico", en Obras, op.cit., p. 700)

${ }^{343}$ Charles Baudelaire: "Exposición universal de 1855", en Obras, op.cit., p. 540.

${ }^{344}$ Charles Baudelaire: "Theophile Gautier", en Obras...op.cit., p. 721. Por eso para Baudelaire la crítica de arte debía consistir, como afirma en un texto sobre el pintor Eugène Delacroix, en "buscar la cualidad característica del genio [...] y tratar de definirla; investigar en qué difiere, aun igualándolos, de sus más ilustres antecesores; [...]; en otros términos, averiguar cuál ha sido la especialidad que la Providencia confiara a en el desarrollo histórico de la Pintura."." (Charles Baudelaire: "La obra y la vida de Eugène Delacroix", en Obras, op.cit., p. 651)

${ }^{345}$ Mariano Picón Salas: "Literatura y sociedad", en Viejos y nuevos...op.cit., pp. 509-510.

${ }^{346}$ Ibid., p. 510. 

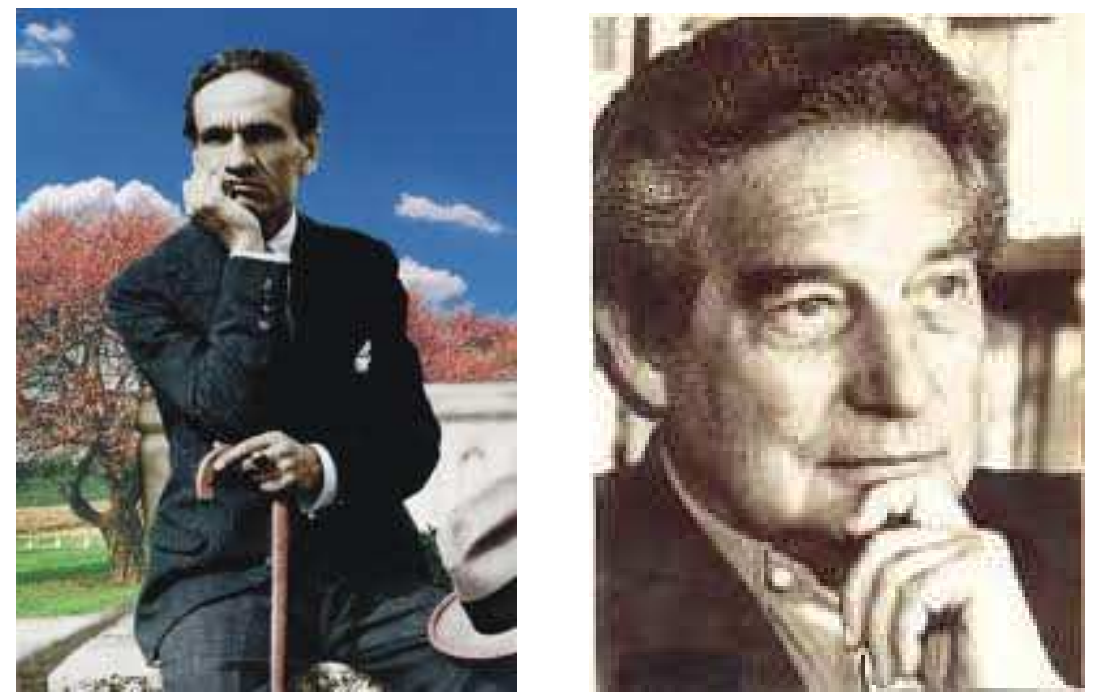

Imágenes 31 y 32. César Vallejo (1892-1938) y Octavio Paz (1914-1998).

El poeta peruano -sobre cuya obra Sucre emprendió una tesis doctoral que nunca terminaría- se había ocupado en los ensayos agrupados en El arte y la revolución precisamente de establecer un criterio para determinar la autenticidad en literatura. En esos textos el poeta peruano señalaba que la veracidad de una obra no dependía del empleo de un léxico o de la aplicación de una doctrina determinados sino de la sensibilidad particular que el poema pudiera encarnar y transmitir. Así, por ejemplo, decía que el poeta socialista

no reduce su socialismo a los temas ni a la técnica del poema. No lo reduce a introducir palabras a la moda sobre economía, dialéctica o derecho marxista, a movilizar ideas y requisitorias políticas de factura y origen comunista, ni a adjetivar los hechos del espíritu y de la naturaleza, con epítetos tomados de la revolución proletaria. El poeta socialista supone, de preferencia, una sensibilidad orgánica y tácitamente socialista. Sólo un hombre temperamentalmente socialista, aquel cuya conducta pública y privada, cuya manera de ver una estrella, de comprender la rotación de un carro, de sentir un dolor, de hacer una operación aritmética, de levantar una piedra, de guardar silencio o de ajustar una amistad, son orgánicamente socialistas, sólo ese hombre puede crear un poema auténticamente socialista. ${ }^{347}$

${ }^{347}$ César Vallejo: "Ejecutoria del arte socialista", en El arte y la revolución, en Obras completas vol. 4, Barcelona, Laia, 1978, pp. 27-28. La cita continúa: "El poeta socialista no ha de ser tal únicamente en el momento de escribir un poema, sino en todos sus actos, grandes y pequeños, internos y externos, 
Igualmente, en lo concerniente a la búsqueda de novedad que impulsaba a la vanguardia europea y latinoamericana de la época en la que escribía, Vallejo advertía que muchos poetas querían pasar por modernos con recurrir simplemente a palabras y expresiones novedosas. Para él, sin embargo, la verdadera modernidad de una obra no dependía del vocabulario sino de su asimilación profunda por el creador:

Poesía nueva ha dado en llamarse a los versos cuyo léxico está formado de las palabras "cinema", "avión", "jazz-band", "motor", "radio" y, en general, de todas las voces de la ciencia e industrias contemporáneas, no importa que el léxico corresponda o no a una sensibilidad auténticamente nueva. Lo importante son las palabras. [/] Pero no hay que olvidar que esto no es poesía nueva ni vieja, ni nada. Los materiales artísticos que ofrece la vida moderna, han de ser asimilados por el artista y convertidos en sensibilidad. [...] Muchas veces, el poema no dice "avión", poseyendo sin embargo, la emoción aviónica, de manera oscura y tácita, pero efectiva y humana. Tal es la verdadera poesía nueva. ${ }^{348}$

Esta misma postura la había defendido con respecto al americanismo literario en su artículo "Contra el secreto profesional" (1927) donde había establecido que "la autoctonía no consiste en decir que se es autóctono, sino en serlo efectivamente, aun cuando no se diga"349. Como contraparte de estas ideas, Vallejo consideraba que la inautenticidad resultaba de una desconexión entre la expresión y lo expresado, es decir, de una distancia entre la obra y el verdadero sentimiento del escritor. El peruano advertía esta escisión en el poeta ruso Maiakowsky, quien con la llegada de la Revolución Rusa se había adherido superficialmente a la estética socialista pero cuya sensibilidad más profunda seguía siendo futurista:

La verdadera vida interior del poeta, aherrojada en fórmulas postizas de un leninismo extremo e inorgánico, seguía sufriendo silenciosamente y sintiendo todo lo contrario de lo que decían sus versos. Mientras Maiakowsky continuaba confundiéndose en literatura con esa farándula de artistas "revolucionarios", que aparentan serlo con la misma facilidad con que aparentarían ser valientes, mayores de edad o nocherniegos, la vida interior del poeta, en abierto desacuerdo con un arte que no la traducía, seguía pugnando subterráneamente y debatiéndose en la agonía. Fue la ruptura trágica y desgarrada de todo sincronismo entre la obra y la vida del autor. [...] Su lucha interior neutralizó su sensibilidad y su expresión artística, totalmente. Maiakowsky fue un mero literato, un simple versificador, un retórico hueco. ${ }^{350}$

conscientes y subconscientes, y hasta cuando duerme y cuando se equivoca y cuando se traiciona voluntaria o involuntariamente y cuando se rectifica y cuando fracasa." (Ibid.)

${ }^{348}$ César Vallejo: "Poesía nueva" en El arte y la revolución...op.cit., p. 113.

${ }^{349}$ César Vallejo: "Contra el secreto profesional”, en Variedades, Lima, 1927, no 1001, p. 204.

${ }^{350}$ César Vallejo: "El caso Maiakovski", en El arte y la revolución...op.cit., p. 121. Al reivindicar el concepto de la autenticidad, Vallejo estaba retomando ideas que Trotsky había expuesto en 
De este modo vemos que, para Vallejo, una obra se puede considerar auténtica cuando se establece una coincidencia sincera entre la escritura y el espíritu, es decir, cuando la obra encarna la verdadera sensibilidad del creador.

Con respecto al concepto de la autenticidad Guillermo Sucre retomó asimismo la enseñanza que Octavio Paz había establecido en El arco y la lira (1956). En esta obra el ensayista mexicano había señalado que "las palabras no viven fuera de nosotros. Nosotros somos su mundo y ellas el nuestro" y que el lenguaje "consiste en ser algo indivisible e inseparable del hombre" ${ }^{, 351}$. Apoyándose en esta afinidad entre la persona y el verbo, afirmaba además que "cuando un poeta encuentra su palabra, la reconoce: ya estaba en él. Y él ya estaba en ella. La palabra del poeta se confunde con su ser mismo. Él es su palabra. [...] La creación consiste en sacar a luz ciertas palabras inseparables de nuestro ser. Ésas y no otras. El poema está hecho de palabras necesarias e insustituibles"352. Establecido este vínculo entra vivencia y escritura, el creador mexicano podía afirmar en un artículo sobre la obra de Mutis escrito en 1959: "Estoy seguro de que las imperfecciones de algunas obras -no excluyo a las más grandesprovienen casi siempre, más que de ausencia de talento, de una falta espiritual del poeta. La moral, en el sentido profundo de la palabra, interviene más de lo que se piensa en la

su obra Literatura y revolución (1924). Quizás por este motivo el concepto de la autenticidad se ha asociado con el pensamiento de izquierda, y puede ser que esta filiación haya determinado que algunos autores -entre los que se cuentan el propio Sucre y el narrador venezolano José Balza- mantengan a día de hoy una cierta prudencia al emplear esta noción. En una carta reciente nuestro autor afirmaba al respecto: "Cada vez tengo más cuidado en el empleo de vocablos como autenticidad y auténtico. Desde cualquier punto de vista resultan vocablos muy inasibles y con frecuencia se emplean de manera contradictoria." (Guillermo Sucre: "Carta II, abril de 2013", infra en Apéndice I, p. 481)

${ }^{351}$ Octavio Paz: El arco y la lira, en OOCC, Vol. I, La casa de la presencia. Poesía e historia, Barcelona, Galaxia Gutenberg, $2^{a}$ ed., 1999, p. 59. La cita sigue: "El lenguaje es una condición de la existencia del hombre y no un objeto." Además había señalado que en el lenguaje "las fronteras entre objeto y sujeto se muestran aquí particularmente indecisas. La palabra es el hombre mismo. Estamos hechos de palabras. Ellas son nuestra única realidad o, al menos, el único testimonio de nuestra realidad." (Ibid.)

$$
{ }^{352} \text { Ibid., p. } 76 .
$$


creación artística. He escrito moral. Quizá debería haber dicho: amor, entrega a la obra, arrojo, integridad espiritual" ${ }^{353}$.

Aplicando a su ámbito particular las ideas de estos pensadores, Sucre se sirvió del concepto de autenticidad para desterrar la ética y la estética inadecuadas que él advertía en la literatura venezolana. Haciéndose eco de las ideas de Vallejo y tras ver los excesos en que incidía cierta literatura comprometida en Venezuela, Guillermo Sucre planteó que era preciso calibrar la sinceridad interior de la escritura para determinar su validez:

Creemos que el acto en sí mismo [es decir, el poema, la novela] no resulta suficiente para una valoración objetiva de la influencia y proyección que él implique. Y nos resulta más esclarecedor y apremiante analizar la manera, el esfuerzo y sinceridad interior con que se realice. Es decir, una doble visión sobre la plenitud y validez del compromiso y sobre la dimensión existencial del hombre que lo asume. ${ }^{354}$

En consonancia con este reclamo de afinidad entre la identidad profunda del escritor y su expresión literaria, en el primer texto que escribió sobre la crítica Guillermo proponía que la función de ésta debía ser hallar y explicar la correspondencia que en todo auténtico creador se establece entre la visión del mundo y la escritura:

la nueva crítica venezolana ha de fundarse sobre una base estética definida, sobre una capacidad más reflexiva ante la literatura, sobre un espíritu de mayor profundidad que nos revele a la obra literaria a un nivel más complejo y significativo, esencial y dominante. Una crítica estética y una crítica de "contenidos" -pero no en el sentido tradicional que se le asigna a este

353 Octavio Paz: "Los "Hospitales de ultramar": Álvaro Mutis", en OOCC, Vol. II, op.cit., pp. 1134-1141, p. 1138. Este ensayo se escribió en 1959 y se publicó en Puertas al campo en 1966. En un texto un poco posterior Paz consideraba que "la actividad poética tiene por objeto, esencialmente, el lenguaje: cualesquiera que sean sus creencias y convicciones, el poeta nombra a las palabras más que a los objetos que éstas designan. No quiero decir que el universo poético carezca de significado o viva al margen del sentido; digo que en poesía el sentido es inseparable de la palabra, es palabra, en tanto que en el discurso ordinario [...] el sentido es aquello que denotan las palabras y que está más allá del lenguaje. La experiencia del poeta es ante todo verbal; o si se quiere: toda experiencia, en poesía, adquiere inmediatamente una tonalidad verbal. Es algo común a todos los poetas de todas las épocas pero que, desde el romanticismo, de convierte en lo que llamamos conciencia poética” (Octavio Paz: “¿Qué nombra la poesía?”, en OOCC, Vol. II, op.cit., pp. 487-490. Publicado originalmente en Corriente alterna, 1967). Por eso, según nos dice Guillermo, el propio Paz es un "poeta en incesante movimiento, cuyo lenguaje se encadena y se desencadena al ritmo de su propia existencia." (Guillermo Sucre: "Octavio Paz: Salamandra", en La República, Caracas, 07-04-63, p. 7). Barthes había propuesto algunos años antes ideas similares. En 1953, el teórico francés había establecido la dimensión ética de la escritura: "Pero toda forma es también valor; por lo que entre la lengua y el estilo, hay espacio para otra realidad formal: la escritura. En toda forma literaria, existe la elección general de un tono, de un ethos si se quiere, y es aquí donde el escritor se individualiza claramente porque es donde se compromete."(Roland Barthes: El grado cero de la escritura, op.cit., capítulo II, “QQué es la escritura?”)

${ }^{354}$ Guillermo Sucre: “Testimonio. El intelectual de izquierda...”, loc.cit., pp. 430-431. 
término, sino en el de "visión del mundo"- podrían ser dos de los caminos más fecundos para el ejercicio de esa crítica. ${ }^{355}$

Asimismo, en el ensayo "Situación actual de la poesía de Vallejo" (1963), donde ya es evidente la lectura de Octavio Paz, nuestro autor dejaba a un lado las interpretaciones deterministas que se habían hecho sobre el poeta peruano (la de Mariátegui $^{356}$ y la de Abril $^{357}$, por ejemplo) y proponía una crítica que sirviera para comprender "por qué Vallejo escribe de esta forma y no de otra", pues la respuesta a esta pregunta "nos llevaría a ver cómo a través del lenguaje se va formando el «oscuro» proyecto vital del poeta. Para ello habría que establecer una suerte de sistema de «vasos comunicantes»: del lenguaje a las motivaciones existenciales, y recíprocamente" ${ }^{\natural 58}$.

Fiel a esta concepción, Guillermo valoró a lo largo de este período muchas obras literarias de acuerdo a la correspondencia que en ellas advertía entre la ética y la estética. En las creaciones auténticas la afinidad entre la vivencia y la escritura era total. Así, a propósito de Animal de costumbre (1959) de Juan Sánchez Peláez, Sucre afirmaba que "el reencuentro del poeta con su fuerza expresiva y con los problemas dominantes de su existencia, es siempre indicio de un verdadero ejercicio creador. Reconocemos en Animal de Costumbre la veracidad con que Juan Sánchez Peláez ha emprendido ese reencuentro"359. En los poemarios Áspero (1924) y Parsimonia (1932)

355 Guillermo Sucre: "La crítica literaria”, loc. cit. En este texto reconocía además la radical relatividad de toda crítica, lo que hay que vincular con la necesidad de que arraigue personal e históricamente: "Ninguna crítica, por lo tanto, puede ser universalmente aceptada. Es siempre visión parcial, y comprometida, de la obra literaria. Y hasta llegamos a creer que, ya dentro de la historia de la cultura, una crítica tendrá valor más por lo que nos expresa de la actitud del crítico, de su propia generación y del mundo complejo en que se movió su experiencia espiritual y estética, que por lo que nos revela de la obra misma." (Ibíd.)

356 Sucre se refiere a la crítica en la que Mariátegui señalaba que "lo fundamental, lo característico" del arte de Vallejo "es la nota india." (José Carlos Mariátegui: "César Vallejo", en 7 ensayos de interpretación de la realidad peruana, Caracas, Biblioteca Ayacucho, 2007, p. 260). En el rechazo de la crítica determinista, Guillermo coincidía con Roland Barthes (Vid. "Las dos críticas", en Ensayos críticos, Buenos Aires, Seix Barral, 2003)

${ }^{357}$ Xavier Abril: Vallejo: ensayo de aproximación crítica, Buenos Aires, Front, 1958.

${ }^{358}$ Guillermo Sucre: "Situación actual de la poesía de Vallejo", en La República, Caracas, 14-0463, p. 7.

${ }^{359}$ Guillermo Sucre: “Juan Sánchez Peláez: Animal de costumbre”, en Sardio, Caracas, núm. 5-6, ene.-abr. 59, p. 412. 
del venezolano Antonio Arráiz, nuestro autor vislumbraba igualmente una correspondencia satisfactoria entre la mirada y el lenguaje. En esas obras, según nos dice, “encontramos su verdadera «estética»-ligada, por supuesto, a una actitud ética ante el mundo- que podríamos condensar de la manera siguiente: al vigor y a la expansión del instinto a través de la desnudez y del despojamiento"360. El crítico destacaba asimismo la autenticidad del libro Dictado por la jauría (1962) de Juan Calzadilla, puesto que el cambio artístico se correspondía con una transformación semejante en el plano de la experiencia: "al mundo aparentemente alucinado pero todavía intimista de Los Herbarios rojos, sucede ahora el desencadenamiento de un lenguaje lleno de vigor [...] No se trata, creemos, de imposturas literarias. Todo ha tenido origen en un cambio igualmente extremo y profundo en el plano de la vida"361. Del mismo modo, pensaba que la obra de Enriqueta Arvelo Larriva era auténtica porque "no surge por simple contagio literario, sino por imperiosa necesidad"362.

Por otra parte, Sucre consideraba carentes de autenticidad aquellas obras en las que por un motivo u otro se había producido una desconexión entre la actitud vital y la escritura. La falsedad estética podía ser el resultado o bien de que la expresión literaria hubiera nacido de una ética inadecuada o bien de que la falta de conciencia crítica del escritor hubiera provocado una desconexión entre la vivencia y la escritura. En cuanto al primer caso es llamativo que Sucre considerara que la estética vanguardista de grandes escritores hispanoamericanos resultaba inapropiada como consecuencia de una actitud vital impropia. Así, por ejemplo, explicaba la desproporción expresiva que advertía en

${ }^{360}$ Guillermo Sucre: “La poesía de Antonio Arráiz”, en La República, Caracas, 23-09-62, p. 7.

361 Guillermo Sucre: “Juan Calzadilla: Dictado por la jauría; Pascual Venegas Filardo: Los cantos fluviales", en La República, Caracas, 20-01-63, p. 7. Cursiva nuestra. Como es evidente, Sucre no se refiere a la vida biográfica sino a la experiencia que se genera en la propia obra, lo que nos remite a la afirmación de Paz citada más arriba. (Vid. nota 353, p. 130)

${ }^{362}$ Guillermo Sucre: "Enriqueta Arvelo Larriva", en La República, Caracas, 16-12-62, p. 7. En el autor de También los hombres son ciudades Sucre advertía asimismo una expresión literaria auténtica pues "la creación para Trejo no es acto arbitrario o gratuito, sino respuesta a ciertas constantes que su propia vida le ha planteado." (Guillermo Sucre: "Oswaldo Trejo: También los hombres son ciudades", en La República, Caracas, 05-08-62, p. 7) 
los primeros libros de Huidobro como el resultado de una conducta igualmente desmesurada:

Todo un abismo parece separar al autor de "Altazor", o de "Últimos poemas" o de "Ciudadano del olvido" del joven alucinado que escribió esos primeros libros. Huidobro no tenía entonces más de veinte y cinco años. Una vida ardiente y evasiva lo llenaba de una inagotable lujuria verbal o de una desenfrenada embriaguez ante el hallazgo. Acaso era aún el poeta irresponsable y vanidoso. [...] rindió culto a una novedad que no le pertenecía y llegó a escribir muchos de los poemas de esa época a la manera de los "Calligrames" de Guillaume Apollinaire. ${ }^{363}$

Este mismo criterio lo empleaba nuestro autor para explicar los desmanes del Borges ultraísta y sus diferencias con respecto al Borges "clásico", que para él era el genuino, según se advierte en su libro Borges, el poeta (1967). La poesía vanguardista del argentino -la más alejada de su verdadera imagen, la clásica- se explica en este ensayo como la consecuencia de una carencia espiritual más profunda. Los poemas que Borges publicó en las revistas ultraístas españolas, nos dice el crítico, "resultan hoy frecuentemente abigarrados, llenos de cierto ímpetu prepotente, seducidos por una suerte de solidaridad ecuménica"364. Y añade: "El poema "Trinchera”, escrito en 1919, nos da la medida de su poesía y de su estado espiritual de entonces”365. Asimismo, en la obra de Pablo Neruda, Guillermo apreciaba que la inconsistencia estética era el efecto de una ética inadecuada. El poeta chileno, nos dice el crítico, "ha vivido siempre con manías de único y gran poeta hispanoamericano, rodeado además por la complacencia y los halagos. Ello ha influido sensible y negativamente en su obra más reciente ${ }^{\text {366 }}$. Lo

363 Guillermo Sucre: “Obras selectas de V. Huidobro”, en El Papel Literario de El Nacional, Caracas, 13-11-58. Cursiva nuestra.

${ }^{364}$ Guillermo Sucre: Borges, el poeta, Caracas, Monte Ávila, $2^{\text {a }}$ ed., 1974, p. 29. A no ser que diga expresamente, las citas pertenecen a esta edición. La segunda edición incluye dos capítulos más y elimina el "Epílogo" de la primera edición, pero en la mayor parte coinciden.

365 Ibid., p. 29.

${ }^{366}$ Guillermo Sucre: "Sobre Pablo Neruda", loc.cit., p. 254. Antes que Sucre, Picón Salas había cuestionado a Neruda porque su poesía tendía a ser "pasión e himno desatado" y representaba cierta tendencia continental a lo informe y a lo azaroso que él quería desterrar. El vate chileno, dice Picón, es "fundamentalmente un poeta impuro" y en su obra "desembocan como un enorme río sucio muchas de las pesadillas de una época desesperada, rota, sin moldes. Como en algunas grandes corrientes del trópico, en él se disuelven el caimán y la mariposa, la mayor podredumbre y el más matinal perfume. [...] Es todo lo contrario de un poeta apolíneo. [...] Su guiado desorden, su tristeza sensual, su máscara de insomnio se han identificado con todo lo que hay de mágico y azaroso en el alma del criollo suramericano." (Mariano Picón Salas: "Paseo por nuestra poesía (1880-1940), en Viejos y nuevos...op.cit., p. 116). Sobre él 
que nos encontramos en estas críticas es que Sucre, basándose en la tradición simbolista, consideraba que había una "ética de escritor" 367 , que se caracterizaba por una actitud vital y estética que era inseparable de la verdadera literatura. Esta conducta era la que apreciaba precisamente en César Vallejo, que para él era el epítome de la autenticidad literaria porque había sido siempre consecuente consigo mismo. En contraste con el Neruda de España en el corazón (1937), en sus obras sobre la guerra civil española el poeta peruano fue

infinitamente más irreductible y despersonalizado, jamás hizo literatura ni propaganda con la aventura que le tocó vivir. No tuvo que enterrar su vieja poesía ni su metafísica para cantar el drama colectivo de todo un pueblo que era consustancial a su espíritu y a su mundo. Vallejo era una inteligencia evidentemente más recia y problemática, radicalmente más lúcida y crítica. Su militancia comunista, decidida y existencial, fue siempre un compromiso con lo esencial del hombre. Nunca alimentó tampoco vanas obsesiones de grandeza poética. No hizo un ritual falso de su vida. ${ }^{368}$

Según la concepción de Sucre no sólo era preciso que el escritor tuviera una

actitud "literaria" (que daría lugar a una escritura que también lo sería) sino, además, que la nobleza de su vivencia guardara una afinidad con la culminación expresiva de los poemas. En algunas ocasiones Guillermo advertía una experiencia noble que sin embargo el autor había sido incapaz de trasmitir con propiedad a la escritura. Así, por ejemplo, a propósito de la obra Huellas del silencio (1958) del poeta Manuel Vicente

afirmaba también: "Bajo el signo de un Romanticismo de nuevo tipo -Romanticismo de la disolución total, donde todo fluye y se deshace en corriente de angustia cósmica, donde no hay un elemento fijo a qué asirse- se puede colocar, por ejemplo, la contemporánea poesía de Pablo Neruda." (Mariano Picón Salas: "Lo hispanoamericano desde los EEUU", en Viejos y nuevos...op.cit., p. 431). Por lo tanto, la crítica de Picón a Neruda se hacía en base a que representaba una ética y una estética alejadas del modelo de orden que él quería para Venezuela.

${ }^{367}$ En el libro sobre Borges, Sucre afirmaba citando unos versos del poema "Jactancia de quietud": "Seguro de mi vida y de mi muerte, miro los ambiciosos y quisiera entenderlos". ¿No hay en ese mismo poema una ética de escritor e incluso toda una actitud panteísta en que el poeta se identifica con todos, se afirma y se niega como tal al mismo tiempo? Borges reacciona contra los que se creen "imprescindibles, únicos, merecedores del mañana"; esa reacción es a la vez una visión ejemplar de sí mismo: "Mi nombre es alguien y cualquiera", dice luego. Fidelidad a la poesía, secreta y lúcida pasión por ella, pero a la vez cierta distancia, es lo que Borges nos propone siempre como su verdadera imagen." (Guillermo Sucre: Borges, el poeta, op.cit., p. 25). Guillermo pensaba el poeta de una manera esencial, pues para él serlo implica una ética o una actitud determinadas: "Rosamel del Valle es una de esas raras excepciones, en el ámbito hispanoamericano, que representan la esencia misma del poeta: su imagen ideal y profunda. Su vida no se cuenta en peripecias externas o en alardes exhibicionistas, sino en ejercicio ejemplar del espíritu poético." (Guillermo Sucre: "El viajero vestido de ardor silencioso", en Zona Franca, Caracas, núm. 26, oct. 65, pp. 8-9)

${ }^{368}$ Guillermo Sucre: "Sobre Pablo Neruda", loc. cit., p. 254. 
Magallanes, Guillermo señalaba que "su voz no alcanza siempre auténtica jerarquía estética": "Un excesivo tono enfático y hasta discursivo, cierto regocijo por la sonoridad gratuita de las palabras, el mismo lenguaje desprovisto en ocasiones de matices y de sugerencias poéticas y alambicado, parecen haber diluido la nobleza en que debieron nutrirse inicialmente estos poemas" ${ }^{369}$. Igualmente, sobre Los herbarios rojos (1958) de Juan Calzadilla, el crítico advertía: "no es que no se sienta una conmovida vivencia [...], como en la evocación de la infancia, pero ello no guarda correspondencia con la culminación expresiva de los poemas" ${ }^{370}$. Para solventar esta desconexión entre la ética vital y la escritura, Sucre reclamaba a los autores un esfuerzo crítico mayor. Por eso decía a propósito de este último poemario: “creemos que es al propio Calzadilla a quien le toca hacerse su crítica interior, ${ }^{, 371}$. En efecto, en la concepción de Guillermo la autenticidad no era un don que perteneciera a algunos escritores sino que resultaba de la lucidez y de la capacidad reflexiva, virtudes que permitían a los autores vincular la visión del mundo y la escritura y lograr así una expresión literaria perfecta, es decir, sin suplementos de cosas ni de palabras.

En consonancia con este requerimiento de autenticidad, a lo largo de estos años Guillermo concedió mucha importancia a la personalidad de los autores en la creación literaria y repitió que los grandes escritores siempre lograban imponer su genio sobre los movimientos o las tendencias a las que en principio pertenecieron ${ }^{372}$. A este

${ }^{369}$ Guillermo Sucre: "Huellas del silencio", en El Papel Literario de El Nacional, Caracas, 0708-1958 $01-59$

${ }^{370}$ Guillermo Sucre: “Los herbarios rojos", en El Papel Literario de El Nacional, Caracas, 22-

${ }^{371}$ Ibid.

${ }^{372}$ A este respecto un antecedente fundamental de Sucre era Baudelaire, quien se había opuesto, por una parte, a los creadores "positivistas" que pretendían representar las cosas tal como eran y, por otra, a quienes se sometían "a reglas de pura convención, completamente arbitrarias, que no surgen del alma humana, y que han sido impuestas simplemente por la rutina de algún célebre taller." Baudelaire prefería en cambio a los autores "imaginarios", es decir, a aquellos para los que "todo el universo visible no es más que un repertorio de imágenes y de signos a los que la imaginación asignará un lugar y un valor relativos; es una especie de pábulo, que la imaginación debe digerir y transformar." (Charles Baudelaire: “Salón de 1859", en Obras...op.cit., p. 554) 
respecto, en una crítica temprana, Sucre decía preferir al Huidobro posterior a Altazor (1929) pues "sólo cuando logró liberarse de las mismas limitaciones de su teoría pudo Huidobro realizar su gran destino creador"373. Asimismo, Paul Éluard y Gonzalo Rojas eran para él algo más que escritores surrealistas, pues su fuerte personalidad les había permitido trascender las pautas del movimiento surrealista ${ }^{374}$. Y pese a la proximidad de sus teorías estéticas, el respectivo genio artístico de Revérdy y de Huidobro hizo de ellos "dos poetas radicalmente distintos. Cada uno su propio mundo y su particular «temple» creador. Como todo gran artista, ambos trascendieron sus mismos principios estéticos $^{, 375}$.

\section{2. EL RECHAZO DE LOS EXCESOS EXPRESIVOS}

Además de reivindicar el valor de la autenticidad, Guillermo trató por otros medios de que las obras literarias venezolanas alcanzaran ese ideal de orden y saturación que él apreciaba en la literatura de la tradición moderna. Siguiendo ese paradigma, Sucre impugnó las obras que incurrían en excesos de cosas y de palabras, que muchas veces estaban vinculados. Las obras realistas presentaban para nuestro autor un exceso descriptivo que las hacía caer en lo anecdótico y lo trivial y que además solía estar acompañado de un regusto en el color local que él rechazaba. La literatura esteticista, por su parte, suponía el apego a moldes formales que no venían impuestos por una verdadera necesidad interior del autor o de la obra y se aproximaba a las posturas cosmopolitas. Vemos, por lo tanto, que al rechazar los excesos expresivos (el

${ }^{373}$ Guillermo Sucre: "Obras selectas de V. Huidobro", loc. cit.

${ }^{374}$ Sucre nos dice que si bien Gonzalo Rojas "estuvo ligado al grupo surrealista «Mandrágora»", ese "contacto deja indudables huellas en su poesía, pero sin determinarla totalmente." Gonzalo Rojas fue más bien un "temperamento solitario y poco permeable a las modas"; "sus búsquedas se orientan [...] a descifrar su propia y radical experiencia en el mundo." (Guillermo Sucre: "La poesía de Gonzalo Rojas", en La República, Caracas, 10-02-63, p. 7). También Paul Éluard, a decir de Sucre, trascendió el movimiento el que se le adscribe, pues su poesía, "surrealista en su origen", más tarde "desbordó esta central experiencia, se despojó de los ritos de escuela, hasta hacerse profundamente personal y colectiva al mismo tiempo." (Guillermo Sucre: "Paul Éluard", en La República, Caracas, 18-11-62, p. 7)

${ }^{375}$ Guillermo Sucre: "Revérdy y Huidobro", en La República, Caracas, 02-12-62, p. 7. 
realismo y el formalismo) Guillermo estaba censurando igualmente la distancia entre el escritor y su circunstancia (el nacionalismo y el cosmopolitismo). En este texto que cito a continuación se aprecia bien cómo para él estos defectos estéticos y culturales eran en verdad lo mismo:

No confundimos universalidad con cosmopolitismo, pero se nos hace evidente que el exceso de color local, con todas sus derivantes, ha viciado de raíz gran parte de nuestras manifestaciones artísticas. Así como condenamos cualquier esteticismo, condenamos también cualquier nacionalismo exacerbado y arrogante. Respetamos en el folklore y en nuestras mejores tradiciones el alma esclarecida del pueblo, pero nos parece que ciertos artistas han insurgido en una suerte de depredadores irreverentes de ese patrimonio. Asimismo toda esa literatura de esquemas y de soluciones preconcebidas nos resulta insustancial. ${ }^{376}$

Frente a estas desmesuras Guillermo intentó que la literatura venezolana asimilase la estética armónica y virtuosa que él consideraba propia de la tradición moderna. De acuerdo a ese modelo, las obras debían ser expresiones saturadas y perfectas en las que los excesos de cosas y de palabras no tuvieran lugar. Además, como ya lo había propuesto Picón Salas, al trascender estos defectos estéticos y culturales, las obras venezolanas estarían en condiciones de operar el paso de lo particular a lo universal y de adquirir repercusión más allá de las propias fronteras.

En las críticas que escribió en este lapso -que, excepcionalmente, trataron tanto sobre novela como sobre poesía ${ }^{377}$ - Guillermo rechazó insistentemente el realismo descriptivo porque suponía el acceso en la narrativa de detalles triviales y amenazaba la autonomía literaria que era un puntal fundamental de la estética que él quería implementar en Venezuela. Sucre denunció tanto la morosidad propia del realismo ingenuo como la pervivencia del costumbrismo que para él no eran "más que fraudes a

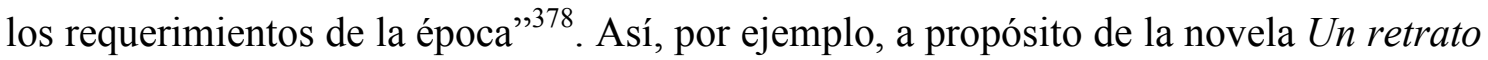
en la geografía, señalaba que

${ }^{376}$ Guillermo Sucre: "Testimonio", loc.cit., p. 3.

377 Esto es una particularidad de esta etapa ya que en los años posteriores nuestro autor se dedicará casi exclusivamente a este último género que es más afín a la política estética que defiende, pues la novela -como también lo vio Borges- es el género moroso por excelencia.

${ }^{378}$ Guillermo Sucre: "Testimonio", loc.cit., p. 3. 
Dominado por el deseo de evocar una atmósfera, de recrear una época determinada de nuestra historia, Uslar se deja llevar por el prurito del cronista. Las escenas, los diálogos siempre excesivos-, las pequeñas historias, las anécdotas se suceden sin mayor coherencia ni profundidad. Más que verdaderas situaciones en las que los personajes enfrenten su destino, son simple muestrario de la sociedad venezolana. De modo que sin una estructura narrativa sólida, los personajes se desdibujan progresivamente, pierden relieve. Y la supuesta libertad que el autor les concede es sólo una libertad abstracta, conceptual. ${ }^{379}$

El crítico cuestionó igualmente la falta de autonomía de la literatura venezolana, es decir, la incorporación a ella de elementos ajenos a lo puramente literario como las significaciones políticas o el recurrente “mensaje”. En este sentido, Guillermo retomaba la lección del simbolismo francés, que había propuesto que la literatura debía permanecer ajena a cualquier meta extraliteraria. "La poesía -decía Baudelaire- no puede, bajo pena de muerte o de extinción, asimilarse a la ciencia o a la moral; no tiene la verdad por objeto, sólo se tiene a sí misma"380. En la misma línea, Jean Paul Sartre había señalado que "la littérature d’une époque determinée est alienée lorsqu'elle n'est pas parvenue á la consciente explicite de son autonomie et qu'elle se soumet aux puissances temporelles ou á une ideologie, en un mot, lorsqu'elle se considére ellemême comme un moyen et non comme un fin inconditionée" 381 . Guillermo reaccionó contra la ancilaridad de la narrativa venezolana y contra su sumisión a fines que debían permanecer ajenos a la literatura. A este respecto, sobre la novela La muerte de Honorio (1963) de Miguel Otero Silva, nuestro autor señalaba que

Una intencionalidad demasiado consciente perjudica siempre al novelista. De este defecto no escapa Otero Silva. Es muy significativo que cada uno de sus personajes "represente" un sector especial del país [...]. Todo ello revela más que una necesidad novelesca, una necesidad puramente política. El novelista quiso complacer al espíritu "unitario" que tan en boga estuvo entre nosotros. Actitud loable tal vez, y generosa además. Pero ello influyó negativamente en la creación de verdaderos personajes. En efecto, los personajes de Otero Silva son más bien "tipos" y no profundas individualidades humanas. Los rasgos de ellos están determinados por lo que son -o deben ser- en un plano genérico y conceptual. ${ }^{382}$

${ }^{379}$ Guillermo Sucre: "Uslar Pietri: Un retrato en la geografia", en La República, Caracas, 22-0762, p. 7. La cursiva corresponde a la negrita del original.

380 Charles Baudelaire: "Nuevas notas sobre Edgar Poe", en VVAA: Matemática tiniebla ...op.cit., pp. 135-154, p. 150.

${ }^{381}$ Jean Paul Sartre: "Qu'est-ce que la littérature?", en Situations II, op.cit., pp. 55-350, p. 190.

382 Guillermo Sucre: "La muerte de Honorio. Un buen testimonio, no una novela", en La República, Caracas, 12-01-64, p. 7. 
La intromisión de elementos extraliterarios perjudicaba, como vemos, el propio desarrollo de la narración y por ello Sucre consideraba que esa obra era sólo "un buen testimonio" que "acaso mañana sólo tendrá valor para los historiadores y los sociólogos ${ }^{383}$.

El exceso de cosas - es decir, la insistencia en lo banal y en lo pintoresco- solía estar vinculado a otro defecto igualmente pernicioso: el exceso de palabras, es decir, el recurso a técnicas o moldes formales que no eran reclamados ni por la coherencia de la obra ni por la personalidad del autor. La falta de motivación entre la expresión y lo expresado daba lugar a la entrada en la narrativa de detalles vanos y prescindibles que se compensaba (se creía compensar) con el empleo de técnicas ajenas a la necesidad interior del creador. Así, por ejemplo, en la novela Casandra (1957) de Díaz Sánchez, el crítico advertía una complementariedad entre el exceso narrativo y la impropiedad técnica. En esta obra, según afirma Sucre,

en lugar de algún intento de monólogo interior, de trasposición o convergencia de planos en el tiempo [...] nos encontramos con los procedimientos más morosos y desabridos de la tradición realista: un absorbente interés por la trama y la acción, con su abigarrado muestrario de episodios y situaciones un tanto truculentas; un exceso de diálogos desprovistos de todo apremiante dinamismo intercalada entre ellos la clásica y ya fatigante pero esta vez moderada pincelada paisajista [...], y un prurito, de reciente estirpe, de extenuante cientificismo enciclopédico $^{384}$

También en la novela de Otero Silva anteriormente citada, Sucre establecía una relación entre ambos excesos con las siguientes palabras: "a una narración llanamente realista, a veces demasiado convencional y sin relieve, es decir, sin complejidad alguna, se superpone una suerte de monólogo interior que, como veremos, no resulta de la necesidad interior de cada personaje, sino que es un puro ardid del autor"385. Guillermo destacaba esta misma coincidencia entre la abundancia descriptiva y el formalismo a

${ }^{383}$ Ibid.

${ }^{384}$ Guillermo Sucre: “Casandra de Díaz Sánchez”, en El Papel Literario de El Nacional, Caracas, 25-09-58. Cursiva nuestra.

${ }^{385}$ Guillermo Sucre: "La muerte de Honorio. Un buen testimonio...", loc.cit. La cita sigue: "Y para "rematar" tan extraña amalgama se cae en un simbolismo tan fácil, evidente y por lo demás patético, que rompe la supuesta objetividad que el narrador quiere asumir desde el comienzo de la obra." 
propósito de las obras de Neruda posteriores al Canto general (1950). Nuestro crítico advertía en ellas "un tono blanduzco, de confusa y vaga efervescencia espiritual, una artesanía sin esfuerzo y sin grandeza, elementos narrativos prosaicos y pueriles y una versificación arbitraria, en la que, sin embargo, parece poner mucho énfasis, han reemplazado la intuición genial que presidió estas grandes tentativas [las obras anteriores al Canto general]"386. Es decir, que "al poeta desencadenado, material, hondo y al gran cantor épico ha venido a sucederle un cronista en verso, desigual y fatigante, no menos formalista que otros que regresan a la métrica clásica” ${ }^{\text {387. }}$.

En otras ocasiones, Sucre cuestionaba esas obras en las que la técnica literaria no había sido verdaderamente asimilada por el creador y que, por lo tanto, resultaba impostada. A propósito de La misa de Arlequín (1962) de Guillermo Meneses, el crítico señalaba que "la modernidad parece ser su propósito fundamental", "pues ser modernos nos hace invulnerables, nos dota de ciertos privilegios de intelectual de avanzada, creando cierta ambigüedad que encubre nuestras penurias íntimas, nuestros defectos, y nos proyecta siempre hacia el futuro" 388 . Esta ansia de novedad hacía que el autor de la obra mostrase cierto "culto por lo ajeno", lo que determinaba que ella no pasase de ser "un mero juego de técnicas. Y, lo que es peor, de técnicas copiadas" $" 389$. En referencia al

${ }^{386}$ Guillermo Sucre: "Sobre Pablo Neruda", loc.cit., p. 255. Cursiva nuestra.

387 Ibíd., p. 255. Cursiva nuestra. La cita sigue: "Por otra parte, el precario sentido crítico y libérrimo de Neruda se revela en los poemas políticos de esta misma época." (Ibíd.)

${ }^{388}$ Guillermo Sucre: “Guillermo Meneses: La Misa de Arlequín”, en La República, Caracas, 1410-62, p. 7. Un poco antes, en su artículo: "Tres cuentos del concurso de «El Nacional»” (La República, Caracas, 19-08-62, p. 7) nuestro autor recurre a Barthes para justificar su rechazo del esteticismo. El crítico francés advertía, a propósito de una novela de Garaudy, que "allí nada se nos ofrece sin metáfora, pues es necesario saber expresamente al lector que esto está bien escrito, es decir, que lo que consume es literatura." Es decir, que en esa novela la retórica se empleaba, nos dice Sucre, para "disimular un vacío más hondo del espíritu o de la inteligencia". Las cursivas en la cita y en la nota sustituyen a la negrita del original.

${ }^{389}$ Guillermo Sucre: “Guillermo Meneses...”, loc. cit. Sobre esta novela Sucre afirmaba también que: "No pasa de ser un buen pastiche de literatura de vanguardia. Con su gusto por una ambigüedad preconcebida y rebuscada [...] con sus falsos ímpetus de ferocidad y de crudeza; [...] con sus "juegos de espejos" donde la realidad se refracta y se vuelve finalmente inaccesible; con su radicalismo irritante e irrisorio y, para que nada falte, su buena dosis de cinismo de buen tono y esa ironía que nos distancia de la realidad y de nuestro propio yo, para no aparecer muy enfáticos, para dar la impresión de que no creemos mucho en lo que decimos, que somos nuestros propios críticos [...] Todo esto y algo más 
poemario Los herbarios rojos el crítico señalaba que, en comparación con su obra anterior, Calzadilla había “pasado a una poesía tal vez más desencadenada y libre, pero confusa y aun literaria. El exceso metafórico, la obsesión por los símbolos y las aparentes audacias formales lo han vuelto rebuscado y vacío" 390 .

En relación con esto, Guillermo discutió la sumisión del creador a propuestas estéticas ajenas a su situación histórica o a su ética personal. En uno de los "Testimonios" de Sardio se oponía al realismo socialista y denunciaba que "ciertos intelectuales $-\mathrm{y}$ de izquierda- han hecho de la sumisión y de la idolatría las nuevas «tablas de la ley» así, en las formas más anacrónicas y en los moldes más vacíos de significación [...], han injertado vagas consignas de una Revolución que no alcanzan a asimilar sino a través de lecturas tardías y de esquemas simplistas”391. Guillermo advertía un esteticismo similar en la "reacción hispanizante" que había recorrido la poesía venezolana en los años 40 y 50 del siglo XX, y rechazaba, en consecuencia, ese movimiento:

El siglo de oro español parecía revivir entonces, sin los menores cambios, en la poesía venezolana. No podía darse una mayor aberración poética. Se escribe con ostensible apego no sólo a la métrica y a los ritmos clásicos españoles, sino también a su mismo lenguaje. Pero como todo intento de restauración, éste cae en un neo-clasicismo extemporáneo. En arte no se puede regresar impunemente en el tiempo; siempre se sacrifica lo esencial: el temple humano e histórico de la creación. ${ }^{392}$

Como hemos visto antes, la autenticidad que nuestro autor exigía para las obras literarias implicaba que para él no existieran estilos apropiados de antemano ni formas o palabras poéticas a priori. La expresión literaria debía ser siempre una lucha de la lucidez y de la conciencia crítica del creador para adaptar la escritura a los imperativos de su circunstancia y de su ética vital. Por este motivo, además de impugnar el realismo

fermenta y se fusiona, sin mucha alquimia, en La Misa de Arlequín. Buen pastiche de puro literato, ni siquiera de epígono con talento." (Ibíd.) La cursiva corresponde a la negrita del original.

390 Guillermo Sucre: "Los herbarios rojos", loc.cit.

${ }^{391}$ Guillermo Sucre: "Testimonio. El intelectual de izquierda...", loc. cit., pp. 432-433.

392 Guillermo Sucre: "Sobre poesía venezolana", en Revista Nacional de Cultura, Caracas, núm. 161, nov.-dic. 63, p. 237. 
socialista y el neoclasicismo anacrónico, Sucre censuraba el recurso a moldes formales establecidos antes del instante de la creación. Para Guillermo ni siquiera el propio estilo de un autor podía fijarse sin acarrear un perjuicio en la calidad estética de su obra. En referencia a esto nuestro autor se hacía eco de algo que había afirmado Octavio Paz en El arco y la lira: "Cuando un poeta adquiere un estilo, una manera, deja de ser poeta y se convierte en constructor de artefactos literarios"393. En consonancia con este argumento Guillermo indicaba en una crítica de esta época que

cuando un estilo se hace simplemente técnica o manera, que es lo que en ocasiones descubrimos en Gerbasi, se corre el grave riesgo de caer en la penuria poética. En ese sentido, creemos que Gerbasi -ya que lo sabemos dueño de un alto sentido creador- debería ser más dinámico y crítico frente a su misma poesía y extender los indudables dominios de originalidad que ya ha conquistado. ${ }^{394}$

Sucre encontraba este mismo defecto en los poemas contenidos en la plaquette titulada Moneda del forastero (1958), del ecuatoriano Carrera Andrade, que no pasaban a su juicio "de ser puro aunque no menos estéril divertimento de un escritor que ha descubierto ya la clave de su estilo",395.

\section{3. SATURACIÓN, FABULACIÓN, UNIVERSALIDAD}

Como hemos visto en el apartado precedente, Sucre cuestionaba aquellas obras en las que no se producía una coincidencia entre el autor, el contexto y la escritura. Los textos que hemos visto incurrían en excesos de forma o de contenido e impedían que la literatura venezolana adquiriera un valor universal. Ante estos desmanes, nuestro crítico anhelaba que el creador nacional fuese capaz de expresar "un mundo", es decir, de hallar una unidad entre el contexto, la mirada y el lenguaje. Como expresa el propio Guillermo en una encuesta sobre el estado de la narrativa nacional:

\footnotetext{
${ }^{393}$ Citado por el propio Sucre en: "Octavio Paz: Salamandra", loc.cit.

${ }^{394}$ Guillermo Sucre: "Vicente Gerbasi: Por arte de sol”, en Sardio, Caracas, núm. 3-4, sep.-dic. 1958 , p. 258.

${ }^{395}$ Guillermo Sucre: "Moneda del forastero", en El Papel Literario de El Nacional, Caracas, 18 09-58.
} 
El novelista venezolano no ha sabido diferenciar el hecho social en sí de la creación de un mundo de ficciones, donde lo humano y lo estético han de comulgar en una aspiración más alta: revelar las urgentes y dominantes esencias del hombre en la historia. Así, hemos tenido una larga lista de novelas que más bien parecen crónicas, muestrario de paisajes y costumbres, de problemas políticos y sociales vistos en su inmediatez menos significativa. Apegados a la tierra como a una gran madre oscura que no ha revelado su ser, apegados a lo pasajero y pintoresco, pocas veces nuestros narradores nos han iluminado un Mundo. ${ }^{396}$

Más adelante insistía en la misma idea: "el problema [de la novela venezolana] reside en que [los autores venezolanos] no han plasmado una radical visión de nuestro Mundo, en que no han asimilado con plenitud las determinantes experiencias de la cultura, de la historia y por ello se han visto reducidos a límites menos que nacionales" ${ }^{\text {397 }}$. Después del hito representado por la obra de Gallegos, Guillermo se lamentaba de que en la novelística nacional

No sólo se ha defraudado la tensión espiritual del hombre contemporáneo. No sólo se han evadido los temas dominantes y convulsivos de nuestra historia y de nuestra realidad. Sino que las mismas jerarquía, técnica y exigencias de la novela se han empobrecido en un afán por prodigar lo puramente pintoresco y circunstancial de nuestro mundo, en una incapacidad por penetrar el temple de nuestra verdadera humanidad. ${ }^{398}$

Para "penetrar este temple" era preciso hacer de la literatura una expresión necesaria y libre de excesos que pudiera encarnar las constantes del hombre universal desde la situación venezolana. Para ello el arte debía rechazar los defectos representados por el realismo ingenuo y el esteticismo superficial y convertirse en una transfiguración o recreación imaginaria de lo real a través de la personalidad del creador. A este respecto, nuestro autor parecía hacerse eco de las ideas defendidas por uno de los escritores que leyó con más fruición durante sus años juveniles. En efecto, oponiéndose a los extremos del formalismo y del realismo, Albert Camus había propuesto en El hombre rebelde (1951) y en referencia a la creación novelesca que "la unidad en arte surge del término de transformación que el artista impone a lo real”399. Para lograr esta

\footnotetext{
${ }^{396}$ Guillermo Sucre: "Nuestra novela no ha culminado"...loc.cit.

397 Ibid.

398 Guillermo Sucre: "Balance de una encuesta. Sobre novela venezolana", loc.cit.

${ }^{399}$ Albert Camus: El hombre rebelde, en Obras 3, Madrid, Alianza, 1996, p. 314.
} 
corrección del mundo a través del arte era preciso que se diera una superación de los excesos esteticistas y contenidistas a través del estilo:

La obra en la que el fondo desborda a la forma, o aquélla en que la forma sumerge al fondo, no hablan sino de una unidad decepcionada y decepcionante. En este dominio, lo mismo que en los otros, toda unidad que no es de estilo es una mutilación. Cualquiera que sea la perspectiva elegida por un artista, sigue habiendo un principio común a todos los creadores: la estilización, que supone, al mismo tiempo, lo real y el espíritu que da su forma a lo real. El esfuerzo creador rehace con ella el mundo, y siempre con una ligera desviación [transfiguración] que es la marca del arte y de la protesta. [...] La creación, la fecundidad de la rebelión están en esta desviación que simboliza el estilo y el tono de una obra. El arte es una exigencia de dar forma imposible. ${ }^{400}$

Para dar con esta unidad era imprescindible que la literatura fuera un modelo de saturación y de mesura: a través de la conciliación de los excesos el artista conseguía imponer una corrección a lo real y dotarlo de verdadera trascendencia. Por eso, en la concepción de Sucre, las obras que lograban una expresión mesurada presentaban también una gran "capacidad de fabulación" y la posibilidad, en consecuencia, de dotar a la realidad venezolana de una dimensión estética universal. En esta crítica temprana sobre la poesía de Vicente Gerbasi, Guillermo destacaba el hecho de que el creador venezolano hubiera sido capaz de trascender los excesos de cosas y de palabras:

$\mathrm{Ni}$ épica ni desmesurada, sin pruritos de mesianismo o de mensaje de dudosa trascendencia social, tampoco intimista ni reconcentrada en evanescentes requiebros emocionales, su poesía ha sabido mantenerse en un equilibrado plano de recia y matizada subjetividad y, al mismo tiempo, de vasta proyección hacia lo terrestre e inminente del hombre. Nutrida de la alucinante realidad de la naturaleza venezolana, poseída por la magia del trópico y plasmada en un lenguaje de firme resonancia universal, acaso ninguna como ella, entre nosotros, revele una concepción tan singular de nuestro paisaje y nuestras gentes. Al paisajismo tradicional, realista y tosco, en el que se desvanecía toda posible presencia de lo humano, Gerbasi ha puesto límites y sellos definitivos. ${ }^{401}$

Al ser una expresión saturada, la obra del poeta venezolano se vuelve mítica y posibilita una comunión entre el sujeto y el objeto o, lo que es lo mismo, entre el artista

${ }^{400}$ Ibid., pp. 316-317.

401 Guillermo Sucre: "Vicente Gerbasi: Por arte de sol" loc.cit., p. 257. En un comentario posterior, Sucre seguía insistiendo en lo mismo: "Sin caer en exotismos, sin buscar «perplejidades», sin proponerse deliberadamente nada grandioso, la escritura sobria de Gerbasi nos dio una visión universal del hombre. Aún más, nos dio una reconfortante lección estética: el incorporar un tema aparentemente ajeno a nuestra tradición y a nuestra historia de hoy e imprimirle verdadera significación." (Guillermo Sucre: "La venganza contra la poesía", en La República, Caracas, 17-03-63, p. 7) 
y su circunstancia que permite operar un paso de lo anecdótico a lo trascendente. Por eso, en el poema "Intemperie" de este mismo creador venezolano Sucre apreciaba que

a la visión puramente caleidoscópica y sensorial de la naturaleza se va sobreponiendo, por medio de una progresiva y existencial comunión con lo real, una poderosa corriente emocional que sitúa a los seres y elementos designados por el poeta en una dimensión más significativa e implicatoria. [...] Lo que en manos de otro poeta más simplista se hubiera quedado en desvaída estampa de un destellante paisaje tropical, en manos de Gerbasi, por obra de una incesante capacidad de transmutación, se convierte en dinámica conjunción del hombre y del universo. ${ }^{402}$

Sucre destacaba esta misma relación entre la ausencia de excesos y la trascendencia artística a propósito de la obra El Reino (1958) de Ramón Palomares.

Según nos dice el crítico, en este poemario el autor consigue trascender las desmesuras en que se debatía la literatura venezolana más convencional:

La extremada postura conceptualista, con sus dudosas gravedades metafísicas y sus estériles laberintos de palabras, y la exuberancia mágica e incontrolada de quienes se sienten alucinados por la tierra o por los terribles sueños de un pretendido exterminio -tendencias que parecen resumir las más definidas tentativas de la última poesía venezolana-, no encuentran resonancia alguna en este joven poeta tan dueño de su instrumento creador, tan singular y decidido a romper con las vaguedades de los esteticistas o de los enajenados. ${ }^{403}$

La poesía del autor trujillano surge con "un ímpetu embriagador y saludable en medio de las monsergas líricas y los remedos épicos de gran parte de la poesía venezolana"404 y por eso logra trascender el realismo convencional y dotar de una significación especial al mundo que presenta: "Más sensorial que reflexivo, tiene sin embargo esa especial sabiduría que logra extraer un sentido trascendente de los seres y de las cosas mismas. Por eso nadie menos anecdótico que él. La casa familiar, un pájaro, un nadador, son temas para una incesante transfiguración. Y los padres y demás seres que le son familiares, constantemente evocados en sus poemas, se nos imponen como seres míticos y enigmáticos" ${ }^{405}$. A propósito de esta obra Guillermo constataba además que "toda labor creadora implica traducir un mundo con la fuerza avasallante de

${ }^{402}$ Guillermo Sucre: "Vicente Gerbasi: Por arte de sol", loc.cit., pp. 257-258. Como se advierte en esta cita, gracias a la transfiguración de lo real que se opera en el poema se produce una comunión entre el hombre y el universo. Caracas, 21-08-58.

403 Guillermo Sucre: “El Reino de Ramón Palomares”, en El Papel Literario de El Nacional,

\footnotetext{
${ }^{404}$ Ibid.

${ }^{405}$ Guillermo Sucre: "Sobre poesía venezolana", loc. cit., p. 244.
} 
su realidad, pero también recrearlo a imagen del hombre, conferirle significaciones espirituales y humanas. «El Reino» pone en evidencia esta cualidad esencial a toda auténtica poesía"406.

Sucre apreciaba esta misma cualidad en algunas novelas que habían logrado una expresión estética libre de excesos. Así, por ejemplo, refiriéndose a La resaca (1958) de Juan Goytisolo -“extraordinario ejemplo para otros novelistas, sobre todo los de nuestro

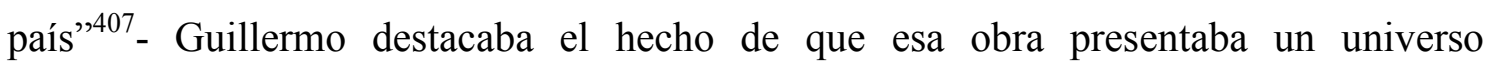
autónomo e independiente de las intenciones del creador. En ella, el autor español "no solo deja que su mundo y sus criaturas se desencadenen según la avasallante necesidad de su existir, sino que tampoco pretende juzgar ni reducir el desarrollo de sus novelas a un fácil comercio de apologías o condenaciones"408. Además, en contraste con cierta narrativa venezolana, en la prosa de Goytisolo quedaban "relegadas sutilezas, resultantes preconcebidas y analíticas, dudosas posturas sociológicas, juegos subjetivos, para dar paso a la aplastante y oscura facticidad de una sociedad y de una época"409. Gracias a su autonomía y a su carácter mesurado la obra dejaba a un lado los desmanes expresivos y constituía un cuerpo armónico:

Lenguaje escueto y directo, sin recaídas líricas ni regustos estilísticos, profusión de diálogos muy vivos y punzantes, le imprimen un dinamismo envolvente y denso. Nada de análisis morosos en la psicología de los personajes, nada de desarrollo lineal y progresivo de evocaciones, de pasajes descriptivos. Y, sin embargo, revela una arquitectura y una construcción muy lúcida, y precisa. ${ }^{410}$

Asimismo, en la novela Habitación para hombre solo (1963) de Segundo Serrano Poncela -autor español que vivía exiliado en Venezuela- Guillermo valoraba que la técnica era "algo esencial no sólo a ella misma, como narración, sino también a la

${ }^{406}$ Guillermo Sucre: "El Reino...", loc. cit.

407 Guillermo Sucre: "La resaca de Juan Goytisolo", en El Papel Literario de El Nacional, Caracas, 21-05-59.

${ }^{408}$ Ibíd. En relación a este reclamo de autonomía, en otro texto Guillermo afirma: "Una obra de ficción ha de tener su propia autonomía, sus propias claves y exigencias, y difícilmente puede permitirse rupturas o incoherencias de planos sólo por satisfacer inclinaciones o regustos teóricos del autor." (Guillermo Sucre: “Casandra de Díaz Sánchez”, loc.cit.)

${ }_{409}$ Guillermo Sucre: "La resaca...", loc.cit.

${ }^{410}$ Ibid. 
mirada que el autor proyecta sobre el mundo" ${ }^{\text {411. }}$ Y destacaba el hecho de que en esta obra "podemos intuir a un novelista auténtico, dueño no sólo de un lenguaje -lo que nos había revelado en sus ensayos también- sino de un poder de trastocar la realidad, de penetrar en la existencia y de darnos una visión del mundo"412. Como vemos, lo que Sucre esperaba de la literatura no era un simple recuento de anécdotas sino una encarnación subjetiva, y por eso significativa, de la realidad. Él pensaba además que esta transformación del mundo operada por el arte permitiría a los autores satisfacer el requerimiento de universalidad, requerimiento que Guillermo concebía como un término medio entre las posturas nacionalistas y las cosmopolitas y que suponía, por lo tanto, una conciliación entre lo particular y lo universal:

el fenómeno literario venezolano se vuelve puramente gratuito y banal cuando, pretextando una búsqueda universal, se cae en el mimetismo, en el snobismo o, simplemente, en la confusión estética. [...] Dentro de una literatura que aún carece de rasgos dominantes y de audacia creadora, el autor joven tiende a escribir en función de modelos ya consagrados en la literatura contemporánea, a creer que la universalidad es una categoría abstracta que se conquista alegremente con una sumisión a la moda o a la publicidad. Lo que no pasaría de ser sino cosmopolitismo. [...] La verdadera universalidad se sitúa en otro campo de experiencias. En la búsqueda, paciente o alucinada, desbordada o lúcida, de nuestro rango de hombres en el mundo; en la revelación de nuestra personalidad dentro de una situación que nos es dada y que sólo nos habla a nosotros mismos. ${ }^{413}$

Nuestro crítico establecía una relación entre el anacronismo de la literatura

venezolana y su falta de significación universal. Por eso reclamaba desde las páginas de

Sardio la necesidad de modernizar las obras nacionales:

El hombre de hoy está volcado hacia una experiencia más vasta y compleja, que sería inútil simplificar con limitaciones regionales o partidistas, y está urgido por anhelos profundos de universalidad. Orientados hacia esa gran experiencia es como debemos tratar los problemas nacionales. Es imperioso elevar a perspectivas más universales los alucinantes temas de nuestra tierra. La anécdota, el paisajismo, la visión pintoresca de la realidad, no son más que fraudes a los requerimientos de la época. ${ }^{414}$

${ }^{411}$ Guillermo Sucre: "La novela del exilio", en La República, Caracas, 16-02-64.

412 Ibíd.

${ }^{413}$ Guillermo Sucre: "Cuando la literatura pierde autenticidad”, en La República, Caracas, 1609-62. La cita sigue: "Tentativa que dará realidad a una literatura de fundación como decía un gran poeta mexicano. Es la tentativa de Rómulo Gallegos entre nosotros. La de Miguel Ángel Asturias y Alejo Carpentier. La de Jorge Luis Borges. La de Octavio Paz y la de Juan Rulfo."

${ }^{414}$ Guillermo Sucre: “Testimonio", loc. cit., p. 2. 
En consonancia con esta afirmación, Sucre advertía una dimensión ecuménica precisamente en aquellas obras que habían sido capaces de liberarse de la morosidad descriptiva y del formalismo superficial, es decir, de los excesos de cosas y de palabras que impedían una repercusión más amplia de la literatura. Un buen ejemplo de esta concepción crítica se aprecia en el artículo que Guillermo escribió sobre el poemario Pido la paz y la palabra (1955) de Blas de Otero. En esa obra, nos dice Sucre, el vate consigue trascender los excesos localistas y cosmopolitas en que se debatía la poesía española ${ }^{415} \mathrm{y}$, al mantener una posición estéticamente mesurada, confiere significación global a un drama particular. El autor del libro, según palabras de Sucre,

Ha vivido las tremendas desgracias contemporáneas, la guerra, la destrucción, el odio, pero sin patetismos insulsos, sin enlutados ropajes, sin evanescencias ni éxtasis ni amagos metafísicos, a veces demasiado seco y adusto, no sólo representa la historia de su patria o de su generación, sino también la desquiciante experiencia de nuestro tiempo y del hombre universal. $^{416}$

En algunos autores hispanoamericanos Guillermo advertía esta misma capacidad para elevar el conflicto particular a una dimensión universal. Cuando las obras se liberaban de lo anecdótico e insustancial alcanzaban precisamente esta capacidad de trascender la problemática concreta y se proyectaban a un ámbito más universal. Esto es lo que el crítico destacaba en la novelística del cubano Alejo Carpentier, cuya obra, según nos dice Sucre,

ha sabido trascender la exigua y no menos anacrónica problemática de nuestra literatura y crear una vasta secuencia de temas que satisfacen los más inflexibles requerimientos de universalidad. Sus criaturas novelescas, llenas de lucidez, de revelación interior, están proyectadas hacia esas "situaciones límites" en las que se desvanecen las fronteras que separan lo anecdótico de lo permanente. ${ }^{417}$

${ }^{415}$ Blas de Otero conseguía trascender los excesos nacionalistas y cosmopolitas y presentaba por tanto la estética mesurada que Sucre quería para Venezuela: "Así, lo vemos, con agrado, muy personal y distante de esa fatigante y gratuita poesía andaluza que aún parece proliferar, no ya en España sino en América, y de esa otra poesía amanerada y cultista, llena de requiebros, de falsas intimidades y de vagas fabulaciones que parece jefaturar en la Península el melancólico Vicente Aleixandre." (Guillermo Sucre: "Pido la paz y la palabra", en El Papel Literario de El Nacional, Caracas, 06-11-58)

${ }^{416}$ Ibid.

417 Guillermo Sucre: “Guerra del tiempo, de Alejo Carpentier”, en El Papel Literario de El Nacional, Caracas, 31-07-58. 
Esto no debe interpretarse, en ningún caso, como una voluntad de alejarse o desdeñar lo hispanoamericano o lo venezolano. Se trata más bien de lo contrario, pues lo que buscaba Sucre era dotar de trascendencia artística a la realidad venezolana para que lo nacional resistiera una comparación con la literatura de otras latitudes. Por eso dejaba claro que lo universal para él no estaba enfrentado a lo particular, sino que más bien lo suponía:

Nuestra novela pierde vigor universal no porque se limite al ámbito rural o de la pura y avasallante naturaleza y no penetre en la vida de la ciudad moderna. De la universalidad de "Hombres de maíz" nadie podrá dudar, y es precisamente novela que se desarrolla en medio de la patética y milenaria violencia de los campesinos de Guatemala. Y una obra de tanta grandeza como "Los pasos perdidos" incorpora la magia envolvente de nuestra naturaleza tropical. El problema radica en el alma de los personajes, en la tensión del clima narrativo, y es lo que no parece comprenderse. ${ }^{418}$

En línea con la concepción de su maestro Picón Salas, lo que Sucre anhelaba era que la literatura venezolana e hispanoamericana fuera capaz de revelar una dimensión universal del hombre ${ }^{419}$. En este comentario a propósito de los poemas agrupados en $L a$ estación violenta (1958) de Octavio Paz se aprecia particularmente bien cómo el compromiso del vate con su destino y con su contexto histórico redunda en la significación universal de la creación literaria:

el hombre -escribe Guillermo- que acepta su destino y su compromiso detrás de estos temas no es un ente puramente abstracto, sino un ser histórico y real, envuelto por la aventura de nuestro tiempo, en batalla obstinada por conquistar su verdad o su absoluto, una criatura terrestre y americana que atraviesa los enigmáticos paisajes de su país natal o las ciudades de otro mundo penetradas por el sombrío paso de las edades, pero cuya vivencia es una y semejante a la grandiosa vivencia universal de todo hombre. ${ }^{420}$

En suma, en las críticas que escribió a lo largo de este período Guillermo Sucre analizó las obras nacionales y extranjeras de acuerdo a un paradigma de orden y saturación que quería implementar en la literatura nacional. Ante los excesos formalistas y contenidistas que mantenían la realidad venezolana en un tratamiento insustancial y

${ }^{418}$ Guillermo Sucre: "Balance de una encuesta...", loc. cit.

419 Por eso destacaba que el poeta senegalés Sedar Senghor quería "asimilar, no asimilarse", y que "sin acallar sus diferencias, al contrario, exaltándolas, Senghor aspira a reintegrar al negro a una dimensión universal del hombre." (Guillermo Sucre: "La poesía de Sedar Senghor", en La República, Caracas, 02-09-62)

${ }^{420}$ Guillermo Sucre: "La "violenta estación” de Octavio Paz", en El Papel Literario de El Nacional, Caracas, 16-10-58. 
que limitaban su proyección universal, Guillermo propuso una estética saturada en que la mirada del autor, el contexto de producción y la obra establecieran una relación necesaria. La creencia de Sucre era que cuando esta coincidencia virtuosa se produjera la literatura superaría tanto su insistencia en aspectos triviales como su sumisión a fines extraliterarios y conseguiría ofrecer, al fin, una perspectiva venezolana de la estética y del hombre universales. 


\section{CAPÍTULO IV}

\section{EL PENSAMIENTO LITERARIO DE GUILLERMO SUCRE (1964-1968)}

El pensamiento de Guillermo no sufre modificaciones bruscas a lo largo de los años, pero se va enriqueciendo progresivamente, siempre al amparo de una misma política estética y cultural. Por tanto, lo que pretendemos al marcar esta división cronológica es señalar las diferentes etapas de un crecimiento espiritual y teórico para poder así apreciar los cambios paulatinos que sobrelleva su ideario estético y su crítica literaria.

A partir de 1964, nuestro autor colaboró en la fundación de la revista Zona Franca, en cuya jefatura de redacción permaneció hasta 1966, y después creó Imagen, publicación que dirigió durante un año largo entre 1967 y 1968. La diferente dimensión de estos dos proyectos en relación con los anteriores supuso también un cambio en la función de su crítica y de su intervención cultural. En el periodo comprendido entre 1958 y 1963 la repercusión de sus escritos se había limitado al ámbito nacional. Como su intención era corregir la actitud impropia de la intelectualidad y la consiguiente falta de universalidad de la literatura venezolana, en esos años Sucre se dedicó a valorar las obras de acuerdo al ideal estético que él quería implementar en su país. En ese primer lapso, el crítico juzgó las obras nacionales y extranjeras de acuerdo al paradigma de orden y saturación que él consideraba esencial a la literatura de todos los tiempos con el objetivo de que la escritura quedara libre de cualquier falsedad.

Las revistas en las que Sucre participó en este nuevo periodo estaban pensadas primordialmente para el lector nacional pero tenían una dimensión continental. Por eso, sus críticas dejaron de presentar ese carácter de actualidad que marcaba sus escritos anteriores. En estos años, el número de reseñas disminuyó y Guillermo dedicó sus ensayos casi exclusivamente a autores que eran de su predilección, es decir, a aquellos 
con los que compartía una misma política estética y cultural. Además, muchos de sus escritos se concibieron como homenajes a trayectorias de autores ya consagrados Enrique Bernardo Núñez, Picón Salas, Octavio Paz, Rosamel del Valle, André Breton, etc.- o fueron textos plenamente teóricos como muchos de los que publicó en Imagen, con los que trataba de repercutir en Venezuela la estética de modernidad que se estaba poniendo de moda en los centros de cultura.

En esta etapa, por lo tanto, Guillermo no se ocupó de valorar las obras de acuerdo al ideal de orden y saturación que quería promover en Venezuela sino que trató casi exclusivamente sobre creaciones en las que ya advertía ese ideal. Se puede decir entonces que su crítica perdió en parte la voluntad de intervención que tenía en los años previos y que Sucre trató sobre aquellas obras que coincidían con su propia concepción estética. A los estudios sobre autores reconocidos y del gusto de nuestro autor se sumó en este periodo una veta teórica y de difusor intelectual que Sucre emprendió sobre todo desde las páginas de la revista Imagen. Además, otro rasgo característico de este periodo es que desapareció prácticamente la crítica de novela y que su interés se centró definitivamente en la poesía, que será el género al que consagre su obra crítica posterior.

\section{1. REINTEGRAR EL ABSOLUTO}

Un texto teórico fundamental para apreciar la variación en la visión de nuestro autor durante este periodo y para estudiar sus ideas sobre la poesía moderna es el titulado “Álgebra y fuego”, que Sucre publicó en Zona Franca en 1965. Haciéndose eco de lo que Heidegger había expuesto en "La época de la imagen del mundo"421, Sucre

${ }^{421}$ Martin Heidegger: "La época de la imagen del mundo", en Caminos de bosque, Madrid, Alianza, 1998, pp. 63-90. En este texto el filósofo alemán plantea que el pensamiento metafísico se sustenta sobre la división entre el sujeto y el objeto, desde Descartes: "A diferencia de la percepción griega, la representación moderna tiene un significado muy distinto, que donde mejor se expresa es en la palabra raepresentatio. En este caso, representar quiere decir traer ante sí eso que está ahí delante en tanto que algo situado frente a nosotros, referirlo a sí mismo, al que se lo representa y, en esta relación consigo, 
afirmaba que con la llegada del cogito cartesiano en los albores del mundo moderno apareció una "fisura en la conciencia del hombre" que abrió "un abismo" "entre el hombre y el universo, entre el sujeto y el objeto, aun entre el poeta y la inspiración" El vate del mundo antiguo no percibía división alguna entre su ser y el mundo y, por lo tanto, la poesía era simplemente un "magnetismo misterioso y universal" que prendía en él "por azar". Como en la Antigüedad había una afinidad total entre el sujeto y el objeto, el vate podía confiarse a un soplo divino, ajeno a él y a su conciencia, para convertirse en el poeta de un mundo que ya era en sí mismo poético. Por eso, según afirma Borges en "Flaubert y su destino ejemplar" (1932) -texto que inspiró también el ensayo de Guillermo- la doctrina platónica del poema "era hostil a una valoración personal del poeta, rebajado a instrumento momentáneo de la divinidad"423.

Sin embargo, con la llegada de la modernidad, el sujeto y el objeto se escinden, las musas vuelven al Parnaso y el entusiasmo en que se amparaba el poeta antiguo se dispersa en la niebla. La separación entre el yo y el mundo que resulta del exceso

obligarlo a retornar a sí como ámbito que impone las normas. En donde ocurre esto, el hombre se sitúa respecto a lo ente en la imagen. [...] El hombre se convierte en el representante de lo ente en el sentido de lo objetivo." (Ibid., p. 75). Sucre había cursado un seminario sobre la estética de Heidegger con el profesor Federico Riu, en el que habían leído esta obra. (Guillermo Sucre: "Carta I, octubre de 2012", infra en Apéndice I, p. 477). Esta misma conciencia de la separación aparece en Octavio Paz: "La distancia entre la palabra y el objeto - que es la que obliga, precisamente, a cada palabra a convertirse en metáfora de aquello que designa- es consecuencia de otra: apenas el hombre adquirió conciencia de sí, se separó del mundo natural y se hizo otro en el seno de sí mismo. La palabra no es idéntica a la realidad que nombra porque entre el hombre y las cosas [...] se interpone la conciencia de sí. La palabra es un puente mediante el cual el hombre trata de salvar la distancia que lo separa de la realidad exterior. Mas esa distancia forma parte de la naturaleza humana. Para disolverla [la distancia], el hombre debe renunciar a su humanidad, ya sea regresando al mundo natural, ya transcendiendo las limitaciones que su condición le impone. Ambas tentaciones, latentes a lo largo de toda la historia, ahora se presentan con mayor exclusividad al hombre moderno. De ahí que la poesía contemporánea se mueva entre dos polos: por una parte, es una profunda afirmación de los valores mágicos; por la otra una vocación revolucionaria." (Octavio Paz: El arco y la lira, en OOCC, Vol. I, op.cit., pp. 65-66).

${ }_{422}$ Guillermo Sucre: “Álgebra y fuego", en Zona Franca, Caracas, núm. 15-16, abr. 65, p. 3.

423 Jorge Luis Borges: "Flaubert y su destino ejemplar" en Discusión, en OOCC, Vol. I, Barcelona, RBA, p. 263. Guillermo Sucre parafrasea este texto en la p. 152 de su obra Borges, el poeta donde dice, por ejemplo: "De igual modo, poetas sacerdotales son Mallarmé, Valéry y también el mismo Joyce. Borges pertenece a parecido linaje. Como a éstos, lo definen tanto la inteligencia como la supremacía que asigna a lo verbal; pero lo verbal que supone toda una metafísica: la tentativa por alcanzar la "palabra del universo", por cifrar el mundo en un libro." Y más adelante: "El Borges que rechaza la doctrina del Ion es, sin embargo, un platónico. El poeta, para él, es aquel que busca secretamente los arquetipos, las formas esenciales; aquel que busca un orden superior del que la obra sea un símbolo y donde el azar se vea cada vez más reducido." (Guillermo Sucre: Borges, el poeta, op.cit., p. 152) 
racionalista modifica radicalmente la concepción del poeta y del poema. En la nueva situación, el creador moderno "no puede confiarse en una realidad superior a él sino en su propia conciencia" y debe asumir enteramente "la responsabilidad de su actitud creadora"424. Además, la poesía pasa a ser "producto de la energía del espíritu, del entusiasmo de la inteligencia y de la secreta fuerza del propio lenguaje"425, pues ya "no hay un mundo eidético o una divinidad anterior de la que ella es simple mediadora" ${ }^{426}$. En este contexto desfavorable, los poetas modernos se imponen "la ambición desmesurada" de "cambiar la vida"427, es decir, de conciliar los contrarios entre los que el hombre se debate para que la existencia recupere su plenitud perdida. La poesía aspira entonces a alcanzar la unidad del Ser, es decir, la concordancia entre el sujeto y el objeto, con la intención de que el hombre anule la distancia que se establece entre sí mismo y aquello que le rodea. A este respecto es evidente en Sucre la huella del pensamiento de Octavio Paz, para quien la poesía debía culminar "en la experiencia de la Unidad"428. En El arco y la lira el escritor mexicano había señalado lo siguiente:

La identidad última entre el hombre y el mundo, la conciencia y el ser, el ser y la existencia, es la creencia más antigua del hombre y la raíz de ciencia y religión, magia y poesía. Todas nuestras empresas se dirigen a descubrir el viejo sendero, la olvidada vía de comunicación entre ambos mundos. Nuestra búsqueda tiende a redescubrir o a verificar la universal correspondencia de los contrarios, reflejo de su original identidad. ${ }^{429}$

${ }^{424}$ Guillermo Sucre: “Álgebra y fuego", loc.cit.

${ }^{425}$ Ibid.

426 Ibid.

${ }^{427}$ Rodrigo Antúnez [Guillermo Sucre]: "Literatura crítica”, en Imagen, Caracas, núm. 27, 15/30 jun. 68 , p. 2.

${ }^{428}$ Octavio Paz: El arco y la lira, en OOCC, Vol I, op.cit., p. 174. En un escrito sobre Paz de esta época Guillermo se hacía eco precisamente de esta tendencia a la unidad: "La poesía de Paz se caracteriza por una conciencia desgarrada ante el mundo; una conciencia que encarna la duplicidad del hombre dividido entre la plenitud de ser y el vacío de no ser, entre la vida y la muerte, entre la posesión del amor y la desposesión de una soledad más radical, entre lo sagrado y lo cotidiano, entre una aspiración de eternidad y la disolución de la historia. Tal hecho, sin embargo, no relega a Paz a un puro aniquilamiento de la conciencia, sino que lo proyecta hacia el universo en busca de una unidad superior, de un absoluto. El poema y el amor son las dos grandes fuerzas que lo impulsan hacia esa unidad. Así, el poema comienza por la palabra misma. La palabra no expresa o recrea simplemente un mundo; lo funda, lo hace posible. [...] La palabra es la única garantía para el hombre: es invención que a su vez inventa." (Guillermo Sucre: "El diálogo con el mundo", en Zona Franca, Caracas, núm. 33, may. 66, pp. 12-17)

${ }^{429}$ Octavio Paz: El arco y la lira, en OOCC, Vol. I, op.cit., pp. 143-144. 
Ahora bien, alcanzar el absoluto desintegrado por la modernidad no es una labor fácil para el poeta moderno. En el pensamiento de Guillermo Sucre obtener la plenitud del Ser a través de la poesía requiere que el vate moderno, a partir de su personalidad y de su contexto particular, sea capaz de ver el mundo como verdaderamente es y de revelarlo en un lenguaje apropiado a esa esencia. La unidad del Ser, dice Sucre,

es el reino superior a que el hombre aspira; el reino del Ser en su elemental, paradisíaca y exaltante integridad [...]. A él sólo tendrán acceso quienes hayan sido fiel [sic] a esa integridad. [...] El poeta es por ello severo: es un sitio para elegidos, para los que se eligen a través de una voluntaria ascesis. De modo que sólo aquellos que viven en y con toda la plenitud de su propio ser y comprenden el sentido de su profunda simplicidad, podrán descubrirlo y reconocerlo ${ }^{430}$

Como se aprecia por la cita, la labor del poeta consiste en reconocer y descubrir el Ser, es decir, la plenitud original que todos compartimos. Para ello es imprescindible que el creador sea capaz de vivir con integridad, es decir, de conocerse y ejercitarse a sí mismo hasta dar con el Ser perfecto, cuya revelación constituye la meta de la poesía moderna. Como afirma el crítico en el mismo ensayo:

Acceder al deslumbramiento del Ser por lo cotidiano, a lo infinito por lo finito, a lo absoluto por lo eventual, a la gracia por el rigor, a la plenitud por la humildad, no es tarea fácil de realizar. No sólo dominio técnico se requiere. Madurez y grandeza de espíritu son también indispensables. No una estética formal, sino una estética que se arraigue en todos los planos del hombre. Una ética, una visión del mundo. Signo de todo ello en Fombona Pachano lo encontramos en su autodominio, en su sobriedad misma. ${ }^{431}$

A través de la ascesis interior, el poeta consigue alcanzar una mirada plena y original del mundo y comunicarla en un lenguaje prístino capaz de transmitir esa plenitud a la escritura. Por lo tanto, para alcanzar el absoluto es necesario que el poeta presente una ética propia de escritor ${ }^{432}$ y que esa ética se comunique a través de un lenguaje que no desmienta la plenitud alcanzada. Por eso, según nos dice Sucre, si bien la poesía de Saint-John Perse "encierra una gran sabiduría del mundo", ese

\footnotetext{
${ }^{430}$ Guillermo Sucre: "Introducción” a Jacinto Fombona: Poesías, Caracas, Dirección de Cultura de la Universidad Central de Venezuela, 1964, p. 48. La cursiva corresponde a la negrita del original. En otro sitio afirma: "esa unidad no es dádiva, don gratuito, sino equilibrio tenso, paz superior que sólo se conquista a través de la lucha en el mundo, y aun a través del sufrimiento.” (Ibid., p. 49)

${ }^{431}$ Ibid., p. 17.

${ }^{432}$ Sobre esta concepción de Sucre vid. supra nota 367, p. 134.
} 
conocimiento "no hubiera logrado proyectarse sin un lenguaje que tuviese su misma amplitud y profundidad"433. A este respecto resulta igualmente esclarecedora una afirmación que Guillermo hace a propósito del poemario Rosa de espadas (1967) de Coronil Hartmann ${ }^{434}$. El crítico afirma que en esa obra el encuentro inicial del autor con la poesía

tiene, sin duda, un sentido para él: lo rescata de la "soledad dormida" y le hace ver la verdadera realidad del mundo. No basta, claro está, con esa mirada; se requiere el lenguaje que la exprese, que la vuelva visión comunicante. Dar a ver, es la misión del poeta. Y ello impone, además de cierto rigor: despojar a la palabra de todo lastre retórico, también cierta inocencia: que la palabra sea la mirada misma. ${ }^{435}$

Sucre piensa, como es evidente por esta cita, que para alcanzar el absoluto al que aspira la poesía moderna es imprescindible que se establezca una continuidad entre la mirada del autor y su escritura, y que esa afinidad se cumpla en un marco ético y estético apropiado, es decir, afín a ese mundo esencial y perfecto que la poesía debe revelar. Como se trata de comunicar una realidad plena y conciliada, tanto la visión como la expresión del vate deben ser armónicas y perfectas, para lo cual es indispensable que el autor controle los posibles excesos éticos y estéticos. En la concepción de nuestro autor el creador debe conciliar los opuestos entre los que se debate para coincidir con el ser perfecto -y, por tanto, universal- y estar en disposición de revelar un mundo pleno y reintegrado.

\section{2. ÁlgeBra y FUEGO}

Como es evidente por lo que acabamos de señalar, también en este período Sucre estaba reclamando un ideal de saturación expresiva, sólo que ahora explica este

${ }^{433}$ Guillermo Sucre: "Honrar al mundo con la escritura", en Imagen, Caracas, Supl. 17, 15/30 ene. 68 , pp. 9-16.

${ }^{434}$ Alfredo Coronil Hartmann (Caracas, 1943) es abogado y doctor en Administración Pública, y trabaja como profesor en la Universidad Santa María de Caracas. En su labor como escritor ha publicado doce títulos de poesía y ha recibido el Premio Municipal de Literatura del Distrito Federal por su obra Trabajos del amor y de la muerte (1979).

${ }^{435}$ Guillermo Sucre: “Rosa de espadas”, en Imagen, Caracas, núm 10, 1/15 oct. 67, p. 22. 
ideal como un resultado de la conciliación entre la pasión y la inteligencia. Según afirma en "Álgebra y fuego", la poesía moderna no se debe a una fuente exterior sino que se forja en la conciencia del vate, que asume la plena responsabilidad ante la creación literaria. Como la poesía se genera ahora en el interior del escritor dos fuerzas opuestas van a luchar por su control: la pasión y la inteligencia o, lo que es lo mismo, la sensibilidad y la reflexión, el sueño y la vigilia, etc. Ante la presión que ejercen estas potencias dispares,

el poeta moderno tiende a la lucidez: la integración y la mutua trascendencia entre la pasión y la inteligencia. Su obra aspira a ser la unidad de los contrarios. Y para lograr esa aspiración debe imponerse el rigor. El rigor más alto y acaso más válido, pues implica el dominio y el control sobre el hechizo y el encantamiento, sobre las fuerzas más oscuras y desconocidas del hombre. ${ }^{436}$

Al reclamar la conciliación de estas energías contrarias, Guillermo estaba retomando la lección del simbolismo y, en particular, de Charles Baudelaire ${ }^{437}$. Como el propio Sucre lo indicaba, el vate francés "fue el primer vidente y el primer poeta moderno no sólo por sus poemas mismos, sino también porque supo expresar la idea de la nueva poesía crítica, reflexiva, que se desarrolla a la par entre la pasión y la inteligencia" ${ }^{438}$. Además, al igual que nuestro autor, el padre del simbolismo percibía

${ }^{436}$ Guillermo Sucre: “Álgebra y fuego”, loc.cit.

${ }^{437}$ La concepción estética de los poetas simbolistas y, en particular, su rechazo de lo instintivo aparece ya, como hemos visto, en la etapa anterior (58-64). A partir de su participación en Zona Franca, Sucre comienza a reclamar una conciliación precisa entre la pasión y la inteligencia que no hemos apreciado antes y que remite directamente a Baudelaire.

${ }^{438}$ Guillermo Sucre: "La lucidez crítica", en Imagen, Caracas, editorial núm. 16, 15/30 ene. 68, p. 2. En otro lugar Sucre afirmaba: "La poesía, para Baudelaire, como para Poe, no es la embriaguez del corazón, el reino de los puros sentimientos, sino la expresión de una fuerza superior: la pasión de la imaginación. Con Baudelaire surge -o más bien, se reafirma- un tipo de escritor en quien la lucidez se da como una dialéctica dramática entre la inteligencia más extrema y la más profunda intensidad del alma." (Guillermo Sucre: "Baudelaire. Soñar y saber soñar", en Imagen, Caracas, Supl. 19, 15/29 feb. 68, s/p.) Sobre Poe afirmaba Baudelaire: "concediendo su parte al poeta natural, a lo innato, Poe le concedía otra a la ciencia, al trabajo y al análisis [...]. No sólo dedicó esfuerzos considerables para someter a su voluntad el demonio fugitivo de los minutos felices, para requerir cuando lo deseara, las exquisitas sensaciones, los apetitos espirituales, los estados de salud poética, tan raros y tan preciosos que se les podría tomar verdaderamente por gracias exteriores al hombre y por visitaciones; sino que también sometió la inspiración al método, al análisis más severo." (Charles Baudelaire: "Nuevas notas sobre Edgar Poe", en VVAA: Matemática tiniebla...op.cit., p. 148). Para Valéry, Baudelaire está "en la cumbre de la gloria" porque supo aunar intelecto y sensibilidad: "esta fecundidad espiritual, esta gloria que está en su periodo más alto, deben de depender no sólo de su propio valor en cuanto poeta, sino también de circunstancias excepcionales. Es una circunstancia excepcional una inteligencia crítica asociada al don de la poesía. Baudelaire debe a esta rara alianza un descubrimiento capital. Había nacido sensual y preciso; tenía una 
que la conciliación "de cálculo y ensueño" “constituye el ser perfecto" $\$ 339$. Paul Valéry,

por su parte, había hecho de la lucidez uno de los conceptos básicos de su pensamiento

literario y la había definido, replicando a Mallarmé y en referencia a Edgar A. Poe, como "el pensamiento consciente y la conciencia del pensamiento consciente" ${ }^{440}$. El

teórico principal del simbolismo advertía la presencia de esta facultad precisamente en

el autor de Un coup de dés y en un ensayo sobre él afirmaba lo siguiente:

un hombre que se mide a sí mismo y se rehace gracias a su lucidez me parece una obra superior que me emociona más que cualquier otra. El esfuerzo más bello de los humanos es cambiar su desorden en orden y la suerte en poder; ésta es la verdadera maravilla. Me gusta que uno trate con dureza a su propio genio. Si no sabe volverse contra sí mismo, a mis ojos el "genio" no tiene más que un virtuosismos innato, pero desigual e infiel. ${ }^{441}$

Al igual que este grupo de poetas, Picón Salas había reclamado severidad y rigor

a los creadores venezolanos y se había opuesto en consecuencia a la poesía instintiva y

anárquica representada por cierto romanticismo vernáculo:

La abundancia del corazón inflamado, la vida y el amor desparramándose, eran el trance y el ideal del poeta para esos románticos nuestros, ripiosos y descuidados, cuyo ejemplo más revelador fue un Abigaíl Lozano. La poesía es generalmente, en ellos, crónica en primera persona, erizada de exclamaciones. Entre nuestros poetas modernos no faltan, en cambio, quienes conviertan la poesía en tema de estudio. Acercarse a la sugerencia de otras Artes; frenar la inspiración con la disciplina de la forma, pesar las palabras, buscar no el sentimiento común sino el peculiarísimo, es ahora una aspiración consciente. Contra Víctor Hugo, Baudelaire, es una de las fórmulas más valederas de la Poesía desde la época de los parnasianos. ${ }^{442}$

sensibilidad cuya exigencia le conducía a las investigaciones más delicadas de la forma; pero, sin duda, estas cualidades no habrían hecho de él más que un émulo de Gautier o un excelente artista del Parnaso, si no se hubiera ganado, gracias a la curiosidad de su mente, la oportunidad de descubrir en las obras de Edgar Poe un nuevo mundo intelectual. El demonio de la lucidez, el genio del análisis, y el inventor de las más nuevas y seductoras combinaciones de la lógica con la imaginación, del misticismo con el cálculo, el psicólogo de la excepción, el ingeniero literario que profundiza y utiliza todos los recursos del arte, se le manifiestan en Poe y le maravillan." (Paul Valéry: "Situación de Baudelaire", en VVAA: Matemática tiniebla...op.cit., p. 261). En base a este mismo criterio, Valéry le concedía a Baudelaire el rango de escritor clásico, pues "clásico es el escritor que lleva un crítico en sí mismo, y que lo asocia íntimamente a su trabajo." (Ibid., p. 266)

${ }^{439}$ Baudelaire había señalado a propósito del personaje Madame Bovary que "todas las mujeres intelectuales le agradecerán el haber elevado la hembra a tan alta potencia, tan lejos del animal puro y tan cerca del hombre ideal, y el haberla hecho participar de ese doble carácter de cálculo y de ensueño que constituye el ser perfecto." (Charles Baudelaire: "Madame Bovary de Gustave Flaubert” en Obras, op.cit., p. 818)

${ }^{440}$ Paul Valéry: "Las ideas de Edgar Poe”, en VVAA: Matemática tiniebla ...op.cit., p. 225.

441 Paul Valéry: "Le decía yo a veces a Stéphane Mallarmé", en VVAA: Matemática tiniebla...op.cit., p. 321. La cita sigue: "Las obras que sólo proceden de él están curiosamente construidas con oro y con barro: detalles deslumbrantes, aunque recargados, el tiempo las disgrega pronto y arrastra la arcilla; de muchos poemas sólo quedan algunos versos." (Ibíd.)

${ }^{442}$ Mariano Picón Salas: "Paseo por nuestra poesía (1880-1940)”, en Viejos y nuevos...op.cit., p. 113. 
Además, siguiendo la división establecida por Nietzsche, el maestro de Sucre decía preferir la épica de hacedores como Homero que "gobiernan y embridan la poesía” a la lírica de quienes, como Arquíloco, "se dejan gobernar por ella como por desbocado caballo nocturno"443.

En línea con el ensayista merideño y con la tradición simbolista, Guillermo rechazaba la poesía que se entregaba exclusivamente a la inspiración y exigía que la creación poética estuviera templada por el rigor y la inteligencia. Cuando la poesía procedía del rapto o del impulso primario, el creador perdía el control sobre ella y esta ausencia de autocrítica llenaba la obra de desmesuras expresivas que le impedían entroncar con la verdadera tradición intelectual y con los valores universales del espíritu. Por eso Guillermo se opuso firmemente y denunció las creaciones venezolanas que carecían de rigor y que eran simple pasión desatada. Así, por ejemplo, en una afirmación no exenta de malicia sobre la joven poesía venezolana, el crítico señalaba que "le falta mayor lucidez: no sólo la emoción de lo real sino también de las ideas. Le sobra, por el contrario «instinto». Entre nosotros se tiende a creer que la literatura es sólo «instinto». Si así fuera cabría preguntarse por qué la venezolana no es una de las más importantes del mundo"444. Esta falta de autocrítica era la responsable, según Sucre, de que la UNESCO no hubiera sido capaz de formar en Venezuela un equipo de intelectuales para participar en el volumen América Latina en su literatura, que se publicaría en 1972. Nuestro autor declaraba al respecto:

Podemos lamentarlo, pero ello no debe asombrarnos. Estamos tan poseídos por el sagrado impulso de la creación (somos un país de intuitivos geniales), que parecería irrisorio distraerse en reflexiones (que además serán "subsidiarias") sobre nuestra literatura. Pero habría que preguntarse si ese extraordinario impulso creador nos ha llevado a escribir una gran literatura, y si justamente no ha sido la ausencia de un espíritu crítico lo que ha contribuido a mitificar valores que en otros países estarían ya reducidos a sus justas proporciones. ${ }^{445}$

\footnotetext{
${ }^{443}$ Mariano Picón Salas: "Lugones, un gran argentino", en Viejos y nuevos...op.cit., p. 309.

${ }^{444}$ Guillermo Sucre: "Nuestra joven poesía", en Zona Franca, Caracas, núm. 33, may. 66, pp. $36-37$.

445 Guillermo Sucre: "Lo precario de nuestra crítica", en Imagen, Caracas, editorial núm. 28, $1 / 15$ jul. 68 , p. 2 . Como contraparte de estas actitudes perniciosas, Sucre valoraba positivamente la obra
} 
Ante la ausencia de crítica y de reflexión que advertía en la literatura nacional, Guillermo reclamaba la necesidad de armonizar la pasión con el rigor. Con ello, el crítico quería desterrar la tendencia hispanoamericana a la creación instintiva o "natural" que conducía a una escritura desmesurada, y además impulsar un ideal de orden y saturación que promovería obras de validez universal. A este respecto es esclarecedora la distinción que Sucre establecía entre los autores inspirados y los rigurosos:

Hay poetas en quienes la inspiración es una suerte de flujo que va configurando, casi en el vacío, la propia expresión. En ellos el azar mismo se convierte en un absoluto y no hay otro límite que el desencadenamiento, la acumulación continua; el poema, con frecuencia, queda abierto a muchas posibilidades. Fombona Pachano no pertenece a este linaje de poetas. Sin ajustarse a normas o a ideas preestablecidas, su inspiración se ve configurada, sin embargo, desde adentro, una permanente vigilia va rigiendo su lenguaje. Su instinto estético se ejerce por exclusión y no por superposiciones. Sus imágenes parecen, así, como el resultado de una sutil imposición del espíritu, más fuerte que toda capacidad de rechazo o de simple selección. El poema llega a ser un mundo cerrado, total. Es decir, que en Fombona Pachano se manifiesta únicamente el resultado de una confrontación que se ha realizado adentro. Se produce, si se quiere, una verdadera cristalización. En los poetas anteriores [los del otro grupo] se manifiesta no sólo el resultado, sino todo el proceso que lo ha gestado, con sus más extrañas "adherencias". 446

Frente a la profusión de lo accesorio que advertía en los poetas que se confiaban

a las musas, Guillermo ponía de manifiesto que la poesía de este autor venezolano

llegaba a ser "un mundo cerrado, total”, es decir, un cuerpo armónico y sin desmesuras.

En la poesía de Juan Liscano, un escritor todavía estimado por nuestro autor en esta

época, el crítico advertía una conciliación de los excesos expresivos que procedía de una

unión conveniente entre el instinto y la reflexión:

Ni poeta puro ni enajenado por irracionalismos a la moda, ha conservado siempre, dentro de su propio arrebato, cierta lucidez en que se armonizan la inteligencia y el ímpetu elemental. Su poesía tiene la densidad, la materialidad y aun la exuberancia propias a una forma americana de expresión; pero todo ello está sustentado por un indudable rigor, por una sensibilidad despierta que busca el sentido de las cosas. Poeta elemental y poeta reflexivo.

de autores como Pedro Grases, que "es el mejor testimonio de que nada en la cultura es el producto de la improvisación. Contra esa tendencia nuestra a la «genialidad» (que, en fin de cuentas no es más que ignorancia), este trabajador fervoroso, ha opuesto el sentido del rigor." (Guillermo Sucre: "La discreta pasión de un bibliógrafo", Imagen, Caracas, editorial núm. 25, 15/30 may. 68, s/p.)

${ }^{446}$ Guillermo Sucre: “Introducción” a Jacinto Fombona: Poesías, op.cit., p. 14. 
Pocos, en la poesía venezolana y aún en la hispanoamericana, los que pueden conciliar tales actitudes. $^{447}$

En lo que concierne a los poetas continentales, Guillermo destacaba igualmente aquellas obras en que se producía una conciliación adecuada entre el rigor y la sensibilidad. A este respecto, Sucre valoraba a Rubén Darío -a quien consideraba además el iniciador de la poesía moderna en el continente- porque la creación literaria "no se redujo en él a un puro instinto; la concibió y la realizó, en sus mejores momentos, como un sistema de secretas referencias, como un acto cultural. [...] Para fortuna de la poesía en lengua española, Darío cortó de lleno con la tendencia puramente espontánea y sentimental de su tiempo, con el exceso de «inspiración»"448. En consonancia con esta lectura Guillermo creía que era preciso apreciar la obra del nicaragüense en la tradición simbolista -que para él constituía el verdadero canon de la literatura universal- y no, como se había hecho convencionalmente, en la parnasiana:

La renovación poética que implica Darío es un hecho que se impone más allá de su propio manierismo. Pero hay en esa renovación una zona que nos parece ser la más esencial: la relación mágica con la palabra y con el universo. En otros términos, habría que precisar lo que hay en Darío de poeta simbolista. Lo que supondría a la vez una nueva ubicación de Darío con respecto a esa poesía francesa con la que tanto se le relaciona: más cercanía con Baudelaire, Nerval y aun Mallarmé; más distancia con Verlaine, Gautier y Banville. ${ }^{449}$

Sucre advertía este mismo acuerdo entre pasión y reflexión en las obras de Borges y de Paz, dos de los creadores que, a partir de este momento, se convertirán en

${ }^{447}$ Guillermo Sucre: "Un poeta elemental y reflexivo”, en Sur, Buenos Aires, núm. 283, jul-ago. 63, p. 35. Esto es lo que el crítico advertía también en Gonzalo Rojas: "Poesía desencadenada, seducida por una inspiración planetaria, pero al mismo tiempo regida por el rigor de la aspereza y de la inclemencia, en ella la imaginación se ha cargado de una dura y honda realidad. Es una poesía llena de mundo. Contrasta, por ello, con otra poesía hispanoamericana donde el verbalismo y la simple imaginería no hacen sino delatar una cierta vaguedad interior, una carencia de realidad." (Guillermo Sucre: "Una poesía sin mitos", en Zona Franca, Caracas, núm. 12, 15/28 feb. 65, pp. 12-13)

${ }^{448}$ Guillermo Sucre: "Relectura de Darío", en Revista de Occidente, Madrid, núm. 61, abr. 68, pp. 46-68, p. 47. "Como buen simbolista, creía que el universo es una suerte de código por descifrar («toda forma es un gesto, una cifra, un enigma»). Como buen poeta, sentía el lenguaje como algo más que un simple instrumento: como signo de una revelación («cada palabra tiene un alma»). Por ello su poesía es canto y danza [...], pero también reflexión y lucidez («la música es solo de la idea, muchas veces»).” (Ibid., p. 47)

449 Ibíd., p. 53. Guillermo vincula también a Fombona con la estética simbolista: "esa suerte de estética de lo callado, de lo no dicho y, sin embargo, significativo, es uno de los más característicos en la obra de Fombona Pachano, y lo aproxima de manera sorprendente a la tradición de los mejores poetas simbolistas." (Guillermo Sucre: "Introducción” a Jacinto Fombona: Poesías, op.cit., p. 15) 
referencias permanentes de su pensamiento. A propósito del escritor porteño, del que tomó el nombre del artículo que da título a este apartado, el crítico afirmaba que "su poesía está hecha de esa pasión; pero está hecha igualmente de lucidez. Ambas se oponen y se trascienden incesantemente la una en la otra"450. Asimismo, en un ensayo dedicado al gran poeta mexicano, nuestro autor señalaba que tanto él como el argentino rompieron "con una agobiante tradición que parecía condenarnos al puro instinto de la emoción. En Borges y en Paz ese instinto se ve transfigurado y enriquecido por la inteligencia. Ambos se mueven, por ello, en distintos planos: el pensamiento y la imaginación establecen sus «vasos comunicantes». El ejercicio del primero prolonga la experiencia y la búsqueda de la segunda"451.

Ahora bien, como hemos afirmado antes, lo que estaba en juego en esta conciliación de los opuestos entre los que se debate la conciencia del creador moderno era la búsqueda del absoluto que la modernidad había desintegrado. Al dar con una expresión mesurada y sin excesos, los poetas eran capaces de armonizar las desmesuras éticas y estéticas y de comunicar, a través de la escritura, la integridad del ser. Esto es precisamente lo que Sucre destacaba a propósito del lenguaje poético de Saint-John Perse, un autor al que Guillermo había leído y traducido desde finales de los años 50: "Material y abstracto a la vez, abarca todos los registros de la expresión. Encantamiento y profecía, su misión ha sido la de darnos la medida de la plenitud del hombre" ${ }^{452}$. Al establecer una comunión entre las potencias contrarias del hombre -la sensibilidad y la inteligencia, el sueño y la vigilia, etc.- el poeta moderno conseguía reunificar su

${ }^{450}$ Guillermo Sucre: Borges, el poeta, op.cit., p. 79. La cita sigue: "El temple poético borgiano resulta de esa tensa combinación. "Álgebra y fuego" le fueron dados en el poema "Mateo, XXV, 30". Jorge Luis Borges afirma en ese poema que "álgebra y fuego" le fueron dados, "y también/ el antiguo alimento de los héroes:/ la falsía, la derrota, la humillación.” (Jorge Luis Borges: "Mateo, 25, 30", en El otro, el mismo, OOCC, Vol. I, op.cit., p. 874)

${ }^{451}$ Guillermo Sucre: "El diálogo con el mundo", loc.cit.

452 Guillermo Sucre: "Honrar al mundo con la escritura”, loc.cit. La cita continúa: “[...]. Y a través de la escritura, honrar el mundo, o salvar la distancia, como él mismo lo expresa, «que dejamos crecer entre el hombre temporal y el hombre intemporal»." (Ibíd.) 
integridad olvidada y, al mismo tiempo, agrupar la experiencia escindida del hombre, es decir, establecer una continuidad entre el sujeto y el objeto, entre el ser y el estar. En un fragmento de su "Relectura de Darío", en el que es evidente el rastro de la teoría de Paz sobre el ritmo en la poesía, el propio Sucre afirmaba lo siguiente:

Porque el hombre es múltiple y contradictorio en su naturaleza misma, es por lo que siente nostalgia de la unidad. Esa nostalgia se realiza a través del ritmo. Ritmo es fusión de contrarios, armonización de opuestos. La unidad a que tiende Darío no es conceptual, sino vital. Hay un ritmo del individuo: integración del cuerpo con el alma. Hay también un ritmo universal: la subordinación de la unidad individual a la del cosmos. [...] Unión de contrarios, paso de lo individual a la totalidad ${ }^{453}$

Según esta cita, el poeta moderno tiende a integrar su naturaleza escindida, pero realiza esto en un doble plano: al fundir las potencias opuestas que pugnan por el control de su conciencia -el cuerpo y el alma, en este ejemplo- es capaz de establecer la comunión del individuo con el cosmos y devolver al hombre la plenitud olvidada. De este modo, la conciliación entre la pasión y la inteligencia a la que tiende la creación moderna supone restablecer la continuidad entre la subjetividad y la objetividad, lo que permite a su vez operar el paso de lo anecdótico a lo trascendente. Al conciliar el instinto y la reflexión el escritor moderno encuentra su verdadero rostro, ese que comparte con los demás hombres, así como la genuina faz del mundo: su pureza original. La personalidad del creador transfigura lo real y revela entonces la verdad del hombre y del mundo.

En muchos de los autores que estudia a lo largo de este periodo, Sucre destacaba la capacidad para establecer una continuidad entre la subjetividad y la objetividad y llevar a cabo así la elevación de lo particular a lo universal ${ }^{454}$. Guillermo valoraba en

${ }^{453}$ Guillermo Sucre: "Relectura de Darío", loc.cit., p. 59. Octavio Paz expone su teoría sobre el ritmo en la poesía en El arco y la lira, en OOCC, Vol I, op.cit., pp. 82 y ss.

${ }^{454}$ Como afirmaba a propósito de un grupo de jóvenes narradores venezolanos: "en todos estos relatos [de Edrás Parra, José Balza, David Alizo, Francisco Massiani, etc.] la distancia entre la cosa narrada y el narrador se acorta sensiblemente e, insensiblemente, entramos en un juego de espejos donde se diluye toda objetividad y toda subjetividad. El escritor narra, pero es también personaje; propone una ficción que es su única realidad. De este modo, nos da no sólo una visión más compleja y dinámica del mundo real; su verdadero rostro se va perfilando igualmente dentro de esa visión." (Guillermo Sucre: "En la línea más cercana", loc.cit.) 
ellos su gran "capacidad de fabulación”, es decir, su habilidad para conferir a lo real una dimensión mítica capaz de elevar lo banal a lo trascendente. Para que esto fuera posible era imprescindible que estos creadores hubieran sido capaces de armonizar en su expresión los contrarios de la pasión y de la inteligencia y, por lo tanto, que hubieran desterrado de ella los excesos de cosas y de palabras. Sólo tras esa depuración los autores estarían en una situación propicia para establecer a través de su escritura una continuidad entre el mundo interior y el exterior y operar así la transmutación de lo real que es propia del arte. En verdad, esta teoría cancelaba la división entre lo interno y lo externo y, por lo tanto, concedía a la palabra poética la condición de fundadora de lo real. A este respecto, es evidente que Guillermo había recibido el influjo de las ideas de Octavio Paz sobre la imagen poética. El escritor mexicano había señalado que el lenguaje poético tiende a suprimir la distancia entre las palabras y las cosas -distancia que es la condición de posibilidad del lenguaje- y que esa supresión se produce gracias a la imagen:

el lenguaje es sentido de esto o aquello. El sentido es el nexo entre el nombre y aquello que nombramos. Así, implica distancia entre uno y otro. [...] Con la imagen sucede lo contrario. Lejos de agrandarse, la distancia entre la palabra y la cosa se acorta o desaparece del todo: el nombre y lo nombrado son ya lo mismo. El sentido - en la medida en que es nexo o puentetambién desparece: no hay nada ya que asir, nada que señalar. ${ }^{455}$

Y ejemplificaba su concepción con el siguiente paradigma:

En el poema la silla es una presencia instantánea y total, que hiere de golpe nuestra atención. El poeta no describe la silla: nos la pone enfrente. Como en el momento de la percepción, la silla se nos da con todas sus contrarias cualidades y, en la cúspide, el significado. Así, la imagen reproduce el momento de la percepción y constriñe al lector a suscitar dentro de sí al objeto un día percibido. El verso, la frase-ritmo, evoca, resucita, despierta, recrea. O como decía Machado: no representa, sino presenta. Recrea, revive nuestra experiencia de lo real. ${ }^{456}$

En efecto, este poder mágico que Paz concedía al lenguaje poético implicaba que para él la poesía no era una mera copia de lo real, sino su invención misma.

${ }^{455}$ Octavio Paz: El arco y la lira, en OOCC, Vol. I, op.cit., p. 153. Había señalado también: “por obra de la imagen se produce la instantánea reconciliación entre el nombre y el objeto, entre la representación y la realidad. Por tanto, el acuerdo entre el sujeto y el objeto se da con cierta plenitud. Ese acuerdo sería imposible si el poeta no usase del lenguaje y si ese lenguaje, por virtud de la imagen, no recobrase su riqueza original." (Ibid., p. 150)

${ }^{456}$ Ibid., p. 149. 
Siguiendo en este aspecto a Heidegger ${ }^{457}$, el escritor mexicano pensaba que el lenguaje permitía fundar lo real mismo y, además, que lo instituía como de verdad es: “el acto mediante el cual el hombre se funda y revela a sí mismo es la poesía. [...] La poesía nos abre la posibilidad de ser que entraña todo nacer; recrea al hombre y lo hace asumir su condición verdadera" ${ }^{458}$. Este género literario deviene entonces un medio privilegiado para que el hombre recupere su plenitud perdida, es decir, para anular la distancia entre el sujeto y el objeto y lograr, por fin, que hablar sea hacer. Antes que Paz, Valéry había insistido también en el origen mágico de la palabra poética y había afirmado a propósito de Mallarmé que "el arte implica y exige una equivalencia y un intercambio perpetuamente ejercido entre la forma y el fondo, entre el sonido y el sentido, entre el acto y la materia. La modificación y, a veces, la invención del acto por la materia" ${ }^{459}$. En el ámbito venezolano, el filólogo Ángel Rosenblat, profesor y amigo personal de Guillermo, había tratado este tema en un volumen de ensayos que había sido reseñado por nuestro autor para Zona Franca ${ }^{460}$. En ese libro, titulado Primera visión de América y otros ensayos (1965) el erudito incluía el ensayo "Sentido mágico de la palabra”, en el

${ }^{457}$ Vid. Martin Heidegger: "El origen de la obra de arte", en Arte y poesía, México, FCE, $2^{\mathrm{a}}$ ed., 2006, pp. 29-91.

${ }^{458}$ Octavio Paz: El arco y la lira, en OOCC, Vol. I, op.cit., p. 201. Como expone en un ensayo que fue importante para Guillermo Sucre, la literatura hispanoamericana era esencialmente una literatura de fundación: "Nuestra literatura es la respuesta de la realidad real de los americanos a la realidad utópica de América." Ante el determinismo que habían resultado de la mirada europea, Paz proponía que "la literatura hispanoamericana es una empresa de la imaginación. Nos proponemos inventar nuestra propia realidad [...] ¿Inventar la realidad o rescatarla? Ambas cosas. La realidad se reconoce en las imaginaciones de los poetas; y los poetas reconocen sus imágenes en la realidad. Nuestros sueños nos esperan a la vuelta de la esquina. Desarraigada y cosmopolita, la literatura hispanoamericana es regreso y búsqueda de una tradición. Al buscarla, la inventa. Pero invención y descubrimiento no son los términos que convienen a sus creaciones más puras. Voluntad de encarnación, literatura de fundación." A decir de Sucre, en ese ensayo, Paz afirmaba que "toda la literatura americana, en sus obras más significativas, ha sido creación verbal, invención que se trasciende a sí misma y funda una realidad. El escritor americano no ha descubierto, en propiedad, nada; lo ha inventado todo, lo ha fundado." (Octavio Paz: "Literatura de fundación”, en OOCC, Vol. II, op.cit., pp. 672-680. Este texto se escribió en 1961 y se publicó en Puertas al campo, 1966, p. 674. Un comentario de Sucre sobre este ensayo de Paz se puede consultar en Guillermo Sucre: "Les lettres nouvelles: Nouveaux Ecrivains de l'Amérique Latine", en Revista Nacional de Cultura, Caracas, núm. 148-149, sep.-dic. 61, pp. 254-256)

459 Paul Valéry: "Mallarmé”, en VVAA: Matemática tiniebla ...op.cit., p. 332.

${ }^{460}$ Para la lectura de nuestro autor vid. Guillermo Sucre: "En la magia del lenguaje", en Zona Franca, Caracas, núm. 30, feb. 66, pp. 16-18. 
que reivindicaba el potencial alquímico del lenguaje como una vía para purificarlo. El ensayo comenzaba así:

Asistimos hoy a tal profanación de la palabra, que parece justificada la frase atribuida a Talleyrand: "El lenguaje le ha sido dado al hombre para que pueda ocultar el pensamiento". Y llega a tales extremos la dilapidación de la palabra hablada y escrita, que a cada paso se recuerda la variante de Kierkegaard: "La gente se sirve a menudo del lenguaje para ocultar que carece de pensamiento". Vamos a evocar los tiempos en que la palabra era materia sagrada. ${ }^{461}$

El filólogo pensaba que si las palabras recuperaban su capacidad de encarnar lo real, el idioma quedaría libre de falsedades e inexactitudes, concepción que implicaba como veremos todo un ideal político y social ${ }^{462}$.

\section{3. LA PLENITUD DEL MUNDO INFANTIL}

Esta capacidad para conciliar la mirada y la escritura y fundar lo real mismo a través del lenguaje era precisamente lo que Sucre reivindicaba en aquellos poetas que habían conseguido erigir un mundo de plenitud a través de sus obras. Entre ellos ocupaban un lugar privilegiado aquellos que habían evocado el mundo original e inocente de la infancia, por el que nuestro autor sentía una predilección especial. En este sentido, Sucre estaba proyectando su propio criterio estético, pues como lo reconoció en una entrevista reciente y como es patente en su obra poética, nuestro autor ha conservado "un amor por el amor o por la felicidad que sólo se tiene en la infancia"463 y ha vivido siempre la memoria y el pasado de una forma muy intensa. De estos autores lo que le interesaba a Guillermo no era la rememoración de la puericia "al nivel de la madurez sino al nivel de lo que es esencial a la infancia misma: su inocencia fabuladora,

461 Ángel Rosenblat: "Sentido mágico de la palabra", en La primera visión de América...op.cit., pp. $65-101$, p. 67.

${ }_{462}$ Para la dimensión política de la concepción del lenguaje de Rosenblat se pueden consultar infra las pp. 210 y ss.

${ }^{463}$ La cita completa dice así: "Conservo un amor por el amor o por la felicidad que sólo se tiene en la infancia. Y, claro, por eso el pasado y la memoria son tan intensos en mí." (Guillermo Sucre: "Entrevista por escrito, octubre de 2011", infra en Apéndice I, p. 469). El fragmento in extenso está citado supra en p. 12. 
su capacidad mítica"464. Como dice en su ensayo sobre Fombona Pachano, Sucre no sentía especial predilección por aquellos poemas "en que un adulto se acerca a lo infantil y lo recrea" sino por esos otros "en que lo infantil irradia como una actitud, como una manera de ser, como un modo de reflejar el mundo"465. Al introducirse en esa etapa de la vida, los poetas recobran un "espacio de gracia original" través de una mirada pura, "un tiempo mítico y como paradisíaco"467. Con respecto a esta recreación maravillosa del mundo infantil, Guillermo tenía como referencia fundamental Le Grand Meaulnes (1913) de Alain Fournier, novela que le había marcado en su juventud de una manera decisiva. Esta obra -según nos dice el propio Sucre en la edición que "Letras y Artes” le dedicó al autor francés-

es el mito de la juventud y del amor, o en otras palabras: el mito de la pureza integral del Ser. No sólo integral, también radical: esa pureza se proyecta como un absoluto, como un imposible. Descubrir o lograr poseer esa pureza produce tal plenitud y tal espanto a la vez que hay que renunciar a ella. [...] Pero esa renuncia implica al mismo tiempo un exilio, un sentimiento de nostalgia: se vive en el mundo proyectándose siempre hacia el pasado, sintiendo desdén por la realidad cotidiana. En ese exilio, en esa nostalgia, sin embargo, hay como una suprema alegría, como una purificación. ${ }^{468}$

Esta plenitud se vuelve posible en la novela porque en ella se establece una comunión entre la pasión y la inteligencia y entre lo interior y lo exterior. En ella, según nos dice Sucre, "el arte y la espontaneidad," "el sueño y la realidad, lo imaginario y lo simplemente ocurrido se integran y trascienden sin cesar" ${ }^{\text {"469 }}$. Ello había permitido que

\footnotetext{
${ }^{464}$ Guillermo Sucre: "En el resplandor de la infancia", en Zona Franca, Caracas, núm. 28, dic. 65 , pp. 38-39.

${ }^{465}$ Guillermo Sucre: "Introducción” a Jacinto Fombona: Poesías, op cit., p. 28

${ }^{466}$ Guillermo Sucre: "En el resplandor de la infancia", loc.cit.

${ }^{467}$ Sucre toma esta idea del psicoanálisis: "Este paraíso perdido es para Vallejo, por supuesto, la infancia. El psicoanálisis ha demostrado que el niño vive siempre en un tiempo mítico y como paradisíaco. Pero además, como dice Mircea Eliade, es por ello por lo que el inconsciente tiene el carácter de una mitología personal: a través de él el hombre entra en contacto con lo cósmico. Cargada de tanta energía inconsciente, la poesía de Vallejo es retorno a un tiempo original (representado en la infancia) e igualmente apertura a un tiempo cósmico que, como lo veremos, encarnará en el futuro, en la utopía revolucionaria." (Guillermo Sucre: "Vallejo: la nostalgia de la inocencia", en Imagen, Caracas, Supl. núm. 23, 15/30 abril 68, s/p.) Con respecto a esta proyección simbólica de lo imaginario Sucre coincide también con Gaston Bachelard, al que cita en varias ocasiones a lo largo de La máscara, la transparencia.

${ }^{468}$ Guillermo Sucre: “Alain Fournier: Una pasión de absoluto”, en La República, Caracas, 24-1163, p. 7. ${ }^{469}$ Ibid.
} 
la realidad exterior se transmutara "en la corriente profunda del espíritu de Fournier" y que perteneciera ya "a sus sueños, a sus laberintos interiores"

En varias de las críticas que escribió en este periodo, en particular en las dedicadas a Elizabeth Schön, Jacinto Fombona y César Vallejo, Sucre ponía de relieve el hallazgo de un reino de inocencia original vinculado a la vivencia de la niñez y al ejercicio de la memoria. Al recuperar el absoluto de la puericia a través de la imaginación, estos poetas creaban una "atmósfera poética"471, es decir, que erigían un espacio simbólico que aspiraba a ser temporalidad pura y a integrar los contrarios entre los que el hombre se debate, permitiendo así su acceso a un dominio de plenitud. Así, por ejemplo, en el libro El abuelo, la cesta y el mar (1965) la autora venezolana Elizabeth Schön transfiguraba la experiencia "en una trama de símbolos" y conseguía restituir "un espacio puro donde no existe el tiempo"472. En este poemario, la poetisa "no ha rehecho su infancia, sino que la ha rescatado: el producto es un mundo en el que el asombro se vuelve lucidez, la perplejidad se trueca en conocimiento. Su libro es, así, un aprendizaje, la búsqueda de un estado de gracia original”, ${ }^{, 43}$. Asimismo, la poesía de Fombona Pachano, a decir de Guillermo, "es la infancia misma que se asume como nostalgia, pero a la vez como presencia plena. [...] Paraíso siempre rescatado, la infancia lo domina con inquebrantable, compacto y más bien renovado esplendor. Su nostalgia, por ello, no es desgarramiento, ni sentimiento dramático ante lo perdido, sino fabulación mítica, serena y reconfortante afirmación" ${ }^{\text {474 }}$. En la lectura que hace sobre la obra de Vallejo en esta época, el crítico concedía un lugar fundamental a "la nostalgia

${ }^{470}$ Ibíd. En el mismo artículo Guillermo concluía que "acaso el impacto más poderoso que ejerce sobre el lector al concluir su lectura sea el de suscitar la misma reflexión que hace Meaulnes cuando cree perdido ya para siempre su Dominio maravilloso: «Pero cuando un hombre ha vislumbrado una vez el Paraíso, ¿cómo puede luego conformarse con la vida de los demás?»"

${ }^{471}$ Guillermo Sucre: "En el resplandor de la infancia", loc. cit.

${ }^{472}$ Ibid.

${ }^{473}$ Guillermo Sucre: "En el resplandor de la infancia", loc. cit.

474 Guillermo Sucre: "Introducción" a Jacinto Fombona: Poesías, op.cit., p. 26. La cursiva corresponde a la negrita del original. 
de la inocencia”, es decir, a la añoranza que el poeta peruano sentía por el pasado familiar y por la plenitud a él vinculada. La continuidad de la vida de Vallejo, decía el crítico,

está fundada en una búsqueda: de lo anterior, de su vida pasada, de su paraíso perdido. [...] Y toda búsqueda de este tipo se ejerce a través de la memoria. El paraíso perdido es evocado inicialmente en Los heraldos negros (1918). Evocado, Vallejo se siente ausente de él: es el mundo del hogar, no sólo el familiar sino también, por decirlo así, el racial [...]. Esta evocación lo purifica sin embargo [...]. El contacto es doloroso y pleno a la vez; doloroso: ese mundo se le desvanece; pleno: su imagen aun desvanecida es la posibilidad de reencuentro con lo original y lo puro, con el orden de la inocencia. ${ }^{475}$

Como hemos visto antes, para recrear el mundo pleno vinculado con la infancia y lograr una continuidad entre la mirada primigenia y la escritura que debía revelarla, estos poetas debían conciliar los excesos éticos y estéticos. Al crear un espacio simbólico donde sólo se despliega la visión poética, estos tres poetas cancelaban toda separación entre la expresión y lo expresado y conseguían, como quería Paz, fundar lo real mismo a través de la escritura. Las huellas de la teoría paciana de la imagen poética se advierten en este comentario sobre el lenguaje de Fombona Pachano, un poeta que según nos dice Sucre,

Ve lo real en su elementalidad, y lo nombra. De ese nombrarlo surge lo real mismo. Y surge porque la palabra no es asumida como concepto, sino vivida como imagen. [...] No es la palabra la que se vuelca sobre el mundo; al contrario, de la palabra, del poema va a nacer un mundo. Es decir, no es que la palabra reemplace a la realidad; para el poeta, ella es la realidad: más aún, es la fuerza, el soplo que la crea y le da forma. Sólo que, por ser creada, esta realidad trasciende todo espacio y todo tiempo: vive en la imaginación, con un vivir que únicamente tiene sentido para el hombre y que, acaso por ello mismo, es un vivir más puro, más plano, más libre. [...] De modo que ésta [la palabra] llega a ser invención pura que el espíritu se propone a sí mismo en la búsqueda de la totalidad de lo real. ${ }^{476}$

Igualmente, si bien la poesía de Rubén Darío no está directamente relacionada con la vivencia de lo infantil, Sucre advertía en ella una voluntad de recobrar la "plenitud del mundo", "una suerte de armonía original y casi paradisíaca". Para evocar esa integridad, el poeta nicaragüense cree "en la virtualidad de todo lo que su imaginación construye y vislumbra": por eso "en pocos poetas como él la palabra ha

\footnotetext{
${ }^{475}$ Guillermo Sucre: "Vallejo: la nostalgia de la inocencia", loc.cit.

476 Guillermo Sucre: "Introducción” a Jacinto Fombona: Poesías, op.cit., p. 23. Las cursivas corresponden a la negrita del original.
} 
tenido tanta fuerza de fundación" ${ }^{\natural 77}$. Asimismo, a propósito de la obra de Perse -que a decir de Sucre era "un inmenso y luminoso elogio del mundo" $" 478$ - nuestro autor destacaba que

el arte se nos presenta como una operación mágica: la imagen sustituye al objeto y éste sometido a sucesivas situaciones se metamorfosea hasta que surge el verdadero milagro: la "unidad recobrada bajo la diversidad". Inmersión en lo real, abstracción, mutaciones, rapto: el arte, para Perse, está sometido a la fuerza de la imaginación. Por ello cumple una doble función: es alquimia y es conocimiento. Gracias a esas mismas analogías y correspondencias, conquista la totalidad: la relación de lo visible y lo invisible, de la materia y el espíritu. Es así como, para Perse, "el poeta nos enlaza con la permanencia y unidad del ser". ${ }^{479}$

Al conciliar la expresión y lo expresado o lo interior y lo exterior, y conferir una dimensión mítica a su escritura, todos estos creadores quedaban libres de las desmesuras realistas y formalistas que impedían alcanzar una continuidad entre la visión y la creación. La fabulación imaginaria que estos poetas operaban recurriendo a la mirada infantil y al vigor de la memoria permitía establecer una continuidad entre el nombre y lo nombrado que liberaba a la literatura de las desproporciones expresivas que, en la noción de Sucre, volvían anacrónicas e impostadas muchas obras nacionales y continentales. Por eso lo que estaba en juego en el ajuste entre la mirada y la palabra era el mismo ideal de saturación que nuestro autor venía defendiendo ya desde la etapa anterior, pero expuesto ahora en nuevos términos: la visión debía coincidir con el lenguaje y, ambos, revelar la verdad original del hombre y del mundo. En base a este ideal, Guillermo concedía a la niñez - no como tema, sino como punto de vista- un papel determinante en la modernización de la literatura nacional, pues había conseguido liberarla de los fines extraliterarios y de los excesos de cosas y de palabras: "es posible considerar lo infantil como una de las maneras -la más maravillante tal vez- con que la poesía venezolana empieza a liberarse de su tradicional exceso retórico, de su rígida

${ }^{477}$ Guillermo Sucre: "Relectura de Darío", loc.cit., p. 63.

${ }^{478}$ Guillermo Sucre: "Honrar al mundo con la escritura", loc.cit. Asimismo, Sucre afirma que los poemas contenidos en Éloges (1911), el primer libro de Saint-John Perse, "revelaban la maravillosa y maravillada experiencia de una infancia vivida en medio de la naturaleza y el mar tropicales."

${ }^{479}$ Ibíd. 
formalidad y hasta de su precario «realismo» descriptivo"480. Al lograr una continuidad entre el enfoque y la expresión estos creadores restituían la totalidad del ser y presentaban lo real en su integridad.

En relación con esto hay que decir además que al rescatar poéticamente un reino o un espacio prístino los autores buscaban salvar la inocencia de un mundo que la había perdido. “¿No es evidente -se pregunta el propio Sucre- que a través de esa tentativa por salvar la infancia lo que se busca es transformar el mundo mismo?"481 Por eso, siguiendo al filósofo Merleau-Ponty, nuestro crítico afirmaba que aquellos poetas que concedían un lugar privilegiado a la infancia eran seres que

fascinados por su infancia, se ven como poseídos y encantados por ella dentro de un orden privilegiado e inalterable. Dominados de tal modo por esa fascinación, son seres que viven llenos de nostalgia, ausentes [...] del mundo, no incapaces sino radicalmente imposibilitados para aceptar la realidad o la historia, es decir, aspirando a detener el tiempo mismo. Seres memoriosos, en ellos el pasado quiere siempre actualizarse. ${ }^{482}$

Efectivamente, en estos creadores la recreación del mundo de la puericia era una vía para rescatar una experiencia original que permitiera trascender la degradación de la realidad y de la historia. En muchos de los autores que compartían la evocación de la infancia, Sucre advertía que esa rememoración funcionaba como "un poderoso refugio". Así, por ejemplo, en Fombona Pachano "el sentimiento de la infancia" "como fuerza fabuladora y como actitud ética" le permitió trascender "su propio desamparo"483 y vivir intensamente el presente. Igualmente, en la obra de César Vallejo el crítico destacaba la presencia de "diversos mundos, diversos yo":

${ }^{480}$ Guillermo Sucre: "Introducción” a Jacinto Fombona: Poesías, op.cit., p. 28. Picón Salas había señalado que la "magia del mundo infantil" era una de las características de la última poesía: "Ya sin conceptos, los poetas de hoy se sumergen en lo infantil como en una materia de colorido único, donde la palabra no tiene un sentido lógico, sino mágico." (Mariano Picón Salas: "Paseo por nuestra poesía (18801940)", en Viejos y nuevos...op.cit., p. 114)

${ }^{481}$ Guillermo Sucre: “Introducción”, a Jacinto Fombona; Poesías, op.cit., p. 30.

482 Ibíd., p. 26. El libro de Merleau-Ponty al que se refiere Sucre es Signes (1960). La cursiva corresponde a la negrita del original. Maurice Merleau-Ponty (1908-1961) fue un filósofo fenomenólogo francés, clasificado como existencialista por su cercanía con Sartre y de Beauvoir. Entre sus obras más importantes están La structure du comportement (1942), Fenomenologie de la perception (1945), Humanisme et terreur, essai sur le problème communiste (1947), Les aventures de la dialectique (1955) y Signes (1960).

${ }^{483}$ Ibid. 
Hay, por una parte, un yo original: el orden y a veces también la plenitud de la infancia y del hogar [...]; un universo donde todo es o podría ser reencuentro con lo absoluto. Hay también un yo existencial, en el que se está irremediablemente, y que en Vallejo asume los rasgos de una alienación frente a la vida y el mundo. ${ }^{484}$

Ante esta duplicidad, "la continuidad" de la vida del peruano "está fundada en una búsqueda: de lo anterior, de su vida pasada, de su paraíso perdido" pues, como matiza Guillermo, el mundo de su pasado familiar "es un presente vivo y victorioso contra el que no pueden ni el tiempo ni la muerte" ${ }^{\text {485 }}$. Asimismo, los poemas del venezolano Argenis Daza "se nutren de la polarización entre lo irreparable del tiempo y la fabulación mítica que trasciende toda desintegración. El tiempo vuelve irreales las experiencias de Daza, pero la imaginación las restituye al mundo"486.

En lo que respecta a esta cuestión de la temporalidad se aprecian de nuevo nexos evidentes entre el pensamiento de Sucre y la teoría poética de Octavio Paz. En este párrafo extraído del estudio sobre Fombona Pachano, Guillermo relacionaba la plenitud imaginaria que logra el poeta con la anulación del transcurso temporal y en él es evidente, tanto por las ideas como por el estilo, el poso de la lectura del escritor mexicano:

De esta memoriosa plenitud se deriva igualmente una visión privilegiada del tiempo. Para el poeta ya no hay paso del minuto, no hay tiempo que mude, hoy es ayer y mañana es hoy [...]. El tiempo ya no es cronología, sino acendrado equilibrio, clarividencia, éxtasis donde cada instante se eterniza por la propia intensidad que encierre. Aquella gloria de un minuto, que exaltaba el poeta, viene a confundirse con la eternidad: ésta no es sino el vislumbrar, por fugaz que sea, de un absoluto. Pero el poder de la memoria es todavía más integral: actúa como un eterno retorno. [...] Y es poseído por esta imagen del retorno incesante como el poeta comprende, en intuición culminante, que en el destino del hombre todo es presencia viva $y$ volverá. ${ }^{487}$

En El arco y la lira, Paz había indicado que "como en el mito, en el poema el tiempo cotidiano sufre una transmutación: deja de ser sucesión homogénea y vacía para

\footnotetext{
${ }^{484}$ Guillermo Sucre: "Vallejo: la nostalgia de la inocencia", loc.cit. La cursiva corresponde a la negrita del original.

${ }^{485}$ Ibíd.

486 Guillermo Sucre: "Nuevos poetas venezolanos”, en Mundo Nuevo, París, núm. 19, ene. 68, pp. 21-23.

${ }^{487}$ Guillermo Sucre: "Introducción” a Jacinto Fombona: Poesías, op.cit., p. 57. Las cursivas se corresponden con la negrita del original.
} 
convertirse en ritmo" 488 , y había afirmado asimismo que "la poesía no nos da la vida eterna, sino que nos hace vislumbrar aquello que llamaba Nietzsche «la vivacidad incomparable de la vida»" "489. También para Sucre, en el espacio fabuloso recreado por el poema se alcanza una presencia plena y cada instante se confunde con la eternidad.

Como se dice en "Álgebra y fuego", una vez separado de la inspiración, el poeta debía asumir la total responsabilidad ante su creación y emplear todos los medios disponibles para establecer un orden a partir del desorden y crear una plenitud con el desacomodo como materia prima. A través de la recreación de la mirada infantil y, en general, de la evocación de lo que Sucre llama "la verdadera realidad del mundo", el creador moderno lograba establecer una armonía entre el fuego y el álgebra y entre el sujeto y el objeto y alcanzaba así el absoluto desintegrado por la modernidad. Ahora bien, Guillermo no se llevaba a engaño y sabía perfectamente que la solución que los poetas ofrecían a la desintegración de la experiencia que tiene lugar en los tiempos modernos era solo un recurso imaginario. La dimensión del absoluto que la poesía moderna se impone obtener determina que éste concluya siempre en los más rotundos fracasos, fracasos que constituyen sin embargo el corpus mismo de la literatura moderna. Para nuestro autor esta literatura oscila entre la "ambición desmesurada" de conciliar los contrarios entre los que el hombre se debate y "el desengaño lúcido"490 en

${ }^{488}$ Octavio Paz: El arco y la lira, en OOCC, Vol. I, op.cit., p. 97.

489 Ibid., p. 200.

${ }^{490}$ Rodrigo Antúnez [Guillermo Sucre]: "Literatura crítica", loc.cit. Como afirma en "Álgebra y fuego", la poesía moderna para Sucre está "templada tanto en el orgullo como en la humildad", pues procede de una experiencia escindida $\mathrm{y}$, aunque supone una promesa de plenitud, siempre acaba fracasando. (Guillermo Sucre: "Álgebra y fuego", loc.cit.) Las nociones de orgullo y humildad proceden de Valéry, para quien el orgullo es sinónimo de rigor: "El amor, el odio, la envidia son luces del espíritu; pero el orgullo es la más pura. Ha iluminado a los hombres en todo lo más difícil y lo más bello que tenían que hacer. Consume las pequeñeces y simplifica a la propia persona. La separa de las vanidades, porque el orgullo es a las vanidades lo que la fe a las supersticiones." (Paul Valéry: "Stéphane Mallarmé", en VVAA: Matemática tiniebla...op.cit., p. 330) Esta duplicidad que Sucre establece entre el orgullo y la humildad o entre la ambición y el desengaño, es paralela a la que Octavio Paz propondrá más tarde para la poesía moderna entre analogía e ironía: "Para todos los fundadores [de la poesía moderna] Wordsworth, Coleridge, Hölderlin, Jean-Paul, Novalis, Hugo, Nerval- la poesía es la palabra del tiempo sin fechas. Palabra del principio: palabra de fundación. Pero también palabra de desintegración: ruptura 
que concluyen estos intentos: "la totalidad-dice Sucre- resulta un fin que no se alcanza, pero que precisamente por ello despierta en el espíritu todas sus potencias, sus energías olvidadas"491. El crítico advertía paradigmáticamente en Borges esta situación contradictoria del escritor moderno pues el creador argentino buscaba "lo inaccesible" sabiendo "de antemano" que era "imposible" de alcanzar, por lo que "su fracaso" "implica cierto modo de afirmación" ${ }^{492}$. La literatura moderna para Sucre se ve marcada por esta ambivalencia: por una parte, quiere conciliar los contrarios y alcanzar el absoluto disuelto por la modernidad; por otra, sabe que esta conciliación es finalmente imposible. Y lo es porque el lenguaje depende de la distancia que se establece entre la palabra y el mundo o, lo que es lo mismo, porque siempre hay una separación entre la obra y la realidad que vuelve inanes todos los consuelos imaginarios. Como lo dice memorablemente el autor al que acabamos de referirnos: "el mundo, desgraciadamente, es real; yo, desgraciadamente, soy Borges"493.

\section{4. GUILLERMO SUCRE Y LA ESTÉTICA DE MODERNIDAD}

A partir del momento en que asumió la dirección de la revista Imagen, Guillermo Sucre comenzó a defender con intensidad una concepción moderna de la literatura. Los teóricos de la estética de modernidad -que provenían sobre todo de los sectores de la izquierda intelectual desencantados con el rumbo que había tomado la

de la analogía por la ironía, por la conciencia de la historia que es conciencia de la muerte." (Octavio Paz: Los hijos del limo. Del romanticismo a la vanguardia, Barcelona, Seix Barral, $1^{\text {a }}$ edición, 1974, p. 85)

${ }^{491}$ Guillermo Sucre: "Álgebra y fuego"...loc.cit.

${ }^{492}$ Guillermo Sucre: Borges, el poeta, op.cit., p. 62. Según dice Sucre, este mismo sentimiento contradictorio es el que experimenta el personaje Borges en uno de sus cuentos: "después de haberse extraviado ante el aleph, que encierra todo el universo, sólo termina por sentir «infinita veneración, infinita lástima». Este sentimiento contradictorio es signo de reverencia y también de comprensión. Borges sabe entonces que ese poder es intocable: lo admira, pero renuncia a él. En tal renuncia hay, sin embargo, una doble actitud: el vislumbramiento de un absoluto que es inalcanzable y el secreto propósito de llegar a él a través de la humillación, de la humildad." (Ibíd.)

${ }^{493}$ Jorge Luis Borges: "Nueva refutación del tiempo", en OOCC, Vol. I, op.cit., p. 771. 
Revolución soviética ${ }^{494}$ - habían establecido que lo propio de cada arte era un ahondamiento en su propia materialidad y que esa penetración en su forma particular implicaba un componente crítico al que la creación no podía renunciar. Según ha señalado Ranciére, al hacer de "la modernidad literaria" "la explotación de los puros poderes del lenguaje"495 estos teóricos establecieron una distinción entre lo que es arte y lo que no lo es y propusieron, al mismo tiempo, que al "preservar la autonomía del arte de todas las formas de estatización de la mercancía o del poder", la literatura revelaría "la contradicción irresuelta entre la promesa estética y la realidad de un mundo de opresión",496.

La estética de modernidad que se difundió en este momento supuso un verdadero cambio de discursividad al que fueron sensibles muchos de los intelectuales y escritores de la época. Roland Barthes fue uno de los teóricos que tuvo un papel determinante en la expansión de estas ideas. En el "Prefacio" a sus Essais critiques (1964) había señalado que "quizá se escribe, más que para materializar una idea, para agotar una tarea que lleva en sí su propia felicidad”497. Y en Critique et verité (1966) oponiéndose a los postulados positivistas de la crítica tradicional- había insistido en que los propios escritores, desde Mallarmé hasta Blanchot, no habían "dejado de reconocer que el lenguaje es la materia misma de la literatura, avanzando así, a su manera, hacia la verdad objetiva de su arte"498. En el ámbito hispanoamericano el intelectual que tuvo una relevancia mayor en la transmisión de estas ideas fue Emir Rodríguez Monegal. En la ponencia que leyó en el XIII Congreso del IILI celebrado en Caracas en 1967, el intelectual uruguayo propuso una lectura teleológica de la narrativa hispanoamericana

${ }^{494}$ Vid. supra nota 193, p. 71. mía.

495 Jacques Ranciére: "Les antinomies du modernisme”, en Malaise...op.cit., p. 94. Traducción

${ }^{496}$ Jacques Ranciére: "Le tournant étique de l'ésthetique et de la politique", en Malaise...op.cit., p. 169. Traducción mía.

497 Roland Barthes: Ensayos críticos, Buenos Aires, Seix Barral, 2003, p. 11. A este respecto se puede consultar también su ensayo "«Écrivains» y «écrivants»", en el mismo libro.

498 Roland Barthes: Crítica y verdad, Buenos Aires, Siglo XXI, 1972, [1966], p. 39. 
contemporánea tomando como referencia el ahondamiento progresivo en la conciencia de la forma y del lenguaje, cuya culminación se hallaría en la obra de los novísimos y, en particular, en De donde son los cantantes (1967):

Con esta novela de Sarduy, un tema que había sido planteado y puesto en cuestión por Borges y por Asturias, desarrollado luego deslumbrantemente por Lezama Lima y por Cortázar, que fue enriquecido por Fuentes y por Cabrera Infante, llega a un verdadero delirio de poesía prosaica. Es el tema subterráneo y decisivo de la novela latinoamericana de hoy: el tema del lenguaje como lugar (espacio y tiempo) en que "realmente" ocurre la novela. El lenguaje como la realidad única de la novela. ${ }^{499}$

La revista Mundo Nuevo que Monegal dirigió desde París y que, según hemos visto, tuvo un impacto notorio en Imagen, actuó también como un medio de difusión de la estética de modernidad en el contexto hispanoamericano. Precisamente dos escritores jóvenes que participaron con asiduidad en esta revista promovieron esta concepción de la literatura. Uno de ellos fue Carlos Fuentes, que en su obra La nueva novela hispanoamericana (1969) expondría que la "voluntad de lenguaje” era el valor principal de la narrativa que se estaba escribiendo en el continente y que constituía, además, el punto de contacto entre las más diversas obras. Como afirmó Sucre, parafraseando un artículo del narrador mexicano previo a la publicación de esa obra: "la literatura que se escribe, que se está escribiendo en nuestros países, constituye un movimiento solidario de gran empuje, único en la historia literaria de América. Hay una zona donde parecen encontrarse, sin distinciones nacionales o regionales, todos los novelistas latinoamericanos, desde Borges a García Márquez. Esa zona es lo que Carlos Fuentes llama una voluntad de lenguaje ${ }^{, 500}$. Otro de ellos fue Vargas Llosa, que en su discurso de recepción del Premio Rómulo Gallegos en 1967, titulado "La literatura es fuego", había señalado que "la literatura es una forma de insurrección permanente y ella no admite las camisas de fuerza. Todas las tentativas destinadas a doblegar su naturaleza

\footnotetext{
${ }^{499}$ Emir Rodríguez Monegal: “Diario de Caracas”, en Obra selecta, op.cit., p. 274.
}

${ }^{500}$ Guillermo Sucre: Editorial del núm. 3, en Imagen, Caracas, 15/30 jun. 67, p. 2. 
díscola, fracasarán. La literatura puede morir, pero no será nunca conformista” ${ }^{, 501}$. El autor de La casa verde (1966) pensaba que la literatura no necesitaba asumir explícitamente un compromiso político o ideológico: su potencial crítico residía en su propia materialidad y dependía de su autonomía. También el freudomarxismo y en particular Herbert Marcuse habían insistido en la capacidad esencialmente crítica de la literatura y en su oposición a los valores que rigen en la sociedad ${ }^{502}$.

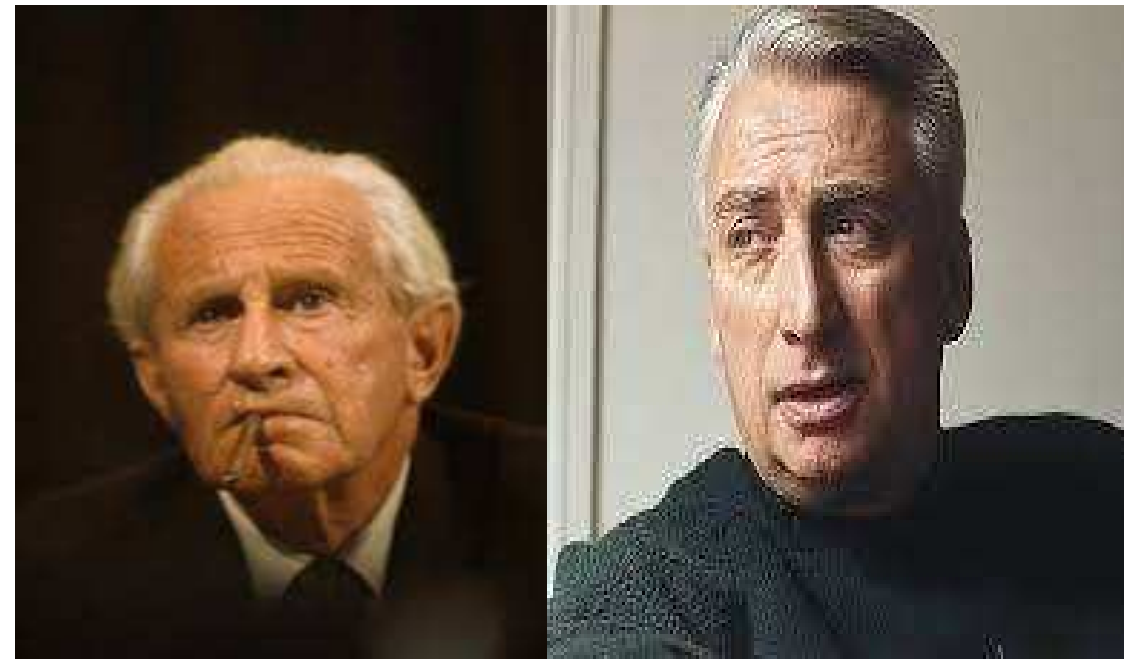

Imágenes 33 y 34. Herbert Marcuse (1898-1979) y Roland Barthes (1915-1980), teóricos influyentes en esta época.

La estética de modernidad que, como vemos, constituía un verdadero lugar común en esta época ${ }^{503}$, se aprecia en muchos de los editoriales y escritos teóricos que

${ }^{501}$ Mario Vargas Llosa: "La literatura es fuego", en Imagen, Caracas, Supl. núm. 7, 15/31 ago. 67. Sucre se hace eco de las ideas de Vargas Llosa en el editorial del núm. 5 de Imagen y le dedica el Suplemento mencionado.

502 A este respecto, en El hombre unidimensional (1954), Marcuse planteaba lo siguiente: "La distinción decisiva no es psicológica, entre el arte creado en medio del placer y el arte creado en medio del dolor, entre la cordura y la neurosis, sino la que distingue entre la realidad artística y la social. La ruptura con la segunda, la transgresión mágica o racional, es una cualidad esencial incluso del arte más positivo [...]. Ritualizado o no, el arte contiene la racionalidad de la negación. En sus posiciones más avanzadas es el Gran Rechazo; la protesta contra aquello que es." (Herbert Marcuse: El hombre unidimensional. Ensayo sobre la ideología de la sociedad industrial avanzada, Barcelona, Ariel, 1987, p. 93)

503 Escritores e intelectuales de diferentes posturas políticas promovieron una estética de modernidad. Además de Vargas Llosa, que en este momento era partidario de la Revolución cubana, Julio Cortázar también defendió una concepción modernista de la literatura. Una muestra de la repercusión de estas ideas se puede apreciar en los ensayos contenidos en América Latina en su literatura (1972). En esa compilación se advierte que la estética de modernidad se había convertido prácticamente en un lugar 
aparecieron en Imagen durante el tiempo en que Sucre estuvo a cargo de su dirección. Y no se trató de una simple impostura, puesto que este pensamiento guardaba afinidades evidentes con lo que nuestro autor venía defendiendo desde finales de los años 50. En muchos de los artículos publicados en esta época, Guillermo insistió en que la literatura consistía, ante todo, en un ahondamiento en su propia materialidad. En un texto publicado en Imagen bajo el pseudónimo de Rodrigo Antúnez señalaba que "la validez de la literatura no podría provenir de la simple realidad empírica" ni tampoco "de una suerte de ideal platónico de belleza" sino que "esa validez está dada en el propio universo formal de la obra, en sus potencias constructivas" ${ }^{204}$. En el editorial publicado en ese mismo número de la revista afirmaba igualmente: "De todas las artes, la literatura es la que ha estado más ligado [sic] a la significación, es decir, a cierto orden conceptual, al llamado «mensaje» de la obra. Sin embargo, la estética moderna se caracteriza por su empeño en conquistar un lenguaje cada vez más autónomo y libre"505. Pero no sólo en sus textos teóricos sino también en sus ensayos críticos Sucre consideraba que la conciencia o la voluntad de lenguaje era una característica fundamental de las obras literarias. Así, por ejemplo, sobre la novela De donde son los cantantes (1967) de Severo Sarduy, Guillermo argumentaba, haciéndose eco de lo señalado por Monegal, que "el lenguaje no cumple en ella tan solo, como sería lo normal, una función expresiva; no es un simple vehículo, sino que es su tema central, su ámbito de irradiación, su verdadero personaje y hasta su única aventura"506. Asimismo, en la introducción al Suplemento que la revista dedicó a los jóvenes narradores

común. A este respecto se pueden consultar por ejemplo los siguientes ensayos: José Miguel Oviedo: "Una discusión permanente" en César Fernández Moreno (coord.): América Latina en su literatura, op.cit., pp. 424-440; Adolfo Prieto: "Conflictos de generaciones”, pp. 406- 423; Emir Rodríguez Monegal: “Tradición y renovación”, pp. 139-166.

${ }^{504}$ Rodrigo Antúnez [Guillermo Sucre]: "Literatura crítica”, loc.cit., p. 3.

${ }^{505}$ Guillermo Sucre: "La nueva literatura", loc.cit.

506 Guillermo Sucre: "Sarduy: los plenos poderes de la retórica”, loc.cit. Sucre afirma asimismo que todo en ella "tiene un aire burlesco que le restituye a la narración su única validez: no sólo la de ser pura y libre ficción, sino también la de ser ante todo creación lingüística." (Ibíd.) 
venezolanos, Sucre destacaba que sus obras no se definían "por una temática sorprendente", "sino por la conciencia del lenguaje"

Este pensamiento sobre la literatura dependía a su vez de una teoría sobre el lenguaje. Guillermo consideraba que la literatura tenía un carácter esencialmente irrealista, lo que significa que, en su concepción, la escritura no podía reflejar fielmente lo real sino sólo aludir a ello. Como nos dice Sucre: "si entre las simples palabras y los objetos que designan no existe una relación analógica sino convencional (como apunta graciosamente Barthes, la palabra «buey» no se parece en nada al buey), mucho menos podría establecerse semejante relación entre la literatura (lenguaje doble y ambiguo) y la realidad" ${ }^{, 508}$. El escritor, para Sucre, tenía que ser consciente de la distancia que se establece entre el verbo y el mundo, y debía estar al tanto en todo momento de que "no trabaja con los modos de ser de la realidad, sino con los del lenguaje" ${ }^{\text {"509. Esta }}$ conciencia de la distancia que se establece entre el verbo y el mundo, era lo que determinaba que nuestro autor fuera crítico con todos aquellos creadores que se tomaban en serio a sí mismos y que creían, en consecuencia, que la literatura era capaz de representar fielmente lo real o un simple medio para lograr fines políticos o ideológicos. Basándose en estas ideas sobre el lenguaje, en uno de los editoriales de Imagen el crítico señalaba que la literatura continental había alcanzado madurez porque

ya el nuevo escritor latinoamericano no se deja chantajear por dudosas pretensiones ideológicas. Su obra sí expresa nuestra realidad, pero en una dimensión estética y no vagamente sociológica. La expresa, pero no la refleja simplemente. La constituye: revela sus significados más secretos, traduce sus claves, que no están dadas tan sólo en la apariencia de los conflictos sociales, sino en todo el comportamiento del hombre. ${ }^{510}$

${ }^{507}$ Guillermo Sucre: "En la línea más cercana", loc.cit.

${ }^{508}$ Rodrigo Antúnez [Guillermo Sucre]: "Literatura crítica", loc.cit.

509 Ibid.

${ }^{510}$ Guillermo Sucre: "El arte y la realidad”, loc.cit. La cita sigue: "Justamente, es una literatura revolucionaria porque tiene conciencia de la palabra, de su autonomía y de su validez. Y no deja de ser importante que esa conciencia estética traduzca paralelamente una conciencia social, incluso más despierta e incisiva." En este fragmento se aprecia la huella de las ideas de Lucien Goldmann, teórico al que nuestro autor había traducido en esta época. 
El prototipo del escritor que confiaba en el lenguaje era Carlos Argentino

Daneri, el personaje parodiado en "El Aleph", que aparece en el relato escribiendo un poema titulado "La Tierra" que aspiraba a ser "el resumen del universo",511. Como decía jocosamente Borges en ese cuento, y nos recuerda Sucre en varias ocasiones, ese poeta

se proponía versificar toda la redondez del planeta; en 1941 ya había despachado unas hectáreas del estado de Queensland, más un kilómetro del curso del Ob, un gasómetro al norte de Veracruz, las principales casas de comercio de la parroquia de La Concepción, la quinta de Mariana Cambaceres de Alvear en la calle Once de Setiembre, en Belgrano, y un establecimiento de baños turcos no lejos del acreditado acuario de Brighton. ${ }^{512}$

En efecto, el autor que así se mofaba de la actitud de Daneri es uno de los que determinó la concepción irrealista del lenguaje que se advierte en el pensamiento de Sucre. El escritor argentino había insistido en la distancia infranqueable que separa el orden de la sintaxis y el de la realidad, y por eso había pedido con humor que alguien le enseñara a no confundir "el vuelo de un pájaro con un pájaro que vuela",513. A decir de Guillermo, Borges, “como todo escritor, sabe que la realidad no es verbal. El poeta impone su visión a la realidad y ésta se ve así modificada. El poeta no ve ciudades, calles, suburbios, ocasos, noches, sino como palabras, imágenes y metáforas susceptibles de integrar su poema" ${ }^{, 514}$. Otro autor del círculo teórico de nuestro autor que había insistido en el carácter irrealista del lenguaje y de la literatura era Roland Barthes. En una entrevista publicada en los años sesenta el pensador francés había indicado que

en relación con los objetos mismos, la literatura es fundamentalmente, constitutivamente, irrealista: la literatura es lo irreal mismo; o más exactamente, dista mucho de ser una copia analógica de lo real, ya que la literatura es, por el contrario, la conciencia misma

511 Guillermo Sucre: Borges, el poeta, op.cit., p. 119.

512 Jorge Luis Borges: "El Aleph", en OOCC, Vol. I, op.cit., p. 620. Sucre cita este párrafo en Borges, el poeta...op.cit., p. 119 y en el ensayo "Literatura crítica", loc.cit.

247.

${ }^{513}$ Citado por Guillermo Sucre en La máscara, la transparencia, México, FCE, $2^{\mathrm{a}}$ ed., 1985, p.

514 Guillermo Sucre: Borges, el poeta, op.cit., p. 73. Ya en 1957, Ana María Barrenechea consideraba que la expresión de la irrealidad era el aspecto más significativo de la obra de Borges: "Acosado por un mundo demasiado real pero que al mismo tiempo carece de sentido, busca liberarse de su obsesión creando otro mundo de fantasmagorías tan coherente que nos hace dudar, de rechazo, de la misma realidad en que nos apoyábamos. [/] Para socavar nuestra creencia en un existir concreto, Borges ataca los conceptos fundamentales en que se basa la seguridad del propio vivir: el universo, la personalidad, el tiempo." (Ana María Barrenechea: La expresión de la irrealidad en la obra de Borges, Buenos Aires, Centro Editor de América Latina, 1984, p. 16). Esta concepción tiene su aplicación también, como lo vio Sucre, al ámbito del lenguaje. 
de lo irreal del lenguaje: la literatura más "verdadera" es la que se sabe más irreal, en la medida en que se sabe esencialmente lenguaje [...]. El realismo aquí [en literatura] no puede ser pues la copia de las cosas, sino el conocimiento del lenguaje; la obra más "realista" no será la que "pinte" la realidad, sino la que, sirviéndose del mundo como contenido (este contenido mismo es, por otra parte, ajeno a su estructura, es decir, a su ser), explorará lo más profundamente posible la realidad irreal del lenguaje. ${ }^{515}$

Ambos pensadores impugnaron por lo tanto el carácter logocéntrico de la literatura realista y simbólica. Para el teórico francés, la literatura es "lenguaje segundo, sentido parásito, de modo que sólo puede connotar lo real, no denotarlo" ${ }^{„ 516}$. Igualmente, la conciencia del lenguaje que tiene Borges le vuelve consciente "de sus propias limitaciones" pues sabe que "no puede expresar el universo sino tan sólo aludirlo, mencionarlo" ${ }^{, 517}$. En lo que atañe a la conformación del pensamiento de Sucre, las ideas de estos pensadores se vieron enriquecidas además por la concepción de Octavio Paz, que en su ensayo “¿Qué nombra la poesía?” (1967) había insistido en la condición inmanente del lenguaje literario. El mexicano afirmaba en ese texto:

la actividad poética tiene por objeto, esencialmente, el lenguaje: cualesquiera que sean sus creencias y convicciones, el poeta nombra a las palabras más que a los objetos que éstas designan. No quiero decir que el universo poético carezca de significado o viva al margen del sentido; digo que en poesía el sentido es inseparable de la palabra, es palabra, en tanto que en el discurso ordinario [...] el sentido es aquello que denotan las palabras y que está más allá del lenguaje. La experiencia del poeta es ante todo verbal; o si se quiere: toda experiencia, en poesía, adquiere inmediatamente una tonalidad verbal. ${ }^{518}$

Como se ve, para Paz la poesía tiende a anular la distancia que separa las palabras de la realidad, lo que implica que éstas no se deben a algo preexistente sino que son una creación en el vacío y dependen de su propia materialidad. Por eso, el mexicano

515 Roland Barthes: "La literatura hoy”, en Ensayos críticos, op.cit., p. 225. Para Barthes, esta distancia que se impone entre las palabras y el mundo permite que la literatura adquiera una "naturaleza a la vez significante y deceptiva" que tiene implicaciones críticas: "impotente para realizar el lenguaje, es decir, para superarlo hacia una transformación de lo real, privada de toda transitividad, condenada a significarse incesantemente a sí misma, en el momento en que sólo quisiera significar el mundo, la literatura es entonces un objeto inmóvil, separado del mundo que se hace. Pero también, cada vez que no se cierra la descripción, cada vez que se escribe de un modo suficientemente ambiguo como para dejar huir el sentido, cada vez que se hace como si el mundo significase, pero sin decir el qué, el escribir libera una pregunta, sacude lo que existe, sin llegar nunca, sin embargo, a preformar lo que aún no existe, da aliento al mundo: en suma, la literatura no permite andar, pero permite respirar. (Roland Barthes: "Literatura y significación", en Ensayos críticos, op.cit. p. 361)

516 Ibid., p. 361.

${ }^{517}$ Guillermo Sucre: Borges, el poeta, op.cit., p. 152.

518 Octavio Paz: “QQué nombra la poesía?”, en OOCC, Vol. II, op.cit., p. 487. Este texto fue publicado originalmente en Corriente alterna (1967) 
podía conceder a la palabra un estatuto fundador: la poesía es una vía para instituir lo real y revelar la verdadera condición del artista, del hombre y del mundo ${ }^{519}$. En algunos artículos publicados en esta etapa, Guillermo se hacía eco de esta concepción de Paz sobre el lenguaje poético. Por ejemplo, en un ensayo dedicado a la obra de Perse señalaba que "la realidad es verbal y el verbo es realidad" puesto que el poeta comprende "que el mundo no se ilumina sino a partir de las palabras" $" 520$. Igualmente, a propósito de Blanco (1967) de Octavio Paz, Sucre indicaba que "el lenguaje y el mundo tienden a reemplazarse incesante y dialécticamente en el poema"521.

En la concepción de nuestro autor, el ahondamiento de la literatura -“actividad verbal pura" ${ }^{, 522}$ - en su propia materialidad estaba vinculado, como querían los teóricos de la estética de modernidad, a una dimensión crítica que le era esencial. Como afirma Sucre: "por ser actividades donde lo que domina es el valor desinteresado de las formas", el arte y la literatura "se constituyen en actitudes críticas frente a la realidad" ${ }^{253}$. Al desprenderse de una utilidad circunstancial y efímera y profundizar en sí misma, la literatura no se evade "sino que traduce, por el contrario, una manera más radical de percibir y revelar el mundo, así como una voluntad por reintegrar a la palabra poética y al hombre una plenitud hasta ahora menguada por el exceso racionalista" ${ }^{\natural 24}$.

${ }^{519}$ En este sentido, Paz coincidía con Borges, pues también el escritor argentino consideraba que la distancia que se impone entre las palabras y el mundo es precisamente lo que permite ordenarlo imaginariamente y concederle unos rasgos definitivos más allá del azar y de la prolijidad amenazante que en ella rige. Como diría Sucre: "a través de la desrealización de la realidad se proyecta otra realidad más esencial; de igual modo, a través de la despersonalización se vislumbra y prefigura otra personalidad más auténtica. La coherencia de la obra de Borges y el sentido que ella le imprime al mundo, residen en esta trasmutación paradójica." (Guillermo Sucre: Borges, el poeta, op.cit., p. 65). El propio Sucre ha establecido esta relación entre ambos: "la obra de Borges no es sólo recreación o transfiguración de la realidad. Es algo más difícil: un hacer realidad de lo imaginario. En cierta ocasión, Octavio Paz ha escrito que las mejores tentativas de la literatura hispanoamericana consisten en fundar un mundo. Nadie más americano que Borges en este sentido; por ello el "europeísmo" que despectivamente le asignan algunos críticos no pasa de ser mala fe o apego a lo pintoresco." (Ibíd., p. 64)

${ }_{520}$ Guillermo Sucre: "Honrar al mundo con la escritura", loc.cit.

${ }^{521}$ Guillermo Sucre: "El poema: un archipiélago de signos", en Imagen, Caracas, núm. 24, 1/15 mayo 68, p. 24.

${ }_{522}$ Rodrigo Antúnez [Guillermo Sucre]: "Literatura crítica”, loc.cit.

${ }^{523}$ Guillermo Sucre: "El arte y la moda", loc.cit.

${ }^{524}$ Guillermo Sucre: "La nueva literatura", loc.cit. 
Por lo tanto, el carácter gratuito de la nueva literatura "es de un insospechable poder

revolucionario, es decir, transformador":

Al romper los esquemas tradicionales del lenguaje y de la realidad, pero sobre todo al despojar a la obra de todo patetismo y de toda sublimación dramática, el escritor contemporáneo sabe que está cumpliendo su único gran compromiso: el de desmistificar la vida, el de situar al hombre en el centro de su propia plenitud ("El hombre propone y dispone", decía Breton), el de crear una grieta entre la conciencia y la realidad que haga posible un cuestionamiento profundo de todos los valores tradicionales. ${ }^{525}$

Entonces, cuando la literatura no pretende representar el mundo como un espejo ni ser un medio para alcanzar metas extraliterarias es cuando cumple una función crítica que le es esencial. Es más, este cometido crítico que es consustancial a la literatura sólo se cumple cuando la obra evita someterse a un compromiso explícito, pues las obras auténticas tienen una mayor capacidad para encarnar lo real. Siguiendo lo expuesto por Lucien Goldmann en El teatro de Jean Genet (1967), obra que tradujo para Monte Ávila en esta época, Guillermo sostenía que cuando la literatura asumía una responsabilidad manifiesta resultaba superficial:

El arte como reflejo de la realidad o de la sociedad es una teoría de perezosos, esto es, de conservadores. En un ensayo sobre el teatro de Genet [...], un sociólogo marxista como Lucien Goldmann nos dice que mientras la obra es más reflejo de la sociedad y de sus estructuras evidentes, resulta no sólo más banal desde el punto de vista estético, o lo que es igual, menos creadora, sino también más superficial. [...] Las obras más complejas estéticamente son también las más reveladoras de mundo. Sólo aquellas que se fundan en un "mensaje" deliberado resultan a la postre vacías y precarias, incluso en un nivel ideológico. ${ }^{526}$

Por eso Sucre se sorprendía de que en Venezuela algunos quisieran "reducir la

obra del escritor a un puro ejercicio de denuncia social, concebida siempre ésta entre los

límites mezquinos del partisanismo y el alineamiento" pues para él "toda obra literaria

${ }^{525}$ Ibid. "el arte y la literatura, cuando son auténticos, se resisten a esta suerte de alienación de lo material, se sustraen al éxito fácil que imponen las modas. No es, por supuesto, que se evadan de la realidad y de una época. Al contrario, por ser actividades donde lo que domina es el valor desinteresado de las formas, se constituyen en actitudes críticas frente a la realidad. Pero para lograr profundizar esa actitud crítica deben procurar asumir una perspectiva que sea a la vez de distancia y de participación." (Guillermo Sucre: "El arte y la moda", loc.cit.). En este sentido es evidente que Sucre estaba retomando los planteamientos de Herbert Marcuse. (Vid. supra nota 502, p. 177)

526 Guillermo Sucre: "El arte y la realidad", loc.cit. Guillermo piensa por eso que los artistas que se someten a teorías o compromisos impuestos, o quienes se dejan llevar por el éxito y "se han mostrado como los exponentes de una época, se han visto relegados, con el transcurrir del tiempo, a tener una significación marginal o puramente documental. En cambio, los que no se han dejado seducir por esa gloria instantánea del impacto y de las modas y han sabido ser fieles a la verdad de su obra, han encarnado luego los verdaderos valores tanto del arte como del hombre mismo." (Guillermo Sucre: "El arte y la moda", loc.cit.) 
auténtica encierra una crítica social, propone incluso una requisitoria más profunda de la condición humana". En definitiva, para Guillermo, "la literatura es revolucionaria a partir de sus propios valores y no de aditamentos que le son ajenos" ${ }^{\text {,527. }}$.

La crítica que contiene toda literatura auténtica se ejerce en un doble plano: al ahondar en su propia materialidad y evitar someterse a valores extraños, la literatura se vuelve crítica de sí misma y, en consecuencia, crítica de la realidad social. De nuevo nos encontramos aquí con Octavio Paz quien, al haber establecido una continuidad en la experiencia del escritor entre el lenguaje y el mundo, había determinado que la crítica del uno implicara la del otro: "la poesía moderna es inseparable de la crítica del lenguaje que, a su vez, es la forma más radical y virulenta de la crítica de la realidad. El lugar de los dioses o de cualquier otra entidad o realidad externa, lo ocupa ahora la palabra. El poema no tiene objeto o referencia exterior; la referencia de una palabra es otra palabra"528. También en la concepción de Sucre, al emprender un cuestionamiento del lenguaje y de la obra misma, el poeta está ejerciendo una crítica de lo real. Esto se lleva a cabo a través de un movimiento de negación y afirmación: el escritor problematiza la obra en lo que es un paso previo para alcanzar su verdadero propósito: cambiar, aunque sea imaginariamente, el mundo:

Al evidenciar [los escritores] su carácter gratuito [el de la literatura] y desenmascarar su juego (de puras palabras), llegan a problematizarla. No le dan paz ni reposo. Que continuamente se confronte a sí misma: que reconozca su inanidad (¡qué buena palabrita!), que se trague, como diría Octavio Paz, todas sus palabras. Pero el problema no termina aquí, sino que comienza: después de este proceso de autonegación se propone entonces una empresa realmente desmesurada: no sólo descifrar el mundo y rescatarlo en su realidad más secreta e invisible, sino también reemplazarlo (aunque sea por un instante de comunicación con el lector). ${ }^{529}$

${ }^{527}$ Guillermo Sucre: "La opción de la literatura", en Imagen, Caracas, editorial núm. 9, 15/30 sep. 67 , p. 2 .

${ }^{528}$ Octavio Paz: “¿Qué nombra la poesía?”, en OOCC, Vol. II, op.cit., pp. 487-488. En otro texto publicado en Corriente alterna (1967), Paz estableció el siguiente vínculo entre la crítica y la creación: "en nuestra época la crítica funda la literatura. En tanto que esta última se constituye como crítica de la palabra y del mundo, como una pregunta sobre sí misma, la crítica concibe a la literatura como un mundo de palabras, como un universo verbal. La creación es crítica y la crítica, creación. Así, a nuestra imaginación le falta rigor crítico y a nuestra crítica, imaginación." (Octavio Paz: "El espacio del reconocimiento", en OOCC, Vol. II, op.cit., p. 1151)

${ }^{529}$ Rodrigo Antúnez [Guillermo Sucre:] "Literatura crítica", loc.cit. 
La literatura cuestiona el lenguaje con el fin de aclarar el mundo y rescatarlo en su realidad original "secreta e invisible". Este arte es, por lo tanto, una purificación del lenguaje que tiene como meta "reconciliar en el poema al mundo",530. Como afirma el crítico a propósito de la obra de Nicanor Parra, la poesía "quiere hacer estallar el mundo, pero no para aniquilarlo, sino para rehacerlo", porque es ante todo "una búsqueda de la plenitud original de la vida" ${ }^{, 531}$. En ese sentido, el arte elaborado con palabras es para Sucre, como quería Paz, una fundación de la verdadera realidad: "La literatura no expresa la realidad sino en la medida en que la constituye: alude a ella para crear otra más significativa a partir de palabras cargadas de nuevos sentidos. Aún más, la literatura funda la verdadera realidad: nos hace tomar conciencia de ella en toda su complejidad al despojarla de su carácter mudo y cerrado y hacerla viva y abierta" ${ }^{, 532}$. El poeta critica al lenguaje y al mundo para inventar y revelar la realidad como de verdad es, y esto coincide con las ideas vistas en el apartado anterior acerca de la transfiguración imaginaria de lo real a través de la memoria y del mundo infantil. Al profundizar en sus potencias constructivas, la obra de arte busca rescatar el absoluto que había sido desintegrado por la modernidad, aunque esto sólo sea posible en un momento de comunicación con el lector, pues Sucre es consciente de que ese mundo reconciliado sólo puede vislumbrarse en el poema y no se alcanza nunca de manera definitiva ${ }^{533}$.

Como hemos visto más arriba, la condición crítica que es esencial a la literatura supone que ésta debe mantener una distancia crítica con respecto a la sociedad y no

${ }^{530}$ Ibid.

531 Guillermo Sucre: “La desmistificación por el humor”, en Imagen, Caracas, Supl. núm. 13, 15/30 nov. 67.

532 Rodrigo Antúnez [Guillermo Sucre:] "Literatura crítica", loc.cit.

533 Por eso afirma a propósito de la poesía de Paz que ella es "un acto dual y paradójico: comunión y distancia frente al mundo, aspiración a lo absoluto y reconocimiento de la imposibilidad de alcanzarlo. La libertad del hombre y la del mundo mismo es libertad bajo palabra: un acto vertiginoso que vive entre la plenitud y el vacío." (Ibíd.) 
puede asumir compromisos "a lo duro" que resultan frecuentemente impostados ${ }^{534}$. Sucre pensaba que la relación del escritor con el grupo social debía ser siempre ambivalente ("de distancia y de participación",535) pues su manera de comprometerse con él consiste en rechazar los valores implícitos que lo constituyen y revelar una existencia plena. El verdadero arte debe mantener siempre "una zona irreductible a la simple y a veces circunstancial influencia de la sociedad, a las modas del momento, a la publicidad y al éxito. Esa zona no es únicamente la personalidad del artista, sino también la naturaleza inherente al arte mismo: su capacidad constructiva de formas auténticas" ${ }^{536}$.

La condición crítica que Sucre consideraba esencial a la literatura genuina supone que las creaciones artísticas deben resistir su asimilación por la sociedad o por el mercado. En línea con lo que habían propuesto pensadores freudomarxistas como Marcuse -al que Imagen concedió bastante espacio ${ }^{537}$ - Guillermo consideraba que “mientras la literatura sigue siendo una búsqueda de valores auténticos, esa búsqueda no parece coincidir con los valores dominantes de la sociedad en que vivimos" ${ }^{\text {"538 }}$. Por ello

\footnotetext{
534 “el escritor de buena conciencia, quiéralo o no, tiende siempre a servir más bien los valores que le impondría cualquier clase dominante (burguesa o proletaria). La eficacia, la utilidad, la precisión y el realismo serían sus supremos objetivos; bien cumplidos, con celo y devoción progresistas, esos objetivos aportan la consagración y el éxito. [/] Pero el escritor olvida así (o aparenta olvidar) que él no trabaja con los modos de ser de la realidad, sino con los del lenguaje; su buena conciencia está alimentada de mala fe." (Ibid.) "Ya el escritor sabe que la verdadera eficacia no reside en los falsos y con frecuencia acomodaticios compromisos sociales, compromisos que, por cierto, exaltan tanto tirios como troyanos, tanto la estética de cierta burguesía «progresista» como la de cierto socialismo dogmático." (Guillermo Sucre: "La nueva literatura", loc.cit.)

${ }_{535}$ Guillermo Sucre: "El arte y la moda", loc.cit.

${ }^{536}$ Ibíd. De este modo mismo modo, el verdadero escritor participa de su sociedad pero, al mismo tiempo, está alejado de ella: “el propio Valéry -nos dice Guillermo- gustaba definir al artista [...] de la manera siguiente: es el ermitaño que sabe a qué hora sale el tren. Con lo cual quería decir que hay siempre en todo arte una zona irreductible a la simple y a veces circunstancial influencia de la sociedad, a las modas del momento, a la publicidad y al éxito." (Ibíd.)

${ }^{537}$ Marcuse fue el pensador al que Imagen dedicó más estudios. Esto se explica porque, como es sabido, este filósofo fue uno de los que más influyó en el clima espiritual de 1968. En la revista se publicaron dos artículos de Eduardo Vázquez: "La filosofía como subversión”, en Imagen, Caracas, núm. 9, 15/30 sep. 67, p. 24; “4 ensayos de Herbert Marcuse”, núm. 17, 15/30 ene. 68, pp. 6-7. También publicó sobre él un artículo de Antonio Pasquali: "Por Marcuse y por la utopía", en Imagen, Caracas, núm. $29,15 / 30$ jul. 68 , pp. 6-7.

${ }_{538}$ Guillermo Sucre: "El arte y la moda", loc.cit. Así parafraseaba Sucre las ideas del pensador alemán: "En Eros y civilización, en efecto, Marcuse define a la civilización occidental como el mundo de
} 
-siguiendo la crítica que Octavio Paz había formulado en su breve ensayo "Hartazgo y náusea"539 (1967)- Guillermo cuestionaba a la neovanguardia porque "desasistida de un pensamiento crítico y de una visión del mundo" tendía "cada vez más a la neutralidad" 540 . Para evitar que el arte se convirtiera en un mero "objeto de decoración" nuestro autor reclamaba la vuelta de éste por "los fueros de la lucidez crítica" pues "la estética moderna se fundó siempre en esa lucidez, a la vez participación y rechazo" ${ }^{541}$. Esta ambivalencia entre la negación y la afirmación se debía establecer -según lo habían propuesto pensadores influyentes como Sartre y Camus $^{542}$ - en la relación del arte

la represión. Esa represión se traduce en sus mitos. De ahí nuestra tradicional exaltación del mito prometeico del hombre, que se nutre del esfuerzo, del sacrificio y del dolor como los únicos caminos para alcanzar un sentido en la vida. Y no deja de ser significativo que, frente a él, haya permanecido marginal y secundario el mito de Orfeo, que vive del eros, del placer y de la contemplación. Si aquél implica una continua represión de los instintos del hombre y de su busca de la verdadera plenitud, éste sugiere los dominios de un orden donde todo sería, como lo diría Baudelaire, "luxe, calme et volupté." Aparentemente irresponsable, la tendencia que encierra este segundo mito traduce, como lo expresa el propio Marcuse, "la rebelión contra la cultura basada en el esfuerzo, la dominación y la renuncia". Es esta misma rebelión la que está presente en la nueva literatura; su gratuidad, pues, es de un insospechable poder revolucionario, es decir, transformador." (Guillermo Sucre: "La nueva literatura", loc.cit.)

${ }^{539}$ En ese texto Paz señalaba: "Ayer la rebelión fue un grito o un silencio; ahora es un alzarse hombros: el porque sí como razón de ser. El viejo sueño de la poesía, desde los románticos hasta los surrealistas, fue la fusión de los contrarios, la metamorfosis de un objeto en su opuesto. La creación y la destrucción eran los polos de una misma energía vital y la tensión entre ambos polos alimentó el arte moderno. [...] La nueva estética es la indiferencia. No la metáfora: la yuxtaposición, que crea una suerte de neutralidad entre los elementos del cuadro o del poema. Ni arte ni anti-arte: no-arte." (Octavio Paz: "Hartazgo y náusea", en OOCC, Vol. VI, op.cit., pp. 1403-1404. El texto se publicó originalmente en Corriente alterna (1967))

${ }^{540}$ Guillermo Sucre: "La lucidez crítica", loc.cit. En cambio, los movimientos de la vanguardia histórica "fueron grandes empresas de esclarecimiento" y quisieron "hacer de la estética una ética de la acción".

${ }^{541}$ Ibid.

${ }^{542}$ En este doble movimiento de negación y afirmación de la literatura con respecto a lo real habían insistido intelectuales muy leídos en esta época como Sartre o Camus. Para el primero de ellos "el rol del escritor en la sociedad es el siguiente: en tanto que la literatura es negatividad, ella reprobará la alienación del trabajo; en tanto que es creación y sobrepasamiento, presentará al hombre como acción creadora, ella le acompañará en su esfuerzo para sobrepasar su alienación presente hacia una situación mejor." (Jean Paul Sartre: "Qu'est-ce que la littérature?", en Situations II, op.cit., p. 262. Traducción mía). Igualmente, en su discurso de recepción del Premio Nobel en 1957, Albert Camus había afirmado que "el arte no es ni la negación total ni el consentimiento total a lo que es. Es al mismo tiempo negación y consentimiento, y por eso no puede ser sino un desgarramiento perpetuamente renovado. El artista se encuentra siempre en esta ambigüedad, incapaz de negar lo real y, sin embargo, enteramente dedicado a negarlo en lo que tiene de eternamente inacabado." (Albert Camus: "Discurso de Suecia", en Obras 5, Madrid, Alianza Tres, 1996, pp. 163-192, p. 185). Esta voluntad de corregir lo real a través del arte está presente también en Borges, en Paz y en el propio Sucre, que en un editorial dedicado a Vargas Llosa señalaba: "Pero la experiencia personal no lleva a Vargas Llosa por las zonas amorfas de lo subjetivo. Narrar es afirmar su yo, imponer una realidad construida sobre base empírica frente a una realidad natural y difusa. Y así tomando el verdadero sentido de lo personal, es como Vargas Llosa nos da una visión excepcional del mundo, de los hechos y acciones del mundo, a la vez que una visión de su experiencia vivida." (Guillermo Sucre: Editorial del núm. 5, en Imagen, Caracas, núm. 5, 15/30 jun. 67, p. 2) 
con la sociedad, pero también en el vínculo de la obra con la tradición literaria, pues de otro modo ésta corría el riesgo de no encontrar el arraigo necesario y de ser un simple grito en el vacío ${ }^{543}$.

Al despedirse de su participación en Imagen en el verano de 1968 Guillermo Sucre hizo un balance de su trayectoria en la revista donde señalaba que ella representaba "una nueva actitud venezolana, y me atrevería a decir latinoamericana, frente a la cultura y a la responsabilidad de la inteligencia" ${ }^{, 44}$. Y definía esta perspectiva con "dos rasgos esenciales": "una actitud crítica que permita ir más allá de las jerarquías establecidas y crear un estado de conciencia menos deferente" y, asociada a ese “espíritu crítico", "una voluntad solidaria por encima de mezquindades regionalistas, con todo lo que en nuestro país y fuera de él constituye un riesgo creador y de una nueva formulación de la cultura" ${ }^{, 545}$. Guillermo establecía así un vínculo entre la estética de modernidad defendida por Imagen y su voluntad decididamente universalista ${ }^{546}$. Al

${ }^{543}$ Para Sucre era imprescindible que los artistas establecieran una relación de afirmación o negación con la tradición. Por eso nuestro autor definía de la siguiente manera el carácter herético del arte contemporáneo: "Lo que caracteriza justamente al arte contemporáneo -al menos, el que más cuenta como renovación- es un espíritu no tan sólo crítico sino herético. El anti es el prefijo que con más pasión busca para definirse. Así como se habla de la antinovela, podría hablarse también de la antipintura o de la antimúsica. Esta suerte de autonegación no responde a un sentido exhibicionista o excéntrico, pero quizás tampoco a una voluntad -lo que sería ingenuo- de arrasar con el hecho estético.” (Guillermo Sucre: “НHa muerto el arte?" en Imagen, Caracas, editorial núm. 10, 1/15 oct. 67, p. 2). Y en un ensayo sobre Vallejo definía la antipoesía de la siguiente manera: "dominado por una voluntad de destruir todas las formas, no es éste su único objetivo; aspira también a crear otras más auténticas y afines con el mundo actual. [...] este proceso de destrucción-recreación se cumple visiblemente en la poesía de Vallejo." (Guillermo Sucre: "Vallejo: la nostalgia de la inocencia", loc.cit.). A este respecto Guillermo coincidía con Octavio Paz, que había afirmado: "No digo que los jóvenes deban continuar, repetir o imitar a sus predecesores; digo que toda negación, si no es un grito vacío contra el vacío, implica una relación polémica con aquello que se niega. No me preocupa la rebelión contra la tradición: me inquieta la ausencia de tradición. Es un signo de enajenación y más: al cercenarse de su tradición, los acólitos se automutilan...” (Octavio Paz: "Los nuevos acólitos", en OOCC, Vol. II, op.cit., pp. 1144-1145. Este texto se publicó originalmente en Corriente alterna, 1967)

${ }^{544}$ Guillermo Sucre: "Con la misma adhesión", loc.cit.

${ }^{545}$ Ibíd.

${ }^{546}$ Uno de los objetivos de la revista era lograr una igualación de nivel con los centros de cultura. En un editorial, Sucre se defendía así de las críticas recibidas por la revista a este respecto: "al reconocer y estimular nuestros verdaderos valores, hemos tratado al mismo tiempo de que lo «extranjero» pierda en nuestro contexto cultural esa suerte de sacralización con que se le rodea y se le hace inaccesible. Es decir que hemos intentado suscitar un diálogo entre lo venezolano, lo latinoamericano y lo europeo, estableciendo verdaderos vasos comunicantes entre la inteligencia creadora de todos los países. Pretender que porque somos venezolanos teníamos únicamente el deber (ya sabemos que «sagrado») de informar al mundo entero de lo que somos culturalmente, nos parecía una de esas arrogancias que ha venido 
asumir esta concepción estética la publicación trascendía los nacionalismos estrechos, revelaba el testimonio del hombre contemporáneo, y manifestaba su adhesión a las ideas que estaban siendo difundidas desde los centros metropolitanos.

\section{5. HACIA UNA CRÍTICA POÉTICA}

Como es lógico, el pensamiento de Sucre sobre la literatura afecta decisivamente a su manera de concebir la crítica literaria. Según hemos visto en apartados precedentes, la conciliación de la subjetividad y la objetividad o de la pasión y la inteligencia permitía a las obras adoptar una expresión necesaria y trascender los excesos de cosas y de palabras. Al atenerse a este paradigma de saturación expresiva, la literatura resultaba ser un vínculo preciso entre la mirada y el lenguaje que no procedía de algo previo sino que se creaba en el momento de la escritura, ante la página en blanco.

Esta concepción del arte elaborado con palabras implica una manera particular de estudiarlo. Si la literatura es un espacio en el que se revela un carácter o un destino, la crítica se impone hallar y describir la originalidad de esa visión que encarna en la escritura. Esto no significa que Guillermo estableciera una relación simplista entre la obra de un autor y su biografía, pues era perfectamente consciente de la distancia que

alimentando cierto sector en nuestro país. ¿Por qué no informar también a los venezolanos de lo que sucede culturalmente más allá de sus fronteras? Conciliar uno y otro objetivo nos resultaba tarea más positiva. Creíamos, y aún lo seguimos creyendo, que con ello podríamos superar la excesiva solemnidad con que se plantean en nuestro país los temas y problemas de la cultura. Suponer, por ejemplo, que un escritor venezolano, o de nuestra lengua, no puede escribir sobre temas europeos tal como se ha hecho en nuestra revista (Blake, Dante, Baudelaire, Sartre, Marcuse, Nouveau roman, Saint-John Perse, etc.), sería proclamar, entre nosotros, una carencia de horizontes intelectuales que, curiosamente, se cuidan mucho de confesar o de asumir quienes así se convierten en nuestros censores. Sería, además, un sentimiento de verdadero vasallaje intelectual. Implica, por ejemplo, que Maurice Nadeau sí puede escribir sobre Ernesto Sábato y Georges Sadoul sobre Margot Benacerraf (cf. No 1 de "Imagen”), en cambio que Serrano Poncela no lo puede hacer sobre Blake (cf. $\mathrm{n}^{\circ} 7$ ), ni Federico Riu sobre Sartre (cf. $\mathrm{n}^{\mathrm{o}}$ 12), ni Eduardo Vásquez sobre Marcuse (cf. nos. 9 y 17), ni José Balza sobre Roland Barthes (cf. no 23). ¿Habría que insistir, una vez más, en el carácter universal que ha dominado siempre en la mejor tradición de la cultura venezolana y, en general, latinoamericana?" (Guillermo Sucre: "Primer aniversario", loc.cit., pp. 2-3) Para apreciar la postura universalista que adoptó Imagen se pueden consultar además los siguientes artículos: Guillermo Sucre: "Contra la parcelación de la cultura", en Imagen, Caracas, editorial núm. 18, 1/15 feb. 68, p. 2; Guillermo Sucre: "En el umbral de una nueva literatura", loc.cit. 
separa la escritura de la vida ${ }^{547}$. Y tampoco trataba de proponer una correspondencia simplista entre el fondo y la forma. En el pensamiento de Sucre, la ética del autor se genera a la par que la estética, hasta el punto de que ambas resultan indistinguibles. Por eso, en muchos de los comentarios de nuestro autor sobre la crítica literaria se aprecia una afinidad con aquellos trabajos que tendían a estudiar el "movimiento interior" las obras y a definir la originalidad de las experiencias que revelan. A este respecto es esclarecedora la siguiente reflexión de Sucre sobre el libro César Vallejo (1967) de Américo Ferrari:

Toda obra auténtica es siempre una creación, es decir, algo nuevo que trasciende todo aquello que la precede; contexto vital e histórico, influencias literarias e inclusive estructuras de la lengua misma. No todos los poetas que han tenido iguales experiencias en la vida y en la sociedad, son iguales a Vallejo. Ni tampoco se le asemejan quienes inicialmente recibieron una misma influencia literaria (de Dario, Herrera y Reissig, Lugones), ni los que han expresado parecidas vivencias raciales. Por comprender bien esto, Ferrari no dirige su mirada sino a lo esencial: al movimiento interior de la obra de Vallejo. Lo que le interesa es dilucidar la originalidad (y no la "novedad", como replicaría la conciencia estética de Vallejo) con que el gran poeta peruano supo asumir el mundo, la literatura y la historia de su tiempo, y crear así una poesía que tiene su propia coherencia y su significación particular. ${ }^{549}$

${ }^{547}$ Para Sucre, en la literatura tiene lugar una transfiguración o una fabulación de la experiencia real del poeta. A este respecto señalaba que "en gran medida, la poesía moderna no es tanto la expresión de un yo, como su búsqueda. Esta búsqueda la emprende el poeta a través de un yo que todavía no es él (es el otro) o que ha sido marginado por su yo aparente. El yo del poeta es también ficticio como el del novelista. Paul Éluard llegaba incluso a concebir que el poeta crea e inventa sus propias emociones. La crea, es decir, las proyecta en una dimensión más profunda que la afectividad contingente. «La vida es una cosa -decía Vallejo-, el arte es otra cosa, aunque se mueva dentro de la vida». No es posible reducir la obra a un mero reflejo de las circunstancias vitales del artista. El arte -añade el propio Vallejo- es «una verdadera operación de alquimia, una transmutación»." (Guillermo Sucre: "Vallejo: la nostalgia de la inocencia", loc.cit. La cursiva corresponde a la negrita del original). Igualmente a propósito del libro de Monegal El viajero inmóvil (1966), Sucre destacaba que el autor parte de "la íntima relación entre la experiencia vital de Neruda y su poesía; pero para llegar a algo más concluyente y revelador: esta poesía no es una crónica realista de aquella experiencia, sino su fabulación. Como Whitman, Ezra Pound, y yo añadiría Borges, Neruda es de los poetas que inventan su vida." (Guillermo Sucre: "Neruda y el tiempo recobrado", loc.cit.)

${ }^{548}$ Guillermo Sucre: "La trayectoria poética de Vallejo", en Imagen, Caracas, núm. 21, 15/30 mar. 68, p. 5. En el epílogo a la $1^{\text {a }}$ edición, Sucre declaraba sus defectos y revelaba el método que había seguido: "Faltó perfilar más el ámbito cultural en que surge Borges y la relación de su poesía con la poesía hispanoamericana y aun española. Reconozco que el apego a los textos mismos me alejó de esta perspectiva. Podría excusarme diciendo que no quise hacer sino lo que hoy llaman «crítica interna», aunque sé que con ello no quedo totalmente a salvo." (Guillermo Sucre: Borges, el poeta, México, UNAM, $1^{\text {a }}$ ed., 1967, p. 117)

${ }^{549}$ Guillermo Sucre: "La trayectoria poética de Vallejo", loc.cit. Guillermo valora la crítica que tiene en cuenta la singularidad de la experiencia poética. Sin embargo, en el texto "Las influencias literarias" había señalado que lo fundamental en la literatura no era "un afán precario de originalidad, sino el majestuoso desarrollo del espíritu a través de la historia." La divergencia es sólo aparente, pues para Sucre, cuando los autores son auténticos son también originales, pero su originalidad no es novedad radical, sino que les permite entroncar con la ética y la estética universales. (Vid. Guillermo Sucre: "Las influencias literarias", en Zona Franca, Caracas, núm. 13-14, mar. 65, pp. 25-26). A este respecto, a Sucre le gustaba recordar una frase de Baudelaire: "Como no ha progresado, no habrá de envejecer." 
Como vemos por la cita, Sucre destacaba que el intelectual peruano se hubiera ocupado de "dilucidar la originalidad" de la experiencia poética que encarna en la obra de Vallejo y que hubiera trascendido los reclamos de la crítica determinista. Lo importante para Guillermo era que el crítico había estudiado la singularidad de la vivencia poética de Vallejo y que había establecido, a partir de ella, "su propia coherencia y su significación particular". Nuestro autor advertía estas mismas virtudes en Cuadrivio (1965) de Octavio Paz, quien ya sabemos que había propuesto un vínculo necesario entre la moral del escritor y su actitud ante el lenguaje ${ }^{550}$. En los ensayos críticos contenidos en ese libro, nos dice Sucre, el escritor mexicano "nos pone en camino de un conocimiento y simultáneamente de una revelación: conocimiento de la obra en sí y revelación de lo que hay en ella de verdadera experiencia creadora y existencial" $" 551$. Así nos da una imagen de los poetas estudiados que va "más allá de los puros rasgos estilísticos; penetra en el universo mismo de la poesía de Darío, de López Velarde, de Pessoa y de Cernuda"552.

Estas opiniones de Sucre sobre la crítica de otros autores se corresponden con su propia manera de concebir esta disciplina. En efecto, en sus artículos críticos Guillermo buscaba revelar la poética de las obras, es decir, el vínculo entre la mirada y el lenguaje que se genera en la escritura. En el "Epílogo" a la primera edición de su obra Borges, el poeta (1967), nuestro autor "se disculpaba" por no haber entrado a valorar la obra del autor argentino, pues por encima de los reparos que podía haberle hecho le interesaba “indagar en el espíritu poético de Borges”, es decir, que "más que los resultados, [le]

(Charles Baudelaire: "Exposición universal de 1855. Bellas artes”, en Obras, op.cit., p. 541). (Guillermo parafrasea esta sentencia en su ensayo "Juarroz: sino/si no", en La máscara...op.cit., p. 205)

${ }^{550}$ Vid. supra el fragmento que remite a la nota 353, en p. 130.

${ }^{551}$ Guillermo Sucre: "El diálogo con el mundo", loc.cit.

${ }^{552}$ Ibid. 
atrajo el espíritu en que ellos se gestaron"553. El objetivo del libro era estudiar la poesía de Borges, "aunque no de manera exhaustiva ni sistemática. El propósito [era] más limitado aún: desentrañar la «poética» que ella encierra, así como la actitud anímica e intelectual que la sustenta" ${ }^{554}$. Aunque en otros ensayos críticos no lo afirme de manera tan explícita, la crítica de Sucre tratará siempre de dilucidar la poética de los autores, es decir, la correspondencia entre ética y estética que se cumple en sus obras.

Un resultado de esta concepción es que al establecer una continuidad entre la mirada y el lenguaje se anula la posibilidad del suplemento: la obra literaria se concibe como un sistema en que todo tiene su razón de ser. Guillermo pensaba que las obras auténticas eran coherentes porque persistía en ellas una misma visión. Por eso, si bien era consciente de que podía haber diferencias dentro de una misma obra, su mirada crítica trataba de suavizar los contrastes y de favorecer la continuidad ${ }^{555}$. A este respecto, en su libro sobre Borges afirmaba: "No se cree que pueda haber una coherencia en su obra: el Borges que construye la laberintos es en sí mismo laberíntico. Sin pretender reducirlo a una sola pieza, creemos, por nuestra parte, que esa coherencia existe" ${ }^{, 556}$. Ahora bien, establecer una unidad en las obras implicaba determinar una "verdad" del autor o una "actitud esencial" del mismo que permitiera ordenar sus escritos y limitar la proliferación potencial de su sentido. Así, en el ensayo recién

${ }^{553}$ Guillermo Sucre: Borges, el poeta, México, UNAM, 1ª ed., 1967, p. 118. Por eso quiso "que la poesía de Borges hablara por sí misma", y se limitó "a dar paso a lo que ella encierra: su profunda verdad." (Ibid., p. 117)

${ }^{554}$ Guillermo Sucre: Borges, el poeta, Caracas, Monte Ávila, 2a ed., 1974, p. 22.

${ }^{555}$ En este sentido afirmaba Sucre: "En todo hombre hay diversos hombres (yo tengo multitudes, decía Whitman). Así también en todo poeta hay varios poetas. Ello es verdad aun cuando la obra poética se reduzca a un solo libro; siempre su unidad será su diversidad. En Las flores del mal coexisten varios mundos: el paradisíaco y el demoníaco, la inocencia y el mal, la pura voluptuosidad y la desesperada metafísica, las formas suntuosas y la violenta realidad. El rostro de Baudelaire en este libro, como en toda su obra, es uno y múltiple" (Guillermo Sucre: "Vallejo: la nostalgia de la inocencia", loc.cit.) Asimismo, a pesar de la multiplicidad que apreciaba en la poesía de Tomás Segovia, Sucre consideraba que en ella había una unidad esencial. Refiriéndose al ensayo "La piedra y el fuego", publicado en Mundo Nuevo, Guillermo señalaba que "como su poesía misma, la reflexión de Segovia en estas notas se bifurca y aun se explaya en múltiples direcciones, tras las cuales hay siempre un tema recurrente que las reúne y las concentra. Ese tema parece ser el exilio y la errancia del hombre." (Guillermo Sucre: "La poesía como reconocimiento", loc.cit.)

${ }^{556}$ Guillermo Sucre: Borges, el poeta, Caracas, Monte Ávila, 2a ed., 1974, p. 63. 
citado, Sucre proponía que la imagen más definitiva del autor argentino era la "clásica" ${ }^{557} \mathrm{y}$, a partir de ella, explicaba toda su obra. Al estudiar la poesía del argentino en base a esta constante que según el crítico es la que condensa su "verdadera significación" ${ }^{558}$, Guillermo tendía a atenuar las diferencias entre el periodo ultraísta y su creación posterior. Por eso afirmaba que la segunda época de su poesía, "tan distinta de la primera por el lenguaje y las formas", está sin embargo "estrechamente ligada a ella en la continuidad de una misma meditación poética, de un mismo espíritu”, y concluía que "ambas épocas parecen estar regidas por un mismo sentimiento ante el destino, por esa suerte de secreta sabiduría del mundo con que el Borges de la juventud ya se definía",559. Asimismo, en el ensayo "Relectura de Darío", Sucre estudiaba al iniciador de la poesía moderna hispanoamericana en la órbita simbolista y al final de ese escrito definía qué era lo esencial de su obra:

En el primer poema de Cantos llega a expresar su verdadera arte poética: la purificación a través de la palabra. "De desnuda que está, brilla la estrella", escribe. Esta simplicidad como búsqueda de lo auténtico es lo que más puede conmover de la poesía de Darío. Algo más que búsqueda estilística: búsqueda vital. Ante ella se desvanecen todas las falsas imágenes que han ido enmascarando el rostro de Darío. ${ }^{560}$

Basándose en la actitud fundamental que advertía en este texto, el crítico evitaba distinguir diferentes etapas en su creación y prefería hablar de una profundización: "Se

557 “Borges un espíritu clásico? Si el clasicismo es más una actitud esencial que una simple escuela con su connotación histórica, Borges es ciertamente clásico. No sólo porque aspira a un «sentido ecuménico, impersonal» del arte, sino también porque convierte sus propias limitaciones en punto de partida. [...] la poesía de Borges, como toda su obra, es en gran medida una inmensa metáfora sobre el hombre y el universo. En tal sentido es también clásica. Como lo dice Borges en uno de sus últimos ensayos: «Clásico es el libro que una nación o un conjunto de naciones o el largo tiempo han decidido leer como si en sus páginas todo fuera deliberado, fatal, profundo como el cosmos y capaz de interpretaciones sin término». El destino de Borges se identifica, en última instancia, con el destino de la palabra, del poema, de la poesía misma. De ahí su valor ejemplar." (Ibíd., p. 153)

558 Al final de la obra sobre Borges, nuestro crítico se pregunta lo siguiente: “¿Cómo condensar finalmente la verdadera significación de la poesía de Borges? No deja de ser difícil. Cada momento de esta poesía -lo mismo ocurre con toda la obra borgiana- se debate entre múltiples contradicciones; en el sentido último que resulta de tales contradicciones es donde hallamos su línea de intensidad, su última coherencia. El despojamiento del lenguaje que ella persigue no es sólo tentativa de ascesis interior; también el mundo se ve así reducido a sus formas esenciales.” (Ibíd., p. 149)

${ }^{559}$ Ibid., p. 24. A este respecto Sucre afirmaba también lo siguiente: "Si, desde un punto de vista teórico, Borges, como lo hemos visto, se mostraba ultraísta, lo esencial de su poesía no sólo trasciende el método ultraísta, sino que en cierto modo podría ser su negación.” (Ibíd.)

${ }^{560}$ Guillermo Sucre: "Relectura de Darío", loc.cit., p. 68. 
dice que a partir de Cantos de vida y esperanza se produce un cambio sustancial en Darío. El propio poeta parece reconocerlo en muchos poemas de este libro. Ello es cierto, pero solo en la medida en que ese cambio significa una visión más radical de las cosas. Ciertamente, una lucidez crítica e implacable se apodera de Darío" ${ }^{\text {561 }}$. De modo semejante, en un artículo sobre la poesía de César Vallejo, Sucre establecía que la constante fundamental de la obra del peruano era la búsqueda de la inocencia e interpretaba toda su creación a partir de ella: "Vallejo es el poeta en exilio. Desterrado de su morada, de su verdadero reino, vive errante: no sólo geográfica sino también, y sobre todo, espiritualmente. Errante, no logra fundar nada estable: es el perpetuo movimiento del hombre que se siente extraño en el mundo, pero que extraña su origen. [...] toda su poesía está dominada por este rapto de la partida y de la huida"562. Guillermo fundaba la coherencia de la obra de Vallejo en base a ese topos, cuyo apogeo se hallaba en su poemario póstumo España, aparta de mí este cáliz (1939). En ese libro “el tema de la madre y del hogar culminan en una dimensión realmente cósmica. La madre personal se transfigura en un ser colectivo, la «madre España». Y a la vez las estructuras del hogar (la solidaridad familiar) se proyectan en un sentido universal: la solidaridad humana y social en el combate y el nuevo orden histórico que habrá de surgir de ese combate" ${ }^{, 563}$.

${ }^{561}$ Ibid., p. 65. Cursiva nuestra.

${ }_{562}^{562}$ Guillermo Sucre: "Vallejo: la nostalgia de la inocencia", loc.cit.

${ }^{563}$ Ibíd. Sobre este libro, Sucre indicaba además que era "algo más que un libro de circunstancia. En él culmina toda la energía recóndita de la obra de Vallejo en más de un sentido: retorno a la morada y a la unidad del Ser, ascesis, liberación, trascendencia de la historia misma." Del mismo modo, en la poesía de Fombona Pachano, Guillermo advertía una continuidad en base a la fidelidad que el autor establecía consigo mismo: "Iluminado a su manera, con irreductible fidelidad a su propio mundo, su poesía sigue [...] la verdad que en ella misma se iba revelando." El carácter necesario y auténtico de la obra del venezolano imponía que no se pudiera hablar en ella de evolución, sino de intensificación: "De Virajes a Estelas [primer y último libros de Fombona] se desarrolla toda una rica, diversa y compleja corriente de creación. Hablamos de desarrollo en el sentido no de superación técnica o formal, sino de una progresiva y cada vez más honda conquista del ideal estético que todo poeta asume, casi siempre sin formulárselo explícitamente, en lo más profundo de su espíritu." (Guillermo Sucre: "Introducción", a Jacinto Fombona: Poesías...op.cit., p. 10 y p.12. La cursiva corresponde a la negrita del original.) 
Esta concepción crítica de Guillermo es una consecuencia del desarrollo del pensamiento estructuralista y, en particular, de las ideas de Roland Barthes y Octavio Paz. Ambos intelectuales había rechazado los postulados deterministas y había insistido en que la crítica debía ocuparse exclusivamente del sistema-obra. En su texto "Las dos críticas" Barthes había impugnado la crítica tradicional porque se basaba en el "postulado de analogía" y relacionaba "la obra estudiada con otra cosa, con algo distinto de la literatura". En vez de conceder tanto peso a las "circunstancias de la obra" Barthes defendía "el análisis inmanente"564 que permitía acercarse al "sentido funcional" $" 565$ de la misma. En otro ensayo proponía que para él la literatura "no es más que un lenguaje, es decir, un sistema de signos: su ser no está en su mensaje, sino en su «sistema». Y de ahí que la crítica no tenga que reconstruir el mensaje de la obra, sino solamente su sistema" ${ }^{\text {566 }}$. Estas ideas coinciden con la concepción crítica de Guillermo que, haciéndose eco de lo propuesto por el pensador francés, había señalado que la validez de la literatura "está dada en el propio universo formal de la obra, en sus potencias constructivas", y afirmaba, citando a Ionesco, que "«el valor de una obra reside en el hecho de que uno percibe que es idéntica a sí misma»»"567.

También Octavio Paz se había acercado en estos años al pensamiento estructuralista, sobre todo a partir de la lectura de Lévi-Strauss ${ }^{568}$ y Roman Jakobson. El mexicano tomó de esa corriente dos ideas fundamentales -el concepto de sistema y la noción de las diferencias significativas- y las aplicó al estudio de la literatura. De

${ }^{564}$ Roland Barthes: "Las dos críticas”, en Ensayos críticos, op.cit., p. 343.

565 Ibíd., p. 340. La cita continúa: "este algo distinto puede ser otra obra (precedente), una circunstancia biográfica o también una «pasión» realmente experimentada por el autor y que él «expresa» (siempre la expresión) en su obra." (Ibid.)

${ }^{566}$ Roland Barthes: “¿Qué es la crítica?”, en Ensayos críticos, op.cit., p. 351. En consonancia con su concepción irrealista del lenguaje, Barthes pensaba que éste "no es verdadero o falso, es válido o no lo es: válido, es decir, que constituye un sistema coherente de signos. Las reglas que condicionan el lenguaje literario, no afectan a la conformidad de ese lenguaje con lo real [...] sino tan sólo a su sumisión al sistema de signos que el autor se ha fijado." (Ibíd., p. 349)

${ }^{567}$ Rodrigo Antúnez [Guillermo Sucre]: "Literatura crítica", loc.cit.

${ }^{568}$ Octavio Paz: Claude Lévi-Strauss o el nuevo festín de Esopo, en OOCC, Vol. VI, op.cit., pp. 1246-1346. Este texto se publicó por primera vez en 1967. 
acuerdo a la idea de sistema, las diferencias cronológicas pasan a un segundo plano y lo fundamental son los vínculos que mantienen entre sí los componentes que forman parte de esa estructura. La noción de las diferencias significativas implica que dentro de un mismo sistema el valor de cada elemento depende de las relaciones de alteridad que establece con los demás, de manera que cada parte toma su sentido en contraste con el resto. Paz adaptó estas ideas a su concepción de la historia literaria ${ }^{569}$, pero también al estudio de las obras concretas ${ }^{570}$. Como se aprecia en los ensayos contenidos en Cuadrivio (1965), Octavio Paz pensaba la literatura como una actividad autónoma y las obras como sistemas homogéneos y coherentes, concepción que luego Sucre heredaría. Mucho antes del advenimiento del estructuralismo, Charles Baudelaire -a quien Sucre consideraba el verdadero iniciador de la crítica moderna ${ }^{571}$ - ya había afirmado que la labor del crítico consistía en "buscar la cualidad característica del genio",572 y había propuesto asimismo que la obra era un sistema en que todo respondía al control consciente del autor: "No hay azar en el arte, como tampoco lo hay en la mecánica. [...] Un cuadro es una máquina en la que todos los sistemas son inteligibles para la mirada adiestrada; en la que todo tiene se razón de ser, si el cuadro es bueno"573.

\footnotetext{
${ }^{569}$ Para ver de qué manera aplica estas ideas a su estudio de la historia literaria vid. Octavio Paz: “Apéndices" a Claude Lévi-Strauss o el nuevo festín de Esopo, en OOCC...op.cit., pp. 1343-1344.

${ }^{570}$ Estas ideas son aplicables también al estudio de unidades menores como las obras concretas. Como afirma en un texto publicado en Corriente alterna (1967): "la lingüística, la teoría de la información y la antropología estructural de Lévi-Strauss abandonan las explicaciones lineares y coinciden en su visión de la realidad como un sistema de relaciones sincrónicas. Célula, palabra, signo, grupo social: cada unidad es un conjunto de partículas, a la manera de las del átomo; cada partícula, más que unidad aislada, es una relación." (Octavio Paz: "Una forma que se busca", en OOCC, Vol. VI, op.cit., p. 1442)

571 “Con Baudelaire surge -o más bien, se reafirma- un tipo de escritor en quien la lucidez se da como una dialéctica dramática entre la inteligencia más extrema y la más profunda intensidad del alma. «Hay que soñar y saber soñar», decía. Por ello su crítica no sólo fue casi infalible para su época; fue también una crítica visionaria. Tiene una triple validez: es una magnífica traducción de las obras estudiadas, sirve para esclarecer el movimiento interior de la propia obra poética de Baudelaire y, finalmente, funda la estética del futuro: la de Mallarmé y Rimbaud, la de Paul Valéry, y aun la del surrealismo. Más que Sainte-Beuve, el crítico profesional de su época, Baudelaire es el verdadero creador de la crítica moderna." (Guillermo Sucre: "Baudelaire. Soñar y saber soñar”, loc.cit.)

${ }^{572}$ Vid. supra nota 344, p. 126.

${ }^{573}$ Charles Baudelaire: "Salón de 1846”, en Obras, op.cit., p. 486.
} 
Lo que hemos dicho hasta ahora se refiere sobre todo a una concepción particular de la obra literaria y a sus efectos en la crítica. Sin embargo, nos falta por estudiar el papel propio del crítico, al que Sucre asignaba un papel fundamental. En efecto, a partir de este momento (1964-1968) nuestro autor comenzó a hablar de "crítica poética” ${ }^{, 574}$ y a conceder a esta disciplina una dimensión esencialmente creativa. Así, ésta dejaba de ser únicamente un trayecto del crítico hacia la obra dada para ser al mismo tiempo un camino hacia sí mismo. "Paz, como ensayista, -nos dice Sucreescribe no sólo para valorar, definir o situar, sino también para buscarse a sí mismo. Esto le comunica a sus textos críticos un valor distinto: el valor de la creación misma" 575 . Por eso, aunque los cuatro ensayos que componen Cuadrivio "posiblemente fueron escritos sin pensar en reunirlos en volumen. Tienen, sin embargo, una unidad. Esta unidad está dada por la obra misma de los cuatro poetas estudiados; pero es también la unidad del propio Paz, la proyección de sus búsquedas, el espejo de su verdadero rostro" ${ }^{576}$. En los críticos practicantes ${ }^{577}$, como Borges o el propio Paz, Sucre advertía una complementariedad entre los ensayos críticos y la propia práctica poética que le llevaba a afirmar lo siguiente:

El poeta y el ensayista -queremos decir el pensador- se complementan en Paz. Entre los escritores hispanoamericanos habría que situarlo al lado de Jorge Luis Borges. Los ensayos de ambos son autoiluminaciones. Borges discurre sobre la metafísica y el tiempo, sobre poesía inglesa y mitología germánica, sobre Whitman y Paul Valéry; en el fondo discurre sobre sí mismo. Paz nos habla de Rimbaud, del surrealismo, de Rubén Darío, de literatura oriental; en el

574 Este término, Sucre lo toma de Baudelaire: "El propio Baudelaire fue quizá uno de los primeros en hablar de crítica poética, y la concebía como una crítica «parcial, apasionada, política». Pero añadía también: "hecha desde un punto de vista exclusivo, pero desde un punto de vista que abra los mayores horizontes»." (Guillermo Sucre: "Baudelaire. Soñar y saber soñar", loc.cit. La cursiva corresponde a la negrita del original. )

${ }^{575}$ Guillermo Sucre: "El diálogo con el mundo", loc.cit.

${ }^{576}$ Ibíd. La cita sigue: "En Darío, López Velarde, Pessoa y Cernuda, Paz se reconoce. Sabe que no proviene de ellos, sino que se reúne con ellos." Y esto "no por narcisismo, sino porque se tiene un mundo."

${ }^{577}$ Aunque no menciona directamente este concepto, Sucre estaba familiarizado ya en esta época con el pensamiento de Eliot y de hecho le cita en un estudio publicado en Imagen: "Rodríguez Monegal es el crítico por excelencia, o, como diría Eliot, el supercrítico: no está movido ni por el simple fervor ni por complicidades con una práctica literaria. Estudia la obra como algo ajeno a él, pero con la cual de alguna manera se identifica y por lo tanto reconoce su calidad. Tiene, por ello, el don de la crítica verdaderamente creadora, o «poética», como la definía Baudelaire." (Guillermo Sucre: "Neruda y el tiempo recobrado", loc.cit.) 
fondo también nos habla de sí mismo. Pero nos habla de sí mismo no por narcisismo, sino porque se tiene un mundo. Ambos lo tienen. ${ }^{578}$

Considerar la crítica como una actividad esencialmente creativa supone que la personalidad del exegeta ha que participar irrenunciablemente en ella. De nuevo nos topamos aquí con Charles Baudelaire, quien en el texto “¿Para qué la crítica?”-citado con frecuencia por Sucre- había reclamado la intervención en ella de la pasión y del carácter del intérprete: "munido de un criterio seguro, criterio tomado de la naturaleza, el crítico tiene que cumplir su deber con pasión; pues por ser crítico no se deja de ser hombre, y la pasión aproxima los temperamentos análogos y levanta la razón a nuevas alturas" esa otra, fría y algebraica que, bajo pretexto de explicarlo todo, no tiene odio ni amor y se despoja voluntariamente de toda especie de temperamento" ${ }^{980}$. Pero además, la dimensión creativa que Guillermo asignaba a la crítica literaria tenía que ver con la "crisis general del Comentario",581 que en estos años Roland Barthes estaba poniendo de manifiesto. En su obra Crítica y verdad (1966), el teórico francés había señalado que la nueva crítica redistribuía "los papeles del autor y del comentador" y atentaba "mediante ello, al orden de los lenguajes" $" 582$. Firme en su postura anti-logocéntrica, este pensador cuestionaba la división tradicional entre los géneros literarios pues todos ellos dependen del empleo del lenguaje: "no hay ya poetas, ni novelistas: no hay más que una escritura" ${ }^{583}$. Esto determinaba que el propio crítico pasara a considerarse escritor, pues

Es escritor aquel para quien el lenguaje crea un problema, que siente su profundidad, no su instrumentalidad o su belleza. [...] Si la crítica nueva tiene alguna realidad, ésta se halla, no en la unidad de sus métodos, menos aún en el esnobismo que, según dicen cómodamente, la sostiene, sino en la soledad del acto crítico, afirmado en adelante, lejos de las coartadas de la ciencia o de las instituciones, como un acto de plena escritura. En otra época separados por el

${ }^{578}$ Guillermo Sucre: “El diálogo con el mundo", loc.cit.

${ }^{579}$ Charles Baudelaire: “¿Para qué la crítica?” en Obras, op.cit., p. 478.

${ }^{580}$ Ibíd., p. 478. Allí proponía también: "para ser justa, es decir, para tener razón de existir, la crítica debe ser parcial, apasionada, política, es decir, realizada desde un punto de vista exclusivo, pero que sea el punto de vista que abra mayor número de horizontes.” (Ibíd., p. 478)

${ }^{581}$ Roland Barthes: Crítica y verdad, op.cit., p. 50.

${ }^{582}$ Ibid., pp. 13-14.

${ }^{583}$ Ibid., p. 47. 
gastado mito del "soberbio creador y del humilde servidor, ambos necesarios, cada cual en su lugar, etc.”, ahora el escritor y el crítico se reúnen en la misma difícil condición, frente al mismo objeto: el lenguaje. ${ }^{584}$

La participación necesaria en la crítica de la subjetividad del intérprete implicaba que esta disciplina dependiera ahora de dos subjetividades y de dos lenguajes: el de la obra literaria y el del crítico-escritor. Según afirmaba Guillermo en un texto sobre Baudelaire, la crítica poética "es sobre todo aventura del espíritu: nace frente a la individualidad misma de la obra como un encuentro de dos espíritus privilegiados" Sucre reconocía esta misma cualidad en la obra El viajero inmóvil (1966) de Emir Rodríguez Monegal. La crítica del intelectual uruguayo “es «poética» [...] en la medida en que sabe situarse dentro de la pasión misma que engendra a la poesía de Neruda, sin rehuir las contradicciones ni aun los excesos de esa pasión"586.

Al tener el mismo estatuto que la creación y depender esencialmente del temperamento del sujeto que escribe, la crítica debía cancelar los excesos y aunar de forma equilibrada la pasión y la inteligencia. De la misma manera que en la creación literaria propiamente dicha la visión del autor debía coincidir con su lenguaje, así también en la crítica la mirada sobre la obra debía ajustarse a la escritura del crítico. Por lo tanto, Guillermo estaba aplicando a la actividad crítica el mismo ideal de saturación que vimos a propósito de la creación literaria. Siguiendo ese modelo, Guillermo rechazaba aquellos estudios que no lograban conciliar adecuadamente la sensibilidad y la reflexión, como la crítica impresionista y la universitaria. En la primera "la lucidez y el análisis se ven reemplazados por un supuesto lenguaje lírico que pretende así «recrear» el sentido de la obra"587; la segunda, por su parte, se quedaba en las fórmulas abstractas propias del conocimiento erudito. Sucre se interesaba, en cambio, por esa

\footnotetext{
${ }^{584}$ Ibid., p. 48.

${ }^{585}$ Guillermo Sucre: "Baudelaire. Soñar y saber soñar", loc.cit.

${ }^{586}$ Guillermo Sucre: "Neruda y el tiempo recobrado", loc.cit.

${ }^{587}$ Ibid.
} 
crítica que presentaba un "desenvolvimiento poético" y que, por tanto, no se olvidaba

del rigor. Eso es lo que representaban para él los estudios de Octavio Paz:

Sin caer en el rapto lírico de cierta crítica impresionista, los ensayos de Paz tienen un desenvolvimiento poético. Se siente que no es un crítico profesional, mucho menos universitario, el que habla en ellos; sino un poeta, pero un poeta de lógica impecable. Ese desenvolvimiento tiene un especial rigor: no excluye la objetividad, pero detrás de ésta una intuición más profunda sabe rescatar la obra en toda su riqueza y complejidad. ${ }^{588}$

También en este sentido nuestro autor retomaba la lección de Barthes, que en su texto “QQué es la crítica?” había respondido diciendo que es ante todo un ajuste entre dos lenguajes, el del crítico y el de la obra, por lo que su cometido

no es "descubrir" en la obra o en el autor analizados, algo "oculto", "profundo", "secreto" que hubiera pasado inadvertido hasta entonces [...] sino tan sólo ajustar [...] tanteando "inteligentemente", dos piezas de un mueble complicado, el lenguaje que le proporciona su época (existencialismo, marxismo, psicoanálisis) con el lenguaje, es decir, con el sistema formal de sujeciones lógicas elaborado por el autor según su propia época. ${ }^{589}$

La crítica es entonces "una especie de anamorfosis" de la obra, "una transformación vigilada" en que ella no es nunca "un puro reflejo" ${ }^{\natural 90}$. Por lo tanto,

Agregando su lenguaje al del autor y sus símbolos a los de la obra, el crítico no "deforma" el objeto para expresarse en él, no hace el predicado de su propia persona; reproduce una vez más, como un signo desprendido y variado, el signo de las obras mismas cuyo mensaje, infinitamente examinado, no es tal "subjetividad", sino la confusión misma del sujeto y del lenguaje, de modo que el crítico y la obra digan siempre: soy literatura, y que, por sus voces conjugadas, la literatura no enuncie jamás la ausencia del sujeto. ${ }^{591}$

La perfección crítica consiste entonces en alcanzar un ideal de precisión y de “justeza”. Según Barthes, para que el estudio literario sea válido "es menester que el crítico sea justo y que intente reproducir en su propio lenguaje [...] las condiciones simbólicas de la obra; de no hacerlo así, precisamente, no puede «respetarla»" ${ }^{\natural 92}$. O,

${ }^{588}$ Guillermo Sucre: "El diálogo con el mundo", loc.cit. En el mismo ensayo dice "La tentativa crítica de Paz no es, pues, valoración de «scholar»; mucho menos simple recreación emotiva."

${ }^{589}$ Roland Barthes: “¿Qué es la crítica?”, en Ensayos críticos, op.cit., p. 350.

${ }^{590}$ Roland Barthes: Critica y verdad, op.cit., p. 66.

${ }^{591}$ Ibid., p. 73-74. "Como la del escritor, la anamorfosis que el crítico imprime a su objeto está siempre dirigida: debe siempre ir en el mismo sentido. ¿Cuál es ese sentido? ¿Es el de la «subjetividad» con el cual aturden [cuestionan] al nuevo crítico? [...] la crítica afronta un objeto que no es la obra, sino su propio lenguaje. ¿Qué relación puede tener un crítico con el lenguaje? Es por ese lado que debemos tratar de definir la «subjetividad» del crítico." (Ibid., p. 72)

${ }^{592}$ Ibid., pp. 75-76. Roland Barthes pensaba, como Sucre, que la crítica debía tratar de establecer una coherencia con la obra estudiada. En referencia a la obra de Richard, El universo imaginario de Mallarmé afirmaba lo siguiente: "Lo que el crítico trata de encontrar serán pues transformaciones reglamentadas, no aleatorias, que atañen a cadenas muy extendidas (el pájaro, el vuelo, la flor, el fuego de 
dicho de otro modo, “en crítica, la palabra justa sólo es posible si la responsabilidad del «intérprete» hacia la obra se identifica con la responsabilidad del crítico hacia su propia palabra" ${ }^{, 593}$. Este ideal de saturación, es decir, este reclamo de fidelidad entre la obra literaria y el discurso sobre ella, hacía de la crítica un género relativo e histórico. Al ser un ajuste entre la obra literaria y la mirada/escritura del intérprete, Sucre pensaba que debía surgir "desde la perspectiva vital de cada generación" 594 y de cada crítico: no se la podía concebir "como un simple género que ya se ha estratificado en la historia" que debía actualizarse permanentemente. La crítica, por lo tanto, es incapaz de determinar el sentido definitivo de una obra pues -como nos enseña magistralmente el cuento de Borges "Pierre Menard, autor del Quijote"596 - éste es siempre múltiple y no se

artificio, el abanico, la mariposa, la bailarina, en Mallarmé), que permiten relaciones lejanas pero legales (el gran río calmo y el árbol otoñal), de suerte que la obra, lejos de ser leída de una manera «delirante», se halle penetrada por una unidad cada vez más vasta." (Ibíd., p. 71)

${ }^{593}$ Ibid., pp. 76-77.

${ }^{594}$ Guillermo Sucre: "Presencia de la crítica", loc.cit.

595 Ibíd. Esta concepción histórica de la crítica es aplicable a su concepción de la literatura. En verdad, crítica y literatura tienen en Sucre una relación complementaria. La relación del crítico con la obra literaria es semejante a la del escritor convencional con el mundo. Antes que Guillermo esta homología la habían establecido Baudelaire y Octavio Paz. Según nos dice el propio Sucre, para el primero, "así como el poeta es el traductor de las analogías universales, así también el crítico es el traductor de los signos ocultos de una obra." (Guillermo Sucre: "Baudelaire. Soñar y saber soñar", loc.cit.). Octavio Paz, por su parte, había establecido una complementariedad entre la crítica y la creación de manera que ninguna de las dos podía existir sin la otra. "Crítica y creación viven en perpetua simbiosis. La primera se alimenta de poemas y novelas pero a su vez es el agua, el pan y el aire de la creación." Y señalaba también que la relación de la obra literaria con el mundo es simétrica a la relación de la crítica con la obra: "en nuestra época la crítica funda la literatura. En tanto que esta última se constituye como crítica de la palabra y del mundo, como una pregunta sobre sí misma, la crítica concibe a la literatura como un mundo de palabras, como un universo verbal. La creación es crítica y la crítica, creación." (Octavio Paz: "El espacio del reconocimiento", en OOCC, Vol. II, op.cit., p. 1146; p. 1151) Siguiendo estas ideas, Guillermo establecía para muchos de los autores que estudia una relación complementaria entre la poesía y la crítica que conducía en ambos géneros a una conciliación adecuada de la pasión y el rigor. "La poesía de Baudelaire - dice Sucre- es crítica por su extremada lucidez; pero, a la vez, su crítica es poética por el impulso que ella toma en la imaginación y en la pasión." (Guillermo Sucre: "Baudelaire. Soñar y saber soñar", loc.cit) Esta misma simetría la destacaba nuestro autor a propósito de Octavio Paz, que si como poeta "nos restituye la intensidad intelectual de la palabra poética", como ensayista "nos devuelve la pasión universal de las ideas." (Guillermo Sucre: "El diálogo con el mundo", loc.cit.). También en André Breton, Sucre destacaba una complementariedad entre el instinto y la reflexión, entre la lógica y la revelación (Guillermo Sucre: "Reconciliar el universo", en Zona Franca, Caracas, núm. 39, nov. 66, pp. 2-3)

596 Jorge Luis Borges: "Pierre Menard, autor del Quijote", en OOCC, Vol. I, op.cit., pp. 444-450. A este respecto, Barthes afirmaba que "la obra detenta al mismo tiempo muchos sentidos, por estructura, no por la invalidez de aquellos que la leen." Y también: "sea lo que piensen o decreten las sociedades, la obra las sobrepasa, las atraviesa, a la manera de una forma que vienen a llenar, uno tras otro, los sentidos más o menos contingentes, históricos: una obra es «eterna», no porque imponga un sentido único a hombres diferentes, sino porque sugiere sentidos diferentes a un hombre único, que habla siempre la 
puede fijar como pretendía la filología tradicional. La crítica entonces es un ajuste entre dos subjetividades y dos lenguajes que, si bien busca la perfección en su relatividad, está siempre datado y debe actualizarse sin cesar.

En suma, vemos que en la concepción de Sucre la crítica literaria implica un paradigma de saturación en dos sentidos: por una parte, el intérprete debe determinar "la verdad" de la obra y establecer, a partir de ella, su coherencia interna; por otra, debe ajustar su propia escritura con la visión que tiene de la obra. Ambas ideas son coherentes con la apreciación de Guillermo sobre la literatura que, como hemos visto, debía ser un modelo de orden y completitud en que el exceso de cosas y de palabras no tuviera lugar. 


\section{CAPÍTULO V}

\section{LA POLÍTICA ESTÉTICA DE GUILLERMO SUCRE (1958-1968)}

En este capítulo nos proponemos, a modo de conclusión de los capítulos precedentes, exponer la política estética que está implícita en el pensamiento literario y en la crítica de Guillermo Sucre. Con la expresión "política estética" no nos referimos a la toma de posición del artista en los conflictos políticos o sociales de la época, a su pertenencia a un determinado partido o a la manera en que su obra representa un tema o un motivo susceptible de tener consecuencias políticas. Con ella aludimos al hecho de que toda estética implica una política en tanto que estética, es decir, que contribuye como tal "a diseñar un paisaje nuevo de lo visible, de lo decible y de lo factible"597. Es en este sentido que Ranciére ha establecido una complementariedad entre la política y la estética:

Hay una estética de la política en el sentido en que los actos de subjetivación política redefinen lo que es visible, lo que se puede decir de ello y qué sujetos son capaces de hacerlo. Hay una política de la estética en el sentido en que las formas nuevas de circulación de la palabra, de exposición de lo visible y de producción de los afectos determinan capacidades nuevas, en ruptura con la antigua configuración de lo posible. Hay entonces una política del arte que precede a las políticas de los artistas, una política del arte como recorte singular de los objetos de experiencia común, que opera por sí misma, independientemente de los anhelos que puedan tener los artistas de servir a una u otra causa. ${ }^{598}$

Ahora bien, para comprender adecuadamente la política estética que está implícita en la propuesta de Guillermo Sucre es imprescindible que expliquemos primero de qué manera y en qué medida la literatura, en tanto que literatura, tiene alcances políticos, para lo que tomaremos como base las ideas de Jacques Ranciére.

597 Como ha dicho el propio pensador: "Las prácticas del arte no son instrumentos que proporcionen formas de conciencia ni energías movilizadoras en beneficio de una política que sería exterior a ellas. Pero tampoco salen de ellas mismas para convertirse en formas de acción política colectiva. Contribuyen, más bien, a diseñar un paisaje nuevo de lo visible, de lo decible y de lo factible." (Jacques Ranciére: "Las paradojas del arte político", en El espectador emancipado, Pontevedra, Ellago ediciones, 2010, p. 78)

${ }^{598}$ Ibid., p. 67. 
En el Fedón, Platón había establecido que la escritura es ante todo "un régimen específico de enunciación y de circulación de la palabra y del saber, el régimen de una enunciación huérfana, de una palabra que habla sola, olvidada de su origen, despreocupada con respecto a su destinatario" ${ }^{\text {599 }}$. Para el discípulo de Sócrates este nuevo régimen se identificaba con el principio mismo del orden político -la democracia ${ }^{600}$ - en la medida en que, alejada del respaldo de la autoridad que supone la palabra hablada, permitía a cualquiera apropiarse de ella y a cualquiera recibirla. En cuanto que podía ser empleada y recibida por no importa quién, la escritura constituía una amenaza para el orden social conservador que el filósofo proponía en La República, de acuerdo al cual cada sujeto se ocuparía solamente de la labor que le era propia y que le venía asignada por naturaleza.

La poética aristotélica que gobernó el panorama estético en la Antigüedad primero y, después, en la época clásica (siglos XVI-XVIII), trató de controlar el igualitarismo potencial de la escritura y estableció para ello una relación necesaria entre los cuerpos y las significaciones que anulaba la presencia de agentes sobrenumerarios que pudieran amenazar la estabilidad del sistema. Sin embargo, a finales del siglo XVIII y principios del XIX se empezó a tambalear la estructura que había instituido la poética clasicista y asistimos a un resurgimiento de la escritura democrática, cuyo "modo propio de visibilidad y de disponibilidad" "confunde toda relación de pertenencia legítima de la

599 Jacques Ranciére: La palabra muda. Ensayo sobre las contradicciones de la literatura, Buenos Aires, Eterna Cadencia, 2009, p. 108.

${ }^{600}$ Es imprescindible comprender bien qué quiere decir Ranciére cuando habla de democracia: "Lo que caracteriza la democracia, es la suerte, la ausencia de título para gobernar. Es el estado de excepción donde no funciona ningún par de opuestos, ningún principio de repartición de roles. [...] La democracia es la situación específica donde es la ausencia de título quien da título al ejercicio del arkhé. Es el comienzo sin comienzo, el mandato de lo que no manda. Lo que se arruina con esto, es lo propio del arkhé, sin redoblamiento, que hace que ella se preceda siempre a sí misma, en un círculo de la disposición y de su ejercicio. Pero esta situación de excepción es idéntica a la condición misma de una especificidad de la política en general." (Jacques Ranciére: "Diez tesis sobre la política", en Política, policía, democracia, Santiago, LOM, 2006, p. 64). Y afirma también: "La democracia, entonces, no es para nada un régimen político, en el sentido de constitución particular entre las diferentes maneras de reunir hombres bajo una autoridad común. La democracia es la institución misma de la política, la institución de su sujeto y de su forma de relación." (Ibid., p. 65) 
letra escrita a la instancia que la enuncia, a la que debe recibirlo y a los modos según los cuales debe ser recibido"601. La literatura es precisamente el resultado de esa alteración, pues ella nace cuando se suprime el nudo que la poética clasicista había instaurado entre los cuerpos y las significaciones. En oposición al orden estético anterior, la literatura "no se dirige a ninguna audiencia específica que comparta una misma posición social y que extrajera de ese ethos unas reglas de interpretación y unos modos de sensibilidad ordenados",602. En ella la letra circula en libertad de manera que "cada cual puede retomarla a su propia cuenta, ya sea para apropiarse la vida de los héroes o heroínas de la novela o para hacerse él mismo escritor. [...] Se trata entonces de un nuevo reparto de lo sensible, de un nuevo vínculo entre el acto de la palabra, el mundo que él configura y las capacidades de quienes pueblan ese mundo" ${ }^{\circ 03}$.

Por lo tanto, la literatura se funda en lo que Ranciére llama la "literariedad democrática" ${ }^{604}$, que es precisamente lo contrario de la noción de literariedad difundida por el pensamiento modernista. Como dice el pensador francés, "la literariedad que ha vuelto posible la literatura como forma nueva del arte de la palabra no es ninguna propiedad específica del lenguaje literario. Al contrario, ella es la radical democracia de la letra de la que nadie puede adueñarse" ${ }^{, 605}$. Esta concepción hace de la novela realista la forma literaria por excelencia, pues ella marca la ruina de la coherencia y del todo que estaban en juego en la poética clasicista, introduciendo un exceso de cosas y un exceso de palabras. Por una parte, este género novelesco introduce detalles vanos y prescindibles que cuestionan la continuidad entre las causas y los efectos que proponía la lógica aristotélica. Por otra, emplea un lenguaje "petrificado" que tiene valor por sí mismo y que es el complemento formal de la ausencia de selección de cosas - es decir,

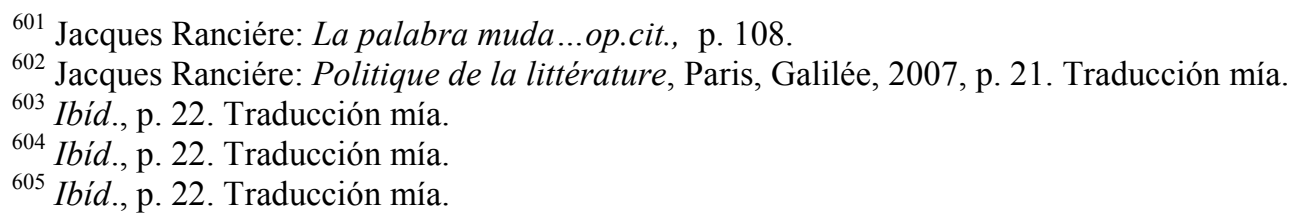


del principio de indiferencia que implica el nuevo paradigma ${ }^{606}$. Estos excesos en que incurre la novela realista son una consecuencia directa de la caída del decoro y de la pérdida del vínculo entre los cuerpos y las significaciones que estableció el sistema representativo y, curiosamente, fueron censurados tanto por los críticos reaccionarios del siglo XIX como por los progresistas del XX. Mientras que los segundos -entre los que podemos citar a Sartre o a Barthes- veían en el privilegio de la función referencial la defensa de un orden conservador del mundo, los primeros señalaron adecuadamente que el exceso realista de cosas y de palabras era la expresión misma de la democracia en literatura. Evidentemente, las desproporciones que los críticos del siglo XIX reprochaban a autores como Flaubert no tenían que ver con la estadística, sino con "la supuesta armonía" entre "la cuenta de los cuerpos y la cuenta de las palabras y las significaciones $" 607$ que había establecido el paradigma de las Bellas Letras. Como lo explica Ranciére, la democracia tiene que ver con la invención de palabras (como "proletario") que permiten contar a aquellos que no eran contados anteriormente, lo que supone introducir términos nuevos y enredar la división establecida entre los que hablan y los que callan que hacía de la comunidad política "una totalidad orgánica"608. El exceso de la democracia y de la literatura consiste entonces "en introducir otra cuenta que deshace el ajuste de los cuerpos a las significaciones" ${ }^{\$ 609}$ con el cual se consolidaba el orden social y literario anteriormente establecido. Como lo explica el profesor francés, el canon político y estético del sistema clasicista era

606 “el «exceso de palabras» se vincula al «exceso de cosas». La «elección de palabras» es estrictamente correlativo a la ausencia de selección de «cosas». El «estilo absoluto» es aquel que no selecciona [...]. Si el campeón del arte por el arte [Flaubert] es también el de las descripciones de los dramas de pueblo es porque el «tema» que corresponde exactamente a la potencia de desindividuación del estilo es la exploración de esas vidas en las fronteras de la individualidad." (Jacques Ranciére: "Borges et le mal français", en Politique de la littérature...op.cit., p. 157. Traducción mía)

607 Jacques Ranciére: "Le malentendu littéraire", en Politique de la littérature...op.cit., p. 51. Traducción mía. La cita sigue: "Lo que se compara no es densidad social de los cuerpos con su densidad novelesca, sino el orden o el desorden del vínculo entre los cuerpos y las palabras que regía esas dos formas de la ficción que son la ficción política y la ficción literaria.” (Ibíd., p. 51. Traducción mía)

${ }^{608}$ Ibid., p. 51. Traducción mía.

${ }^{609}$ Ibid., p. 51. Traducción mía. 
un paradigma de proporción entre los cuerpos y las significaciones, un paradigma de correspondencia y de saturación: no debe haber en la comunidad cuerpos de más, nombres-decuerpos que circulen en exceso a los cuerpos reales; no debe haber nombres flotantes y sobrenumerarios, susceptibles de constituir ficciones nuevas capaces de dividir el todo o de deshacer su forma y su ficcionalidad. Y tampoco en el poema debe haber cuerpos sobrenumerarios en relación a lo que necesita el agenciamiento de las significaciones, ni tampoco estados de cuerpos no vinculados por un lazo de expresividad definido a un estado de significaciones. ${ }^{610}$

Por lo tanto, la crítica conservadora del siglo XIX a la novela realista nos permite apreciar lo que verdaderamente estaba en juego: el esteticismo y la enumeración de detalles vanos resultaban impropios en relación al modelo de saturación a un tiempo político y estético que ofrecían las obras de las Bellas Letras, en que las partes estaban subordinadas al todo y los miembros obedecían a la cabeza. Frente a ese paradigma armónico, la novela realista era en cierta medida una creación monstruosa y desarreglada, en que la concatenación de las causas y los efectos ya no funcionaba y en que estaban mezcladas, sin ninguna jerarquía, personajes y cosas de cualquier condición. Pero, como decimos, la crítica a la novela realista y al exceso de cosas y de palabras que ella implicaba no se redujo a los críticos conservadores del siglo XIX sino que ha sido una constante en la teoría estética del siglo XX. Entonces se puede hablar de política de la literatura en la medida en que se trata de reglar la literariedad democrática que es la condición de posibilidad del arte de escribir que surge a comienzos del siglo XIX. En esas reglamentaciones lo que se pretende ordenar no son sólo desproporciones estéticas, sino más bien una profusión de elementos en relación a un orden político que se quiere para la sociedad y que implica un ajuste determinado de los cuerpos a las significaciones. En suma, lo que está en juego en esos planteamientos artísticos son diversos repartos de lo sensible.

El pensamiento estético y la crítica literaria que Guillermo Sucre expone a lo largo de los años sesenta tienen implicaciones políticas en el sentido que acabamos de 
explicar. Cuando comienza a participar en el campo literario venezolano, Guillermo se encuentra con una intelectualidad sin valores estéticos que escribía una literatura anárquica y provinciana. La carencia de jerarquías había dado lugar a que los méritos de los escritores se estableciesen en virtud de aspectos extraliterarios, como la pertenencia del autor a un determinado grupo o la sumisión de las obras a fines políticos, sociológicos o, simplemente, personales. La ausencia de criterios artísticos había motivado que las obras nacionales presentaran excesos de cosas y de palabras, es decir, que establecieran una desconexión entre la expresión y lo expresado que impedía a la literatura venezolana entroncar con la tradición literaria occidental. La inautenticidad que nuestro autor advertía en la literatura nacional era el resultado de dos vicios complementarios: el realismo y el esteticismo. Cuando la literatura se limitaba a comunicar un referente exterior incurría en un exceso de cosas que implicaba la sumisión de la forma a la significación. Las obras se veían colmadas entonces por detalles prescindibles que impedían su trascendencia estética. Por otro lado, cuando la forma se imponía sobre la significación, la literatura incurría en el exceso de palabras, es decir, en el empleo de procedimientos formales que no eran verdaderamente requeridos por el sentido de la obra. Estas desproporciones eran además las responsables de que la literatura venezolana no alcanzase la ansiada universalidad. Las creaciones que presentaban un exceso de cosas quedaban apegadas a una temática nacionalista que no conseguía repercusión más allá de las propias fronteras, y las que incurrían en el exceso de palabras resultaban cosmopolitas, pues caían en la imitación de técnicas modernas sin haberlas asimilado verdaderamente. Al impugnar estas profusiones que él consideraba el resultado de la inautenticidad de los escritores nacionales, Sucre retomaba la crítica que los lectores conservadores del siglo XIX y los progresistas del XX habían hecho a la novela realista decimonónica. Sin embargo, 
Guillermo no ejercía esta crítica porque echase de menos la armonía de las obras de la época clásica o para vincular la "petrificación" del estilo del novelista con la nostalgia de un orden conservador. Siguiendo la concepción humanista de Picón Salas, para él lo fundamental era que la literatura venezolana entroncase con una ética y una estética universales, pues al hacerlo conseguiría superar su dependencia y responder a las constantes del hombre y del arte de todos los tiempos. Para lograr este objetivo era imprescindible que la literatura tuviera un valor de verdad: las obras venezolanas debían ser saturadas y perfectas, y presentar una continuidad precisa entre los cuerpos y las significaciones de manera que la distancia entre la mirada y el lenguaje desapareciera. Sólo así se dejarían de alimentar las pretensiones vanas de una intelectualidad mezquina y se alcanzaría la política artística de las mejores obras de la tradición occidental, en las que Guillermo apreciaba los valores humanos, estéticos (y políticos) esenciales. En efecto, tal como expone en "Álgebra y fuego", Sucre pensaba que la poesía moderna debía armonizar los contrarios que dividen al hombre para que éste pudiera recuperar su verdadera naturaleza. En este sentido, nuestro autor remitía a lo expuesto en las Cartas sobre la educación estética del hombre de Schiller, texto que resumía así al comienzo de su ensayo:

El objetivo superior al que parece tender el hombre es la totalidad de su propia naturaleza. Y acaso el medio más privilegiado para alcanzarla sea, como decía Schiller, el poder de la belleza. El poder creador del arte. [...] En lo esencial, decía Schiller, el hombre no tiene una relación puramente racional ni puramente sensible con las cosas. Lo que ha de prevalecer en su contacto con el mundo es una relación estética. Lo que él llamaba el "instinto del juego", en el cual vienen a fusionarse el instinto de las formas y el instinto de la materia. Es así como el hombre se sustrae al reino de la necesidad y accede al reino de la libertad. ${ }^{611}$

En la concepción de Guillermo, los grandes poetas posteriores al romanticismo vivían "en un estado de nostalgia por la totalidad" que les llevaba a buscar una unidad superior capaz de conciliar los contrarios (el sujeto y el objeto, la pasión y la reflexión,

${ }^{611}$ Guillermo Sucre: “Álgebra y fuego”, loc.cit. 
lo individual y lo colectivo, etc. ${ }^{612}$ ) y de hacer que el hombre recuperara su ser original. Para alcanzar ese mundo conciliado, el poeta debía asumir la entera responsabilidad de su actitud creadora, con lo que llegamos a una paradoja que es solo aparente. Por una parte, la obra debía ser la expresión necesaria de una personalidad y debía establecerse en ella una continuidad precisa entre la mirada y el lenguaje que no dejara lugar al suplemento. Pero, por la otra, cuando se establecía esta coherencia entre la visión del poeta y su palabra, la creación conseguía revelar un mundo ético en que se ajustaban los opuestos y se alcanzaba el ser original del hombre y del mundo. Al hacer coincidir con precisión su mirada y su escritura, el poeta daba lugar, aunque fuera imaginariamente, a una realidad esencial, utópica y perfecta. De este modo, Sucre proponía una igualación entre la literatura (venezolana y universal) y un determinado reparto de lo sensible. Para él, el arte con palabras implicaba un ideal de saturación expresiva y era inseparable del establecimiento de una continuidad feliz entre las palabras y las cosas, y era en esa continuidad en la que Guillermo intuía los principios éticos y estéticos (y también políticos) del hombre universal.

La política del proyecto estético que Guillermo Sucre emprendió a lo largo de los años sesenta es correlativa a la "estética política"613 que puso en marcha a partir de 1958 la democracia venezolana, con la que nuestro autor se había comprometido desde su adolescencia. El objetivo fundamental del nuevo sistema político era consolidar por todos los medios la democracia representativa de partidos que comenzaba a instaurarse

${ }^{612}$ A este respecto Sucre ofrece los siguientes ejemplos: "«Todo lo que es visible se relaciona con lo invisible, lo audible con lo inaudible, lo sensible con lo insensible, y quizá lo pensable con lo impensable», era creencia arraigada en Novalis. «El mundo se convierte en sueño, y el sueño se convierte en mundo», era también idea suya. Idea dominante en los más grandes románticos. «Hacer lo externo interno, lo interno externo, volver la naturaleza pensamiento y el pensamiento naturaleza», constituía para Coleridge la actividad del genio. En ambos poetas, esta doble transmutación era un modo de romper la dualidad, de destruir la contradicción misma. «El objetivo supremo de la cultura -afirmaba igualmente Novalis- consiste en que uno se apodere de su Yo trascendental, convirtiéndolo así en el Yo de su yo». ¿No era éste ya un movimiento hacia la totalidad, hacia lo absoluto? «Creo en la solución futura de esos dos estados, aparentemente contradictorios, que son el sueño y la realidad, en una suerte de realidad absoluta, de superrealidad», afirmaba Breton en su primer Manifiesto." (Ibíd.)

${ }^{613}$ Para una explicación de este concepto vid. supra la cita de Ranciére en p. 203. 
en Venezuela tras una década de dictadura. Para lograr esta meta se estableció un sistema que hiciera posible el reparto de poder entre las principales agrupaciones políticas y en el que se sintieran representadas todas las fuerzas significativas del país. Además, el Estado se ocupó de repartir lo más ampliamente posible el poder político y económico de la nación de manera que no hubiera ningún grupo descontento con la democracia o, en todo caso, que los grupos descontentos fueran los menos posibles. La búsqueda del consenso en estos términos implicó la exclusión de los extremismos políticos que se oponían a la consolidación institucional: el golpismo militar, nostálgico del orden anterior a 1958, y el terrorismo de la izquierda revolucionaria que, siguiendo el ejemplo cubano y amparado por el gobierno de Fidel Castro, formó a partir de 1960 una guerrilla terrorista que trató de desestabilizar al gobierno. En ese contexto, la democracia se definió por ser el término medio entre las amenazas extremistas de la dictadura militar y del comunismo revolucionario. Frente a los radicalismos de cualquier signo, el Estado venezolano se convirtió en la expresión política de la mesura y del consenso.

Por lo tanto, el sistema puntofijista que fundó las bases de la IV República venezolana trató de crear un Estado ideal en que el suplemento de cuerpos o de nombres no tuviera lugar. La "mística democrática" resultante de la visión liberal y occidentalista propia de las élites venezolanas llevó a pensar que ese sistema político acabaría con todos los males del país y ello determinó una identidad entre el sistema democrático y el fin de la política. Esta equivalencia dio lugar a que el Estado venezolano adoptase un carácter policial, en el sentido que Ranciére da a esta palabra. Para este pensador la "policía" consiste en "un reparto de lo sensible caracterizado por la ausencia de vacío y de suplemento" y es, por lo tanto, lo opuesto de la política, que trata de perturbar "este arreglo suplementándolo de una parte de los sin-parte identificada con el todo mismo de 
la comunidad" ${ }^{\prime 614}$. En efecto, todo intento de establecer un consenso es policial porque precisamente "la esencia del consenso es la anulación del disenso como distancia de lo sensible consigo mismo, la anulación de los sujetos excedentarios, la reducción del pueblo a la suma de las partes del cuerpo social y de la comunidad política a relaciones de intereses y de aspiraciones de esas diferentes partes. El consenso es la reducción de la política a la policía"615. La democracia venezolana encaja en esta definición pues trató de establecer un sistema que acogiera a todos y excluyó de él solamente a aquellos que se oponían a las bases de su funcionamiento. En este sentido, su intención era utópica ya que buscaba crear "un buen lugar", "un reparto no polémico del universo sensible, en donde lo que hacemos, lo que vemos y lo que decimos se ajustan exactamente ${ }^{, 616}$. Ciertamente, cuando se cumple la armonía consensual y la sociedad no percibe ninguna distancia con respecto a sí misma los cuerpos y las significaciones coinciden a la perfección y la política desaparece, pues ella es precisamente un planteamiento litigioso sobre la relación entre las palabras y las cosas ${ }^{617}$.

Vemos, entonces, que la estética que Guillermo Sucre propuso a partir de 1958 y en la que basó su propia crítica literaria implicaba un determinado reparto de lo sensible que estaba vinculado a un ideal político. Al plantear un paradigma de saturación expresiva y tratar de que las obras nacionales lo secundaran, la estética de nuestro autor coincidía estructuralmente con las modificaciones que la democracia venezolana estaba impulsando en el mismo momento. Al igual que este sistema político quería fundar un

${ }^{614}$ Guillermo Sucre: "Diez tesis sobre la política", en Politica, policía...op.cit., p. 71.

${ }^{615}$ Ibid., p. 78. Es por eso que el consenso contribuye a crear un mundo ético, pues confunde su condición particular con el orden universal. "Al tratar de reducir el pueblo a la población, el consenso reduce el derecho al hecho. Su trabajo incesante consiste en tapar todos los intervalos entre el derecho y el hecho, por los cuales el derecho y el pueblo se dividen a sí mismos. La comunidad política es así transformada tendencialmente en una comunidad ética, en una comunidad de un solo pueblo en que todo el mundo se supone que está contado." (Jacques Ranciére: "Le tournant étique de 1'esthetique et de la politique”, en Malaise...op.cit., p. 153. Traducción mía)

${ }^{616}$ Jacques Ranciére: "Si es necesario concluir que la historia es ficción. De los modos de la ficción”, en El reparto de lo sensible...op.cit., pp. 51-52.

${ }^{617}$ Ibid., pp. 51-52. 
orden utópico y apolítico en que no hubiera cuerpos ni palabras de más, a través de su estética nuestro autor establecía una relación necesaria entre la visión y la escritura que no dejaba lugar a elementos sobrantes. Las obras debían ser organismos armónicos sin excesos de cosas ni de palabras, modelos de completitud capaces de conciliar el sujeto y el objeto, la pasión y la inteligencia, lo particular y lo general. Una vez alcanzado ese ideal la literatura revelaría un hombre conciliado y un mundo verdadero y esencial - sin cuerpos ni palabras de más y, por lo tanto, sin lugar para la disputa política.

Esta búsqueda de un orden ético, Guillermo la compartía con Picón Salas, que es su fuente más próxima y evidente, pero es visible también - de diverso modo y con diferentes consecuencias- en los grandes autores que fueron una referencia permanente de su pensamiento y de su crítica literaria. Aquí resumiremos, para no extendernos demasiado, la política estética de tres de estos autores: Picón Salas, Ángel Rosenblat y César Vallejo. La selección de los dos primeros está motivada porque compartieron el mismo contexto y una política artística semejante a la de Guillermo y son, de algún modo, sus maestros en este sentido ${ }^{618}$. En el caso del autor peruano se trata de ver que, si bien se comprometió con el comunismo, su estética implica un reparto de lo sensible similar al defendido por Sucre.

A través de sus escritos, Picón Salas defendió un paradigma de orden y saturación que era inseparable de un ideal político que anhelaba para Venezuela y para el continente. Este ensayista pensaba que los valores humanos y estéticos eran universales y trataba, por lo tanto, de que encontraran un arraigo en la cultura nacional. Los principios que Picón consideraba esencialmente humanos resultaban de la mesura y de la conciliación de los extremos: a través de la síntesis armónica de los opuestos se

${ }^{618}$ En la carta ya citada más arriba Guillermo destacaba la importancia de ambos en el desarrollo de su pensamiento y afirmaba lo siguiente: "Siento que he tratado de guiarme por la obra de Picón-Salas y la de Rosenblat, sobre todo en lo relativo al lenguaje." (Guillermo Sucre: "Carta I, octubre de 2012", infra en Apéndice I, p. 472). Apoyándome en las ideas de Ranciére, creo que con esa declaración Sucre está revelando en verdad que esos profesores moldearon su política estética y lingüística. 
alcanzaría la ordenación de la cultura venezolana y ésta hallaría las constantes del hombre universal. Esta búsqueda de la unidad se aprecia en todos los ámbitos del pensamiento de Picón Salas. En el aspecto cultural era preciso acordar la cultura europea con la tierra americana para lograr así que las manifestaciones artísticas e intelectuales tuvieran un arraigo en lo concreto. Por eso el ensayista reclamaba un ajuste entre las posturas cosmopolitas y las nacionalistas, pues sólo a través de esa conciliación sería posible crear obras verdaderamente significativas. En cuanto a la estética, Picón quería que los autores se implicaran personalmente en la creación, porque de otra manera ésta podía quedarse en lo superficial y, siguiendo la corriente simbolista, proponía una síntesis adecuada entre la pasión y la inteligencia. El ideal conciliador del merideño implicaba también un modelo de precisión lingüística: él quería que la palabra fuera la cosa o estuviera lo más cerca posible de ella.

El paradigma de orden defendido por el ensayista implicaba un reparto de lo sensible análogo al que estaba promoviendo la democracia social en Venezuela, todavía en ascenso ${ }^{619}$. La prueba de que esto es así la encontramos en que para Picón la desarmonía -es decir, el distanciamiento entre los cuerpos y las significaciones- estaba vinculada al caudillismo o a la montonera, es decir, a los sistemas políticos que la democracia venezolana quería dejar atrás. En esas situaciones se producía una desconexión entre la cultura y el medio que daba lugar a excesos que el ensayista desdeñaba:

Buscando el instinto más que la reflexión hemos solido olvidar el pensamiento de los héroes civiles -Gual, Fermín Toro, [...] Juan Vicente González, Cecilio Acosta- que supieron ver como pocos y teniendo la esperanza de mejorarla, la oscura y tumultuosa verdad autóctona. Después de ellos [...] comenzó la era de los "caudillos únicos", de los "césares democráticos"

${ }^{619}$ La obra de Picón se desarrolla aproximadamente entre 1917 y su muerte en 1965. Por lo tanto, es estrictamente paralela al ascenso político de la generación del 28 y de la democracia social en Venezuela. La relación entre Picón Salas y la democracia social la ha estudiado también Javier Lasarte, pero desde el punto de vista de la política discursiva. (Javier Lasarte Valcárcel: "Picón Salas: pensamiento crítico y democracia social", en Al filo de la lectura, Caracas, Universidad Católica Cecilio Acosta, Editorial Equinoccio, Universidad Simón Bolívar, 2005, pp. 131-144) 
bajo cuyo reinado el pensamiento nacional perdió su fuerza creadora y combativa o se ocultó y proliferó en el matorral de la inofensiva retórica. ${ }^{620}$

El hecho de que las ideas de Picón implicaban un modelo político se aprecia bien en un ensayo que escribió sobre Alfonso Reyes. En ese texto, el maestro de Sucre consideraba que la prosa del mexicano era un arquetipo de precisión que se oponía a las profusiones estéticas (y políticas) del XIX y valoraba positivamente el acuerdo que había logrado establecer entre el instinto y la reflexión: "Y por todo lo desmalezado, exuberante e inútil que había en la prosa y el saber hispanos en el siglo XIX, Alfonso Reyes forjó su idioma como puntal de exactitud y pulcra belleza. La inspiración y la arbitrariedad, los buenos gramos de locura que necesita también la obra de arte, pasaron siempre por el exigente tamiz de su inteligencia"621. Ese paradigma de completitud que Picón apreciaba en la obra de Reyes era un ejemplo, ante la amenaza de los fanatismos políticos, para la América en construcción: "Todo se decantó del desorden e impureza en esta obra ofrecida a una América conciliadora y cordial. La América del espíritu que debe ser. Es uno de los pocos y universales maestros que ofrecen «sofrosine» y «caridad» en los días de discordia» ${ }^{\prime 62}$. Ante el ideal armónico representado por Alfonso Reyes, el ensayista venezolano desdeñaba todo lo anárquico, lo informe, lo excesivo o lo no arraigado que apreciaba en la cultura hispanoamericana, pues en esas desmesuras apreciaba la pervivencia de un orden político que él quería desterrar.

Por su parte, Ángel Rosenblat propuso un reparto de lo sensible similar pero en su caso a partir de una concepción del lenguaje. En su ensayo "Sentido mágico de la palabra" el filólogo reivindicaba el poder creador del verbo como una vía para devolver

${ }^{620}$ Mariano Picón Salas: "Proceso del pensamiento venezolano", en Viejos y nuevos...op.cit., p. 60. Para otras citas donde se aprecia esto mismo vid. supra nota 332, p. 121.

${ }^{621}$ Mariano Picón Salas: "Varón humanísimo", en Viejos y nuevos...op.cit., p. 317. Asimismo, en un ensayo sobre Rosenblat, Picón Salas defendía un ideal de saturación lingüística: para él era fundamental que la palabra se ajustase a la cosa con la mejor precisión posible y que ese ajuste se cumpliera en la historia: "Y al concepto estático de «pureza» quisiera oponer el de propiedad o adecuación lingüística, es decir, que la palabra se ajuste a la cosa con la mayor precisión posible." (Mariano Picón Salas: "La lengua impura", en Viejos y nuevos...op.cit., p. 518)

${ }^{622}$ Mariano Picón Salas: "Varón humanísimo", en Viejos y nuevos ...op.cit., p. 318. 
a los vocablos su precisión perdida. Ante la amenaza representada por el utilitarismo y el empleo fraudulento de la lengua, Rosenblat pensaba que era necesario volver a establecer una relación necesaria entre la expresión y lo expresado, de modo que la palabra dejara de ser algo vano o engañoso y recuperara su capacidad para encarnar lo real. En el texto de que estamos hablando, el estudioso hacía un recorrido por todas aquellas teorías o tradiciones en las que el lenguaje presenta una fuerza generativa:

En el viejo mundo semítico la palabra estaba identificada con la acción, y decir y hacer eran una sola y misma cosa [...]. Goethe, en su Fausto, introducía una variante muy legítima en la traducción del famoso versículo de San Juan: "En un principio era la acción..." Hablar era hacer. La identificación entre palabra y acción, que se encuentra en muchas lenguas antiguas, reposaba en el poder mágico, fáctico, de la palabra: era eficaz, hacía. ${ }^{623}$

El intelectual estudiaba esta condición del verbo en las cosmogonías, en el derecho, en las maldiciones y las bendiciones, en el libro como elemento mágico, etc. y afirmaba que, si bien en un momento dado la palabra se seculariza, la nostalgia de ese potencial creador inherente al lenguaje pervivía en los filósofos y en los poetas. Pero lo que aquí nos interesa es que Rosenblat asociaba la función mágica del lenguaje a un ideal político y social. El filólogo proponía recuperar esta capacidad del lenguaje para restablecer a través de ella una afinidad entre los cuerpos y las significaciones que permitiera restaurar un orden conservador en que cada elemento ocupase el lugar al que estaba destinado. Para explicar esto, el maestro de Guillermo recurría a una leyenda china en la que se aprecia claramente el vínculo entre el reclamo de exactitud del lenguaje y el establecimiento de un orden clásico. Dice Rosenblat:

Hace unos dos mil quinientos años, Tsen Lu le dijo a Confucio: [/] “-El Príncipe de Wei se propone confiaros el gobierno. ¿Cuál sería la primera medida que tomaría el Maestro? [/] Confucio respondió: [/] "-Restablecer la significación verdadera de los nombres." [/] La propiedad de las palabras implica un orden moral y político. Los sabios han atribuido a cada realidad una designación, y los nombres deben conformarse entre sí y realizarse en la acción. Otro discípulo le pregunto cuál era el principio de buen gobierno, y Confucio respondió: [/] “Que el Príncipe sea Príncipe; el ministro, ministro; el padre, padre; el hijo, hijo.” [/] Es decir, cada nombre tiene unas implicaciones que constituyen su esencia. El Príncipe tiene la obligación de poner orden en las cosas y en las significaciones. Si no procede así, no es Príncipe, aunque así se llame. En el principado de Wei no había orden moral: la Princesa era incestuosa; el marido y

${ }^{623}$ Ángel Rosenblat: "Sentido mágico de la palabra", en La primera visión de América y otros estudios...op.cit., p. 98. 
el hijo habían intercambiado las designaciones; la esposa no se conducía como esposa, ni el padre como padre, ni el hijo como hijo. Había que restablecer la verdadera significación de los nombres. El nombre correcto -es decir, la adecuación entre nombre y realidad- es el instrumento de ordenación de la vida pública y privada. ${ }^{624}$

Igualmente, al final de este mismo ensayo, Rosenblat citaba unas palabras del poeta catalán Juan Maragall en las que éste requería el valor de la autenticidad -es decir, una relación necesaria entre las palabras y las cosas- como un medio para corregir la degradación del lenguaje. A decir del vate citado por el filólogo:

deberíamos hablar mucho menos y sólo por un profundo anhelo de expresión, cuando el espíritu en su plenitud se estremece y las palabras brotan como flores en la primavera. Cuando una rama no puede más con la primavera que lleva dentro, entre la abundancia de las hojas brota una flor como expresión maravillosa. ¿No veis en la quietud de las plantas su admiración de florecer? Así nosotros cuando brota en nuestros labios la palabra verdadera. ${ }^{625}$

Por lo tanto, el ideal lingüístico propuesto por Rosenblat implicaba una política: la palabra debe llevar lo que dice y, en consecuencia, cada elemento del orden social debe permanecer en su lugar. Lo que este intelectual anhelaba era restituir un orden conservador en que los cuerpos estuvieran vinculados a las significaciones, y en que tanto el lenguaje como la sociedad controlaran el acceso de nombres o elementos sobrenumerarios que amenazaban su estabilidad.

Además de sus maestros venezolanos, prácticamente todos los autores que nuestro autor leía con asiduidad y que marcaron su concepción de la literatura presentan una política estética similar, que por supuesto tiene implicaciones diferentes según el contexto de cada uno. Como no podemos hacer aquí un estudio sistemático de todos ellos, vamos a destacar exclusivamente -y como tercero de los autores comentados- el caso de Vallejo, donde se aprecia bien la diferencia entre su adscripción política y la política estética que implica su obra. Según hemos visto más arriba en este trabajo, el reclamo de la autenticidad expresiva era una de las constantes de la teoría poética de Vallejo. Con este concepto, el peruano exigía una continuidad entre la expresión y lo

\footnotetext{
${ }^{624}$ Ibid., p. 97.

${ }^{625}$ Juan Maragall citado por Ángel Rosenblat., en Ibíd., p. 100.
} 
expresado, es decir, un ideal de saturación entre el ser y el decir. El poeta censuraba aquellas obras que no se atenían a este modelo y consideraba que ello era una consecuencia de la "manía de grandeza, enfermedad burguesa", como tituló uno de sus

textos:

Algunos escritores creen infundir altura y grandeza a sus obras, hablando en ellas del cielo, de los astros y sus rotaciones, de las fuerzas interatómicas, de los electrones, del soplo y equilibrio cósmico, aunque en tales obras no alienta en verdad, el menor sentimiento de esos materiales estéticos. En la base de esas obras están sólo los nombres de las cosas, pero no el sentimiento o noción emotiva y creadora de las cosas. ${ }^{626}$

En efecto, para Vallejo, el sistema capitalista había dado lugar a un mundo

impreciso, en que cada uno hablaba y pensaba de acuerdo a sus intereses particulares.

La confusión en este punto refleja la confusión y contradicciones inherentes al espíritu y a la sociedad capitalista en general. Dentro de ella operan las más opuestas filosofías, según el interés de clase, de patria, de raza, etc. Las filosofías varían hasta dentro de una misma estructura social. En cada país viven tantas filosofías y conciencias sociales, como clases hay en ellas. Las ideologías se superponen según la jerarquía de esas clases. Esto puede verse también reflejado en las formas de la educación, con su multitud de escuelas de tipos diversos y con su caos de métodos y fines. [...] [/] Así pues, mientras subsista el régimen capitalista, con sus contradicciones emanadas de la concurrencia económica, subsistirá el caos ideológico y cultural en el mundo. ${ }^{627}$

Esta disparidad de valores había dado lugar a la degradación lingüística: en el

sistema burgués las palabras carecían de contenido porque significaban algo diferente

para cada persona:

¿Cuáles son los más saltantes signos de decadencia de la literatura burguesa? [...] Todos pueden, no obstante, filiarse por un trazo común: el agotamiento del contenido social de las palabras. El verbo está vacío. Sufre de una aguda e incurable consunción social. Nadie dice a nadie nada. La relación articulada del hombre con los hombres se halla interrumpida. El vocablo del individuo para la colectividad, se ha quedado trunco y aplastado en la boca individual. Estamos mudos, en medio de nuestra verborrea incomprensible. Es la confusión de las lenguas, proveniente del individualismo exacerbado que está en la base de la economía y política burguesas. [...] El vocablo se ahoga de individualismo. ${ }^{628}$

${ }^{626}$ César Vallejo: "Manía de grandeza, enfermedad burguesa", en El arte y la revolución...op.cit., p. 53.

${ }^{627}$ César Vallejo: “Acerca del concepto de cultura”, en El arte y la revolución ...op.cit., p. 98.

${ }^{628}$ César Vallejo: "El duelo entre dos literaturas", en El arte y la revolución...op.cit., pp. 107108. "El juego de intereses de que se nutre semejante literatura, habla, ciertamente, un idioma diverso y extraño a los intereses comunes y generales de la humanidad. Las palabras aparecen ahí incomprensibles o inexpresivas. Los vocablos fe, amor, libertad, bien, pasión, verdad, dolor, esfuerzo, armonía, trabajo, dicha, justicia, yacen vacíos o llenos de ideas o sentimientos distintos a los que tales palabras enuncian. Hasta los vocablos vida, dios e historia son equívocos o huecos. La vaciedad y la impostura dominan en el tema, la contextura y el sentido de la obra." (Ibíd., p. 109) 
Frente a este mundo desordenado y anárquico, en que se advertía una desconexión entre el lenguaje y la referencia, Vallejo pensaba que la sociedad comunista, al armonizar los intereses de todos en un orden superior, conseguiría dotar de contenido a las palabras y daría lugar a una literatura que encarnaría los verdaderos valores universales:

¿Cuáles son los más saltantes signos de la surgente literatura proletaria? El signo más importante está en que ella devuelve a las palabras su contenido social universal, llenándolas de un substratum colectivo nuevo, más exuberante y más puro, dotándolas de una expresión y de una elocuencia más diáfanas y humanas. El obrero, al revés del patrón, aspira al entendimiento de seres e intereses. Su literatura habla, por eso, un lenguaje que quiere ser común a todos los hombres. A la confusión de lenguas del mundo capitalista, quiere el trabajador sustituir el esperanto de la coordinación y justicia sociales, la lengua de las lenguas. ¿Logrará la literatura proletaria este renacimiento y esta depuración del verbo, forma suprema ésta y la más fecunda del instinto de solidaridad de los hombres? ${ }^{629}$

Por lo tanto, Vallejo pensaba que en la sociedad comunista se alcanzaría un orden de saturación semejante al que Sucre y otros autores próximos a él esperaban de otras formas de gobierno. En el sistema socialista coincidirían los intereses de todos los hombres, por lo que no habría ya desconexiones entre los cuerpos y las significaciones y se alcanzaría el consenso - el acuerdo de todos con todos. De este modo vemos que tanto Sucre como Vallejo defendieron una política estética semejante, aunque cada uno de ellos la identificaba con una política real diferente. Precisamente el hecho de que compartieran un mismo reparto de lo sensible (aunque sus implicaciones fueran diferentes) permitió que Guillermo se interesara por la obra y el pensamiento del poeta peruano, que él leía sin entrar a valorar las consecuencias políticas efectivas, que debían permanecer al margen de la literatura. En definitiva, las afinidades de Sucre se establecieron a partir de la política estética que él apreciaba en los escritores, sin tener en cuenta los resultados de ella en sus respectivos contextos. A partir del reparto de lo

${ }^{629}$ Ibid., p. 110. Vallejo propone que el arte socialista es aquel que encarna lo universal frente a lo meramente individual del arte burgués: "Cuando una obra de arte responde, sirve y coopera a esta unidad humana, por debajo de la diversidad de tipos históricos y geográficos en que ésta se ensaya y realiza, se dice que esa obra es socialista. No lo es cuando, por el contrario, la obra limita sus raíces y alcances sociales a la psicología e intereses particulares de cualquiera de las fracciones humanas en que la especie se pluraliza según el medio espacial y temporal.” (César Vallejo: “¿Existe el arte socialista?”, en El arte y la revolución...op.cit., p. 40) 
sensible que su estética implicaba y que, como hemos dicho, tuvo un antecedente fundamental en la concepción de Picón Salas, Guillermo creó vínculos con un "linaje” de autores que va de Borges a Barthes, pasando por T. S. Eliot, Camus y Octavio Paz. Guillermo estableció una relación entre todos ellos y fundó a partir de su propia visión una definición de la literatura que era inseparable de un modelo de orden y de un ideal político. 


\section{CAPÍTULO VI}

\section{EL PENSAMIENTO LITERARIO DE GUILLERMO SUCRE DESDE 1969}

La estancia de Guillermo Sucre en los Estados Unidos (1968-1975) trajo consigo cambios decisivos en su perspectiva intelectual y, por consiguiente, en su concepción estética. Como ya explicamos con anterioridad, al intervenir en el campo cultural venezolano entre 1958 y 1968, nuestro autor había tratado de que la literatura nacional se modernizara en base a los criterios de las grandes obras occidentales. En las revistas y en los proyectos culturales en los que participó durante esa década, Sucre escribió sobre autores venezolanos, hispanoamericanos y europeos, pero siempre con el objetivo de introducir a la literatura nacional en el diálogo que mantenían entre sí las mejores obras de la tradición universal. Por lo tanto, la escritura de Guillermo en el periodo 1958-1968 se estableció marcando la distancia que separaba a las obras nacionales de la estética que él quería implementar en Venezuela. En estos años, las obras que estudiaba y sobre las que escribía podían estar o no de acuerdo con la concepción artística que él trataba de impulsar, pero ese modelo siempre estaba presente en su crítica literaria.

La llegada de Sucre a los Estados Unidos y su desempeño como docente en la Academia norteamericana modificó su trayectoria intelectual en tres aspectos. En primer lugar, la nueva situación de nuestro autor provocó cambios en la naturaleza de sus escritos. Si antes de 1968 sus ensayos habían pretendido sobre todo indicar el rumbo que debía seguir la literatura venezolana, la llegada a los Estados Unidos le permitió liberarse de la necesidad de medir las obras con relación a un patrón determinado. En este nuevo contexto desapareció definitivamente la distancia que había fundado su crítica en el período 1958-1968 y esa mayor libertad se tradujo en un interés casi exclusivo por aquellos autores que presentaban una estética similar a la suya. Asimismo, al relegar su compromiso inmediato con la literatura nacional, la crítica de 
Sucre alcanzó un verdadero valor estético y se materializó en auténticos ensayos literarios. Aunque ya podemos encontrar algunas excepciones en la década anterior, es a partir de su llegada a los EEUU cuando los textos de Guillermo adquieren categoría de escritura y admiten ser leídos “como se leen las mejores construcciones verbales",630.

En segundo lugar, el nuevo contexto determinó también un cambio de perspectiva. Tanto el medio académico como las revistas en las que publicó artículos y estudios desde finales de los años 60 -como la Revista Iberoamericana ${ }^{631}$ (Pittsburgh) o Plural (México), entre otras- presentaban un marcado carácter latinoamericanista.
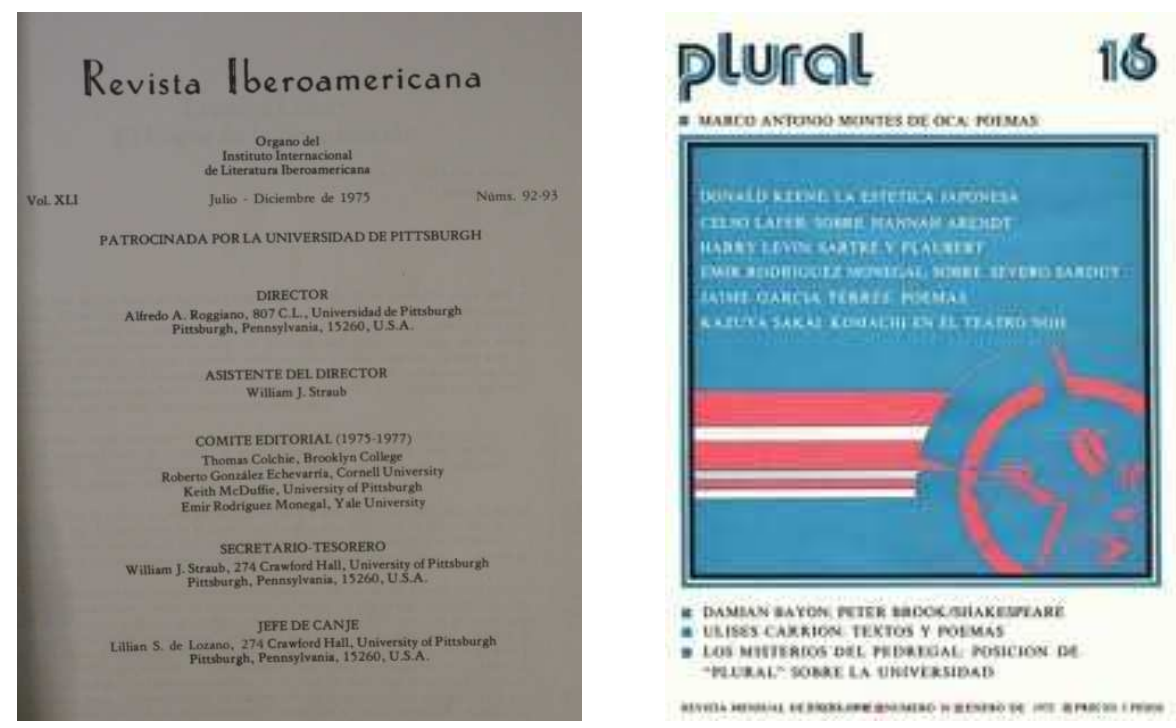

Imágenes 35 y 36. Portada interior de la Revista Iberoamericana (Pittsburgh) y portada de Plural (México).

Ello obligó a Guillermo a “deterritorializar” su discurso y le llevó a centrarse en la construcción de la poesía continental, labor en la que parecía responder a los reclamos de Octavio Paz. En efecto, el escritor mexicano había denunciado en múltiples ocasiones la falta de una crítica solvente en América Latina y la necesidad que había de

${ }^{630}$ El propio Sucre destacaba este rasgo como prueba de la "excelencia de una obra crítica". (Guillermo Sucre: “Inscripciones, de Francisco Rivera”, en Vuelta, México, feb. 1982, p. 39)

${ }^{631}$ Esta revista es, todavía hoy, el órgano editorial del Instituto Internacional de Literatura Iberoamericana, con sede en la Universidad de Pittsburgh. Al menos entre 1969 y 1973, Guillermo Sucre formó parte del Comité Editorial de esta publicación junto a otros intelectuales como Fred P. Ellison, Seymour Menton, Gonzalo Sobejano y Emir Rodríguez Monegal. 
ella en el continente. Según expresaba en un texto aparecido en Corriente alterna

(1967),

La misión de la crítica, claro está, no es inventar obras sino ponerlas en relación: disponerlas, descubrir su posición dentro del conjunto de acuerdo con las predisposiciones y tendencias de cada una. En este sentido, la crítica tiene una función creadora: inventa una literatura (una perspectiva, un orden) a partir de las obras. Esto es lo que no ha hecho nuestra crítica. Por tal razón no hay una literatura hispanoamericana aunque exista ya un conjunto de obras importantes. De ahí también que sea inútil preguntarse, como se hace con frecuencia, qué es la literatura hispanoamericana. Es una pregunta que, según se ha visto, aún no puede tener respuesta. En cambio, es urgente preguntarse cómo es nuestra literatura: sus fronteras, su forma, su estructura, su movimiento. Responder a esta pregunta será poner en comunicación a las obras y revelarnos que no son monolitos aislados, estelas conmemorativas del desastre plantadas en el desierto, sino que forman una sociedad. Un conjunto de monólogos que constituyen, ya que no un coro, un diálogo contradictorio. ${ }^{632}$

En su texto "La nueva crítica" (1969) el propio Sucre recordaba que, según Paz, nos "ha faltado [...] tanto un pensamiento o un sistema de doctrinas como esa capacidad que tiene la crítica de situar a la obra en su espacio intelectual, es decir, en ese lugar donde las obras se encuentran y dialogan entre sí haciendo posible una literatura"633. Como respondiendo a esta carencia que destacaba su maestro y amigo, a partir de 1968 nuestro autor se dedicó a elaborar un discurso coherente sobre la poesía hispanoamericana cuyo resultado más visible es La máscara, la transparencia.

En tercer lugar, la estancia de Sucre en Norteamérica impuso ciertas transformaciones en el proyecto estético que había emprendido hasta ese momento, las cuales son el resultado de su inserción en un nuevo contexto político y social, y de su acercamiento a algunos autores de la tradición literaria anglosajona. En los años 60 y 70 la sociedad estadounidense se encontraba inmersa en un notable proceso de

${ }^{632}$ Octavio Paz: "El espacio del reconocimiento", en OOCC, Vol. II, op.cit., pp. 1147-1148. En el mismo ensayo indicaba también: "En lugar de repetir como mirlos persas o loros americanos lo que dicen anónimos revisteros de Chicago o Milán, los críticos deberían leer a nuestros autores como Caillois ha leído a Borges: desde la tradición moderna y como parte de esa tradición. Dos tareas complementarias: mostrar que las obras hispanoamericanas son una literatura, un campo de relaciones antagónicas; describir las relaciones de esa literatura con las otras.” (Ibíd., p. 1149)

${ }^{633}$ Guillermo Sucre: "La nueva crítica", en César Fernández Moreno (coord.): América Latina en su literatura, Paris, UNESCO y Siglo XXI, 1972, p. 266. En el mismo ensayo decía también Sucre: "la crítica latinoamericana, en general, no se ha nutrido de un pensamiento propio ni ha sabido fundar nuestra literatura, tal como lo señala Paz. Ha sido, más bien, una crítica externa, impresionista o vagamente sociológica; rara vez se ha estructurado sobre una verdadera visión del mundo o en torno a una noción de la literatura como estética del lenguaje." (Ibíd.) 
transformación y estaba planteando un nuevo reparto de lo sensible, lo que sin duda afectó a la estética de Sucre. Además, si durante la década 58-68 el pensamiento de Guillermo se había fraguado en la órbita intelectual francesa, en este momento nuestro autor entró en contacto con una serie escritores anglosajones que marcarán decisivamente su concepción del arte de escribir, entre los que se encuentran John Cage, Susan Sontag, Gertrude Stein, George Steiner, Wallace Stevens y William Carlos Williams.

En cualquier caso, a pesar de estos cambios que se advierten en el pensamiento y en la escritura de Sucre después de 1968, su estética no presenta una modificación radical, sino que revela más bien una adaptación al nuevo entorno y a las nuevas incitaciones intelectuales y poéticas. Para entender bien las modificaciones que tuvieron lugar en el ideario de Guillermo Sucre durante esta época es preciso que describamos, así sea someramente, la situación de la sociedad norteamericana durante estos años. En lo que concierne a la estética de nuestro autor, lo importante no es describir la historia política de los EEUU ni los episodios más relevantes de la Guerra Fría sino comprender el cambio de mentalidad y las consiguientes modificaciones en el reparto de lo sensible que estaban en marcha a finales de los 60 y principios de los 70.

En los treinta años siguientes a la Segunda Guerra Mundial (esto es, aproximadamente entre 1945 y 1973) la sociedad norteamericana vivió un proceso de enriquecimiento gradual y de mejora progresiva de la calidad de vida ${ }^{634}$. La alta productividad empresarial dio lugar a una época de bonanza que, a diferencia de los años veinte, permitió prosperar tanto a las clases trabajadoras como a las clases altas. En las décadas de 1950 y 1960 los EEUU se transformaron en una sociedad de consumo, de manera que la producción y adquisición de bienes se volvió casi una obsesión, y el

${ }^{634}$ La información que resumo a continuación está tomada de Carl N. Degler et. al.: Historia de los EEUU, México, Noriega, 1998. 
ocio y la recreación comenzaron a jugar un papel determinante en la vida cotidiana. La mejora de las condiciones económicas permitió que, para principios de los años 70, un norteamericano medio (que seguramente viviría en el área metropolitana de una de las grandes ciudades) se pudiera permitir un automóvil, un teléfono y una televisión. Además, la posibilidad de disfrutar del tiempo libre hizo que, aparte de la pequeña pantalla y del cine, los deportes -sobre todo el béisbol y el fútbol americano- y los hobbies -como la carpintería, la jardinería o la caza- comenzaran a adquirir importancia en la nueva sociedad.

A pesar de esta situación económicamente estable, la sociedad norteamericana tuvo que enfrentar bastantes cuestiones delicadas de política interior a lo largo de los años 60 y principios de los 70 . Un rasgo característico del período fue el reconocimiento cada vez mayor de las minorías que vivían en los EEUU. A este respecto tuvo un lugar destacado el Movimiento por los derechos de los afroamericanos, que actuó como un modelo para el surgimiento de la autoconciencia del resto de minorías.

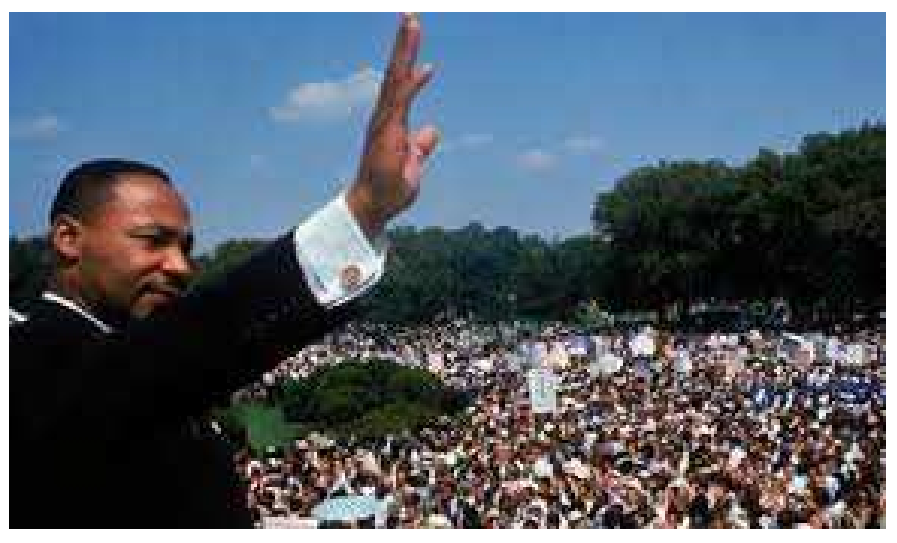

Imagen 37. Martin Luther King (1929-1968), estuvo al frente del Movimiento por los derechos civiles para los afroamericanos durante esta época.

Además de los afroamericanos, los chicanos y los pueblos indígenas reclamaron en esta época un reconocimiento social del que hasta este momento habían carecido, y otros grupos étnicos -como irlandeses, judíos, polacos o italianos- comenzaron a ser 
más respetados por el ascenso a posiciones influyentes de ciudadanos con esos orígenes. Al igual que estos colectivos, las mujeres reclamaron también en este periodo una mayor igualdad de oportunidades en relación al género masculino. Después de la Segunda Guerra Mundial, la mujer norteamericana se incorporó con fuerza al mercado laboral pero muchas veces se vio obligada a aceptar peores condiciones que los hombres o salarios poco remunerados en relación a su formación. La lucha por el reconocimiento social de estos sectores desfavorecidos se vio materializada en la Ley de Derechos Civiles, promulgada en 1964 por el Presidente Johnson. Esta ley prohibía la discriminación racial y la distinción en el empleo por razones de sexo, nacionalidad o religión, y tuvo una relevancia decisiva para la situación de las mujeres y de los afroamericanos. En referencia a estos cambios, el sociólogo Daniel Bell, en su prognosis acerca de la sociedad post-industrial publicada por primera vez en 1973, afirmaba lo siguiente:

La cuestión de qué constituye la revolución acelerada de nuestra época es demasiado amplia y vaga. Evidentemente, es en parte tecnológica. Pero también es política en cuanto que, por primera vez, estamos observando la inclusión en la sociedad de vastas masas de gente, un proceso que implica la redefinición de los derechos sociales, civiles y políticos. Es sociológica en cuanto que presagia un inmenso giro en la sensibilidad y en las costumbres: en las actitudes sexuales, definiciones de metas, vínculos sociales y responsabilidades, y otras semejantes. ${ }^{635}$

Además, a finales de los 60 y principios de los 70 se produjeron manifestaciones y disturbios en diversas ciudades y campus universitarios. Estas protestas, encabezadas sobre todo por jóvenes, cuestionaban el modelo vigente de educación superior, apoyaban el movimiento por el reconocimiento de los derechos civiles de las minorías y se oponían a la guerra de Vietnam. Y en sus manifestaciones subyacía una verdadera crítica a los valores que regían a la sociedad norteamericana. En efecto, a través de su vestimenta y de su estética la juventud marcaba una distancia con respecto a los principios imperantes, pues lo que estaba en juego en su apariencia y en sus actitudes

${ }^{635}$ Daniel Bell: El advenimiento de la sociedad post-industrial, Madrid, Alianza, 1991 [1973], pp. $225-226$. 
era un rechazo de las jerarquías de rango o condición responsables de la discriminación.

De acuerdo a sus planteamientos, las personas debían reconocerse por su igual dignidad humana y no de acuerdo a las divisiones arbitrarias impuestas por la sociedad. Como indicaba Bell en esta misma época:

En lo que concierne a la política, es palpable, por doquier, que una parte de la sociedad se alza contra la burocracia y desea participación, tema que se resume en la afirmación, convertida ya en consigna, de que "la gente debería tener la facultad de influir en las decisiones que controlan sus vidas". En buena medida, la revolución de la participación es una de las formas de reacción contra la "profesionalización" de la sociedad y la toma democrática de decisiones de una sociedad post-industrial. Lo que hace años comenzó en la fábrica a través de los sindicatos se ha extendido ahora a los barrios - a causa de la politización de las decisiones en los asuntos sociales- y dentro de las universidades; en las próximas décadas se extenderá igualmente a otras organizaciones complejas. No cabe duda de que los más viejos modelos burocráticos de organizaciones centralizadas jerárquicamente y que funcionan mediante una división intensiva del trabajo, serán reemplazados por nuevas formas de organización. ${ }^{636}$

La defensa de la igualdad que emprendió la juventud norteamericana se aprecia también en los movimientos anticoloniales y en la búsqueda de una mayor democratización de la sociedad. Este impulso igualitario dio lugar a que los estudiantes quisieran intervenir activamente en el desarrollo de los programas de estudios y en el gobierno de los colleges y a que se reclamase, en general, una mayor participación política de los colectivos tradicionalmente discriminados.

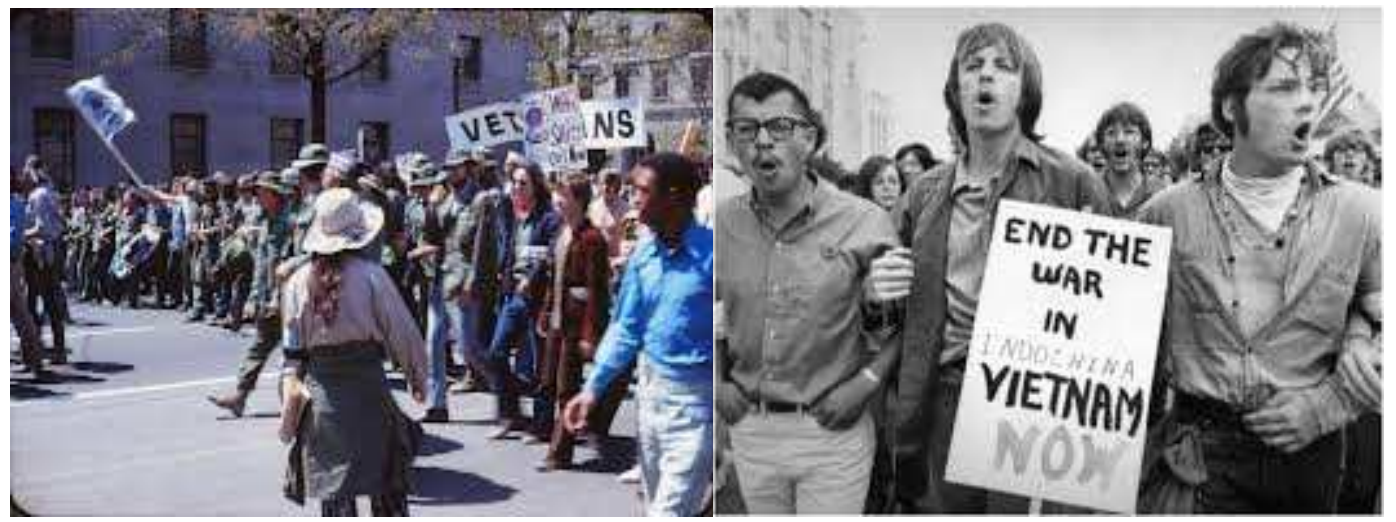

Imágenes 38 y 39. Protestas en contra de la guerra de Vietnam. 
La búsqueda de una sociedad más justa emprendida por los jóvenes implicaba además el cuestionamiento directo de la cosmovisión de las generaciones precedentes. A diferencia de sus padres y de sus abuelos -que habían vivido directamente las consecuencias del crack de 1929- las nuevas generaciones concedieron una gran importancia al sentimiento, a la emoción y a la imaginación ${ }^{637}$, lo que explica su interés por el misticismo y por el budismo zen, así como por la liberación sexual ${ }^{638}$ y el consumo de drogas. Acompañando a esta valoración de la experimentación y de las sensaciones, el presente adquirió una importancia decisiva ${ }^{639}$. Mientras que los adultos insistían en la necesidad de fomentar el trabajo y el ahorro y de postergar el disfrute, los jóvenes pensaban que la vida debía vivirse aquí y ahora. Para ellos había que hacer lo que a uno le interesaba y ocuparse de tener relaciones satisfactorias con los demás en lugar de competir con ellos. Este énfasis que la generación joven puso en el sentimiento, en la experiencia y en el presente implicaba un rechazo directo a la racionalidad científica y tecnológica que el auge de las empresas multinacionales estaba convirtiendo en un factor determinante del progreso económico ${ }^{640}$.

${ }^{637}$ A este respecto es pertinente que recordemos que en el pensamiento de este momento se estaba dando mucho peso a la imaginación y a las sensaciones. Herbert Marcuse en Eros y civilización (1955), contradiciendo la concepción freudiana, se plantea la posibilidad "de una civilización no represiva" a partir de una revalorización de la fantasía y de la imaginación como funciones no enfrentadas a la razón. Este pensador intentaba reconciliar así el principio de placer con el principio de realidad, y los instintos con la razón: "liberados de la tiranía de la razón represiva, los instintos tienden hacia relaciones existenciales libres y duraderas: generan un nuevo principio de la realidad." (Herbert Marcuse: Eros y civilización, Barcelona, Seix Barral, 1969, p. 185)

${ }^{638}$ A este respecto Octavio Paz señalaba lo siguiente: "En los últimos años dos movimientos han sacudido a Occidente: la revuelta del cuerpo y la rebelión de los jóvenes. Ambas corresponden, por su filiación y su significación, a la revuelta del arte. [...] ambos movimientos, especialmente la revuelta del cuerpo, tienden a volver al revés los signos que definen a nuestra civilización: cuerpo y alma, presente y futuro, placer y trabajo, imaginación y realidad." (Octavio Paz: "La nueva analogía: poesía y tecnología", en OOCC, Vol. I, op.cit., p. 393. [1973])

${ }^{639}$ Paz concedía una importancia fundamental al presente. "La preeminencia del ahora podría, quizá, reconciliarnos con una realidad que la religión del progreso ha tratado de esconder y disfrazar: la muerte. [...] ¿Por qué no imaginar una civilización en la que los hombres, capaces al fin de afrontar sin temor su mortalidad, celebren la conjunción vida/muerte no como dos principios enemigos sino como una sola realidad? Metáfora del cambio, el ahora disuelve al pasado y al futuro y así se disuelve a sí mismo. Disolución del tiempo, no en una eternidad inconmensurable sino en una vivacidad igualmente sin medida." (Ibíd., p. 394)

${ }^{640}$ Bell destacaba esta dualidad de la sociedad post-industrial de la siguiente manera: "En la organización de la producción y del trabajo, el sistema demanda prevención, laboriosidad y auto-control, 
Esta coyuntura político-social que hemos descrito brevemente se fue diluyendo por la crisis económica que trajo consigo el alza de los precios del crudo decretada por los países de la OPEP en 1973. A partir de ese año, la nueva situación económica dio al traste con la concepción del mundo de los años 50 y 60 e impuso la necesidad de enfrentarse a una realidad más competitiva. Además, cuando en 1975 el Presidente Gerald Ford retiró definitivamente las tropas de Vietnam se fueron enfriando las inquietudes políticas y sociales que habían marcado la década anterior.

Todos estos cambios que estaban en marcha en la sociedad norteamericana durante esta época eran el resultado de una nueva concepción del tiempo que iba a modificar decisivamente la cosmovisión moderna. Es por estos mismos años que Octavio Paz había comenzado a llamar la atención sobre una variación en nuestra manera de comprender el tiempo y a poner de manifiesto sus consecuencias. Así, en 1967 anunciaba que:

La relación con la idea del tiempo rectilíneo empieza a cambiar y ese cambio será aún más radical que el de la modernidad, hace dos siglos, frente al tiempo circular. Pasado, presente y futuro han dejado de ser valores en sí; tampoco hay una ciudad, una región o un espacio privilegiados. [...] El fin de la modernidad es, asimismo, el fin del nacionalismo y el de los "centros mundiales de arte". [...] Todos hablamos simultáneamente, si no el mismo idioma, el mismo lenguaje. No hay centro y el tiempo ha perdido su antigua coherencia: este y oeste, mañana y ayer se confunden en cada uno de nosotros. Los distintos tiempos y los distintos espacios se combinan en un ahora y un aquí que está en todas partes y sucede a cualquier hora. ${ }^{641}$

Como vemos, la nueva percepción del tiempo implicaba un descrédito de la univocidad de la historia y de la teleología del progreso, nociones típicamente modernas, y cuestionaba, en consecuencia, la existencia de una "realidad sólida, unitaria, estable y «autorizada»»" ${ }^{, 642}$. Entonces, esta renovada visión de la temporalidad es la condición de posibilidad de los cambios que estaban teniendo lugar en los EEUU

dedicación a una carrera y éxito. En el terreno del consumo, fomenta la actitud del carpe diem, la prodigalidad y la ostentación, y la búsqueda compulsiva de diversiones. Sin embargo, el sistema es completamente mundano en ambos terrenos, ya que ha desaparecido toda ética trascendente." (Daniel Bell: El advenimiento...op.cit., p. 550) [1967].

${ }^{641}$ Octavio Paz: "Invención, subdesarrollo, modernidad", en OOCC, Vol. II, op.cit., p. 496.

${ }^{642}$ Gianni Vattimo: "Posmodernidad: ¿una sociedad transparente?", en Gianni Vattimo y otros: En torno a la posmodernidad, Barcelona, Anthropos, 2003, p. 16. 
con respecto a la igualdad y al reconocimiento de las minorías, pues, como afirma

\section{Gianni Vattimo:}

Una vez desaparecida la idea de una racionalidad central de la historia, el mundo de la comunicación generalizada estalla como una multiplicidad de racionalidades "locales" - minorías étnicas, sexuales, religiosas, culturales o estéticas [...]-, que toman la palabra y dejan de ser finalmente acallados y reprimidos por la idea de que sólo existe una forma de humanidad verdadera digna de realizarse, con menoscabo de todas las peculiaridades, de todas las individualidades limitadas, efímeras, contingentes. ${ }^{643}$

Según este mismo profesor, esta "liberación de las racionalidades locales" caracteriza a lo que él llama una sociedad "posmoderna" o "transparente", en la que advierte posibilidades emancipatorias. Al multiplicar "las imágenes del mundo"644 esta sociedad se hace tolerante y plural, pues a la aceptación igualitaria de todos los dialectos sigue el reconocimiento de la contingencia y relatividad de cada uno. Como sigue afirmando el propio Vattimo:

La causa emancipante de la liberación de las diferencias y de los "dialectos" consiste más bien en el compendioso efecto de desarraigo que acompaña al primer efecto de identificación. $\mathrm{Si}$, en fin de cuentas, hablo mi dialecto en un mundo de dialectos, seré también consciente de que no es la única lengua, sino cabalmente un dialecto más entre otros muchos. Si profeso mi sistema de valores -religiosos, estéticos, políticos, étnicos- en este mundo de culturas plurales, tendré también una conciencia aguda de la historicidad, contingencia, limitación de todos estos sistemas, comenzando por el mío. ${ }^{645}$

El impulso igualitario de la sociedad estadounidense durante el periodo en que Guillermo residió allí revela la formación incipiente de una sociedad transparente, como se aprecia en la tendencia a suprimir las jerarquías tradicionalmente establecidas y a ampliar el consenso hasta incluir en él a los diferentes grupos que componían la $\operatorname{sociedad}^{646}$.

${ }^{643}$ Ibid., p. 17.

${ }^{644}$ Ibid., p. 16.

${ }^{645}$ Ibid., pp. 17-18.

${ }^{646}$ A pesar de la visión optimista de Vattimo, la inclusividad de la sociedad posmoderna ha sido interpretada por la teoría crítica como una vía para controlar un hipotético cambio social. Ya en 1964, Herbert Marcuse llamaba la atención sobre el carácter consensual (y totalitario) de la sociedad norteamericana y vinculaba la asimilación por la sociedad de los agentes potencialmente contestatarios a la consolidación del orden establecido, "un sistema omnipresente que devora o rechaza todas las alternativas" (Herbert Marcuse: El hombre unidimensional, op.cit., p. 26). Marcuse afirmaba, en el mismo sentido: "El progreso técnico, extendido hasta ser todo un sistema de dominación y coordinación, crea formas de vida (y de poder) que parecen reconciliar las fuerzas que se oponen al sistema y derrotar o refutar toda protesta en nombre de los prospectos históricos de liberación del esfuerzo y la dominación. La sociedad contemporánea parece ser capaz de contener la posibilidad de un cambio social, un cambio 
Estas modificaciones sociales y políticas coincidieron en el tiempo con un cambio epistemológico que consistió en un cuestionamiento sistemático de las bases del pensamiento metafísico. La filosofía post-metafísica (en sus tres ramas: la hermenéutica, la analítica y la posmoderna) puso en tela de juicio las grandes construcciones heredadas del siglo XIX -esto es, las nociones de sujeto histórico, de progreso, de revolución y de ciencia- dando lugar así al "paso desde una filosofía orientada por la verdad hacia una filosofía orientada por el sentido" ${ }^{, 647}$, y situando en un lugar fundamental "a la pregunta por el lenguaje",648. Estas corrientes negaban la existencia de una verdad única o de un sentido preexistente y eterno, pues si sólo se puede hablar de una pluralidad de principios y de valores, las certezas son relativas y sólo existen en un lenguaje que es necesariamente parcial.

Antes de exponer el pensamiento de Guillermo Sucre durante este período posterior a 1969 debemos hacer algunas aclaraciones. En esta parte de la presente investigación nos hemos propuesto reconstruir una mirada crítica a partir de una serie de textos que no se escribieron con un propósito sistemático; o, dicho de otra manera, hemos intentado elaborar un discurso coherente y estructurado a partir de un conjunto de ensayos que carecen de intención doctrinaria alguna. Como comprenderá el lector esta tarea no ha resultado nada sencilla, pues implica rastrear las constantes críticas que aparecen en los diversos textos de Sucre, y elaborar a partir de ellas una narrativa que el propio autor no había previsto. Ello supone, además, que quizá estemos falseando sus

cualitativo que establecería instituciones esencialmente diferentes, una nueva dirección del proceso productivo, nuevas formas de existencia humana. Esta contención del cambio social es quizá el logro más singular de la sociedad industrial avanzada; la aceptación general del Propósito Nacional, la política bipartidista, la decadencia del pluralismo, la unión de la Empresa y el Trabajo dentro del Estado fuerte atestiguan la integración de los opuestos que es el resultado tanto como el prerrequisito de este logro." (Ibid., p. 22)

${ }^{647}$ Alain Badiou: "El deseo de filosofía y el mundo contemporáneo", en La filosofía, otra vez, Buenos Aires, Errata Naturae, 2010, p. 55.

${ }^{648}$ Ibid., p. 56. 
intenciones y su ética, pues él nunca planteó sus escritos como un plan o un proyecto sistemáticos. Si nos hemos decantado, aun así, por describir la mirada crítica de nuestro autor, si hemos pensado que este falseamiento merecía la pena, es porque consideramos que sus escritos ofrecen una visión sobre la literatura sumamente importante, y que es necesario contribuir a que su obra y su pensamiento gocen de una atención mayor de la que han recibido hasta ahora.

Para llevar adelante esta compleja labor hemos considerado que los textos de Sucre constituyen un sistema coherente de relaciones. Si en la primera parte de este trabajo pudimos dividir su pensamiento en dos etapas, en este lapso del que nos ocupamos ahora no ha sido posible establecer distinciones cronológicas precisas. Por supuesto que después de 1968 se advierten cambios en su discurso a través del tiempo; sin embargo, estos cambios no presentan la misma nitidez que en la década 58-68 y por eso nos ha resultado imposible dar cuenta de ellos. Además, como ya hicimos en la sección inicial de esta investigación, hemos tratado de ver la mirada crítica de Sucre en relación con aquellos autores y teóricos con los que su pensamiento mantiene un diálogo permanente. Cómo él mismo lo reconoció ${ }^{649}$, sus ideas no son ni pretenden ser originales, y están tomadas casi siempre de otros escritores que presentan una estética afín a la suya. Este hecho, sin embargo, no resta originalidad a su visión, pues a pesar de que las nociones consideradas aisladamente no le pertenecen, nuestro autor se las

${ }^{649}$ En un ensayo, después de aludir a varias teorías relativas al lenguaje y a la crítica, Sucre señalaba: "Ya es tiempo de concluir estas consideraciones preliminares. No soy un teórico, ni he venido a formular teorías (que, por lo demás, no me pertenecen)." (Guillermo Sucre: "Poesía hispanoamericana y conciencia del lenguaje”, en Eco, (Bogotá), núm. 200, 1978, p. 614). Asimismo, en un ensayo publicado en Zona Franca, nuestro autor indicaba que los más grandes escritores de la tradición occidental nunca quisieron "aparentar una falsa e imposible original", sino que "les bastaba con integrarse al gran movimiento del espíritu en todas las épocas". Al tomar abiertamente ideas de escritores como Picón Salas, Paz, Borges, Barthes, y un largo etcétera, Sucre no renuncia a expresar su propia personalidad sino que se vale de ellas para entroncar, desde su propia perspectiva, con los valores universales del hombre y del mundo. (Vid. Guillermo Sucre: "Las influencias literarias", loc.cit.) 
apropia y las unifica a través de su propia mirada, dando lugar así a una estética singular y digna de estudio.

\section{1. LA CONCIENCIA DEL LENGUAJE}

Guillermo Sucre escribe desde un horizonte filosófico donde "la metafísica de la verdad se ha vuelto imposible" 650 y en que, por tanto, "el lenguaje es el sitio crucial del pensamiento porque allí es donde la pregunta por el sentido está en juego"651. En oposición a la concepción logocéntrica, según la cual la realidad tenía un sentido unívoco que era posible comunicar en el lenguaje, Sucre piensa que las palabras están directamente implicadas en la creación del sentido y del conocimiento. Por eso, sus planteamientos estéticos se enmarcan en lo que se conoce en filosofía como "el giro lingüístico", que él mismo explicaba así:

Antes, en efecto, el lenguaje no fundaba sino que estaba fundado en una verdad o en un orden superior y trascendente. El escritor podía o no interrogarse sobre el lenguaje, pero finalmente confiaba su validez a esa garantía superior; creía en su mundo y lo expresaba, lo ponía en palabras. El lenguaje, pues, no podía serle problemático: tenía confianza en él y, por tanto, no podía cuestionarlo. Con la historia moderna, toda garantía superior desde una trascendencia desaparece y así el lenguaje pierde su fundamentación. Ya Nietzsche observaba que no se puede decir esto es, sino esto significa; con lo cual no sólo ponía de relieve el paso de la trascendencia o lo absoluto a la inmanencia o lo relativo, sino que, además, le daba al lenguaje una función central en el mundo. Así, todo problema -teológico o filosófico, pero también el más cotidiano- se volvía un problema lingüístico, un problema semántico. Si el lenguaje, por una parte, perdía su fundamentación, se convertía, por la otra, en la fundamentación de todo. En el pensamiento moderno -podría decirse-, el lenguaje sustituye a la verdad. De igual modo, en la poesía moderna, el lenguaje sustituye a la realidad. ${ }^{652}$

Esta concepción sobre el lenguaje supone que éste ya no se considera, como

quería la metafísica tradicional, un simple instrumento que vincula de una manera natural al hombre y al mundo. Las palabras no son una herramienta para comunicar una idea o una realidad preexistente sino que ellas mismas son la fuerza donde esas entidades toman cuerpo y existen. Por lo tanto, el lenguaje es el espacio donde se genera

${ }^{650}$ Alain Badiou: "El deseo de filosofía...", loc.cit., p. 56.

${ }^{651}$ Ibíd., p. 56. En la filosofía de la segunda mitad del siglo XX "la pregunta por el sentido reemplaza a la clásica pregunta por la verdad". (Ibíd.)

${ }^{652}$ Guillermo Sucre: La máscara, la transparencia. Ensayos sobre poesía hispanoamericana, Caracas, Monte Ávila, 1975, $1^{\mathrm{a}}$ ed., p. 256. 
la experiencia del mundo que se comunica en la obra de arte, y ello invierte la tradicionalmente aceptada sumisión del lenguaje a la realidad o al pensamiento. Los vocablos ya no son, como en la concepción logocéntrica, un mero reflejo del mundo o un instrumento a su servicio: son un "principio constitutivo de lo real" y no "un reflejo de él"653. Ya que la "verdadera energía creadora" reside en las palabras, no hay "contenidos previa e intencionalmente ya formados, sino un lenguaje que crea su propia presencia" ${ }^{\circ 54}$. Por lo tanto, ni el poeta ni el novelista tienen "una materia original que es el mundo. Su verdadera materia es el lenguaje; no ven el mundo sino a través de palabras ${ }^{, 655}$.

De entre los autores próximos a Sucre fue sin duda Roland Barthes uno de los que se opuso más fervientemente al logocentrismo. Este teórico concedía al lenguaje una posición central en la creación literaria contemporánea y vinculaba el surgimiento de esa concepción del lenguaje al cambio social que había acontecido en Francia hacia 1850. "Durante mucho tiempo -decía Barthes- la sociedad clásico-burguesa ha visto en la palabra un instrumento o una decoración; ahora vemos en ella un signo y una verdad"656. Y en otro texto indicaba que el nuevo estatuto del lenguaje era característico de la poética moderna, pues en ella

las pretendidas relaciones entre el pensamiento y el lenguaje se invierten; en el arte clásico, un pensamiento ya formado engendra una palabra que lo "expresa" y lo "traduce". [...] Por el contrario, en la poética moderna, las palabras producen una suerte de continuo formal del que emana poco a poco una densidad intelectual o sentimental imposible sin ellas; la palabra es entonces el tiempo denso de una gestación más espiritual, durante la cual el "pensamiento" es preparado, instalado poco a poco en el azar de las palabras. Esta suerte verbal, de la que caerá el fruto maduro de una significación, supone entonces un tiempo poético que ya no es el de una "fabricación", sino el de una aventura posible, el encuentro de un signo y de una intención. ${ }^{657}$

${ }^{653}$ Guillermo Sucre: "La nueva crítica", loc.cit., p. 271.

${ }^{654}$ Guillermo Sucre: "Poesía hispanoamericana y conciencia...”, loc.cit., p. 617.

${ }^{655}$ Guillermo Sucre: "La nueva crítica”, loc.cit., p. 264. Por lo tanto, como afirma nuestro crítico, "la verdadera realidad con que se enfrenta" el escritor consciente de los poderes de las palabras no es la realidad del mundo sino "la realidad del lenguaje". (Guillermo Sucre: La máscara ...op.cit., p. 255.)

${ }^{656}$ Roland Barthes: Crítica y verdad, op.cit., p. 50. Ante esta nueva posición central adoptada por el lenguaje, decía el teórico francés, "todo lo tocado por el lenguaje es pues de cierta manera puesto de nuevo en tela de juicio: la filosofía, las ciencias humanas, la literatura.” (Ibíd., p. 50.)

${ }^{657}$ Roland Barthes: El grado cero de la escritura, cap. 5, “¿Existe una escritura poética?”. 
Otro escritor cercano a Guillermo que concedía al lenguaje poético el papel de encarnar la experiencia era Octavio Paz, quien en su ensayo “¿Qué nombra la poesía?”

(1967) afirmaba que

la actividad poética tiene por objeto, esencialmente, el lenguaje: cualesquiera que sean sus creencias y convicciones, el poeta nombra a las palabras más que a los objetos que éstas designan. No quiero decir que el universo poético carezca de significado o viva al margen del sentido; digo que en poesía el sentido es inseparable de la palabra, es palabra, en tanto que en el discurso ordinario [...] el sentido es aquello que denotan las palabras y que está más allá del lenguaje. La experiencia del poeta es ante todo verbal; o si se quiere: toda experiencia, en poesía, adquiere inmediatamente una tonalidad verbal. Es algo común a todos los poetas de todas las épocas pero que, desde el romanticismo, se convierte en lo que llamamos conciencia poética ${ }^{658}$

Como se aprecia por las citas anteriores, tanto Barthes como Paz piensan que las palabras son el lugar de encarnación de una experiencia y no un mero instrumento al servicio de una visión anterior. No son los primeros, sin embargo, en pensar así sino que, como ha indicado Jacques Ranciére, esta idea se remonta al menos a los filósofos y poetas del Romanticismo europeo. Efectivamente, el cambio decisivo a este respecto tuvo lugar a principios del siglo XIX cuando, al derrumbarse el viejo paradigma de las Bellas Letras, se pasó del círculo de la palabra en acto al paradigma de la escritura, y de un régimen de encadenamiento causal a un régimen de expresividad ${ }^{659}$. El lenguaje poético se convirtió entonces en una inscripción o en un jeroglífico que portaba en sí las marcas de su significación y que hablaba menos por lo que decía que por lo que encarnaba. Por eso, según nos explica el pensador francés Ranciére, las referencias de los románticos al carácter intransitivo o autotélico del lenguaje ${ }^{660}$ no aluden a un hermetismo o a un formalismo absolutos: "si el lenguaje solo se ocupa de sí mismo no

${ }^{658}$ Octavio Paz: “¿Qué nombra la poesía?”, en OOCC...op.cit., p. 487.

${ }^{659}$ Jacques Ranciére: La palabra muda...op.cit., pp. 43 y ss. Esta concepción del lenguaje de los Románticos también la había puesto de manifiesto Albert Béguin: "Puesto que de la imaginación y de todos los productos espontáneos del inconsciente [...] se cree que aprehenden una realidad a la vez interior y objetiva, el poeta buscará un método que le permita captar, en la trampa del lenguaje, fragmentos de la vida secreta. Reunirá las palabras según sus afinidades sonoras, se abandonará a los ritmos, a los ecos de las sílabas, a todas las relaciones interiores del material lingüístico. Admitirá que más allá de su significación, buena para los intercambios de la vida colectiva, las palabras tienen otra virtud, propiamente mágica, gracias a la cual pueden captar esa realidad que escapa a la inteligencia." (Albert Béguin: El alma romántica y el sueño, México, FCE, 1954, p. 484)

${ }^{660}$ Como esta famosa sentencia de Novalis: "Es un error prodigiosamente ridículo el pensar, como lo hace la gente, que se habla en razón de las cosas. Todos ignoran justamente lo que es propio del lenguaje, a saber, que no se ocupa, sencillamente, más que de sí mismo”. (Citado ibíd., p. 59.) 
es porque se trata de un juego autosuficiente sino porque ya es en sí mismo experiencia de mundo y texto de saber, porque él mismo dice, antes que nosotros, esa experiencia" ${ }^{661}$.

A partir del movimiento romántico, como vemos, las palabras comienzan a presentar "en su propio cuerpo la fisonomía de lo que dice[n]",662 y la obra se vuelve en sí misma un texto de saber porque encarna en el lenguaje una determinada experiencia de la realidad. Guillermo Sucre comparte esta concepción que, revitalizada por la crisis de la metafísica, había sido planteada también por teóricos modernistas como Barthes o Paz que eran conscientes de los poderes del lenguaje. En línea con estos autores y con el cambio que había tenido lugar a comienzos del siglo XIX, el formalismo para Sucre no tiene nada que ver con una supuesta intransitividad del lenguaje, sino que para él ese término significa "que en el arte no hay contenidos previos o, lo que es igual, que es en las formas donde se percibe, ya encarnado, todo contenido" ${ }^{\prime 63}$. A la idea de que el sentido es inseparable de la palabra Guillermo se refiere con la expresión "conciencia del lenguaje" (siguiendo, quizás, a Octavio Paz, que había hablado de "conciencia poética" ${ }^{, 664}$ ) y para él es una constante en todos los grandes escritores modernos $-\mathrm{O}$, al menos, en todos aquellos a los que estima. Por eso afirmaba que lo más llamativo de la obra de Darío era su formalismo, es decir, "la conciencia de que la palabra es una con lo que enuncia, de que toda visión depende, en última instancia, del lenguaje" ${ }^{\text {665 }}$. Igualmente, a propósito de la obra de Huidobro, nuestro autor destacaba que "el pensamiento se hace forma, o es la forma misma" y que sus mejores poemas "no sólo rescatan la plenitud de la palabra, también hacen que lo significado surja como

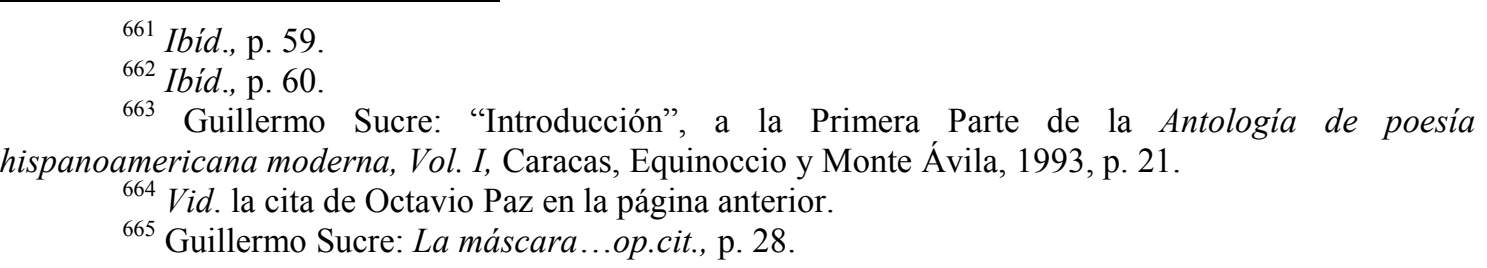


aprehensión profunda del significante",666. Sucre reconocía, en suma, que "saber escribir" consiste en encontrar "el punto alquímico de un lenguaje en que resulta ya imposible distinguir lo que se dice de la manera en que se dice" ${ }^{\prime 67}$.

La conciencia del lenguaje, es decir, la certeza de que las palabras hacen sensible en su propio cuerpo una significación que no existe sin ellas, tiene implicaciones de mayor alcance. Supone, para empezar, que el mundo no tiene un sentido preexistente que las palabras deben simplemente reflejar o expresar. En el pensamiento de Sucre toda significación preestablecida de la realidad es arbitraria y está vinculada al poder y a sus instrumentos ideológicos, la metafísica y la historia. El poder fija una interpretación sobre el universo que hace pasar por natural o verdadera, y se sirve de ella para justificar su situación privilegiada. Frente a esta posición, nuestro autor considera que el hombre ya no puede recurrir al amparo que ofrecían los sistemas ideológicos o las utopías históricas y que debe vivir, por lo tanto, en la intemperie del sentido. Cancelada la verdad única de la metafísica y cualquier concepción unitaria del mundo ${ }^{668}$, Guillermo piensa que el hombre no puede reproducir objetivamente la realidad, sino sólo comunicar una experiencia subjetiva de la misma en el espacio del lenguaje. Por eso indicaba que las palabras del poeta "no expresan al mundo, sino que aluden (interrogan, ordenan) a una experiencia del mundo"669 y señalaba, en el mismo sentido, que toda creación literaria "sólo tiene una validez imaginaria y como tal no es ni la realidad ni el mundo; sólo un modo de ver la realidad y el mundo, y de estar en

${ }^{666}$ Ibid., p. 105.

${ }^{667}$ Guillermo Sucre: "La metáfora incompleta", en Plural, (México), (46), jul. 75, p. 72.

${ }^{668}$ Haciéndose eco de lo que había propuesto Paz en "Los signos en rotación" (1967), Sucre afirmaba que "cualquier visión del mundo sufre hoy una ruptura y un resquebrajamiento: su coherencia es un perpetuo móvil. No una unidad compacta, sino un conjunto de relaciones." (Guillermo Sucre: "La nueva crítica", loc.cit., p. 261)

${ }^{669}$ Guillermo Sucre: La máscara ...op.cit., p. 23. 
ellos ${ }^{\text {} 670}$. El relativismo de estas frases es solo aparente pues, si bien Sucre reconoce la singularidad de cada obra, para él toda gran creación literaria debe inventar y revelar el verdadero sentido del mundo que está antes (y después) de las construcciones ideológicas e interesadas que el poder ha establecido sobre lo sensible.

\section{2. LA INVENCIÓN DE LO REAL}

La conciencia del lenguaje implica, entonces, que el hombre y la realidad no son entidades fijas y autosuficientes que en un momento dado participan en la obra, sino que ambos son absorbidos por la propia creación y sólo existen después de encarnar en las palabras. Esto significa que la obra no imita un sentido preestablecido del mundo o del escritor sino que lo inventa, y se convierte así en un nuevo nacimiento. Por eso Guillermo define la "escritura" como el juego de un lenguaje que se inventa a sí mismo y a su creador "a medida que inventa al mundo",671.

Esta invención de la identidad y de la realidad que tiene lugar en la poesía no es arbitraria, sino que restituye al hombre y al mundo su verdadera presencia. En la visión de Sucre, los grandes poetas modernos han tratado incansablemente de restablecer la unidad primordial que alguna vez existió entre el individuo y el universo. Como él mismo afirma, desde el Romanticismo la poesía ha estado marcada por el sentimiento “de nuestra falla original”, es decir, por esa herida o esa carencia "que signa la relación del hombre con el mundo",672. Pero la búsqueda del absoluto que emprenden los vates modernos "no puede ser sino irónica: reinstaurar la unidad perdida es inventarla,

${ }^{670}$ Ibíd., p. 21. "En última instancia, -decía el propio Guillermo- la realidad en que participamos reside en la mirada, en el lenguaje. El verdadero realismo, o quizá el único posible, es el de la imaginación. Y el primer poder de ésta en literatura es, sabemos, verbal.” (Ibíd., p. 23.)

${ }^{671}$ Guillermo Sucre: "La nueva crítica", loc.cit., p. 264.

672 Guillermo Sucre: "Introducción" a la Tercera Parte de la Antología de la poesía hispanoamericana moderna, Vol. II, op.cit., p. 15. 
inventarla es redescubrirla"673. Entonces, la poesía moderna es a un tiempo creación y descubrimiento, pues el mundo original que la obra instaura no se encuentra en un más allá, sino en la realidad aparente y concreta que nos rodea. Por eso, más que novedad radical, la poesía es un reconocimiento: “en el presente ver o buscar la imagen original que gravita sobre nosotros" ${ }^{\prime 674}$.

Nuestro autor cree en la existencia de una realidad esencial y unificada, donde no tienen lugar las divisiones y las jerarquías impuestas por el poder en lo sensible. La labor de la poesía es inventar y revelar a un tiempo ese mundo maravilloso que ha sido opacado por la metafísica y por la historia. Ella debe por tanto redescubrir el universo esencial y primordial que no se encuentra en una dimensión trascendente, sino aquí y ahora: surge de la aceptación de lo que vemos y vivimos cada día. Como él mismo dice, no se trata de "hacer claro el sentido del mundo", sino de "hacer del sentido del mundo la única claridad posible” ${ }^{\text {675 }}$. Para crear y descubrir el universo esencial el poeta no puede limitarse a copiar una versión ya establecida sobre lo real, pues eso supondría ceñirse a una interpretación interesada y anular el potencial generativo de la imaginación. El vate debe ser capaz de ver y de escribir la realidad con ojos límpidos, pues sólo así conseguirá inventar una versión sobre ella que será, al mismo tiempo, un reconocimiento de lo esencial. En palabras de Sucre: "por medio de las palabras nombramos el ser, pero al nombrarlo lo que estamos haciendo es inventarlo,

${ }^{673}$ Guillermo Sucre: "Introducción” a la Primera Parte de la Antología...., Vol. I, op.cit., p. 23.

${ }^{674}$ Guillermo Sucre: "Introducción” a la Tercera Parte de la Antología..., Vol. II, op.cit., p. 18. Guillermo afirmaba que la "ironía romántica" dio lugar a "una modernidad ambigua y ambivalente" que "vive de lo actual, pero en busca de lo inactual; se arraiga en el presente, pero para hacer posible la verdadera presencia: el advenimiento del hombre originario". (Guillermo Sucre: "Introducción" a la Primera Parte de la Antología..., Vol. I, op.cit., p. 23.)

675 Guillermo Sucre: Contraportada a Eduardo Mitre: Mirabilia, La Paz, Hipótesis, s/p. Igualmente, Rubén Darío, según nos dice Sucre, "quería expresar no sólo su mundo sino el mundo («siento como un eco del corazón del mundo/ que penetra y conmueve mi propio corazón»). Lo importante para él era buscar la correspondencia [simbolista] entre los seres y las cosas. «El corazón la forma tiene de un corazón», dirá en un poema.” (Guillermo Sucre: La máscara...op.cit., p. 29) 
proponiendo una metáfora más" ${ }^{676}$. Al designar la realidad, el poeta ofrece una versión sobre ella que la muestra en su verdad esencial y original. Ante las opacidades que el poder y la costumbre han establecido sobre el mundo, la literatura está vinculada a la revelación de la verdad del ser. Cuando la creación literaria es apropiada, la obra consigue inventar el mundo y al creador ${ }^{677}$ como verdaderamente son. Como veremos más adelante, esta idea implica aceptar que la literatura está vinculada al ethos esencial del hombre y del mundo. Sin embargo, ahora vamos a centrarnos en la explicación de las fuentes de esta idea de Sucre para pasar después al estudio de cómo se inventa la realidad esencial y cómo es esa realidad que se inventa.

La idea de que como el mundo ha perdido una significación definitiva la obra sólo puede tratar de restituir ese sentido imaginaria y parcialmente en el cuerpo del lenguaje aparece, para Sucre, en muchos autores fundamentales. El primero al que hay que referirse es Octavio Paz. De este escritor mexicano, Guillermo toma la idea de que ya no hay una imagen unitaria del mundo y de que su verdadero sentido se nos escapa o no existe. En "Los signos en rotación” (1967), Paz había establecido que "la universalidad de la técnica [...] no nos ofrece una imagen del mundo sino un espacio en blanco. [...] La técnica libera a la imaginación de toda mitología y la enfrenta con lo desconocido. La enfrenta a sí misma y, ante la ausencia de toda imagen del mundo, la

\footnotetext{
${ }^{676}$ Guillermo Sucre: "Poesía hispanoamericana y conciencia...”, loc.cit., p. 615.

${ }^{677}$ En la visión de Sucre, la creación literaria inventa la identidad del autor de manera semejante a como instaura la realidad. Para nuestro autor la obra no refleja simplemente la personalidad definitiva del artista, sino que ella (si es que existe) es el resultado de la propia obra. Como afirma Guillermo: "si ya no podemos ver la obra de arte como la expresión de una personalidad, no es porque el autor haya renunciado simplemente a expresarla, sino porque esa personalidad se ha vuelto también problemática: si existe, existe no antes sino después de la obra, y ya sólo como una metáfora más de ésta". (Guillermo Sucre: La máscara...op.cit., p. 97) La obra se niega a ser una copia de la realidad preexistente y logra revelar la verdadera realidad. De la misma manera, al rechazar convertirse en el simple resultado de una personalidad ya determinada, la creación consigue encarnar una identidad humana universal. Aunque esta invención de la identidad se da en todos los grandes poetas modernos, es quizás Borges uno de los autores más conscientes de ella. Con las propias palabras de Sucre, el autor argentino "invierte la consabida relación entre la personalidad del autor y el arte: éste no es la expresión de aquélla, sino lo que la constituye y la hace posible. Al despojamiento del yo biográfico corresponde, entonces, la conquista de otro yo imaginario o virtual." (Ibid., p. 163)
} 
lleva a configurarse ${ }^{, 678}$. El mundo para Paz es un sistema de relaciones que carece de una significación estable y que sólo existe al contacto de una mirada y un lenguaje necesariamente parciales. Al aceptar la imposibilidad de reproducir una imagen unitaria y definitiva de la realidad o un sentido de la misma establecido de antemano, la creación se convierte necesariamente en una invención o fundación. Pero, en la visión de Paz, "fundar un mundo" "es a un tiempo inventar y rescatar lo real"679: para el escritor mexicano, la creación instaura, pero al instaurar, revela. Esto es precisamente lo que Guillermo destacaba del prólogo titulado "Libertad bajo palabra", al que considera "resumen y proyecto" de la "empresa poética" de Paz. En ese texto, nos dice nuestro crítico, "el poeta no inventa un sino el mundo, no otro sino este mundo. La invención, por tanto, remite a la búsqueda de lo real. También es cierto que esa búsqueda remite a la invención: lo real, soñado, es infinitamente más vasto que su pura contingencia: reconciliación de los opuestos: lo real recobra su verdadero sentido y es entonces visto con «ojos límpidos»" ${ }^{680}$. Así vemos que al fundar lo real, el poeta lo muestra como de verdad es. Ante la pérdida de un sentido definitivo del mundo, el creador propone una metáfora del mismo que lo descubre en lo que es, original y esencialmente.

También en otros autores Sucre encuentra una concepción similar. Entre ellos hay que citar a Roberto Juarroz que, según nos recuerda en varios ensayos, "alude al mundo como una metáfora cuyo primer término hemos perdido o que quizá no ha

${ }^{678}$ Octavio Paz: “Los signos en rotación”, en OOCC, Vol. I, op.cit., p. 319.

${ }^{679}$ Guillermo Sucre: "La nueva crítica", loc.cit., p. 268.

${ }^{680}$ Guillermo Sucre: La máscara...op.cit, p. 218. El propio Sucre reconoce la proximidad de Paz con el surrealismo en lo que atañe a este punto: "Inventar lo real: esto es, creo, lo que separa a la poesía de Paz de la de Huidobro, cuyo intento era crear otra realidad paralela a la del mundo. Al mismo tiempo es lo que aproxima a Paz del surrealismo y lo que distancia, como es sabido, a Huidobro de este movimiento. Lo extraordinario de lo maravilloso -decía Breton- es que ya lo maravilloso no existe, sino lo real. Para los surrealistas y para Paz, la invención es una nueva conquista verbal del mundo." (Ibíd., p. 218). El propio Paz reconocía su cercanía con las ideas de André Breton. Según nos dice, para Breton "la poesía era creación de realidades por la palabra y no mera invención verbal." El teórico del surrealismo "amaba la novedad y la sorpresa en arte, pero el término invención no era de su gusto; en cambio, en muchos de sus textos brilla con luz inequívoca el substantivo revelación." (Octavio Paz: "André Breton o la búsqueda del comienzo", en OOCC, Vol. II, op.cit., p. 192) 
existido nunca. Simplificando, podríamos decir que en toda metáfora el primer término es lo real. El mundo, pues, para Juarroz es irreal: si existe es porque podemos no prefigurarlo sino figurarlo en el acto mismo del lenguaje, esto es, inventarlo" ${ }^{681}$. Como vemos, ante la pérdida de una significación estable del mundo, el poeta se impone la labor de inventar su verdadero sentido imaginariamente. Una visión parecida se advierte en el pensamiento de Lezama Lima, como nos recuerda Guillermo en varias ocasiones $^{682}$. Para el escritor cubano la poesía inaugura una causalidad capaz de originar una "naturaleza segregada o elaborada"683. Según lo explicaba el autor de Paradiso:

La penetración de la imagen en la naturaleza engendra la sobrenaturaleza. En esa dimensión no me canso de repetir la frase de Pascal que fue una revelación para mí, «como la verdadera naturaleza se ha perdido, todo puede ser naturaleza»; la terrible fuerza afirmativa de esa frase me decidió a colocar la imagen en el sitio de la naturaleza perdida de esa manera frente al determinismo de la naturaleza, el hombre responde con el total arbitrio de la imagen. Y frente al pesimismo de la naturaleza perdida, la invencible alegría en el hombre de la imagen reconstruida. ${ }^{684}$

Como la naturaleza se ha perdido, el hombre la restituye gracias a la imagen: la invención que acontece en la obra literaria es un nacimiento que, al mismo tiempo, restablece la verdadera presencia del mundo. A este respecto, podríamos mencionar a muchos más autores ${ }^{685}$, pues la concepción de que la poesía crea y descubre la

${ }^{681}$ Guillermo Sucre: "Poesía hispanoamericana y conciencia...", loc.cit., p. 633.

${ }^{682}$ A este respecto afirma Sucre: "Como Pascal, Lezama Lima decía que hemos perdido el sentido de la naturaleza; pero advertía: hay que restituirla, no sustituirla. En Roberto Juarroz encontramos una variación del mismo tema: el mundo es el segundo término de una comparación cuyo primer elemento se ha perdido." (Guillermo Sucre: "Introducción", a la Tercera Parte de la Antología..., Vol. II, op.cit., p. 15)

${ }^{683}$ José Lezama Lima: "Pascal y la poesía", en Tratados en La Habana, en Obras completas, Vol. II, México, Aguilar, 1977, p. 564.

${ }^{684}$ José Lezama Lima: "Confluencias", en La cantidad hechizada, en Obras completas, Vol. II, op.cit., p. 1213. Decía también: "Hay inclusive como la obligación de devolver la naturaleza perdida. De fabricar naturaleza, no de recibirla como algo dado. «Como la verdadera naturaleza se ha perdido, dice Pascal, todo puede ser naturaleza». La elaboración de la naturaleza en el hombre, que nada tiene que ver con el hombre como enfermedad o excepción de la naturaleza de los existencialistas. Si la pérdida de la naturaleza se debió al pecado, no lo puede ser en el hombre el afán de colocar en el sitio de la naturaleza después de la caída, otra naturaleza segregada o elaborada." (José Lezama Lima: "Pascal y la poesía", en Tratados en La Habana, en Obras completas, Vol. II, op.cit., p. 564)

${ }^{685}$ Entre ellos podemos mencionar, por ejemplo, a Huidobro. Como nos dice Guillermo, "sus poemas no quieren expresar nada previo a ellos: ni ideas ni, mucho menos, «états d’âme». No desarrollan, como suele decirse, un tema [...]. El poema no es un objeto acabado, hecho, sino por rehacer; tampoco traduce ni interpreta nada que sea anterior a él. El poema quiere abrir algo que es como decir abrirse él mismo: "Que el verso sea como una llave/ Que abra mil puertas», es el principio del arte poética de Huidobro." (Guillermo Sucre: La máscara...op.cit., p. 105). El vate chileno planteaba también que "la 
significación verdadera de lo real se convierte en una constante de la mirada crítica de Guillermo Sucre. Lo que sí debemos destacar es que todos ellos -y, quizás, también el propio Sucre- tienen en común el antecedente del filósofo alemán Martin Heidegger.

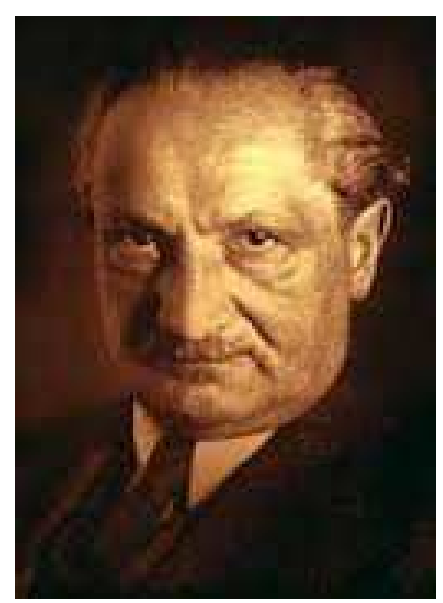

Imagen 40. Martin Heidegger (1889-1976)

En su ensayo "El origen de la obra de arte", este pensador había establecido que "todo arte es como dejar acontecer el advenimiento del ente en cuanto tal, y por lo mismo es en esencia Poesía. La esencia del arte, en la que especialmente descansan la obra de arte y el artista, es el ponerse en operación la verdad" ${ }^{, 686}$. Ahora bien, la “instauración de la verdad” que es la esencia de la Poesía (y aquí parece que nos estuviera hablando Lezama) "nunca se deduce ni se comprueba por lo hasta ahora ocurrido. Esto en su exclusiva realidad queda anulado por la obra. Por eso lo que el arte instaura nunca se compensa ni se suple con lo existente disponible. La instauración es una superabundancia, una ofrenda" ${ }^{687}$. Pero este carácter de acontecimiento que tiene el advenimiento del ente en la obra de arte no es injustificado o inoportuno. El arte crea

poesía no es tanto una clave como una llave: más que transcribir los símbolos del universo y descifrarlos, se trata quizá de revelar algo que aún no se conoce del todo”. (Ibíd., p. 106). En este apartado, en verdad, podríamos citar también a todos aquellos autores que, como Barthes, Borges o Ramos Sucre presentan una concepción irrealista del lenguaje. Esta concepción implica la idea de que la literatura es un código diferente a la realidad y que constituye, por tanto, un nuevo nacimiento.

${ }^{686}$ Martin Heidegger: "El origen de la obra de arte", en Arte y poesia, op.cit., p. 83.

${ }^{687}$ Ibid., p. 86. 
algo nuevo, pero esa creación no es arbitraria: "La ofrenda y la fundamentación tienen lo repentino de lo que se llama un comienzo. Sin embargo, esto repentino del comienzo, lo propio del salto desde lo inmediato, no excluye sino precisamente incluye que el comienzo se preparaba disimuladamente mucho tiempo antes" ${ }^{\text {,68 }}$. Como vemos, en el pensamiento de Heidegger, ya estaba contenida la idea de que la poesía es fundación de la verdad mediante la palabra: esa verdad es una invención, pero esa invención “jamás se realiza en lo vacío e indeterminado" sino que "es la patentización de aquello en lo que el existente (Dasein) está ya proyectado como histórico"689.

Volviendo al pensamiento de Sucre, vamos a ver a continuación de qué manera él piensa que la obra literaria funda la realidad. La instauración de lo real está estrechamente vinculada a la conciencia del lenguaje, que es el eje que sostiene toda la estética de nuestro autor. Esta teoría, que plantea que el significado surge como aprehensión profunda del significante, supone que la creación y la realidad dejan de ser dominios separados. Si el nombre coincide con lo nombrado, se establece una homología entre la obra y la realidad, de manera que ambas entidades se identifican y la utopía política coincide pues con la utopía literaria. Por eso, inventar y revelar la verdadera realidad implica crear una obra perfecta, donde no haya excesos de cosas ni de palabras. En la visión de Guillermo, para crear y revelar el mundo esencial, la creación literaria debe establecer una continuidad perfecta entre el sujeto y el objeto y

${ }^{688}$ Ibid., p. 86.

${ }^{689}$ Ibíd., p. 86. En este texto de Heidegger se aprecian ideas que luego Paz retoma en su ensayo "Literatura de fundación", el cual dejó una huella importante en Guillermo Sucre. Dice Heidegger, por ejemplo: "La instauración de la verdad no es sólo instauración en el sentido del libre ofrecimiento, sino a la vez instauración en el sentido de fundamento que funda. La proyección poética sale de la nada, en cuanto a que nunca toma su ofrenda de lo corriente y ya ahora ocurrido. Sin embargo, no sale jamás de la nada debido a que lo proyectado por ella sólo es el destino mismo ya previamente contenido del existente histórico mismo (Dasein)." (Ibíd., p. 86). Y en otro momento dice: "El arte permite brotar a la verdad. El arte brota como la contemplación que instaura en la obra la verdad del ente. Lo que significa la palabra origen es que algo brota, en un salto que funda, de la fuente de la esencia al ser. [/] El origen de la obra de arte, es decir, a la vez, de los creadores y los contempladores, es decir, de la existencia histórica de un pueblo, es el arte. Esto es así porque el arte en su esencia es un origen y no otra cosa: una manera extraordinaria de llegar a ser la verdad y hacerse histórica." (Ibíd., p. 88) 
entre lo imaginario y lo real que implica asimismo (en la medida en que esto es posible) la coincidencia entre las palabras y las cosas. Al conciliar la subjetividad y la objetividad en el cuerpo del lenguaje, la obra nos muestra una visión prístina y original de lo real que cancela las jerarquías y las distancias impuestas en lo sensible por el poder y que permite restituir el absoluto desintegrado por la modernidad.

Entonces, para revelar la verdadera realidad, es preciso que la obra sea capaz de fusionar -con el grado más alto de saturación posible- lo objetivo y lo subjetivo, lo real y lo soñado, y también, en último término, el lenguaje y el universo. La creación deviene entonces, como la define el propio Sucre, una "encarnación imaginaria de lo real" ${ }^{190}$ en la que es imposible distinguir la realidad física de la visión imaginaria. Cuando se alcanza ese punto, lo mirado coincide con la mirada y la creación consigue ofrecernos la visión del mundo esencial, que carece de jerarquías y de contrarios. Obtener la saturación expresiva en la obra supone construir una utopía política que nos devuelve el orden original de la existencia.

A esta utopía literaria (pero también política) Guillermo se refiere con el término "transparencia", que es la forma que adopta la realidad al ser aprehendida imaginariamente por el creador y encarnada en la escritura. Con este concepto, nuestro autor alude a la concordancia entre el sujeto y el objeto, entre lo visible y lo soñado, y entre las palabras y las cosas, que tiene lugar en la obra literaria. “¿Qué nos transparenta el cristal de la transparencia? -se pregunta Sucre irónicamente. Quizá sólo esto: disolución de la realidad de la imagen, pero realidad de esa disolución"691. Según señalaba él mismo en otro lugar, la transparencia consiste en la "revelación de las cosas en lo que son y de lo que son como aparecen, [...] una contemplación que se apodera de

${ }^{690}$ Guillermo Sucre: "La nueva crítica", loc.cit., p. 270.

${ }^{691}$ Guillermo Sucre: "Entretextos”, en Vuelta, (México) may. 77, p. 10. De manera semejante afirmaba en el mismo texto: "La transparencia del mundo sería, pues, la disolución de lo real. Representación de las cosas en nuestra percepción: visibilidad de esa disolución" (Ibíd.) 
lo mirado pero sólo como acto de la mirada" ${ }^{692}$. Esta noción supone, por lo tanto, la pervivencia imaginaria (o memoriosa, que es 10 mismo ${ }^{693}$ ) de lo real, que implica la comunión del sujeto y del objeto, y que permite restituir la realidad esencial y verdadera desintegrada por el poder y la modernidad. Nuestro autor advierte que esta continuidad entre lo real y lo soñado se puede ver en la obra del poeta venezolano Ramos Sucre:

Las mejores imágenes de Ramos Sucre [...] reúnen lo distante y lo justo. El que muchas veces tiendan a la abstracción no hace sino conferirles quizá una mayor intensidad: parecen dibujar una suerte de escritura de la materia. Escribir la materia, ¿qué podría significar esto? Posiblemente una suerte de dialéctica entre la densidad física y la transparencia imaginaria, entre lo "pleno" y lo "vacío" del objeto; en una palabra: la naturaleza convertida en signo mental, en esa secreta fatalidad del deseo. ${ }^{694}$

En este ejemplo, sin embargo, no se aprecia bien la dimensión "política" o

utópica de la transparencia, que sí es visible en esta otra cita, donde el poeta consigue revelar un mundo original que implica un reparto de lo sensible diferente al que el poder y sus instrumentos ideológicos, la metafísica y la historia, nos han habituado. Como dice Guillermo:

Lo que ve [Homero] Aridjis es un mundo que es nuestro mundo real, pero también su encarnación primordial: una naturaleza mítica a la que se tiene acceso por los sentidos y el ascetismo, por la reconciliación de todo. Así como en su poesía lenguaje y silencio son lo mismo, en el mundo que figura cuerpo y alma lo son también. De ahí que se exalte tanto lo corpóreo [...]: la materia es sagrada y consagrada por una suerte de presencia cósmica, una divinidad que es espacio reencontrado. Aridjis asume ese espacio: descubre en él lo vivo, la energía, la pureza de todo reino tocado por la inocencia. ${ }^{695}$

${ }^{692}$ Guillermo Sucre: La máscara ...op.cit., p. 235. Por eso, la transparencia es "la revelación de lo inmanente del mundo como una relatividad que es también un (el único) absoluto.” (Ibíd., p. 235)

${ }^{693}$ Como dice Sucre: "Lo que se propone Darío es encontrar la inocencia original, la memoria que ya no es memoria porque es la realidad misma”. (Ibíd., p. 44). Al ser una apropiación imaginaria del mundo, la transparencia tiene que ver con la ambivalencia entre la presencia y la ausencia o entre la posesión y la desposesión que para Sucre era la constante más significativa de la obra de Borges. "La ausencia sería, pues, un camino hacia la plenitud y aun hacia lo absoluto. Imaginar que no ser es más que ser algo y, de alguna manera, serlo todo: esta aparente falacia (de la que él se hace cómplice) es lo que propone Borges en uno de sus ensayos de los años cincuenta. Ella es la que sustenta toda su obra." (Guillermo Sucre: "Borges, una poética de la desposesión”, en Revista Iberoamericana, (Pittsburgh), vol. XXXVIII, núm. 79, abr.-jul. 1972, p. 197). Para Guillermo la transparencia es una "(des)posesión: no el objeto poseído, sino su dispersión en la fijeza (¿de la memoria?)”. (Guillermo Sucre: "Entretextos", loc.cit., p. 10)

${ }^{694}$ Guillermo Sucre: "Ramos Sucre: Anacronismo y/o renovación”, en Revista Iberoamericana, (Pittsburg), vol. XLV, núm. 106-107, ene.-jun. 1979, p. 83. Como afirma en el mismo texto, las del poeta venezolano son "imágenes imaginantes", ya que "no pretenden describir o situar un objeto, sino modularlo con su espacio, hacerlo a un tiempo necesario y virtual" (Ibid., p. 83)

695 Guillermo Sucre: "Poesía Crítica: Lenguaje y silencio", en Revista Iberoamericana, (Pittsburgh), vol. XXXVII, núm. 76-77, jul.-dic. 1971, p. 592. También en las obras de Huidobro, Ramos Sucre o Juarroz, Sucre advierte una visión semejante de la realidad. 
Al ligar lo visible y lo soñado en el cuerpo del lenguaje, este vate mexicano consigue revelar una realidad esencial donde todo se reconcilia y donde se rectifican las jerarquías que habían sido establecidas arbitrariamente. En el mundo inventado y revelado a un tiempo por el poema, se cancelan las dualidades instauradas por siglos de metafísica y se recupera una significación prístina del universo. En el cosmos generado y descubierto por la poesía de Aridjis todo está reconciliado, el cuerpo coincide con el alma, y la materia se carga, en sí misma, de una dimensión trascendente. De la misma manera, Guillermo destacaba que la poesía de Roberto Juarroz es una "confrontación con lo esencial, con lo que de alguna manera ha sido inesencial a la historia y, al parecer, sobre todo en nuestra época"696. En esa obra "lo cotidiano", "sin dejar de serlo, es igualmente original, primordial" y "es, además, sagrado"697; y esto es así porque "el universo de Juarroz no admite un centro [...]; no hay uno sino múltiples centros: cada ser y objeto en el mundo lo es. Centros múltiples, lo importante es aprehender sus relaciones, contrastes y oposiciones ${ } 698$. En esta lectura, como vemos, Sucre pone en valor que el poeta argentino ha sido capaz de mostrar lo esencial: en su visión, lo cotidiano y lo actual se vuelve también sagrado, y todas las cosas establecen relaciones horizontales porque presentan una importancia similar.

Entonces, cuando se logra establecer una continuidad satisfactoria entre el sujeto y el objeto y entre lo imaginario y lo real -es decir, cuando se obtiene la transparencia-, la obra (re)descubre una realidad esencial donde se aprecia un reparto de lo sensible muy concreto. Como resultado de la conciencia del lenguaje, la creación literaria y la realidad son estrictamente equivalentes, por lo que este reparto se puede estudiar a partir de la visión del mundo o de la obra indistintamente. A continuación, abordaremos la cosmovisión de nuestro autor, pero hay que recordar que al hacerlo estaremos

\footnotetext{
${ }^{696}$ Ibid., p. 580.

${ }^{697}$ Ibid., p. 580.

${ }^{698}$ Ibid., p. 581.
} 
describiendo también su percepción del arte, pues en el pensamiento de Sucre ambos dominios resultan imposibles de distinguir.

El reparto de lo sensible que implica la estética de Guillermo Sucre surge de una oposición al poder y a sus instrumentos ideológicos, la metafísica y la historia. En el pensamiento de nuestro autor el poder es "todo lo que funcion[a] como un «dispositivo ya armado» para posesionarse del mundo"699, es decir, todo aquello que impone un sentido definitivo sobre el mundo y exige que ese sentido sea respetado unánimemente. En vez de aceptar la realidad tal y como es, el poder fija una interpretación arbitraria sobre el universo que hace pasar por la verdadera y se sirve de ella para justificar su situación privilegiada. Además, Guillermo cree que el poder introduce en lo sensible una dimensión profunda y compleja que lo convierte en la consecuencia vana e insignificante de un fundamento más relevante. El poder se vincula entonces con la profundidad característica del pensamiento metafísico, que hace que la verdad del mundo aparente sólo sea accesible a aquellos que poseen sus claves interpretativas. A este respecto Sucre se preguntaba retóricamente: “¿Por qué el mundo ha de ser complejo o profundo sino justamente para hacerlo inaccesible, para que haya siempre los que poseen o desposeen su clave, que es el poder?" $" 700$ En vez de aceptar el mundo en su dimensión visible, el poder introduce un trasfondo secreto que le sirve para legitimar su propia posición de dominio. Asimismo, nuestro autor consideraba que este poder era el responsable de haber establecido falsas dualidades en la realidad y de haber prestigiado de manera interesada el alma sobre el cuerpo, lo espiritual sobre lo material o el futuro sobre el presente:

${ }^{699}$ Guillermo Sucre: “Memorial, de Rafael Cadenas”, en Vuelta, (México), nov. 1978, p. 41. El poder toma su legitimidad de la existencia de un sentido previo y, por eso, sus instrumentos ideológicos son la metafísica y la historia que, a decir de Sucre, "han hecho imposible vivir en el mundo en nombre de la complejidad y profundidad de éste”. (Ibíd., p. 41.)

${ }^{700}$ Ibid., p. 41. 
Nuestra filosofía, nuestra religión y nuestra moral lo que han hecho es acentuar la dualidad o, cuando no, proponer una falsa unidad, abstracta. Según lo primero, hay un centro en el universo que supuestamente empieza por residir en el Hombre y termina por enraizarse en una clase; según lo segundo, la unidad es sólo la represión de uno de los contrarios: la materia en beneficio del espíritu, el presente en beneficio del futuro, esta vida en beneficio de la otra prometida, acá o allá, siempre trascendente $\measuredangle y$, por ello mismo, siempre postergada? ${ }^{701}$

Frente a las opacidades y las jerarquías interesadas y arbitrarias que el poder impone en lo sensible, la visión de Guillermo reivindica una realidad esencial: "el mundo -dice él- se nos revela más allá de todo valor: es la realidad -el esplendor- que nos rodea y en la que estamos sin ser individuos privilegiados" ${ }^{, 702}$. Esta realidad se caracteriza por dos aspectos básicos: la inmanencia y la igualdad.

Nuestro autor piensa que las cosas son maravillosas en lo que tienen de concreto y actual, es decir, en su propia materialidad, sin necesidad de remitirlas a ninguna dimensión trascendente. Como él mismo afirmaba: "No hay más allá (que sólo ha existido para corromper el más acá, advertía Nietzsche). Todo es liso. Cristal destellante: de sus reflejos múltiples están hechas nuestra persona (nuestra máscara), nuestra visibilidad del mundo"703. Al reivindicar las cosas en su elementalidad, Guillermo impugna toda la tradición metafísica anterior, que es la responsable de la fragmentación de la experiencia. Frente a las divisiones convencionalmente aceptadas entre el alma y el cuerpo o entre el espíritu y la materia a favor siempre del primer término, Sucre reivindica -como decía a propósito de Huidobro- "este mundo y no otro, este yo concreto y no otro mediatizado por los dogmas, este cuerpo y no las abstracciones" ${ }^{, 704}$. En vez de establecer jerarquías y anteponer uno de los términos sobre el otro, nuestro autor plantea que cada elemento depende sólo de su condición de

\footnotetext{
${ }^{701}$ Guillermo Sucre: "La cerebración de la celebración”, en Plural, (México), (42), mar. 75, p.
}

69.

${ }^{702}$ Guillermo Sucre: "La nueva profundidad: superficies nítidas”, en Plural, México (V-2), nov. 75, pp. 78-81, p. 79. Cursiva nuestra.

${ }^{703}$ Guillermo Sucre: "Entretextos", loc.cit., p. 10.

${ }^{704}$ Guillermo Sucre: La máscara ...op.cit., p. 110. 
posibilidad. Por eso indica en un texto sobre John Cage ${ }^{705}$, otro gran defensor de la inmanencia: "todo movimiento supone la fijeza; ningún silencio existe sin estar preñado de sonido; la materia no está separada del espíritu; la vida encierra la muerte o, mejor, la aceptación de la muerte es la fuente de toda vida" ${ }^{\text {706 }}$. No se trata, por lo tanto, de elegir entre dos términos enfrentados sino de asumir que cada uno depende de su contrario y de reconocer que las divisiones que establece el poder son arbitrarias y no coinciden con la verdadera realidad. Además, al recuperar el valor de la experiencia y de lo que es simplemente visible, Guillermo estaba desestimando la profundidad y el simbolismo característicos del pensamiento metafísico. En su manera de ver la realidad no hay secretos ni hay nada oculto: "todos somos la clave del mundo, o nadie lo es. No hay adentro ni afuera, interior o exterior: existe lo que vemos (y al revés), aunque sea frágil, cambiante"

Esta defensa de la inmanencia (cada cosa depende de su contrario; todo es plenamente visible) supone que el mundo es un sensorium de igualdad radical. En la concepción estética de Sucre, el universo es un sistema de relaciones horizontales que "no tiene centro ni privilegia nada de lo que en él habita. O más bien, todo en ese espacio puede ser centro, y, por tanto, todo en él es ambigüedad"708. Cuando somos capaces de ver la realidad más allá de las relaciones de dominio impuestas por el poder, ella aparece como de verdad es -un conjunto de vínculos igualitarios sin jerarquías de ninguna clase:

Si las cosas son claramente lo que son, esa claridad las vuelve transparentes también: se ven y se reflejan entre sí; se encuentran o se buscan unas a otras no para intercambiarse ni para adjurar de su identidad [...]: lo hacen para confrontarse, para reconocerse y aceptarse. Por consiguiente, la unidad no es más que la diversidad; no una sustancia fija sino una relación: el

705 John Cage (1912-1992) fue uno de los compositores musicales norteamericanos más influyentes del siglo XX. Sus obras revelan la huella de Cowell y de Schoenberg, y además le marcó de manera decisiva el pensamiento oriental. Sus principales escritos sobre estética están recogidos en los volúmenes Silence (1961) y A Year from Monday (1967).

${ }^{706}$ Guillermo Sucre: “La cerebración de la celebración”, loc.cit., p. 69.

707 Guillermo Sucre: "Memorial...", loc.cit., p. 41.

${ }^{708}$ Guillermo Sucre: “La poética de Georges Braque”, en Plural, (México), (38), nov. 74, Supl. 
ser de las cosas es el estar-entre-sí de ellas, no porque sean idénticas sino porque viven en el mundo y participan en él. ${ }^{709}$

En el universo esencial todo es visible y nada remite a un sentido velado o secreto; por lo tanto, todo tiene una importancia similar y la quimera de restituir la unidad de lo sensible comienza a parecer factible. Como ya no se puede hablar de jerarquías entre las cosas, lo fundamental es ver los lazos que los diferentes elementos mantienen entre sí y con el sujeto que los contempla. Al aceptarse la radical igualdad del mundo aparente (el único que existe para Sucre) se anulan las categorías y las divisiones inventadas por el poder, se privilegia el instante frente a la historia, la contigüidad se impone a la causalidad, y la espacialidad a la cronología.

En un breve ensayo donde trataba la cuestión de la transparencia, Guillermo parecía resumir sus planteamientos estéticos con las frases de tres autores fundamentales para entender su pensamiento durante este periodo. En ese texto Sucre copiaba estas ideas: "Susan Sontag: «transparencia significa experimentar la luminosidad de la cosa en sí, de las cosas que son lo que son». John Cage: la vida es «la manifestación visible de una invisible nada». Pierre Reverdy: «quizá no haya profundidad de espíritu sino solamente facultad de ver, de cerner o de crear relaciones $[\ldots] »{ }^{\wedge, 710}$. Y a continuación pasaba a dilucidar su sentido:

La primera proposición, de Susan Sontag, nos pone ante la presencia casi absoluta, y luminosa, de los objetos; pero éstos no hablan por nosotros sino a través de nosotros; de algún modo, también nosotros somos o podemos ser los objetos, sin reemplazarlos. La de Cage, por su parte, niega toda trascendencia: el esplendor del mundo que se consume a sí mismo en sí mismo. La de Reverdy, finalmente, postula la visibilidad del misterio: exalta la superficie contra la profundidad; nuestra piel es profunda, nuestro cuerpo, no nuestra alma. ${ }^{711}$

Después resumía lo antedicho de esta manera: "Transparencia es no interpretar sino ver; no sólo ver sino relacionar, es decir, saber ver; no sólo relacionar sino hacer de las relaciones una trama visible: hacer ver" ${ }^{, 712}$. Como parece intuirlo el propio Sucre,

\footnotetext{
${ }^{709}$ Guillermo Sucre: “La cerebración de la celebración”, loc.cit., p. 69.

${ }^{710}$ Guillermo Sucre: “Entretextos”, loc.cit., p. 10.

711 Ibid., p. 10.

${ }^{712}$ Ibid., p. 10.
} 
estas tres sentencias revelan también los puntos básicos de su propia estética. En primer lugar, se trata de mostrar la verdadera presencia de las cosas en el mundo, lo que -como hemos visto al explicar el concepto de la transparencia- se consigue estableciendo una continuidad entre el sujeto y el objeto o entre la visión de los ojos y la mirada de la mente -pues según dice en la cita "también nosotros somos o podemos ser los objetos, sin reemplazarlos”. En segundo lugar, hay que descubrir el esplendor del mundo en su materialidad y elementalidad. Como la realidad sensible no remite a ningún más allá trascendente o secreto, las cosas son maravillosas en sí mismas y sólo dependen de su condición de posibilidad. En tercer lugar, como se han cancelado las jerarquías características del pensamiento metafísico, lo fundamental son las relaciones horizontales que las cosas mantienen entre sí y con el sujeto que las contempla. Como dice el propio Guillermo, de lo que se trata es de ver la verdadera realidad, de saber verla, y de hacer verla. Si bien estas frases sirven como resumen de la estética de Sucre, las fuentes de la misma son mucho más amplias y analizarlas nos servirá para tener una visión más completa del pensamiento de nuestro autor.

\section{3. EN LA ÓRBITA ESTRUCTURALISTA Y CUBISTA}

En la visión de Guillermo, como resultado de la conciencia del lenguaje, la obra literaria debe establecer una continuidad entre el sujeto y el objeto o entre lo imaginario y lo visible que permita hallar una realidad prístina y unificada donde rige un reparto de lo sensible diferente al que el poder y la costumbre nos han habituado. La transparencia - es decir, la coincidencia entre lo mirado y la mirada- se vincula entonces a una manera de ver y de vivir lo real. La poética de la transparencia y su vínculo con un reparto de lo 
sensible similar al que defiende nuestro autor se aprecia en varios autores próximos a él ${ }^{713}$.

El primero sobre el que vamos a tratar es Octavio Paz. En oposición a las divisiones impuestas por el pensamiento occidental y a la escisión que la modernidad impone entre el hombre y el universo, el escritor mexicano busca incansablemente, desde el principio de su obra, la posibilidad de reconciliar al ser humano con su

713 A pesar de que en el cuerpo del texto sólo trataremos sobre aquellos autores próximos a Sucre, hay que decir que la poética de la transparencia hunde sus raíces en el Romanticismo europeo. Los poetas románticos fueron sin duda, como lo reconoce el propio Guillermo, los primeros que establecieron una continuidad entre lo real y lo imaginario para tratar de paliar la brecha en la experiencia que había acontecido con la llegada de la modernidad. Esto reconocía, al menos, nuestro autor en un texto de 1965, "Álgebra y fuego": "El poeta romántico por excelencia era el que vivía en un estado de nostalgia por la totalidad. Esa nostalgia ponía a funcionar en él unos sutiles y misteriosos «vasos comunicantes» y le abría de nuevo una relación dialéctica con el mundo. "Todo lo que es visible se relaciona con lo invisible, lo audible con lo inaudible, lo sensible con lo insensible, y quizá lo pensable con lo impensable», era creencia arraigada en Novalis. «El mundo se convierte en sueño, y el sueño se convierte en mundo», era también idea suya. Idea dominante en los más grandes románticos. «Hacer lo externo interno, lo interno externo, volver la naturaleza pensamiento y el pensamiento naturaleza», constituía para Coleridge la verdadera actividad del genio." (Guillermo Sucre: “Álgebra y fuego", loc.cit.) (Vid. asimismo Albert Béguin: "La estrella matutina (Novalis)" en El alma romántica...op.cit., pp. 242 y ss.). Esta unión que proponían los románticos entre el sujeto y el mundo, y entre lo real y lo imaginario, implicaba -como lo vio el gran ensayista norteamericano Emerson siguiendo los planteamientos de Coleridge y Carlyle- que todas las cosas están habitadas por una potencia suprema, que el artista, al contemplarlas con una percepción superior, es capaz de apreciar. Como decía Emerson en su conferencia "The Poet” (1844): "As the eyes of Lyncaeus were said to see through the earth, so the poet turns the world to glass, and shows us all things in their right series and procession. For, though that better perception, he stands one step nearer to things, and sees the flowing or metamorphosis; perceives that thought is multiform; that within the form of every creature is a force impelling it to ascend to a higher form; and, following with his eyes the life, uses the forms which express that life, and so his speech flows with the flowing of nature. All the facts of the animal economy, sex, nutriment, gestation, birth, growth, are symbols of the passage of the world into the soul of man, to suffer there a change, and reappear a new and higher fact." (Ralph Waldo Emerson: "The Poet", en Essays: Second Series, Boston, Phillips, Samson and Company, 3rd edition, 1857, p. 25). La concepción de Emerson tuvo continuidad en la poesía norteamericana y fue defendida ya en el siglo XX por poetas como William Carlos Williams o Wallace Stevens, a los que Guillermo leyó y tradujo en los años setenta. Ambos escritores concedían un peso fundamental a la imaginación en la creación literaria, y pensaban que ella era capaz de revelar la verdadera realidad. El primero de ellos señalaba en el volumen Spring and all (1923) que era necesario distanciarse de "la bella ilusión" del realismo convencional para que la obra encarnara la verdadera realidad que sólo existe en el "mundo de la imaginación, enteramente nuestro". (William Carlos Williams [trad. de Julieta y Guillermo Sucre]: $L a$ primavera y todo, Caracas, Monte Ávila, 1980, p. 58). Williams afirmaba, en consecuencia, que "no es necesario contar cada copo de la verdad que cae; es necesario habitar la imaginación si la verdad ha de ser contada. Es necesario hablar desde la imaginación". (Ibíd., 36). Por su parte, Wallace Stevens dialogaba con Coleridge y Emerson al señalar que "quizá hay un grado de percepción en el cual lo que es real y lo que es imaginado son una misma cosa: un estado de percepción clarividente, accesible o posiblemente accesible al poeta, o, digamos, al poeta más agudo". (Wallace Stevens [trad. de Guillermo Sucre]: Adagia, Caracas, Fundarte, 1977, p. 16). Y establecía un vínculo entre lo visible y lo invisible, hasta el punto de que ambas entidades resultaban para él idénticas: "the world is a compact of real things so like the unreal things of the imagination that they are indistinguishable from one another". (Wallace Stevens: "The Figure of the Youth as Virile Poet", en Collected Poetry and Prose, New York, The Library of America, 1997, p. 684) 
"otredad constitutiva" $" 714$, es decir, de hacerle regresar a la unidad primordial de la que fue separado: "la experiencia de lo Otro culmina en la experiencia de la Unidad. [...] El precipitarse en el Otro se presenta como un regreso a algo de que fuimos arrancados. Cesa la dualidad, estamos en la otra orilla. Hemos dado el salto mortal. Nos hemos reconciliado con nosotros mismos" ${ }^{\text {715 }}$. Uno de los medios privilegiados que tiene el hombre para restituir el vínculo del hombre con el universo es la poesía, que "no sólo proclama la coexistencia dinámica y necesaria de los contrarios, sino su final identidad" ${ }^{, 716}$. En la concepción de Paz, la poesía establece una continuidad entre dominios o entidades que normalmente aparecen enfrentados y así logra restablecer la unidad de la experiencia. El escritor mexicano aspira a que la poesía alcance la continuidad entre el sujeto y el objeto, y entre el significante y el significado, porque así obtendrá, aunque sea momentáneamente, el absoluto disuelto con la llegada de la modernidad. Ahora bien, la plenitud que el poema restituye no se da en un más allá trascendente sino en la vida concreta y actual. Como él dice: "La experiencia de la otredad es, aquí mismo, la otra vida. [...] Recuperar la vida concreta significa reunir la pareja vida-muerte, reconquistar lo uno en lo otro, el tú en el yo, y así descubrir la figura

714 Octavio Paz: El arco y la lira, en OOCC, Vol. I, op.cit., p. 277. Paz ponía de manifiesto su oposición al esfuerzo de la metafísica occidental por suprimir la otredad: "El modelo de Occidente es la unidad indivisible, trátese de metafísica (el ser), psicología (el yo), o del mundo social (la nación, la clase, los cuerpos políticos). Un modelo que, por lo demás, no corresponde a la realidad y que ésta destruye continuamente: la poesía, el erotismo, la mística y, en la esfera de la historia, la guerra y los conflictos intestinos, son las formas violentas y extemporáneas con que la otredad le recuerda al Uno su existencia." (Octavio Paz: "La persona y el principio", en OOCC, Vol. VI, op.cit., p. 1365) El escritor mexicano se aproximó por eso a otras formas de reflexión: "El pensamiento oriental no ha padecido este horror a lo otro, a lo que es y no es al mismo tiempo. El mundo occidental es el del «esto o aquello»; el oriental, el del «esto y aquello», y aun el de «esto es aquello»." (Octavio Paz: El arco y la lira, en OOCC, Vol. I, op.cit., p. 141)

715 Ibid., p. 174.

${ }^{716}$ A este respecto Paz había afirmado que "en la experiencia de lo sobrenatural, como en la del amor y en la de la poesía, el hombre se siente arrancado o separado de sí. Y a esta primera sensación de ruptura sucede otra de total identificación con aquello que nos parecía ajeno y al cual nos hemos fundido de tal modo que ya es indistinguible e inseparable de nuestro propio ser." (Octavio Paz: El arco y la lira, en $O O C C$, Vol. I, op.cit., p. 177.) Y también: "La identidad última entre el hombre y el mundo, la conciencia y el ser, el ser y la existencia, es la creencia más antigua del hombre y la raíz de ciencia y religión, magia y poesía. Todas nuestras empresas se dirigen a descubrir el viejo sendero, la olvidada vía de comunicación entre ambos mundos. Nuestra búsqueda tiende a redescubrir o a verificar la universal correspondencia de los contrarios, reflejo de su original identidad.” (Ibid., pp. 143-144) 
del mundo en la dispersión de sus fragmentos" ${ }^{, 717}$. La realidad maravillosa y original que el poema descubre se encuentra en el mundo visible que nos rodea. Por eso para él, como ya hemos visto, la poesía constituye al mismo tiempo una invención y una revelación: "la realidad se reconoce en las imaginaciones de los poetas; y los poetas reconocen sus imágenes en la realidad"718. De lo que se trata es de correr la cortina de la costumbre para descubrir, en la realidad circundante, y así sea por un momento de vivacidad, el mundo esencial y absoluto donde los contrarios no existen. A este hallazgo se refería con el término "transparencia", como vemos en un ensayo que escribió a propósito de un poeta español muy estimado por él: "la transparencia de [Jorge] Guillén refleja al mundo y su palabra es perpetua voluntad de encarnación. Pocas veces la lengua castellana ha alcanzado tal plenitud corporal y espiritual. [...] Han llamado a Guillén: poeta del ser. Es exacto, a condición de no concebir al ser como una idea o una esencia sino como una presencia. En Cántico el ser aparece efectivamente. Es el mundo, la realidad de este mundo" ${ }^{, 719}$. Asimismo, en un texto sobre la poesía de Blanca Varela, Paz anunciaba el nacimiento de una nueva estética en la que la labor del poeta consistiría en reconocer y aceptar la verdadera realidad:

La nueva poesía quiere ser un reconocimiento. El mundo exterior, ayer negado en provecho de mundos imaginarios o de sueños utópicos, comienza a existir -aunque no a la manera ingenua de los «realistas». Para algunos nuevos poetas la realidad no es algo que hay que negar o transfigurar sino nombrar, afrontar y, así, redimir. Operación delicada entre todas ya que implica una reconciliación con esa realidad, es decir, una búsqueda de su sentido y, al mismo tiempo, una transformación de la actitud del poeta. ${ }^{720}$

${ }^{717}$ Octavio Paz: "Los signos en rotación”, en OOCC, Vol. I, op.cit., p. 327. Por eso el escritor mexicano proponía una poética fundada en el presente: "Breton ha dicho: la véritable existence est ailleurs. Ese allá está aquí, siempre aquí y en este momento. La verdadera vida no se opone ni a la vida cotidiana ni a la heroica; es la percepción del relampagueo de la otredad en cualquiera de nuestro actos". (Ibid., p. 322). Y afirmaba también: "Mientras dure este tiempo que es nuestro tiempo, no hay pasado ni futuro, edad de oro anterior a la historia o falansterio ulterior. El tiempo del poeta: vivir al día; y vivirlo, simultáneamente, de dos maneras contradictorias: como si fuese inacabable y como si fuese a acabar ahora mismo. Así, la imaginación no puede proponerse sino recuperar y exaltar-descubrir y proyectar- la vida concreta de hoy." (Ibíd., p. 322)

718 Guillermo Sucre: "La nueva crítica", loc.cit., p. 268.

${ }^{719}$ Octavio Paz: "Jorge Guillén", en OOCC, Vol. II, op.cit., pp. 906-907. [se escribió en 1977, se publicó en In/mediaciones, 1979]

${ }^{720}$ Octavio Paz: "Destiempos, de Blanca Varela", en OOCC, Vol. II, op.cit., p. 1133. [escrito en 1959, publicado en Puertas al campo, 1966] 
Por lo tanto, como en Sucre, la transparencia en Paz supone el hallazgo del absoluto en la realidad cotidiana y actual. Al establecerse una correspondencia entre lo subjetivo y lo objetivo en el cuerpo de un lenguaje capaz de encarnar la referencia, los contrarios se disuelven y se vislumbra el mundo primordial y esencial.

Además, en el escritor mexicano la poética de la transparencia implica un reparto de lo sensible semejante al propuesto por nuestro autor. Según vimos en la primera parte de este trabajo, el maestro de Sucre toma de Lévi-Strauss la idea de que la estructura es "un sistema regido por una cohesión interna"721, de manera que en él "ningún elemento" "puede ser valorado si no se le considera en relación con los otros elementos $^{\$, 722}$. El escritor mexicano aplica esta noción tanto a la realidad como a la obra literaria pues, en su concepción, ambos dominios "pueden ser vistos como sistemas o configuraciones en rotación que, a su vez, engendran otras figuras en movimiento" ${ }^{\text {,723. }}$. Esta concepción estructural o sistémica de la realidad y de la obra (que son indistinguibles ${ }^{724}$ ) da lugar a que el reparto de lo sensible que implica su estética se asiente en los mismos aspectos que hemos destacado a propósito de Sucre: la inmanencia y la igualdad. En el caso de nuestro autor este reparto conllevaba un rechazo al poder y a sus instrumentos ideológicos: la metafísica y la historia. En cambio, la distribución de lo sensible que vemos en Paz es el resultado de su enfoque estructuralista. Según ha señalado Barthes, "el estructuralismo" "puede definirse históricamente como el paso de la conciencia simbólica a la conciencia 1252.

${ }^{721}$ Octavio Paz: Claude Lévi-Strauss o el nuevo festín de Esopo, en OOCC, Vol. VI, op.cit., p. ${ }^{722}$ Ibid., p. 1254.

${ }^{723}$ Octavio Paz: "Lectura y contemplación”, en Entre uno y muchos, en OOCC, Vol. I, op.cit., p

${ }^{724}$ Al plantear (como después Guillermo) que toda visión de la realidad depende de la mirada y del lenguaje, el mundo y la creación literaria devienen estrictamente homólogos. Como afirma memorablemente en El arco y la lira: "el lenguaje, como el universo, es un mundo de llamadas y respuestas [...]. Unas palabras se atraen, otras se repelen y todas se corresponden. El habla es un conjunto de seres vivos, movidos por ritmos semejantes a los que rigen a los astros y las plantas". (Octavio Paz: $E l$ arco y la lira, en OOCC, Vol. II, op.cit., p. 83) 
paradigmática"725. Mientras que la primera "implica una imaginación de la profundidad" y "vive el mundo como la relación de una forma superficial y de un Abgrund multiforme, masivo, poderoso", la segunda "por el contrario, es una imaginación formal; ve el significado ligado [...] a algunos significantes virtuales, de los que es a un tiempo próximo y distinto; ya no ve (o ve menos) al signo en su profundidad, lo ve en su perspectiva"726. Entonces, la misma noción de estructura invalida la profundidad y la anterioridad características del pensamiento simbólico o metafísico, y conduce, en consecuencia, a una visión igualitaria e inmanente del mundo. La idea de sistema implica que se anula la prioridad que el fundamento tenía en la concepción metafísica, y lo que pasa a un primer plano son los vínculos horizontales que establecen entre sí los diferentes elementos que componen la estructura. Lo importante es la relación actual que mantienen las cosas entre sí y no la relación de anterioridad o de causalidad. Además, en el sistema los componentes ya no dependen de un sentido velado o secreto, sino sólo de su condición de posibilidad, hecho que invalida las jerarquías tradicionalmente aceptadas por la tradición occidental (entre el cuerpo y el alma, la materia y el espíritu, etc.). De acuerdo a la visión estructuralista de Paz todo es plenamente visible y equivalente, las dualidades carecen de valor, y las relaciones espaciales y horizontales se anteponen a las cronológicas.

Aparte de la huella evidente del escritor mexicano, la estética de Sucre se sitúa en la estela del cubismo literario y pictórico de principios del siglo XX. En una carta que nos envió recientemente, nuestro autor reconocía así su aprecio por esta corriente artística:

Desde que en 1955 vi en El Louvre la primera Retrospectiva de su obra, siempre me gustó Braque. Me seducía también mucho que fuese un pintor que pensaba y escribía muy bien. Al menos yo me identificaba con sus ideas. En 1973, traduje para Plural sus "Cahiers", acompañados de un breve comentario. Antes había publicado en Imagen "Pájaros", el poema de

${ }^{725}$ Roland Barthes: "La imaginación del signo", en Ensayos críticos, op.cit., p. 287.

${ }^{726}$ Ibid., p. 291. 
Saint-John Perse, cuyo tema visible son los cuadros de Braque y que es también como una reflexión sobre los nexos de la realidad (la naturaleza) y el arte, y la celebración de otro nacimiento. Por supuesto, esto me llevó a interesarme por la relación entre el Cubismo y la poesía que escribían Reverdy, Huidobro, Gertrude Stein y Octavio Paz. Sobre Reverdy y Huidobro di un curso en La Maestría de Literatura Hispanoamericana de la USB, y de él traduje varios de sus textos teóricos para un libro que publiqué en Monte Ávila en 1977, titulado Escritos para una poética. [...] Igualmente traduje de Reverdy otro texto, Notas sobre la poesía, de 1942, que reprodujo en 1974 una revista francesa de poca duración, Argile, que aglutinaba a poetas jóvenes importantes. [...] Reverdy me atrajo por la limpidez de su poesía y su imaginación nomológica así como por su nueva visión de la imagen y su lucidez crítica en general. $^{727}$

En el ensayo "La poética de Georges Braque”, nuestro autor expuso los aspectos del cubismo a los que él concedía una mayor relevancia y es evidente que al hablar sobre el pintor francés estaba expresando también su propia estética. En ese texto, Guillermo llegaba incluso a proponer que la concepción de Braque sobre el arte abría un espacio donde se podían encontrar muchos de los autores a los que más estimaba: “a nadie se le escapa que una corriente central de la poesía y, en general, de la literatura moderna tiene evidentes correspondencias con Braque y Picasso, con el cubismo. Apollinaire, Reverdy, Gertrude Stein, Huidobro, Paz: ¿no sería posible concebirlos en un espacio unido por la poética de Braque?"728

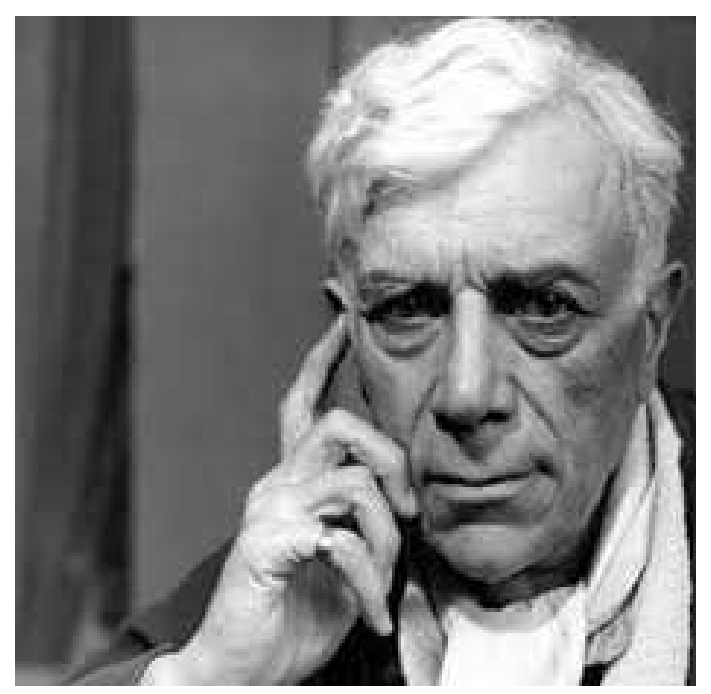

Imagen 41. El pintor Georges Braque (1882-1963)

${ }_{727}^{727}$ Guillermo Sucre: “Carta II, abril de 2013”, infra en Apéndice I, p. 484.

${ }^{728}$ Guillermo Sucre: "La poética de Georges Braque”, loc.cit., p. 50. 
En la interpretación de Sucre, el pintor francés se aleja del realismo convencional y no se somete a las leyes de la mímesis: su arte transparente fusiona lo subjetivo y lo objetivo, lo soñado y lo visible. En su caso la realidad "no es sólo lo que está en lo exterior (objetos aislados y autónomos), no sólo en lo que vemos, sino también en la manera como lo vemos. [...] La realidad, en suma, participa de una visión",729. Al establecer una continuidad entre lo real y lo imaginario, su obra nos muestra "un espacio a la vez fijo y cambiante, real y transfigurado", es decir, una "metamorfosis" que revela lo real en su originalidad. Al alcanzar la transparencia, los cuadros de Braque inventan y descubren un mundo prístino y esencial, donde se da un reparto de lo sensible similar al que estimaba el propio Guillermo. El universo que presentan sus pinturas no nos remite a un más allá sino que supone una revelación de la maravilla contenida en lo concreto y en lo actual: de la materia que está aquí y ahora. Esa realidad es un conjunto de relaciones horizontales que "no tiene centro ni privilegia nada de lo que en él habita"730; por lo tanto, el artista "no se preocupa porque las cosas tengan o no semejanzas entre ellas, sino por el hecho de que viven en un espacio común"731. En ese entorno no hay ninguna profundidad: todo es visible, los contrarios se han reconciliado, y ya no hay jerarquías entre las cosas.

\footnotetext{
${ }^{729}$ Ibid., p. 48.

${ }^{730}$ Ibid., p. 49.

${ }^{731}$ Ibid., p. 49.
} 


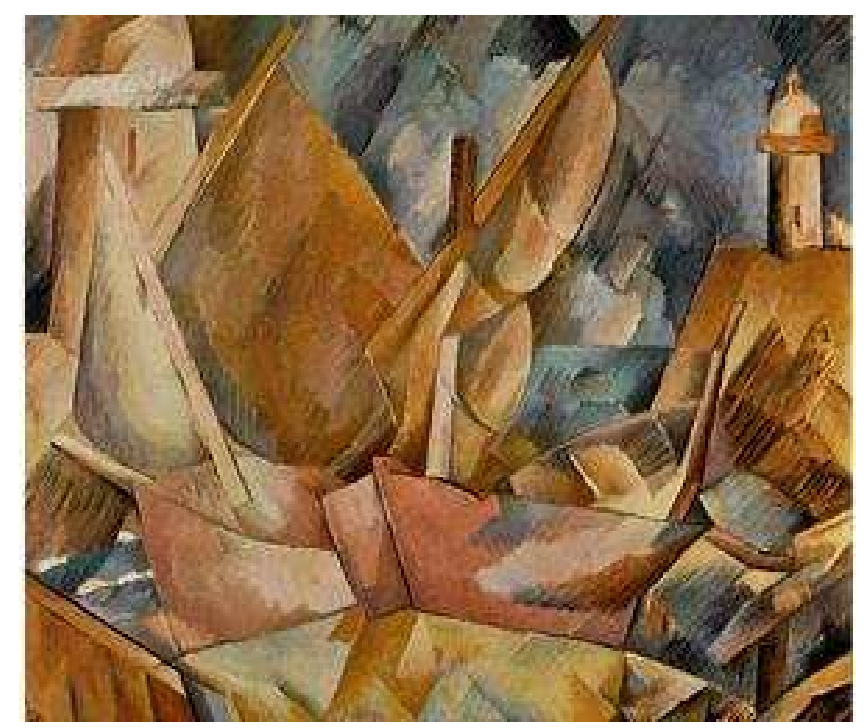

Imagen 42. El cuadro de Braque "Puerto en Normandía" (1909)

En lo que concierne al vínculo de Sucre con la estética cubista, además de Braque, una escritora que resultó fundamental para él fue Gertrude Stein. Durante el tiempo que residió en París a principios del siglo XX, la autora norteamericana estuvo estrechamente vinculada a los pintores y literatos que darían origen al cubismo, y su propia estética tiene muchos puntos en contacto con esta corriente artística. En el libro que escribió sobre Picasso, Stein nos descubre su visión de este movimiento y también, de manera indirecta, su propia concepción del arte.

Para la autora de The Making of the Americans (1925) el cubismo inaugura ante todo una nueva manera de ver la realidad y, por tanto, un nuevo reparto de lo sensible. La mirada cubista concede al mundo aparente una importancia determinante porque es capaz de verlo como de verdad es, más allá de relaciones culturales o intelectuales, y de cualquier simbolismo. Esa visión no pretende ser objetiva, sino que surge de la fusión de lo subjetivo y lo objetivo, de lo imaginario y lo real. A este respecto la escritora afirmaba que "cuando [Picasso] comía un tomate, ese tomate no era como el de todo el mundo, en absoluto, ni era su objetivo expresar a su manera las cosas que veía tal como 
las ve todo el mundo, sino expresarlas como él las veía"732. Entonces la fusión de lo interior y lo exterior que tiene lugar en la obra de arte permite al cubismo mostrar las cosas como verdaderamente son. Como explicaba Stein, el cubismo es una "lucha por expresar las cosas", pero "sólo las cosas realmente visibles"733.

la mayoría de las veces sólo se ve un rasgo de la persona con la que se está; los demás rasgos quedan cubiertos por un sombrero, la luz, la ropa, y todos estamos acostumbrados a completar la totalidad con los propios conocimientos. Pero cuando Picasso veía un ojo, el otro no existía para él y sólo existía el que veía como pintor, y especialmente como pintor español tenía razón: se ve lo que se ve, lo demás es una reconstrucción basada en la memoria y los pintores no tienen nada en común con la reconstrucción ni con la memoria, pues sólo les preocupan las cosas visibles. Por eso el cubismo de Picasso supuso un esfuerzo por pintar un cuadro de las cosas visibles $^{734}$

El creador cubista inventa y descubre la realidad que existe verdaderamente y no aquella que creemos conocer de antemano: "las cosas que Picasso podía ver eran las que tenían su propia realidad, no la realidad de las cosas que se ven sino la de las cosas que existen",735. Para el cubismo lo importante no es reproducir o copiar una realidad preexistente, sino revelar la maravilla contenida en el universo sensible. A través de la fusión de la subjetividad y la objetividad, la obra de arte nos muestra un mundo prístino y original, que es inmanente e igualitario.

${ }^{732}$ Gertrude Stein: Picasso, Madrid, La esfera de los libros, 2002, p. 49. "Don Quijote era español y no imaginaba las cosas, las veía y no eran un sueño, no era locura, sino que realmente las veía." (Ibid., p. 49)

${ }^{733}$ Ibid., p. 46.

${ }^{734}$ Ibíd., p. 46. "Picasso no entabló aquella larga lucha [la del cubismo] para expresar lo que veía sino para no expresar lo que no veía, es decir, lo que todo el mundo está seguro de ver pero en realidad no ve. Como ya he dicho, al mirar a una amiga sólo se ve uno u otro rasgo de su rostro, pero Picasso no tenía nada de simple y analizaba su visión, no deseaba pintar lo que no veía, mientras que los demás pintores se conformaban con la apariencia, siempre la apariencia, que no era lo que podían ver sino lo que sabían que estaba allí.” (Ibid., p. 52)

${ }^{735}$ Ibid., p. 52. 


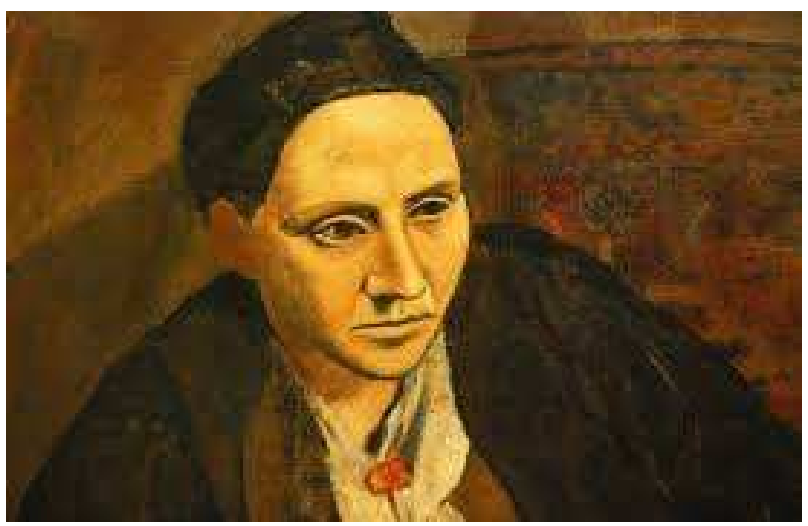

Imagen 43. Gertrude Stein (1874-1946), retratada por Pablo Picasso (1905-1906)

La nueva manera de mirar que inauguró el cubismo supone igualmente un determinado reparto de lo sensible. A él se refería Stein al establecer las causas que dieron origen al movimiento. En primer lugar, dice la escritora,

como había cambiado el modo de vida la composición de la vida se amplió y una cosa era tan importante como cualquier otra. En segundo lugar, empezó a disminuir la fe en lo que ven los ojos, es decir, la creencia en la realidad de la ciencia. [...] [/] En tercer lugar, desapareció el marco de la vida, la necesidad de que un cuadro exista en su marco, que se mantenga dentro de él. Un cuadro en su marco era algo que siempre había existido, pero los cuadros comenzaron a desear abandonar sus marcos, y también esto creó la necesidad del cubismo. ${ }^{736}$

El movimiento surgió a partir del reconocimiento de la radical igualdad de todo lo sensible, de los propios objetos entre sí y también de la relación entre el arte y la vida, de manera que cualquier cosa podía ser material artístico. Esta concepción implica que se rechaza la profundidad característica del pensamiento metafísico y que la realidad se concibe como un conjunto de relaciones igualitarias y horizontales. En ese espacio todo es simplemente lo que es y la propia materialidad de las cosas, al ser inventada por la mirada del artista, se vuelve maravillosa. El cubismo es entonces un arte inmanente que concibe la realidad como un entorno diáfano, sin opacidades ni jerarquías, y que concede a la materialidad y elementalidad de las cosas una dimensión extraordinaria que no es necesario interpretar, sino simplemente ver. El pensamiento y la estética de Gertrude Stein fue reivindicado en los años sesenta por dos teóricos que

$$
{ }^{736} \text { Ibid., p. } 36 .
$$


tuvieron mucha influencia en la época, Susan Sontag y John Cage. Ambos fueron importantes para Sucre, pero sobre ello trataremos en las secciones de este trabajo dedicadas a la concepción del lenguaje y a la crítica literaria. Ahí se verán también las relaciones de nuestro autor con otros artistas vinculados al cubismo, como Pierre Reverdy y Vicente Huidobro.

\section{4. LA BÚSQUEDA DE UN LENGUAJE DIÁFANO}

Como hemos visto, en el pensamiento de Guillermo, la poesía trata de alcanzar una continuidad entre la subjetividad y la objetividad o, lo que es lo mismo, entre lo real y lo imaginario que cancele la distancia que se interpone entre el hombre y el universo y que permita vislumbrar el mundo esencial. Para que esta conciliación tenga lugar es necesario que el lenguaje poético sea equivalente a la realidad, es decir, que las palabras coincidan con los objetos a los que remiten. Por eso Sucre piensa que la literatura debe esforzarse por hallar un lenguaje prístino que sea capaz de reencontrar "la Palabra primera, cuya (re)conquista sería el fundamento de la armonía entre el hombre y el universo" ${ }^{, 737}$. O, dicho de otra manera, Guillermo cree que los grandes escritores aspiran a obtener una "escritura absoluta" que sea capaz de disolver "todas las dualidades" y de alcanzar "la reconciliación del signo y la cosa, y por tanto, la del poema y el mundo"738. Nuestro autor considera que esta aspiración ha sido una constante en los grandes poetas modernos, y que ella ha generado una doble actitud de pasión y crítica ante el lenguaje y ante la propia poesía. Por un lado, estos escritores han tratado de exaltar al máximo los poderes de las palabras para que éstas alcanzaran las cotas más altas de expresividad; por el otro, no han podido sino reconocer que la búsqueda del absoluto a través del lenguaje era imposible de lograr. La poesía resulta entonces ser al mismo tiempo "una

\footnotetext{
${ }^{737}$ Guillermo Sucre: "Poesía hispanoamericana y conciencia...", loc.cit., p. 632.

${ }^{738}$ Guillermo Sucre: "La metáfora incompleta", loc.cit., p. 71.
} 
exigencia extrema y una imposibilidad"739, y Sucre pone de manifiesto este doble valor

en los grandes autores de la poesía hispanoamericana:

Altazor, de Huidobro, es una de nuestras grandes arquitecturas verbales; a la vez que la construye con su poder mágico, es la palabra misma la que la desconstruye; triunfo o fracaso, es el poema del drama del lenguaje por encarnar los estados límites del hombre. "El que no haya sentido el drama que se juega entre la cosa y la palabra, no podrá comprenderme", había escrito Huidobro en un manifiesto de 1921. Más escueto, Vallejo es también más concreto y humano; sólo que lo "humano" en él (como en Nietszche) es otra forma de desmesura: quiere ser lo absoluto y lo sagrado realizado en la propia historia; de ahí que si en su poesía habita "el verbo encarnado", ésta no deja de ser también una continua problematización del lenguaje. Neruda puede ser el más exuberante y afirmativo en toda su obra; pero la poesía que escribe entre fines de los veinte y principios de los treinta vive sobre todo de la contradicción ("el río que durando se destruye") y de la oscura búsqueda por fundar el ser del mundo, "sin excluir deliberadamente nada, sin aceptar deliberadamente nada”. Borges alía lo entrañable cotidiano y la metafísica interrogativa; todo espacio se le vuelve laberíntico; escribe un poema infinito que nunca concluye y así su obra parece fundarse en el vértigo: vislumbramiento de la Obra e imposibilidad de hacerla presencia. Ni siquiera los más perfeccionistas y artífices del lenguaje logran escapar de estos dilemas. José Gorostiza construye un poema que es un monumento a la forma como eternidad; pero esa eternidad se va congelando en los páramos de la conciencia: es sólo una "muerte sin fin”. ¿Para qué seguir citando casos análogos? Visión adánica y visión crítica: ésta es una de las constantes de nuestra poesía, que se inicia, en lo fundamental, con la vanguardia. ${ }^{740}$

Ahora bien, esta ambivalencia entre la búsqueda del absoluto y la imposibilidad

de alcanzarlo implica que la poesía es una indagación siempre recomenzada, que no se

puede asentar cómodamente en un sentido fijo y limitarse a repetirlo, sino que debe tratar de crear ese sentido a cada instante. Como decía el propio Sucre, citando una frase de los Manifestes de Huidobro: "Nada de caminos verdaderos y una poesía escéptica de sí misma. ¿Entonces? Hay que buscar siempre" ${ }^{\text {741 }}$. La insistencia permanente de la poesía, su búsqueda constante e incansable, hace de ella una actividad heroica, pues el vate escribe sabiendo de antemano que fracasará, ya que nunca podrá alcanzar el absoluto que se ha propuesto - esa palabra original que cancele la división entre el individuo y el universo.

${ }^{739}$ Guillermo Sucre: "Poesía Crítica: Lenguaje y Silencio", loc.cit., p. 582.

${ }^{740}$ Guillermo Sucre: "Introducción" a la Segunda Parte de la Antología..., Vol. I, op.cit., pp. 303304. En su ensayo "Poesía Crítica: Lenguaje y Silencio", Sucre traza un recorrido por diversos poetas hispanoamericanos atendiendo a esta ambivalencia entre la pasión y la crítica ante el lenguaje. En ese artículo afirmaba además que la obra de Borges "oscila entre el impulso hacia un absoluto poético (como Mallarmé, el libro que sea el Libro que, a su vez, sea el Universo) y la no menos radical intuición de que ese impulso concluye siempre en el fracaso." (Guillermo Sucre: "Poesía Crítica: Lenguaje y Silencio", loc.cit., pp. 575-576). Igualmente, nos dice nuestro crítico, Enrique Lihn "escribe una poesía con "mala conciencia" porque intuye que el lenguaje nunca alcanza a ser la verdadera ruptura: el paso a otro mundo que de alguna manera sea el absoluto que busca." (Ibid., p. 584)

${ }^{741}$ Guillermo Sucre cita esta frase en la "Introducción" a la Segunda Parte de la Antología..., Vol. I, op.cit., p. 303. 
La imposibilidad de restituir la unidad primordial se debe principalmente a dos "fatalidades" presentes en el lenguaje. Por un lado, está la fatalidad constitutiva que surge del reconocimiento de la distancia infranqueable que separa a las palabras de la realidad. Para decirlo con las palabras de Guillermo, esta fatalidad consiste en que el lenguaje "nos pone en contacto con el mundo a la vez que nos aleja de él", "72, es decir, que siempre se impone una distancia entre el signo y la cosa que dificulta o imposibilita el proyecto poético de establecer la concordia entre el hombre y el universo. La condición irrealista del lenguaje había sido puesta de manifiesto por muchos autores de la órbita de Sucre ${ }^{74}$. Sin embargo, el autor que más insistió en el intento de trascender esta fatalidad fue quizá Octavio Paz, quien llegó a hacer de esta problemática el verdadero tema de su obra. Para el creador mexicano la distancia entre la palabra y la cosa forma parte de la condición humana, y la poesía es precisamente el recurso con que el hombre trata de establecer una continuidad entre el lenguaje y la realidad que supondría su reconciliación con el universo: “es evidente que la fusión -o mejor: la reunión- de la palabra y la cosa, el nombre y lo nombrado, exige la previa reconciliación del hombre consigo mismo y con el mundo. Mientras no se opere este cambio, el poema seguirá siendo uno de los pocos recursos del hombre para ir, más allá de sí mismo, al encuentro de lo que es profunda y originalmente" ${ }^{\text {744 }}$. Esta concepción no es exclusiva de Paz, sino que es compartida por todos los grandes literatos y pensadores modernos ${ }^{745}, \mathrm{y}$

${ }_{742}^{743}$ Guillermo Sucre: La máscara ...op.cit., p. 257.

${ }^{743}$ Como nos recuerda Sucre, Borges señalaba en un poema: "Nadie puede escribir un libro. Para/ Que un libro sea verdaderamente,/ Se requieren la aurora y el poniente,/ Siglos, armas y el mar que une y separa". Esta frase, según nuestro autor, "se refiere, obviamente, a la imposibilidad del escritor para traducir una experiencia total del mundo: éste es inagotable, aquélla es limitada." (Guillermo Sucre: "Poesía Crítica: Lenguaje y Silencio", loc.cit., p. 575). Ramos Sucre, por su parte, afirmaba: "no podemos asir directamente la realidad y por ello inventamos el símbolo, decía; también agregaba: un idioma es el universo traducido a ese idioma". (Guillermo Sucre: "Ramos Sucre: Anacronismo y/o Renovación", loc.cit., p. 79). Esta misma perspectiva la comparte, como hemos visto en la primera parte de este trabajo, Roland Barthes.

${ }^{744}$ Octavio Paz: El arco y la lira, en OOCC, Vol. II, op.cit., p. 66.

${ }^{745}$ En una reseña sobre un libro de Rosenblat, afirmaba Sucre: "La palabra poética quiere ser también la palabra esencial a través de la cual se revela el orden del cosmos. También el derecho se ha fundado en ciertas fórmulas rituales de la lengua; esas fórmulas confirman la autenticidad del acto 
también, según acabamos de ver, por los grandes autores de la poesía hispanoamericana.

Como lo expresó Roland Barthes: "En el fondo, el escritor tiene siempre la creencia de que los signos no son arbitrarios y que el nombre es una propiedad natural de la cosa: los escritores están del lado de Cratilo, no de Hermógenes”746.

Además de esta distancia con la realidad que es su condición de posibilidad, el lenguaje presenta una segunda fatalidad a la que Sucre llama "de carácter social"747. Esta consiste en que el lenguaje ha sido degradado por el poder, que lo ha empleado para falsificar los hechos y manipular las conciencias. Como la política ha utilizado las palabras para alcanzar sus objetivos particulares, ellas han adquirido un espesor semántico que les es impropio y que les obliga a decir cosas diferentes a las que dicen o deberían decir. "Ya el lenguaje no sólo sirve para todo y, por supuesto, para nada denunciaba Sucre-; también se ha creado un doble lenguaje cuyo código sigue funcionando para robustecer el poder: la astucia, no la verdad"748. El problema que advierte nuestro autor es que, al ser usado con fines políticos, el lenguaje pierde su capacidad para transparentar lo real, y sólo puede ocultarlo o disfrazarlo. Como él mismo decía: "El mundo de las apariencias se ha vuelto [...] una realidad jurídico. La palabra encierra lo que evoca. El nombre revela el ser de la persona. ("Preguntar ¿qué es eso? Quiere decir ¿cómo se llama?”, escribía también Unamuno). Nombrar algo es neutralizarlo: conjurar el poder maléfico que encierra. Pero se pasa de la palabra oral a la escrita: tiende a perder su fuerza original. No obstante persiste el libro como elemento sagrado. Sólo después la palabra se seculariza, se despoetiza. Pero queda como una realidad por rescatar, como una nostalgia, su origen mágico y sagrado. Lo mejor de la filosofía y de la poesía modernas viven de esta nostalgia. Un poeta como Mallarmé afirmaba que el mundo debía existir para llegar a ser un libro. Jorge Luis Borges concibe al poeta en busca de la palabra del universo. Para Sartre la palabra es al mismo tiempo sagrada y mágica. Heidegger considera a la palabra como fundante. Todo gran artista o filósofo descubre el universo a través del lenguaje." (Guillermo Sucre: "En la magia del lenguaje", loc.cit., p. 18.)

${ }^{746}$ Roland Barthes: Crítica y verdad, op.cit., p. 54. Esta misma concepción se aprecia en dos autores a los que Sucre leyó durante su estancia en los EEUU. Gertrude Stein pensaba que las verdaderas palabras establecían una relación necesaria con la cosa: "I became more and more excited about how words which were words that made whatever I looked at look like itself were not the words that had in them any quality of description. [...] the words or words that make what I looked at be itself were always words that to me very exactly related themselves to that thing at which I was looking." (Gertrude Stein: "Portraits and Repetition", en Writings 1932-1946, New York, The Library of America, 1998, p. 303). Por su parte, Wallace Stevens había indicado: "La palabra debe ser la cosa misma que representa; de otro modo sería un símbolo. Es un asunto de identidad." (Wallace Stevens [trad. de Guillermo Sucre]: Adagia, op.cit., p. 18.)

\footnotetext{
${ }_{747}^{748}$ Guillermo Sucre: La máscara ...op.cit., p. 258.

${ }^{748}$ Ibíd., p. 258.
} 
continuamente contaminada de irrealidad. Todo está manipulado y enmascarado (el travesti es una de las figuras más actuales). Pero todo se manipula a través del lenguaje: el de la política es, hoy, una de las formas de la publicidad"749. El poder provoca entonces una desconexión intencionada entre el vocablo y la referencia y eso priva a las palabras de su capacidad para revelar lo real. De la misma manera que impone sobre la realidad una serie de códigos y opacidades que impiden experimentarla en su inmediatez, el poder emplea el lenguaje para su propio interés, adulterando los significados de las palabras e impidiendo que se aproximen a la referencia. El idioma del poder antepone la astucia y las intenciones políticas a la plenitud de los vocablos que, de este modo, pierden su energía mágica y su capacidad para mostrar la verdad. Esto se vincula, además, a lo que Barthes llamaba "la fatalidad del signo literario", es decir, al hecho de que "el escritor no puede trazar el menor signo sin tomar la manera o la pose peculiar de un lenguaje ya hecho, convencional" ${ }^{, 750}$. Al emplear el lenguaje como una herramienta de uso cotidiano, las palabras se fijan semánticamente y pierden su capacidad para encarnar la referencia. Por lo tanto, los dos enemigos fundamentales del lenguaje poético son el poder, es decir, la manipulación interesada de los vocablos, y la costumbre, o sea, la fijación del sentido por el uso convencional.

En los años sesenta y setenta el tema de la degradación del lenguaje era casi un lugar común, al menos en aquellos autores que, como Sucre, creían en la capacidad fundadora del lenguaje. Al pensar que las palabras encarnan nuestra experiencia de la realidad, Octavio Paz consideraba que toda degradación del idioma implicaba un defecto moral. Por eso señalaba en Posdata (1970), según cita de memoria el propio Sucre, que "cuando una sociedad se degrada, política y socialmente, lo primero que se

${ }^{749}$ Guillermo Sucre: "Poesía Crítica: Lenguaje y Silencio", loc.cit., p. 590. Decía también: "Nunca como ahora, se ha dicho, hemos tenido tantas palabras y, sin embargo, nos faltan las palabras. Si el equívoco es el signo de nuestra época, éste parece engendrarse en la proliferación verbal: enmascaramiento de lo real a través de la inflación del lenguaje”. (Ibíd., p. 593)

${ }^{750}$ Ibid., p. 584. 
gangrena es el lenguaje ${ }^{, 751}$. Establecida esta relación, como nos recuerda también Guillermo, para el escritor mexicano "toda justicia, política y social, tiene que comenzar por el reencuentro de la palabra justa",752. El propio Octavio Paz consideraba que el lenguaje se había degradado y experimentaba por eso "el desgaste, el equívoco y, más aún, la infección del lenguaje: las palabras no dicen lo que dicen y aun lo que dicen se desdice"753. Por eso, es consciente de que "obligada a ser lenguaje", la poesía "tiene que luchar contra él, despojarlo de sus rutinas, su ritual vacío, para librar luego su energía original"754. Esta pugna contra el idioma se aprecia bien en uno de los poemas de ¿Águila o sol? (1951), donde Paz afirmaba:

No bastan los sapos y culebras que pronuncian las bocas de albañal. Vómito de palabras, purgación del idioma infecto, comido y recomido por unos dientes cariados, basca donde nadan trozos de todos los alimentos que nos dieron en la escuela y de todos los que, solos o en compañía, hemos masticado desde hace siglos. Devuelvo todas las palabras, todas las creencias, toda esa comida fría con que desde el principio nos atragantan. ${ }^{755}$

Otro autor muy próximo a Sucre, Ángel Rosenblat, había planteado en su ensayo "Sentido mágico de la palabra" la necesidad de recuperar "el nombre correcto" que supondría "la adecuación entre nombre y realidad",756. Según este filólogo, la palabra se ha degradado porque ha sido empleada como un simple instrumento, cuando ella es precisamente el lugar mismo donde el pensamiento acontece: "El lenguaje se nos aparece hoy como un sistema de signos ciegos, arbitrarios, tiránicos. La palabra se está transformando en utensilio, al servicio de las necesidades y afanes cotidianos, o al servicio de la razón. Hoy nos inclinamos a pensar que el lenguaje es una conquista de la

${ }^{751}$ Citado por Guillermo Sucre: La máscara ...op.cit., p. 258.

752 Ibid., p. 258.

${ }^{753}$ Guillermo Sucre: "Poesía Crítica: Lenguaje y Silencio", loc.cit., p. 576.

754 Ibid., p. 577.

755 Octavio Paz: "Trabajos del poeta”, fragmento X, en Guillermo Sucre (coord.): Antología de la poesía hispanoamericana moderna, Vol. II, op.cit., p. 152.

${ }^{756}$ Ángel Rosenblat: "Sentido mágico de la palabra", en La primera visión de América...op.cit., p. 97. 
razón humana, un instrumento de su poder. Más justo es creer que la razón humana es una conquista del lenguaje" ${ }^{, 757}$.

Por su parte, George Steiner -un autor que fue leído por Sucre desde su marcha a los Estados Unidos- cuestionaba la decadencia del lenguaje en términos semejantes a los de Rosenblat. Steiner responsabilizaba al totalitarismo y a la cultura de masas de la degradación lingüística ${ }^{758}$ y para paliar esa decadencia (que para él era la de toda la cultura humanista clásica) proponía la necesidad de ratificar la soberanía de la literatura y de devolver la claridad a los significados:

la cultura literaria debe reafirmar su autoridad contra la jerga. No sé si esto puede hacerse; pero hay mucho en juego. En nuestro tiempo, el lenguaje de la política se ha contaminado de oscuridad y de locura. Ninguna mentira es tan burda que no pueda expresarse tercamente, ninguna crueldad tan abyecta que no encuentre disculpa en la charlatanería del historicismo. Mientras no podamos devolver a las palabras en nuestros periódicos, en nuestras leyes y en nuestros actos políticos algún grado de claridad y de seriedad en su significado, más irán nuestras vidas acercándose al caos. Vendrá entonces una nueva edad oscura. ${ }^{79}$

${ }^{757}$ Ibíd., p. 101. La cita sigue: "El pensamiento -es la concepción de Guillermo de Humboldtestá consubstanciado con el lenguaje, que es su encarnación. «Más son los hombres formados por la lengua -decía Fichte, en 1807- que la lengua por los hombres.» Sin duda el hombre hace la lengua y la lengua hace al hombre." (Ibíd.)

758 A este respecto afirmaba: "la falsificación planeada y la deshumanización del lenguaje realizadas por los regímenes totalitarios han tenido efectos y reflejos más allá de sus propias fronteras. Se reflejan, aun cuando de manera menos asesina, en el idioma de la propaganda, de los deseos realizados y del consenso de las tecnocracias de consumidores. Vivimos rodeados por olas de mendacidad. Millones de palabras nos cubren sin la menor intención de significado. El silencio se está convirtiendo en la prerrogativa de las élites resguardadas o de los marginados enjaulados. Como resultado de todo esto, los modos de expresión han sufrido una enorme inflación. Su precisión discriminatoria, su contenido claro y verificable, ha sido erosionado para que el público lo encuentre agradable. El porcentaje de clichés, de muletillas que todos comparten y en las que nadie cree, ha crecido constantemente." (George Steiner: "El lenguaje animal", en Extraterritorial. Ensayos sobre literatura y la revolución lingüística, Barcelona, Barral editores, 1973. [1971], p. 122.)

${ }^{759}$ George Steiner: "El abandono de la palabra", en Lenguaje y silencio, Barcelona, Gedisa, 2003 [1967], p. 51. Susan Sontag, por su parte, denunciaba la doble fatalidad del lenguaje en términos semejantes a los planteados por Sucre. Para ella, como para nuestro autor, el artista debía lidiar con el problema del significado (fatalidad constitutiva) y con los sentidos de segundo orden (fatalidad social) que se adherían a las palabras: "Se experimenta el lenguaje no sólo como algo compartido sino como algo corrompido, aplastado por la acumulación histórica. Por consiguiente, para todo artista consciente, la creación de una obra implica lidiar con dos ámbitos potencialmente antagónicos del significado y sus relaciones. Uno es el de su propio significado (o falta de él); el otro consiste en el conjunto de significados de segundo orden que expanden su lenguaje y al mismo tiempo lo entorpecen, lo comprometen y lo adulteran." (Susan Sontag: "La estética del silencio", en Estilos radicales, Madrid, Taurus Bolsillo, 1985 [1969], pp. 30-31). Ella pensaba, como Steiner, que los responsables de la decadencia del verbo eran los medios de comunicación de masas y la degradación pública del lenguaje: "Factores tan diversos como la "reproducción tecnológica" ilimitada y la difusión casi universal del lenguaje y la palabra impresa así como de las imágenes (desde las "noticias" hasta los "objetos artísticos"), por un lado, y la degeneración del lenguaje público en los ámbitos de la política, la publicidad y los espectáculos, por otro, han producido, sobre todo entre los miembros más cultos de la sociedad de masas moderna, una desvalorización del lenguaje." (Ibíd., p. 38) 
Según hemos visto más arriba, en la concepción de Sucre la poesía debe inventar y revelar a un tiempo el mundo original, donde todo es visible y complementario, y donde se cancelan las jerarquías y las divisiones arbitrarias impuestas por el poder, la metafísica y la historia. Para ser capaz de restituir esa realidad esencial, el lenguaje poético debe recuperar su capacidad para transparentar la referencia y encarnar la verdad; ello implica superar la degradación a que ha sido sometido por la acción de la rutina y, sobre todo, del poder. Como resultado de la conciencia del lenguaje (es decir, de la certeza de que cualquier visión del mundo depende de las palabras) nuestro autor considera que toda crítica del lenguaje es al mismo tiempo una crítica de la realidad ${ }^{760}$. $\mathrm{Si}$ "al mundo no lo aprehendemos o hacemos inteligible sino a través del lenguaje" ${ }^{\text {761, }}$ es en los vocablos donde se producen las grandes transformaciones de nuestra visión del mundo. Entonces "renovar la poesía, crear poéticamente es ya crear en un sentido social; todo enriquecimiento verbal lo es también espiritual: modifica y hace más compleja nuestra relación con la realidad, destierra los clisés con que solemos simplificarla",762. Esto es lo que Sucre advertía en los "experimentos estilísticos” de Rubén Darío, que

fueron una verdadera renovación del español: lo liberaron de la rutina, el tono discursivo, y aún del "eterno clisé", decía, del Siglo de Oro. ¿No se trataba simultáneamente de una liberación espiritual, de un acto de purificación colectiva? "El clisé verbal es dañoso porque encierra en sí el clisé mental, y, juntos, perpetúan la anquilosis, la inmovilidad", escribe, con impresionante lucidez, en el prólogo de El canto errante (1907). Sin duda, Darío comprendía lo que implicaba la proposición de Mallarmé: "Donner un sens plus pur aux mots de la tribu". ${ }^{763}$

${ }^{760}$ Aunque esta idea es una consecuencia directa de la conciencia del lenguaje, ya había sido planteada antes por Octavio Paz, quien había afirmado: "La poesía moderna es inseparable de la crítica del lenguaje que, a su vez, es la forma más radical y virulenta de la crítica de la realidad. El lugar de los dioses o de cualquier otra entidad o realidad externa, lo ocupa ahora la palabra. El poema no tiene objeto o referencia exterior; la referencia de una palabra es otra palabra”. (Octavio Paz: "¿Qué nombra la poesía?", en $O O C C$, Vol. II, op.cit., p. 488 [1967])

761 Guillermo Sucre: "Introducción" a la Primera Parte de la Antología de la poesía hispanoamericana moderna, Vol. I, op.cit., p. 20.

${ }^{762}$ Ibid., p. 20.

763 Guillermo Sucre: La máscara...op.cit., p. 28. 
En consonancia con Darío y otros creadores $^{764}$, nuestro autor plantea que la literatura debe reconquistar "la energía original del lenguaje"765, es decir, que debe "restituirle al lenguaje cotidiano [...] su elementalidad naciente: «le vierge, le vivace et le bel aujourd'hui»» de la palabra. Se trata de deslastrarlo de las escorias que lo petrifican; de encontrar «un alfabeto con menos historia», dice Juarroz" ${ }^{\text {766 }}$. Además, la conciencia del lenguaje que define la visión de Guillermo implica la conciliación del sujeto y del objeto en el espacio de la escritura; para que esa comunión se produzca es imprescindible que las palabras empleadas por el poeta sean capaces de establecer una continuidad con la referencia. Entonces, tanto por la necesidad de transformar nuestra visión convencional del mundo y de la realidad esencial, como por el requerimiento de que lo real y lo imaginario establezcan una continuidad en la escritura (ambos aspectos son, en verdad, el mismo ${ }^{767}$ ) Sucre valora especialmente a aquellos autores que consiguen devolver a las palabras la precisión y la claridad que habían perdido y que escriben, en consecuencia, con un lenguaje nítido, capaz de transparentar la cosa misma que nombra.

764 Por el mismo motivo Sucre valoraba positivamente que en la obra de Ramos Sucre "la retórica recupera sus poderes: la capacidad de decir la palabra precisa sin recurrir a la palabra ya dicha o a la transgresión de la palabra imposible; también la capacidad para cambiar incesantemente la piel del lenguaje y así articular una nueva visión del mundo". Y más adelante apuntaba: “¿Y qué es escribir sino asombrar, es decir, proponernos a través del lenguaje una experiencia inédita del mundo aun siendo la misma?" (Guillermo Sucre: "Ramos Sucre: Anacronismo y/o renovación”, loc.cit., p. 86). También la poética de Huidobro nace como un rechazo a las convenciones establecidas, pues "empieza por un ideal de precisión verbal. «La poesía castellana está enferma de retoricismo», afirma Huidobro en el prólogo del mismo libro ya citado. Esa retórica estaba ligada no sólo al énfasis o a la falsa emotividad; le parecía que también al convencionalismo expresivo. En un libro anterior (Pasando y pasando, 1914) proponía: «Guerra al cliché... que si hay una montaña no sea una alta o encumbrada cima. Es preferible que sea una montaña que dialoga con el sol o con pretensiones de desvirgar a la pobre luna»." (Guillermo Sucre: $L a$ máscara...op.cit., p. 102)

${ }^{765}$ Guillermo Sucre: "Poesía Crítica: Lenguaje y Silencio”, loc.cit., p. 593.

766 Ibid., p. 591.

767 Como dice Sucre: "No importa lo que separa a Juarroz del surrealismo, los une esta aspiración por una escritura absoluta, más allá de la estética y que, en sí misma, implicaría una teoría y una praxis del mundo. Esa escritura absoluta sería, en verdad, el espacio en que se disuelven todas las dualidades: la de la psique y el cuerpo (la mente y la mano), la del hombre y la historia, la de ésta y la naturaleza. ¿No conlleva también la aparición del lenguaje original, la reconciliación del signo y la cosa, y, por tanto, la del poema y el mundo?” (Guillermo Sucre: “La metáfora incompleta”, loc.cit., p. 71) 
En muchos de estos poetas a los que admira, Sucre destaca precisamente el carácter diáfano de su lenguaje, es decir, el hecho de que en él no haya profundidades ni secretos. En esos vates, la nitidez de la palabra transparenta la referencia; por lo tanto, el lenguaje es mirada y la lectura, visión. Purificados de todo lastre semántico y de toda degradación es como los vocablos recuperan su capacidad para inventar y revelar el mundo esencial y para encarnar, por tanto, la verdad. Ahora ya no hay por un lado el universo y por otro el lenguaje, ni existe tampoco el sujeto separado del objeto, sino que las palabras se acercan a la realidad hasta el punto de convertirse (casi) en ella. Guillermo subraya esta condición del lenguaje en la poesía de Homero Aridjis, para quien "la palabra es mundo". El vate mexicano "nombra, sólo que su nombrar «no revela ni oculta»: quiere ser el mundo mismo. Por ello también la palabra se identifica con la mirada" ${ }^{968}$. En otro texto sobre el mismo autor, Sucre valora la nitidez de su palabra, que "no quiere ser sino la cosa misma, que toma cuerpo en el poema"769. Para lograr esta transparencia, Aridjis tiene que dominar el impulso verbal: "despojarlo, hacerlo a un tiempo presente y secreto, singular e impersonal” ${ }^{, 770}$. También en la poesía de Roberto Juarroz, Sucre destaca que el lenguaje es "total despojamiento y desnudez en que, sin embargo, otra palabra habla". Lo que así busca el poeta argentino es "que el lenguaje, a través de su ausencia, reencuentre otra presencia: la elementalidad y originalidad de las cosas en el mundo; que tenga «la mirada pura de la tierra», «la secreta nitidez de las cosas»" ${ }^{\natural 71}$. Asimismo, en Memorial (1976) de Rafael Cadenas,

\footnotetext{
${ }^{768}$ Guillermo Sucre: "Poesía Crítica: Lenguaje y Silencio”, loc.cit., p. 592.

${ }^{769}$ Guillermo Sucre: "La nueva profundidad: superficies nítidas”, loc.cit., p. 79.

${ }^{770}$ Ibid., p. 79.

771 Guillermo Sucre: "Poesía Crítica: Lenguaje y Silencio”, loc.cit., pp. 581-582. En esta
} concepción hay una posible afinidad de Sucre con la teoría de Roland Barthes. La obra de Juarroz, dice nuestro autor, "nada tiene que ver con la llamada «poesía pura»; recuerda, más bien, l'écriture blanche de que habla Barthes. Su ascetismo es crítica a la historia, comunión con lo original y vislumbramiento de un nuevo goce de la palabra." (Ibíd., p. 582.) En el texto antes citado sobre Aridjis, nuestro autor también aludía a la noción del pensador francés: "«Escritura blanca», la llamaría Barthes-; pero habría que precisar: no para encarnar una presencia ya ausente, sino para transparentarla, dándole un contorno especial." (Guillermo Sucre: "La nueva profundidad: superficies nítidas”, loc.cit., p. 79) 
Guillermo estima la diafanidad del idioma empleado. Ese poemario, dice Sucre, "es un libro de superficies: dice lo que dice, y no más; no dice lo que no dice, y no menos. Por ello mismo es un libro paradójico. (Qué palabra hoy no dice algo distinto de lo que dice o quiere decir; qué palabra no sirve a alguien?),"772. Al no emplear las palabras en su propio beneficio, el poeta venezolano Cadenas consigue hablar en esa obra con un "lenguaje preciso y veraz"773 pues, como afirma Guillermo, "el lenguaje es o puede ser la verdad si dice la palabra justa"774 -que es aquella "que nombra con justeza el mundo" 775 .

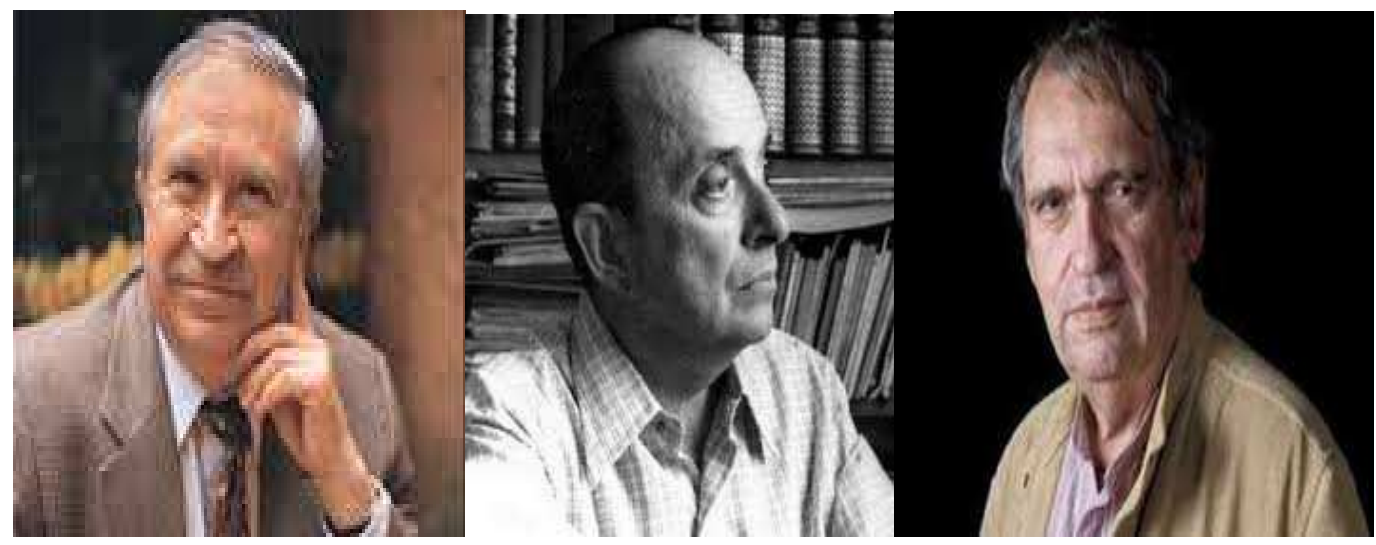

Imágenes 44, 45 y 46. Los poetas Homero Aridjis (1940), Roberto Juarroz (1925-1995) y Rafael Cadenas (1930).

De lo que se trata, entonces, es de encontrar un idioma claro que -privado de toda adherencia semántica impropia- permita establecer (en la mayor medida posible) una continuidad entre las palabras y las cosas, y sea así capaz de transparentar la verdad. Nuestro autor destacaba esta unión en la poesía de Vicente Huidobro. En los libros posteriores a Adán (1916), dice Sucre,

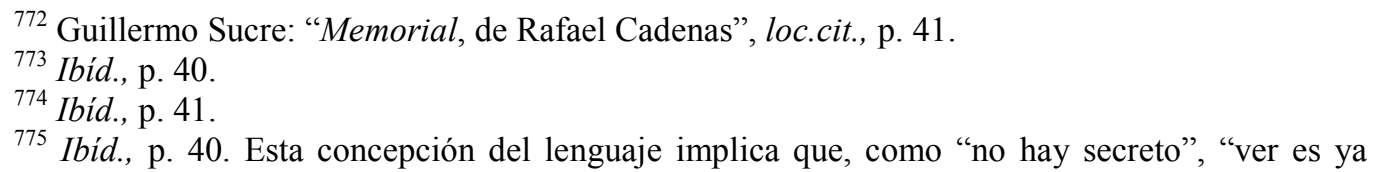
conocer y, por tanto, la palabra encarna o ha de encarnar a la mirada. El ojo no sólo ve sino que es el que habla; no conocemos el mundo a través de nuestras ideas, de nuestras opiniones, es decir, a través de nuestros "puntos de vista". No pensar el mundo sino verlo y de este modo poder enunciarlo: ¿no es toda una tradición occidental lo que se derrumba? Veo, luego existo, luego hablo." (Ibid., p. 40) 
el lenguaje alcanza a unir la precisión con la intensidad; en ellos se cumple, además, otra alianza más importante: el pensamiento es la forma misma. [...] Lo decorativo, la complacencia en las frases líricas queda excluido en los nuevos textos [...]. A su vez, el vocabulario deliberadamente elemental y reducido, hasta recurrente, al igual que la simplificación de la sintaxis, le comunican al lenguaje una distinta resonancia: las palabras parecen recuperar su desnudez, su inocencia semántica. ${ }^{776}$

La búsqueda de la máxima nitidez no significa imponer -como se encarga de aclarar Sucre- "un sentido único, lo que implicaría excluir la ambigüedad y la connotación propias de todo lenguaje"777, pero sí reducir a lo mínimo el espesor semántico para que la palabra pueda transparentar lo real. Lo que propone Sucre es que el lenguaje poético alcance la máxima saturación posible entre el sujeto y el objeto y entre las palabras y las cosas, de manera que los excesos (de realidad o de lenguaje) no tengan lugar. Para lograr una expresión de este tipo, la mirada del poeta tiene que estar regida por la lucidez y por la conciencia crítica, pues sólo a través de ellas conseguirá contener el impulso verbal y generar una escritura sin revés y sin profundidad que sea capaz de revelar el mundo esencial.

Ahora bien, cuando se alcanza verdaderamente este lenguaje nítido se produce la conciliación de las palabras con el mundo y del hombre con el universo. Se llega entonces al reino de la pureza donde solo son posibles el silencio y la contemplación, pues en ese entorno los vocablos salen sobrando. Como dice Guillermo, de tanto dominarse a sí misma, de tanto intentar traslucir la referencia, la escritura de Aridjis "se va borrando a sí misma y sólo nos deja el espacio de una limpidez, de una profunda reconciliación" y también "de una felicidad"778. De esta manera vemos que el régimen

${ }^{776}$ Guillermo Sucre: La máscara ...op.cit., pp. 102-103.

777 Guillermo Sucre: “Memorial...”, loc.cit., p. 41. En esta misma época Barthes y Adorno ya habían destacado la necesidad de respetar la pluralidad de sentidos de las palabras, pues vinculaban el sentido unívoco de los vocablos a la política totalitaria. A este respecto decía Barthes: "si las palabras no tuvieran más que un sentido, el del diccionario, si una segunda lengua no viniera a turbar y a liberar «las certidumbres del lenguaje», no habría literatura letra, sino las de la alusión: son reglas lingüísticas, no reglas filológicas." (Roland Barthes: Crítica y verdad, op.cit., p. 54) "R. Jakobson ha insistido en la ambigüedad constitutiva del mensaje poético (literario); [...] la lengua simbólica a la cual pertenecen las obras literarias es por estructura una lengua plural, cuyo código está hecho de tal modo que toda habla (toda obra) por él engendrada tiene sentidos múltiples." (Ibíd., p. 55)

${ }^{778}$ Guillermo Sucre: "La nueva profundidad...", loc.cit., p. 79. 
de expresividad del lenguaje que había nacido a principios del siglo XIX encuentra su límite: ni las palabras ni las cosas portan ya en su cuerpo la marca de su significación ${ }^{779}$. Como lo que cuenta ahora es "el esplendor de lo visible" y "lo sagrado de la presencia» $^{, 780}$, lo fundamental ya no es el sentido que encarnan las palabras sino la propia realidad que transparentan. Así, el poema tiende a la anulación del lenguaje en el mundo que le sirve de referencia, y se convierte por tanto en una especie de cristal que establece una coincidencia perfecta entre los vocablos y la realidad.

En cierta medida, la llegada a ese puerto supone que se ha alcanzado el absoluto al que aspiraba la poesía moderna, pero el problema es que esta plenitud resulta indecible. Son muchos los autores modernos en los que se advierte esta ambivalencia entre el vislumbramiento de la unidad primordial y su incomunicabilidad. Quizás el autor donde mejor se aprecia esta dualidad entre la obtención del absoluto y el obligatorio mutismo que este conlleva es otra vez Octavio Paz. Como afirma Guillermo en el párrafo que cierra su ensayo más importante dedicado a la obra poética de este escritor mexicano:

la transparencia conduce al silencio: no porque lo verdadero sea indecible, sino porque ya no necesita ser dicho. Así, en cierta manera, Paz parece concluir en la misma evidencia que el Igitur mallarmeano: «Le Néant parti, reste le château de la pureté.» Pero esta pureza ¿no será la forma última en que se nos revela el mundo, o se nos transparenta? Vale decir: la forma última en que el mundo encarna y se hace real, plenamente real. Lo cual correspondería con la pasión utópica de Paz: la aparición del mundo - del mundo original, se entiende- implica la desaparición del lenguaje y de la poesía. Vivir la poesía: escribir el mundo. ${ }^{781}$

La idea de que, alcanzada la transparencia, la poesía se disuelve en la realidad es puesta de manifiesto en varias ocasiones por el propio Octavio Paz a lo largo de su libro

${ }^{779}$ Para el concepto de régimen de expresividad vid. supra nota 659, p. 235. Guillermo se da cuenta de que con la poética de la transparencia este régimen llega a su fin. Afirma por eso que el radicalismo de Aridjis "consiste, simplemente, en reconciliarnos con lo que una ética tradicional parecía prohibir y condenar: el esplendor de lo visible, la realidad (paradisiaca o no) del cuerpo; no tanto la presencia de lo sagrado (en el sentido de una trascendencia) como lo sagrado de la presencia: el universo y cuanto lo constituye. Para bien o para mal, ponen punto final, por supuesto, a una concepción romántica y a la vez simbolista." (Guillermo Sucre: "La nueva profundidad...”, loc.cit., p. 78. Cursiva nuestra)

\footnotetext{
${ }^{780}$ Ibid., p. 78.

${ }^{781}$ Guillermo Sucre: La máscara...op.cit., p. 236.
} 
El mono gramático (1970). En ese texto inclasificable el escritor mexicano señalaba que

la función de la poesía era convertir al lenguaje en mundo:

La crítica del paraíso se llama lenguaje: abolición de los nombres propios; la crítica del lenguaje se llama poesía: los nombres se adelgazan hasta la transparencia, la evaporación. En el primer caso, el mundo se vuelve lenguaje; en el segundo, el lenguaje se convierte en mundo. Gracias al poeta el mundo se queda sin nombres. Entonces, por un instante, podemos verlo tal cual es -en azul adorable. Y esa visión nos abate, nos enloquece; si las cosas son pero no tienen nombre: sobre la tierra no hay medida alguna. ${ }^{782}$

Como vemos, en la concepción de Paz, cuando se alcanza la comunión entre la

palabra y la referencia, la poesía se interna y se disuelve en la realidad, y el lenguaje

(ese puente que a un tiempo nos une y nos separa del universo) desaparece:

La búsqueda del sentido culmina en la aparición de una realidad que está más allá del sentido y que lo disgrega, lo destruye. Vamos de la búsqueda del sentido a su abolición para que surja una realidad que, a su vez, se disipa. La realidad y su esplendor, la realidad y su opacidad: la visión que nos ofrece la escritura poética es la de su disolución. La poesía está vacía como el claro del bosque en el cuadro de Dadd: no es sino el lugar de la aparición que es, simultáneamente, el de la desaparición. Rien n'aura eu lieu que le lieu. ${ }^{783}$

En otros autores, Guillermo Sucre percibe esta misma dualidad entre el hallazgo

del absoluto y el silencio necesario. Así señala, por ejemplo, que en el poemario Elogio

de la sombra (1969) Borges llega a vislumbrar el secreto de la Obra, "pero la posesión

del secreto lo remite igualmente al silencio; como uno de los personajes de sus relatos, quien ya tiene la última respuesta no puede decirla» ${ }^{, 784}$. El cuento al que se refiere

782 Octavio Paz: El mono gramático, en OOCC VII, Obra poética (1935-1998), Barcelona, Galaxia Gutenberg, 2004, [1970], pp. 593-594.

${ }^{783}$ Ibíd., pp. 602-603. Paz afirma también en el mismo texto: “Al final de camino ¿está la visión? El patio de los vecinos con su mesita negra y su borde oxidado, la arboleda de las hayas sobre una eminencia del terreno deportivo de Churchill College, el paraje de los charcos y los banianos, a unos cuantos cientos de metros de la antigua entrada de Galta, son visiones de realidades irreductibles al lenguaje. Cada una de estas realidades es única y para decirla realmente necesitaríamos un lenguaje compuesto exclusivamente de nombres propios e irrepetibles, un lenguaje que no fuese lenguaje: el doble del mundo y no su traducción ni su símbolo. Por eso verlas, de verdad verlas, equivale a enloquecer: perder los nombres, entrar en la desmesura. Es más: volver a ella, al mundo de antes del lenguaje. Pues bien, el camino de la escritura poética se resuelve en la abolición de la escritura: al final nos enfrentamos a una realidad indecible. La realidad que revela la poesía y que aparece detrás del lenguaje -esa realidad visible sólo por la anulación del lenguaje en que consiste la operación poética- es literalmente insoportable y enloquecedora. Al mismo tiempo, sin la visión de esa realidad ni el hombre es hombre ni el lenguaje es lenguaje. La poesía nos alimenta y nos aniquila, nos da la palabra y nos condena al silencio. Es la percepción necesariamente momentánea (no resistiríamos más) del mundo sin medida que un día abandonamos y al que volvemos al morir. El lenguaje hunde sus raíces en ese mundo pero transforma sus jugos y reacciones en signos y símbolos. El lenguaje es la consecuencia (o la causa) de nuestro destierro del universo, significa la distancia entre las cosas y nosotros. También es nuestro recurso contra esa distancia." (Ibid., p. 604.)

${ }^{784}$ Guillermo Sucre: "Poesía Crítica: Lenguaje y Silencio", loc.cit., p. 576. 
nuestro autor es, por supuesto, "La escritura del Dios", donde el mago de la pirámide de Qaholom, después de entender el mensaje cifrado en la piel del jaguar, indica:

Es una fórmula de catorce palabras casuales (que parecen casuales) y me bastaría decirla en voz alta para ser todopoderoso. Me bastaría decirla para abolir esta cárcel de piedra, para que el día entrara en mi noche, para ser joven, para ser inmortal, para que el tigre destrozara a Alvarado, para sumir el santo cuchillo en pechos españoles, para reconstruir la pirámide, para reconstruir el imperio. Cuarenta sílabas, catorce palabras, y yo, Tzinacán, regiría las tierras que rigió Moctezuma. Pero yo sé que nunca diré esas palabras, porque ya no me acuerdo de Tzinacán. [/] Que muera conmigo el misterio que está escrito en los tigres. Quien ha entrevisto el universo, quien ha entrevisto los ardientes designios del universo, no puede pensar en un hombre, en sus triviales dichas o desventuras, aunque ese hombre sea él. Ese hombre ha sido él y ahora no le importa. Qué le importa la suerte de aquel otro, qué le importa la nación de aquel otro, si él, ahora es nadie. Por eso no pronuncio la fórmula, por eso dejo que me olviden los días, acostado en la oscuridad. ${ }^{785}$

Otro autor hispanoamericano donde aparece esta certeza es Vicente Huidobro, que concluía uno de sus grandes poemas de la madurez ("Balada de lo que no vuelve") con estas palabras: "Oh hermano nada voy a decirte/ Cuando hayas tocado lo que nadie puede tocar/ Más que el árbol te gustará callar" ${ }^{\text {,766 }}$. Y también Susan Sontag, una autora norteamericana que fue leída por Sucre en esta época, señalaba en uno de sus ensayos publicados en los años 60 que "el silencio es una metáfora para una visión limpia, que no interfiere, apropiada para las obras de arte que son imposibles antes de ser vistas y cuya integridad esencial no puede ser violada por el escrutinio humano" ${ }^{\text {787 }}$. Lo que con estas palabras quería decir es que el mutismo funciona como una metáfora en aquellas obras que alcanzan la transparencia.

Se alcance o no este absoluto, lo cierto es que Guillermo valora positivamente el hecho de que el lenguaje poético trate de reducir al máximo su espesor semántico para lograr que la referencia se transparente. En consonancia con su concepción de la realidad, el poema debe ser (o, más bien, tender a ser) un cuerpo traslúcido, donde no haya secretos ni opacidades y donde todo sea perfectamente visible. Lo importante para Sucre es el presente de la escritura, es decir, el cuerpo o la superficie del lenguaje, y no

\footnotetext{
785 Jorge Luis Borges: “La escritura del Dios”, en OOCC, Vol. I, op.cit., p. 599.

${ }^{786}$ Vicente Huidobro: "Balada de lo que no vuelve", en Guillermo Sucre (coord.): Antología de la poesía hispanoamericana moderna, Vol. I., op.cit., p. 362.

${ }^{787}$ Susan Sontag: "La estética del silencio", en Estilos radicales, op.cit., p. 30.
} 
la remisión a una dimensión más profunda capaz de legitimar el sentido. Guillermo, ciertamente, está del lado de Cratilo: para él lo significado surge como aprehensión profunda del significante y es inseparable de él. Esta perspectiva implica que nuestro autor rechaza todas aquellas figuras retóricas que separan la significación de la forma y la hacen depender de una clave interpretativa que no todo el mundo posee. Por eso se opone radicalmente a la alegoría y al símbolo, que remiten lo visible a un determinado patrón hermenéutico. Para Guillermo la obra es en sí misma una experiencia que no requiere ser interpretada, puesto que en ella la significación encarna y es plenamente visible. En consecuencia, él concede mucha importancia a la materialidad del signo y a la imagen poética, que no envían el sentido a una dimensión profunda e invisible, sino que tienden a convertir la escritura en un vidrio transparente. La imagen poética para Sucre no tiene nada que ver -como él mismo apuntaba a propósito del Borges de los años veinte- con la "mera decoración sensorial" ni con "la aparente audacia inventiva que era más bien confusión”. Para él, como para el escritor argentino, "la imagen había de ser $[\ldots]$ una visión profunda y esencial del mundo, que exprese los momentos «de alguna intensidad de pasión»» ${ }^{, 788}$. Esto mismo advierte nuestro autor en la imagen que Paz comienza a emplear a partir de Blanco (1967), la cual consigue borrar "más profundamente los límites entre lo figurado y lo real; a esa imagen hay que tomarla literalmente (y en todos los sentidos, como diría Rimbaud): no es una sustitución del mundo, quiere ser un mostrar el mundo",789. En la visión de Guillermo, de lo que se trata es de "revalorar el cuerpo del lenguaje" y de "revivir el placer de su materialidad"790.

En muchas de las críticas que escribió en estos años, Sucre valoraba positivamente el hecho de que los autores o movimientos presentaran un lenguaje poético que contuviese en su propia forma una dimensión visionaria. Así, a propósito de

\footnotetext{
${ }^{788}$ Guillermo Sucre: “Borges, una poética de la desposesión”, loc.cit., p. 188.

${ }^{789}$ Guillermo Sucre: La máscara ...op.cit., p. 233.

${ }^{790}$ Guillermo Sucre: "La nueva profundidad...", loc.cit., p. 80.
} 
Ramos Sucre, nuestro crítico destacaba que "si muchos de sus poemas son paráfrasis o glosas [...], lo son desde un presente de la escritura: la palabra que no regresa al referente, sino que rescata lo imaginario del signo"791. Y si el escritor cumanés afirmaba -según nos recuerda Guillermo- que "no podemos asir directamente la realidad y por ello inventamos el símbolo", para él esta figura "no es alegoría, sino organización del

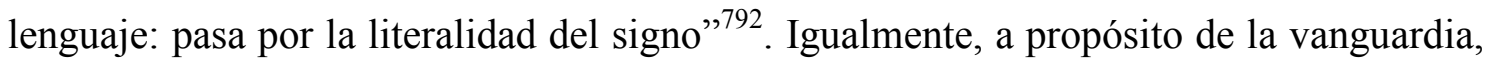
nuestro autor destacaba el hecho de que lejos "de ser una estética de lo informe, la vanguardia es una estética de las formas: subraya la autonomía de éstas, su virtualidad, su poder imaginario. Las formas como deseo: hacer de la obra un campo de atracciones magnéticas y eróticas" ${ }^{\text {793 }}$. Por eso también Sucre prefería aquellas obras en las que el lenguaje es una superficie diáfana que no remite a ningún sentido secreto. Esto es lo que advertía en Memorial de Cadenas, al que nuestro autor consideraba un "libro de superficies". En él todo depende de su condición de posibilidad y es plenamente visible, es decir, que en él -y aquí el crítico parece referirse simultáneamente a la estética y a la visión del mundo del autor-

ya no existen el verso o el reverso de las cosas, o si existen es porque aparecen en la superficie donde uno y otro se igualan, donde uno supone al otro. Es por lo que creo en la conciencia crítica de Memorial. Conciencia crítica no quiere decir, acá, sólo lucidez de un yo privilegiado que percibe lo que los demás no perciben. Quiere decir esto: el mundo es translúcido: todo en él es visible, todo en él es cuerpo que se manifiesta, aun en su ausencia. ${ }^{794}$

Además, al concebir la realidad y la creación como conjuntos de relaciones igualitarias, el sistema analógico que más valora Guillermo Sucre no privilegia el vínculo por semejanza sino las correspondencias inesperadas que establecen entre sí los

${ }^{791}$ Guillermo Sucre "Ramos Sucre: Anacronismo y/o renovación”, loc.cit., p. 82.

${ }^{792}$ Ibíd., p. 79. A este respecto, Guillermo decía también que los textos de Ramos Sucre "son continuidad y ruptura: muestran la presencia y el esplendor de una tradición, pero, a un tiempo, la denuncian, al subrayar esa fisura entre las palabras y las cosas con que se inaugura la modernidad (esta vez desde Cervantes). A esa fisura fue quizá lo que él llamó símbolo: un signo que (ya) no puede aprehender directamente la realidad, ni siquiera figurarla o trasponerla, sino referirse a sí mismo." (Guillermo Sucre: "Introducción", a la Primera Parte de la Antología de la poesía hispanoamericana moderna, Vol. I, op.cit., p. 27)

793 Guillermo Sucre: "Introducción" a la Segunda Parte de la Antología de la poesía hispanoamericana moderna, Vol. I, op.cit., p. 300.

${ }^{794}$ Guillermo Sucre: "Memorial...", loc.cit., 41. 
diferentes elementos que componen la estructura. Por eso rechaza la comparación y la metáfora convencionales, pues de acuerdo a estas figuras las cosas pierden su dimensión sensible para convertirse en algo diferente de ellas mismas. No se trata de cambiar una cosa por otra, sino de mostrar (¿de inventar?) la equivalencia entre entidades diversas para así reducir a unidad la multiplicidad de lo real. En este sentido, el sistema analógico que Sucre más estima es el que había propuesto Octavio Paz y, antes que él, los creadores cubistas. El escritor mexicano consideraba, según nos dice Guillermo, que "el mundo se ha fragmentado porque hemos perdido la relación entre las cosas y, sobre todo, porque nuestros prejuicios han creado jerarquías entre ellas". De lo que se trata entonces es de "ver primero las cosas en lo que son", es decir, "en su apariencia" y, a partir de esa visión relacionar los fragmentos entre sí, pero "no tanto por semejanza o contraste previos, sino por contigüidad: están en un mismo espacio, se encuentran o se rechazan, desaparecen o se prolongan en otros; es a través de este movimiento como se van constituyendo en una verdadera trama". El poema, entonces, "no habla de una analogía" sino que "la hace posible por su propia estructura verbal" pues "antes que por símbolos, el poema de Paz está constituido, en verdad, por signos" ${ }^{\text {,795 }}$. El sistema analógico del escritor mexicano establece la identidad entre los diferentes elementos de la realidad ("el poeta nombra las cosas: éstas son plumas, aquéllas son piedras. Y de pronto afirma: las piedras son plumas, esto es aquello",796) y atenta, a través de esta reconciliación, contra el fundamento del pensamiento occidental, que había tratado por todos los medios de negar la otredad a favor de lo Uno.

La concepción de Paz tiene su origen en los planteamientos del cubismo que, como nos dice Sucre en su ensayo sobre Braque, había inaugurado "una nueva formulación del pensamiento analógico", de acuerdo a la cual "la creación analógica ya

\footnotetext{
${ }^{795}$ Guillermo Sucre: La máscara...op.cit., p. 234.

${ }^{796}$ Octavio Paz: El arco y la lira, en OOCC, Vol. I, op.cit., p. 138.
} 
no se basa tan sólo en similitudes; lo central en ella es la relación (inesperada, sorprendente, $[\ldots])$ entre las cosas. El artista no se preocupa porque las cosas tengan o no semejanzas entre ellas, sino por el hecho de que viven en un espacio común"797. Acaso el primero en formular estas ideas sobre la imagen y la analogía fue el poeta francés Pierre Reverdy. Él afirmaba que el cubismo había sido originariamente un movimiento poético que pasó posteriormente a la pintura pues, como él dice, "despejar, para crear, los vínculos que las cosas tienen entre sí, para acercarlas, fue en todas las épocas lo propio de la poesía" ${ }^{, 798}$. Si lo propio de este arte es inventar y revelar las relaciones que las cosas establecen entre sí, las comparaciones convencionales resultan inservibles y se llega a una formulación metonímica: "La palabra «como» puede servir para acercar dos realidades y dejar en libertad al espíritu que comprueba ese acercamiento. [/] Yo he preferido acercar todavía más directamente elementos diversos por sus simples relaciones y prescindir de todo intermediario para obtener la imagen"799. Nuestro crítico aprecia esta misma concepción en la obra de Vicente Huidobro. Si bien el poeta chileno no deja de practicar el símil ni la metáfora, lo que más cuenta en él es "la imagen paralela", en la que "se trata de eludir lo más posible la dependencia de lo real y constituir en sí misma su propio contexto; el como si es sustituido por el es, pero no sólo en un plano sintáctico" ${ }^{\sharp 00}$. De este modo, como el propio vate lo reconocía, la

\footnotetext{
${ }^{797}$ Guillermo Sucre: "La poética de Georges Braque”, loc.cit., p. 49.

798 Pierre Reverdy: "El cubismo, poesía plástica", en Escritos para una poética, Caracas, Monte Ávila, 1977, p. 42.

${ }^{799}$ Pierre Reverdy: "Self defense", en Ibid., p. 38. Decía también: "La imagen es una creación pura del espíritu. [/] No puede nacer de una comparación sino del acercamiento de dos realidades más o menos distantes". (Pierre Reverdy: "La imagen", en Ibíd., p. 25). Para el poeta francés la emoción causada por la imagen "es poéticamente pura, puesto que nace al margen de toda imitación, de toda evocación, de toda comparación. [/] Hay la sorpresa y la alegría de encontrarse ante una cosa nueva. [...] [/] Es posible crear [...] una imagen fuerte, nueva para el espíritu, aproximando sin comparación dos realidades distantes cuyas relaciones sólo el espiritu ha captado." (Ibíd., p. 25.)

${ }^{800}$ Guillermo Sucre: La máscara ...op.cit., p. 107.
} 
imagen constituye una revelación, que "es más intensa $[\ldots]$ en la medida en que sorprende una relación nueva entre las cosas más distantes entre sí” ${ }^{\prime 801}$.

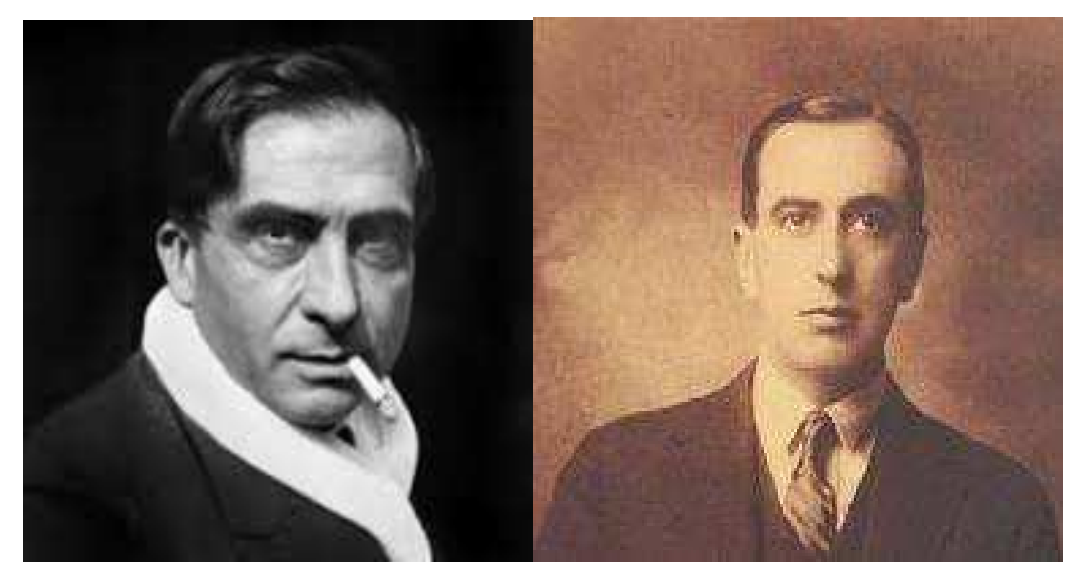

Imágenes 47 y 48. Pierre Reverdy (1889-1960) y Vicente Huidobro (1893-1948).

La concepción de la imagen y de la analogía que vemos en estos autores y que era la preferida por Sucre implica un nuevo distanciamiento con respecto a la perspectiva metafísica y logocéntrica. Al privilegiar el vínculo por contigüidad y rechazar la relación por semejanza, nuestro autor estaba impugnando la anterioridad y la profundidad características de estas formas de pensamiento. En efecto, como lo ha visto Foucault, "la semejanza tiene un «patrón»: elemento original que ordena y jerarquiza a partir de sí todas las copias cada vez más débiles que se pueden hacer de él. Parecerse, asemejarse, supone una referencia primera que prescribe y clasifica" ${ }^{\prime 802}$. Frente a esta relación que supone la fidelidad a una referencia y, por lo tanto, el establecimiento de una relación jerárquica, Guillermo prefiere la similitud, es decir, el vínculo por contigüidad, que ya no se debe a ningún modelo ni privilegia ninguna clave. Como afirma el pensador francés citado más arriba:

Lo similar se desarrolla en series que no poseen ni comienzo ni fin, que uno puede recorrer en un sentido o en otro, que no obedecen a ninguna jerarquía, sino que se propagan de

${ }^{801}$ Ibid., 106. 64.

${ }^{802}$ Michel Foucault: Esto no es una pipa. Ensayo sobre Magritte, Barcelona, Anagrama, 1981, p. 
pequeñas diferencias en pequeñas diferencias. La semejanza sirve a la representación, que reina sobre ella; la similitud sirve a la repetición que corre a través de ella. La semejanza se ordena en [función del] modelo al que está encargada de acompañar y dar a conocer; la similitud hace circular el simulacro como relación indefinida y reversible de lo similar con lo similar. ${ }^{803}$

Vemos, por tanto, que la concepción de la imagen y de la analogía de Sucre es estrechamente pareja a su visión de la realidad y de la obra de arte. Si estas entidades son plenamente visibles y carecen de profundidad, es evidente que esas figuras (imagen y analogía) no pueden remitir a una dimensión secreta sino que deben tratar de encarnar la referencia a partir de su propia materialidad y de someter a unidad la diversidad de lo real.

\section{5. MORALIDAD, IMPERSONALIDAD, UNIVERSALIDAD}

En el pensamiento de Sucre la literatura no puede limitarse a reproducir un sentido del mundo previamente establecido, sino que debe encarnar el verdadero sentido del mundo. Frente a la interpretación arbitraria que el poder y sus instrumentos ideológicos -la metafísica y la historia- han impuesto sobre la realidad, nuestro autor piensa que la literatura debe inventar y revelar el mundo esencial. Al hablar de los poetas de su misma generación en la Introducción al segundo volumen de la Antología de la poesía hispanoamericana moderna, Guillermo Sucre señalaba que lo que caracteriza a los vates de la segunda mitad del siglo XX es "la conciencia de vivir a la intemperie" $" 804$, y precisaba que esa intemperie es sobre todo ideológica: "el desencanto ante las utopías, el rechazo de los sistemas convertidos en dogmas, en fin, la crítica a la historia como poder, trampa o manipulación" ${ }^{805}$. Sucre reconocía así que la mayor parte de los poetas continentales contemporáneos escriben “desde esta desilusión” dejaba intuir que, quizás, todos ellos convergen en el intento por rescatar de otra

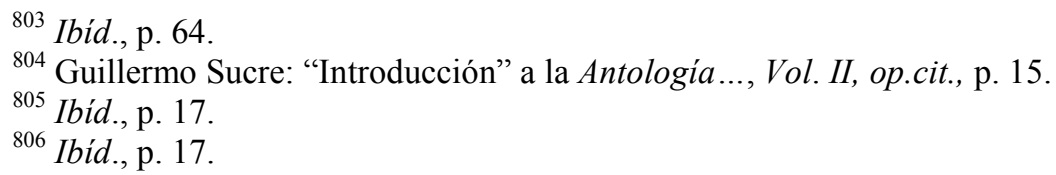


manera las promesas de las religiones y de los sistemas políticos. Y para explicar lo que quería decir con esto, Guillermo se apoyaba en una idea de Rafael Cadenas:

El poeta moderno habla desde la inseguridad. No tiene más asidero que la vida. Seguramente una voz queda le dice en los adentros: La época de las causas terminó. Ya no puedes aferrarte a religiones, ideologías, movimientos, ni siquiera literarios. Se acabaron las banderas. Pero este desengaño lo libera para luchar en otra clave por lo que religiones, ideologías, movimientos dicen defender: lo religioso, lo humano, lo valedero. Esa voz, que parece la del nihilismo, podría ser la voz de la vida que desea recuperarnos. ${ }^{807}$

A esta cita nuestro autor añadía que "rescatar lo religioso, lo humano, lo valedero es ya volver a nuestros fundamentos; dejar que la vida nos rescate es ya fundarla en lo que ella tiene de sagrado" $" 808$.

Para que sea posible regresar a nuestros principios originales e instaurar la vida esencial, la creación literaria debe estar en consonancia con el ethos primordial del hombre y del mundo. Como ya sabemos, la conciencia del lenguaje es fundamental en el pensamiento de Sucre. Esta noción implica que la realidad sólo se puede conocer a través de una mirada y de una escritura. Si la poesía funda la realidad como de verdad es, la visión y el lenguaje del autor deben estar necesariamente en conformidad con el ethos esencial que la poesía crea y descubre. Para que esto se produzca es preciso que el artista respete los límites marcados por el orden primordial de su propia naturaleza y de la realidad. En consonancia con esta idea, Sucre hallaba "el fundamento de nuestra verdadera poesía moderna” en sendas frases de Martí y de Huidobro que dicen, respectivamente, así: "El universo habla mejor que el hombre", "El universo es más claro que mi espejo" ${ }^{\sharp 09}$. Para nuestro autor, la gran poesía moderna es aquella que reconoce el sentido primordial del mundo y es capaz de ceñirse a él.

Para lograr esto es imprescindible que los autores tengan conciencia del lenguaje, pues sin ella es imposible la instauración poética de la realidad esencial. Esta

${ }^{807}$ Cita del libro Anotaciones (1983) de Rafael Cadenas, en Guillermo Sucre: "Introducción” a la Antología..., Vol. II, op.cit., pp. 17-18.

${ }^{808}$ Ibid., p. 18.

${ }^{809}$ Citadas por Sucre, en Guillermo Sucre: La máscara ...op.cit., p. 100. 
conciencia (o su culminación: la transparencia) implica la comunión del sujeto y del objeto en el cuerpo del lenguaje, y es solo cuando esta coincidencia se produce que la poesía puede estar de acuerdo con el ethos esencial del hombre y de cuanto nos rodea ${ }^{810}$. La conciencia del lenguaje supone que en el texto se produce una saturación entre el sujeto y el objeto o entre lo interior y lo exterior, de manera que ambas entidades dejan de existir de forma autónoma. Solo cuando esa unión se da plenamente y no se puede hablar del sujeto y del objeto como dominios escindidos, la poesía puede comunicar la verdad esencial a la que aspira: el sentido del mundo. Esta comunión presupone además que el autor presenta una ética apropiada y que se aproxima a un ideal de nobleza -por eso los grandes creadores constituyen en la visión de Sucre un auténtico "linaje". En "la estética de lo visible" de Homero Aridjis, Guillermo destacaba precisamente la capacidad para hallar una escritura plena, sin profusiones de forma o de

${ }^{810}$ En la visión Sucre, la ética esencial del hombre, su ideal de nobleza (al igual que el de la literatura misma) consiste en concordar con el sentido del mundo. La visión esencialista del hombre que él defiende se advierte, por ejemplo, en el texto "De la elegancia y otros anacronismos", donde nuestro autor reivindica la elegancia como el ideal ético del hombre. En ese ensayo, Guillermo indica que "la elegancia tiene que ver con el alma", la cual "se rige por una sabiduría secreta y, aun oscuramente, conoce la primordial justicia del mundo". Y afirma también: "Nada más íntimo que la elegancia, nada más impersonal también. De otro modo, se negaría a sí misma. Si tiene algún oficio es el de aceptar el mundo, no el de condenarlo; el de amar la vida antes de comprender su sentido". (Guillermo Sucre: "De la elegancia y otros anacronismos", en Vuelta, (México), núm. 167, oct. 1990, pp. 41 y 42). En la concepción de Sucre, la elegancia supone el encuentro de la conducta del hombre con el ethos del mundo, y por eso es una cualidad tan valorada por él. La elegancia supone un ideal de nobleza e implica valores como la mesura, la defensa del término medio, el compromiso con la verdad por encima de las disquisiciones partidistas, la impersonalidad, la humildad, la defensa de la inmanencia (el cuerpo, el presente), y la lucidez. Algo similar a lo que acabamos de ver con respecto a la elegancia aparece en otro texto donde Guillermo reivindica por motivos similares la ética implícita en el ocio. Allí afirmaba, por ejemplo, que el ocio "no es desgana ni bribonada de artista bien subvencionado. Es otro tipo de actividad: contemplativa pero crítica, marginal pero no indiferente, que conduce al único fin liberador: sólo vivir, sin tener que confesarlo - menos, proclamarlo- mucho". Y decía asimismo que los ociosos tienen "tiempo de vivir el mundo como tal, sin buscar otra gratificación que la de un día llegar a ser el mundo mismo: apenas un poco de tierra oscura y transparente (o transparente y oscura), y nunca una más o menos opaca estatua". (Guillermo Sucre: "Del ocio", en "Entretextos", loc.cit., p. 11). Es evidente entonces que para Sucre hay un ideal ético de nobleza que consiste en adecuarse al orden fundamental que gobierna la vida y el mundo. Esta concepción del hombre se duplica en la de la literatura. En la visión de Guillermo, el arte elaborado con palabras debe adecuarse a unos límites muy precisos que están definidos por el ethos que rige en el mundo y que, como hemos visto, debe regir también en el hombre. Como debe ceñirse a las normas esenciales que gobiernan la realidad, la expresión literaria es inseparable, ella también, de un ideal de nobleza y debe presentar, en consecuencia, los mismos valores éticos (que llevan implícitos los estéticos) que hemos visto más arriba a propósito del ser humano: la mesura, la defensa del término medio, el compromiso con la verdad por encima de las disquisiciones partidistas, la impersonalidad, la humildad, la defensa de la inmanencia (el cuerpo, el presente) y la lucidez. 
contenido, de subjetividad o de objetividad. La obra de este poeta, según dice nuestro crítico, excluye "por igual dos peligros: el del realismo descriptivo y el de esos precipitados modernosos, que consisten en rodearlo todo de metáforas". Y después de afirmar esto, se preguntaba retóricamente: “№ constituyen ambos procedés una jerarquización del mundo, que es como decir una manera de distorsionarlo y aun de negarlo: por tratar de empobrecerlo o por tratar de enriquecerlo?" ${ }^{\prime 811}$. Vemos entonces cómo Sucre reconocía explícitamente que los excesos de objetividad y de subjetividad o de cosas y de palabras (el "realismo descriptivo"; "esos precipitados modernosos") jerarquizan el mundo e impiden revelarlo como verdaderamente es. En cambio, cuando se da con éxito la continuidad entre lo mirado y la mirada, la creación es capaz de transparentar la verdadera realidad ${ }^{812}$.

En el lado opuesto a aquellos autores que tienen conciencia del lenguaje se encuentran esos otros que presentan una concepción logocéntrica del mismo. Los escritores que se ciñen a esta teoría piensan que el sentido de la realidad ha sido establecido de antemano y emplean las palabras como simples instrumentos para comunicar esa significación previa. Esto implica que son incapaces de establecer una continuidad entre el sujeto y el objeto y que incurren en excesos de cosas y de palabras. Esta disonancia entre lo interior y lo exterior revela que el creador no ha sido capaz de armonizar su ética y su estética con la del mundo esencial y, por lo tanto, su creación resulta inapropiada y fraudulenta. Como no muestra el sentido primordial del universo, la literatura logocéntrica resulta además novedosa y arbitraria.

${ }^{811}$ Guillermo Sucre: “La nueva profundidad...”, loc.cit., p. 79.

812 Además, cuando esta unión se cumple, la originalidad absoluta es imposible, pues si las palabras son el núcleo de la relación entre el hombre y el universo, ninguna obra puede ser enteramente novedosa: "es cierto que hay espacios diferentes -geográfica, social e históricamente hablando-, pero el universo es uno; es cierto también que hay lenguas diferentes, pero todas son lenguaje". (Guillermo Sucre: "Poesía hispanoamericana y conciencia...", loc.cit., p. 610) 
Entonces vemos que la conciencia del lenguaje implica un ideal de saturación entre lo interior y lo exterior y entre las palabras y las cosas que, al anular la existencia independiente del sujeto y del objeto, permite revelar la verdadera realidad. Cuando este ideal se cumple, el ser del autor (la entidad imaginaria creada en y por la propia obra) coincide con el ser esencial del mundo; esto implica que el texto se despersonaliza y que se vuelve universal. En efecto, como el propio Sucre intuye, la omisión de la personalidad del escritor real en la creación literaria es estrictamente simultánea a la conciencia del lenguaje ${ }^{813}$. Cuando se establece una continuidad entre el nombre y lo nombrado, la interioridad del autor se funde con el universo, de manera que ya no se puede hablar del hombre y del mundo como entidades separadas. Por eso Guillermo afirma que la impersonalidad "trae consigo el rescate de los poderes secretos del lenguaje aún no arruinados por la manipulación ideológica, y la obra vista como [...] reconciliación entre el cuerpo emblemático del texto y el cuerpo del mundo" ${ }^{814}$. Esta unión del sujeto y del objeto en el cuerpo del lenguaje permite vislumbrar una realidad esencial donde no hay separación entre las personas y aquello que les rodea. Entonces, como dice Sucre, la despersonalización implica "la busca de una realidad humana incontaminada, el yo en comunión con el universo" ${ }^{\text {815 }}$. Vemos, así, que esta resulta de la afinidad entre la identidad del hablante y las leyes esenciales del mundo: esa coincidencia es lo que permite que el autor disuelva en ellas su propia personalidad. De este modo, la impersonalidad supone que los autores, sin dejar de ser entidades singulares y con rasgos diferenciables, presentan un ética (y una estética) que constituye un ideal común a todos los hombres ya que supone la coincidencia con la realidad

\footnotetext{
${ }^{813}$ Para nuestro autor, la conciencia del lenguaje "implica igualmente la estética -y la ética- de la impersonalidad”. (Guillermo Sucre: La máscara ...op.cit., p. 100).

${ }^{814}$ Ibid., p. 99.

${ }^{815}$ Guillermo Sucre: "Poesía Crítica: Lenguaje y Silencio", loc.cit., p. 587.
} 
original. La voz de la gran poesía es impersonal porque, al hallar el ethos esencial del mundo y del hombre, permite a cualquiera reconocerse en ella ${ }^{816}$.

En varias ocasiones Guillermo vincula la impersonalidad con la verdad y con el hallazgo del sentido de la realidad. Por ejemplo, en Memorial de Cadenas, nuestro autor advierte la presencia de "un hombre que, fascinado (y aun obsesionado) por la verdad, no quiere imponerla, sino hacerla posible. Esa fascinación (esa obsesión) lo hace impersonal: de algún modo, habla, desde su ausencia, para recuperar la presencia de todos" $"$. Como vemos, la despersonalización supone el relegamiento "de la falsa significación del Yo" ${ }^{\text {818 }}$ para (re)descubrir la realidad esencial: la verdad común a todos y a cualquiera. Esto mismo se aprecia en uno de los poemas de Borges más valorados por nuestro autor, que revela no sólo la concepción ética y estética del maestro argentino, sino también la del propio Sucre. El texto se titula "Jactancia de quietud", y Guillermo lo estudia a partir de la versión que aparece en la Obra poética de 1967:

Escrituras de luz embisten la sombra, más prodigiosas que meteoros.

La alta ciudad inconocible arrecia sobre el campo.

Seguro de mi vida y de mi muerte, miro los ambiciosos y quisiera entenderlos.

Su día es ávido como el lazo en el aire.

$\mathrm{Su}$ noche es tregua de la ira en el hierro, pronto en acometer.

Hablan de humanidad.

Mi humanidad está en sentir que somos voces de una misma penuria. Hablan de patria.

Mi patria es un latido de guitarra, unos retratos y una vieja espada,

la oración evidente del sauzal en los atardeceres.

El tiempo está viviéndome.

Más silencioso que mi sombra, cruzo el tropel de su levantada codicia.

Ellos son imprescindibles, únicos, merecedores del mañana.

Mi nombre es alguien y cualquiera.

$\mathrm{Su}$ verso es requerimiento de ajena admiración.

${ }^{816}$ Según nos recuerda Sucre, a esto mismo parecía referirse Lezama Lima cuando señalaba, en un texto sobre el pintor Portocarrero, que transmutarse en máscara es la única vía que tiene el yo para alcanzar "el misterio de su yo separado y superior". (José Lezama Lima: "Máscaras de Portocarrero", en Tratados en La Habana, en Obras completas, Vol. II, op.cit., p. 485. Esta frase la cita Sucre en "Entretextos", loc.cit.). Como afirma el autor cubano en ese mismo ensayo, "en cada hombre hay la infinitud del mundo alcanzado por su máscara, que es su rostro reconocible por lo estelar figurativo. Toda especie perfecta, nos dice el orgulloso humanismo de Goethe, debe de convertirse en un ser incomparable. Ese ser de naturaleza superior comienza por su máscara." (Ibíd., p. 485). La máscara sería entonces esa variación en que la personalidad adquiere una dimensión maravillosa y empieza a ser reconocible universalmente.

${ }^{817}$ Guillermo Sucre: “Memorial...”, loc.cit., p. 41.

${ }^{818}$ Rimbaud, citado por Guillermo Sucre: La máscara ...op.cit., p. 96. 
Yo solicito de mi verso que no me contradiga y es mucho.

Que no sea persistencia de hermosura, pero sí de certeza espiritual.

Yo solicito de mi verso que los caminos y la soledad lo atestigüen.

Gustosamente ociosa la fe, paso bordeando mi vivir.

Paso con lentitud, como quien viene de tan lejos que no espera llegar. ${ }^{819}$

Aunque lo transcribimos completo, lo fundamental para el asunto que aquí estamos tratando son los ocho versos finales. En ellos se aprecia, y Sucre así lo pone de manifiesto en su análisis, la oposición ética y estética entre los otros y el hablante lírico. Mientras que ellos son únicos y sus textos buscan la hermosura y la admiración ajena, el yo poético es impersonal ("mi nombre es alguien y cualquiera" 820 ), y en vez de solicitar "una justificación puramente estética de su poesía", espera de ella sólo una "certeza espiritual”. Esa certeza, como dice Guillermo, "no será sólo de orden individual, aunque la fidelidad con la visión de Borges sea un primer requerimiento («que no me contradiga y es mucho», dice); ha de ser, igualmente, una fidelidad con el mundo: «los caminos y la soledad» deben atestiguarla» ${ }^{\natural 21}$. Vemos, entonces, cómo en el texto del escritor argentino se plantea un vínculo, que el propio Guillermo suscribe, entre la despersonalización del poeta y la consonancia de sus versos con el sentido esencial del mundo.

Además, en la interpretación de nuestro autor, la impersonalidad poética implica "una ética, una actitud frente al mundo" $\$ 22$, es decir, una conducta determinada que coincide con ese ideal de nobleza que Sucre considera inherente a la literatura. En primer lugar, que una obra sea impersonal supone que el escritor es consciente del lenguaje y que sabe, por tanto, que no puede remitir el texto a su propia experiencia

${ }^{819}$ Citado por Guillermo Sucre: “Borges, una poética de la desposesión”, loc.cit., p. 192.

${ }^{820}$ En este verso, dice Sucre, se aprecia la idea borgeana "de que un hombre es todos los hombres y ninguno, un autor todos los autores; la despersonalización como la manera más auténtica de ser" (Ibíd., p. 195). Esta idea conlleva además una crítica "ante los que hacen de la poesía un desmesurado ejercicio del yo y de su vanidad”. (Ibid., p. 195). Como afirma nuestro autor, la despersonalización tiene que ver con la idea de Borges de que "no ser es más que ser alguien y, de alguna manera, serlo todo", que aparece en su poema "The Unending Gift".

${ }^{821}$ Citado en ibíd., p. 195. Con esto el escritor argentino, según interpreta Guillermo, "no intenta formular ningún realismo «terre à terre», sino una ética de la creación que, a su vez, se constituye en una estética más amplia: la visión del universo." (Ibíd., p. 195)

${ }^{822}$ Guillermo Sucre: La máscara ...op.cit., p. 98. 
biográfica. Las propias palabras crean "metamorfosis del yo" pues, como afirma Guillermo citando de memoria a Pound, "uno dice soy éste, ése o aquél, y ya con sólo enunciarlo en palabras se deja de serlo" ${ }^{\wedge 23}$. En segundo lugar, y como resultado de lo anterior, la impersonalidad significa que "el poeta reconoce su excentricidad":

si sale del centro es porque en el fondo, quiere estar en el todo; pero habría que recordar que hoy la totalidad es también fragmentación para comprender que no busca situarse nuevamente en un punto privilegiado. Lo que el poeta busca, en verdad, es que todos se reconozcan en la marginalidad y actúen desde ella; que nadie se sienta único, o se crea representativo y hable en nombre de los otros. ${ }^{824}$

Asimismo, la impersonalidad implica un cuestionamiento al poder. La despersonalización permite descubrir la identidad humana esencial, y así se opone a los excesos y las desmesuras propias de las relaciones de dominio. Nuestro autor piensa que el poder trata el asunto de la identidad de dos maneras opuestas pero complementarias: por una parte, "todos los sistemas sociales tienden hoy a uniformar al hombre y a privarlo de toda intensidad personal" y, por la otra, "practican el exhibicionismo del yo, la idolatría de los supuestos seres excepcionales" ${ }^{825}$. En esta ambivalencia no hay nada contradictorio, puesto que "una cosa exige la otra" $" 826$. Ante esta doble degradación del individuo que el poder obra en la sociedad contemporánea, el poeta moderno propone la "impersonalidad", que "es un rechazo implícito de ambas" y que contiene un impulso redentor: "ni represión del yo ni sublimación, sino verdadera liberación: inventarse en los otros y descubrirse en ellos" ${ }^{\$ 27}$. Por todo ello vemos que la impersonalidad está estrechamente ligada a un ideal ético que Guillermo considera propio del mundo, del hombre y de la literatura. La despersonalización implica la mesura, pues concilia lo mirado y la mirada en el cuerpo del lenguaje; la aceptación de la verdad esencial frente a los excesos del poder; la humildad, ya que el poeta sabe que no es el centro y por lo

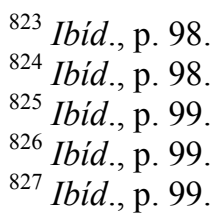


tanto no asume la representatividad de personas o ideas; la lucidez, porque reconoce la distancia que separa la identidad real de la escritura, etc. Todas estas cualidades suponen una consonancia de la voz poética y del poema con el ethos esencial del mundo, permiten que la obra invente y revele la realidad primordial y que acceda al diálogo de la gran literatura de todos los tiempos.

En la medida en que nuestro autor exige la adecuación de la literatura a una norma intemporal (la consonancia con el ethos esencial del mundo y del hombre) podemos decir que tiene una concepción clásica (pero no clasicista) de la misma. Como el arte con palabras presenta (o, más bien, debe presentar) los mismos valores éticos y estéticos a lo largo del tiempo, la literatura para Guillermo es un discurso transhistórico: "una sola obra, un solo texto que atraviesa a la historia, sin dejarse simplemente atravesar por ésta" ${ }^{\$ 28}$. La creación literaria es universal cuando está en consonancia con el ethos esencial del mundo; por lo tanto, las obras que contienen excesos de subjetividad y de objetividad no pueden ser ecuménicas, pues esas profusiones les impiden entroncar con ese ethos y las vuelven novedosas y arbitrarias. Entonces, más que un innovador radical, para Sucre el poeta es alguien que inventa y descubre el sentido del mundo que se ha perdido. La poesía entonces no es cambio sino continuidad, y tampoco es ruptura, sino ahondamiento o profundización en unos mismos valores. Incluso aunque no lo pretenda, toda creación adecuada entra a formar parte de ese conjunto de obras que comparte un mismo ethos: "el arte es un espacio que va generando sus propias correspondencias. Una obra que parece surgir de la invención más radical, y aun arbitraria, va encontrando luego [...] sus inesperadas afinidades, se va modulando en una clave más vasta" ${ }^{829}$.

\footnotetext{
${ }^{828}$ Guillermo Sucre: "Poesía hispanoamericana y conciencia...”, loc.cit., p. 612.

${ }^{829}$ Guillermo Sucre: “Inscripciones, de Francisco Rivera”, loc.cit., p. 40.
} 
Esta concepción de la historia literaria como persistencia de unos mismos valores universales se puede apreciar, por ejemplo, en la interpretación que Guillermo ofrece de las vanguardias históricas. En su visión, las corrientes que "lograron fundar de verdad una poética fueron aquellas que justamente no pretendieron hacer tábula rasa del pasado". Si estos movimientos asumieron el cambio y la ruptura, "no confundieron la modernidad con la modernolatría” y "tuvieron cierta lucidez secreta, cierta sabiduría lúdica que les impidió quedarse en esa cómoda manera del estatismo: la adoración de la novedad por la novedad misma" ${ }^{\$ 830}$. Lo que estas tendencias intuyeron fue que "el arte atravesaba la historia sin dejarse simplemente atravesar por ella; que el arte no era sucesión sino simultaneidad"831. Igualmente, en lo que concierne a la poesía hispanoamericana de la segunda mitad del siglo XX, Sucre valoraba que se hubiera mantenido al margen de lo que él llamaba las "modas o modalidades" (es decir, de las corrientes novedosas o desmesuradas que no concuerdan con el ethos propiamente literario) y que hubiera dado una especial importancia a "la reflexión crítica" y al "asentimiento ante la vida":

${ }^{830}$ Guillermo Sucre: “Introducción” a la Segunda Parte de la Antología..., Vol. I, op.cit., p. 299.

${ }^{831}$ Ibid., p. 300. Guillermo cuestionaba el impulso modernólatra de la vanguardia también al hablar de los poetas de la segunda mitad del siglo XX: "Lo que más abrumaba ya de la vanguardia, en ella misma y no sólo en sus epígonos: el afán de continua invención, el exhibicionismo de lo sorprendente y de la novedad, la idolatría por los acoplamientos arbitrarios; bien, todo ello está hoy como relegado y se vuelve caricatura en quienes pretenden revivirlo. Pero, ¿quién, entre nosotros, dijo que el poeta es menos inventor que un descubridor sino Jorge Luis Borges, quien, de joven, había sido famoso ultraísta y "novelero de metáforas"? Tal vez ello explica que Paz apenas hable de postvanguardia. Al contrario, cuando se refiere a su generación la define como «una vanguardia otra, crítica de sí misma y en rebelión solitaria contra la academia en que se había convertido la primera vanguardia». Añade: «No se trataba, como en 1920, de inventar, sino de explorar. El territorio que atraía a estos poetas no estaba fuera ni tampoco adentro. Era esa zona donde confluyen lo interior y lo exterior: la zona del lenguaje» (Los hijos del limo, 1974). Ni nuevo radicalismo, ni abrupta ruptura, como se ve, sino otro lenguaje, lo que supone otra visión." (Guillermo Sucre: "Introducción” a la Tercera Parte de la Antología..., Vol. II, op.cit., p. 16). En la misma línea, Guillermo discute la noción convencionalmente aceptada de la vanguardia como un movimiento experimental y desmesurado, y de la posvanguardia como una corriente que significaría una vuelta generalizada al orden. La prueba que aduce nuestro crítico para invalidar esta división es que el libro que se considera iniciador de la estética de vanguardia en la poesía hispanoamericana -El espejo de agua (1916) de Huidobro- es un libro "que excluye las complejidades sintácticas, la estridencia y el abigarramiento metafórico". Lo fundamental en este libro - "construido con nitidez y gran despojamiento verbal"- no es el experimentalismo sino el hecho de que concibe el poema "como actividad estructurante de la realidad y no como la descripción de ésta." (Guillermo Sucre: "Introducción" a la Segunda Parte de la Antología..., Vol. I, op.cit., p. 305) 
Entre los años cincuenta y sesenta, los peligros fueron otros, aunque de muy distinto orden. La seducción, sin embargo, tenía visos de ser mayor. ¿Cómo podía un hispanoamericano distinguir entre el "telurismo" y el "realismo socialista" que iba imponiendo Pablo Neruda con el vigor verbal de Canto general o la elaborada sencillez de sus Odas? Tampoco era fácil ser insensible al grito $(h o w l)$ de la "beat-generation" que tanto se expandía entonces: lo visceral como única forma de intensidad y la vida de las ciudades modernas como patrimonio sólo del arrebato y el patetismo, como en las técnicas de publicidad. Ya estábamos como curados en salud cuando nos llegó la suprema irreverencia de los novísimos de España; su desprecio por el pensamiento haciendo de ello otro pensamiento, es decir, otra "doctrina"; su gusto por los mass media, el camp, el Kitsch, ¿qué podía decirnos todo esto? No, los mejores poetas hispanoamericanos de esas décadas no se dejaron deslumbrar por tales modas o modalidades. Nos liberaron del "telurismo" y de la didascalia edificante. Tampoco recurrieron al impacto del desgarramiento. [...] Ni la vociferación ni el desenfado les son propios. Aun la más aguda angustia adquiere en ellos un tono de soslayado humor: la reflexión crítica y también el asentimiento ante la vida. En muchos sentidos, ellos han sido los guardianes de la imagen, no de los idola. ${ }^{832}$

Como se aprecia en la cita, los poetas hispanoamericanos de la segunda mitad del siglo XX se mantuvieron al margen de los extremismos éticos y estéticos. Por eso pudieron ser "los guardianes" de la verdadera imagen, no de los falsos ídolos, y entroncar con el ethos común a la gran literatura de todos los tiempos. Vemos, entonces, que la literatura para Sucre no tiene nada que ver con un espíritu sectario, sino con un ideal de nobleza: no implica la mera búsqueda de novedad, sino el hallazgo de una actitud esencial. En la visión de nuestro autor las obras deben entroncar con el ethos que él considera inherente a la literatura, porque solo al participar de él las creaciones serán capaces de inventar y descubrir a un tiempo el mundo ético en su inocencia primordial.

Hay que decir, por otra parte, que la visión ética de la realidad y de la literatura se aprecia en el pensamiento y en la escritura del propio Guillermo. A lo largo de toda su obra vemos que Sucre privilegia siempre el término medio y la opción de la mesura, porque considera que esa es la opción virtuosa. Ello lo logra a través de dos mecanismos: o bien armoniza o bien cancela los extremos que se oponen, los cuales en su concepción suelen ser complementarios. Un caso de esta unión o armonización de contrarios lo tenemos cuando nuestro autor propone, como hemos visto en la primera parte de esta investigación, la conciliación de pasión e inteligencia, de instinto y

${ }^{832}$ Guillermo Sucre: “Introducción” a la Primera Parte de la Antología..., Vol. II, op.cit., pp. 1920. 
reflexión. Ante la viciosa autonomía de cada uno de los dos términos (el instinto conduce a una poesía natural; la reflexión a una poesía conceptual) Guillermo propone conciliarlos, y en esa unión encuentra la posición adecuada. En lo que concierne a la cancelación de los extremos, podemos citar el siguiente fragmento: "Un hombre que ha profesado la pasión del lenguaje: así se describe Borges a sí mismo en uno de sus libros. Pero no es nada nuevo reconocer que esa pasión ha sido profunda sin llegar a la idolatría; que a un tiempo ha sido pasión crítica, sin llegar, esta vez, a la violencia -la otra cara, a veces, de la idolatría." ${ }^{833}$ En este caso vemos cómo la pasión profunda y crítica (el término medio) permite trascender los dos vicios opuestos pero complementarios que se oponen a la virtud: la idolatría y la violencia. Otro ejemplo de esto, de los muchos que recorren la obra de nuestro autor, lo advertimos cuando señala que la crítica que busca obsesivamente las influencias literarias de una obra persigue también descubrir su grado de originalidad: “Quizá en lo que ha fallado cierta crítica latinoamericana, frente a nuestra propia literatura, sea en haber reducido ese sistema comparativo a una mera investigación $[\ldots]$ de influencias $[\ldots] \mathrm{y}$, como secuela inevitable, al asedio obsesivo de una originalidad americana que muchas veces colinda con una nueva forma de exotismo - esta vez cultivado por y para nuestro propio regocijo" ${ }^{\nexists 34}$. Como vemos, la indagación de las fuentes es un vicio complementario al asedio de la singularidad y, frente a ambas posturas, nuestro autor propone la opción de la mesura: una crítica que trate de situar a la obra en el espacio de la gran literatura y de escuchar su voz en él.

En otras ocasiones, el marco moral se delimita con una ligera variación del significante. A partir de dos términos con una pequeña diferencia, uno de ellos aparece

\footnotetext{
${ }^{833}$ Guillermo Sucre: "Poesía hispanoamericana y conciencia...”, loc.cit., p. 626.

${ }^{834}$ Guillermo Sucre: “Imitar una imagen o fundar una experiencia?", en Guillermo Sucre (coord.): Perspectivas sobre la literatura latinoamericana, Caracas, Equinoccio-Universidad Simón Bolívar, 1980, p. 66. Este mismo fenómeno lo acabamos de ver al tratar sobre la actitud del poder con respecto a la identidad. Ante las posturas desmesuradas del poder, Sucre defendía el término medio.
} 
prestigiado y el otro no, y a través de esta selección Sucre va definiendo su propia visión de la literatura. Así, por ejemplo, sobre El sol ciego del poeta Humberto Díaz Casanueva, nos dice Guillermo: "Ese libro es una extensa elegía (no "elegíaca") a la muerte de Rosamel del Valle" ${ }^{\natural 35}$. De esta manera nuestro autor precisa que el libro del escritor chileno no cae en lo elegíaco, que para él está vinculado con la pasión no controlada por la lucidez o la reflexión. Un caso similar lo tenemos en un ensayo sobre Ramos Sucre donde Guillermo afirma lo siguiente: "Pero si para él escribir es asombrar, no se trata de exhibir una originalidad sino de rescatar lo original: evocar a través del lenguaje la intensidad y la magia con que vivimos (y diariamente gastamos) nuestra primera relación con el mundo. Insisto: lo original, no la originalidad" ${ }^{\prime 836}$. De nuevo aquí, una mínima diferencia distingue entre un término positivo -lo original vinculado con la transparencia- y otro negativo -la originalidad, la falsa novedad. Al introducir un ligero matiz o una precisión en el significante Guillermo va definiendo una actitud moral y estética que para él es inseparable de la literatura. Además, ya sabemos que para Sucre el lenguaje rige nuestra experiencia de la realidad; por lo tanto, las distinciones léxicas que así establece tienen que ver con la búsqueda de un lenguaje preciso, del que dependerá la justicia social ${ }^{837}$.

La visión ética del ser y de la literatura que aparece en el pensamiento de Sucre, y la consiguiente búsqueda de una nobleza conductual y expresiva tiene tres fuentes fundamentales. En primer lugar, hay que reconocer la huella del humanismo de Picón Salas, un autor que fue determinante en la formación inicial de nuestro autor. El ensayista venezolano creía en la existencia de una actitud humana esencial, como se

${ }^{835}$ Guillermo Sucre: "Poesía Crítica: Lenguaje y Silencio", loc.cit., p. 577.

${ }^{836}$ Guillermo Sucre: La máscara, la transparencia, México, FCE, 1985, 2a ed., p. 75.

${ }^{837}$ Guillermo Sucre: "Poesía hispanoamericana y conciencia...", loc.cit., p. 624. Como ya hemos visto, para Sucre cualquier cuestionamiento de la realidad comienza por la crítica del lenguaje; y, complementariamente, cualquier crítica del lenguaje implica un cuestionamiento de la realidad. Para apreciar bien el vínculo que Sucre establece entre la moral del escritor y el empleo del lenguaje se pueden consultar los textos de la polémica que en 1993 estableció con cierta intelectualidad venezolana como, por ejemplo, Guillermo Sucre: “La indefensión de las palabras", en Vuelta, México, jun. 1993, p. 58. 
aprecia en su "Pequeña confesión a la sordina". En este texto, que Guillermo situó en el primer lugar en una recopilación que hizo de su obra, se aprecia cómo Picón creía en la persistencia de un mismo ethos humano y literario a lo largo de la historia:

Los años, naturalmente, arrojaron por la borda un inmenso lastre de cosas decorativas. Lo primero que tuve que suprimir en este proceso de simplificación y resignada conquista de la modestia, fue el abuso del "yo". Mis páginas de los veinte y los treinta años estaban casi todas escritas en primera persona. Semejante yoísmo no es sino la ilusión de que las cosas que a uno le acontecen son excepcionales y que sólo uno puede expresarlas con su más entrañable autenticidad. El tiempo nos enseña con el viejo Montaigne que hay una ley y condición común de los hombres que uniforma lo vario y narcisistamente individualizado, y que bajo tensiones parecidas otras gentes sintieron como nosotros hubiéramos sentido. [...] la soledad e incomunicabilidad de cada ser no es tan desgarrada e irremediable como lo propalan ciertas filosofías existencialistas. Y la literatura, para ser eficaz y hablar al alma de nuestros semejantes, no puede prescindir de esa clave común. Desde los griegos hasta Sartre los grandes temas del drama humano casi pudieran reducirse a poco más de una docena de motivos con sus respectivas combinaciones. Casi hemos olvidado aquellos seres tan refinados y excepcionales, tan pretenciosamente únicos dentro de su especie en que se complacía la novela de "fin de siglo", pero nos sigue conmoviendo en su universalidad de todos los tiempos Ifigenia, El rey Lear o Pére Goriot. ${ }^{838}$

Como se ve por la cita, el maestro de Sucre considera que hay "una ley y

condición común de los hombres” y que la literatura debe responder a esa clave común.

Ello le lleva a defender la impersonalidad, pues si todos nos regimos por un ideal de conducta semejante, "lo narcisistamente individualizado" no debe tener cabida en la creación literaria. Al confiar en la existencia de un ideal ético universal, Picón Salas fue asimismo un firme defensor de la mesura y del término medio tanto en el dominio moral como en el estético. En su concepción, el ideal compartido por todos los hombres implica valores como la tolerancia, la humildad, el respeto a la diferencia, el rechazo de la novedad por la novedad, etc. Por eso afirmaba, en el mismo texto antes citado:

Y como son las palabras las que producen las más enconadas e irreparables discordias de los hombres, a veces he cuidado - hasta donde es posible- la sintaxis y la cortesía, con ánimo de convencer más que de derribar. (Al lado de los estetas puros, el Modernismo produjo en América gentes de naturaleza irrefrenable; violentos a la manera de un Rufino Blanco Fombona, y este culto de la ecuanimidad es en mí hasta una reacción literaria contra los hombres de las promociones anteriores.) ¿A qué gritar, cuando las gentes pueden también entenderse en el tono normal de la voz humana? ${ }^{839}$

${ }^{839}$ Ibid., p. 6.


Según muestran estas palabras, Picón eligió el término medio como un rechazo a

los extremismos éticos y estéticos a los que había estado sujeta la generación

modernista: "los estetas puros" y las "gentes de naturaleza irrefrenable". Frente a estas

actitudes opuestas pero complementarias, el ensayista prefería la ecuanimidad, que según su interpretación implica el respeto al "tono normal de la voz humana", es decir, a la ética humana esencial. Esta búsqueda de la conciliación de los excesos perniciosos se aprecia a lo largo de toda su obra, y este rasgo lo heredará, como hemos visto, el propio Guillermo. Picón proponía una unión entre lo abstracto y lo concreto ${ }^{840}$, entre la cultura y la naturaleza ${ }^{841}$, entre lo universal y lo nacional ${ }^{842}$, entre la inteligencia y la pasión ${ }^{843}$, y entre el significante y el significado ${ }^{844}$. Cada uno de estos términos por separado

840 "Es ahora el instante de volver por esa tradición cultural que perdimos, pero que vivió con anhelo constructivo en algunos de los mejores y excepcionales hombres que ha dado el país. Contra el empirismo, la violencia, la eterna sorpresa y la aventura criolla, podríamos invocar la inteligencia que planea. La inteligencia no como adorno y objeto inútil, como evasión y nostalgia, sino como comprensión y revelación de la tierra." (Mariano Picón Salas: "Proceso del pensamiento venezolano", en Viejos y nuevos mundos, op.cit., p. 66)

${ }^{841}$ Picón proponía así que la educación venezolana debía acercarse a la naturaleza: "Siendo el [sic] grado principal, Naturaleza, es precisamente el paisaje y el medio físico de nuestro país lo que menos se ha incorporado y menos se dice en nuestros librescos programas escolares. Porque sólo la ha mirado a través de libros y discursos, hay que poner al hombre venezolano frente a su tierra no sólo en cuanto ella puede ser conflictivo problema, sino también como emoción y goce estético. (Mariano Picón Salas: "Una voluntad nacional", en Viejos y nuevos mundos, op.cit., p. 83)

${ }^{842}$ A este respecto afirmaba, por ejemplo: "toda auténtica Educación como toda auténtica Cultura sólo tiene valor en cuanto se elabora en las profundidades del ser; en cuanto surge como voluntad y necesidad interna más que como mecánica imitación de lo que viene de fuera. Su carácter foráneo, inadaptado, es el mayor obstáculo que pesa sobre nuestro régimen educativo.” (Ibíd. p. 83)

843 "Desde Rousseau y Goethe muchos grandes europeos viven en nostalgia de Naturaleza como los suramericanos queremos aplacar el instinto y la pasión ciega en el orden de la Cultura. Cuando la Cultura pierde el contacto de la Naturaleza, se convierte en intelectualismo frío, en el cálculo abstracto e inhumano. La Naturaleza sin el Cultura es el reino sombrío y casual del instinto, la sorpresa hecha terror, la crueldad sedienta, el pánico del que no sabe. "Hay una barbarie de la reflexión como hay una barbarie del instinto", decía Schiller. Los grandes momentos de la Humanidad son aquellos que -como en la clara mañana del clasicismo griego- la inteligencia y la vida pueden marchar juntas; el espíritu no niega al cuerpo, sino lo comprende y lo integra. [/] La Cultura de Europa y la Naturaleza de América se desean, pues, y se buscan, como en un vasto sueño de humanidad total." (Mariano Picón Salas: "Preguntas a Europa. Prólogo de 1937”, en Viejos y nuevos mundos, op.cit., p. 336). "Junto a sus pensadores trágicos que confundieron la vida con el pensamiento - [...] un Rousseau-, Francia siempre dispuso, y con más frecuencia, de toda una familia de espíritus que aceptaron la vida y que sólo quisieron hacerla más bella y tolerante al armonizarla con la inteligencia: un Montaigne, un Voltaire. Así, en este equilibrio entre lo que Pascal llamaba espíritu geométrico y espíritu de fineza, entre intelectualismo y comprensión de lo humano, se realiza cabalmente su genio nacional. [/] [...] Para el francés siempre existieron los sentidos y no quiso acallarlos y destruirlos bajo la hipocresía social y religiosa como el puritano inglés." (Mariano Picón Salas: "Meditación francesa", en Viejos y nuevos mundos, op.cit., p. 342)

${ }^{844}$ Por eso denunciaba: "La herencia de la educación colonial y española, educación de palabras más que de cosas, educación que tras de los claustros del siglo XVII parecía amurallarse contra la 
implicaba la caída en excesos éticos y estéticos, y por eso el maestro de Sucre hallaba la virtud en la posición armónica y reconciliada. Al plantear este ideal, Picón se aproximaba a una concepción clásica del hombre, $\mathrm{y}$, también en su caso, la virtud consistía en acercarse a una sagesse presente en el mundo natural. Como afirmaba a propósito de la cultura francesa, que él tanto estimaba:

Entre los pueblos modernos es, precisamente, Francia, el que más se aproxima a esta prudencia vital, como la concibió la antigüedad clásica. La vieja Francia tiene un fondo campesino sobre el cual se edifica la maravillosa permanencia de su Historia. Junto al racionalismo de sus doctores, ha colocado siempre como, para completar la visión del mundo, cierta sagesse, que parece venir de la tierra y del campo. ${ }^{84}$

Una concepción similar a la de Picón aparece en otro autor que fue de capital importancia para nuestro autor: Jorge Luis Borges. El gran creador argentino presenta una visión panteísta según la cual un hombre es todos los hombres. Esta idea se aprecia, por ejemplo, en el poema “Tú":

Un solo hombre ha nacido, un solo hombre ha muerto en la tierra.

Afirmar lo contrario es mera estadística, es una adición imposible.

No menos imposible que sumar el olor de la lluvia y el sueño que anteanoche soñaste.

Ese hombre es Ulises, Abel, Caín, el primer hombre que ordenó las constelaciones, el hombre que erigió la primer pirámide, el hombre que escribió los hexagramas del Libro de los Cambios, el forjador que grabó runas en la espada de Hengir, el arquero Einar Tambarskelver, Luis de León, el librero que engendró a Samuel Johnson, el jardinero de Voltaire, Darwin en la proa del Beagle, un judío en la cámara letal, con el tiempo, tú y yo. [... $]^{846}$

Aplicada a la creación literaria, esta noción supone que un autor es todos los autores y, por lo tanto, que la literatura es un discurso transhistórico elaborado por las sucesivas generaciones de escritores y lectores:

el panteísta que declara que la pluralidad de los autores es ilusoria, encuentra inesperado apoyo en el clasicista, según el cual esa pluralidad importa muy poco. Para las mentes clásicas, la literatura es lo esencial, no los individuos. George Moore y James Joyce han incorporado en sus obras, páginas y sentencias ajenas; Oscar Wilde solía regalar argumentos para que otros los

Naturaleza [...] vino a complicarse con la retórica delirante que nos cerraba un contacto más directo con nuestro medio físico y moral. Nuestro atrasado sistema educativo prolongó hasta hoy lo que llamaríamos el período fraseológico de la cultura venezolana: la palabra divorciada del hecho, suelta y autónoma en su vaga sonoridad. Y se impone por ello a las generaciones nuevas que quieren comprender y definir su país, entrar en él como derribando un inmenso muro de frases: frases de los discursos académicos, de los documentos oficiales que tan frecuentemente se escribían en la más bizantina de las prosas; frases de los partidos y los grupos políticos de ayer cuyos apetitos y pasiones se enredaban en las más culteranas fórmulas." (Mariano Picón Salas: "Notas sobre el problema de nuestra cultura", en Viejos y nuevos mundos, op.cit., p. 74)

${ }^{845}$ Mariano Picón Salas: "Meditación francesa", en Viejos y nuevos mundos, op.cit., p. 340.

${ }^{846}$ Jorge Luis Borges: “Tú”, en El oro de los tigres, en OOCC, Vol. I, op.cit., p. 1111. 
ejecutaran; ambas conductas, aunque superficialmente contrarias, pueden evidenciar un mismo sentido del arte. Un sentido ecuménico, impersonal... Otro testigo de la unidad profunda del Verbo, otro negador de los límites del sujeto, fue el insigne Ben Jonson ${ }^{847}$

Esta "unidad profunda del Verbo" implica que la literatura presenta a lo largo del tiempo una misma ética y estética que está por encima de los autores particulares: la creación literaria es, por lo tanto, ecuménica e impersonal. Al tener una validez permanente, la actitud ética y estética de la literatura es también esencial, e implica la consonancia de la escritura con el ser universal del hombre ("el arte debe ser como ese espejo/ que nos revela nuestra propia cara"848) y del mundo (como veíamos en "Jactancia de quietud": "los caminos y la soledad deben atestiguarla"849).

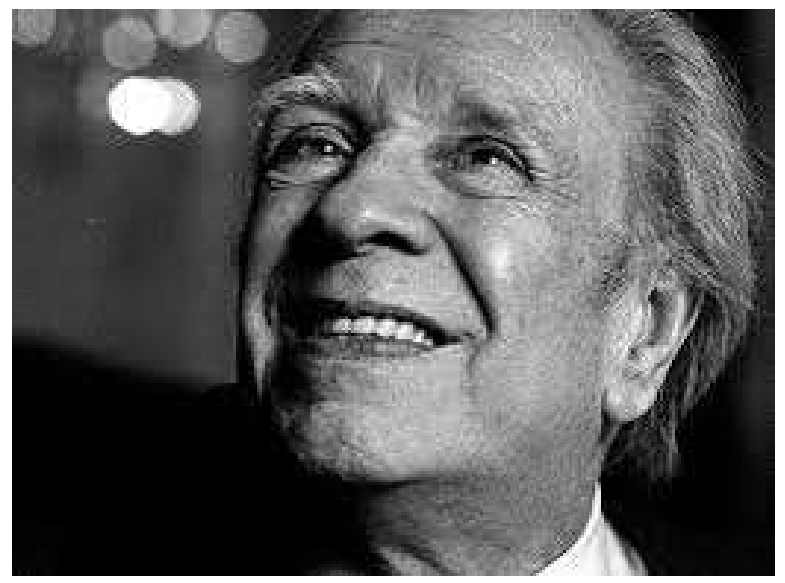

Imagen 49. Jorge Luis Borges (1899-1986)

Vemos, entonces, que Borges presenta una visión clásica de la creación literaria. En oposición a la modernolatría de sus años vanguardistas (de la que él mismo se arrepentiría ${ }^{850}$ ) Borges piensa que el arte no debe buscar la originalidad o la novedad

${ }^{847}$ Jorge Luis Borges: "La flor de Coleridge", en Otras inquisiciones, en OOCC, Vol. I, op.cit., p. 641 .

848 Jorge Luis Borges: “Arte poética”, en El hacedor, en OOCC, Vol. I, op.cit., p. 843.

849 Jorge Luis Borges: "Jactancia de quietud", citado supra en pp. 288-289.

${ }^{850}$ En Borges, la crítica de la modernolatría es paralela a la crítica del nacionalismo. Como afirma en el prólogo de Luna de enfrente, escrito en 1969: "Hacia 1905, Hermann Bahr decidió: «El único deber, ser moderno». Veintitantos años después, yo me impuse esa obligación del todo superflua. Ser moderno es ser contemporáneo, ser actual: todos fatalmente lo somos. Nadie [...] ha descubierto el arte de vivir en el futuro o en el pasado. No hay obra que no sea de su tiempo: la escrupulosa novela historia, Salammbô, cuyos protagonistas son los mercenarios de las guerras púnicas, es una típica novela francesa 
absolutas, sino que se debe ocupar del hallazgo de lo permanente y de lo esencial. Como dice memorablemente en su "Arte poética": "Cuentan que Ulises, harto de prodigios,/ lloró de amor al divisar su Itaca/ verde y humilde. El arte es esa Itaca/ de verde eternidad, no de prodigios" ${ }^{951}$. En su visión, la literatura es ante todo anacronismo y repetición; por eso no consiste en descubrir algo original sino en presentar adecuadamente los temas y las metáforas primordiales en una expresión lingüística adecuada:

El primer monumento de las literaturas occidentales, la Ilíada, fue compuesto hará tres mil años; es verosímil conjeturar que en ese enorme plazo todas las afinidades íntimas, necesarias (ensueño-vida, sueño-muerte, ríos y vidas que transcurren, etcétera), fueron advertidas y escritas alguna vez. Ello no significa, naturalmente, que se haya agotado el número de metáforas; los modos de indicar o insinuar estas secretas simpatías de los conceptos resultan, de hecho, ilimitados. Su virtud o flaqueza está en las palabras, el curioso verso en que Dante (Purgatorio, I, 13) para definir el cielo oriental invoca una piedra oriental [...] Dolce color d'oriental zaffiro es, más allá de cualquier duda, admirable; no así el de Góngora (Soledad, I, 16): En campos de zafiros pace estrellas que es, si no me equivoco, una mera grosería, un mero énfasis. ${ }^{852}$

La concepción clásica que se aprecia en el escritor argentino implica que para él la literatura es inseparable de una actitud universal e impersonal: el poeta es a un tiempo todos y cualquiera porque desde su visión particular logra encarnar la verdad esencial del mundo. Guillermo se siente atraído precisamente por este Borges clásico, que es el que reivindica en el libro que publicó sobre su poesía en 1967.

El tercer autor cercano a Sucre sobre el que vamos a tratar aquí es Octavio Paz. El escritor mexicano piensa que la actitud ante el lenguaje es inseparable de la

del siglo XIX. Nada sabemos de la literatura de Cartago, que verosímilmente fue rica, salvo que no podía incluir un libro como el de Flaubert. [/] Olvidadizo de que ya lo era, quise también ser argentino." (Jorge Luis Borges: "Prólogo" a Luna de enfrente, en OOCC, Vol. I, op.cit., p. 56)

${ }^{851}$ Jorge Luis Borges: “Arte poética”, en El hacedor, en OOCC, Vol. I, op.cit., p. 843.

852 Jorge Luis Borges: "La metáfora", en Historia de la eternidad, en OOCC, Vol. I, op.cit., p. 387. Esta misma idea se repite también en este otro párrafo que nos recuerda Sucre: "Suele suponerse que la literatura ya ha dicho las palabras esenciales de nuestra vida y sólo puede innovar en las gramatiquerías y en las metáforas. Me atrevo a asegurar lo contrario: sobran laboriosidades y faltan preservaciones válidas de lo eterno: de la felicidad, de la muerte, de la amistad". (Citado por Sucre en la "Introducción" a la Segunda Parte de la Antología..., Vol. I, op.cit., p. 422) Según dice en un famoso ensayo el propio Borges: "Quizá la historia universal es la historia de la diversa entonación de algunas metáforas". (Jorge Luis Borges: "La esfera de Pascal", en Otras inquisiciones, en OOCC, Vol. I, op.cit., p. 638. Como nos enseña su cuento "Pierre Menard, autor del Quijote", el arte es eterna repetición, pero también eterna novedad. 
cosmovisión del autor, es decir, que también para él la ética y la estética están estrechamente vinculadas. Para Paz, toda obra estéticamente satisfactoria resulta también adecuada desde un punto de vista moral, sólo que en su caso esta moralidad no se mide con un patrón humanista como el que se advierte en el pensamiento de Picón Salas o Borges. En lo que a él atañe, la universalidad de la poesía no viene determinada por la consonancia con un ethos esencial, sino por el hecho de que es capaz de reintegrarnos con lo que él llama nuestra "otredad constitutiva". El autor de Piedra de sol piensa que la poesía es transhistórica (al menos desde el Romanticismo en adelante) porque consigue reintegrar el absoluto desintegrado por la modernidad y conciliar los contrarios entre los que el hombre se debate. En su concepción, el poema tiene una dimensión histórica que es constantemente disuelta para rescatar, así sea por un momento, un instante de plenitud que permita vislumbrar la realidad original y esencial. Como dice el propio escritor: "Cada vez que el lector revive de veras el poema, accede a un estado que podemos llamar poético. La experiencia puede adoptar esta o aquella forma, pero es siempre un ir más allá de sí, un romper los muros temporales, para ser otro. Como la creación poética, la experiencia del poema se da en la historia, es historia y, al mismo tiempo, niega a la historia"853. Y, con el mismo sentido, afirmaba: "El poema es un tejido de palabras perfectamente fechables y un acto anterior a todas las fechas: el acto original con el que principia toda historia social o individual; expresión de una sociedad y, simultáneamente, fundamento de esa sociedad, condición de su existencia" ${ }^{854}$. Independientemente del tema que trate y del momento de escritura o lectura, la poesía es universal porque supone un cuestionamiento de la historia que

${ }^{853}$ Octavio Paz: El arco y la lira, en OOCC, Vol. I, op.cit, pp. 55-56.

${ }^{854}$ Ibíd., p. 232. Paz argumentaba también: "El conflicto no está en la historia sino en la entraña del poema y consiste en el doble movimiento de la operación poética: transmutación del tiempo histórico en arquetípico y encarnación de un arquetipo en una ahora determinado e histórico. Este doble movimiento constituye la manera propia y paradójica de ser de la poesía. [...] Afirmación de aquello que niega: el tiempo y la sucesión." (Ibíd., p. 235). Y decía asimismo: "para que las palabras nos hablen de esa "otra cosa" de que habla todo poema es necesario que también nos hablen de esto y aquello." (Ibíd., p. 236) 
permite (aunque sea por un segundo) reconciliarnos con la otredad y reintegrarnos al universo. Por eso la poesía es ecuménica e impersonal: aunque diga siempre algo diferente no para de decir la misma cosa, pues su propósito es unirnos a aquello de lo que fuimos separados.

Además, Paz piensa que la impersonalidad está vinculada con la conciencia del lenguaje y que tiene consecuencias éticas. Como Mallarmé y Breton ${ }^{855}$ antes que él, y como Sucre después, el escritor mexicano considera que, al reconocer el poder de las palabras, el poeta se despersonaliza para liberar ese poder, y desaparece del centro de la escena. En la concepción de Paz "el lenguaje crea al poeta y sólo en la medida en que las palabras nacen, mueren y renacen en su interior, él a su vez es creador" ${ }^{\circ 56}$. Puesto que la voz que escuchamos en el texto no es la del poeta real sino la del lenguaje, y como el decir del vate es al mismo tiempo el de todos los hombres, se cancelan las pretensiones mesiánicas y representativas de ciertos autores. Por eso Paz afirmaba que el creador auténtico desaparece “detrás de su voz, una voz que es la voz del lenguaje, la voz de nadie y la de todos" y que, por lo tanto, no puede considerarse ya "«un pequeño dios», como quería Huidobro" ${ }^{~} 857$. Además, en base a esta misma idea establecía una división significativa que el propio Sucre nos recuerda en varias ocasiones: "El falso poeta habla de sí mismo, casi siempre en nombre de los otros. El verdadero poeta habla con los otros al hablar consigo mismo" ${ }^{\text {}}$. Ahora bien, a pesar de que Paz reconoce este carácter impersonal de la gran poesía, no llega a eliminar completamente la

${ }^{855}$ A decir del propio Paz, el movimiento surrealista había acabado con "la idea del poeta como un ser de excepción", pues muchos de sus procedimientos, como la intervención del azar o la escritura automática, tienen por objeto "desplazar el centro de la creación y devolverle al lenguaje lo que es suyo". (Octavio Paz: "Los signos en rotación”, en OOCC, Vol. I, op.cit., pp. 334-335)

${ }^{856}$ Ibid., p. 335. Paz decía en ese mismo texto: "El poema devora al poeta." (Ibíd.)

${ }^{857}$ Octavio Paz: Los hijos del limo, op.cit., p. 207.

858 Citado por Guillermo Sucre: La máscara...op.cit., p. 98. "El verdadero poeta -nos dice Guillermo parafraseando a Paz- no puede arrogarse la representación de nada ni de nadie, a menos de caer en la impostura; sólo puede hablar de sí mismo como un modo de dialogar con los otros; el yo, en la poesía moderna, es un tú, dice con razón Octavio Paz". (Guillermo Sucre: "Poesía hispanoamericana y conciencia...", loc.cit., p. 618-619) 
participación del artista en la creación pues, como él mismo dice, "suprimir al sujeto que habla sería consumar definitivamente el proceso de sumisión espiritual del hombre״ ${ }^{859}$. También Guillermo, como veremos más adelante, concede a la noción de autor - esto es, a la instancia imaginaria que se genera en la obra y no a la personalidad biográfica- un lugar principal en su crítica literaria ${ }^{860}$.

Por lo tanto, podemos decir que la concepción de Sucre con respecto a las relaciones entre la ética y la literatura surge de una combinación del pensamiento de -al $\operatorname{menos}^{861}$ - los tres autores cuyo pensamiento acabamos de resumir. De Picón Salas, nuestro autor toma la creencia humanista de que hay un ideal ético del hombre y, por tanto, de la literatura. Este ideal consiste en defender el término medio frente a los

${ }^{859}$ Octavio Paz: "Los signos en rotación”, en OOCC, Vol. I, op.cit., p. 336.

${ }^{860}$ A este respecto señalaba Sucre: "El poeta debe ceder la iniciativa a las palabras, sugería Mallarmé. No es la dimisión del poeta, obviamente, sino la aceptación al extremo de su verdadera energía creadora: la que le comunican las palabras." (Guillermo Sucre: "La nueva crítica", loc.cit., p. 265). Sobre la importancia del autor en Sucre, Vid. infra apartado VI. 7. "Guillermo Sucre y la crítica literaria”, p. 327 y ss.

861 También Susan Sontag pensaba que la literatura estaba estrechamente ligada a un ethos esencial. En su ensayo "Sobre el estilo", escrito en los años sesenta, defendía la universalidad de la literatura y establecía que todas las grandes obras presentan una "moralidad" universal. "La moralidad es un código de actos, de juicios y de sentimientos, por el que reforzamos nuestro hábito de actuar de un modo determinado, que prescribe una norma de conducta o una tendencia a comportarse, para con otros seres humanos en general [...] moralidad es una forma de actuar y no un repertorio particular de elecciones. [/] Si entendemos moralidad de este modo [como un ethos universal] -como uno de los logros de la voluntad humana, que se impone un modo de actuar y de estar en el mundo- aparece claro que no existe un antagonismo genérico entre esa forma de conciencia, orientada a la acción, que es la moralidad, y la nutrición de la conciencia, que es la experiencia estética. Sólo cuando las obras de arte quedan reducidas a afirmaciones que proponen un contenido específico, y cuando la moralidad se identifica con una moralidad particular [con un ethos parcial] (y toda moralidad particular lleva sus subproductos, elementos éstos que sólo están en defensa de intereses sociales y valores de clase limitados), sólo entonces puede la obra de arte considerarse como determinante de la moralidad. Es más, sólo entonces puede prosperar la distinción plena entre lo estético y lo ético." (Susan Sontag: "Sobre el estilo", en Contra la interpretación, Madrid, Alfaguara, 1996, [1966], p. 52). Esta autora establecía por eso una relación entre la transparencia y el ethos universal: las obras no esconden nada y no deben ser interpretadas porque revelan la moralidad universal: "El arte satisface la misión «moral» porque las cualidades intrínsecas a la experiencia estética (desinterés, contemplación, atención, despertar de los sentimientos) y el objeto estético (gracia, inteligencia, expresividad, energía, sensualidad) son también elementos fundamentales de una respuesta moral a la vida." (Ibíd., p. 53.) También John Cage planteaba que entre el arte y la vida no se debía establecer una separación tajante: "When we separate music from life what we get is art (a compendium of masterpieces). With contemporary music, when it is actually contemporary, we have no time to make that separation (which protects us from living), and so contemporary music is not so much art as it is life and any one making it no sooner finishes one of it than he begins making another just as people keep on washing dishes, brushing their teeth, getting sleepy, and so on." (John Cage: "Composition as process", en Silence, Hanover, Wesleyan University Press, 1961, p. 44). Ello implica que, como querían Picón y Borges, el arte no debe presentar una lógica distinta a la de la vida esencial. 
extremos y en plantear la unidad de los contrarios. La literatura es universal cuando consigue adecuarse a la moralidad propia del hombre de todos los tiempos, lo que, a su vez, es el resultado de su consonancia con el ethos natural del mundo. En Borges, Guillermo encuentra la confirmación de que la literatura no es novedad o experimentación sino hallazgo de lo esencial y repetición. La concepción del argentino implica que la literatura es, como quería Emerson, la obra de "un solo caballero omnisciente" ${ }^{962}$, y que por lo tanto ella se rige a lo largo del tiempo por una ética y una estética esenciales que están vinculadas al verdadero ser del hombre y del mundo. La visión de estos autores se complementa en la estética de Sucre con los planteamientos de Octavio Paz. Para nuestro autor la creación se vuelve universal porque al adecuarse como proponían Picón y Borges- al ethos esencial de la vida y de la realidad, consigue inventar y revelar -como quería Paz- el orden utópico y absoluto disuelto por la modernidad. Entonces vemos que Guillermo enlaza las búsquedas de Paz con la ética que Picón y Borges consideran estrechamente vinculada a la literatura. La creencia de nuestro autor es que cuando la visión y el lenguaje de los textos revelan una actitud humana adecuada (lo que supone la cancelación de los excesos y la adecuación al ethos esencial del hombre y del mundo) la obra logra conciliar al sujeto y al objeto y restituir la fragmentación de la experiencia que había acontecido con la llegada de la modernidad.

\section{6. GUILLERMO SUCRE Y LA LITERATURA HISPANOAMERICANA}

Si bien Guillermo Sucre concibe la estética en términos universales y establece un vínculo estrecho con los grandes autores de la tradición occidental, su pensamiento

${ }^{862}$ En "La flor de Coleridge" Borges citaba la siguiente frase de Emerson, que sin duda suscribiría el propio Sucre: "Diríase que una sola persona ha redactado cuantos libros hay en el mundo; tal unidad central hay en ellos que es innegable que son obra de un solo caballero omnisciente" (Emerson citado por Jorge Luis Borges: "La flor de Coleridge", en OOCC, Vol. I, op.cit., p. 639) 
sobre la literatura alcanza toda su significación cuando lo referimos al ámbito propiamente hispanoamericano. En efecto, nuestro autor elabora su estética teniendo en mente la problemática concreta que él advertía en la literatura continental y es en ese campo donde su ideario adquiere su verdadera dimensión y donde se pueden apreciar todas sus consecuencias. Aunque no se reduce exclusivamente a eso, pensamos que los planteamientos estéticos de Sucre se construyen a partir del rechazo de los fundamentos sobre los que se instituyó la literatura hispanoamericana desde principios del siglo XIX. En esta institución Guillermo aprecia una vinculación del discurso literario continental con una estética que él considera asociada al poder autoritario. Aspectos que han estado ligados tradicionalmente a la literatura hispanoamericana como la representatividad, el logocentrismo, la egolatría, el nacionalismo o la identidad son, para Sucre, el resultado de la fundación de la estética continental sobre bases equivocadas. Por eso, nuestro autor se impone la tarea de desenmascarar la ideología que se encontraba detrás de ese discurso y de elaborar una estética diferente que se opusiera prácticamente punto por punto a la teoría establecida a principios del siglo XIX y a sus resultados posteriores.

En la concepción de Guillermo Sucre el problema fundamental de la literatura hispanoamericana lo constituye lo que él llama la "teoría de la originalidad americana" ${ }^{\natural 63}$, que fue una de las consecuencias del proceso independentista. En efecto, como corolario de la emancipación, algunos intelectuales hispanoamericanos -entre los cuales el más relevante fue quizás Andrés Bello- quisieron alcanzar también la

${ }^{863}$ Guillermo Sucre: La máscara...op.cit., p. 22. A este respecto, González Echevarría ha indicado que desde la Independencia habría operado en el continente un "mito" de legitimidad según el cual la naturaleza se considera el fundamento del ser hispanoamericano. A partir de este vínculo entre tierra e identidad se elaboró un discurso cultural que se convirtió en un puntal básico y en una "fuente de autoridad" para el "funcionamiento de la literatura latinoamericana como institución." A consecuencia de este "mito" la identidad hispanoamericana se convirtió en una imagen preestablecida de sí misma, y la literatura devino una actividad a la que se exigía imitar esa imagen (parcial, arbitraria y, además, orientalista) que los hispanoamericanos habían construido sobre sí mismos. Además, este discurso sobre la identidad basaba su efectividad en la "clausura" o "ilusión representativa" es decir, que establecía una relación unívoca entre el mundo y el lenguaje. (Las citas proceden de Roberto González Echeverría: $L a$ voz de los maestros, Madrid, Verbum, 2001, pp. 29 y ss.) 
autonomía intelectual, cultural y estética. Para obtener esta última "supusieron que bastaba con formular un discurso patriótico y moral sobre las sociedades nacientes, describir nuestra naturaleza y nuestras costumbres, para que ya cristalizaran las formas de un arte autónomo" ${ }^{, 864}$.

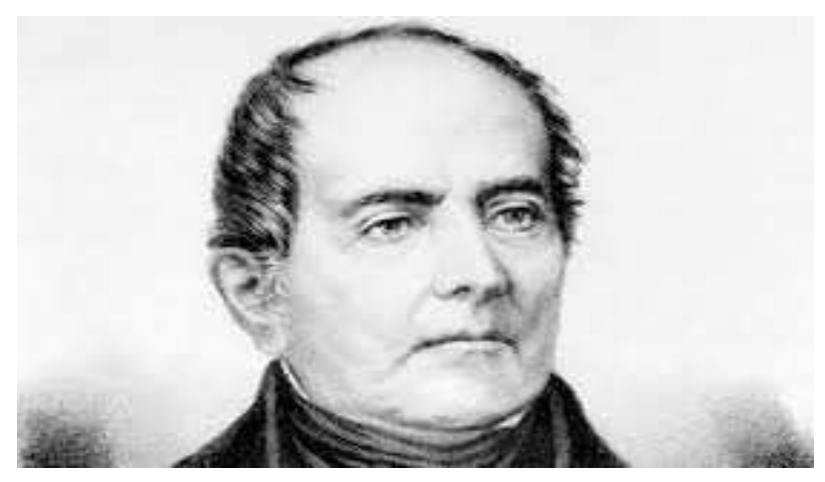

Imagen 50. Andrés Bello (1781-1865).

Estos intelectuales consideraban que la esencia de América Latina era telúrica pero también social, por lo que la identidad hispanoamericana (la originalidad aplicada esta vez a un sujeto personal o social) se convirtió también en un punto de referencia irrenunciable para las obras del continente. De acuerdo a esta teoría la literatura debía ceñirse a una esencia predeterminada sobre el ser hispanoamericano y, por lo tanto, el lenguaje empleado no podía constituir un problema: era un simple útil al servicio del escritor para reflejar la originalidad del referente. Al establecer lo que la literatura continental debía ser, esta concepción dio lugar al carácter marcadamente representativo y logocéntrico de las obras hispanoamericanas y las obligó a ceñirse a un sentido (a una identidad) preestablecido, arbitrario y, además, exotista. Como se creía que la originalidad ya estaba dada en el referente humano o geográfico y que el escritor tenía simplemente que describir ese referente para crear una estética autónoma, la

${ }^{864}$ Guillermo Sucre: "Poesía hispanoamericana y conciencia...”, loc.cit., p. 615. 
literatura devino "un asunto de contenidos" ${ }^{\$ 65}$. En consecuencia, el lenguaje adoptó una función ancilar y se estableció una enorme distancia entre lo que se decía y la manera de decirlo $^{866}$, por lo que la expresión se volvió superficial y externa. El valor de las obras estaba en función del modelo que debían imitar y, por lo tanto, la literatura se vio obligada a reflejar una significación preestablecida del continente y de sus habitantes. Ya sabemos que Sucre piensa que no es posible establecer un sentido definitivo de la realidad pues ésta, al ser ilimitada e inagotable, está siempre sujeta a la interpretación de una mirada particular. Al convertir lo hispanoamericano en una consigna oficial, los ideólogos de la identidad estaban en verdad reduciendo la multiplicidad de la realidad y de la experiencia hispanoamericana a una imagen parcial que querían confundir intencionalmente con una definición objetiva y esencial. En consecuencia, las obras literarias hispanoamericanas, para merecer este calificativo, estaban obligadas a imitar una imagen muy precisa de lo que había sido, era y debía ser América Latina y así la literatura continental se vio condenada a seguir un "principio absolutista" de acuerdo al cual "todo el que escribe en nombre de América Latina (de la imagen que tenemos de América Latina) es un buen o un gran escritor; viceversa: todo buen o gran escritor tiene que hablar en nombre de América Latina (de la imagen que tenemos de ella) ${ }^{\text {} 867}$. Las obras que se escribían de acuerdo a estos parámetros quedaban vinculadas automáticamente a una definición de lo hispanoamericano que resultaba a un tiempo oficial y superficial, y como lo importante era reflejar los signos más groseros y visibles

${ }^{865}$ Ibid., p. 616.

${ }^{866}$ Así, por ejemplo, como se encarga de recordarnos Sucre, a lo largo del siglo XIX los contenidos "autóctonos" eran presentados en formas procedentes de la tradición poética española. (Ibíd., p. 616, y también Guillermo Sucre: "La nueva crítica", loc.cit., p. 268)

${ }^{867}$ Guillermo Sucre: “iImitar una imagen o fundar una experiencia?”, loc.cit., p. 58. 
del continente, esta concepción dio lugar a obras que, para decirlo con palabras de Lezama, habitaron "los detalles sin asegurarse de la legitimidad de una sustancia"

Asimismo, y esto es quizás lo más grave, la interpretación o el sentido previos del continente a los que las obras debían inequívocamente responder eran el resultado de la proyección de una mirada colonial que los propios hispanoamericanos arrojaban sobre sí mismos: un caso de lo que se conoce como "autoorientalismo" u orientalismo interno. La idea de que había unos temas americanos cuya simple expresión daría como resultado obras genuinas era la prueba de la sumisión de los escritores del continente a una visión europea. En efecto, pensar que Hispanoamérica era un espacio singular y que la autonomía estética procedería de la representación de esa singularidad sólo tiene sentido a partir de una mirada ajena, pues como afirma Sucre, "somos originales en la medida en que tal vez todo el mundo lo es: tenemos una experiencia concreta del mundo. Pero sería distinto suponer que la originalidad está ya dada en la realidad, por fascinante que ésta sea o haya sido para el europeo"869. Por tanto, según lo advierte Guillermo, la teoría de la originalidad americana es el resultado de la concepción de América como un Nuevo Mundo desde el momento de la Conquista, y de la pervivencia de esa ilusión después del siglo XIX: "fuimos un descubrimiento sólo en la medida en que fuimos una invención de Europa. Estar a la altura de ese sueño europeo ha sido una de nuestras fascinaciones y ello ha dominado, conscientemente o no, gran parte de nuestra literatura» ${ }^{\nexists 70}$. En este sentido, Sucre se hacía eco de una idea que ya había sido

\footnotetext{
${ }^{868}$ José Lezama Lima: “Coloquio con Juan Ramón Jiménez”, en Analecta del reloj, en Obras completas, Vol. II, op.cit., p. 59.

${ }^{869}$ Guillermo Sucre: La máscara ...op.cit., p. 22.

${ }^{870}$ Guillermo Sucre: “IImitar una imagen o fundar una experiencia?”, loc.cit., p. 59. A este respecto nuestro autor indicaba también: "ni aquella visión [cronológica] de la historia [a la que se suponía que debía responder el arte] ni esta pasión adánica, así como tampoco ciertas técnicas expresivas que se emplearon, podían originarse del todo en nuestra cultura: de algún modo las tomábamos de Europa. Aún más, esa actitud estaba mediatizada por una mirada foránea: curiosamente coincidía con la manera con que nos han visto, y aún nos ven, desde afuera. De esta manera, la aventura de lo latinoamericano se fue convirtiendo en una imagen un tanto clisé, al gusto del exotismo que despertábamos en los otros." (Guillermo Sucre: La máscara ...op.cit., p. 21)
} 
repetida en múltiples ocasiones por Octavio Paz quien -basándose a su vez en Reyes y O'Gorman- había propuesto que América, al ser bautizada por los conquistadores, fue condenada asimismo "a ser el proyecto histórico de una conciencia ajena: la europea ${ }^{871}$.

Al ser la prolongación de un sueño extranjero, la literatura hispanoamericana se vio obligada a oscilar entre la necesidad de representar (una idea de) la realidad continental y la "pasión adánica" 872 que llevó a muchos poetas hispanoamericanos a convertir a la literatura en un inventario de la naturaleza. Como América se consideraba un mundo nuevo, los escritores se creyeron en la obligación de nombrar las cosas para que las cosas fueran, con lo que la teoría de la originalidad dejó de ser una simple poética para convertirse, como afirma Guillermo irónicamente, en "un programa americanista de colonización de tierras vírgenes" ${ }^{\$ 73}$. Esta circunstancia vinculó a la literatura con lo genésico o lo cosmogónico: había que "mostrar la exuberancia de la naturaleza americana: enumerar todos sus dones y seguir alimentando los mitos de una posible «tierra de gracia»" $" 874$. Por consiguiente, como señala Sucre, "todo poeta latinoamericano -por y para serlo" debía "tener una vocación ilimitada de conocimiento físico" ${ }^{875}$ y debía convertirse, además, en una suerte "de pioneer que va poblando (con palabras) un espacio que el destino le ha deparado" ${ }^{\text {876 }}$. Esta situación propició el surgimiento de vates enumerativos y planetarios cuyo mejor ejemplo lo constituye Carlos Argentino Daneri, el personaje ficticio parodiado en "El Aleph" de Borges, pero cuya actitud es bien visible también en autores reales como Chocano, cierto Lugones y el Neruda posterior a las Residencias. Asimismo, es la concepción nuevomundista de

\footnotetext{
${ }^{871}$ Octavio Paz: "Literatura de fundación”, en $O O C C$, Vol. II, op.cit., p. 675.

${ }^{872}$ Guillermo Sucre: La máscara ...op.cit., p. 21.

${ }^{873}$ Ibid., p. 26.

${ }^{874}$ Ibid., p. 21

${ }^{875}$ Ibid., p. 21.

${ }^{876}$ Ibid., p. 26.
} 
América la que está detrás de aquellas poéticas que postulan que el continente es en sí mismo una realidad extraordinaria, pues esta concepción sólo puede provenir de una mirada extranjerizante. Por este motivo, nuestro autor rechaza propuestas como "lo real maravilloso" de Alejo Carpentier o el "realismo mágico" 877 que practica García Márquez.

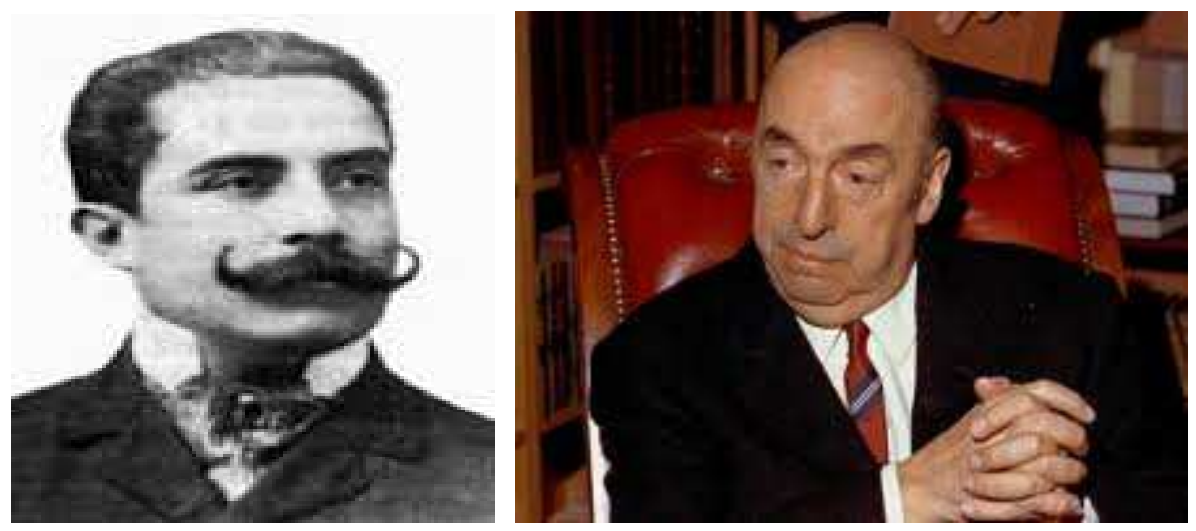

Imágenes 51 y 52. José Santos Chocano (1875-1934) y Pablo Neruda (1904-1973), vates a los que Sucre vincula con la poética mesiánica y representativa del continente.

Además de la proyección de una mirada extranjerizante, lo que Sucre cuestiona de aquellos escritores que se creen capaces de representar la originalidad telúrica o social es que ese gesto implica una seguridad excesiva en sus propias posibilidades, pues como él mismo afirma, es imposible "creerse representativo sin caer en el abuso

${ }^{877}$ Al hablar sobre la literatura de la segunda mitad del siglo XX en Hispanoamérica, Sucre hacía una apreciación interesante para entender su postura con respecto a esta corriente estética: "Es cierto, después de la guerra adquirió más vigencia el existencialismo y con esta nueva etiqueta -que uniformaba a los escritores más disímiles- se aplacó la avidez de los sufijos. Aun en Hispanoamérica empezamos a tener nuestros poetas y narradores existencialistas, o que tocaban temas «entrañablemente existenciales». Porque expresara su angustia o desencanto ante la historia, cualquier escritor ya se veía clasificado en tal tendencia. También surgió entonces - ¿cómo iba a faltar la nostalgia novomundista?- nuestro "realismo mágico»: el asombro y la mitificación de nosotros mismos." (Guillermo Sucre: "Introducción" a la tercera parte de la Antología de la poesía hispanoamericana moderna, Vol. II, op.cit., p. 13. Cursiva nuestra). En otro texto posterior iba más allá en su rechazo de la insistencia en la identidad cultural: "Me gustaría añadir que Inscripciones es un libro ejemplar dentro de nuestra crítica literaria; pero, aparte de que este calificativo ya sirve para todo, no estoy muy seguro de que sea el que mejor le convenga o lo defina. El lector podría aterrarse, en todo caso, y creer que habrá de vérselas con un tratado monumental y/o edificante: ya sea de uno de esos arcanos «scholars» que lo reordenan todo y todo lo clasifican según los dogmas más prestigiosos y también casi siempre triviales; ya sea de uno de esos denodados defensores de la identidad cultural, fantasma que recorre Occidente desde los mitos del nacionalsocialismo hasta los de nuestro original «realismo mágico»" (Guillermo Sucre: "Inscripciones...", loc.cit., p. 40. Cursiva nuestra) 
de la egolatría, que es también un abuso de confianza"878. En efecto, para Guillermo, que un autor se sienta representativo es "un acto de prepotencia" $\$ 79$ y de "arrogancia", pues supone "verse a sí mismo como sujeto prestigioso del cual emana o en el cual finalmente cristaliza la suprema objetividad" ${ }^{880}$. Vemos entonces que la teoría de la originalidad americana está detrás de otro de los grandes vicios que Sucre percibía en la literatura continental: el mesianismo de ciertos escritores. En efecto, si en Bello y los románticos esa teoría era simplemente el resultado de la ingenuidad, con el paso del tiempo se fue convirtiendo en una estrategia vinculada al poder y a la egolatría de algunos poetas continentales. A este respecto afirmaba Sucre: "si la tesis de los contenidos llamados americanos revelan muy poco desde el punto de vista de la creación, han revelado mucho desde el punto de vista ideológico: con ellos, muchos poetas hispanoamericanos han elaborado no tanto una poesía como una estrategia cuyo fin último es pasar a la categoría de vates mesiánicos, de cantores representativos, que por sí solos encarnan el destino de un continente" ${ }^{881}$. En lo que concierne a esta relación entre la vocación representativa y el culto de la propia personalidad es revelador algo que el propio Guillermo me escribía en una carta reciente, hablando sobre la noción de la autenticidad:

Exagerar el lenguaje o los sentimientos pone en peligro la autenticidad, pues se nota el esfuerzo por lograrla. El realismo-socialista (cierto Neruda) y el realismo-mágico (Carpentier, García Márquez) se nutren de esta exageración: el culto a la Historia, al Pueblo, a la Naturaleza

${ }^{878}$ Guillermo Sucre: La máscara ...op.cit., p. 21.

${ }^{879}$ Guillermo Sucre: “¿Imitar una imagen...?”, loc.cit., p. 53.

${ }^{880}$ Ibíd., p. 53. Guillermo se lamentaba, todavía en 1980, de la cantidad de escritores que en América Latina se creían "la conciencia de su país, el escriba que con sólo trazar unos signos ya está dando las claves de toda una historia." Estos autores se imitaban a sí mismos "debido a una razón superior: todo lo que ellos dicen representa un mundo, la secreta complejidad de un alma colectiva." (Ibid., p. 54)

${ }^{881}$ Guillermo Sucre: "Poesía hispanoamericana y conciencia...", loc.cit., p. 618. La "representatividad poética" es el resultado de eso que Lezama Lima llamó el "feudalismo de la sensibilidad" y que para Sucre tiene que ver con el énfasis, "ya sea como posesión, ya sea como desamparo": "Lo primero [el énfasis como posesión] se relaciona con la naturaleza: cualquier poeta representativo se cree en la obligación de proponerse como una potencia genésica y planetaria. Lo segundo [el énfasis como desamparo] se relaciona con la historia: creer que la conciencia crítica tiene que recurrir al patetismo del padecimiento. Adanes de la naturaleza y víctimas de la historia: nuestra mala fe poética ha discurrido entre estas dos tentaciones." (Ibíd., p. 618) 
mágica, paradisíaca, que concluye en el culto al autor. Si Baudelaire me parece más auténtico o me gusta más que Víctor Hugo no es porque me parezca poéticamente superior, sino porque el vínculo entre poesía y vida no se convierte en apoteosis o teatralidad del yo. ${ }^{882}$

Vemos entonces que, al oponerse a la teoría de la originalidad, Sucre estaba marcando asimismo una distancia con aquellos autores que, ya en el siglo XX, siguieron alimentando las aspiraciones de representatividad y de objetividad. Ello implicaba que se creían en posesión del sentido de la realidad, que confiaban en el lenguaje para representarlo y que, en algunas ocasiones, se encomendaban a sí mismos la portavocía de una clase o de una raza. Todo ello deja suponer que estos autores se consideraban superiores a la realidad (dado que poseían su sentido), al lenguaje (que era su simple instrumento) y a los demás hombres (que necesitaban de su voz), y ello les vincula al poder y al autoritarismo. Además, el asedio obsesivo de la originalidad convirtió a buena parte de la literatura continental en una inmensa "secta", "la de la identidad y su mitomanía"883. Ello determinó que la expresión literaria hispanoamericana se volviera un "enconado monólogo" 884 , hecho que retrasó su participación en el diálogo de la gran literatura universal. Al establecer que el sentido y la verdadera identidad del continente se hallaban en (una interpretación sobre) el referente y al pensar que la expresión genuina surgiría de la fidelidad a ese referente, la literatura hispanoamericana se distanció de los valores propios de la gran literatura, que en el ideario de Sucre son universales. Por lo tanto, la búsqueda de la originalidad y la egolatría que a ella se vincula no solo privaron a las obras del potencial creativo que les es propio sino que les impidieron establecer un diálogo con las grandes creaciones de Occidente, prolongando así su situación de dependencia cultural. En oposición a la teoría de la originalidad y a los vicios que ella implicaba, Guillermo fundó su propia concepción sobre la literatura hispanoamericana, que pasamos a ver a continuación.

\footnotetext{
${ }^{882}$ Guillermo Sucre: “Carta II, abril de 2013”, infra en Apéndice I, p. 481.

${ }^{883}$ Guillermo Sucre: “Octavio Paz: La otra voz”, en Vuelta, (México), 175, jun. 91, p. 24.

${ }^{884}$ Ibid., p. 24.
} 
La conciencia del lenguaje -que es el eje central en el pensamiento estético de Guillermo Sucre- implica que para él la escritura no puede consistir en la remisión a un sentido previamente establecido, sino que el acto de escribir surge, contrariamente, de la necesidad de buscar ese sentido y de la certeza de que no se encontrará nunca: "Se escribe por descolocación [...]; no porque se esté, bien situado, en el centro de algo o de nada: esa nada o ese algo que hoy llamamos Historia, Raza, Nación" ${ }^{885}$. Más allá de pueblos y razas, más allá de idiomas y tradiciones diferentes, Sucre concibe que "la literatura es la manera con que el lenguaje sabe crear un ámbito de verdadero reconocimiento: no el habituarse a realidades o costumbres contingentes, sino el revelar esa verdad (esa profundidad, esa inmediatez) que cada ser humano modula a partir de su experiencia con la palabra, vale decir: con el mundo" ${ }^{„ 886}$. En la concepción de Guillermo la obra es ante todo una creación verbal y, como tal, no es un asunto de contenidos ni se puede reducir a la representación de una solución previamente establecida. El lenguaje es un mecanismo activo que gobierna los textos: al ser un código autónomo no puede mimetizar lo real sino sólo configurar una (otra) realidad. Entonces la literatura no se puede referir al mundo en sí mismo sino solo a una experiencia subjetiva del mismo que es traducida en palabras. Por eso, el escritor consciente de "los poderes innatos del lenguaje ${ } 887$ sabe que en ningún caso le es dado representar la realidad ni representarse a sí mismo: sólo puede comunicar una vivencia parcial y aun para esto depende del lenguaje. Al reducir la importancia del referente en la creación verbal, Sucre piensa que la singularidad de una obra literaria no puede residir en una supuesta particularidad de lo real, pues para él, como ya sabemos, "la verdadera originalidad, así como la

885 Guillermo Sucre: “¿Imitar una imagen...?”, loc.cit., p. 54. Sucre afirmaba también: “escribimos no porque (nos) conozcamos, sino para conocer (nos); no para expresar el mundo, sino, más bien, para intentar descifrarlo cuando lo nombramos, y en la operación irnos descifrando a nosotros mismos". (Ibid., p. 54)

${ }^{886}$ Ibid., p. 67.

${ }^{887}$ Guillermo Sucre: La máscara...op.cit., p. 33. 
intensidad, no reside en lo nombrado sino en la manera de nombrarlo; no está en lo visto sino en la manera de verlo" ${ }^{\$ 88}$. En literatura solo pueden ser singulares la mirada y la escritura, pues en ella no interviene directamente ningún elemento más.

Por todo lo antedicho vemos que la conciencia del lenguaje se opone radicalmente a la teoría de la originalidad y a todas sus consecuencias. Mientras que esta teoría hacía a la literatura subsidiaria de la realidad y exigía que las obras imitaran un sentido unívoco del continente y de sus habitantes, Sucre propone invertir la relación tradicionalmente establecida entre la naturaleza o la identidad continentales y los textos literarios. Por eso nuestro autor señalaba en referencia a la famosa sentencia de José Martí ("no habrá literatura hispanoamericana hasta que no haya Hispanoamérica") que es posible invertir esa frase "sin que pierda su validez: no habrá Hispanoamérica hasta que no haya una literatura hispanoamericana. Esto es: no imitar una imagen, sino fundarla" ${ }^{989}$. Al estar construida con lenguaje, la obra tiene un potencial creador que le es intrínseco: su función no es mimetizar un sentido o una identidad ya establecidos sino más bien crearlos. En consecuencia, nos dice Guillermo, "la realidad americana no puede ser ni expresada, ni descubierta, hay que inventarla y no simplemente inventariarla" ${ }^{, 890}$.

Al defender que la literatura no debía imitar un sentido preestablecido, sino que tenía que fundarlo, Guillermo Sucre estaba retomando la lección de Octavio Paz. En línea con el poder creativo que este autor asignaba al lenguaje, en su texto "Literatura de fundación” (1961) había establecido que la literatura hispanoamericana era esencialmente "una empresa de la imaginación" y que su función principal consistía en

${ }^{888}$ Ibid., p. 23.

${ }^{889}$ Guillermo Sucre: “¿Imitar una imagen...?”, loc.cit., p. 58. En otro ensayo anterior había afirmado: "nuestra literatura es tentativa por fundar la realidad, una empresa de la imaginación." (Guillermo Sucre: "La nueva crítica”, loc.cit., p. 268)

${ }^{890}$ Guillermo Sucre: La máscara ...op.cit., p. 22. 
“inventar nuestra propia realidad" $" 891$. En efecto, para el escritor mexicano, la literatura continental tenía que fundar lo real, pero esa fundación era al mismo tiempo un rescate: "la realidad se reconoce en las imaginaciones de los poetas; y los poetas reconocen sus imágenes en la realidad” ${ }^{\$ 92}$. En la concepción de Paz el escritor hispanoamericano debía crear sin atenerse a un sentido previo pero, sin embargo, esas creaciones que no se sometían a una idea anterior eran capaces de revelar, sin proponérselo, una cierta verdad sobre el continente. A este respecto, también las ideas de Gertrude Stein fueron decisivas para el pensamiento de Sucre. En su texto "What Are Master-pieces and Why Are There So Few of Them" (1936), la escritora norteamericana establecía una oposición radical entre la creación y la identidad, y proponía que las grandes obras de arte tenían que ver ante todo con la entidad y no con la memoria: "And so then why are there so few of them [master-pieces]. There are so few of them because mostly people live in identity and memory that is when they think. They know they are they because their little dog knows them, and so they are not an entity but an identity. And being so memory is necessary to make them exist and so they cannot create master-pieces." ${ }^{, 893}$ Además, al igual que Paz, Stein pensaba que si las obras maestras son contrarias a la identidad es porque de alguna manera ellas fundan la verdadera identidad: "Think about how you create if you do create you do not remember yourself as you do create. And yet time and identity is what you tell about as you create only while you create they do not exist. That is really what it is"

${ }^{891}$ Octavio Paz: “Literatura de fundación”, en OOCC, Vol. II, op.cit., p. 679.

${ }^{892}$ Ibíd., p. 680. También este ensayo de Paz acusa la huella de Martin Heidegger.

${ }^{893}$ Gertrude Stein: "What Are Master-pieces and Why Are There So Few of Them", en Writings 1932-1946, op .cit., pp. 359-360. En ese texto Stein afirmaba también: "one has no identity that is when one is in the act of doing anything. Identity is recognition, you know who you are because you and others remember anything about yourself but essentially you are not that when you are doing anything. I am I because my little dog knows me but, creatively speaking the little dog knowing that you are you and your recognising that he knows, that is what destroys creation. That is what makes school. Picasso once remarked I do not care who it is that has or does influence me as long as it is not myself." (Ibid., p. 355)

${ }^{894}$ Ibid., p. 361. 
En línea con estos autores, Guillermo Sucre pensaba que si existe algo así como una esencia de lo hispanoamericano ella resultará de las obras y no será simplemente su causa. Ahora bien, esa esencia en ningún caso puede hallarse en la supuesta originalidad del referente -como pretendía la teoría de la originalidad americana- sino sólo en una sensibilidad particular, es decir, en una manera de mirar y de escribir, que es lo que verdaderamente concierne a la literatura. La creencia de nuestro autor es que siempre que las obras del continente han sorteado la teoría de la originalidad y han comunicado "una experiencia sin mediaciones previas" una sensibilidad característicamente hispanoamericana. En este sentido, nuestro autor retomaba las ideas que Borges había expuesto en su texto "El escritor argentino y la tradición" (1928). El gran creador planteaba en ese trabajo que era una equivocación exigir a la literatura argentina que abundase en temas o asuntos pintorescos, pues la “argentinidad" de una obra no se podía calibrar por su cantidad de color local. Según Borges, el Martín Fierro de José Hernández y La urna de Enrique Banchs eran igual de argentinos, pues aunque en el segundo no aparecen el paisaje, la topografía o la zoología nativas, sí lo hacen "el pudor argentino, la reticencia argentina" ${ }^{„ 896}$. El maestro de Sucre se distanciaba así y desenmascaraba a aquellos escritores que se empeñaban en mostrar los signos visibles y groseros de la nacionalidad, pues para él la argentinidad no era simplemente un conjunto de particularidades sino una sensibilidad que arraigaría necesariamente en la obra, fuera cual fuera el tema de que tratase. De este modo, Borges acababa con el orientalismo interno y el exotismo de algunos de sus compatriotas; abría

${ }^{895}$ Guillermo Sucre: “¿Imitar una imagen...?”, loc.cit., p. 63. A este respecto Guillermo señalaba también: "nuestra [verdadera] tradición ha sido un debate contra ciertos postulados deterministas que se erigieron en el pasado. Es lo que Octavio Paz busca subrayar cuando afirma en uno de sus ensayos: [/] «Una literatura nace siempre frente a una realidad histórica y, a menudo, contra esa realidad. La literatura hispanoamericana no es una excepción a esa regla. Su carácter singular reside en que la realidad contra la que se levanta es una utopía. Nuestra literatura es la respuesta de la realidad de los americanos a la realidad utópica de América»." (Ibíd., p. 65)

896 Jorge Luis Borges: "El escritor argentino y la tradición", en Discusión, en OOCC, Vol. I, op.cit., p. 269. 
la posibilidad de que la literatura nacional explorase cualquier tema; y establecía, en suma, que la creación es propia de un lugar no por afectación sino por fatalidad.

Guillermo tomó del escritor porteño estas ideas y las aplicó a la literatura continental, como se aprecia explícitamente en esta paráfrasis que aparece en uno de los ensayos de nuestro autor: "Como decía Borges, nuestros escritores no deben preocuparse tanto por ser hispanoamericanos -que es una condición fatal en nosotros-, sino preocuparse por ser escritores: lo bueno que ellos lleguen a crear es lo que fundará una tradición hispanoamericana" ${ }^{\natural 97}$. Además, en la comparación que hace en La máscara entre Santos Chocano y Vallejo se aprecia claramente que Sucre había asimilado los planteamientos de Borges: "En la obra de Santos Chocano, por ejemplo, hay quizá más elementos «indígenas» que en la César Vallejo: nadie pondría en duda, en cambio, no sólo que Vallejo es un poeta y aquel un mero retórico, sino también que en él hay una vivencia profunda y no pintoresca de lo racial" ${ }^{198}$. Precisamente en César Vallejo, otro de sus autores predilectos, Sucre descubría una concepción similar sobre la identidad hispanoamericana a la que había sostenido el escritor argentino antes citado. A este respecto, Guillermo recordaba en varias ocasiones la respuesta del vate peruano a las acusaciones de extranjerizante que Rodó había arrojado sobre Darío. Vallejo indicaba que "Rodó olvidaba que para ser poeta de América, le bastaba a Darío la sensibilidad americana, cuya autenticidad, a través del cosmopolitismo y universalidad de su obra, es evidente y nadie puede poder en duda..." ${ }^{899}$ Con esa réplica, nos dice Sucre,

lo que [Vallejo] nos quería decir es que no hay "contenidos" inherentes a nuestra identidad; lo que hay es una sensibilidad americana capaz de enfrentarse a un mundo como si fuera el mundo, capaz de enfrentarse a un lenguaje como si fuera el lenguaje. En otras palabras: dejar de ser objetos para ser sujetos, no tanto de la historia, del poder o de la cultura, sino para ser sujetos de nuestra propia experiencia. ${ }^{900}$

${ }^{897}$ Guillermo Sucre: "Poesía hispanoamericana y conciencia...", loc.cit., p. 618.

${ }^{898}$ Guillermo Sucre: La máscara ...op.cit., p. 22.

${ }^{899}$ Vallejo citado por Sucre en ibid., p. 26.

${ }^{900}$ Guillermo Sucre: “¿Imitar una imagen o fundar una experiencia?”, loc.cit., p. 58. 
"Ser sujetos de nuestra propia experiencia": esta expresión resume bien lo que Sucre esperaba de la literatura continental. La creencia de Guillermo es que cuando los escritores hispanoamericanos son capaces de escribir sin la necesidad de ceñirse a una idea categórica de sí mismos (que venía acompañada normalmente por una mirada exotista y extranjerizante) crean a partir de su propia sensibilidad y están más cerca de revelar (así sea momentáneamente) una experiencia hispanoamericana auténtica. Además, y esto es fundamental para nuestro autor, cuando la literatura continental se olvida de buscar obsesivamente su identidad, se sitúa en un plano de igualdad con el resto de la literatura occidental. Esto no significa que pierda su particularidad sino más bien lo contrario: si entra en el dialogo de la gran literatura universal es precisamente porque es capaz de encarnar una experiencia propia. En el "Coloquio con Juan Ramón Jiménez” (1938), Lezama Lima -un autor fundamental para Sucre en esta época- trataba precisamente sobre asuntos similares. En ese texto el escritor cubano opone "la tesis de la expresión mestiza" -que es "disociativa" y "nos obliga a retrotraernos a la solución de la sangre, al feudalismo de la sensibilidad"- a la "sensibilidad insular" que, en cambio, "no rehúye soluciones universalistas" 901 :

Preferir la música elemental de la sangre a las precisiones del espíritu es lo mismo que habitar los detalles sin asegurarse de la legitimidad de una sustancia. Hasta ahora hemos preferido los detalles, gozosos de su presencia más grosera, de sus exigencias más visibles, sin intentar definir la sustancia, que es 10 único que puede otorgar una comprobación universalista. [/] La expresión de los andaluces no tiene que ver nada con el andalucismo; las exigencias de una sensibilidad insular no tienen tangencias posibles con una solución de mestizaje artístico. Aquélla asciende de la historia al espíritu, ésta no es más que un recuerdo bizantino del detalle, un disfrute epicúreo y elemental de factores exógenos. ${ }^{902}$

En el "Coloquio" vemos que Lezama plantea ideas semejantes a las de Borges y Vallejo que hemos visto más arriba, pues señala que es precisamente al distanciarse de

901 José Lezama Lima: “Coloquio con Juan Ramón Jiménez”, en Analecta del reloj, en Obras completas, Vol. II, op.cit., pp. 58-59. A este respecto afirma también: "la sensibilidad principia humildemente planteando meros problemas existenciales, y luego intenta llegar a las soluciones universales, regalándonos las razones de su legitimidad, con el anhelo de ofrecer un momento de su aislamiento, la delicia de su particularismo." (Ibid., p. 58)

${ }^{902}$ Ibid. p. 59. 
la sangre -esto es, de las partes más evidentes de la identidad- cuando la obra consigue encarnar una sensibilidad propia y alcanzar la verdadera universalidad ${ }^{903}$. Aparte de estos autores, en la concepción de Sucre sobre la cultura hispanoamericana es evidente la huella de Mariano Picón Salas. Como lo explica el propio Guillermo en el prólogo que encabeza la selección Viejos y nuevos mundos, Picón Salas consideraba que Hispanoamérica debía hacer "de nuevo posible el diálogo y la convivencia en la Cultura occidental" $" 904$ pues así se entendería y se definiría "«dentro de las corrientes y las formas históricas universales»»"905. Al tratar de integrar la cultura continental en el marco representado por las grandes creaciones de Occidente, este ensayista cuestionaba que fuera posible una peculiaridad hispanoamericana absoluta y se oponía asimismo al pensamiento nuevomundista, conformista y mistificador. Para el maestro de Sucre, la singularidad cultural de América Latina existía, sin duda, "pero integrada al

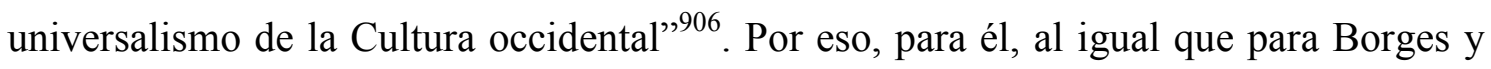
Paz, no había que "empeñarse tanto en definir o redefinir, aislar y casi refinar nuestra

${ }^{903}$ El anhelo de alcanzar la igualdad con Occidente aparece asimismo en un ensayo posterior del mismo autor cubano, La expresión americana (1957) que, como el mismo Sucre ha reconocido, dejó una huella perdurable en él: "Mi conocimiento de Lezama Lima se remonta al año 1957 cuando Alejo Carpentier me regaló un ejemplar de la primera edición de La expresión americana, que contenía cinco conferencias dictadas en el Centro de Altos Estudios, La Habana, [...]. Este libro me impresionó mucho por sus ideas y su lenguaje y sentí que estaba frente a un escritor considerable, distinto, por ejemplo, al propio Carpentier. En efecto, pequeño tratado sobre la expresión americana, el nacimiento de la expresión criolla, nuestro barroco, nuestro romanticismo (en el que estudia tres figuras venezolanas tan admirables como Simón Rodríguez, Miranda, Bolívar), nuestras sumas críticas (el paisaje como un espacio gnóstico, el complejo americano de creer que su expresión no es forma alcanzable sino cosa por resolver, por ejemplo), este libro de Lezama es, en sí mismo, una muestra de una expresión lograda que puede hablar de lo americano sin complejos de inferioridad o de superioridad." (Guillermo Sucre: "Carta II, abril de 2013", infra en Apéndice I, p. 484). Lezama Lima concibe que allí donde hay paisaje, es decir "naturaleza amigada con el hombre", "tiene que existir posibilidad de cultura" pues "el más frenético poseso de la mímesis de lo europeo, se licúa si el paisaje que lo acompaña tiene su espíritu y lo ofrece, y conversamos con él siquiera sea en el sueño." (José Lezama Lima: La expresión americana, en Obras completas, Vol. II, op.cit., p. 378). Por eso el escritor cubano estimaba al indio Kondori que, al insertar los símbolos incaicos en las construcciones de la Compañía, consiguió que los hispanoamericanos pudieran acercarse “a las manifestaciones de cualquier estilo sin acomplejarnos ni resbalar, siempre que insertemos allí los símbolos de nuestro destino y la escritura con que nuestra alma anegó los objetos." (Ibíd., pp. 322-323). Nos encontramos aquí, de nuevo, con la misma idea que hemos visto en Borges y Vallejo, que aplicada a la literatura quedaría así: al mirar y escribir desde una vivencia hispanoamericana sin mediaciones se puede asimilar cualquier estilo y cualquier tradición y por lo tanto alcanzar, desde la propia perspectiva, una dimensión estética universal.

${ }^{904}$ Guillermo Sucre: "Prólogo" a Viejos y nuevos mundos...op.cit., p. XXXII.

${ }^{905}$ Ibíd., p. XXXV.

${ }^{906}$ Ibid., p. XXXVI. 
quintaesencia cultural como hacerla posible y visible a través de la creación" $" 907$. Al dedicarse simplemente a crear de manera espontánea, los hispanoamericanos se librarían de su ensimismamiento y se harían dueños de su propio destino, pues la cultura no es una simple cuestión de orgullo nacional (idea que conduce necesariamente a la exaltación de lo exótico y de lo particular) sino una transfiguración que nos permite ser ese otro universal sin dejar de ser nosotros mismos.

Estas ideas acerca de la literatura hispanoamericana tienen varias consecuencias en la concepción de la tradición literaria planteada por Guillermo Sucre. Los autores que le interesan son precisamente aquellos que cuestionaron la "teoría sustancialista" de lo hispanoamericano y -en vez de basarse en un sentido determinado del continente y de proyectar una mirada europea- consiguieron crear a partir de una visión propia. En lugar de sustentar su expresión en una particularidad resultante del ojo europeo la sustentaron en una "mitología" que iba surgiendo de su "propia mirada"908 . En este sentido, nuestro autor se hacía eco de una idea ya planteada por Octavio Paz, pues para el escritor mexicano la literatura hispanoamericana comienza a existir cuando se enfrenta precisamente con el utopismo europeo que había estado vinculado a América desde la época de la conquista: "Una literatura nace siempre frente a una realidad histórica y, a menudo, contra esa realidad. La literatura hispanoamericana no es una excepción a esta regla. Su carácter singular reside en que la realidad contra la que se levanta es una utopía. Nuestra literatura es la respuesta de la realidad real de los americanos a la realidad utópica de América"909 . En línea con este razonamiento, la que Sucre considera

${ }^{907}$ Ibid., p. XL.

${ }^{908}$ Guillermo Sucre: “¿Imitar una imagen...?”, loc.cit., p. 63.

${ }^{909}$ Octavio Paz: "Literatura de fundación”, en OOCC, Vol. II, op.cit., p. 674. Al rechazar ser un reducto de exotismo, la literatura continental podría igualarse a la occidental y encontrar así una situación propicia para establecer un verdadero diálogo. Paz proponía esta misma igualdad en términos políticos: "lo más urgente es que el Tercer Mundo recobre su propio ser y se enfrente a su realidad. Esto requiere una crítica rigurosa y despiadada de sí mismo y de la verdadera índole de sus relaciones con las ideas modernas." (Octavio Paz: "La revuelta", en OOCC, Vol. VI, op.cit., p. 1451). "Los poderosos [Occidente, el centro] conciben la historia como un espejo: ven en el rostro deshecho de los otros -humillados, 
que es la verdadera tradición hispanoamericana "es una tradición a la que paradójicamente podríamos llamar del futuro"910. Con esa expresión aparentemente contradictoria Guillermo se refería a que las grandes obras hispanoamericanas eran precisamente las que habían surgido de una experiencia inmediata y de una sensibilidad propia. Es decir, que no había sido un discurso previo y abstracto acerca de la realidad o de la identidad lo que había establecido el vínculo entre las obras, sino que ellas mismas habían creado el diálogo a partir de una sensibilidad común ${ }^{911}$ generada autónomamente por cada una de ellas. Al ser el resultado de afinidades espontáneas, la verdadera tradición hispanoamericana constituye un "linaje": "ese aire de familia que no se hereda pero al que se llega por afinidades inevitables, pese al origen o a la diversidad de sus miembros, y que, por ello mismo, se vuelven un destino" ${ }^{912}$. En la concepción de Guillermo ese linaje está formado por escritores como Darío, Huidobro, Vallejo, Borges, Reyes, Lezama Lima, Picón Salas, Octavio Paz, etc., quienes sin proponérselo deliberadamente -es decir, abandonándose simplemente a la creación, como quería

vencidos o "convertidos"- el esplendor del suyo propio. Es el diálogo de las máscaras, ese doble monólogo del ofensor y del ofendido. La revuelta es la crítica de las máscaras, el comienzo del verdadero diálogo. También es la invención del propio rostro. América Latina empieza a tener cara." (Ibíd., p. 1459)

${ }^{910}$ Guillermo Sucre: “¿Imitar una imagen...?”, loc.cit., p. 65. En consonancia con el resto de su pensamiento, nuestro autor no concibe la tradición como un espacio autosuficiente sino más bien como un diálogo "que entablan entre sí obras muy diversas en el tiempo y hasta con notables divergencias estéticas e ideológicas." Hablar de tradición del futuro significa que el diálogo entre las obras no es el resultado de la sumisión a un sentido preestablecido sino que la relación entre ellas se establece de una manera "natural" a partir de lazos espontáneos. Para enfatizar este punto, Sucre emplea una metáfora botánica: "Ese diálogo es sólo posible gracias al impulso de un principio de germinación creadora; éste, a su vez, se ve regido por un dinamismo progresivo y circular: suscita el diálogo, pero no alcanza su madurez y expansión sino a través del diálogo mismo. Darío y el modernismo constituyen el núcleo germinativo de nuestra verdadera tradición poética; pero sin Huidobro, Vallejo, Borges, Neruda, Lezama Lima, Paz, no sentiríamos hoy con igual fuerza su presencia." (Guillermo Sucre: La máscara., la transparencia, $2^{\mathrm{a}}$ ed., op.cit., pp. 388-389). Esta idea de la tradición no implica rechazar el pasado, pero sí leerlo retrospectivamente a partir de estas obras que han elaborado la verdadera tradición continental: "No se trata de negar el pasado, o de desligarse de él, se trata de reconocer que éste no hubiera podido adquirir sentido sin la validez de unas obras que hemos ido creando apenas hace unas décadas." (Guillermo Sucre: “¿Imitar una imagen...?”, loc.cit., p. 65). Lezama Lima planteaba una paradoja similar: "La imitación de lo desconocido es por el costado americano más inmediata y deseosa. Lo desconocido es casi nuestra única tradición. Apenas una situación o palabras, se nos convierten en desconocido, nos punza y arrebata.” (José Lezama Lima: “A partir de la poesía”, en Obras completas, Vol. II, op.cit., p. 823)

${ }^{911}$ Para Sucre, la sensibilidad americana "se identifica finalmente con un conjunto de obras." (Guillermo Sucre: La máscara, la transparencia, $2^{\mathrm{a}}$ ed., op.cit., p. 388)

${ }^{912}$ Guillermo Sucre: “Octavio Paz: La otra voz", loc.cit., p. 24. 
Borges- han ido formando con sus obras un "texto hispanoamericano",913 a partir de una sensibilidad común.

Ahora bien, esta tradición del futuro o de lo desconocido que se ha generado a partir de una sensibilidad americana sin mediaciones previas es lo que ha permitido a la literatura hispanoamericana alcanzar una dimensión universal. Al desbloquear "el enconado monólogo con nuestra ya un poco tramposa «originalidad»", las obras de estos grandes autores permitieron a la literatura continental establecer "un diálogo más verdadero con el mundo"914. Siguiendo algo que había señalado antes Octavio Paz ${ }^{915}$, Sucre llega incluso a establecer una relación directa entre el desarraigo característico de la literatura hispanoamericana y su capacidad para adueñarse de su propio punto de vista, pues para él es un hecho que cuanto "más universal se ha vuelto nuestra literatura, con más intensidad [...] ha logrado encarnar su propia experiencia"916. Entonces, la que para nuestro autor es la auténtica tradición hispanoamericana ha sido el resultado de una serie de obras que rechazaron seguir buscando la singularidad continental y dejaron a un lado la exigencia de representarla. Este cambio implica que, por una parte, tomaron conciencia del lenguaje y de la naturaleza imaginaria de toda creación verbal y, por otra, que dejaron de prolongar una mirada europea para adueñarse de su propia perspectiva. Al rechazar la búsqueda de la originalidad continental y crear obras a partir de su propia sensibilidad, la literatura hispanoamericana abandonó la posición ancilar a la que había estado condenada y estableció una relación horizontal con las grandes obras de la tradición occidental.

${ }^{913}$ Guillermo Sucre: La máscara, la transparencia, $2^{\text {a }}$ ed., op.cit., p. 389.

${ }^{914}$ Guillermo Sucre: “Octavio Paz: La otra voz”, loc.cit., p. 24.

915 "Reprocharle a la literatura hispanoamericana su desarraigo es ignorar que sólo el desarraigo nos permitió recobrar nuestra porción de realidad. La distancia fue la condición del descubrimiento. La distancia y los espejismos que suscitó - no es malo alimentarse de ilusiones si las transformamos en realidades. Uno de nuestros espejismos fue la naturaleza americana; otro, el pasado indio." (Octavio Paz: “Literatura de fundación”, en OOCC, Vol. II, op.cit., p. 677)

${ }^{916}$ Guillermo Sucre: “¿Imitar una imagen....?”, loc.cit., p. 67. 
Pero, además, al mostrarse consciente de los poderes del lenguaje y de la irrealidad constitutiva de la literatura, este "linaje" de autores estaba inaugurando una ética de la escritura. Si la expresión de la realidad y la identidad continentales no estaba prefigurada en ninguna concepción previa sino que era elaborada por el propio lenguaje, la posición del poeta o del escritor quedaba alejada de cualquier mesianismo. En oposición a quienes -vinculados al poder- se sentían dueños del sentido del continente y delegados de la colectividad, los autores a los que Sucre estima crean desde de su propia experiencia y a partir de la conciencia del lenguaje, por lo que presentan una voz impersonal a un tiempo singular y universal. En lo que respecta a la impersonalidad del poeta, Sucre sigue, como hemos visto, a Octavio Paz. El escritor mexicano había establecido en múltiples ocasiones que el poeta era un instrumento en manos del lenguaje y que, por lo tanto, la personalidad biográfica no podía aparecer en la creación literaria. Así, hablando sobre la obra del vate peruano Westphalen, Paz valoraba positivamente que no hablara "en nombre de la historia ni en nombre de la patria, la Iglesia, el partido o la cofradía. Tampoco habla en nombre de Emilio Adolfo Westphalen: la poesía-confesión no es menos sospechosa que la poesía-sermón. En un acto de crítica que es asimismo un acto de autocrítica, el poeta auténtico pone en entredicho a su yo"917. Al distanciarse del mesianismo y de la insistencia en la personalidad -actitudes estrechamente vinculadas- el poeta consigue hablar con una voz que es propia y que es también la de todos. De esta manera, en la concepción de Sucre, los grandes escritores del continente comparten una suerte de nobleza moral que les opone a aquellos otros autores que se consideraban a sí mismos superiores a la colectividad y que constituían el otro polo del campo literario: la "secta" de la identidad y su mitomanía.

917 Octavio Paz: "Iluminación y subversión: Emilio Adolfo Westphalen”, en OOCC, Vol. II, op.cit., p. 1153. [1979] 
El movimiento literario hispanoamericano donde nació esta nueva actitud y, con ella, el nuevo "linaje" de escritores, fue el modernismo ${ }^{918}$. Mientras que, como afirma el propio Darío, la literatura hispanoamericana del siglo XIX no tenía "como fin y objeto poético más que la celebración de las glorias criollas, los hechos de la Independencia y la naturaleza americana"919, en el movimiento que él encabezó, por fin la poesía, según dice Sucre, empezó a ser "lo que debía ser: simplemente poesía; sin programas patrióticos, sin manifiestos moralizantes, o propósitos representativos"920. Así Rubén situaba el acto poético en un plano individual y lo separaba de las formas convencionales de la tradición peninsular, lo que muestra que ya tenía "conciencia de que la palabra es una con lo que enuncia, de que toda visión de la realidad depende, en última instancia, del lenguaje ${ }^{, 921}$. Con ese gesto, el modernismo se distanciaba del discurso de la originalidad continental y concedía una posición central al lenguaje en la creación literaria, lo que le permitió desencadenar "los poderes de la imaginación, como acto creador y como acto crítico" ${ }^{, 922}$. Gracias a la conciencia de las palabras, este movimiento fue el primero en hacer posible la expresión de una vivencia hispanoamericana inmediata, y su cosmopolitismo fue en verdad el comienzo de la oscilación característica del espíritu hispanoamericano “entre el desarraigo y el arraigo, la evasión y el retorno"923.

${ }^{918}$ Sucre compartía esta opinión con Paz, para quien "La literatura moderna comienza, en nuestra lengua, con Rubén Darío y el modernismo." (Octavio Paz: "Prólogo" a Fundación y disidencia. Dominio hispánico, en OOCC, Vol. II, op.cit., p. 651. [1991])

${ }_{919}$ Darío citado por Sucre, en Guillermo Sucre: La máscara ... $1^{\mathrm{a}}$ ed., op.cit., p. 28.

${ }^{920}$ Guillermo Sucre: "Poesía hispanoamericana y conciencia", loc.cit., p. 618.

${ }^{921}$ Guillermo Sucre: La máscara ...op.cit., p. 28.

922 Guillermo Sucre: "Poesía hispanoamericana y conciencia...", loc.cit., p. 619. A decir de nuestro autor, el modernismo fue el primer movimiento literario hispanoamericano en reconocer "que la obra es sobre todo trama verbal y [...] que la naturaleza de ésta es polivalente -un juego de sugerencias y tonalidades, y no un mero acto denotativo, aseverativo. Al mismo tiempo, [tomó] conciencia de que esa trama verbal puede revelar la del propio universo: no como copia o descripción, sino como analogía." (Ibid., p. 620)

${ }^{923}$ Guillermo Sucre: La máscara...op.cit., p. 27. 

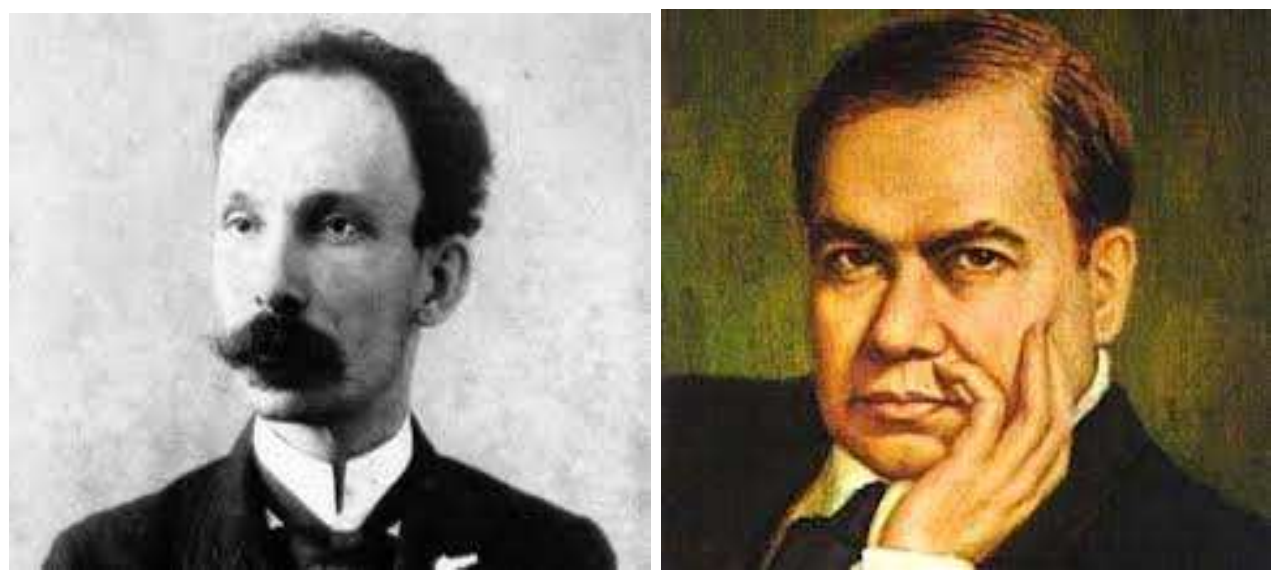

Imágenes 53 y 54. José Martí (1853-1895) y Rubén Darío (1867-1916), poetas fundamentales del modernismo hispanoamericano.

Sin embargo, "lo que no encarnó del todo" el modernismo "fue la modernidad"924. Siguiendo a Octavio Paz -que había establecido que "la modernidad es el reino de la crítica: no un sistema sino la negación y confrontación de todos los sistemas"925 - Guillermo Sucre pensaba que lo característico de la modernidad es "la conciencia crítica: someter a examen todos los órdenes de la existencia humana, desmontar los mecanismos de las verdades ya establecidas”. En consecuencia, la poesía sólo es plenamente moderna cuando en ella "pasión por el lenguaje y crítica del lenguaje son ya una sola y misma cosa"926, y si esto sucede es porque ya hay conciencia de que lo que está en juego en la obra de lenguaje es una versión de la historia y del mundo.

${ }^{924}$ Guillermo Sucre: "Poesía hispanoamericana y conciencia del lenguaje", loc.cit., p. 623.

${ }^{925}$ Octavio Paz: "El espacio del reconocimiento", en OOCC, Vol. II, op.cit., p. 1147.

${ }^{926}$ Guillermo Sucre: "Poesía hispanoamericana y conciencia del lenguaje", loc.cit., p. 623. Paz consideraba la "pasión crítica" un rasgo característico de la modernidad: "la palabra crítica posee demasiadas resonancias intelectuales y de ahí que prefiera acoplarla con otra palabra: pasión. La unión de pasión y crítica subraya el carácter paradójico de nuestro culto a lo moderno. Pasión crítica: amor inmoderado, pasional, por la crítica y sus precisos mecanismos de desconstrucción, pero también crítica enamorada de su objeto, crítica apasionada por aquello mismo que niega. Enamorada de sí misma y siempre en guerra consigo misma, no afirma nada permanente ni se funda en ningún principio: la negación de todos los principios, el cambio perpetuo, es su principio. Una crítica así no puede sino culminar en una amor pasional por la manifestación más pura e inmediata del cambio: el ahora." (Octavio Paz: Los hijos del limo, op.cit., pp. 19-20) 
En la concepción de nuestro autor, esta poesía que encarna plenamente los valores críticos de la modernidad, y establece un verdadero "debate con el lenguaje״"927 se inicia en el continente con la obra de Vicente Huidobro ${ }^{928}$. A partir de él, las obras de los grandes poetas hispanoamericanos $\mathrm{y}$, en particular, las de todos aquellos sobre los que escribe Guillermo, presentan de una u otra manera las constantes que caracterizan a la modernidad literaria. Por eso, en lo que atañe a sus búsquedas y a sus métodos, la poesía hispanoamericana no se diferencia del resto de la poesía occidental. Sólo se distingue de ella por el hecho de que entona esas búsquedas y esos métodos con una voz peculiar:

lo fundamental que ha conseguido la literatura hispanoamericana no es, como se cree, el haber entrado en el diálogo por uno de esos virajes que una sociedad fetichista, como la actual, estimula; no es tampoco el haber logrado resonancia internacional gracias a algunos de sus autores. Lo importante de ella es el haber asumido una voz, con su peculiar entonación, en el diálogo [de la literatura occidental] -aunque se la oiga o no. ${ }^{929}$

Esto que Sucre destacaba hacia 1980 no hubiera sido posible si los escritores hispanoamericanos no hubieran dejado de lado la teoría de los contenidos americanos para elaborar pacientemente, a partir de su propia sensibilidad, una tradición que no existía y que ellos inventaron plasmándola pacientemente en sus obras. Al rechazar la tesis de la originalidad, los escritores del continente tomaron conciencia de los poderes del lenguaje y adoptaron una actitud crítica frente a todo poder verbal. Sólo así pudieron fundar una voz auténtica y participar con su propia entonación y desde su propia mirada en el diálogo de la gran literatura universal.

927 "El debate con el lenguaje no surge en nuestra poesía sino con los movimientos posteriores al modernismo." (Guillermo Sucre: "Poesía hispanoamericana y conciencia del lenguaje", loc.cit., p. 624)

${ }^{928}$ En este punto, Sucre coincidía con Octavio Paz, quien había establecido: "López Velarde nos conduce a las puertas de la poesía contemporánea. No será él quien las abra sino Vicente Huidobro." (Octavio Paz: El arco y la lira, en OOCC, Vol. I, op.cit., p. 134)

${ }^{929}$ Guillermo Sucre: “¿Imitar una imagen o fundar una experiencia?”, loc.cit., pp. 67-68. 


\section{7. GUILLERMO SUCRE Y LA CRÍTICA LITERARIA}

La concepción de la crítica literaria de Sucre está estrechamente vinculada a sus planteamientos estéticos. Ya hemos visto cómo para él lo decisivo de la creación literaria no son los contenidos de la obra ni las ideas que contiene, sino la vivencia del mundo y del lenguaje que toma forma en la escritura. Por lo tanto, su crítica literaria trata de dilucidar la experiencia imaginaria y verbal que se origina en una creación determinada pues, como él mismo dice, la significación de una obra reside en "la visión totalizadora que del mundo tenga el escritor $\mathrm{y}$, finalmente, [en] el comportamiento frente a su propio lenguaje" ${ }^{930}$. Lo que le importa a Guillermo es la vivencia de la realidad que encarna en las propias palabras, por eso es la escritura lo que ocupa el primer plano de su atención. Al interrogarse por el método crítico que había seguido en su obra fundamental, nuestro autor señalaba lo siguiente:

He seguido más a los textos que a sus autores. Por ello, pienso, me decidí por el título: la máscara, la transparencia. ¿No tiene también algo misterioso? Lezama Lima, de quien lo tomo, ve en estos dos términos la alternativa que se le presenta al poeta para hacerse invisible y dejar que su obra hable por él. Esa alternativa y las diversas técnicas que suscita, conducen, sin embargo, a un mismo punto: la aparición del lenguaje. [/] Toda poesía adquiere sentido a partir de su lenguaje y de la conciencia que el poeta tenga de él. ${ }^{931}$

Según vemos por la cita, Sucre concede un lugar decisivo al lenguaje en la creación literaria pero con ello no alude a ningún formalismo sino que deja claro que lo que a él le interesa es la aventura imaginaria y verbal que encarna en la obra. Guillermo se centra en el lenguaje porque las palabras son el espacio donde toma cuerpo la experiencia del mundo que la creación literaria pone en juego. Por eso, en una revisión de los estudios sobre J. L. Borges, proponía que "la crítica borgiana verdadera es aquella que se funda en los textos de Borges y lo que ellos proponen"932, es decir, que

\footnotetext{
${ }^{930}$ Guillermo Sucre: "La nueva crítica”, loc.cit., pp. 271-272. Cursiva nuestra. La cita continúa: "Lo que podríamos llamar la moral tanto del escritor como del crítico reside en esta remisión a los poderes del lenguaje."

${ }^{931}$ Ibíd., p. 14. Asimismo indicaba: "Lo indudable para el escritor es que la verdadera realidad con que se enfrenta es la realidad del lenguaje." (Ibid., p. 255)

932 Guillermo Sucre: "Tendencias de la crítica borgiana", en Revista Iberoamericana, (Pittsburgh), vol. XXXV, núm. 68, may.-ago. 1969, p. 366.
} 
"no se trata de ver a Borges dentro de su vida cotidiana y parcial, sino dentro del universo de sus propias ficciones. Son esas ficciones las que nos dan el verdadero rostro de Borges: su yo simbólico y profundo. Es un yo creado por su obra y que vive a expensas del otro Borges de carne y hueso que pasea por Buenos Aires"933. Al centrarse en la vivencia de lo real que acontece en las palabras, lo que verdaderamente acapara la atención de nuestro crítico no es el texto en sí mismo, sino la cosmovisión y la actitud ante el lenguaje de un autor -que no tiene nada que ver con el escritor real, sino que es la entidad imaginaria creada en y por la propia obra ${ }^{934}$. En este sentido, Guillermo se distanciaba de la concepción de Emir Rodríguez Monegal -que no solo indagaba en la obra y en el lenguaje, sino también en la biografía del escritor ${ }^{935}$ - y se aproximaba, en cambio, a la perspectiva crítica de Octavio Paz y de Lezama Lima ${ }^{936}$.

El hecho de centrarse en la experiencia imaginaria y verbal de un autor trae consigo varias consecuencias en su manera de concebir la crítica literaria. Siguiendo las

${ }^{933}$ Ibid., p. 369.

934 Según afirmaba en un ensayo dedicado a Picón Salas: "No sé si el lenguaje expresa exactamente al hombre que lo escribe. De lo que es casi imposible dudar es que expresa a un autor: su visión y su conducta como tal" (Guillermo Sucre: "Prólogo" a Mariano Picón Salas: Viejos y nuevos...op.cit., p. XX). También en estos fragmentos, sin ser tan explícito, Sucre se está refiriendo a la figura del autor. Sobre la crítica de Raimundo Lida, Sucre destacaba lo siguiente: "No los rasgos universales de una forma artística, no los estilos en su amplitud más bien simplificadora, sino la peculiaridad decisiva que distingue la energía de cada obra: eso era lo que le interesaba." Y también: "No los estilos sino un estilo. Y no la letra sino el espíritu de ese estilo; no las abstracciones o vagas categorías en que se funda o se quiere fundarlo, sino su presencia concreta y su fuerza de irradiación. En esta fórmula tan sencilla de concebir, pero tan difícil de practicar en el análisis mismo, podría resumirse el arte crítico de Raimundo Lida." "No la vana indagación de influencias, sino el espacio que va dibujando un estilo a partir de su propio dinamismo." (Guillermo Sucre: "Recuerdo de Raimundo Lida" en Raimundo Lida: Rubén Darío...op.cit., pp. 15 y 16)

935 Como afirma nuestro autor, en el libro dedicado a Neruda (El viajero inmóvil, 1966), Monegal analiza el "texto como el suceder de un yo simbólico e imaginario, creado por la obra misma. Es decir, no la búsqueda de la biografía del autor de la obra, sino la búsqueda [...] de la persona poética. Pero en esta tentativa, Rodríguez Monegal no sólo lee en el texto sino en la vida del autor." (Guillermo Sucre: "La nueva crítica", loc.cit., p. 273.)

${ }^{936}$ Octavio Paz y Lezama Lima practican un tipo de crítica, a la que Guillermo llama "de las grandes correspondencias". En los ensayos de estos autores, "la obra se ilumina no sólo en su propio texto, sino también en un contexto más amplio: el diálogo con las demás obras, con una tradición viva. La obra es, por lo tanto, un verdadero haz de relaciones y la labor del crítico es revelar las proyecciones y conexiones de su trama. No se trata ya de singularizar un lenguaje, y tras ese lenguaje la "personalidad" del autor, como de hacer surgir de la obra misma una presencia más universal que sin cesar se trascienda." (Guillermo Sucre: "La nueva crítica", loc.cit., p. 272) 
palabras de Foucault, la figura del autor constituye "el principio de una cierta unidad de escritura" y es, por lo tanto,

lo que permite remontar las contradicciones que pueden desplegarse en una serie de textos: es preciso que exista -a un cierto nivel de su pensamiento o de su deseo, de su conciencia o de su inconsciente- un punto a partir del cual las contradicciones se resuelven, los elementos incompatibles finalmente se encadenan unos a otros o se organizan alrededor de una contradicción fundamental y originaria. ${ }^{937}$

El autor para Foucault es pues "la figura ideológica mediante la que se conjura la proliferación del sentido" o, dicho de otra manera, la instancia que "hace posible una limitación de la proliferación cancerígena, peligrosa, de las significaciones"938. Por lo tanto, esta entidad impone una cierta homogeneidad entre los diferentes textos escritos por ella y convierte así a la obra en un sistema coherente, en que las diversas partes establecen entre sí relaciones horizontales.

Al concebir las obras literarias como sistemas controlados por la persistencia en ellos de una misma visión y de una misma actitud ante el lenguaje, la crítica de Sucre tiende a limar las diferencias entre las partes de una misma obra y a controlar la diversidad potencial de sentidos que pueden darse en su interior. Eso le lleva, por ejemplo, a rechazar por "superficial" e "inexacta", la escisión entre una "época preciosista" de Darío ("hasta Prosas") y otra "más profunda, reflexiva y humanística, que comenzaría con Cantos" ${ }^{939}$. De la misma manera, ya en su libro Borges, el poeta nuestro autor impugnaba la partición convencionalmente aceptada entre el Borges ultraísta y su obra posterior, y decía al respecto en La máscara: "Lo que asombra de estos textos iniciales no es, por supuesto, el estilo, con frecuencia pintoresco; ni siquiera el humor. Lo que asombra es la inexorable correspondencia que tendrán sus ideas con la obra escrita luego. Todo en esa obra está signado, en efecto, por un rasgo esencial: el de

${ }^{937}$ Michel Foucault, “¿Qué es un autor?”, en Obras esenciales, Vol. I, Barcelona, Paidós Básica, 1999, p. 342. La cita sigue: "Finalmente, el autor es un cierto hogar de expresión que, bajo formas más o menos acabadas, se manifiesta tanto, y con el mismo valor, en unas obras, en unos borradores, en unas cartas, en unos fragmentos, etc."

${ }^{938}$ Ibíd., pp. 350-351, nota "a".

${ }^{939}$ Guillermo Sucre: La máscara ...op.cit., p. 46. 
ser una creación despersonalizada y mítica"940. Una concepción similar se aprecia en relación a la obra de Octavio Paz:

"Piedra de Sol" -nos dice Sucre- aparece como poema último del libro La estación violenta (1958). Por ello y por el carácter mismo del poema, podría pensarse que en él culmina una época de esta poesía. Creo, en verdad, que es un poema culminante, sobre todo si se tienen en cuenta los cambios que experimenta la obra posterior de Paz. Estos cambios, sin embargo, no son una ruptura $y$, en muchos sentidos, prolongan experiencias de libros anteriores. No sería errado, por ejemplo, ver Salamandra (1962) como la prolongación de ¿Águila o Sol? (1951), o Blanco (1967) como el desarrollo último y por cierto extremo de Semillas para un himno (1954). Así, el poeta de los años cincuenta que parecía haber cerrado un ciclo de su obra con "Piedra de Sol", lo que hace es recoger y nuevamente tramar otros hilos anteriores, más o menos sueltos y dispersos. $^{941}$

El hecho de que Sucre conciba la obra como la experiencia imaginaria y verbal de un autor, le lleva a buscar el aspecto más abarcador de esa experiencia para emprender a partir de él el estudio de la misma. Como todas las creaciones de un autor constituyen un sistema de relaciones igualitarias, nuestro crítico intenta hallar la constante más significativa de ese sistema para elaborar, a partir de ella, una visión coherente de todos los escritos de ese autor. Así, en un ensayo sobre Borges, Guillermo elige partir de "la quietud", porque esa experiencia "nos remite a toda una visión simbólica de Borges"942. De manera semejante, selecciona "la vivacidad" para acercarse a la poesía de Paz, dado que ese motivo constituye "el impulso profundo" "943 de toda la obra del mexicano. Al concebir los trabajos de un mismo escritor como un sistema de relaciones, nuestro crítico reconoce que cualquier aspecto de ese sistema es, o puede ser,

${ }^{940}$ Ibid., p. 162.

${ }^{941}$ Ibíd., pp. 227-228. Exceptuando los títulos de los libros, la cursiva es nuestra.

${ }^{942}$ Ibíd., p. 176. Una vez anunciado esto, pasa a estudiar las "implicaciones" de esta constante en el autor argentino. En otro ensayo sobre Borges indicaba: "Imaginar que no ser es más que ser algo y, de alguna manera, serlo todo: esta aparente falacia (de la que él se hace cómplice) es lo que propone Borges en uno de sus ensayos de los años cincuenta. Ella es la que sustenta toda su obra." (Guillermo Sucre: "Borges, una poética de la desposesión", loc.cit., p. 197). En ese texto decía también: "Este poema ["Jactancia de quietud"] es de la primera época de Borges, pero, en verdad, la trasciende y parece prefigurar toda su obra posterior. [...] Como en su visión del universo, en la obra de Borges un poema o una frase puede remitirnos a la totalidad de esa obra. Y quizá uno de los valores de "Jactancia de quietud" sea el darnos una prueba de ello." (Ibid., pp. 197-198)

${ }^{943}$ Guillermo Sucre: La máscara...op.cit., p. 207. Por la persistencia de unos mismos impulsos, Sucre definía la obra de Paz como un espacio: "Más que transcurrir en el tiempo, lo que el conjunto de esa obra tiende a figurar es un espacio: un espacio arborescente, con múltiples ramificaciones. Es una obra, por tanto, que excluye todo sentido de evolución o progreso. Un poema o un libro de Paz no propone un avance con respecto a los que le preceden, sino una intensificación. También de este modo lo que busca afirmar Paz es la vivacidad." (Ibid., p. 228) 
el centro. Si bien, como acabamos de ver, Sucre intentará siempre partir de aquella constante que condense mejor la significación de la obra, sabe que es posible abordarla a partir de diversas facetas, ya que todas ellas remiten a la totalidad coherente. A este respecto, nuestro crítico afirma a propósito de López Velarde: “Su obra es el resultado de un doble drama: el de su pasión y el de la poesía misma; esos dramas no son paralelos sino que se entrecruzan: se implican y se explican entre sí. Y como uno conduce al otro, cualquiera de ellos puede ser el punto de partida para abordar su obra"944. Y algo similar indica al hablar sobre la obra de Paz: "Si cito, inicialmente, estos momentos del pensamiento y de la experiencia poética de Paz, no es sólo para mostrar la continuidad o coherencia de su obra. También hubiera podido evocar otras reiteraciones de igual modo significativas"945.

La percepción de la obra como un cuerpo homogéneo cuya coherencia está asegurada por la presencia del autor se duplica en la noción sucreana de la historia literaria. De la misma manera que en el interior de las obras nuestro crítico prefiere la continuidad a la división en etapas, al nivel de la historia literaria antepone el encadenamiento a la ruptura. Así, por ejemplo, si bien Sucre no niega que haya diferencias entre Darío y Martí, trata de relativizar la distancia que los separa, pues en ambos autores encuentra "la intuición del poeta como un mediador del lenguaje, que lo sirve y no se sirve de él" ${ }^{946}$. Como ya hemos visto, para Guillermo la literatura está en consonancia con el ethos esencial del hombre y del mundo; por lo tanto, la historia literaria no muestra grandes rupturas, sino la persistencia de una misma actitud. A pesar de las diferencias circunstanciales de estilo o de contexto, todas las obras apropiadas

${ }^{944}$ Ibid. p. 62. Cursiva nuestra.

${ }^{945}$ Ibid., pp. 207-208. Cursiva nuestra.

${ }^{946}$ Guillermo Sucre: La máscara...op.cit., p. 33. Lo mismo proponía en otro lugar: "como todo movimiento auténtico, el modernismo fue un horizonte espiritual: la diversidad dentro de la unidad. La clave de esa unidad reside en la relación con el lenguaje: la validez del poema en tanto creación verbal, en tanto objeto estético." (Guillermo Sucre: "Introducción", a la Primera Parte de la Antología de la poesía hispanoamericana moderna, Vol. I, op.cit., p. 20) 
entran a formar parte del sistema de la literatura y establecen en él una serie de relaciones de afinidad y oposición. Por eso, en el prólogo a la sección de su Antología que concierne a los poetas modernistas y posmodernistas, Sucre afirmaba que, más allá de las divisiones en diferentes escuelas, "lo que se ha intentado en esta introducción es presentar un conjunto de poetas hispanoamericanos que, no obstante las diferencias de estilos y gustos, de tiempos y espacios, lograron crear un campo de mutuas referencias. La literatura es un sistema, pero un sistema plural y dinámico: una confrontación de textos" ${ }^{947}$. Al concebir la historia literaria como un conjunto de relaciones, Sucre considera imprescindible que el crítico sea capaz de situar a la obra "en relación a un conjunto de obras con las que dialoga, estableciendo afinidades u oposiciones" pues, según afirma en un ensayo sobre Francisco Rivera, "no hay lectura más fecunda de un texto que dentro del conjunto de textos que en él subyacen -reflejándose, refractándoseincesantemente" 948 . Es lógico entonces que conciba la crítica "como un vasto sistema de comparaciones en el que cuenta sobre todo la imaginación relacionante" ${ }^{949}$, pues de lo que se trata es de poner en juego el diálogo entre las obras y de escuchar las voces que en él participan. Esta concepción de la crítica se aprecia muy bien en su libro de ensayos

${ }^{947}$ Ibid., p. 28.

${ }^{948}$ Guillermo Sucre: "Inscripciones, de Francisco Rivera”, loc.cit., p. 40. En un artículo sobre un libro de García Ponce, Sucre apuntaba algo que puede explicar su propio método crítico: "ver la obra es proyectarla en su trama, en lo que allí confluye y lo que de allí fluye; fijar el sentido de la obra es ampliarlo en su (im)precisión, así como captar su voz es oírla en el espacio de la literatura." (Guillermo Sucre: "La errancia sin fin, de Juan García Ponce", en Vuelta, México, mar. 1982, p. 36). Conviene aclarar que el método que emplea Guillermo nada tiene que ver con esa crítica hispanoamericana que recurría "a los tristes expedientes de las influencias" o a la tradicional "crítica de fuentes," (Guillermo Sucre: "La nueva crítica", loc.cit., p. 273) pues estas tendencias tenían "como secuela inevitable, [el] asedio obsesivo de una originalidad americana que muchas veces colinda con una nueva forma de exotismo.” (Guillermo Sucre: “¿Imitar una imagen o fundar una experiencia?”, loc.cit., p. 66). En otro artículo, Sucre rechazaba explícitamente este tipo de crítica: "la llamada «crítica de fuentes» tendría muy poca eficacia frente a la obra de Borges. En todo caso, no sería tan iluminadora. ¿Y es que lo ha sido alguna vez este tipo de crítica?" (Guillermo Sucre: "Tendencias de la crítica borgiana”, loc.cit., p. 366). Sobre este aspecto vid. infra nota 974, en p. 341.

949 Guillermo Sucre: “¿Imitar una imagen...?”, loc.cit., p. 66. La literatura para Sucre es esencialmente un diálogo entre obras y, como él mismo dice: "Lo que importa en todo diálogo es oír las voces que lo entonan, si, por supuesto, están bien afinadas y corresponden a una experiencia auténtica. No hay experiencias "únicas" sino compartidas: ni siquiera podrían reconocerse a sí mismas si no saben de la de los otros, y ya ese saber es una forma de compartirla." (Guillermo Sucre: "Octavio Paz: La otra voz", loc.cit., p. 24) 
La máscara, la transparencia. En él, la significación de cada autor en la trama de la literatura se define a partir de las similitudes y diferencias que su obra establece con las demás. Como el propio Sucre indica en el "Prefacio" a ese volumen: "hablar de un poema supone, primero, hacer visible su texto, su trama. Pero si todo poema es espejo de sí mismo, se va volviendo luego espejeante: refleja otros poemas, que, a su vez, reflejan otros, etc. Esa cadena de reflejos, y de refracciones por supuesto, es lo que he intentado dar en relación con las obras estudiadas en este libro" ${ }^{\text {950 }}$. Si bien La máscara trata sobre obras de autores hispanoamericanos, Guillermo señala que le "hubiera gustado situar nuestra poesía en un contexto más amplio de relaciones: la poesía española, por supuesto, y también otras con las cuales la nuestra tiene evidentes nexos"951, lo que en cierta medida se cumple pues a lo largo del libro hay constantes referencias a creadores de otras literaturas. Además, la visión de la historia literaria como un sistema de relaciones implica que ella es un espacio donde las obras establecen entre sí vínculos que trascienden la mera disposición cronológica. De este modo, cada nueva creación que entra a formar parte del sistema puede determinar a las obras del pasado de la misma manera que estas modifican a las creaciones futuras. Por eso en la "Introducción" a la tercera parte de su Antología, Sucre señalaba que "la cronología aquí adoptada no aspira [...] a mostrar ningún orden causal; ni siquiera funciona en ella una idea absoluta de lo que llamamos generación" "952. Y, asimismo, en un ensayo de principios de los años setenta, nuestro crítico ponía de manifiesto la reversibilidad de la historia literaria al señalar que “[Carlos Germán] Belli puede ser (¿también la sombra de

${ }^{950}$ Guillermo Sucre: La máscara ...op.cit., p. 14.

951 Ibid., p. 14.

${ }^{952}$ Guillermo Sucre: "Introducción” a la Tercera Parte de la Antología..., Vol. II, op.cit., p. 12. A pesar de que nuestro autor declaraba haber seguido en La máscara un "cierto hilo cronológico" en el ordenamiento de los poetas estudiados, vemos que en ella Guillermo concibe la literatura como una trama coherente en que las diferentes creaciones (hispanoamericanas y universales) establecen entre sí vínculos de afinidad y oposición que trascienden la mera disposición temporal. (Guillermo Sucre: $L a$ máscara...op.cit., p. 13) 
Borges acá?) un poeta del pasado[Vallejo], pero un poeta del pasado [Vallejo] es también otro a través de Belli" $" 953$.

Guillermo toma de Octavio Paz la concepción de la obra y de la historia literaria como sistemas. Como se puede apreciar en su crítica literaria, el escritor mexicano concibe que la visión del mundo de un autor y su actitud ante el lenguaje están estrechamente relacionadas y, por lo tanto, que las obras son sistemas cohesionados por la persistencia en ellos de una misma ética y estética. Además, para Paz la historia literaria es un sistema de relaciones y las grandes obras establecen entre sí vínculos de afinidad y oposición que trascienden el simple ordenamiento sucesivo. "Si concebimos a la poesía de lengua española más como un sistema que como una historia, la significación de las obras que la componen no depende tanto de la cronología ni de nuestro punto de vista como de las relaciones de los textos entre ellos y del movimiento mismo del sistema" ${ }^{954}$. Esta idea, que se difundió en la literatura moderna a partir del ensayo "La tradición y el talento individual"955 (1919) de T. S. Eliot, aparece también

${ }^{953}$ Guillermo Sucre: “Poesía Crítica: Lenguaje y silencio”, loc.cit., pp. 587-588.

954 Octavio Paz: “Apéndices” a Claude Lévi-Strauss o el nuevo festín de Esopo, en OOCC, Vol. $V I$, p. 1343. Esta misma concepción acrónica de la literatura es la que anima la antología de la poesía mexicana moderna coordinada, entre otros, por Paz y titulada Poesía en movimiento. En ella el pasado se lee a la luz del presente con lo que se altera radicalmente la disposición de la historiografía tradicional: "Movilidad del paisaje contemplado y movilidad del punto de vista: no es lo mismo leer a Segovia o a Sabines desde la perspectiva de un lector de González Martínez que leer a Tablada o a Gorostiza desde la de Montes de Oca o de Aridjis. En el primer caso nuestro punto de vista sería estático: vemos al presente desde un pasado consumado; en el segundo, vemos al pasado desde un presente en movimiento: el pasado insensiblemente se anima, cambia, marcha hacia nosotros. En general la crítica busca la continuidad de una literatura a partir de los autores consagrados: ve al pasado como un comienzo y al presente como un fin provisional; nosotros pretendemos alterar la visión acostumbrada: ver en el presente un comienzo, en el pasado un fin. Este fin también es provisional porque cambia a medida que cambia el presente. Si el presente es un comienzo, la obra de Pellicer, Villaurrutia y Novo es la consecuencia natural de la poesía de los jóvenes y no a la inversa. La prueba de la juventud de estos tres poetas es que soporta la cercanía de los jóvenes. El presente la cambia, le otorga nuevo sentido. En cambio, si no hay una relación viva entre el presente y el pasado, si el pasado es insensible a la acción de los jóvenes, no es aventurado afirmar que hay una ruptura: ese pasado no nos pertenece. Por supuesto, no quiero decir que sea desdeñable: simplemente no es nuestro, no forma parte de nuestro presente." (Octavio Paz: "Poesía en movimiento", prólogo a Poesía en movimiento, México, Siglo XXI, 2006, pp. 6-7. [1966]) En el mismo texto, Paz afirmaba que Tablada -el más "viejo" cronológicamente de los poetas que aparecen en la antología- "tal vez es nuestro poeta más joven." (Ibíd., p. 10)

${ }^{955}$ En ese texto, T. S. Eliot había establecido que "ningún poeta, ningún artista de ningún arte, es inteligible por sí solo. Su importancia y su estimación son la estimación de su vínculo con los poetas y artistas muertos. No se le puede evaluar por sí solo; se le ha de ubicar, por razones de contraste y comparación, entre los muertos. [...] Esta exigencia de conformidad, de coherencia, no es unívoca; lo que 
en otros dos autores fundamentales para Guillermo: Lezama Lima y Jorge Luis Borges.

El primero indicaba, como nos recuerda el propio Sucre, que "la historia de la sensibilidad y de la cultura es una mágica continuación y no un seguimiento. En un desarrollo causal y cronológico, la historia se vuelve monótona y empobrecida cuando en realidad hay una sincronización, una simultaneidad" $" 956$. Al concebir la obra como un espacio acrónico, el escritor cubano planteaba también que las obras del futuro podían modificar a las del pasado, como indica en este pasaje encantador:

El esplendor, la fuerza irradiante de esa esencia [la intensidad de Mallarmé] era capaz de reobrar sobre el pasado, en una hiperbólica paradoja, como causa. [...] En ese sentido la école lyonnais, en sus dos ramificaciones de Maurice Scéve y de Louise Labé, no puede ser considerada como el antecedente de la factura y de los prodigiosos hallazgos del verso de Mallarmé, sino, por el contrario, cuando Mallarmé obtuvo el resultado incomparable de la alquimia y de la irradiación de su palabra, aquella zona del siglo XVII, se aclaró como si el destello mallarmeano fuera la chispa para la evaporación histórica de la Plaza de Lyon ${ }^{957}$

También Borges presenta una concepción similar de la historia literaria. Según hemos visto, él concibe la literatura en términos clásicos como la persistencia de una misma ética y estética a lo largo del tiempo. Al negar el tiempo y plantear que el arte con palabras tiene una dimensión transhistórica, puede proponer asimismo, como hace en un famoso ensayo, que "cada escritor crea a sus precursores. Su labor modifica nuestra concepción del pasado, como ha de modificar el futuro"958.

Por otro lado, la concepción de la obra literaria de Guillermo tiene consecuencias en su manera de pensar la crítica. Como resultado de la conciencia del

sucede cuando se crea una nueva obra de arte repercute de forma simultánea en todas las obras de arte que la precedieron. Los monumentos ya existentes constituyen un orden ideal que se modifica con la introducción de la nueva (realmente nueva) obra de arte. Ese orden es un todo completo; si queremos que perdure después de la supervivencia de lo nuevo, la totalidad del orden existente ha de alterarse, siquiera levemente; y así las relaciones, proporciones y valores de cada obra de arte en relación con el conjunto sufren un reajuste; y esto es lo que entendemos por conformidad entre lo viejo y lo nuevo. Nadie que apruebe esta idea de orden, de la forma en que se organiza la literatura inglesa y europea, encontrará ridículo que el pasado se vea tan alterado por el presente como el presente se ve gobernado por el pasado. Y el poeta consciente de esta relación será consciente de grandes dificultades y responsabilidades." (T. S. Eliot: "La tradición y el talento individual", en Matemática tiniebla ...op.cit., p. 392)

956 Citado por Guillermo Sucre como epígrafe a su "Introducción" a la Tercera Parte de la Antología..., Vol. II, op.cit., p. 11.

Vol. II, op.cit., p. 521

${ }_{958}$ Jorge Luis Borges: “Kafka y sus precursores”, en OOCC, Vol. I, op.cit., p. 711. 
lenguaje, Sucre considera que la creación propiamente dicha debe establecer una continuidad entre el sujeto y el objeto, y entre lo imaginario y lo real. Para obtener esta unidad es imprescindible que el escritor sea capaz de dar con un lenguaje diáfano que, privado de todo espesor semántico, consiga transparentar la referencia. Cuando se alcanza este ideal estético, la obra anula la distancia que se establece entre la palabra y la realidad y se convierte en un espacio horizontal donde encarna una experiencia imaginaria que es completamente visible, y donde nada alude a un sentido velado o secreto. Si la obra se concibe como la vivencia diáfana del mundo que encarna en un lenguaje sin espesor ni profundidad, es evidente que la crítica no puede tener nada que ver con la hermenéutica característica de la "conciencia simbólica"959, que remite el sentido a una dimensión trascendente. Por eso Guillermo rechaza las lecturas deterministas que ven la obra como una excusa para indagar en la historia, en la sociedad o en la psicología del autor. En la visión de Sucre la obra es un nuevo nacimiento; por lo tanto, no se limita a copiar o reproducir una certeza o un estado de cosas preexistente, sino que se esfuerza por generar un sentido sobre el mundo desde un punto de vista relativo y parcial. Para él la creación literaria es en sí misma -en el juego que las palabras establecen entre sí- una experiencia imaginaria y verbal, y es eso lo que el crítico debe estudiar ${ }^{960}$. Por lo tanto, nuestro autor no es favorable a las interpretaciones psicoanalíticas o marxistas, pues ellas reducen el sentido de la obra a un

${ }^{959}$ El concepto está tomado de Barthes, vid. supra pp. 256-257.

960 Por eso Sucre cuestionaba, con Borges, la "superstición del estilo", es decir, la "distraída lectura de atenciones parciales". El escritor argentino afirmaba que "los que adolecen de esa superstición entienden por estilo no la eficacia o la ineficacia de una página, sino las habilidades aparentes del escritor: sus comparaciones, su acústica, los episodios de su puntuación y de su sintaxis. Son indiferentes a la propia convicción o propia emoción: buscan tecniquerías (la palabra es de Miguel de Unamuno) que les informarán si lo escrito tiene el derecho o no de agradarles." (Jorge Luis Borges: "La supersticiosa ética del lector", en Discusión, en OOCC, Vol. I, op.cit., p. 202). Guillermo suscribe explícitamente la concepción de Borges: "También es verdad que ha sobrevenido en cierta crítica actual una manía tal de interpretación que se ha perdido no sólo el goce estético espontáneo frente a la obra, sino también la visión de su propia naturaleza. Es lo que Borges denunció hace mucho tiempo con el nombre de «la supersticiosa ética del lector»: subordinar la emoción que comunica la obra a una suerte de análisis, inhibitorio y hasta fetichista, sobre la disposición de las partes que la integran." (Guillermo Sucre: "La nueva crítica", loc.cit., p. 262) 
evento (la infancia del escritor o el contexto social de producción, por ejemplo) que resulta anterior a la obra y ajeno a la vivencia que ella revela e inventa.

Un cuestionamiento explícito de Sucre a la lectura psicoanalítica se aprecia cuando nos recuerda en La máscara que el crítico A. Álvarez, en The Savage God (1972), planteaba que la obra de arte "no es siempre una terapia que libera al autor de las visiones y fantasmas que lo acosan, como ha creído el psicoanálisis" pues, según lo demuestra el caso de Sylvia Plath, "lo que el autor va escribiendo puede convertirse en destino, hacerse un tejido inexorable que finalmente se constituye en su verdadera naturaleza" ${ }^{961}$. En la visión de Sucre la estética y la vida son términos inseparables, de modo que, en algunos escritores auténticos (como es el caso de Alejandra Pizarnik y de Ramos Sucre ${ }^{962}$ ) el suicidio puede incluso llegar a entenderse como una consecuencia de la obra, es decir, como una opción de la lucidez poética. Si la vida es el resultado del arte, una interpretación psicoanalítica -que concibe la creación literaria como un efecto de la biografía- carece de sentido.

${ }_{961}^{961}$ Guillermo Sucre: La máscara...op.cit., p. 365.

962 Sobre el suicidio de Alejandra Pizarnik, Guillermo afirma: "Si todo El infierno musical es un continuo trato con la muerte, estos dos pasajes parecen encerrar la clave del acto mismo del suicidio de Alejandra Pizanik. [...] Toda la obra de Alejandra, en efecto, fue la búsqueda de ese fundamento: transponer la vida a la escritura, transponer la escritura a la vida. Operación doble y única, es decir, dialéctica [...] no tener nada que decir supone que no hay tampoco nada que vivir. [...]" / "Explicar el suicidio en términos estéticos: pura literatura, dirá el lector. Debo, entonces, precisar algunas cosas. No estoy pretendiendo explicar racionalmente el suicidio de Alejandra Pizarnik, sino de comprenderlo a partir de su obra misma; en todo escritor auténtico, como ella, la estética y la vida no son términos separables, mucho menos excluyentes. Tampoco he intentado «mitificar» su suicidio, haciéndolo «poético»y despojándolo de su hiriente intensidad humana, de ese desamparo total que lo acompaña, sobre todo en un ser joven. He querido poner de relieve algo no menos humano aunque más complejo: que un artista puede escoger la muerte por amor a la vida, escoger el definitivo silencio por amor a la palabra, y que justamente esa opción no es el resultado de un extravío (mental o moral), sino de una lucidez que se extravía por exceso de claridad ante la vida y la historia." (Guillermo Sucre: $L a$ máscara...op.cit., pp. 364-365) Y sobre el suicidio de Ramos Sucre: "El último acto de su vida, pues, fue la opción de la lucidez. Lo que ya estaba inscrito en varios pasajes de su obra. Una de las múltiples personas poéticas que creó lo había previsto así: «Yo había concebido la resolución de salir voluntariamente de la vida al notar los síntomas del tedio, al sentir las trabas y cadenas de la vejez». La obra como prefiguración, la muerte haciendo del texto un destino: éste es uno de los signos de la verdadera poética de Ramos Sucre." (Guillermo Sucre: "Ramos Sucre: Anacronismo y/o renovación", loc.cit., p. 77) 


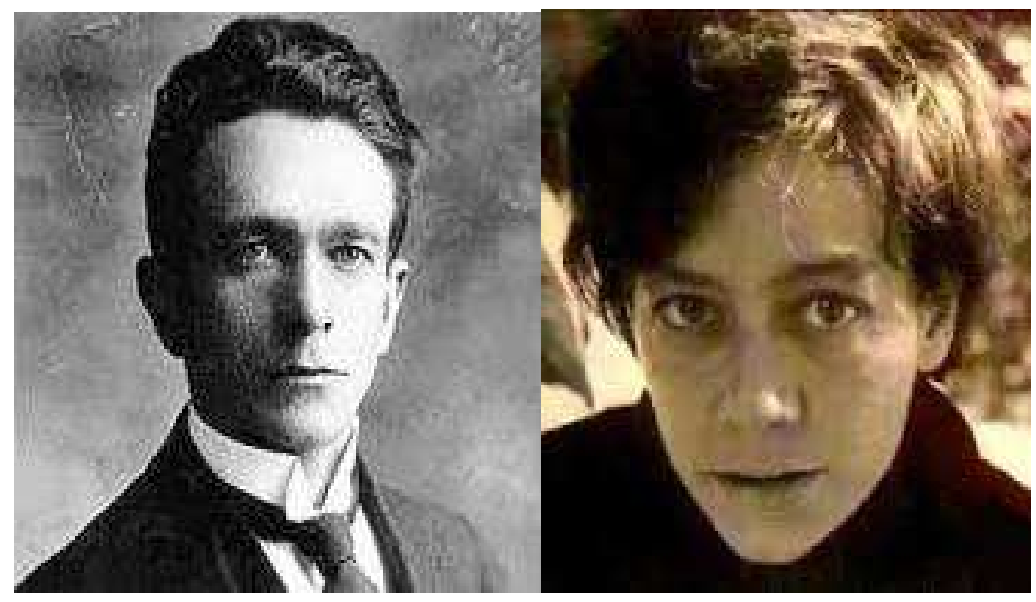

Imágenes 55 y 56. Los poetas José Antonio Ramos Sucre (1890-1930) y Alejandra Pizarnik (1936-1972).

De la misma manera, Guillermo considera que la obra no puede ser una simple excusa para indagar en el contexto histórico o social. Aunque reconoce que toda literatura presupone una situación determinada, el potencial creativo que contiene le permite superar su propio contexto. Como él mismo dice: "Si toda obra supone una realidad cultural, histórica y aun psicológica, no es menos cierto que tales supuestos se integran a otro mayor, que los transfigura: la realidad estética. Es ésta la decisiva y su clave no puede ser sino el lenguaje" ${ }^{, 963}$. Al reconocer la centralidad del lenguaje en la creación literaria se quiebra "la relación causalista entre obra y realidad, obra y sociedad, obra e historia" ${ }^{964}$ y la literatura no es un mero resultado del entorno sino una creación que restituye a la realidad su verdadera presencia. Según afirmaba Sucre en un texto sobre La otra voz (1989) de Octavio Paz:

la poesía nace de una circunstancia y a la vez la trasciende, pero no porque se vuelva una suerte de "metafísica", sino porque le restituye a la circunstancia su verdadera presencia: las imágenes primordiales que hay en ella, el tiempo sin tiempo en que también discurre y es su memoria secreta, todo ese sistema de signos (ideas, pasiones, actos) que se van tramando en ella e imperceptiblemente van configurando el espíritu de los tiempos. Casi, pues, como si fuera la circunstancia la que naciera del poema. [/] A la circunstancia, al igual que al poema, hay que saber descifrarla desde lo que dice y más allá de ese decir. Ese más allá es siempre una presencia: no una inmovilidad abstracta ni un absoluto por alcanzar, sino un tejido vivo y cambiante de relaciones. ${ }^{965}$

\footnotetext{
${ }^{963}$ Guillermo Sucre: La máscara, la transparencia, $2^{\mathrm{a}}$ ed., op.cit., p. 388.

${ }^{964}$ Guillermo Sucre: "La nueva crítica", loc.cit., p. 271.

${ }^{965}$ Guillermo Sucre: “Octavio Paz: La otra voz”, loc.cit., p. 25.
} 
Estas ideas sobre la superación del contexto por el arte, Guillermo las tomaba de los ensayos de Octavio Paz. El escritor mexicano pensaba que, al ser esencialmente una creación lingüística, la literatura supera siempre su propio contexto ${ }^{966}$ y debe ser estudiada de manera inmanente: "la Odisea describe costumbres de indudable interés para el historiador pero no es un relato de historia ni un reportaje de etnografía: es una poema, una creación verbal"967.

En lo que concierne al rechazo de la hermenéutica en general, sin embargo, es evidente que nuestro autor estaba siguiendo los planteamientos de Susan Sontag. En los ensayos reunidos en Contra la interpretación, la escritora norteamericana proponía que "la obra de arte, considerada simplemente como obra de arte, es una experiencia, no una afirmación ni la respuesta a una pregunta. El arte no sólo se refiere a algo; es algo. Una obra de arte es una cosa en el mundo, y no sólo un texto o un comentario sobre el mundo"968. Al poner de manifiesto el carácter experiencial de la obra de arte, Sontag estaba cuestionando aquella crítica -sobre todo la marxista y la freudiana- que reducía la obra de arte a su contenido o a sus implicaciones intelectuales. Como ella misma afirmaba, "el moderno estilo de interpretación excava y, en la medida en que excava, destruye; excava hasta «más allá del texto» para descubrir un subtexto que resulte ser el verdadero"969. En vez de convertir las obras en algo distinto de ellas mismas, es decir, en vez de reemplazar la creación "por alguna otra cosa" $" 970$ y asimilarla constantemente a significados intelectuales o culturales, Sontag defendía que el arte era una experiencia en sí mismo y que encarnaba un saber que no necesitaba ser decodificado puesto que

${ }_{966}$ Asimismo vid. supra pp. 301-302.

967 Y [Paz] -nos dice Sucre- remata este pasaje con una comparación ya inevitablemente picante: "leer así un poema «es como estudiar botánica en un paisaje de Corot o de Monet». Los botánicos de nuestra crítica -un poco menos silvestres que antes, con el amaneramiento que hoy les da el «post-modernismo»- siguen florecientes." (Guillermo Sucre: “Octavio Paz: La otra voz", loc.cit., p. 25)

${ }^{968}$ Susan Sontag: "Sobre el estilo", en Contra la interpretación, op.cit., p. 48.

${ }^{969}$ Susan Sontag: "Contra la interpretación”, en Contra la interpretación, op.cit., p. 29.

${ }^{970}$ Ibid., p. 34. 
suponía el reencuentro con un mundo esencial. Por eso, al igual que Sucre, la pensadora norteamericana establecía una homología entre la relación del receptor (del crítico) con el arte y el vínculo del hombre con la realidad: "El espectador debería abordar el arte como aborda un paisaje. Éste no le exige al espectador «comprensión», ni adjudicaciones de trascendencia, ni ansiedades y simpatías: lo que reclama, más bien, es su ausencia, y le pide que no agregue nada $a$ él, al paisaje"971.

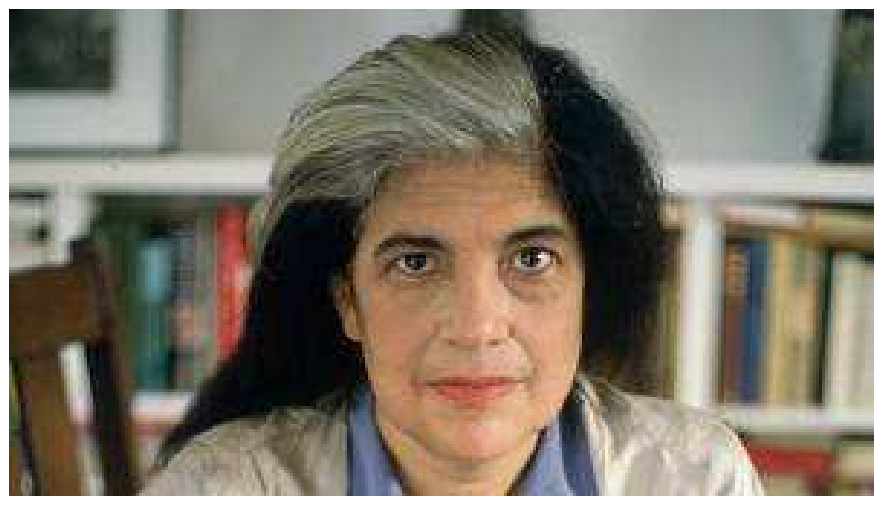

Imagen 57. Susan Sontag (1933-2004).

El origen de estas ideas de Sontag se encuentra en otros autores que fueron leídos también por el propio Guillermo, como Gertrude Stein y Roland Barthes. Stein concedía un valor fundamental a la inmediatez de la experiencia en la escritura pues, como nos recuerda Sucre, para ella "las grandes obras de arte son aquéllas que conocen lo que conocen en el momento mismo en que lo conocen"972. Así reconocía la inmanencia de la creación artística y restaba importancia implícitamente al contenido y

${ }^{971}$ Susan Sontag: "La estética del silencio", en Estilos radicales, op.cit., pp. 30-31. La cita sigue: "En términos estrictos, la contemplación hace que el espectador se olvide de sí mismo: el objeto digno de contemplación es aquel que, en la práctica, aniquila al sujeto perceptor. [/] Gran parte del arte contemporáneo aspira a alcanzar [...] esta plenitud ideal a la que el público no puede añadir nada, análoga a la relación estética con la naturaleza. En principio, es posible que el público ni siquiera añada su pensamiento. Todos los objetos correctamente percibidos ya están completos."

972 Guillermo Sucre: “¿Imitar una imagen...?”, loc.cit., p. 54. En otro lugar, Sucre vuelve a referirse a la escritora norteamericana: "Las obras maestras del arte, para Stein, no han podido nacer sino de lo que ella llama la mente humana: esas estructuras más amplias del ser, ese conocimiento -como ella dice- que "conoce lo que conoce cuando lo conoce". En una palabra: la obra maestra es un presente sin fisuras del lenguaje en su desenvolvimiento como lenguaje." (Guillermo Sucre: "Poesía hispanoamericana y conciencia...", loc.cit., pp. 613-614). Para ver la posición de Stein con respecto al cubismo vid. supra, p. 260 y ss. 
a las significaciones intelectuales de la obra. Por su parte, Barthes, en el texto "Las dos críticas" defendía el "análisis inmanente" de la obra literaria e impugnaba, en consecuencia, aquellas corrientes que pretendían a toda costa relacionar la obra "con otra cosa distinta de sí misma, es decir, con algo que no sea la literatura" ${ }^{\text {"973, }}$, como la historia o la psicología. El teórico francés estaba cuestionando así que la crítica tuviera que limitar sus investigaciones a las "circunstancias" de la obra o a la búsqueda de “fuentes", pues de acuerdo a su concepción la crítica debía hallar "el sentido funcional de la obra, que es su verdad", no "en profundidad, sino en extensión"974.

La visión de Guillermo de la crítica literaria resulta, como hemos visto, de su concepción de la obra, pero también de su manera de pensar la escritura. En consonancia con la conciencia del lenguaje (y siguiendo lo que había propuesto Barthes en Critique et verité) Sucre piensa que tanto el escritor como el crítico "se hacen frente a una misma realidad: el lenguaje" ${ }^{\text {975 }}$. La experiencia del crítico, al igual que la del poeta o el novelista, es ante todo verbal: no hay un sentido previo que el estudio de la obra debe simplemente describir o "expresar", sino que la experiencia de la creación debe encarnar en la mirada y en el lenguaje del exegeta. Entonces la relación del escritor con el mundo es simétrica a la que establece el crítico con la obra. En la visión de Guillermo tanto el universo como la obra literaria son sistemas de relaciones que carecen de una significación definitiva. Su sentido sólo existe momentáneamente cuando se produce una coincidencia entre lo mirado y la mirada o entre el sujeto y el objeto. Como hemos visto, Sucre piensa que el escritor debe ser capaz de conciliar la subjetividad y la objetividad o lo soñado y lo visible, para lograr así una expresión

${ }^{973}$ Roland Barthes: "Las dos críticas", en Ensayos críticos, op.cit., p. 343.

${ }^{974}$ Ibíd., p. 342. Como nos recuerda Sucre, también T. S. Eliot cuestionaba la crítica de fuentes: "De manera que la llamada «crítica de fuentes» tendría muy poca eficacia frente a la obra de Borges. En todo caso, no sería tan iluminadora. ¿Y es que lo ha sido alguna vez este tipo de crítica? Ya Eliot manifestaba su reticencia respecto a ella cuando decía que toda obra auténtica es un hecho nuevo y nada de lo que la antecede -biografía del autor, lecturas, etc.- puede explicarla." (Guillermo Sucre: "Tendencias de la crítica borgiana", loc.cit., p. 366)

${ }^{975}$ Guillermo Sucre: "La nueva crítica", loc.cit., p. 264. 
saturada, sin excesos de cosas o de palabras. Del mismo modo, considera que el crítico debe establecer una continuidad entre su mirada y la obra estudiada, pues sólo entonces se cancelarán las profusiones de subjetividad o de objetividad y se alcanzará, aunque sea por un instante, una coincidencia adecuada (que será absoluta y relativa al mismo tiempo) entre la visión del crítico y la creación literaria. Al igual que la obra propiamente dicha, la crítica literaria debe presentar una coincidencia total entre el sujeto (el crítico) y el objeto (la obra), y esa saturación, que por definición es momentánea, prueba la calidad del trabajo crítico.

Guillermo suele plantear este requerimiento al contrario, es decir, rechazando aquellas visiones críticas que adolecen de un exceso de subjetividad o de objetividad. A este exceso se refiere cuando llama la atención sobre "dos riesgos por igual negativos: caer en el puro impresionismo, o someterse a los cánones de que ha vivido la crítica tradicional"976, o también cuando señala que la crítica debe tratar de "comprender la obra sin petrificarla ni desarticularla" ${ }^{\text {977 }}$. El impresionismo y la desarticulación suponen que se ha dado un exceso de subjetividad del crítico, y la petrificación implica la fijación del sentido de la obra, es decir, el defecto contrario. En otro ensayo, nuestro autor denunciaba los mismos vicios al rechazar tanto la crítica "directa" del "escoliasta", "que busca acotar y fijar el sentido de la obra, reduciéndolo al «buen sentido»", como la crítica "substitutiva" del "virtuosista", que quiere "que la voz de la obra «suene» como la de él"978. Ante estas desmesuras, Sucre busca un término medio, es decir, la coincidencia de la subjetividad y la objetividad: ni congelar la obra, ni emplearla para hacer pasar sobre ella la sola imagen del crítico ${ }^{979}$. Cómo él afirmaba, en

${ }^{976}$ Ibid., p. 263.

977 Ibid., p. 261.

${ }^{978}$ Guillermo Sucre: “La errancia sin fin...”, loc.cit., p. 36.

979 Como dice nuestro autor, "la intuición del crítico no es un alarde de invención; cuando es eficaz, está en sintonía con la intuición que hizo posible a la obra". (Guillermo Sucre: "La nueva crítica", loc.cit., p. 262). Nuestro autor destacaba "la pureza de la actitud crítica" de García Ponce por lo siguiente: 
este caso de manera positiva, la crítica "vive del yo de la obra y del yo que la contempla, vive de la obra como objeto y de la decisión solitaria de un sujeto que la experimenta" 980 .

Esta visión de la crítica supone que ella no debe ocuparse simplemente de "discernir juiciosamente los valores de una obra", sino que su labor debe consistir en “encarnarlos en el doble plano del análisis y de la participación"981. En efecto, si la crítica debe establecer una continuidad apropiada entre la subjetividad y la objetividad es evidente que la misma escritura del crítico está implicada en el proceso cognoscitivo. En el pensamiento de Guillermo, el crítico literario tiene que ser capaz de rescatar la experiencia ética y estética de la obra-objeto y hacerla revivir en una escritura que revele una sensibilidad y un lenguaje particulares, de manera que esa vivencia entre a formar parte de una nueva creación. Por eso afirmaba, siguiendo al joven Lukács de $E l$ alma y las formas, que "el ensayista auténtico [...] es aquel que sabe crear una nueva visión a partir de cualquier texto, sin necesidad de desvirtuarlo" ${ }^{982}$. Nuestro autor destacaba esta cualidad en el texto de Ramos Sucre "Sobre las huellas de Humboldt" (1923), donde advertía un antecedente temprano de su propia concepción de la crítica. Según dice Guillermo, “desdeñado por la crítica, ese texto se nos impone hoy con un signo precursor: la paráfrasis convertida en recreación verbal para revivir lo mítico americano [...]. Así era como Ramos Sucre sabía traducir: a partir de un mismo sentido, producir un nuevo lenguaje y, por tanto, variar, metamorfosear ese sentido

\footnotetext{
"García Ponce no escribe sobre alguien para hacer pasar su propia «imagen»; escribe sobre alguien para (re)encontrarse con él, o para encontrar en él una misma pasión: la escritura."(Guillermo Sucre: "La errancia sin fin...", loc.cit., p. 36)

${ }_{980}$ Guillermo Sucre: "La nueva crítica", loc.cit., p. 263.

${ }^{981}$ Ibíd., p. 274. En base a este criterio, Guillermo situaba a Rodó en el origen de la crítica moderna en Latinoamérica, pues el ensayista uruguayo "tiende a liberar a la crítica de esa empobrecedora disyuntiva de afirmar o negar los valores de una obra, y la hace más bien participar en ellos" (Ibíd., p. 260)

${ }^{982}$ Guillermo Sucre: "Inscripciones de Francisco Rivera", loc.cit., p. 39. En ese texto, Sucre decía también que la crítica es "la mirada instantánea que sabe recrear y prolongar la vivacidad de la experiencia estética" (Ibid., p. 40)
} 
inicial: hacerlo presencia"983. La crítica es entonces una metáfora o una traducción de la experiencia (y no simplemente del mensaje ${ }^{984}$ ) de la obra-objeto a través de una visión nueva y de una nueva escritura.

En este sentido, Sucre estaba retomando los planteamientos de Roland Barthes, que había establecido que la crítica es una "especie de anamorfosis" de la creación literaria que consiste en desdoblar el sentido de la misma, haciendo "flotar un segundo lenguaje por encima del primer lenguaje de la obra"985. En esta superposición lo fundamental es la responsabilidad del crítico hacia su propia palabra pues, como dice Barthes, la crítica es "una lengua [la del crítico] que habla plenamente de otra lengua [la de la creación]” y “es así, finalmente, como se respeta la letra de la obra"986. Estas ideas llevan a concebir la crítica como una actividad esencialmente creativa y semejante, por tanto, a la literatura propiamente dicha. Por eso Guillermo, siguiendo al teórico francés, señalaba que "la crítica es un lenguaje que habla plenamente de otro": "con todos los poderes de la palabra, con su ambigüedad, su energía múltiple, su discurso y su silencio, con su fuerza erótica también" ${ }^{987}$. Como la verdadera materia del crítico son sus propias palabras, su escritura muestra una determinada actitud ante la obra-objeto y ante el lenguaje que es estrictamente simétrica a la que el escritor establece con respecto a los vocablos y a la realidad. Así como el literato revela una experiencia parcial del mundo

983 Guillermo Sucre: "Ramos Sucre: Anacronismo y/o renovación”, loc.cit., p. 81. En otro ensayo sobre el mismo autor Sucre afirmaba que aunque Ramos Sucre calificó ese texto de ensayo, era sin duda algo más: "una suerte de biografía novelada cuya prosa densa y vertiginosa logra no sólo resumir sino reasumir y reanimar el itinerario del sabio alemán en América, su pensamiento, los hallazgos de su mirada." (Guillermo Sucre: "La virtud antropófaga”, en Vuelta, México, núm. 166, sept. 1990, p. 49. Cursiva nuestra)

${ }_{984}$ Guillermo Sucre: "La nueva crítica”, loc.cit., p. 260. “a la crítica eficaz se la reconoce también por el hecho de ser la más inspirada. Es decir, aquella que al recibir el mensaje poético (que no hay que confundir con tesis o aberraciones de propaganda) no sólo lo esclarece e ilumina profundamente, sino que al mismo tiempo lo hace más resonante. Por ello quizá el fundamento de la crítica sea la creación." (Ibid., p. 260)

${ }_{985}$ Roland Barthes: Critica y verdad, op.cit., p. 66.

${ }^{986}$ Ibid., p. 76.

${ }^{987}$ Guillermo Sucre: "La nueva crítica", loc.cit., p. 265. La cita sigue: "La crítica es una erótica en tanto se funda en el placer del lenguaje. Este placer en nada disminuye la lucidez; por el contrario, introduce una relación aún más estimulante con la obra y el mundo." 
en un lenguaje particular, el crítico muestra en sus ensayos una vivencia relativa de ese universo igualmente inacabable que es la obra.

Si la crítica es al mismo tiempo análisis y participación -es decir, si resulta de la consonancia del sujeto y del objeto en una nueva experiencia creativa- es evidente que el crítico nunca puede establecer una significación definitiva de la obra ${ }^{988}$. Ello implicaría que niega la intervención del sujeto y que considera posible fijar el sentido del lenguaje. Al igual que sucedía en la relación del escritor con la realidad, Sucre piensa que la coincidencia plena entre la visión del crítico y la obra de referencia sólo se puede cumplir en un instante privilegiado, que es absoluto y relativo al mismo tiempo. Es absoluto porque cuando se logra un vínculo satisfactorio entre ambas entidades, el sujeto crea y alcanza momentáneamente el límite propuesto por la obra. Y es relativo porque esa creación y ese alcance dependen de la mirada del crítico y del sentido del lenguaje que, al ser eventos históricos, están inmersos en un proceso de transformación permanente. Como la significación de la obra depende siempre de una mirada, la verdad crítica sobre ella no se puede prorrogar sino que debe ser configurada en un nuevo instante en que tanto el sujeto con el objeto serán diferentes:

la obra es un absoluto que, sin embargo, sólo puede revelarse en la mirada; al mismo tiempo, ésta sólo puede captar un instante del absoluto que la obra le propone. Entre una y otra, por tanto, priva una relación de tácita complicidad: si la obra escapa de la mirada que trata de fijarla, no puede vivir sino como objeto de esa mirada; igualmente, si la mirada tiene en la obra su objeto ya dado, sabe de antemano que la validez de su mirar sólo reside en sí misma, en su capacidad para hacer de la obra la misma obra otra. ${ }^{989}$

En consecuencia, Guillermo piensa que la verdad estética es cambiante: "no corresponde a un principio objetivo; no es una sustancia, sino un sistema de relaciones: cambiante fluidez que va de la obra a la mirada, de la mirada a la obra"990. Asimismo, Sucre es consciente de que el significado de las palabras se transforma indefinidamente

988 A este respecto decía Sucre: "el crítico no pretende imponer un código de referencias inamovible y eterno; sabe, por el contrario, que su comprensión de la obra no sólo no es única sino también personal, y hasta la asume como aventura." (Ibíd., p. 261)

${ }_{989}$ Guillermo Sucre: "Poesía hispanoamericana y conciencia del lenguaje”, loc.cit., p. 608.

990 Ibid., p. 608. 
sin tener en cuenta la voluntad del escritor. Esa circunstancia -como nos lo enseña el cuento de Borges, "Pierre Menard, autor del Quijote"- impide la fijación de los textos y hace imposible reducirlos a un sentido final o absoluto. Según afirma nuestro crítico:

podemos fijar la literalidad de un texto, precisar con toda exactitud la significación de cada uno de sus componentes; sin embargo, ese texto sigue fluyendo: dice siempre algo más de lo que hemos creído, y demostrado, que decía; no importa: lo que estamos haciendo es traducirlo. ¿No es la lección que se desprende, justamente, de la experiencia de Pierre Menard, el personaje borgeano, quien, al proponerse escribir no un Quijote más sino el Quijote por excelencia, copia minuciosamente a Cervantes y, al copiarlo, sólo llega a postular, sin saberlo, una nueva significación? No hay texto fijo, ni susceptible de ser fijado. ${ }^{991}$

En este sentido, además de la de Borges, es evidente en Sucre la huella de Roland Barthes y de Octavio Paz. El teórico francés había establecido que "la variedad de los sentidos no proviene pues de un punto de vista relativista de las costumbres humanas; designa, no una inclinación de la sociedad al error, sino una disposición de la obra a la apertura; la obra detenta al mismo tiempo muchos sentidos, por estructura, no por la invalidez de aquellos que la leen" ${ }^{\text {992 }}$. Por su parte, Octavio Paz había indicado que "por tener vida propia", los significados de las obras literarias "cambian para cada generación y aun para cada lector. Las obras son mecanismos de significación múltiple, irreductibles al proyecto de aquel que las escribe" ${ }^{\text {"993. }}$.

${ }^{991}$ Ibíd., p. 609. Por eso se pregunta también en otra parte: “¿no tiende la obra a independizarse de su autor y a revelar significaciones que él no había previsto del todo? Es decir, ¿no hay en el propio lenguaje una energía intrínseca, una fuerza de contagio, que, lejos de ser esclavizante, actúa como una fuerza creadora?"(Guillermo Sucre: La máscara ...op.cit., p. 256)

${ }_{992}$ Roland Barthes: Crítica y verdad...op.cit., p. 52. En este texto Barthes indica además: "sea lo que piensen o decreten las sociedades, la obra las sobrepasa, las atraviesa, a la manera de una forma que vienen a llenar, uno tras otro, los sentidos más o menos contingentes, históricos: una obra es «eterna», no porque imponga un sentido único a hombres diferentes, sino porque sugiere sentidos diferentes a un hombre único, que habla siempre la misma lengua simbólica a través de tiempos múltiples: la obra propone, el hombre dispone." (Ibíd., p. 53). Y también: "la obra no está rodeada, designada, protegida, dirigida por ninguna situación, ninguna vida práctica está allí para decirnos el sentido que hay que darle; siempre tiene algo de «citacional»: la ambigüedad en ella es pura: por prolija que sea, posee algo de la concisión pítica, palabras conformes a un primer código (la Pitia no divagaba) y sin embargo abierta a muchos sentidos, porque estaban pronunciadas fuera de toda situación -salvo la situación misma de la ambigüedad: la obra está siempre en situación profética." (Ibid., p. 56)

993 Octavio Paz: "La excepción de la regla", en OOCC, Vol. VI, op.cit., p. 1422. Asimismo, en el "Prólogo" a la antología Poesía en movimiento (1966), el escritor mexicano establecía así la diferencia entre la concepción crítica que ponía en juego el volumen y planteamientos más tradicionales: "Las antologías aspiran a presentar los mejores poemas de un autor o de un período y, así, postulan implícitamente una visión más o menos estática de la literatura. Inclusive si admite que los gustos cambian, la crítica afirma casi siempre que las obras permanecen; aunque la visión de un crítico sea distinta de la de otro crítico, el paisaje que contemplan es el mismo. Este libro es inspirado por una idea 
En cualquier caso, ya sea por la variación de la subjetividad del crítico o por la modificación incesante de la significación de las palabras, Sucre piensa que la crítica literaria es un discurso inestable, que solo puede alcanzar la plenitud en un instante de comunión entre lo mirado y la mirada. Así como el texto literario sólo puede establecer una experiencia parcial de lo real, el crítico sólo comunica una vivencia relativa de la obra. Entonces tanto el autor de literatura como el crítico pierden la posibilidad de determinar, respectivamente, el sentido total de la realidad y el de la obra, y cada nueva escritura equivale a una nueva creación. Como ya sabemos, para Sucre no existen certezas definitivas: el escritor y el crítico han de conformarse con el parpadeo de esa verdad momentánea que adviene cuando sus miradas se funden con la realidad o con la obra.

distinta: el paisaje también cambia, las obras no son nunca las mismas, los lectores son igualmente autores. Las obras que nos apasionan son aquellas que se transforman indefinidamente; los poemas que amamos son mecanismos de significaciones sucesivas - una arquitectura que sin cesar se deshace y se rehace, un organismo en perpetua rotación. No la belleza quieta sino las mutaciones, las transmutaciones." (Octavio Paz: "Poesía en movimiento", loc.cit., p. 6) 


\section{CAPÍTULO VII}

\section{LA ESCRITURA CRÍTICA DE GUILLERMO SUCRE}

En este capítulo nos proponemos estudiar la escritura de Sucre a partir su propia concepción de la crítica. Según hemos visto en el apartado precedente, nuestro autor piensa que la crítica literaria debe recrear la vivencia imaginaria y verbal de la obraobjeto en una nueva experiencia creativa. Para ello el crítico ha de analizar la creación pero también participar en ella, es decir, que debe alcanzar la máxima saturación posible entre su propia mirada y el conjunto de textos que estudia. Cuando se produce una coincidencia plena entre el sujeto y el objeto, el crítico logra detener momentáneamente el sentido de la obra y volverlo presencia en una nueva expresión verbal. Al buscar esta concomitancia, la escritura de Guillermo encuentra en el ensayo literario su cauce ideal pues, como afirma Pozuelo-Yvancos, es en este género donde "se hacen solidarios los espacios del sujeto y del objeto de la representación, creando, con la invención, un espacio de creación imaginaria, que se sostiene en su propia verosimilitud"994.

Es esta continuidad que la crítica de Guillermo Sucre busca establecer entre lo mirado y la mirada lo que determina el carácter de su escritura ensayística. En primer lugar, como ya sabemos, nuestro autor concibe que la obra es un sistema coherente de relaciones cuya significación está controlada por la figura del autor. Si el conjunto de

994 José María Pozuelo-Yvancos: "El género literario ensayo", en Vicente Cervera (ed.): El ensayo como género literario, Murcia, Universidad de Murcia, 2005, p. 184. La conciencia de este cambio radical es ya patente en la obra de Montaigne. En el prefacio a los Essais, titulado "El autor al lector", el escritor bordelés indicaba que antes que el tema, lo que importa es el sujeto, su visión. Con ello quería decir que importan menos los temas que la perspectiva del autor ante ellos: "Si yo hubiere pretendido buscar el favor del mundo, me hubiera engalanado con prestadas hermosuras; pero no quiero sino que se me vea en mi manera sencilla, natural y ordinaria, sin estudio ni artificio, porque sólo me pinto a mí mismo." (Michel de Montaigne: Ensayos escogidos, México, UNAM, 1997, p. 31). Asimismo, en el capítulo "Del desmentir" (II, 18) Montaigne apuntaba: "No hice tanto mi libro como mi libro me hizo a mí; éste es consustancial a su autor [...]: parte de mi vida y no de una ocupación y fin terceros y extraños, como todos los demás libros." (Ibíd., p. 214). Como indica Pozuelo-Yvancos, en este fragmento se aprecia claramente cómo el escritor es consciente de que "yo y libro forman una unidad indisoluble, plenamente consciente, en el que el modelo de la escritura, tentativa, ensayo de explicación, perspectiva, crea al propio sujeto y lo convierte en medida de las cosas." (José María Pozuelo-Yvancos: "El género literario ensayo", loc.cit., p. 186). Como el asunto encarna en una forma, en una escritura, se produce una fusión entre el sujeto y el objeto y el ensayo deviene el espacio de una presencia. 
los escritos de una misma persona presenta unas características comunes y una cierta homogeneidad, y si la escritura crítica tiende a "reasumir y reanimar" el sentido de la obra, es evidente que el propio ensayo de interpretación estará estructurado también como un sistema. Ya que pretende ser la recreación de una experiencia creativa coherente, la escritura crítica tiende a reproducir esa misma coherencia: en ella, por lo tanto, la ruptura se resuelve en continuidad y el lenguaje tiende a volverse una imagen o un cuerpo total. En segundo lugar, Sucre es consciente de que la fusión entre el sujeto y el objeto que debe darse en toda crítica adecuada es simultáneamente relativa y absoluta. La contingencia de esa unión viene determinada por el hecho de que tanto la mirada que el crítico vierte sobre la creación literaria como el propio lenguaje y el sentido de la misma tienen una dimensión histórica, es decir, variable. Pero el hecho de que Guillermo reconozca la relatividad de toda crítica no implica que en sus ensayos no trate de alcanzar el límite propuesto por la obra. En ellos nuestro autor busca que el proceso de superposición crítica se dé con la máxima saturación posible: desde su perspectiva parcial quiere alcanzar la significación igualmente puntual de la creación que estudia, pero esa fusión circunstancial debe ser absoluta. En la práctica crítica de Sucre, la subjetividad del exegeta busca la objetividad de la obra y el texto es el resultado del encuentro entre esas dos entidades (intérprete y creación) que, aunque están girando y cambiando continuamente, coinciden en un instante de plenitud. Los ensayos críticos de Guillermo son por eso una suerte de work in progress: en ellos asistimos a la dramatización del proceso cognitivo, es decir, a un asedio incesante en que la mirada del sujeto busca aprehender el sentido propuesto por la obra. Su crítica, por tanto, no expresa simplemente una significación previamente establecida, sino que 
nos hace testigos de ese instante erótico en que los ojos del exegeta inventan y descubren en el presente de la escritura el cuerpo fugitivo de la creación ${ }^{995}$.

Vamos a estudiar los rasgos más importantes de la escritura de Sucre agrupándolos en tres apartados. En el primero de ellos veremos de qué manera los ensayos de nuestro autor, para mimetizar la coherencia de la obra, se estructuran como sistemas homogéneos en los que la ruptura y la sucesión tienden a volverse analogía y simultaneidad. En el segundo, trataremos más de cerca el proceso del insight crítico que tiene lugar en sus escritos, atendiendo en particular a las relaciones de la retórica con la metodología crítica. Y en el tercer apartado analizaremos la figura del lector modelo que está implícita en sus ensayos, lo que nos servirá para apreciar la posición enunciativa del ensayista. Además, a lo largo de este capítulo, haremos alusión a los parecidos que su escritura tiene con la de otros autores y, en particular, con la de Octavio Paz. Como es evidente, Guillermo toma muchos de sus recursos estilísticos del gran creador mexicano, aunque en su caso (debido a la voluntad de alcanzar los límites de la obra) estos rasgos escriturales se vuelven más intensos y "se pliegan” más sobre sí mismos. Para no interrumpir el hilo del discurso, señalaremos estas afinidades en las notas a pie de página.

\section{1. LA CRÍTICA COMO SISTEMA. LA DIALÉCTICA ENTRE EL MOVIMIENTO Y LA FIJEZA}

La escritura de Sucre tiende a volver presencia el sentido de la obra en una nueva experiencia creativa donde (idealmente) resulta imposible distinguir el sujeto y el objeto. Si nuestro autor concibe la creación literaria como un sistema coherente, el

${ }^{995}$ La escritura crítica de nuestro autor es la encarnación del presente perpetuo en que se funden el objeto y la mirada crítica en una vivencia original de lenguaje. Con palabras del propio Sucre, "en la relación entre obra y mirada crítica todo tiende a fundarse -para decirlo con una imagen de Octavio Pazen un presente perpetuo: instante absoluto que depende de ser relativo, y viceversa." (Guillermo Sucre: "Poesía hispanoamericana y conciencia del lenguaje", loc.cit., p. 608). A este respecto conviene recordar que, al igual que en el caso de la lírica, la "tensión discursiva" del ensayo asume "una temporalidad del Discurso que emerge como fuerza ejecutiva en el presente de su formulación y cobra desde ese presente toda su fuerza." (José María Pozuelo-Yvancos: "El género literario ensayo", loc.cit., p. 187) 
propio texto crítico tiene que reproducir esa misma homogeneidad. Por eso sus ensayos están gobernados por una serie de relaciones rítmicas que buscan hacer evidente la unidad de las diferentes partes (de la escritura crítica y de la obra de referencia, simultáneamente) y la del texto en su conjunto. La escritura de Guillermo tiende a controlar la proliferación incesante del lenguaje y trata de que el ensayo en su conjunto cristalice en una imagen. Para lograr esto intenta conjurar el carácter sucesivo de la expresión escrita a favor de la simultaneidad y el éxtasis, y vigila el avance del discurso para que cualquier ruptura o interrupción del mismo se resuelva en continuidad. Por eso su crítica presenta un vaivén "entre el movimiento y la fijeza"

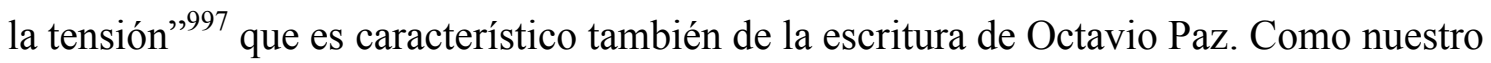
autor afirmaba a propósito de Piedra de Sol, sus propios ensayos son "un discurrir y una continua reiteración", es decir, que "su movimiento es extático: lo uno se disuelve en lo dual, lo cual se concentra en lo uno"998. Sucre piensa que "todo texto, y no sólo el universo, podría definirse en última instancia como una «metamorfosis de lo idéntico»" (431); por eso, la figura que mejor condensa el carácter de su escritura es la metáfora por contigüidad que él estudió en la obra de Paz. En ella, y también en los ensayos de

${ }^{996}$ Sucre advertía esta misma dialéctica en la obra de Octavio Paz: "las recurrencias no sólo son importantes en Paz porque muestren su pasión constructiva; lo son también, y sobre todo, porque él es un poeta de las recurrencias. Quiero decir: su obra es recurrente porque para él, el universo mismo lo es. La dialéctica entre el movimiento y la fijeza no es sólo un tema en su obra; llega a constituirse en su estructura misma y, por tanto, en la visión del mundo que ella encierra. «En perpetuo cambio, la poesía no avanza», afirma Paz. Pero recurrencia no quiere decir simple repetición. En Paz no se prolonga sino lo que, en sí mismo, es fuente de intensidad - de vivacidad, como él dice." (Guillermo Sucre: $L a$ máscara...op.cit., p. 209). También en Piedra de Sol nuestro autor aprecia una dialéctica similar: "Si la concepción del poema es la del tiempo cíclico, lo cual supone una relación mutua entre el movimiento y la fijeza, esa relación está encarnada en las formas mismas del poema. Éste se inicia con los versos arriba citados y concluye con los mismos: la repetición sugiere, por supuesto, el desarrollo de un ciclo que se cierra y a la vez se abre [...] En los tres primeros versos del pasaje, las imágenes combinan el movimiento y la fijeza: algo fijo (árbol bien plantado) que se mueve (mas danzante); los tres siguientes, en cambio, ponen en marcha el movimiento mismo, que toma la imagen del río: de manera inversa, es ahora el movimiento el que tiende a la fijeza: progresa regresando, se va haciendo circular y así llega a un final que es también un comienzo." (Ibíd., p. 222)

${ }^{997}$ Guillermo Sucre: "Entretextos", en En el verano cada palabra respira en el verano, Buenos Aires, Alfa, 1976, p.53.

${ }^{998}$ Guillermo Sucre: La máscara...op.cit., p. 223. A lo largo de este capítulo, los números de página de las citas de esta obra (Guillermo Sucre: La máscara, la transparencia, Caracas, Monte Ávila, $1^{\mathrm{a}}$ ed., 1975) se indicarán entre paréntesis en el texto. Además, a no ser que se indique lo contrario, las cursivas son nuestras. 
Guillermo, "los fragmentos se relacionan no tanto por semejanza o contraste previos, sino por contigüidad: están en un mismo espacio, se encuentran o se rechazan, desaparecen o se prolongan en otros; es a través de este movimiento como se van constituyendo en una verdadera trama"999 (234). Nuestro autor busca convertir la escritura crítica en un texto, es decir, en un tejido que enlace los diferentes hilos y concluya en una pieza armónica que sea capaz de reproducir la continuidad de la obra. Pasamos seguidamente a estudiar los mecanismos mediante los cuales Sucre logra esto. Primero abordaremos aquellos que tienden a establecer la continuidad en la frase o en el párrafo, y después los que tienden estructurar el discurso a un nivel más general.

$\mathrm{Al}$ acercarnos a los ensayos de Guillermo lo primero que llama la atención es la intensidad y la sensación de éxtasis que los recorre. La fluencia de la escritura no permite la interrupción, y la novedad y la diferencia se resuelven en analogía y en continuidad. Como el discurso es un manar que no cesa, el lector se ve envuelto por un ritmo incesante en que lo nuevo parte de lo ya mencionado y lo diferente es también semejante. A crear este efecto contribuye además el hecho de que sus ensayos nos muestran el proceso de un pensamiento pensándose. Como asistimos a la dramatización de una reflexión en presente, el discurso avanza a través de profundizaciones críticas sobre lo ya mencionado. Se da algo por sentado y a partir de ello se produce otro acceso crítico: la intensificación se prefiere a la ruptura y el nuevo punto de vista surge del anterior. De este modo, la escritura de Sucre (como él decía a propósito de Borges) se puede caracterizar como "un juego dialéctico entre [...] un sí y un pero" en el que "los

${ }^{999}$ En este sentido, parece que la concepción de la escritura de Guillermo se acerca asimismo a la de Lezama Lima: “"Como la fresa respira hilando su cristal», es uno de los versos de «Muerte de Narciso». La materia que, en su proceso mismo de gestación, va simultáneamente cristalizando. Tras el «verismo» de esta imagen se abre otra percepción más penetrante: cámbiese el vocablo fresa por (tan próximo, ¿no?) frase, y se tendrá la mejor metáfora de lo que es el lenguaje de la poesía para Lezama: un debate entre la fijeza y la evaporación. La poesía, en efecto, ya lo hemos visto, es un enemigo rumor, devora por su propia fascinación y continuamente se nos escapa. El poema, por tanto, no puede ser una mera sucesión de metáforas, sino, además, la creación de un cuerpo resistente, no evanescente, que es la imagen total." (Ibid., p. 200) 
sucesivos peros no funcionan como simples atenuantes: al oponer una resistencia al es (al si), crean una nueva perspectiva"1000 (290). En los ensayos de Guillermo este juego se da a través de toda una serie de mecanismos que detienen momentáneamente el discurso para emprender, a partir de la pausa, una nueva profundización del mismo. En ellos, como hemos dicho antes, lo diferente se resuelve en semejanza y el progreso queda limitado por una estructuración coherente: "lo uno se disuelve en lo dual, lo cual se concentra en lo uno".

La interrupción prepara un nuevo advenimiento, la fijeza es móvil y el movimiento se detiene: así la escritura se convierte en un sistema imbricado de relaciones que tiende a cristalizar en una imagen total. El dispositivo más simple que confiere a los ensayos de Sucre esa dialéctica característica entre la dispersión y la tensión es la yuxtaposición entre dos sintagmas u oraciones. En este sentido hay que mencionar el empleo de los dos puntos, que sirve para establecer una equivalencia entre diferentes términos u oraciones de manera que el contraste o la novedad, sin dejar de serlo, se resuelve en analogía. Como ejemplo de esto podemos mencionar los títulos de algunos de los ensayos de nuestro autor. Su texto "Ramos Sucre: la pasión por los orígenes" está estructurado en cuatro apartados, que se titulan respectivamente "La perfección: la fatalidad", "El sentido: la paradoja”, "El mal: la historia”, "La verdad: las máscaras"1001. Igualmente, dentro de La máscara, la transparencia, nos encontramos con los siguientes ensayos: "Vallejo: inocencia y utopía", "Borges: marginal, central", "Paz: la vivacidad, la transparencia", etc. Estos encabezamientos proponen la semejanza a partir de la divergencia y muestran además la igualdad que Sucre establece entre los autores y las experiencias que toman cuerpo en sus obras. Las mismas equivalencias se

${ }^{1000}$ En otra parte afirma, también a propósito de Borges, que "el pero [...] es el signo que relativiza lo que parece absoluto, vuelve reversible lo que parece irreversible." (Ibíd., p. 390). Las cursivas de la cita pertenecen al original.

${ }^{1001}$ Guillermo Sucre: "Ramos Sucre. La pasión por los orígenes", en José Antonio Ramos Sucre: Obra poética completa, México, FCE, 1999, pp. 9-38. 
aprecian dentro del propio discurso, donde muchas frases se aclaran a través de otras en aposición y también marcadas con dos puntos. De entre los innumerables fragmentos donde esto sucede podemos citar, por ejemplo, este: "Pero el ideal de justeza expresiva, en Huidobro, es sólo el comienzo de otro intento quizás más ambicioso: hacer del poema una arquitectura que se construye desde sí misma" (103). O este otro: "Como se ve, no tanto un nuevo lenguaje como una nueva manera de articularlo: lo fragmentario y lo total, la simultaneidad también, la superficie plana y la profundidad" (103).

Este recurso estilístico coexiste con el de la adición o "agregación”, que Miguel Gomes destacaba como "el método de exposición preferido" "1002 de La máscara, la transparencia. El profesor Gomes estaba en lo cierto, pues el estilo de esta obra y, en general, el de la ensayística de Guillermo es un proceso permanente de concreción crítica que avanza completando lo ya expresado. Ahora bien, esta tendencia que consiste en problematizar las propias conclusiones y en ahondar sobre lo establecido se lleva a cabo a través de diferentes mecanismos, y todos ellos contribuyen a conferir a la escritura el ritmo incesante que le caracteriza. A este respecto hay que mencionar las expresiones aditivas introducidas normalmente por adverbios como "además", “también”, "igualmente”, etc. En estos casos, la segunda proposición viene a completar lo ya dicho y a introducir una nueva perspectiva. Así, por ejemplo, nuestro autor afirma en un ensayo sobre Vallejo: "De nuevo, consagración de lo elemental, pero también, ahora, como una fuerza histórica. Se comprende que la plenitud que evocan estos

\footnotetext{
1002 Miguel Gomes señala que "el ritornello" es "el método de exposición preferido en el ensayo, que se construye más por agregación que por desarrollo lógico. Se asumen y reasumen premisas; los temas -claros, lúcidos, eso sí- son sometidos a variaciones sutiles o manifiestas." (Miguel Gomes: Poéticas del ensayo venezolano del siglo XX, Maracaibo, Universidad Católica Cecilio Acosta y Universidad del Zulia, 2007, p.194). Por su parte, Francisco Rivera indica que La máscara, la transparencia es fiel a su "método de temas y variaciones", y afirmaba también que la lectura de Sucre es "circular" puesto que en ella "un tema aparece, desaparece y repentinamente vuelve a aparecer, tal como por fin en sí mismo el incansable lector lo transforma, es imposible establecer una progresión espaciotemporal: la forma de la lectura envuelve lo leído tan íntimamente que sería una proeza separarlos." (Francisco Rivera: "Guillermo Sucre y la poesía latinoamericana" en Inscripciones, Caracas, Fundarte, 1981 , pp. 23 y 25 respectivamente)
} 
poemas es la expresión de un fervor revolucionario. Es obvio, además, que la marginalidad coincide con la concepción marxista de Vallejo y con su experiencia de militante comunista" (151). Lo mismo se aprecia en este fragmento en que nuestro autor está escribiendo sobre la poesía de Lezama Lima: "Esta idea es central no sólo por lo que ella contiene en sí misma: vale decir, la visión afirmativa que Lezama tiene de la literatura. Lo es también, y sobre todo, por la desmesura de esa visión" (181). Como se ve en ambos ejemplos, a partir de una idea establecida se produce un nuevo desarrollo que le sirve al crítico para acercarse al objeto y para que su insight logre la máxima precisión. Esta dialéctica entre la fijeza y el movimiento se aprecia también en el empleo de fórmulas contra-argumentativas del tipo "es...pero...”, o "no es...es...". Así tenemos, por ejemplo: "Es cierto que en algunos poemas se trata más de la comprobación de una ausencia a la vez que el enfrentamiento con una actualidad desolada [...] Pero con mayor frecuencia la memoria adquiere el sentido de la ubicuidad" (143). Y también: "No es la visión de la unidad, sin embargo, lo que prevalece en la obra de Parra. Lo que en ella prevalece es una voluntad disociativa y aun de aniquilamiento, lo cual se acentúa en sus textos más recientes y casi actúa como una fuerza ajena al autor"1003 (313). También con estas fórmulas, lo vemos, la novedad es el resultado de la continuidad o bien surge de ella.

El mismo efecto se logra con las anteposiciones del atributo o predicativo. En estos casos, Sucre inicia la oración con un adjetivo que tiene la función de resumir un

${ }^{1003}$ Estas estructuras que vemos en Sucre son constantes también en Octavio Paz, y es de él de donde nuestro autor las toma. Como los ensayos del mexicano nos muestran también el proceso de un pensamiento pensándose, en ellos se emplean las mismas fórmulas aditivas y contra-argumentativas. En la escritura de Paz son frecuentes también las aposiciones (introducidas por dos puntos, o por punto y seguido) que explican o aclaran el sentido de una frase anterior. Esta cita que copiamos a continuación ejemplifica ambos aspectos: "El romanticismo -dice el maestro de Guillermo- fue un movimiento literario, pero asimismo fue una moral, una erótica y una política. Si no fue una religión fue algo más que una estética y una filosofía: una manera de pensar, sentir, enamorarse, combatir viajar. Una manera de vivir y una manera de morir." (Octavio Paz: Los hijos del limo, op.cit., p. 89). Ambos mecanismos se ven también en este otro ejemplo: "La analogía concibe al mundo como ritmo: todo se corresponde porque todo ritma y rima. La analogía no sólo es una sintaxis cósmica: también es una prosodia.” (Ibíd., p. 95) 
contenido previamente expuesto y se sirve de él para proponer una nueva progresión del discurso. Me estoy refiriendo a casos como este: "Abstracta, no se trata, sin embargo, de una poesía de conceptos, sino de pensamiento" (238). O este otro: "Dramático, el monólogo del poema es igualmente vertiginoso: flujo de imágenes, motivos verbales, juegos del lenguaje, conceptos, confesiones" (123). Otras veces el término que se antepone está formado por un sintagma nominal: "Plenitud desterrada y lucha tenaz contra la muerte, lo imaginario en Sánchez Peláez es también una sabiduría para enfrentarse a la complejidad del mundo"1004. Y también: "Poemas sobre una guerra muy concreta, España, aparta de mí este cáliz no es un libro de circunstancias, como otros sobre el mismo tema de la guerra civil española"1005 (153). En todos estos ejemplos, como se ve, los adjetivos o los sintagmas antepuestos resumen un contenido expresado anteriormente o lo anticipan, y a partir de él emprenden un nuevo avance, lo que contribuye a generar ese vaivén característico entre el movimiento y la fijeza. Es frecuente, además, que este recurso coincida con un cambio de párrafo, en lo que parece un giro ya abiertamente lúdico e irónico por parte del autor. En esos casos, la ruptura del párrafo contrasta con la continuidad del discurso, con lo que, al tiempo que se genera sorpresa en el lector, el avance de la enunciación se hace depender de lo mencionado con anterioridad. Un ejemplo llamativo de esto último lo hallamos en el capítulo de $L a$ máscara dedicado a la obra de Octavio Paz:

De ahí que el último texto del centro (final del poema) no sólo sea la condensación recurrencia, valoración y resumen- de la temática del lenguaje, sino también de la erótica. Ambas, pues, finalmente se fusionan.

Pero se fusionan no sin antes enfrentarse en un contrapunto que hace aflorar la tensión que subyace a todo lo largo del poema y que Paz resume en esta fórmula (232)

${ }^{1004}$ Guillermo Sucre: La máscara, la transparencia, $2^{\mathrm{a}}$ ed., op.cit., p. 303. Cursiva nuestra.

${ }^{1005}$ La cursiva referente al título de la obra de Vallejo aparece en el original. Esta estructura también aparece en la obra de Paz. Por ejemplo: "Fin de un período o anuncio de otro, Bécquer y Rosalía viven entre dos luces; quiero decir: no constituyen una época por sí solos, no son ni el romanticismo ni la poesía moderna." (Octavio Paz: Los hijos del limo, op.cit., p. 118) 
En este ejemplo, como es fácil apreciar, el cambio de párrafo no se corresponde con la interrupción del discurso. Por el contrario, la pausa sirve para retomar la misma idea con una fuerza renovada y la ruptura aparente se resuelve en continuidad. Además, al principio del segundo párrafo vemos una estructura contra-argumentativa que mantiene la continuidad con respecto a lo afirmado previamente. Otro buen ejemplo lo tenemos en el ensayo "La poesía: una fértil miseria", que está dedicado a la poesía de Álvaro Mutis. En él se indica:

Voces malditas o inocentes, víctimas o cómplices, todas ellas van formando el enjambre sonoro, oscuro y también luminoso, de muchos de los poemas de Mutis. Son un conjuro y a la par una obsesión: si Mutis las escucha no es para convertirse en esa identidad un tanto pretenciosa que ahora llaman "testigo", sino por pura fascinación y hasta verdadera identificación.

Voces anónimas. Voces también de personajes anónimos que hablan de sus oficios. Ni prestigiosos ni anodinos, esos oficios se sitúan, sin embargo, en una cierta marginalidad: introducen en la opacidad lo imprevisible. (369)

Como vemos, la separación entre los párrafos se podría haber suprimido pues el tema del segundo insiste sobre lo señalado por el primero. Además, al comienzo del nuevo parágrafo aparece una estructura que permite recolectar lo dicho en el anterior ("Voces anónimas") y, a partir de ello, proponer un progreso ("Voces también...”). Estas interrupciones "arbitrarias" del discurso son visibles también a un nivel oracional, y contribuyen a conferir a la escritura esa alternancia característica entre el reposo y la continuidad. Es lo que se aprecia en este ejemplo, donde vemos además la fórmula contra-argumentativa que hemos mencionado más arriba: "La sobreabundancia puede ser en Lezama una gracia (en el sentido teológico) o un don. No es lo que importa. Importa más saber que él la asume como una manera de existir" (197).

Otro recurso que tiene consecuencias parecidas es el procedimiento al que vamos a llamar "de diseminación y recolección". Este mecanismo consiste en recopilar una serie de asuntos aparentemente dispersos tratados hasta un momento dado y plantear a partir de ellos un avance de la enunciación. Se trata, también aquí, de establecer una continuidad en la escritura y de hacer que lo nuevo surja como 
prolongación de lo precedente. Un ejemplo de esta técnica lo tenemos en el ensayo sobre Vallejo incluido en La máscara, la transparencia. Una vez estudiadas en él una serie de ideas por separado, Sucre las reúne para extender el discurso a partir de ellas: "Penuria existencial y social, desposesión del cuerpo y del mundo, dolor que lo trastoca todo, la enajenación penetra inevitablemente hasta la conciencia del hombre. Se produce, así, el desdoblamiento del sujeto poético" (148). Un caso semejante aparece en el estudio titulado "Lezama Lima: El logos de la imaginación". Después de tratar varias cuestiones de una manera dispersa, Sucre las agrupa para emprender un nuevo desarrollo: "Lo estalactito: agua grabada: mano con hojas (escritas) de nieve: el poema es fijeza" (200). En el mismo ensayo encontramos otro ejemplo de este mismo recurso: “Cuerpos visibles: relaciones invisibles creadas por el poeta: también en la obra de Lezama nos encontramos con lo que podríamos denominar, con palabras suyas, «lo semejante ancestral»»"1006 (201). Es así que nuestro crítico consigue establecer una relación entre aspectos diversos de una misma obra y logra que la continuidad se imponga sobre la ruptura.

A generar el ritmo incesante y la dialéctica entre el movimiento y la fijeza contribuye también la aparición de elementos inesperados. Con ellos se crea una expectativa que mantiene viva la intensidad de la escritura y que enfatiza la unidad del discurso. Esto lo logra Sucre mediante el empleo de citas textuales en posición inicial o sin previo aviso. Al introducir fragmentos literales de una manera sorpresiva, Guillermo nos introduce de golpe en la fluencia de la enunciación y consigue asimilar la novedad al ritmo de la escritura. El capítulo titulado "La metáfora del silencio" empieza así:

1006 Este procedimiento lo emplea también Paz: "Tentativa de la imaginación poética por repoblar las almas que había despoblado la razón crítica, búsqueda de un principio distinto al de las religiones y negación del tiempo fechado de las revoluciones, el romanticismo es la otra cara de la modernidad: sus remordimientos, sus delirios, su nostalgia de una palabra encarnada." (Octavio Paz: Los hijos del limo, op.cit., p. 119). Asimismo: "Modernidad antimoderna, rebelión ambigua, el modernismo fue un antitradicionalismo $\mathrm{y}$, en su primera época, un anticasticismo: una negación de cierta tradición española." (Ibid., p. 130) 
“«Enamorado del silencio, al poeta no le queda más recurso que hablar.» Ni inconsecuencia ni simple paradoja, mucho menos desilusión: esta frase de Paz encierra, más bien, otro sentido, que es una doble metáfora" (339). Vemos cómo el punto desde el que comienza a tejerse el discurso crítico es la frase exacta del autor mexicano: la irrupción y la sorpresa son el punto de partida para el despliegue de la escritura. De manera semejante, en el capítulo titulado "Paz: la vivacidad, la transparencia", se copia sin previo aviso la estrofa inicial del poema "Piedra de Sol" (1957) y solo después de esa irrupción se advierte: "Este pasaje es el comienzo de «Piedra de Sol». Es sabido que este poema tiene como trasfondo diversas significaciones míticas"1007 (221). Un recurso menos frecuente pero con consecuencias similares lo constituye la aparición repentina de frases cuyo sujeto se deja voluntariamente sin expresar. El caso más evidente lo tenemos al principio del ensayo que acabamos de citar sobre la obra de Paz. Hablando sobre "la vivacidad" Sucre indica:

No se trata tan sólo de un punto de vista teórico o filosófico, al margen de su creación; constituye, por el contrario, el impulso profundo de toda su obra poética. Una y otra vez aparece a lo largo de esa obra: "en las fronteras del ser y el estar,/ una vida más vida nos reclama", escribe en 1948: "busco una hora viva como un pájaro", en 1958. Igual perspectiva aparece en Ladera Este (1969). Es un poema escrito en la India y evoca una de sus ciudades sagradas; el personaje central es un sadú, asceta vagabundo que vive abstraído del mundo en pura contemplación de la eternidad (207)

En este ejemplo vemos cómo de repente se nos comienza a hablar de un poema como si conociéramos ya su título. Ello genera sorpresa en el lector y mantiene la sensación extática y la continuidad del discurso.

Además de los mecanismos que hemos visto hasta ahora, todos los cuales tienden a controlar la dispersión de la escritura y a crear un vaivén característico entre el movimiento y la fijeza, Sucre utiliza otro tipo de procedimientos que confieren coherencia al ensayo en su totalidad. Uno de ellos consiste en la estructuración de los

1007 Aunque en los ensayos de Paz no hemos encontrado estructuras tan sorpresivas como en Sucre es evidente que muchas veces nombra una idea polémica y comienza a tejer el discurso a partir de ella. Por ejemplo: "La modernidad es una separación. Empleo la palabra en su acepción más inmediata [...]" (Octavio Paz: Los hijos del limo, op.cit., p. 49) 
ensayos mediante hitos o "claves conductoras"1008 que establecen una igualdad entre diversos momentos del discurso. En el subcapítulo "Los números severos y apostólicos", que pertenece al estudio dedicado a la obra de Vallejo, la presencia de estas "rimas" es claramente visible. El apartado al que nos estamos refiriendo comienza así: “Trilce: palabra inventada" (139). En la página siguiente se repite lo mismo: "Ya lo decíamos antes: Trilce es palabra inventada" (141). Un poco después se apunta: "Ahora bien, Trilce es vocablo que encierra una significación numérica” (141). Y al comienzo del párrafo siguiente se insiste en lo dicho para propiciar un nuevo comienzo: "Trilce, como vocablo, encierra, en verdad, una significación numérica" (141). En el mismo ensayo tenemos otro caso semejante. Después de esta serie de alusiones al título de la obra más vanguardista de Vallejo, Sucre indica: “el tres vallejiano, sin embargo, no es tanto una síntesis como su búsqueda: una posibilidad siempre abierta, una dimensión nueva por encontrar" (141). Y a continuación señala: "El tres, por otra parte, es la posibilidad de un nuevo tiempo; no simplemente un futuro, sino un tiempo total que encierre y a la vez trascienda «las tres tardas dimensiones»» (142). Más adelante, cuando ya creíamos olvidada la referencia al tres, esta vuelve a aparecer: "El tres, decíamos, es la cifra dominante en Trilce: ello se hace perceptible hasta por el ritmo ternario de los temas del libro" (145). Este rasgo que, como vemos, aparece en repetidas ocasiones en el ensayo sobre Vallejo, está también presente en otros trabajos contenidos en La máscara. Así, por ejemplo, en el estudio sobre Vicente Huidobro, Sucre indica: "No es sino en los libros inmediatamente posteriores donde el lenguaje alcanza a unir la precisión con la intensidad; en ellos se cumple, además, otra alianza más importante: el pensamiento es la forma misma" (102). Tres páginas después se retoma la misma frase

1008 A propósito de "Piedra de Sol" Sucre indica: "Paz tiene una concepción rítmica de la metáfora: una llama a otra que a su vez llama a otra, en un juego sucesivo de des- y encadenamientos; además, esas metáforas se diseminan a todo lo largo del poema: aparecen, desaparecen y reaparecen como verdaderas claves conductoras. Podría decirse que es a través de ellas como se van delineando y las diversas secuencias que lo constituyen." (Ibid., p. 223) 
para prolongar sus implicaciones: "El pensamiento se hace forma, o es la forma misma.

Así también la experiencia del lector, como tal, ha de ser una experiencia formal" (105).

Un ejemplo más aparece en el apartado dedicado a Alejandra Pizarnik en el mismo libro. En un momento dado el autor afirma: "El infierno musical: título irónico y aun cruel, pero exacto. Decir que en él ya está prefigurado su suicidio [...] es decir mucho y muy poco" (362). En la página siguiente, Guillermo recupera la misma frase para insistir sobre algo que había quedado pendiente entonces: "El infierno musical, dije, es un título irónico y aun cruel, pero exacto: nos está hablando de la muerte en términos

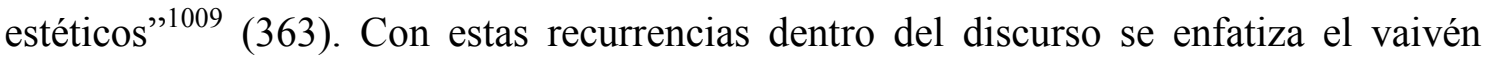
entre la dispersión y la tensión, el progreso de la enunciación da la impresión de interrumpirse y se genera una sensación extática que convierte (o tiende a convertir) el ensayo en un sistema cohesionado, en una imagen total.

Otra vía que emplea Sucre para hacer de su escritura una trama coherente consiste en estructurarla de un modo binario. Así, en el ensayo sobre Vallejo, Guillermo indica que España, aparta de mí este cáliz no es "el libro de ningún cambio personal sino el de una transfiguración y el de una revelación"1010 (153). A partir de estos dos

1009 En los ensayos de Paz también se aprecia esta estructuración. Como ejemplo de la recurrencia de una frase que sirve para dar cohesión a la escritura podemos citar, por ejemplo, el fragmento 4 de El mono gramático, que se organiza sobre la repetición de la frase "La fijeza es siempre momentánea". (Octavio Paz: El mono gramático, en OOCC, Vol. VII, op.cit., p. 547 y ss.) En otras ocasiones, Paz retoma también una idea que había mencionado previamente para completarla con nuevas ideas. Así, primero afirma: "Lo moderno no se caracteriza únicamente por su novedad, sino por su heterogeneidad. Tradición heterogénea o de lo heterogéneo, la modernidad está condenada a la pluralidad: la antigua tradición era siempre la misma, la moderna es siempre distinta." Y dos páginas después recupera esa misma idea: "Dije que lo nuevo no es exactamente lo moderno salvo si es portador de la doble carga explosiva: ser negación del pasado y ser afirmación de algo distinto." (Octavio Paz: Los hijos del limo, op.cit., pp. 16 y 18). Otro ejemplo similar es el siguiente. En un momento dado Paz afirma: "No es menos significativo que entre las obras centrales del verdadero romanticismo francés se encuentre Aurélia, la novela de Nerval, y un puñado de narraciones fantásticas de Charles Nodier." Más adelante, al inicio de un nuevo párrafo, el escritor mexicano rescata, para completarla, una idea previa: "Escribí más arriba: el verdadero romanticismo francés. Hay dos: uno el de los manuales e historias de la literatura, está compuesto por una serie de obras elocuentes, sentimentales y discursivas que ilustran los nombres de Musset y Lamartine; otro, que para mí es el verdadero, está formado por un número muy reducido de obras y de autores: Nerval, Nodier, el Hugo del período final y los llamados «pequeños románticos»." (Ibid., p. 98)

1010 Esta misma organización binaria del texto la vemos también en Octavio Paz: "En la concepción de Baudelaire aparecen dos ideas. La primera es muy antigua y consiste en ver al universo 
términos se organiza lo que resta del escrito: primero se trata de la transfiguración en sus diversas formas, y después de la revelación. Con este mecanismo también nuestro crítico logra controlar la proliferación del lenguaje y de la enunciación, y convertir el texto en un cuerpo homogéneo.

En lo que concierne a esta búsqueda de coherencia y continuidad hay que decir asimismo que muchos de los ensayos de nuestro autor tienen una estructura circular. A veces, en efecto, Sucre remite al principio desde el final de sus escritos, con lo que frena el avance del discurso y lo convierte en un espacio conexo y uniforme. Así, por ejemplo, cuando nos aproximamos al término del capítulo sobre Lezama Lima, Sucre regresa a una referencia citada al comienzo. Entonces nuestro autor afirmaba: "Hay un apólogo de Pascal al que Lezama alude en uno de sus ensayos y que es, en este sentido, revelador: la historia del náufrago que es recibido como el rey desaparecido y decide obrar como tal, sabiéndose impostor" (191). Páginas más adelante, cuando ya se acerca al final, dice Guillermo: “¿No regresamos de algún modo, en este poema, al apólogo de Pascal, ya citado al comienzo? En todo caso, es significativo que la justicia de que se habla en él esté signada por lo que aparentemente la contraría y aun la niega: la bastardía, el regicidio, el disfraz, la parodia” (205). De la misma manera, Sucre explica los últimos poemas de Huidobro a partir de una frase que este autor había empleado en los inicios de su obra, con lo que el círculo (de la escritura crítica y de la obra, simultáneamente) se cierra:

Es significativo, por su parte, que Huidobro casi al final de su labor creadora regresara no al «mensaje» sino a las palabras; volver a ellas, repetirlas, aislarlas, combinarlas: de este modo redescubría el lenguaje, no lo inventaba; aun las imágenes podían ser excluidas (al menos en su obsesión creacionista). Me parece que así intentó realizar algo que ya había intuido casi al comienzo de su obra. En efecto, en uno de sus primeros textos de estética («La Poesía», 1921), escribía esta frase, quizá más memorable que otras suyas inclinadas a la desmesura (¿demiúrgica?): «La poesía es el vocablo virgen de todo prejuicio; el verbo creado y creador, la

como un lenguaje. No un lenguaje quieto sino en movimiento [...]" Y en la página siguiente: "No es menos vertiginosa la otra idea que obsesiona a Baudelaire: si el universo es una escritura cifrada, un idioma en clave, «¿qué es el poeta, en el sentido más amplio, sino un traductor, un descifrador?»." (Octavio Paz: Los hijos del limo, op.cit., pp. 105 y 106) 
palabra recién nacida. Ella se desarrolla en el alba primera del mundo. Su precisión no consiste en denominar las cosas, sino en no alejarse del alba». (127)

Asimismo, al poco de comenzar el ensayo sobre Octavio Paz contenido en $L a$ máscara, Guillermo apunta lo siguiente: “A través de toda su obra persiste, en efecto, la pregunta que se hace en la nota preliminar de El Arco y la Lira (1956): «¿no sería mejor transformar la vida en poesía que hacer poesía con la vida?; y la poesía ¿no puede tener como objeto propio, más que la creación de poemas, la de instantes poéticos?»" (209). Y ya más adelante, en el último párrafo -última línea- del escrito se concluye contestando a esa pregunta: "la aparición del mundo - del mundo original, se entiendeimplica la desaparición del lenguaje y de la poesía. Vivir la poesía: escribir el mundo” (236).

Todos los recursos formales que hemos visto hasta ahora tienden a enfatizar la continuidad en el interior del discurso y a convertir la escritura en un absoluto verbal. Esta búsqueda de continuidad se aprecia también, por supuesto, en la manera de leer las obras literarias. A este respecto debemos destacar que Sucre establece constantemente analogías y diferencias entre segmentos de la escritura de un mismo autor que ponen de manifiesto la coherencia de sus creaciones. Así, en su estudio sobre Rubén Darío, por ejemplo, enlaza un verso del poema "Filosofía" ("Saber ser lo que sois, enigmas, siendo formas") con uno del "Coloquio de los centauros", texto al que se había referido anteriormente ("toda forma es un gesto, una cifra, un enigma") (43-44). Un poco después en el mismo ensayo nuestro crítico pone de manifiesto otra relación: “al mundo de la plenitud elemental que Darío evoca en «Filosofía» corresponde, pero como una réplica, el mundo de la conciencia dividida que se desarrolla en el poema «Lo fatal»" (44). En la visión de Guillermo, ya sea a partir de la semejanza o de la alteridad, la obra 
(y también, en consecuencia, la propia escritura del crítico) es el espacio de la correspondencia y de la continuidad ${ }^{1011}$.

Los vínculos que Sucre destaca entre diferentes partes de una misma creación pueden apreciarse también a un nivel más amplio. Así como la obra es un espacio coherente limitado por la "función-autor", el reino de la literatura es un entorno demarcado por la visión del crítico ${ }^{1012}$. En los ensayos de Guillermo los textos de un autor dialogan con los de otros creadores, de manera que todos ellos se encuentran en un mismo marco de relaciones. Los escritos contenidos en La máscara presentan multitud de comparaciones de este tipo, y un buen ejemplo de ellas lo tenemos cuando Sucre señala los parecidos (“a semejanza") y las diferencias ("pero") entre el Narciso del autor de Paradiso y el de dos escritores franceses: "A semejanza con el de Valéry, el Narciso de Lezama también muere, pero esta muerte no es la negación sino la necesaria expansión de la conciencia individual. A semejanza con el de Gide, el de Lezama se identifica con el universo, pero sacrificando su yo, su imagen" ${ }^{\text {1013 }}$ (193). También podemos citar los paralelos que nuestro autor establece entre Lugones y Laforgue: “Como él, también Lugones penetró en el mundo de los seres lunáticos: no sólo los literarios $[\ldots]$, sino sobre todo los de la vida cotidiana, contemporánea. [...] Pero

${ }^{1011}$ La confirmación de que el absoluto de la escritura quiere reproducir el de la obra estudiada nos llega cuando advertimos que en ciertos momentos la continuidad del discurso se quiebra. Sabemos que para Guillermo la obra es una relación necesaria entre lo que se dice y la manera de decirlo, y que este vínculo está en el origen de la continuidad discursiva que sus escritos quieren reproducir. Cuando el crítico se centra en rasgos puramente formales, la continuidad ética y estética de la obra se rompe y, por lo tanto, la escritura crítica no tiene más remedio que excluir esta enumeración del discurrir como si se tratara de una serie de hilos sueltos que exceden la tela de la escritura (y de la obra). Esto sucede precisamente cuando Sucre enumera rasgos puramente formales de una obra determinada (lo que sucede en Ibid., pp. 75; 118-119; 283-284)

1012 A este respecto nuestro autor señalaba: "la lectura nace de la pasión de un lector, pero esta pasión se subordina a otra mayor, que es la fidelidad a una determinada idea de la literatura." (Guillermo Sucre: “Inscripciones...”, loc.cit., p. 41)

${ }^{1013}$ Esta forma de establecer parecidos y diferencias, como ya sabemos, Guillermo la tomaba de Octavio Paz. Por ejemplo: "La figura de Fourier es central lo mismo en la historia de la poesía francesa que en la del movimiento revolucionario. No es menos actual que Marx (y sospecho que empieza a serlo más). Fourier piensa, como Marx, que la sociedad está regida por la fuerza, la coerción y la mentira, pero, a diferencia de Marx, cree que lo que une a los hombres es la atracción apasionada, el deseo." (Octavio Paz: Los hijos de limo, op.cit., p. 102. Cursiva nuestra) 
mientras en Laforgue ese descubrimiento parece estar ligado a una experiencia poética personal, en Lugones incluso por la evolución general de su obra, tiene mucho de elaboración sin consecuencias" (59). En otras ocasiones el vínculo se establece por contraste con un autor y por afinidad con otro: “A diferencia de Huidobro, que sólo se valió de la combinación de diferentes caracteres tipográficos, Tablada, como Apollinaire, emplea las formas manuscritas" (91). Guillermo, además, no renuncia a establecer comparaciones con otras artes. Así, indica que la descripción del fin del mundo en Vallejo se cumple "con la fuerza sobrecogedora de un Goya" (155) o que Herrera y Reissig "está más cerca del expresionismo que del impresionismo" "1014 (54). De este modo, no sólo el ensayo crítico (y la obra-objeto), sino también el conjunto de ensayos (y las distintas obras) establecen entre sí relaciones de afinidad y oposición, y tienden a devenir una imagen total que coincide con el libro en su conjunto.

\section{2. UNA MATEMÁTICA EXPRESIVA}

El hecho de que Sucre trate de convertir sus ensayos en un tejido coherente de relaciones capaz de reproducir la continuidad de la obra-objeto implica que tiene conciencia del lenguaje, es decir, que se sabe plenamente situado en el espacio de las palabras. En efecto, que sus textos estén surcados de relaciones rítmicas que tienden a resolverse en un cuerpo total supone que concibe la escritura como una "matemática expresiva" en que (como dice a propósito de Ramos Sucre) "las palabras se combinan entre sí según su propia necesidad interna, siguiendo un principio constructivo

${ }^{1014}$ Asimismo, Sucre establece un vínculo entre Martí y los pintores impresionistas: "Si no con los mismos dones de Darío, cultivó las combinaciones sensoriales y, sobre todo, tuvo conciencia de la luz en el poema, tal como los pintores impresionistas. ¿No había escrito un admirable ensayo sobre este movimiento?" (Ibíd., p. 32). Igualmente, indica que al formular el creacionismo, Huidobro "no hacía más que identificarse con una tradición estética muy anterior -Leonardo: la pintura es una cosa mental-, que resurgía y se intensificaba en el arte contemporáneo.” (Ibíd., p. 101) 
autónomo"1015. Puesto que el lenguaje no es un simple medio para comunicar un pensamiento previo, las ideas de Guillermo nacen y se ordenan de acuerdo a las estructuras de la sintaxis, lo que contribuye a controlar el discurso y a conferirle el ritmo que le caracteriza. Además, al reconocer y enfatizar el carácter sígnico de la escritura, Sucre pone de manifiesto el vacío que sostiene a las palabras. Si los vocablos no imitan el estilo "copioso de la realidad" sino el de "la imaginación" o "el deseo"1016, sólo pueden surgir del reverso que los constituye más profundamente: el silencio, la ausencia de lenguaje. Por eso su escritura resulta -como él afirmaba a propósito de Muerte sin fin (1939)- una "victoria en el vacío", es decir, "una arquitectura no simplemente rigurosa, sino de rigor y de claridad, detrás de la cual no hay nada" (300). Esto supone asimismo que Guillermo presenta una doble actitud de pasión y de crítica con respecto al lenguaje. Al enfatizar la materialidad de la escritura, nuestro autor revela al mismo tiempo su vacuidad; en ello, sin embargo, no hay que ver un rechazo del lenguaje sino un intento por depurarlo. Al "poner el acento en la palabra como significante" no trata "de arruinar la significación, sino de purificarla: hacer que las palabras recuperen su inocencia para que el sentido encarne de veras en ellas"1017 (127).

1015 Guillermo Sucre: "Ramos Sucre: La pasión por los orígenes”, loc.cit., p. 18. La cita sigue: "[...] Esto es, las palabras no exponen, no ilustran, mucho menos alegorizan un contenido previo que las rige; ellas mismas van creando su único contenido." (Ibíd.)

${ }^{1016}$ Ibíd., p. 18. Sucre identifica con el lenguaje tanto la imaginación como el deseo; por eso en un ensayo sobre Huidobro afirma: "El poeta busca crear un mundo desde su visión, no reproducir otro; no el mundo que existe, sino el que debiera existir, dice Huidobro. Ese mundo no está edificado, por supuesto, sobre la ética: ha de estar regido por la imaginación y el deseo, por el lenguaje." (Guillermo Sucre: La máscara...op.cit., p. 108)

${ }^{1017}$ En un texto que escribió a propósito de este tema en la poesía hispanoamericana, Guillermo indicaba que "el silencio" es "fascinación por el lenguaje, búsqueda de la Palabra", y aclaraba que "esa fascinación" implicaba "la exaltación de lo verbal" y la "reconquista de la energía original del lenguaje." (Guillermo Sucre: "Poesía crítica: Lenguaje y silencio", loc.cit., p. 593-594). En ese mismo ensayo dice: "El poeta habla sobre el silencio desde el silencio. El silencio es lenguaje, no simple mutismo o mero callarse; presencia de la palabra, no su ausencia." (Ibíd., p. 592). Del mismo modo, después de citar esta conocida sentencia de Paz ("Enamorado del silencio, al poeta no le queda más recurso que hablar") nuestro autor señalaba: "Ni inconsecuencia ni simple paradoja, mucho menos desilusión: esta frase de Paz encierra, más bien, otro sentido, que es una doble metáfora. Hablar a partir de la conciencia que se tiene del silencio, es ya hablar de otro modo: al reconocer sus límites, el lenguaje puede recobrar al mismo tiempo su intensidad." (Guillermo Sucre: La máscara...op.cit., p. 339). En estos dos fragmentos que hemos citado se advierte que Sucre considera que el silencio es una parte constitutiva del lenguaje; resulta 
A lo largo de sus ensayos nuestro autor marca deliberadamente (y con cierta ironía, a veces) que su pensamiento se ajusta a las estructuras formales del lenguaje. Esto se aprecia, por ejemplo, en la distribución binaria de las ideas de la que antes hablamos. Me estoy refiriendo a fragmentos como éste que Guillermo escribe en un ensayo dedicado a la obra de Ramos Sucre: “Aun sus confesiones son más inclementes e iracundas. Inclemencia: «Imagino constantemente la sensación del padecimiento físico, de la lesión orgánica». Iracundia: «Mi alma es desde entonces crítica y blasfema; vive en pie de guerra contra todos los poderes humanos y divinos»»"1018. O también a este otro:

La actitud de Machado, ya lo hemos dicho, no es aislada; representa una cierta perspectiva del arte. Machado no comprendía dos cosas cardinales del arte contemporáneo. Por una parte, que hubiese una sucesión (¡qué lógica!) de presentes que ni siquiera luchan contra el discurrir temporal: son sólo presencias, están allí, los vivimos, por su fulgor reencontramos el mundo. Por la otra, y como consecuencia, que el tiempo del poema no coincida con el de la historia -fugacidad y progresión lineal a la vez-. ${ }^{1019}$ (386)

En estos casos, lo vemos, las ideas se disponen a partir de una combinatoria formal precisa, con lo que se ve claramente que se ajustan al modo de ser de la sintaxis y no al de "la realidad". Esta estructuración permite además controlar la progresión del discurso, y que la nueva información se origine y dependa de la ya mencionada.

Además, al concebir la escritura como una trama coherente y superficial de signos que no remite a ningún otro lugar, Sucre pone de relieve el carácter material de la misma. Esto se advierte, por ejemplo, cuando plantea la posibilidad de revertir una frase determinada. En el ensayo dedicado a la obra de Roberto Juarroz en La máscara, Guillermo apunta: "Lo sagrado como lo humano -o al revés- no implica ninguna

imprescindible, por lo tanto, para que la palabra pueda recuperar su energía original, gastada por el uso y usurpada por el poder.

1018 Guillermo Sucre: "Ramos Sucre. La pasión por los orígenes", loc.cit., p. 30. Esta manera de organizar la escritura aparece también en los escritos de Octavio Paz.

1019 Este rasgo de estilo es también propio de los ensayos de Octavio Paz. Por ejemplo: "La reforma de la prosodia culmina en dos extremos contradictorios: los ritmos rotos y vivaces de Laforgue y Corbière y la partitura-constelación de Un coup de dés. Los primeros influyeron profundamente en los poetas de las dos Américas: Lugones, Pound, Eliot, López Velarde; con el segundo nace una forma que no pertenece ni al siglo XIX ni a la primera mitad del XX, sino a nuestro tiempo." (Octavio Paz: Los hijos del limo, op.cit., p. 98) 
trascendencia ni una nueva divinización" (244). Y también, en ese mismo texto: "lo que intenta esa transgresión es hallar en el lenguaje la relación entre el nombre y lo nombrado. Esa simple relación traerá consigo una nueva fundación del mundo y, por tanto, la conquista verbal de la realidad [...] ¿O será al revés? ¿Será, más bien, o simultáneamente, la conquista de la palabra desde el mundo?”(252). En otros casos, Sucre invierte directamente la frase para dar con el sentido que quiere comunicar. Así, por ejemplo afirma: "no el simple deseo de claridad, sino, más bien, la claridad como deseo"1020. O en este otro: "Más que la perfecta armonía, se trata de la armonía de la perfección" 1021 (314). En estos fragmentos apreciamos claramente cómo el pensamiento de Sucre se ajusta a las estructuras del lenguaje y se sabe limitado por ellas: es plenamente consciente de que está tratando con signos y no con cosas. Además, al enfatizar el carácter material de la escritura, estos ejemplos dejan entrever que detrás de las palabras no hay nada. Lo mismo sucede cuando nuestro autor yuxtapone vocablos con un significante similar pero con un significado diferente, como por ejemplo cuando dice: "Y creo también que en ello reside la tensión - el drama, la trama- de esta obra"1022 . En este caso, como vemos, el parecido de la forma contrasta con la diferencia del sentido: así nuestro autor exalta el valor material de las palabras y al mismo tiempo expresa un distanciamiento con respecto a ellas. Este desapego y esta ironía con respecto al lenguaje se aprecian asimismo en el empleo de paronomasias y aliteraciones, como en este ejemplo: "Por ello las imágenes en esta poesía nunca se extravían en la extravagancia; su misterio no excluye la exactitud de la formulación verbal"1023. Si bien

${ }^{1020}$ Guillermo Sucre: La máscara, la transparencia, $2^{\mathrm{a}}$ ed., op.cit., p. 302.

${ }^{1021}$ Estas inversiones son características del estilo de Paz.

1022 Guillermo Sucre: La máscara, la transparencia, $2^{\mathrm{a}}$ ed., op.cit., p. 72. Cursiva nuestra. Este recurso aparece también en Paz: "Poesía rimada y ritmada, no la prosa coloquial y viva, fuente de poesía, sino la oratoria y el discurso intelectual." (Octavio Paz: Los hijos del limo, op.cit., p. 97. Cursiva nuestra). Otro ejemplo puede ser: "A su vez, la tradición ocultista de los siglos XVII y XVIII se entronca con varios movimientos de crítica social y revolucionaria, simultáneamente libertaria y libertina." (Ibid., p. 101. Cursiva nuestra)

${ }^{1023}$ Guillermo Sucre: La máscara, la transparencia, $2^{\mathrm{a}}$ ed., op.cit., p. 75. Cursiva nuestra. 
este recurso no es muy utilizado por Sucre, sí es revelador -junto a los otros procedimientos que acabamos de ver- de su actitud con respecto a las palabras. En efecto, también en este caso, la forma parecida contrasta con la variación del significado, con lo que el escritor pone de manifiesto la vacuidad que se halla detrás de los vocablos. Si bien es evidente que en la obra de Oliverio Girondo estos experimentos son más constantes y más extremos, lo que Sucre afirma sobre él puede servir para iluminar su propia actitud. El poeta argentino, nos dice Guillermo, "se vale de los poderes mismos del idioma, como el continuo uso de las aliteraciones; pero estas analogías fonéticas no vienen a subrayar una analogía semántica, sino, por el contrario, estimulan la contradicción o, en último caso, parodian toda coherencia del significado" (277). Al poner de manifiesto la falta de sentido de los vocablos, nuestro autor busca recuperar la plenitud original del lenguaje y rescatar una palabra no corrompida por la historia.

La escritura crítica de Sucre presenta pues la misma oscilación entre "la fascinación y el rechazo" (255) que él observaba en el escritor moderno: "Por una parte, -decía- quiere llevar al lenguaje a su máxima posibilidad expresiva; por la otra, tiene conciencia no sólo de la máxima imposibilidad de lograrlo, sino también del equívoco que encierra la expresividad misma" (256-257). Al ser consciente de que está tratando con palabras y no con la realidad, nuestro autor ajusta su discurso al modo de ser del lenguaje y mantiene una actitud de pasión y de crítica con respecto a él. Es además esta percepción de la escritura lo que le permite concebir el ensayo crítico como un sistema de continuidades parciales que oscila entre el movimiento y la fijeza y que se resuelve en un cuerpo total que reproduce la coherencia de la obra que estudia. 


\section{3. EL TONO DUBITATIVO Y LA BÚSQUEDA DE LA PRECISIÓN CRÍTICA}

En este apartado nos proponemos estudiar el tono dubitativo y conversado que se aprecia en la escritura de Guillermo Sucre. La crítica más autorizada ha explicado esta modulación como una consecuencia de la falta de sistematicidad y de rigurosidad que recorre los ensayos de nuestro autor. Así, María Fernanda Palacios reconocía que él establece con las obras una relación indagatoria que abre una "posibilidad infinita" de diálogo:

La relación que Guillermo Sucre instaura con cada obra es el punto de partida para su reflexión, esa relación no es la del que "conoce" sino la del que explora y descubre. Al examinar una obra, Guillermo Sucre se mueve en torno a ella, su mirada la moviliza, su constante interrogación instaura un diálogo con otras obras, con la cultura, con el lector, consigo mismo. Por eso ninguno de sus trabajos apunta a una construcción cerrada; por el contrario, se afinca en la posibilidad infinita del diálogo. Esa invención del objeto de estudio -que es también un invencionarse- es el signo más evidente, más arduo también, del trabajo del ensayista. ${ }^{1024}$

Por su parte, Miguel Gomes, en su estudio sobre el ensayo venezolano del siglo

XX, asumía de entrada que la escritura de Sucre era fragmentaria y explicaba que esta

falta de sistematicidad era una respuesta de nuestro autor a esa "otra" tradición

hispanoamericana que funda secretamente el discurso de La máscara, la transparencia:

El «antagonista» [Neruda y quienes comparten su poética] cataloga la realidad americana (9); hace inventario de ella (18); la abarca: es decir, tiene en la mira una empresa totalizadora. La mejor forma de ofrecer alternativa a tal desmesura no es únicamente rastrear y conocer lo hecho por los poetas que La máscara estudia, desde Darío a Borges o Paz, sino avenirse con un registro incompleto, fragmentario del decir (85-9). [...] El texto no total [La máscara] ha sido el resultado de poner a prueba e ironizar la ambición contraria: el texto-todo, el texto-mundo. ${ }^{1025}$

Desde nuestro punto de vista tanto la apreciación de Palacios como la de Gomes se quedan en lo superficial y resultan, por tanto, insuficientes. El desenfoque de su perspectiva se debe principalmente a dos motivos. En primer lugar, estos investigadores se han contentado con creer lo que nuestro autor dice defender y no han profundizado hasta ver lo que efectivamente defiende. En efecto, el propio Sucre ha tratado de

${ }^{1024}$ María Fernanda Palacios: "Miserias y fulgores del ensayo en la Venezuela de hoy", en Sabor y saber de la lengua, Caracas, Monte Ávila, 1985, p. 116. Cursiva nuestra.

1025 Miguel Gomes: Poéticas del ensayo...op.cit., pp. 194-195. Cursiva nuestra. Según este profesor, la escritura de esta obra sería simplemente "un distanciamiento, una búsqueda de perspectivas con respecto al realismo como lo entienden los imitadores de Neruda”. (Ibíd., p. 195) 
enmascarar discursiva y retóricamente su posición de autoridad y, con ella, su intención de definir patrones estéticos y políticos para la cultura continental. En segundo lugar, la actitud (supuestamente) incierta de la escritura de Guillermo se presta a establecer relaciones fáciles con la definición transhistórica del ensayo como un género contrario a la objetividad científica y también con el contexto "posmundonovista"1026 en que su creación se inserta. Para estos profesores, en suma, hay una correspondencia precisa entre los postulados éticos y estéticos de nuestro autor, la condición del ensayo y el contexto venezolano de la segunda mitad del siglo XX.

Pero nosotros pensamos, por nuestra parte, que el tono vacilante y dialógico de los ensayos críticos de Sucre encubre la actitud contraria. En ellos hemos apreciado que el recurso a la duda contrasta con la búsqueda obsesiva de la perfección crítica, que, como ha dicho Barthes, es siempre asertiva ${ }^{1027}$. Entonces, el estilo de sus textos resulta en cierto sentido contradictorio, pues si, por un lado, vemos en ellos a una instancia enunciativa que se muestra incapaz de establecer una certidumbre absoluta, por el otro, percibimos que esa misma instancia busca incansablemente los límites de la obraobjeto, es decir, una saturación entre su mirada y la creación de referencia. Por lo tanto, contrariamente a lo que han hecho hasta ahora sus mejores exegetas, creemos que es imprescindible concebir la obra de Sucre como crítica literaria y vincularla a su propia

${ }^{1026}$ Los principales estudiosos del ensayo venezolano del siglo XX -Óscar Rodríguez Ortiz y Miguel Gomes- han señalado que los ensayos críticos de Guillermo Sucre se enmarcan en el periodo que ellos llaman, respectivamente, "segunda contemporaneidad" o "posmundonovismo", que abarcaría aproximadamente desde los años cincuenta a los ochenta del siglo XX. (Vid. Miguel Gomes: Poéticas del ensayo...op.cit., pp. 155 y ss. y Óscar Rodríguez Ortiz: Paisaje del ensayo venezolano, Maracaibo, Universidad Cecilio Acosta, 1999, p. 59 y ss.). El problema de la crítica historiográfica es que, a veces, en vez de estudiar las obras en sí mismas, impone sobre ellas las constantes del género, del contexto o de la escuela a la que supuestamente pertenecen.

1027 "Otra separación entre el lector y el crítico; en tanto que no sabemos cómo un lector habla a un libro, el crítico está obligado a tomar cierto «tono», y ese tono, sumando y restando, no puede ser sino afirmativo. El crítico puede muy bien dudar y sufrir en sí mismo de mil maneras y sobre puntos imperceptibles para el más malévolo de sus censores, pero no puede finalmente sino recurrir a una escritura plena, es decir, asertiva. [...] La escritura declara, y por eso es escritura. ¿Cómo podría, sin mala fe, ser la crítica interrogativa, optativa, o dubitativa, puesto que es escritura y que escribir es precisamente encontrar de nuevo el riesgo apofántico, la alternativa ineluctable de lo verdadero/falso?" (Roland Barthes: Critica y verdad, op.cit., p. 81) 
noción de esta disciplina. A pesar de las conclusiones aceptadas, aquí estudiaremos los ensayos de nuestro autor no a partir de lo que dicen defender o de los rasgos más visibles del estilo sino desde su método crítico y desde los objetivos que ese método se impone.

En el apartado anterior dedicado a la concepción sucreana de la crítica hemos visto que nuestro autor pensaba esta disciplina como la coincidencia, en un instante de plenitud, de la subjetividad del crítico con el sentido de la obra. Su escritura trata precisamente de revelar ese momento (absoluto pero fugaz) en que las palabras del crítico crean y alcanzan el límite propuesto por la creación literaria, y en que lo mirado y la mirada dejan de ser términos distinguibles. Su crítica quiere obtener la máxima precisión, es decir, la saturación (la desaparición) del sujeto y del objeto en el cuerpo del lenguaje. Esto no significa que quiera hacer de su acercamiento a la obra una verdad inamovible: Guillermo es consciente de la relatividad de su empresa pero quiere que su aproximación sea lo más perfecta posible.

Entonces, en los ensayos críticos de Sucre asistimos a la dramatización de un pensamiento (y de una enunciación) que busca alcanzar el absoluto de la obra y encarnarlo en una nueva experiencia creativa. Por eso consideramos que el tono vacilante que recorre su escritura no es tanto una voluntad de afincarse "en la posibilidad infinita del diálogo", como dice Palacios, o de distanciarse de los autores mesiánicos y representativos del continente, como propone Gomes. Nosotros creemos que la expresión indecisa revela en verdad el proceso de concreción crítica, es decir, el avance de una mirada que busca los límites de la obra-objeto y que quiere comunicarlos convenientemente. Pensamos, por eso, que el talante dubitativo de su escritura no indica una falta de sistematicidad, sino todo lo contrario. Si Guillermo emplea fórmulas que revelan indecisión no es porque se aviene con un decir incompleto o fragmentario, sino, 
bien al contrario, porque su pensamiento y su escritura pretenden acercarse a la obra lo máximo posible. La indecisión que recorre sus ensayos es sólo aparente: la duda es una estrategia para aproximarse cada vez más al sentido (relativo, inestable) de la creación y para atenuar esa búsqueda de la máxima saturación que rige la enunciación del crítico. Entonces, el tono dubitativo es una estrategia discursiva de la que se vale Guillermo para aprehender el sentido de la obra pero también un recurso que le sirve para aparentar una relatividad que su propio método excluye.

Como en nuestra lectura vinculamos la escritura de Sucre a su propia concepción de la crítica literaria, planteamos que las fórmulas dubitativas que hay en ella son parte del proceso de enfoque de su mirada crítica. Así, el tono vacilante sería el resultado de una subjetividad que busca obsesivamente la coherencia de la obra que analiza. En sus ensayos, el escritor dramatiza su propia reflexión y su propio lenguaje y vuelve presencia el proceso de superposición entre lo mirado y la mirada. Por eso nos encontramos con muchas expresiones que evidencian que el análisis no ha concluido como, por ejemplo, en este fragmento donde Sucre declara que la obra de Macedonio

Puede evocar muchos textos del pasado; también es verdad que parece prefigurar o coincidir con otros: por ejemplo, los de Lezama Lima (¿quién ha escrito con más intensidad que ellos sobre la muerte como presencia?) y los del último Juan Ramón Jiménez. No afirmo esto último de manera definitiva, pero es una relación que me parece tener cierta (¿secreta, oblicua?) validez. (76)

Asimismo, en el ensayo sobre Roberto Juarroz indica:

Poesía inteligente, no simplemente intelectual. Lo abstracto en ella (como cuando se habla de pintura abstracta) está muy lejos de todo simbolismo conceptual. Aún me pregunto si lo que ella quiere revelar no es, en definitiva, una materialidad original, más pura o más real, no una mera significación de esa materialidad. (241-242)

También el empleo de términos incidentales como "creo", "me parece", etc. nos muestra que estamos ante un proceso en que la reflexión del crítico quiere lograr el sentido de la obra creado por su propia visión. Como nos encontramos ante un auténtico work in progress, el tono es necesariamente inseguro y vacilante. Es lo que se aprecia en este ejemplo: 
Según Pessoa, estos poetas son más complejos en la medida en que no se expresan sino construyendo, estructurando. Complejidad estética y espiritual también: disciplina de la forma y la forma como disciplina. Es así, creo, como el propio Paz lo ve. «La moral del escritor -diceno está en sus temas ni en sus propósitos sino en su conducta frente al lenguaje». (209)

Y también en este otro:

De ahí que en la poesía de Lezama sea dominante la metáfora del discurso en relación con el mundo. «En una misma agua discursiva / se bañan el inmóvil paisaje y los animales más finos», dice en un poema; en otro, habla del «discurso del fuego acariciado». Con lo cual sugiere que no sólo vemos el mundo a través del lenguaje sino que, además, lo vemos como lenguaje. Un lenguaje, creo, que en Lezama es sobre todo el de la memoria. O, mejor, que es el lenguaje como memoria. ${ }^{1028}(202)$

Este tipo de expresiones dubitativas aparece además a menudo en estructuras contra-argumentativas (“no es...es...”; “es...pero...”, etc.) que, como hemos visto más arriba, tienen la función de conciliar la escritura con la obra para que el suplemento no tenga lugar. A este respecto, hablando sobre el "Coloquio de los centauros" de Darío, Guillermo indica: "No creo que sea insignificante aludir a estas dos impresiones de luz y sonido; me parece que ellas anuncian, y al final reiteran, una suerte de acoplamiento cósmico que es como el trasfondo de todo el poema: el universo es armonía visual y también rítmica” (36). Asimismo, a propósito de la obra de Borges, señala nuestro autor: "El poeta nace con experiencia, decía Baudelaire. No sé si ello será verdad del todo. Creo sólo que lo que ha experimentado Borges parece vivido primero en su obra" (162). En este sentido podríamos traer aquí a colación todos los mecanismos que hemos estudiado en el apartado anterior, muchos de los cuales son un resultado del método crítico de Sucre y confieren a la escritura ese vaivén característico entre el movimiento y la fijeza. Hay que decir, además, que el yo crítico no sólo muestra incertidumbre en lo

\footnotetext{
1028 Este proceso de concreción crítica se aprecia también en los ensayos de Paz, donde el hablante trata constantemente de ajustar la reflexión y la enunciación a lo que verdaderamente quiere decir. Por ejemplo: “Al cambiar nuestra imagen del tiempo, cambió nuestra relación con la tradición. Mejor dicho, porque cambió nuestra idea del tiempo, tuvimos conciencia de la tradición." (Octavio Paz: Los hijos del limo, op.cit., p. 24. Cursiva nuestra). O también: "Según me propongo mostrar en lo que sigue, hay una íntima conexión entre el verso inglés y alemán -mejor dicho: entre los sistemas de versificación de ambas lenguas- y los cambios que introdujo el romanticismo en la sensibilidad y en la visión del mundo." (Ibíd., p. 94. Cursiva nuestra). También, por supuesto, con todos los mecanismos que hemos citado antes, como por ejemplo: "Pero en 1800, como más tarde en 1920, lo nuevo no era tanto que los poetas especulasen en prosa sobre la poesía, sino que esa especulación desbordase los límites de la antigua poética" (Ibid., p. 91. Cursiva nuestra)
} 
que concierne a las ideas sino también (¿no son ambos aspectos inseparables?) a la propia enunciación. En muchas ocasiones, Guillermo duda sobre la manera apropiada de traducir al lenguaje el resultado de la reflexión crítica. Así tenemos: “en la poesía de Braulio Arenas aparece una suerte de ¿cómo decirlo? perplejidad y encantamiento frente al amor" (407). Lo mismo sucede en el ensayo sobre Huidobro, donde señala que “el sufrimiento visto en la guerra le comunica - ¿cómo decirlo?- una suerte de sabiduría y lo enfrenta más a la condición humana" (124). En otros casos, la instancia enunciativa cuestiona lo que acaba de decir y quiere complementarlo desde una nueva perspectiva. Así, por ejemplo, afirma sobre Hinostroza que

con verdadero dominio, y aun maestría, pasa de lo lírico a lo coloquial, a lo narrativo, o a lo meramente enunciativo; aun su escritura no es sólo fonética sino también "simbólica", en este sentido: usa (¿y abusa?) de ecuaciones algebraicas, de símbolos biológicos, de fórmulas del ajedrez (337)

O también:

Este grado de conciencia es lo que Girri llama igualmente magnitud cero: punto inmóvil del que, sin embargo, emana todo movimiento ("centro de la rueda", "pasivo / centro que hace posible / la rotación"); ese punto, por otra parte, es una aproximación (¿una conquista?) de la verdad ("en el cero no existe error"). ${ }^{1029}$ (348)

En estos incisos el yo crítico vacila sobre la enunciación en la enunciación misma, y lo que eso revela es una voluntad de alcanzar la máxima precisión crítica y de lograr que las palabras hagan justicia a lo que se quiere comunicar.

Como decimos, según nuestra hipótesis, el tono vacilante que se advierte en los ensayos de Guillermo es un resultado del proceso de concreción crítica. En consecuencia, cuando la instancia enunciativa consigue establecer la significación de una obra o de un aspecto de la misma adopta una actitud segura de sí misma y entonces las expresiones de duda se emplean para encubrir o enmascarar la certeza alcanzada. La

1029 Este tipo de reflexiones meta-enunciativas también aparecen en la escritura de Paz. "la segunda [Rosalía] es una escritora no menos intensa que Bécquer y quizá más extensa y enérgica (iba a escribir viril, pero me detuve: la energía también es mujeril)." (O. Paz: Los hijos del limo, op.cit., p. 118). También: "Los superficiales han sido los críticos que no supieron leer en la ligereza y el cosmopolitismo de los poetas modernistas los signos (los estigmas) del desarraigo espiritual." (Ibíd., p. 127) 
seguridad que en esos casos alcanza el hablante ensayístico se aprecia en fragmentos como este:

Pero ¿no sería demasiado monótono un libro que se limitase sólo a tal negatividad? ¿O no se convertiría ésta en otra forma de laberinto: salvar las falsas "rutas" y aun enunciar la verdadera pero sin llegar a hacerla cuerpo del poema? La pregunta es retórica, sólo que de algún modo refleja el debate entre el lector y esta poesía. Despejo las dudas. A ese debate nos incita ella misma, lo que ya es un signo de su intensidad. ${ }^{1030}$

En otros momentos, la voz del crítico se permite incluso ironizar desde la posición privilegiada desde la que controla el discurso. Así, en el ensayo sobre Lezama Lima, tras citar este hermético párrafo del escritor cubano

La certeza del naufragio es aquí la correspondencia al encuentro del rey falso, aceptado violentamente en la necesaria fatalidad de su falsía. He aquí una grandeza que va por encima del ceremonial y del acto de escoger. Devolver en el hombre es intuir el escoger de los dioses. El único indicio que podemos tener de ese escoger de la divinidad, es su correspondencia con el devolver de los humanos. Luego ese devolver es la raíz de la imagen. Devolver con los dones acrecidos en el don de la gracia.

Sucre indica:

Ya sé que es innecesario advertirlo, pero quiero simplemente subrayarlo: ese impostor es el poeta mismo. De ahí que Lezama titule su último libro de poemas con el nombre de Dador (1960). El poeta, en efecto, para él, es siempre un dador y lo que cuenta en su obra, o en su destino, es el acto mismo de dar y no lo dado (191-192)

En estos ejemplos, como se ve, la incertidumbre ha desaparecido. Como es el propio ensayista el que crea e inventa los límites de la obra es él también el encargado de establecer las conclusiones (relativas y absolutas simultáneamente) sobre ella. Vemos, sin embargo, que muchas veces la certeza obtenida por el crítico se acompaña de palabras incidentales que tendrían, en este caso, la intención de disimular su suficiencia. Así tenemos: “Creo que estas técnicas verbales tratan de aumentar no tanto el poder expresivo del lenguaje como su poder lúdico y, además, expansivo. Aún se intenta, en momentos, hacer esto muy explícito" (119). O también: "Es evidente, me parece, que a Borges habría que situarlo (como a Kafka) en el contexto de una literatura quijotesca. Por muchas razones" (169). En estos fragmentos, las expresiones dubitativas

${ }^{1030}$ Guillermo Sucre: La máscara, la transparencia, $2^{\mathrm{a}}$ ed., op.cit., p. 306. Cursiva nuestra. 
("creo que", "me parece") contrastan con la certidumbre alcanzada por la mirada crítica ("se intenta [...] hacer esto muy explícito"; "es evidente", "por muchas razones").

Esta misma ambivalencia entre la obtención de la saturación crítica y la voluntad de rebajar el tono concluyente se advierte en el empleo de preguntas retóricas. En los ensayos de Sucre es frecuente que la interrogación tenga un valor asertivo y que el escritor se sirva de ella para atenuar la expresión de la certidumbre, que de otro modo podría resultar excesivamente pretenciosa y contundente. Así, por ejemplo, vemos que en este ejemplo la pregunta sustituye lo que podría ser una oración afirmativa: "El amor es algo más que una experiencia, espiritual o corporal. ¿No es igualmente una mitología y una mitología que incluso comienza por la de la palabra misma? «Si pronuncian la palabra amor, estoy perdido», decía uno de los personajes de Stendhal cuando ve a su posible rival hablar con su amada"1031 (396). Otras veces, las interrogaciones aparecen en parejas: la primera de ellas cuestiona algo indicado previamente y la segunda tiene ya una función afirmativa, con lo que estamos de nuevo ante ese vaivén característico entre la dispersión y la tensión del que hemos tratado más arriba. Así, en este ejemplo, nuestro autor dice a propósito de Juarroz:

Su propia poesía ¿no será el intento por reencontrar el término desaparecido, por hacer que la metáfora rescate su fundamento inicial? ¿O se tratará de algo todavía más radical y desmesurado, como en toda la poesía contemporánea: hacer que el segundo término de la metáfora, contrariando toda causalidad, sea el que origine al primero, lo invente y al inventarlo lo haga de nuevo original? De ahí que su poesía se presente como una manera de ver: no sólo las cosas sino también lo que rige a las cosas. Lo sensible y lo inteligible. (242)

O también:

El poema evoca el primer encuentro, fortuito, con la mujer en un día de mal presagio: un día 13, de ahí su título; pero, como en esos encuentros en que lo fortuito se vuelve

${ }^{1031}$ En Octavio Paz las interrogaciones tienen muchas veces un valor similar: "Los románticos hacen del sueño «una segunda vida» y, aún más, un puente para llegar a la verdadera vida, la vida del tiempo del principio. La poesía es reconquista de la inocencia. ¿Cómo no ver las raíces religiosas de esta actitud y su íntima relación con la tradición protestante? El romanticismo nació en Inglaterra y Alemania no sólo por haber sido una ruptura de la estética grecorromana sino por su dependencia espiritual del protestantismo." (Octavio Paz: Los hijos del limo, op.cit., p. 92). También: "Incluso si no se comparte un punto de vista tan extremo, ¿cómo ignorar que las épocas que llamamos decadentes son con frecuencia ricas en grandes poetas? Góngora y Quevedo coinciden con Felipe III y Felipe IV, Mallarmé con el Segundo Imperio, Li Po y Tu Fu son testigos del colapso de los T'ang.” (Ibíd., p. 119) 
predestinación, de que ha hablado Bretón (¿no estamos, en verdad, en pleno amour fou?), la pasión se sobrepone al signo adverso. ¿Se sobrepone? ¿No hay algo en el nacimiento de esa pasión que también la condena? Por ello, al final el poeta se confía a los poderes extraños (66)

Como vemos, en ambos casos la segunda pregunta tiene un valor aseverativo y el discurso se prolonga a partir de ella como si se tratara de una afirmación. Es evidente entonces que Sucre se sirve del disfraz de la interrogación para encubrir la certidumbre crítica.

Otro recurso cuyo empleo tiene consecuencias similares es el paréntesis. Para Miguel Gomes, en los ensayos de Sucre este signo de puntuación actúa "como recurso a la duda; el inciso no solo explica, también retrata a un hablante reticente, empeñado en revelarse como incapaz de convicción absoluta -el poeta que «nace» podría, más bien, «renacer» (229); el texto que habla de «descubrimientos» poéticos podría ser sustituido por aquél que habla de «redescubrimientos» $(315)^{, 1032}$. En cambio, de acuerdo a nuestra perspectiva, el paréntesis no revela una disyuntiva sino una adición, y es parte del asedio a la obra que implica el método crítico de Guillermo Sucre. Pensamos entonces que en la explicación de Gomes se debería cambiar el "más bien” por "también”: el poeta que "nace" también "renace"; los "descubrimientos" son, al mismo tiempo, “redescubrimientos". Bajo la apariencia de inconclusión que expresa el paréntesis (y sin la necesidad de desmentir esta apariencia) se esconde en verdad una voluntad de alcanzar la máxima precisión crítica. Guillermo emplea este recurso para conjurar el carácter sucesivo del lenguaje y decir a un tiempo el máximo de cosas posibles, de manera que la escritura se acerque lo más que pueda a la obra que busca aprehender. Así dice, por ejemplo: "parece obvio que el verdadero ámbito de esta poesía es el desasimiento de(l) ser. Es el reverso y no el anverso de(l) ser lo que fascina a Juarroz, y

${ }^{1032}$ Miguel Gomes: Poéticas del ensayo...op.cit., p. 192. 
aun lo abisma"1033 (245). O también: "el texto mismo del discurso no expira en la duda: (se) inspira (en) el mundo y lo espira; palabras y cosas circulan en una misma corriente viva, en un espacio libre y sagrado que es el poema" (250). Como se ve por los ejemplos, en la escritura de Sucre los paréntesis permiten al hablante crítico decir dos cosas simultáneamente. Así, aún confiriendo una impresión de incertidumbre, logran que el texto alcance el máximo de justeza y precisión.

Además, los paréntesis en la obra de Sucre permiten el acceso al discurso de una segunda voz que complementa lo indicado por la primera. Se trata de una instancia que observa desde una óptica distanciada lo que dice la voz principal y que colabora, por tanto, en el proceso de concreción de las ideas y de la escritura ${ }^{1034}$. Ya vimos antes cómo Sucre empleaba a veces estos incisos para preguntarse por una selección léxica alternativa. En otras ocasiones, el paréntesis introduce o anticipa la perspectiva del lector modelo, como en este fragmento: “el verdadero propósito sería éste, que también podemos formular con otra frase mallarméana: hacer posible «le vierge, la vivace et le bel aujourd' hui» de la palabra, restituir al lenguaje cotidiano su intensidad perdida. Liberarlo, en suma, de los malos (y hasta de los buenos, ¿no?) hábitos que lo petrifican”

${ }^{1033}$ En el fragmento se aprecia además el juego con los significantes que revela la vacuidad del sentido, según hemos señalado más arriba.

${ }^{1034}$ Esto es precisamente lo que nuestro autor destacaba sobre el recurso del paréntesis en los poemas de Octavio Paz: "El paréntesis es uno de los recursos de Paz desde Semillas para un himno y aún lo será en su último libro, Ladera Este. En ambos libros sirve para introducir otro discurso en el discurso, para suspender el discurrir central y luego retomarlo, enriqueciéndolo, o para hacerlo más inestable, para relativizarlo, que es otra forma de enriquecerlo, de diversificarlo." (Ibid., p. 305). Asimismo, en Roland Barthes por Roland Barthes, este autor indicaba que ese libro se había elaborado cuestionando sucesivamente las propias ideas: "Sus «ideas»-dice Barthes hablando de sí mismo- tienen cierta relación con la modernidad y hasta con lo que se ha dado en llamar la vanguardia [...]; pero él opone resistencia a sus ideas: su «yo», concreción racional, se les resiste incesantemente. Pese a estar hecho, aparentemente, de una serie de «ideas», este libro no es el libro de sus ideas; es el libro del Yo, el libro de mis resistencias a mis propias ideas; es un libro regresivo (que retrocede, pero, también, que toma sus distancias)." (Roland Barthes: Roland Barthes por Roland Barthes, Barcelona, Paidós Ibérica, 2004, pp. 160-161). Además, al describir las últimas tendencias de la crítica hispanoamericana Sucre indicaba: "A la actitud tan dominante, en lo mejor de nuestra literatura, del escritor que crea y se mira crear (Borges, Paz, Cortázar y el propio Sarduy), viene a corresponder ahora la del crítico que analiza y se mira analizar. Si la mirada del primero lo sustrae momentáneamente a la corriente de la creación y la hace crítica, la del segundo -que es doble, y quizá por ello mismo- lo sustrae al puro análisis y lo inserta en la propia creación: hace de su relación con la obra una experiencia viva y única." (Guillermo Sucre: "La nueva crítica", loc.cit., p. 274). 
(340). O en este otro: "Estos seguidores (futuristas, unanimistas, incluyendo los populistas hispanoamericanos, ¿no?) olvidaron lo más esencial: que Whitman fue también «poeta de un laconismo trémulo y suficiente, hombre de destino comunicado, no proclamado»” (164). Al introducir una perspectiva distanciada, el paréntesis tiene a veces un propósito abiertamente irónico. En esos casos, la segunda voz matiza desde un punto de vista retirado el decir de la instancia que controla la enunciación. En muchas ocasiones se trata de una reducción al sentido literal de una frase hecha o de un término empleado con valor metafórico. Así, en el ensayo sobre Vallejo tenemos:

Poemas humanos es todavía, y de manera que parece más extrema, el libro de la enajenación - del "hombre que ha caído y ya no llora". En efecto, la enajenación tiende a minarlo todo. Empieza (y termina) por ser un signo de la propia condición humana; es por ello, en última (y primera) instancia, fatal e irreductible. (147)

Igualmente, después de tratar sobre la obra de Sánchez Peláez y de Rafael Cadenas, Sucre indica: "No estoy abriendo (ni cerrando) un capítulo de poesía venezolana"1035. En estos casos, la frase hecha ("empieza por ser"; "en última instancia") o los vocablos con valor figurado ("abrir un capítulo") ven cómo su sentido es matizado por una voz que anula el significado fijado por el uso y devuelve el signo a su literalidad. Con esta actitud auto-irónica el hablante ensayístico, al tiempo que reduce el espesor semántico del lenguaje, consigue restar solemnidad a su propia enunciación.

Por todo lo que hemos señalado en este apartado parece evidente que la incertidumbre que recorre los ensayos de Sucre no responde a una voluntad de oponerse al "texto-todo" de la "otra" tradición hispanoamericana o de instaurar una "posibilidad infinita" de diálogo. El tono dubitativo revela, en cambio, la acción de un pensamiento que busca obsesivamente los límites de la obra que estudia y que quiere parecer asistemático precisamente porque no lo es. En efecto, si bien Guillermo impugna la verdad estable y definitiva de la metafísica, no rechaza la posibilidad de hallar una

${ }^{1035}$ Guillermo Sucre: La máscara, la transparencia, $2^{\mathrm{a}}$ ed., op.cit., p. 308. Cursiva nuestra. 
certeza momentánea (absoluta y relativa a la vez) sobre la obra que estudia. Por eso creemos que sus ensayos dejan entrever la actitud característica del maestro hispanoamericano que González Echeverría descubrió en el Ariel (1900) de Rodó. Según nos dice el profesor de Yale,

Hay un efecto dialógico en el Ariel, pero la única voz es la del maestro quien, mediante el truco del montaje dialógico, asume una posición tanto magistral como magisterial. [...] El recurso a la forma del diálogo es una manera de situar a la audiencia, de colocarla en una posición subordinada con respecto al hablante. Aunque ostensiblemente la forma dialógica parecería promover la dialéctica, lo que realmente posibilita es una entronización de la voz del maestro, un despliegue monofónico, un discurso, en resumen, que estratégicamente fomenta la impresión de un discurso polifónico. ${ }^{1036}$

En la tradición posterior del ensayo hispanoamericano, según afirma este crítico cubano, el "vacío" $" 1037$ sobre el que se funda la cultura continental será llenado por la figura del maestro. En el caso de Sucre se trata de un maestro que rechaza la actitud pedagógica y ejemplarizante, pero que no niega su posición magistral ni su competencia para llenar el "hueco" de la cultura hispanoamericana a través de su escritura. El tono vacilante que recorre sus escritos no revela una merma de autoridad sino que, al contrario, es un mecanismo que pretende encubrir las estrategias textuales mediante las cuales ella se reafirma. Quizás por eso Miguel Gomes decía que la voz de La máscara "es calculadamente indecisa y vacilante", y que el hablante está "empeñado en revelarse como incapaz de convicción absoluta" ${ }^{\text {"1038. }}$. Al emplear estas palabras que hemos destacado en cursiva, el investigador venezolano intuía una deliberación en el talante indeciso y conversado de los ensayos de Sucre. También en lo que concierne al estilo de su escritura, Gomes advertía una actitud ambivalente, pues indicaba que "el verdadero reto de La máscara" había sido poner en práctica la negación de "la certidumbre definitiva" y de "la sistematicidad" "en una textualización compleja y

\footnotetext{
${ }^{1036}$ Roberto González Echevarría: La voz...op.cit., p. 47.

1037 Ibid., p. 58.

${ }^{1038}$ Miguel Gomes Poéticas del ensayo...op.cit., p. 192. Cursiva nuestra.
} 
vigorosa" ${ }^{\prime 1039}$. Vemos, en suma, que el talante de nuestro autor entra en contradicción con los propósitos de su escritura: la voz dubitativa e incierta contrasta con el asedio obsesivo de la perfección crítica; el tono aparentemente afable y conversado choca con una escritura que busca la saturación y excluye todo suplemento; y-como veremos con detenimiento en el próximo apartado- la apariencia dialógica está encubriendo a una instancia enunciativa que nos habla desde una posición estético-política determinada.

\section{4. EL LECTOR MODELO}

La escritura de Guillermo Sucre se enmarca en una época que ya no comparte los presupuestos de los ensayistas de la primera mitad del siglo XX pues, en sus textos, el yo crítico se muestra alejado de los discursos totalizadores y del didactismo mesiánico que compartían los creadores mundonovistas ${ }^{1040}$. En efecto, nuestro autor no se considera ya un guía capaz de encarnar el saber absoluto o el sentir general ni lo mueve tampoco una vocación pedagógica. Por eso, al comienzo de La máscara, la transparencia hace estas aclaraciones, en las que se aleja de cualquier pretensión de sistematicidad:

$\mathrm{Al}$ dar a este libro el subtítulo de «ensayos sobre la poesía hispanoamericana», opté por el plural y deliberadamente eliminé el artículo la, para evitar cualquier posible equívoco. Nunca he pensado en hacer un estudio sistemático («concienzudo», «exhaustivo», «penetrante», «riguroso») de toda nuestra poesía. Y así como no he intentado abarcarla toda, tampoco he pretendido reducirla a las obras analizadas acá. (13)

Y un poco más adelante, con el mismo sentido, indica:

${ }^{1039}$ Ibid., p. 192.

${ }^{1040}$ Como lo ha señalado Miguel Gomes en su estudio sobre el ensayo venezolano del siglo XX, los ensayistas mundonovistas -entre los que se hallan Picón Salas, Uslar Pietri, Díaz Sánchez, Briceño Iragorry, etc.- emprendieron una labor que era sobre todo pedagógica, pues se consideraban a sí mismos maestros que debían guiar "sensatamente a sus coterráneos para sacarlos del atolladero de sus circunstancias de ignorancia, pobreza y atraso". (Miguel Gomes: Poéticas del ensayo...op.cit., p. 69). Estos ensayistas compartían una visión humanista y concebían la nación en términos esenciales y trascendentales como una unidad armónica. Como resultado de esta concepción, en ellos "la primera persona de singular carece por completo de autonomía" y "su especificidad como locutor depende de un todo identificable intra y extratextualmente: los venezolanos o los americanos". (Ibíd., p. 70). Además, la voluntad decidida de intervenir en el destino nacional o continental les impidió presentar una actitud lúdica o irónica. Como lo que estaba en juego era de suma importancia, el humorismo y la autocrítica quedaron excluidos de la expresión literaria: la misión de los orbenovistas era clarificar las cosas al lector y encauzar su pensamiento más que impresionarle con el estilo. 
Ya se sobrentiende, pues, que este libro no es una historia de la poesía hispanoamericana; mucho menos un panorama de ella. Apenas me he guiado por cierto hilo cronológico; en cambio, me he abstenido de seguir cualquier orden nacionalista. Claro que no conozco la poesía de cada uno de nuestros países; tampoco me preocupé por incluir siquiera a un poeta «representativo» de cada uno de ellos con el fin de lograr un falso aire continental que contentase y regocijase a todos. (13-14)

Estas declaraciones no significan (como ha creído la crítica) que Sucre rechace radicalmente la rigurosidad o que se niegue a imponer una determinada concepción sobre la cultura hispanoamericana. Lo que ha ocurrido, simplemente, es que la manera de plantear esta sistematicidad y este proyecto ha tenido que adaptarse a un nuevo contexto epistemológico. La situación en que Guillermo escribe está determinada por dos hechos que han sido frecuentemente relacionados por los investigadores: el triunfo de la Revolución Cubana y el cuestionamiento posmoderno del concepto de cultura ${ }^{1041}$. A consecuencia del primer acontecimiento se produjo una polarización ideológica de la intelectualidad y también, en consecuencia, de la crítica literaria continental. Según ha señalado Gonzalo Aguilar, “en los años sesenta la politización fue tan generalizada que aun los críticos más inclinados a la lectura textual se vieron impulsados a reforzar la politicidad de sus prácticas y a definirse en relación con el ideologema de debate del momento: la revolución" ${ }^{\prime 042}$. Como resultado del segundo hecho, las nociones de cultura y de identidad, que habían sido hasta ese momento temas obsesivos para generaciones de escritores hispanoamericanos, empezaron a ser radicalmente cuestionadas.

${ }^{1041}$ Esta es la opinión, al menos, de Aníbal González: “Aunque la crítica del concepto de cultura que precipitaría el período posmoderno de la crítica hispanoamericana se puede atribuir en parte a acontecimientos como la Revolución Cubana (que comenzó en 1959), algunos de sus puntos clave se habían anticipado en el ensayo de 1932 de Jorge Luis Borges «El escritor argentino y la tradición»." (Aníbal González: "La crítica literaria en Hispanoamérica", en Roberto González Echevarría y Enrique Pupo-Walker (eds.): Historia de la literatura hispanoamericana, Vol. II, Madrid, Gredos, 2006 [1996], p. 454)

1042 Gonzalo Aguilar: "Los intelectuales de la literatura: cambio social y narrativas de identidad", en Carlos Altamirano (dir.): Historia de los intelectuales en América Latina, Vol. II. Los avatares de la ciudad letrada en el siglo XX, Madrid y Buenos Aires, Katz Editores, 2010, p. 698. La cita sigue: "La compilación de ensayos América Latina en su literatura por César Fernández Moreno en 1972, es un buen ejemplo de esta radicalización." 
En los ensayos críticos de Guillermo Sucre hemos apreciado una crítica radical al concepto de identidad cultural que había sido defendido hasta ese momento. En efecto, en su creación se aprecia un cuestionamiento permanente al poder hispanoamericano -y a sus instrumentos ideológicos, la metafísica y la historia- porque este poder fijaba a priori una idea superficial y exotista sobre el continente que los escritores debían aceptar acríticamente. Al ceñirse a esa doctrina, la literatura se volvió un asunto de contenidos, y entonces los escritores, para poder considerarse hispanoamericanos, no tenían más remedio que ser representativos y mesiánicos. Lo que Guillermo ponía en cuestión era la sumisión de la creación literaria continental a una concepción oficial de sí misma que llevaba implícita, en verdad, una determinada posición estética y política.

La impugnación explícita de este discurso y la insistencia de nuestro autor en parecer asistemático no deben interpretarse como una voluntad de abandonar el "proceso de instauración cultural"1043 que había estado presente en la tradición

1043 Aníbal González: "La crítica literaria...”, loc.cit., p. 431. Como ha señalado Echevarría, aunque América Latina es heterogénea racial y socialmente, "la literatura latinoamericana se ha visto obligada, desde el comienzo, a imaginar la unidad de la cultura, o a soñar con su advenimiento" porque emergió "en una coyuntura histórica que vio el surgimiento del problema de la identidad cultural como interrogante y como necesidad conceptual." (Roberto González Echevarría: La voz...op.cit., p. 33). El género predilecto para llevar a cabo esta empresa ha sido el ensayo, que, por haber cristalizado en Hispanoamérica en los años que prepararon la independencia política, "con frecuencia se ha homologado con los avatares del destino patrio o continental." (Miguel Gomes: La realidad y el valor estético. Configuraciones del poder en el ensayo hispanoamericano, Caracas, Equinoccio, 2009, p. 44). Es decir que, a causa de su origen, el ensayo hispanoamericano ha implicado una cierta "responsabilidad cívica" (Ibíd., p. 45) y -sin dejar de lado el valor estético- ha estado inmerso en procesos de definición política y de "construcción nacional" (Ibíd., p. 46). Podemos decir, por tanto, que el género ha tratado insistentemente de forjar una imagen coherente de lo que los latinoamericanos eran o debían ser. Al haber nacido estrechamente vinculada a la problemática de la literatura (y del ensayo) continental, la crítica literaria hispanoamericana ha sido también un puntal básico de este proceso. A este respecto, Rodríguez Monegal señalaba que esta crítica no se centra sólo en valorar una obra sino que busca sobre todo establecer una determinada idea de América pues, cómo él dice, "no hay crítica de la literatura hispanoamericana sin crítica de la realidad de nuestra América". (Emir Rodríguez Monegal: "El ensayo y la crítica en la América hispánica”, en Kurt. L. Lévy y Keith Ellis: El ensayo y la crítica literaria en Iberoamérica, Memoria del XIV Congreso del IILI, Toronto, 1970, p. 224). En el mismo sentido, Hugo Achugar considera que la crítica continental está estrechamente vinculada una determinada definición política o cultural de Hispanoamérica y apuntaba por eso que "la tarea y el objetivo del crítico literario latinoamericano no pueden ser otros que comprender y conocer Latinoamérica, o sea, nuestra realidad inmediata, como una forma de participar en el esfuerzo por transformar esta realidad y la visión que de ella nos han dado. Es decir, concretamente, lograr que se haga realidad un proyecto social acerca de lo que queremos que sea Latinoamérica. Esto, por supuesto, no coincidirá con el proyecto social ni cultural 
ensayística y crítica hispanoamericana desde el momento de la Independencia, sino todo lo contrario. En efecto, si Sucre rechaza la "teoría de la originalidad" americana y todas sus consecuencias es porque defiende la fundación de la literatura (y, por tanto, de la identidad) continental sobre unos principios éticos y estéticos diferentes. En el giro operado por Guillermo estos valores no anteceden a las obras literarias sino que son su consecuencia, pero es evidente que en él sigue funcionando una equivalencia entre la visión de la literatura hispanoamericana y un determinado proyecto político para el continente. Debido al contexto en el que Sucre escribe, la instauración de este proyecto la lleva a cabo un sujeto enunciativo que nos habla desde una posición estético-política muy clara, y que trata de enmascarar continuamente su condición de maestro, es decir, su intención de ordenar "el caos" de la cultura hispanoamericana ${ }^{1044}$. Vemos, entonces, que en los ensayos de Guillermo se advierte a nivel ideológico la misma ambivalencia que hemos estudiado a propósito del tono dubitativo y conversado que se aprecia en su escritura. Por un lado, es evidente que hay una voluntad decidida de romper con el discurso profético de los ensayistas de etapas anteriores; esa ruptura, sin embargo, no impide que nuestro autor siga proponiendo una determinada idea sobre la literatura y el ser hispanoamericanos. Así, su voluntad de parecer asistemático debe ser interpretada como un mecanismo para ocultar su posición magistral y su designio de ordenar la heterogeneidad de la realidad continental. Entonces, más que un cambio de propósito con respecto a la ensayística anterior, en los trabajos de Sucre se aprecia sobre todo una nueva actitud. En ellos el hablante ya no encarna una colectividad - un "nosotros" nacional o continental- sino que dialoga desde su propia subjetividad con un

de otra gente en la América Latina." (Hugo Achugar: "Notas para un debate sobre la crítica literaria latinoamericana”, en Casa de las Américas, La Habana, núm. 110, sept-oct. 1978, p. 18)

${ }^{1044}$ Alfonso Reyes afirmaba que el ensayo hispanoamericano ha sido una "continua victoria de la conciencia sobre el caos de las realidades exteriores." (Citado por Peter G. Earle: "El ensayo hispanoamericano como experiencia literaria", en Kurt. L. Lévy y Keith Ellis: El ensayo y la crítica...op.cit., p. 23). Esto significa que los ensayistas hispanoamericanos habrían tratado de ordenar sucesivamente la heterogeneidad de la realidad social del continente. 
interlocutor imaginario que comparte con él unas mismas concepciones éticas y estéticas. Ahora el ensayista ya no habla al pueblo como a una entidad idealmente coherente y homogénea sino a una comunidad transnacional con unos mismos valores artísticos y políticos. La posición magistral sigue presente, pero su perspectiva ya no es humanista y ecuménica, sino política y excluyente ${ }^{1045}$.

Para apreciar bien el punto de vista desde el que Guillermo habla en La máscara, la transparencia nos vamos a acercar críticamente a la instancia del lector modelo o "virtual" (323), como él lo llama. Como hemos dicho, Sucre emite su discurso desde una perspectiva estético-política que se opone diametralmente al "otro" sector del campo literario hispanoamericano: la "secta" de la identidad y la representatividad. A través de la figura del receptor implícito se ve bien cómo nuestro autor establece una distancia con aquellos creadores y críticos que presentan una noción artística y política diferente de la suya.

A lo largo de La máscara, la transparencia Guillermo se desmarca discursivamente de quienes defienden la poética adánica y representativa, pues esa poética constituye el "otro"1046 sobre el que se erige el ensayo. Así, por ejemplo, dice Sucre: "La búsqueda de la intensidad verbal está ligada, en Vallejo, a una búsqueda de intensidad vital. Intensidad vital no quiere decir «aventura», «emociones», «grandes experiencias», mucho menos ese «registro del mundo» que otros han practicado; alude a un hecho mucho más radical" (270). En el mismo sentido, afirma: "Claro que no conozco la poesía de cada uno de nuestros países; tampoco me preocupé por incluir

${ }^{1045}$ Quizás por este motivo Óscar Rodríguez Ortiz planteaba que a La máscara, la transparencia "llegan" "las motivaciones «sectarias» venezolanas que nacidas en el grupo Sardio se prolongan en un pleito estético-político desde los sesenta: el mundo dividido, sin matices, en buenos y malos, las consabidas listas de exclusiones o inclusiones -García Morales en lugar de Silva Estrada-, anatemas, rayos, centellas, los ritos peculiares del «tabú».” (Óscar Rodríguez Ortiz: Paisaje del ensayo venezolano, op.cit., p. 102)

${ }^{1046}$ Francisco Rivera ha señalado que lo que La máscara propone es "una lectura antinerudiana de la producción poética de Latinoamérica" (Francisco Rivera: "Guillermo Sucre y la poesía...", loc.cit., p. 11). Miguel Gomes, por su parte, afirma que "sobre la omisión del inomitible Neruda, en efecto, se erige la totalidad de su discurso." (Miguel Gomes: Poéticas del ensayo...op.cit., p. 192) 
siquiera a un poeta «representativo» de cada uno de ellos con el fin de lograr un falso aire continental que contentase y regocijase a todos. Hay quienes hablan mejor de lo que no saben y son brillantes virtuosos del catálogo de lo hispanoamericano; no me dejé fascinar por esa posibilidad"1047 (13-14). Asimismo, nuestro autor se muestra distante con respecto a quienes se han adherido a cierta poética de la elocuencia: "En efecto, no obstante la naturaleza «oral» de su poesía, el lenguaje de Parra parece estar siempre al borde del silencio. De ahí esa tensión que impide que su obra caiga en el cómodo y a veces mecánico «oralismo» que otros practican. Lo que quiere Parra es borrar el lenguaje para que el mundo aparezca" (313).

A veces, la distancia está aderezada con una dosis de ironía o de humor que se emplea sobre todo al hablar de aquellos autores que no comparten la poética de Sucre. Esto es lo que se aprecia, por ejemplo, cuando Guillermo recuerda en una nota al pie y con cierto sarcasmo la ausencia en el volumen del ensayo sobre Pablo Neruda: "Como he indicado ya en la introducción de este libro, falta, por ahora, el estudio sobre la obra de Neruda" (100). También se percibe una actitud burlesca cuando nuestro autor afirma sobre el mismo poeta lo siguiente:

En todo caso, la historia dejó de ser para él un absoluto, la posibilidad de una verdadera utopía revolucionaria, como en Vallejo, y aceptó, no sin cierto pragmatismo y cálculo estratégico, su relatividad: no la revolución, sino, más precavidamente, la evolución. Lo paradójico (¿y dramático?) en Neruda es que siendo un poeta que gustaba asumir poderes proféticos, parece haber estado siempre a la zaga de los acontecimientos. Veía y no veía, como él mismo llegó a decir. (388)

Asimismo, Sucre hace gala de su humor al hablarnos de Ernesto Cardenal, un vate sobre el que trata en ambas ediciones de La máscara, pero con cuya poética parece

${ }^{1047}$ En este fragmento Sucre parece referirse a intelectuales como Luis Alberto Sánchez, que en 1971 había publicado su obra Escritores representativos de América. En ella, el crítico peruano hace precisamente un catálogo de lo hispanoamericano, incorporando a 144 escritores de 19 países, sin seguir ningún criterio estético y atendiendo exclusivamente al origen (hispanoamericano) de los autores. Por eso comienza diciendo: "Podemos afirmar, con énfasis, de los personajes de este libro, que son todos los que están, aunque, ciertamente, no estén todos los que son." Además, a lo largo de su obra, Sánchez sigue apegado a un criterio biográfico y estableciendo una relación determinista entre la vida y la creación literaria. (Luis Alberto Sánchez: Escritores representativos de América, Madrid, Gredos, Primera serie, 1971, p. 8) 
no concordar del todo. En la primera versión del libro, nuestro autor hace un chiste fácil sirviéndose del apellido del autor:

«Porque la Compañía también corrompía la prosa», dice Ernesto Cardenal en un poema («La hora $0 »)$, identificando la degradación política y la verbal, y empleando esta última como un espejo que es también un arma.

Nombrado Cardenal, habría que decir que él es uno de los iniciadores de esta nueva tendencia. En su obra se combinan diversos tonos y planos [...] (329)

En la segunda edición, Guillermo reescribe el ensayo dedicado a este poeta nicaragüense y, si bien suprime la burla antes citada, no pierde la oportunidad de mofarse de ciertos aspectos de la poética de ese escritor. Así, después de cuestionar la conversión al marxismo que tiene lugar en la obra de Cardenal después de 1970, nuestro autor escribe lo siguiente:

Con razón aclara Cardenal que no habla de política: «No es de política sino de Revolución/ que para mí es lo mismo que Reino de Dios». Ni siquiera dudarlo: tampoco hace arte revolucionario sin valor artístico, porque eso -ya lo dijo Mao, a quien cita en su apoyo- no sería revolucionario. Reino de Dios, Revolución y Poesía son así equivalentes y hablan por boca de Cardenal. Quizá no haya otro poeta en el mundo con más confianza que él: lo asiste una beatitud clarividente. En un poema de los sesenta, a la muerte de su maestro Thomas Merton, ya nos lo hacía prever: «Vivimos como en espera de una cifra infinita/ O que nos llame al teléfono lo inefable». A través de sus últimos libros se siente que lo Inefable le ha revelado y confiado todos sus designios. ${ }^{1048}$

También en otras ocasiones la adscripción política de los escritores es tratada con distancia, como se puede apreciar en el ensayo sobre César Vallejo. Guillermo reconoce la convicción comunista del poeta peruano pero habla de ella con fórmulas que muestran una cierta lejanía: "Pero - hay que decirlo- esta filosofía de la desposesión tiene un carácter social y político muy concreto. A través de ella, Vallejo va formando una suerte de teoría de la marginalidad como agente de todo verdadero cambio histórico" (151). Y también, más adelante: "De nuevo, consagración de lo elemental, pero también, ahora, como una fuerza histórica. Se comprende que la plenitud que evocan estos poemas es la expresión de un fervor revolucionario. Es obvio, además, que la marginalidad coincide con la concepción marxista de Vallejo y con su experiencia de militante comunista -hacia los años treinta, al parecer" (151).

${ }^{1048}$ Guillermo Sucre: La máscara, la transparencia, $2^{\mathrm{a}}$ ed., op.cit., pp. 283-284. 
Hay que decir, además, que Guillermo se aparta enunciativamente de los críticos que no comparten sus postulados estéticos como, por ejemplo, de aquellos que estudian la obra literaria atendiendo a criterios cronológicos o evolutivos. A este respecto señala en el ensayo sobre Vallejo: "Por el lenguaje y los símbolos que emplea en este pasaje y el siguiente, Roberto Paoli señala las analogías entre la utopía vallejiana y los libros proféticos, especialmente de Isaías. Estas analogías son mucho más profundas de lo que creen otros críticos inclinados a la interpretación historicista" (157-158). Lo mismo se aprecia en el texto sobre Juarroz: “A su brevedad (siete volúmenes no muy extensos publicados entre 1958 y 1982) se añade otro rasgo: el suyo es un discurrir que se repite incesantemente, un lenguaje que no varía de manera sensible-que no «evoluciona» dirán ciertos críticos que, por lo general, siempre «involucionan»; su primer libro podría ser el último, y viceversa" (237). Igualmente, en este otro fragmento, Sucre marca una separación con aquellos exegetas que siguen apegados a lo telúrico o a lo histórico: "No es raro, sin embargo, que a Aridjis se le vea como un poeta anacrónico o abstracto, porque le falta "historia" o "geografía" bien definidas y localizables, como dirían ciertos críticos que todavía buscan en la poesía -sobre todo en la hispanoamericana- una buena «tranche de vie»" (360). Vemos también que Guillermo se opone a las categorías críticas aceptadas convencionalmente pero que están vacías de significado y que valen, por eso, para todo y para nada. Ello le lleva a valorar positivamente el hecho de que el poeta chileno Braulio Arenas trascendiera los marcos interpretativos de cierta crítica: "Arenas supo rechazar, en su momento, dos cosas: el «angelismo»y el «bestialismo», el poeta «puro»y el «impuro», toda esa majadería que aún sirve para la madeja de algunos críticos"1049 (408). Nuestro autor se desmarca

${ }^{1049}$ En este caso resulta llamativo el juego de palabras "majadería"-“madeja” y el empleo de esta última palabra para referirse al discurso. 
asimismo de quienes consideran que tener conciencia del lenguaje implica ser un formalista y propone, en cambio, atender a lo que dice el propio autor:

No lo que dice sino la manera de decirlo es lo que importa en el poema, ha señalado también Vallejo en otra ocasión. iDecadente preciosista! Replicarán, tardíamente, algunos; o, más cautos, razonarán que eso nada tenía que ver con la obra de un poeta tan "humano"; argumento que parecería definitivo y anonadante. La verdad, sin embargo, no es otra que la que el propio Vallejo propone, y su obra maestra, en lo esencial, se adecúa perfectamente a ella. (132)

Como vemos por estas dos últimas citas, muchas veces el rechazo de otras perspectivas críticas se vincula a un determinado manejo de las palabras. Ya sabemos que para Sucre la ética y la actitud ante el lenguaje están estrechamente vinculadas; por eso es frecuente que nuestro escritor establezca una distancia con aquellos exegetas que, deslumbrados por la modernolatría, se apartan de un lenguaje sensato y equilibrado. Es lo que se aprecia en este ejemplo: “Así, el valor de la poesía (para ser americana, al menos) está en relación con los materiales que reúne, los temas que enuncia, las zonas naturales que abarque (los contextos ctónicos, dirían hoy, más modernos, otros), etcétera, etcétera" (26). Y también en este otro: "En cambio, ¿no hay otra fatalidad del lenguaje, ya de carácter social, que es todavía más determinante? Sabemos que la ambigüedad -otros dirían hoy la indeterminación- del lenguaje puede ser una riqueza: una manera de encarnar la diversidad del mundo, la secreta complejidad de la vida, diría Borges" (258). Asimismo, en este fragmento del texto sobre Alberto Girri se advierte bien cómo el escritor opta por la expresión mesurada ante las soluciones extremistas: “Cada poema suyo parece una combinación de dominio estilístico y de abandono instintivo, de precisión y de juego (quizá un entendido diría que carece de sutileza; un neófito, que es muy abstruso). Pero no creo que escriba para asombrar ni siquiera para persuadir, sino para obsesionar" (347).

Como vemos, mientras que los otros críticos emplean las palabras con la intención de sorprender, Sucre se mantiene fiel a la expresión convencional, y ese 
simple gesto encierra toda una actitud moral. En relación con esto hay que recordar que Guillermo selecciona constantemente las palabras para definir el marco ético y estético desde el que nos habla. A partir de dos vocablos de sentido cercano, nuestro autor muestra su preferencia por uno de ellos y así delimita el territorio ético y estético que su escritura presupone. A este respecto podemos mencionar, por ejemplo: "Esta poesía, decíamos, encarna (no simplemente ilustra) un debate ontológico. Es quizá lo que Juarroz quiere sugerir con el título de poesía vertical" (243). En esta cita Sucre prefiere el término "encarnar" (que alude a la conciencia del lenguaje) a "ilustrar" (que está vinculado a una concepción logocéntrica) y vemos que, al enfatizar esa elección, nos está dando una clave fundamental de su estética. Otro ejemplo de este tipo de distinción podría ser este: "Poesía inteligente, no simplemente intelectual. Lo abstracto en ella (como cuando se habla de pintura abstracta) está muy lejos de todo simbolismo conceptual" (241). En esta ocasión, lo vemos, el término "inteligente" se prefiere a "intelectual" y la diferencia moral entre ambos vocablos es igualmente clara si los interpretamos a la luz del pensamiento de nuestro autor: mientras que lo "intelectual" alude al "simbolismo conceptual", lo "inteligente" se aleja de ello para revelar una “materialidad original”, según sabemos por la continuación de la cita.

A la demarcación del lector "virtual" contribuye también el empleo de palabras en francés e inglés, con las que Sucre pone de manifiesto que su lector modelo es alguien que entiende la literatura hispanoamericana como parte de una trama universal. A este respecto dice: "El elocuente poeta cívico del primer libro [...], el poeta épico que recrea la historia [...], el inventariador de paisajes (flora y fauna y comprises), el miniaturista no siempre muy refinado de sus libros impresionistas: no creo que sea este Lugones el que pueda despertar hoy verdadero interés" (55). O también: "El poeta modernista buscaba no sólo las sensaciones sino las sensaciones raras, le bizarre 
sensorial; a través de ello se individualizaba" (78). Y por citar un ejemplo en inglés: "Si creemos conocer a Borges es porque preferimos disimular la sospecha que, en el fondo, tenemos de él: su obra parece siempre in progress, entre la inocencia y el efecto más calculado" (162).

En suma, en este capítulo hemos tratado de ver los ensayos de Guillermo en estrecha relación con su propia concepción de la crítica. Ello nos ha permitido apreciar las correspondencias entre la visión de la obra como un sistema y su propia escritura, así como también advertir las contradicciones en que su discurso está inmerso. Estas son consecuencia de un cruce de perspectivas diversas pues si, por un lado, Sucre se inserta en la tradición constructiva y ordenadora del ensayo continental, por el otro, escribe en un marco epistemológico que dificulta la vocación magistral y universalista presente en el ensayo de etapas anteriores. Guillermo, entonces, no renuncia a plantear un proyecto estético y político para el continente pero emprende este proyecto sabiendo que debe enmascarar su propia autoridad y que su posición es parcial e ideológica. Por eso en su escritura se advierte una ambivalencia entre el tono dubitativo y el asedio de la perfección crítica y se prefigura a un lector modelo que comparte con el autor una misma actitud artística y política. Esta problemática nos lleva a tratar en el siguiente capítulo sobre la cuestión del reparto de lo sensible que implica la estética de Sucre, es decir, sobre el orden que él plantea, simultáneamente, para el arte y la cultura del continente. 


\section{CAPÍTULO VIII}

\section{LA POLÍTICA ESTÉTICA DE GUILLERMO SUCRE DESDE 1969}

Al final de la primera parte de este trabajo hemos visto cómo en el periodo anterior a 1968 Guillermo Sucre trataba de que los autores venezolanos consiguieran conciliar la mirada y la escritura para que sus creaciones fueran auténticas y entroncaran con los valores que él advertía en la gran literatura occidental. La ausencia de criterios artísticos había dado lugar a que las obras presentaran una desconexión entre la expresión y lo expresado que las relegaba a un ámbito puramente nacional. A partir de su llegada a los EEUU, sin embargo, nuestro autor no busca solo corregir los desmanes de una intelectualidad corruptible y carente de valores estéticos sino que comienza a participar en una pugna entre diversos repartos de lo sensible ${ }^{1050}$. En efecto el pensamiento sobre la literatura que Sucre plantea a partir de 1969 se opone diametralmente a un orden inseparablemente político y estético -representado, de una parte, por el poder autoritario y caudillista del continente y, de la otra, por la estética que nació en los años posteriores a la Independencia. Guillermo reconocía así, como lo ha establecido después Jacques Ranciére, que toda estética implica una política determinada, es decir, un ordenamiento del mundo que habitamos.

En la concepción de este pensador francés la literatura es un nuevo régimen del arte de escribir que surge a comienzos del siglo XIX como consecuencia de la caída de la poética clasicista. Ante el colapso del viejo paradigma fundado en la inventio, la dispositio y la elocutio, y que descansaba sobre la armonía entre el autor, el personaje representado y el espectador, la literatura introduce dos principios nuevos $\mathrm{y}$ contradictorios. Por una parte está el principio de indiferencia que suprime toda jerarquía y que convierte cualquier vida, acontecimiento o personaje en tema adecuado

${ }^{1050}$ Vid. supra la explicación de este concepto en p. 203 y ss. 
para escribir sobre él. Por otra parte, para evitar la anarquía del punto anterior, la literatura inventa una nueva adecuación entre los cuerpos y las significaciones (principio de poeticidad) según la cual cada objeto o cada elemento comienzan a portar en su propia materialidad la inscripción de su sentido. La literatura según Ranciére es la contradicción nunca resuelta entre estos dos principios -el de indiferencia y el de poeticidad- y la política de la literatura no es sino el intento por volver compatibles estos aspectos que se oponen. Al tratar de reglar estos puntos antagónicos, los escritores y artistas modernos plantean una distribución de las formas de hacer, de ver y de sentir, y establecen un vínculo entre los cuerpos y las significaciones. De esta manera, sin salir en ningún momento del ámbito de la estética, proponen un reparto de lo sensible que supone una ordenación política de lo real.

Cuando Guillermo comienza a intervenir en el campo literario continental a partir de 1969, se encuentra con varios problemas que derivan de esa estética que había surgido en Hispanoamérica a principios del siglo XIX y a la que él llama "la teoría de la originalidad americana". A juicio de nuestro autor esa corriente es la responsable de que las obras del continente hayan incurrido constantemente en dos vicios complementarios: el realismo y el esteticismo, o, lo que es lo mismo, el exceso de cosas y el exceso de palabras. La literatura continental había estado centrada en los contenidos y en el tema y, como complemento necesario, trataba de nombrar o de expresar esos asuntos con un estilo "bello" o "perfecto". Sucre piensa por eso que se ha cultivado una imagen "algo distorsionada" de la poesía hispanoamericana pues, como él dice,

casi siempre se ha querido mostrarla como una poesía de la realidad: inventario de una naturaleza exuberante y de un mundo adánico, crónica o épica de una historia singular o abyecta, testimonio de las pasiones de un hombre elemental o cósmico; o como oposición, el refinadísimo arte de seres decadentes o exotistas. Para un criterio que aspire a ser hispanoamericano no hay sino esta alternativa: poesía preciosista o profunda, artificiosa o representativa, de acuerdo con sus contenidos, con su mensaje. ${ }^{1051}$

${ }^{1051}$ Guillermo Sucre: La máscara...op.cit., p. 99. 
Como se aprecia en la cita, lo que Guillermo impugna es el hecho de que la poesía continental haya sido un mero inventario de la naturaleza o una crónica de la historia y que, correlativamente, haya incurrido en el preciosismo y en la artificiosidad. Nuestro autor advertía estos mismos defectos en la poesía de Andrés Bello -vate al que consideraba el iniciador de esa estética desmesurada en Hispanoamérica- y decía, por eso, que era pertinente dudar de la calidad de sus textos:

Sus poemas más extensos -los que aún se siguen considerando como inicio de nuestra poética- son monumentos a la grandeza americana, pero en sí mismos, como poemas, tienen poca grandeza. Están escritos en el mismo castellano académico de los poetas españoles de su tiempo; son más el estricto cumplimiento con las leyes de un género, que el verdadero esplendor de una escritura. Para Bello la poesía era un asunto de contenidos: concebido un tema, exponerlo luego con el mayor virtuosismo gramatical posible. ${ }^{1052}$

La profusión de cosas y de palabras que Sucre ve en los autores afines a esta corriente estética se ampara en una concepción logocéntrica del lenguaje y conduce a un vicio quizás más grave: la exageración de la objetividad y de la subjetividad. En efecto, el hecho de caer en excesos de contenido y de expresión supone que el escritor se cree en posesión del sentido de la realidad y que los vocablos son un medio para comunicar esa significación previamente establecida. Ello da lugar a que la visión del mundo que el poeta nos ofrece sea "afirmativa y aun concluyente" pues su labor consiste simplemente en recorrer "con seguridad un camino directo entre la palabra y la realidad; no constituye al mundo, ni siquiera lo transpone, sino que pretende reflejarlo" ${ }^{\prime 1053}$. Esta confianza excesiva del creador en sus propias posibilidades ha dado lugar a la representatividad y al mesianismo que Sucre advierte y denuncia en muchos vates del continente. Al establecer una distancia entre lo que se dice y la manera de decirlo, estos

1052 Guillermo Sucre: "Poesía hispanoamericana y conciencia del lenguaje", loc.cit., p. 616.

1053 Guillermo Sucre: La máscara...op.cit., p. 290. Esta separación entre el escritor y su experiencia es lo que Guillermo denunciaba, por ejemplo, en los románticos hispanoamericanos que, a decir de nuestro autor, "intentaron poner más pasión en su discurso poético, pero, aparte de que la pasión no resume ni agota lo poético, sus poemas no hacían más que nombrarla: no eran el lenguaje de la pasión. Incurrieron en el mismo defecto que Bello: empleaban las palabras para designar, no para connotar; no crearon un nuevo lenguaje, o, por lo menos, una nueva entonación del lenguaje. Además, su visión del mundo, como la de los románticos españoles, fue superficial, externa." (Guillermo Sucre: "Poesía hispanoamericana y conciencia del lenguaje”, loc.cit., p. 616) 
autores se han creído los custodios de la suprema objetividad y los elegidos para comunicarla. Entonces, como dice Guillermo, "si la tesis de los contenidos llamados americanos revelan muy poco desde el punto de vista de la creación, han revelado mucho desde el punto de vista ideológico: con ellos, muchos poetas hispanoamericanos han elaborado no tanto una poesía como una estrategia cuyo fin último es pasar a la categoría de vates mesiánicos, de cantores representativos, que por sí solos encarnan el destino de un continente" la portavocía del continente y de sus habitantes, lo cual implica una actitud arrogante y una seguridad colosal en su propio yo. Por eso Guillermo se preguntaba:

¿quién puede hoy creerse representativo sin caer en el abuso de la egolatría, que es también un abuso de confianza? «Soy el cantor de América autóctono y salvaje», escribía un poeta peruano de comienzo de siglo. Aparte de que ese poeta nunca pareció ni tan autóctono ni tan salvaje, pretensiones como éstas ¿no hacen sonreír un poco? Aun cuando Neruda, al referirse al pasado indígena, en uno de sus poemas más memorables, dice: «Yo vengo a hablar por vuestra boca muerta», «Hablad por mis palabras y mi sangre», es difícil no sentir la intromisión del portavoz que se cree elegido o delegado por una raza. ${ }^{1055}$

Observamos así que en la visión de Sucre el realismo está estrechamente vinculado a la teatralidad del yo y al culto de la personalidad, pues creer que se está en posesión del sentido del mundo implica que se tiene una confianza absoluta en las propias capacidades cognoscitivas y creativas. Además, según la concepción de nuestro autor, este distanciamiento entre la palabra y la referencia es lo que caracteriza al poder, que al emplear el lenguaje en su propio beneficio le hace perder su capacidad para encarnar lo real. Al servirse de las palabras, el poder introduce en ellas un espesor semántico que les es ajeno y que las convierte en un instrumento ideológico.

${ }^{1054}$ Ibíd., pp. 617-618. Con el mismo sentido decía: "Cada una de las obras llamadas «realistas» pretende situarse fuera de la literatura; obviamente, pues ellas son la «realidad». Poco importa que traten de devaluar la literatura, sino que lo hagan para sobrevalorarse ellas mismas. Es posible que esas obras nos den la vida, pero no dan vida: finalmente matan toda imaginación." (Guillermo Sucre: $L a$ máscara...op.cit, p. 21)

1055 Ibíd., p. 21. Como hemos indicado más arriba, al cuestionar a los autores "representativos" del continente, Guillermo se distanciaba de críticos como Luis Alberto Sánchez, que había fundado su discurso crítico sobre este rasgo y se había distanciado, en consecuencia, de cualquier criterio estético. (Vid. supra nota 1047 en p. 387) 
Estas abundancias de anécdota y estilo o de objetividad y subjetividad suponen asimismo un distanciamiento entre la poesía y la vida que lleva a ciertos escritores hispanoamericanos a proyectar una mirada auto-orientalista. La creencia de Sucre es que al imponer una separación entre la palabra y el referente los autores supuestamente representativos han escrito el continente desde fuera y han proyectado una visión impostada sobre sí mismos. En las palabras que cito a continuación se aprecia bien el paralelismo que Guillermo establece entre los excesos estéticos y la distancia del escritor con su vivencia: "En la obra de Santos Chocano, por ejemplo, hay quizá más elementos «indígenas» que en la de César Vallejo: nadie pondría en duda, en cambio, no sólo que Vallejo es un poeta y aquel un mero retórico, sino también que en él hay una vivencia profunda y no pintoresca de lo racial" ${ }^{, 1056}$. Como se advierte en la cita, la insistencia en los elementos temáticos indígenas son propios de un retórico (no de un poeta), que al caer en desmesuras de contenido y de expresión proyecta una visión pintoresca y superficial. Guillermo considera además que esta separación entre la poesía y la experiencia que da lugar a excesos e imposturas habría llevado a muchos escritores a ceñirse a una imagen ideológica de América Latina, y ello les habría impedido crear espontáneamente y ser dueños de su propia vivencia del mundo. Vemos así, en suma, que nuestro autor se opone a aquella literatura continental que había incurrido en excesos de cosas y de palabras o de objetividad y subjetividad y que, al distanciar la poesía de la vida, había sido incapaz de comunicar una experiencia sin mediaciones.

Estos defectos que Guillermo considera de alguna manera "crónicos" de la literatura hispanoamericana son en verdad la expresión de esa revolución que, según Ranciére, aconteció a principios del XIX y que se conoce como literatura. Como ha establecido este filósofo, la repulsa al "exceso «realista» de las cosas" y a "la

${ }^{1056}$ Ibid., p. 22. 
superstición «estética» de la palabra"1057 es en verdad una reacción ante esos dos principios antagónicos (el de indiferencia y el de poeticidad) que surgieron al derrumbarse el viejo edificio de la poética clasicista. En efecto, la profusión en la escritura de detalles vanos e insustanciales es el resultado del principio de indiferencia que permitía a cualquier persona escribir sobre cualquier cosa, y el vicio esteticista no es sino la consecuencia de que en la nueva poética "la potencia material de las palabras" se opone a "la potencia intelectual de las ideas"1058. Como consecuencia de lo anterior, según el mismo pensador, la literatura es ese régimen de escritura que rompe con toda continuidad armoniosa entre el verbo y la experiencia:

La literatura es [...] la pérdida de esa forma de continuidad entre la palabra y la vida, de la cual la epopeya-libro del pueblo habría sido el cumplimiento poético. Pero decir que ella es la pérdida de esa continuidad quiere decir dos cosas: por una parte, que ella es el corte efectivo del arte de escribir con un régimen específico de experiencia vivida; por otra, indisolublemente, que ella es el duelo de esa continuidad y se sitúa bajo el signo de ese duelo ${ }^{1059}$

Vemos entonces cómo al enfrentarse a los excesos y las distancias presentes en aquella estética resultante de la "teoría de la originalidad americana", Sucre estaba en verdad tratando de reglar los principios antagónicos de ese paradigma de escritura que conocemos como literatura. En efecto, a través de su estética, Guillermo busca una nueva adecuación entre el principio de indiferencia y el de poeticidad que permita cancelar la distancia entre la poesía y la vida y dar con una literatura verdaderamente hispanoamericana, pues, como él dice, "no se trata de creerse adánico por privilegio, sino de reencontrar la unidad del hombre con el universo, que es la experiencia y aun la motivación de cualquier escritor moderno" $" 1060$.

Para solucionar los múltiples defectos que advertía en la otra tradición continental, Guillermo busca una conciliación total entre la objetividad y la

1057 Jacques Ranciére: "Borges et le mal français", en Politique de la littérature, op.cit., p. 149. Traducción nuestra.

1058 Jacques Ranciére: La palabra muda...op.cit., p. 39.

1059 Jacques Ranciére: “Borges et le mal français", en Politique de la littérature, op.cit., pp. 159160. Traducción nuestra.

${ }^{1060}$ Guillermo Sucre: La máscara ...op.cit., p. 261. 
subjetividad, es decir, una saturación perfecta entre lo dicho y la manera de decirlo que no deje lugar al suplemento. En este párrafo que cito a continuación, según creo, nuestro autor expresa bien lo que esperaba de la creación literaria:

«Hay que mostrar a un individuo que se introduce en el cristal», era para el joven Borges la única posibilidad de la obra de arte. Ese cristal no separa dos zonas, la del sujeto y la del objeto, sino que finalmente las identifica. La única manera de aproximarse a la objetividad ¿no es reconociendo primero la subjetividad? Ésta es, creo, la perspectiva que hace impracticables las pretensiones de representatividad, de totalidad y, en el contexto latinoamericano, de originalidad telúrica. [/] En última instancia, la realidad en que participamos reside en la mirada, en el lenguaje. El verdadero realismo, o quizá el único posible, es el de la imaginación. Y el primer poder de ésta en literatura es, sabemos, verbal. ${ }^{1061}$

Como vemos por la cita, lo que Sucre requiere es la identificación del sujeto y

del objeto en la obra de arte, pues sólo a través de esa equivalencia será posible acabar definitivamente con las profusiones indeseables de cosas y de palabras. Para fundar filosóficamente esta continuidad entre el vocablo y la referencia, Guillermo recurre a lo que él llama la conciencia del lenguaje, que no es sino el principio de poeticidad que descubrieron los románticos como un nuevo ajuste entre los cuerpos y las significaciones. En la visión de nuestro autor esta conciencia del lenguaje supone, como ya sabemos, que las palabras y las cosas establecen entre sí un vínculo necesario que cancela los excesos de subjetividad y de objetividad y que anula la distancia entre la poesía y la vida $^{1062}$. De este modo, frente a la separación entre el vocablo y la referencia

$$
1061 \text { Ibid., p. } 23 .
$$

1062 Como afirma Sucre, la conciencia del lenguaje "atenta contra nuestros prejuicios de «realismo» en arte; por la otra, asume una perspectiva distinta ante lo que se ha llamado «personalidad»individual o colectiva. Nos sitúa, en consecuencia, frente a dos posibilidades que aún parecen chocarnos y que podríamos enunciar de este modo: ¿y si el lenguaje poético, más que hablar de lo real, hablara de sí mismo? ¿y si, en vez de encarnar una personalidad psíquica o social, lo que hace el arte es encarnar una mente estética o una mente humana universal?" (Guillermo Sucre: "Poesía hispanoamericana y conciencia del lenguaje", loc.cit., p. 613). En la opinión de Sucre, cuando se cancelan los excesos y las distancias los autores consiguen establecer una unidad entre el lenguaje y la vida que está lejos de todo pintoresquismo. Por eso valoraba que ciertos poetas hubieran tratado de establecer esta concordancia: “Aun hay otros ensayos de López Velarde no menos importantes: en ellos propone una suerte de nuevo pacto de la sensibilidad hispanoamericana con la lengua castellana. No se trataba de propiciar ningún imposible nacionalismo idiomático, sino, sencillamente, de terminar con el divorcio entre la palabras y el espíritu que la dicta." (Ibíd., p. 625). Y lo mismo advertía en Borges: "En su ensayo El idioma de los argentinos, de 1928, también él [como López Velarde] quería rescatar la «plena entonación argentina del castellano» en la escritura: matices del uso, distinta connotación de los vocablos, ese secreto vínculo espiritual, mitológico- entre el lenguaje y la vida. Entonación argentina: de nuevo no se trataba de ninguna pretensión nacionalista; mucho menos de una empresa programática - «escriba cada uno su intimidad y ya la tendremos»(esa entonación), decía Borges. El paralelismo con López Velarde es 
que establecía la concepción logocéntrica, Sucre reivindica un lenguaje "preciso y veraz"1063 que cancele el trecho entre el nombre y el mundo y consiga encarnar la verdad. El primer movimiento literario del continente donde se produjo esta identidad entre el signo y el sentido fue el modernismo, cuyos poetas, a decir de Sucre, "más que un repertorio de temas, supieron crear un repertorio de formas y sólo a través de esas formas nos dieron una visión del mundo"1064. Además, al conceder al lenguaje un lugar central en la creación literaria, consiguieron relegar a un segundo plano todas aquellas corrientes estéticas fundadas en la distancia entre el escritor y su experiencia. Como afirma nuestro autor, "lo que el movimiento modernista convirtió en literal anacronismo fue el americanismo localista, y regocijado. Y términos como telurismo, adanismo, indigenismo, y otros de igual origen, degeneraron en mera nomenclatura sociológica, estéticamente vacía. Aguzar la sensibilidad y la inteligencia del lenguaje como un modo de penetrar en «lo real»: eso lo debemos al modernismo"1065.

Guillermo, sin embargo, no se contenta con la conciencia del lenguaje sino que llega al extremo de invertir la noción tradicionalmente aceptada según la cual el arte copia o imita la realidad. Sucre piensa que la creación literaria no se puede limitar a reproducir un contenido previo porque de ser así estaría condenada a los excesos y las distancias que él rechaza. Para suprimir definitivamente la tentación representativa y los

notable; al igual que éste, Borges rechazaba, como signo de un habla propia, el pintoresquismo, el localismo locutivo." (Ibid., pp. 625-626)

1063 Guillermo Sucre: "Memorial...", loc.cit., p. 40.

1064 Guillermo Sucre: "Poesía hispanoamericana y conciencia del lenguaje", loc.cit., p. 621. Nuestro autor aprecia este rechazo de los excesos realistas y esteticistas también en otros autores posteriores al modernismo. Así, por ejemplo, nos recuerda que el propio Borges impugnaba estos excesos de cosas y de palabras en la literatura española. Como dice Sucre resumiendo los argumentos contenidos en "El idioma de los argentinos" (1928), "Sin desconocer los genios que la literatura española ha dado para él, Cervantes y Quevedo, sobre todo-, Borges no oculta su radical desacuerdo con ella. Sus múltiples argumentos podrían ser resumidos en dos: lo que él califica de «sueñera mental» y de «concepción acústica del estilo». Lo primero se refiere a la carencia de imaginación y de verdadero sentir metafísico que percibe en la literatura española; es decir, su excesivo realismo, su cotidianería. Lo segundo subraya la tendencia a confundir la eficacia del estilo con la simple riqueza sonora y léxica." (Ibíd., pp. 625-626. Cursiva nuestra)

1065 Guillermo Sucre: "Introducción" a la Primera parte de la Antología de la poesía hispanoamericana moderna, op.cit., p. 21. 
vicios que ella implica, nuestro autor invierte la causalidad convencional y hace del mundo una metáfora de la obra. Este giro tiene sus raíces en la estética de vanguardia, que impugna los excesos y las distancias hasta el límite de convertir la realidad en una invención de la literatura. En efecto, según afirma Guillermo, la rebelión de la vanguardia

contra las formas consagradas por la historia [es decir contra el esteticismo] correspondía a la rebelión contra las formas realistas (temáticas, figurativas) establecidas en el arte. Es cierto que, desde el romanticismo, se había abandonado el principio de fidelidad a la naturaleza, aun el de una belleza ideal; pero la vanguardia le da un nuevo sentido a esa «desviación». No se trataba sólo de no imitar lo real; era necesario hacer de la obra una naturaleza activa, aun desligada de la subjetividad del artista; que la obra naciera de su propio dinamismo interno, del continuo juego de formas. De igual modo, la belleza no precede a la obra sino que surge de ella; o lo que surge ni siquiera es una obra «bella» sino un hecho (estético) inédito, que se impone o que se instala en la realidad. La vanguardia no compara sino crea: crea realidades inexistentes en el mundo aparente, y que éste luego asimila ${ }^{1066}$

Ya sea a través de la conciencia del lenguaje o a través de la inversión del vínculo poesía-realidad, lo cierto es que Sucre piensa que la obra literaria debe ser un modelo de saturación donde no haya cosas o palabras de más y donde los cuerpos y las significaciones coincidan perfectamente. Este paradigma de orden supone una consonancia entre el lenguaje y el mundo que anula toda distancia entre el escritor y su circunstancia y que permite al texto literario crear y descubrir la verdad esencial del hombre y del universo.

Estos planteamientos de nuestro autor se encuentran, sin embargo, con dos limitaciones que él mismo advierte y trata de solventar teóricamente. En primer lugar, el objetivo de alcanzar la máxima saturación entre las palabras y las cosas y entre la poesía y la vida podría conducir a exaltar la figura del creador y a incurrir por tanto en uno de

1066 Guillermo Sucre: "Introducción" a la Segunda parte de la Antología de la poesía hispanoamericana moderna, op.cit., p. 300. También en la obra de Vicente Huidobro Guillermo aprecia que la invención de lo real que tiene lugar en el poema supone la cancelación los excesos de cosas y de palabras. Desde el principio, dice Guillermo, Huidobro "opta por lo más difícil": "no nombrar ni comentar, sino literalmente crear. «Crear un poema como la naturaleza crea un árbol». La poesía es, por tanto, «el lenguaje de la Creación». Añadía igualmente, precisando aún más: «Ella se desarrolla en el alba primera del mundo. Su precisión no consiste en denominar las cosas, sino en no alejarse del alba». De este modo su estética rompía con varios prejuicios: el del «realismo» y el del «poeticismo». El poema, para existir, no requiere reflejar la realidad; inventa otra y, quizá lo más importante, la inventa como «irrealidad»." (Guillermo Sucre: La máscara ...op.cit., p. 263. Cursiva nuestra) 
los vicios que Sucre rechazaba con más fervor: el mesianismo del autor, es decir, el exceso de subjetividad. Para evitar esta desmesura, Guillermo recurre a la solución de la impersonalidad, que también había sido reivindicada por otros escritores continentales como Borges o Paz. Su idea es que al obtener la máxima saturación entre las palabras y las cosas, la poesía descubre un orden esencial en el que se disuelve la identidad del creador. Cuando el poema logra una estética adecuada y sin profusiones nos muestra el mundo como verdaderamente es $\mathrm{y}$, entonces, los rasgos particulares del autor coinciden con los de todos los hombres. Como ya no se puede hablar del sujeto y del objeto como entidades separadas, el descubrimiento del mundo esencial que tiene lugar en el texto trae consigo también el hallazgo de una mente humana universal. La despersonalización es, por lo tanto, una consecuencia lógica de la propia estética de Sucre pues si la consonancia del sujeto y del objeto en el poema implica el hallazgo de la realidad esencial y verdadera, el ser del creador no puede ser ni más ni menos que esa misma realidad. Entonces, el máximo cálculo que supone la adecuación entre los cuerpos y las significaciones no se resuelve en la exaltación de la personalidad del escritor sino en su coincidencia con (y su evaporación en) la realidad esencial inventada por el propio texto.

En segundo lugar, la estética de Guillermo corre el peligro de olvidarse de uno de los principios antagónicos cuya pugna constituía para Ranciére el ser mismo de la literatura $^{1067}$. Al hacer de la obra un modelo de saturación y de completitud que revela un mundo ético y esencial, Sucre está atendiendo exclusivamente al principio de poeticidad y está dejando de lado el de indiferencia. Al anular la contradicción entre los opuestos, nuestro autor corre el riesgo de convertir a la literatura en la figuración de una realidad original. En efecto, al poner todo el peso de su estética sobre la necesidad de

1067 "La literatura es el sistema de los posibles que determina el acuerdo imposible entre la necesidad del lenguaje y la indiferencia de lo que se dice, entre la gran escritura del espíritu vivo y la democracia de la letra desnuda." (Jacques Ranciére: La palabra muda...op.cit., p. 231) 
establecer una coincidencia entre las palabras y las cosas y entre la poesía y la vida, Guillermo establece una homología entre la escritura y el mundo que, de cumplirse efectivamente, nos impediría seguir hablando de literatura, pues, como dice Ranciére, "la pureza literaria no puede deshacer el vínculo que le unía a la democracia de la escritura [el principio de indiferencia] sin suprimirse a sí misma”"1068. Para salir de este impasse, Guillermo ofrece dos soluciones: una de ellas conduce, efectivamente, a la desaparición de la literatura y la otra, en cambio, permite que ésta se salve. En el primer caso nos estamos refiriendo a la poética de la transparencia que consiste en lograr la máxima coincidencia entre los cuerpos y las significaciones. Cuando la creación alcanza este ideal, según hemos visto en páginas anteriores ${ }^{1069}$, aparece lo real mismo, el lenguaje se disuelve en el mundo de referencia y la obra se sume en el silencio y en la contemplación. Sin embargo, en otros lugares, Sucre reconoce que la identidad entre el sujeto y el objeto y entre el lenguaje y la vida constituye la meta de todo poeta moderno, pero es, sin embargo, imposible de alcanzar. Por eso afirma:

crear otro lenguaje no es sólo cambiar el que tenemos; es también postular una suerte de absoluto verbal capaz (¿de nuevo?, ¿por primera vez?) de regir el universo. [/] Esta desmesura, como se ve, es problemática y aun lleva a una extrema tensión. No es extraño, por tanto, que la historia de la poesía moderna sea la historia de diversos fracasos; estos fracasos, sin embargo, pueden ser vistos como otras tantas victorias: la victoria de una conciencia que no renuncia a proponerse siempre lo más alto o lo más difícil y con ello, de algún modo, arroja una luz acusadora sobre la opacidad del mundo actual. Podría decirse que es la victoria del no. La literatura moderna, o lo más vivo de ella, es anti-literatura, pero en la medida en que quiere transgredir toda literatura; las obras optan por ser fragmentos o vestigios de obras, pero en la medida en que intentan, aun sabiendo que no lo lograrán, ser la Obra. ${ }^{1070}$

De acuerdo a esta concepción, la creación literaria moderna sería una búsqueda permanente del absoluto y un reconocimiento del fracaso de esa indagación. Sucre admite así que la poesía tiende a establecer una continuidad con la vida pero reconoce finalmente que este proyecto es inalcanzable por su propia temeridad, pues el lenguaje y la realidad son entidades finalmente irreconciliables. De esta manera, nuestro autor

1068 Jacques Ranciére: "Politique de la littérature", en Politique de la littérature, op.cit., p. 37. Traducción nuestra.

${ }^{1069}$ Vid. supra p. 238 y ss.

${ }^{1070}$ Guillermo Sucre: La máscara ...op.cit., p. 257. 
acepta la contradicción de los principios antagónicos y salva finalmente a la literatura.

Sin embargo, a pesar de que asume esta certeza, en sus propios planteamientos estéticos parece no tenerla en cuenta y en un momento llega incluso a admitir que la literatura logra, en cierta medida, superar la contradicción que la constituye:

El lenguaje es el mayor de los bienes dados al hombre, y el más peligroso también, decía Hölderlin. Es peligroso quizá, y sobre todo, por la fatalidad de su propia naturaleza. Nos pone en contacto con el mundo a la vez que nos aleja de él; introduce un orden o una inteligibilidad en la existencia, pero también la muerte: las palabras son abstracciones que "fijan" o "congelan" una realidad (y a nosotros dentro de ella) que está en continuo movimiento. La literatura, por su parte, no sería más que el intento por trascender esa fatalidad verbal, subrayada desde Hegel hasta Barthes, así como por casi todos los poetas modernos. Ese intento es siempre dilemático: ¿cómo trascender esa fatalidad sin cobrar conciencia de ella y, por otra parte, cómo cobrar conciencia de ella sin que la fuerza creadora de la literatura se vea afectada? No es todo. La literatura se lleva bien con ese dilema y es obvio que si ella existe es porque de algún modo logra superarlo; su lenguaje, en efecto, es un metalenguaje. ${ }^{1071}$

Vemos entonces que, por una parte, nuestro autor admite la contradicción de los principios antagónicos (búsqueda de la totalidad-imposibilidad de obtenerla) que conforman a la literatura. Por la otra, sin embargo, reconoce que la poesía moderna no deja de perseguir el absoluto (es decir, la anulación de la distancia entre las palabras y las cosas y entre el hombre y el universo) y, además, que "de algún modo" logra alcanzarlo. Así, a pesar de que Guillermo es consciente de los límites de la literatura, su propia propuesta estética tiende a pasarlos por alto y, en su empeño por alcanzar la plenitud a través de la escritura, llega a plantear una continuidad entre el lenguaje y la vida.

Por eso, de manera quizás más directa que en otros autores, el paradigma de orden que Sucre plantea a través de su estética lleva implícito al mismo tiempo una distribución de lo sensible. Como la realidad se configura en la obra, las pautas que se imponen a la creación literaria implican simultáneamente una definición de ese mundo original que la poesía revela e inventa. Entonces, la búsqueda de la máxima conciliación entre los cuerpos y las significaciones que nuestro autor quiere para la poesía supone la

${ }^{1071}$ Ibid., pp. 257-258. 
construcción de un orden político clásico y consensual donde no hay elementos sobrenumerarios que amenacen la estabilidad del sistema. En la visión de Guillermo, cuando la literatura es adecuada y carece de profusiones de cosas y de palabras encarna el orden esencial que rige en la realidad y que debe ser un modelo para la organización de la comunidad: "si el universo está bien hecho, la sociedad debe estarlo también: que cada quien se sienta en cualquier parte del mundo como en su casa (y al revés, ¿no?), que no haya ninguna conciencia incómoda de sí misma"1072. Ese mundo primordial que la poesía encarna es inmanente e igualitario y cancela las jerarquías y las divisiones impuestas por el poder en lo sensible. En la realidad esencial que la obra crea y descubre, las cosas carecen de cualquier dimensión trascendente y son maravillosas en su propia materialidad. Ello supone que se niegan las escisiones que la metafísica occidental había establecido entre el alma y el cuerpo, el espíritu y la carne o el futuro y el presente, y que los contrarios se implican entre sí. Ese universo original es un sensorium de igualdad radical, es decir, un sistema de relaciones horizontales en que ningún elemento (y, por supuesto, ninguna persona) es más importante que los demás. Como dice Sucre,

Si las cosas son claramente lo que son, esa claridad las vuelve transparentes también: se ven y se reflejan entre sí; se encuentran o se buscan unas a otras no para intercambiarse ni para adjurar de su identidad [...]: lo hacen para confrontarse, para reconocerse y aceptarse. Por consiguiente, la unidad no es más que la diversidad; no una sustancia fija sino una relación: el ser de las cosas es el estar-entre-sí de ellas, no porque sean idénticas sino porque viven en el mundo y participan en él. ${ }^{1073}$

Entonces, la realidad esencial que se inventa en el poema es un modelo de orden donde coinciden perfectamente los cuerpos y las significaciones y donde no hay agentes suplementarios. De acuerdo a esta ordenación, cada elemento ocupa su lugar dentro del

1072 Guillermo Sucre: "La cerebración de la celebración”, loc.cit., p. 71. En este sentido la creación literaria tiene un valor revolucionario pues, para Sucre, "la revolución no es una ideología, sino que nuestra ideología debe ser la revolución: la reconciliación y celebración de la vida, la naturaleza y el universo." Por eso "hay que hacerla no sólo contra sino fuera de la historia y todos los hábitos mentales que ella nos ha creado: voluntad de poder, exaltación de los nacionalismos, ejercicio de la grandeza, idolatría del progreso". (Ibíd.)

1073 Ibid., p. 69. 
conjunto y establece con el resto de elementos una relación de igualdad. Por lo tanto, el hallazgo de los límites (estéticos y políticos) originales supone también el encuentro de un universo pleno y justo que se opone radicalmente al reparto de lo sensible defendido a un tiempo por el poder autoritario y caudillista del continente y por la "teoría de la originalidad americana" y sus derivados posteriores.

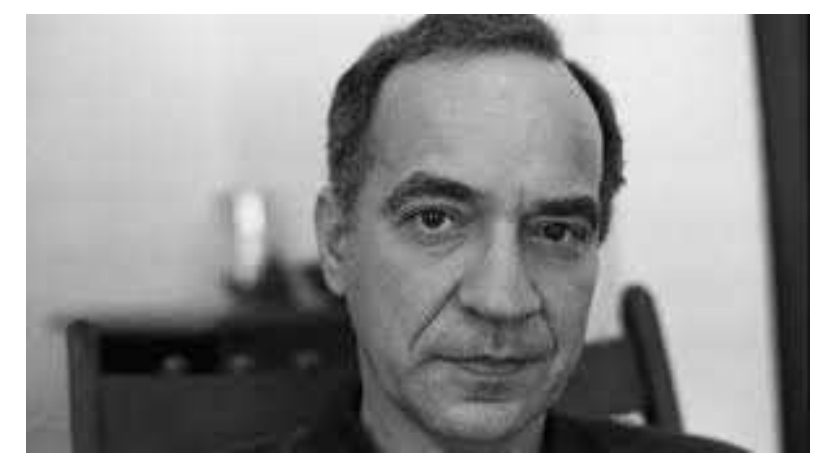

Imagen 58. Guillermo Sucre.

Vemos, por lo tanto, que la política que Guillermo propone a través de su estética procede de la mezcla de dos perspectivas. Por una parte, quizás como resultado de la lectura de Picón Salas, Sucre piensa que la literatura como discurso está ligada a una visión clásica del hombre y del mundo. En efecto, para él la literatura es inseparable de una búsqueda de la conciliación entre el nombre y lo nombrado y entre el lenguaje y la vida, y esa indagación la convierte en la figuración misma de un orden mesurado y esencial. La literatura, como hemos visto, no debe contener profusiones de cosas y de palabras sino que debe ser un modelo de saturación donde todos los elementos coincidan armónicamente. Nuestro autor advertía este paradigma de orden poético y político en las grandes obras de la tradición universal y anhelaba que las obras hispanoamericanas compartieran esos mismos valores que él consideraba esenciales. Por eso afirmaba que "la mejor crítica latinoamericana ha buscado siempre ese siempre ese espacio [...] en el cual nuestra literatura al encontrarse a sí misma, como tal 
literatura, se encuentra también con la literatura de otros países y otras lenguas"1074, y decía también, con el mismo sentido, que el "universalismo no es más que el signo de autenticidad de toda poesía: no un modo de ser, sino un modo del ser" ${ }^{\text {,075 }}$. En la visión de Guillermo, la literatura hispanoamericana debe responder, desde su propia perspectiva, al modelo de orden estético y político esencial que él considera propio de la literatura (y también del hombre) de todos los tiempos.

A este planteamiento que se aprecia ya en la etapa anterior a 1968, Guillermo añade después del 69 otras implicaciones que tienen que ver con los cambios sociales, políticos y epistemológicos con los que entra en contacto en este nuevo periodo. Como hemos visto, Sucre piensa que la creación literaria es capaz de mostrar la verdadera realidad cuando se convierte en un modelo de saturación en el que no sobra ni falta nada, es decir, cuando ajusta perfectamente los cuerpos y las significaciones. Ahora bien, en esta época, marcado sin duda por el impulso progresista de la sociedad norteamericana y por el pensamiento de intelectuales como Paz, Cage o Sontag, nuestro autor concibe que ese orden esencial que la literatura crea y descubre es además igualitario y carece de jerarquías. La poesía figura así un mundo utópico en el que todo está en su lugar y es plenamente visible, y en el que los diferentes elementos establecen entre sí relaciones horizontales. Por tanto, el orden clásico que la creación inventa supone al mismo tiempo el hallazgo de una realidad maravillosa que se encuentra detrás de las apariencias y de las opacidades que el poder ha establecido sobre lo sensible. En esa realidad plena los contrarios no se excluyen sino que se implican entre sí y todo finalmente se corresponde. Así, el mundo verdadero que la poesía encarna está en consonancia con el orden y la justicia esenciales que se advierten en el universo.

1074 Guillermo Sucre: “¿Imitar una imagen...?”, loc.cit., p. 67.

1075 Guillermo Sucre: La máscara, la transparencia, $2^{\mathrm{a}}$ ed., op.cit., p. 389. 
Según nuestro autor establece al final de la segunda edición de La máscara, la transparencia (1985), este paradigma simultáneamente poético y político se identifica finalmente con lo que Guillermo llama "la sensibilidad hispanoamericana"1076. Sucre afirma que esta sensibilidad no antecede a las obras sino que es su resultado y de este modo él plantea una relación entre el reparto de lo sensible que propone su estética y el carácter continental. Así, en contra quizás de lo que él pretendía, no acaba con el discurso culturalista que desde la Independencia había estado vinculado a la tradición del ensayo y de la crítica literaria en América Latina, sino que ofrece un giro de ese discurso desde su propia perspectiva. La otra tradición -esto es, la "secta" de identidad y su mitomanía, vinculada al poder autoritario- imponía una distancia entre la creación y la propia experiencia, lo que daba lugar a excesos éticos y estéticos y a imposturas de diversa índole. Sucre propone, en cambio, que el verdadero carácter hispanoamericano no es el resultado de esas obras representativas y logocéntricas que establecen una separación perniciosa entre las palabras y las cosas, sino de esas otras que se amparan en la conciencia del lenguaje y logran una continuidad feliz entre la poesía y la vida. Al lograr la conciliación entre el sujeto y el objeto o entre el lenguaje y la realidad las creaciones de los mejores poetas hispanoamericanos descubren la verdad esencial del hombre y del mundo, un orden armónico que en la visión de nuestro autor coincide asimismo con la sensibilidad continental.

${ }^{1076}$ Ibid., p. 388. 


\section{CONCLUSIONES}

A lo largo de este trabajo hemos estudiado el pensamiento literario de Guillermo Sucre a través de un enfoque diacrónico, y ello nos ha permitido apreciar el proceso de formación de sus ideas y los cambios operados en su estética a través del tiempo. Para llevar a cabo esta tarea hemos dividido la obra crítica de nuestro autor en dos periodos: primero hemos abordado su etapa "venezolana" -que abarca de 1958 a 1968- y después su etapa de madurez - que comprende desde su llegada a los EEUU en adelante. Esta partición es pertinente porque la diferencia de lugar y contexto impuso cambios decisivos en su perspectiva intelectual y, por consiguiente, en su pensamiento literario.

En la primera parte de esta investigación hemos abordado la intervención de Guillermo Sucre en el campo literario venezolano a lo largo de esa década convulsa que fueron los años 60. Desde que salió de la cárcel en 1958 y hasta su partida a los EEUU en el verano de 1968 nuestro autor dirigió o bien tuvo una presencia destacada en diversas empresas editoriales: Sardio (1958-1959), “Letras y Artes” (1962-1964), Zona Franca (1964-1966) e Imagen (1967-1968). En todas estas publicaciones hemos apreciado la continuidad de un mismo proyecto estético y hemos propuesto, por eso, que la labor de Sucre constituye el núcleo central del "oficialismo" en el campo cultural venezolano de los años 60. En efecto, en estas revistas (exceptuando quizás Zona Franca, donde el proyecto de Sucre tuvo que convivir con el de Liscano) nuestro autor promovió una estética de modernidad -basada en los valores de la autonomía y el universalismo- y trató de familiarizar a los lectores venezolanos con el canon central de la tradición occidental. En este sentido la estética de Guillermo casaba bien con la concepción cultural que en ese momento le interesaba favorecer al nuevo Estado democrático venezolano: un arte claramente separado de las otras esferas de la vida y cuyo valor crítico dependía de esa misma separación. Al defender este paradigma 
cultural, la estrategia discursiva de las publicaciones en las que nuestro autor participó encontró un modelo en la prensa liberal europea y latinoamericana que -respaldada por instituciones norteamericanas como el Congreso por la Libertad de la Cultura (y después el ILARI)- trataba de sumar adeptos en esa pugna ideológica que fue la Guerra Fría. Las publicaciones dirigidas por Sucre manejaron los mismos ideologemas que las grandes revistas liberales de la época y, además, actuaron como una caja de resonancia de las preferencias estéticas de estas mismas revistas. A este respecto resulta paradigmático el vínculo que Imagen -el quincenario cultural que Sucre fundó y dirigió entre 1967 y 1968- estableció con Mundo Nuevo, la revista parisina dirigida por Rodríguez Monegal que era financiada directamente por los EEUU para ejercer una influencia entre los intelectuales latinoamericanos. La publicación de Guillermo reivindicó a los mismos autores que estaban siendo patrocinados por Monegal -como Vargas Llosa y Carlos Fuentes, los "novísimos” como Puig o Sáinz, y algunos autores cubanos como Sarduy o Cabrera Infante- y reprodujo los patrones de lectura legitimados por el crítico uruguayo.

En la primera parte de este trabajo, aparte de analizar la labor de Sucre como promotor cultural, hemos estudiado también las constantes de su pensamiento literario durante la etapa 1958-1968. Para apreciar bien el proceso de formación de sus ideas, decidimos dividir esta década en dos fases, la primera desde 1958 hasta 1963 y la segunda desde 1964 hasta 1968. En los años que van desde su salida de la cárcel hasta el final de la página literaria "Letras y Artes" (1958-1963) hemos apreciado que Guillermo trata de poner límites a la autocomplacencia y el arribismo que advertía en el campo literario venezolano. La deshonestidad del medio intelectual y la consiguiente carencia de principios críticos habían tenido al menos dos consecuencias para el desarrollo de la literatura venezolana. En primer lugar, habían impedido conformar una 
literatura propiamente dicha, es decir, un conjunto de obras ligadas por denominadores comunes. En segundo lugar, habían imposibilitado a la literatura nacional entroncar con la estética de la tradición moderna y esa situación había llevado al aislamiento de las obras literarias venezolanas, que carecían de repercusión más allá de las propias fronteras. Ante este sombrío panorama, Guillermo Sucre se impuso la labor de modernizar y profesionalizar la literatura nacional, y para ello consideró necesario promover nuevas actitudes intelectuales e introducir una conciencia estética en base a criterios objetivos. Para elaborar esta estética firme que debía guiar a los creadores venezolanos, nuestro autor se sirvió del concepto de autenticidad. Esta noción suponía establecer un vínculo ineludible entre la experiencia vital de los creadores y su expresión literaria de manera que la literatura nacional superara los excesos perniciosos de cosas y de palabras en los que estaba incurriendo. Al reclamar de las obras una coincidencia entre la expresión y lo expresado, Sucre estaba impugnando las tendencias estéticas inarmónicas que adolecían de realismo o de esteticismo, y con ello trataba de convertir la literatura en un cuerpo saturado y bien compensado en el que no sobrara ni faltara nada. Además, al rechazar estas profusiones expresivas (el realismo y el formalismo), nuestro autor estaba descartando igualmente la distancia entre el escritor y su circunstancia (que conducía a los vicios del nacionalismo y del cosmopolitismo), pues estas actitudes estéticas y culturales desmesuradas distanciaban a la literatura venezolana del ethos que él consideraba propio de la tradición literaria universal.

En las críticas y los ensayos que escribió durante su participación en Zona Franca e Imagen (1964-1968) hemos advertido que Guillermo continuó reclamando de los escritores venezolanos un ideal de saturación expresiva, solo que ahora pasa a plantear este ideal como el resultado de una conciliación entre la pasión y la inteligencia. En línea con la tradición simbolista y con Mariano Picón Salas, Guillermo 
rechazaba aquella poesía instintiva o natural que se abandonaba a la inspiración, y exigía que la creación literaria estuviera templada por la inteligencia y la lucidez. Cuando la poesía procedía exclusivamente del rapto o del impulso primario, el vate perdía el control sobre ella y este hecho hacía que las obras se llenaran de desmesuras expresivas que les impedían entroncar con la verdadera tradición intelectual y con los valores universales del espíritu. En cambio, si conciliaba adecuadamente el rapto y el rigor, la obra conseguía reunir los opuestos y restituir la verdadera realidad del mundo, es decir, el absoluto que se había disuelto con la llegada de la modernidad. Hemos apreciado además que, desde el momento en que asume la dirección de la revista Imagen, como resultado del auge del pensamiento estructuralista, Sucre comienza a plantear que lo propio de la literatura es un ahondamiento en su propia materialidad y que ese ahondamiento comporta un componente crítico al que la creación literaria no puede renunciar.

En la segunda parte de esta investigación hemos estudiado el pensamiento de Sucre desde su llegada a los EEUU (1969) en adelante. El cambio de contexto modificó su trayectoria intelectual en tres sentidos: en primer lugar, la estancia en Norteamérica le hizo relegar el compromiso que había adoptado en los años anteriores con la cultura venezolana; en segundo lugar, el carácter latinoamericanista del nuevo medio académico le llevó a enfocarse en el estudio de la poesía continental y a elaborar un discurso coherente sobre la misma cuyo resultado más visible es su libro La máscara, la transparencia (1975); y, en tercer lugar, su inserción en un nuevo ámbito político y social y su acercamiento a algunos autores de la tradición literaria anglosajona impuso algunos cambios en su estética. A pesar de estos pequeños cambios, en la obra de Sucre posterior a 1969 continúa persistiendo, con ligeras modificaciones, el proyecto estético y cultural que había emprendido en la etapa anterior. 
Hemos podido apreciar que el pensamiento literario de nuestro autor a partir de 1969 se asienta sobre lo que él llama "la conciencia del lenguaje". Esta noción significa que ni el hombre ni la realidad son entidades fijas y autosuficientes que en un momento dado participan en la obra, sino que ambas entidades son absorbidas por la propia creación y solo existen después de encarnar en las palabras. De acuerdo a esta conciencia, y en contra de lo que planteaba la tradición logocéntrica, la creación literaria no imita un sentido preestablecido del mundo o del escritor sino que lo inventa y se convierte así en un nuevo nacimiento. Siguiendo lo que proponía al respecto Octavio Paz, Sucre concibe que la obra inventa la identidad del autor y la propia realidad; pero esa invención es al mismo tiempo una revelación, porque restituye al hombre y al mundo su verdadera presencia. Según la concepción de Guillermo, la obra crea y descubre la realidad esencial cuando alcanza la saturación expresiva y cancela los excesos de cosas y de palabras, o de objetividad y subjetividad. A esa continuidad perfecta entre el nombre y lo nombrado, nuestro autor se refiere con el término "transparencia", que es la forma que adopta la realidad al ser aprehendida imaginariamente por el creador y encarnada en la escritura. Al lograr la máxima saturación expresiva y obtener una coincidencia precisa entre el sujeto y el objeto y entre las palabras y las cosas, la obra revela un mundo esencial -inmanente e igualitario- donde se cancelan las jerarquías y las opacidades que el poder (y sus instrumentos ideológicos, la metafísica y la historia) ha instaurado en lo sensible. De este modo, hemos observado que en Sucre la utopía literaria es, al mismo tiempo, una utopía política, pues la conciliación de los excesos expresivos supone la figuración de un mundo pleno y original, apartado de las relaciones de dominio. Esto significa, además, que para nuestro autor la literatura es inseparable de un ethos fundamental del hombre y del mundo. En efecto, Guillermo piensa que la gran literatura presenta los 
mismos valores éticos y estéticos a través del tiempo y que constituye, por eso, un discurso transhistórico y universal. No tiene que ver con un espíritu sectario sino con un ideal de nobleza: no es una mera búsqueda de novedad sino el hallazgo de una actitud ética y estética esencial.

Para que la obra pueda conciliar adecuadamente el sujeto y el objeto, nuestro autor piensa que es preciso que el lenguaje poético sea equivalente a la realidad, es decir, que las palabras coincidan con los objetos a los que remiten. Guillermo es consciente de que es imposible encontrar una escritura absoluta, pero sin embargo plantea que la literatura moderna es un intento siempre renovado por alcanzarla. En su opinión, la imposibilidad de restituir la unidad primordial a través de la escritura se debe a dos "fatalidades" presentes en el lenguaje: por un lado, está la fatalidad constitutiva, que surge del reconocimiento de la distancia infranqueable que separa a las palabras de la realidad; y, por el otro, está la fatalidad a la que nuestro autor llama "de carácter social”, que es el resultado de la degradación del lenguaje por el poder y por la costumbre. Para restituir la realidad esencial a través de la poesía es imprescindible que el lenguaje supere estas dos fatalidades y recupere su capacidad para transparentar la referencia. Por eso Guillermo valora especialmente a aquellos autores como Homero Aridjis, Rafael Cadenas o Roberto Juarroz que consiguen devolver a las palabras la precisión y la claridad perdidas, y que escriben, por lo tanto, con un lenguaje nítido, capaz de transparentar la cosa misma que nombra. Hemos advertido que, en consecuencia, para nuestro autor el poema debe ser un cuerpo traslúcido donde no haya excesos ni opacidades y donde todo sea perfectamente visible. Lo importante para Sucre es el presente de la escritura, es decir, el cuerpo o la superficie del lenguaje, y no la remisión de los vocablos a una dimensión más profunda capaz de legitimar su sentido: 
por eso Guillermo rechaza el simbolismo y la alegoría, y prefiere centrarse en la materialidad del signo y en la imagen poética.

Por lo que se refiere a la concepción de nuestro autor sobre la literatura hispanoamericana hemos advertido que él se opone diametralmente a la "teoría de la originalidad americana" y a todas sus consecuencias posteriores. Esta teoría fue ideada por algunos intelectuales hispanoamericanos que, en los años siguientes a la Independencia política, supusieron que, para fundar las bases de una estética propia, era suficiente con que las obras continentales describieran la naturaleza o las costumbres autóctonas. Como se creía que la originalidad ya estaba dada en el referente humano o geográfico y que el escritor tenía simplemente que describir ese referente para crear una estética autónoma, la literatura devino una cuestión de contenidos y se estableció una enorme distancia entre lo que se decía y la manera de decirlo. Además, la interpretación del continente a la que las obras debían inequívocamente responder no era sino el resultado de la proyección de una mirada colonial que los propios hispanoamericanos arrojaban sobre sí mismos, es decir, un caso de lo que se conoce como orientalismo interno. La idea de que había unos temas americanos cuya simple expresión daría como resultado obras genuinas era la prueba de la sumisión de los escritores del continente a un punto de vista europeo. Además de esto, Guillermo cuestionaba el hecho de que los escritores vinculados a la teoría de la originalidad americana se creyeran capaces de representar la originalidad telúrica o social del continente, pues ese gesto implicaba que tenían una seguridad excesiva en sus propias posibilidades. En efecto, la teoría de la originalidad americana está detrás de otro de los grandes vicios que Sucre percibía en la literatura continental: el mesianismo de ciertos escritores. La búsqueda obsesiva de la originalidad y la egolatría que a ella se vincula no sólo privaron a las obras literarias del potencial creativo que les es propio, sino que además impidieron a la literatura 
hispanoamericana establecer una relación de igualdad con el resto de la literatura occidental.

La concepción de nuestro autor sobre la literatura hispanoamericana se estableció pues en oposición a la teoría de la originalidad y a los vicios que ella implicaba. Desde su punto de vista, la obra es ante todo una creación verbal y, como tal, no es un asunto de contenidos ni se puede reducir a la expresión de un saber fijado de antemano. Al estar construida con palabras, la obra tiene un potencial creador que le es intrínseco: su función, por tanto, no es copiar un sentido o una identidad ya establecidos sino más bien crearlos. Por lo tanto, Guillermo pensaba -siguiendo lo que Octavio Paz había establecido en su ensayo "Literatura de fundación" (1961)- que si existe algo así como una esencia de lo hispanoamericano, ella resultará de las obras y no será simplemente su causa. Ahora bien, para Sucre esa esencia en ningún caso puede hallarse en la supuesta originalidad del referente sino solo en una sensibilidad particular, es decir, en una manera de mirar y de escribir. La creencia de nuestro autor es que cada vez que los autores hispanoamericanos han sorteado la teoría de la originalidad y han comunicado una experiencia sin mediaciones, han conseguido revelar, sin pretenderlo, una sensibilidad característicamente hispanoamericana. En consonancia con estas ideas Guillermo valora especialmente a aquellos autores que cuestionaron la "teoría sustancialista" de lo hispanoamericano y que, en vez de basarse en un sentido determinado del continente y de proyectar una mirada europea, consiguieron crear a partir de una experiencia inmediata y de una sensibilidad propia. Este conjunto de obras (entre las que se cuentan las de Darío, Huidobro, Vallejo, Borges, Reyes, Lezama Lima, Picón o Paz) que se han generado a partir de una sensibilidad hispanoamericana sin mediaciones previas es lo que ha permitido a la literatura continental alcanzar una 
dimensión universal y establecer una relación horizontal con las grandes obras de la tradición occidental.

A través de nuestra investigación hemos visto también cómo Sucre concibe la crítica literaria. Como para él lo decisivo de la creación literaria no son los contenidos de la obra ni las ideas que contiene, sino la vivencia del mundo y del lenguaje que toma forma en la escritura, su crítica literaria trata de dilucidar la experiencia imaginaria y verbal que se origina en una creación determinada. Puesto que se centra en la vivencia de lo real que acontece en las palabras, lo que verdaderamente acapara la atención de nuestro crítico no es el texto en sí mismo, sino la cosmovisión y la actitud ante el lenguaje de un determinado autor-figura que no tiene nada que ver con el escritor real, sino que es la entidad imaginaria creada en y por la propia obra. Al concebir la obra literaria como un sistema controlado por la persistencia de la visión y de la actitud ante el lenguaje de un autor, la crítica de Sucre tiende a limar las diferencias entre las partes de una misma obra y a controlar la diversidad potencial de sentidos que podría darse en su interior. Hemos advertido, además, que esta concepción sistémica o estructural de la obra se reproduce en su noción de la historia literaria. Al pensar que esta historia constituye un conjunto de relaciones, Sucre considera imprescindible que el crítico sea capaz de situar a la obra que estudia en relación al conjunto de obras con las que dialoga, estableciendo afinidades y oposiciones. Este diálogo trasciende la mera disposición cronológica de la historiografía tradicional, pues en la visión de Sucre cualquier nueva creación que entra a formar parte del sistema de la literatura puede determinar las obras del pasado de la misma manera que estas modifican a las creaciones futuras.

Por otro lado, hemos comprobado que la noción de la obra literaria de Guillermo tiene consecuencias en su manera de pensar la crítica. Si la creación encarna una 
vivencia diáfana del mundo a través de un lenguaje sin espesor ni profundidad, es evidente que la crítica literaria no puede tener nada que ver con los sistemas hermenéuticos que remiten el sentido a una dimensión trascendente. En la visión de Sucre, el arte no se limita a copiar un saber sobre el mundo previamente establecido, sino que se impone la labor de fundar ese sentido: la obra es un nuevo nacimiento y, por eso, cualquier interpretación determinista (positivista, psicoanalítica o marxista) carece necesariamente de valor.

Igualmente hemos podido apreciar que la concepción de nuestro autor sobre la crítica literaria depende de su manera de pensar la escritura. Guillermo considera, con Barthes, que no hay una diferencia esencial entre la labor del escritor propiamente dicho y la del crítico, ya que ambos trabajan con el lenguaje. Por lo tanto, de la misma manera que el escritor debía ser capaz de conciliar la subjetividad y la objetividad para lograr una expresión saturada, sin excesos de cosas o de palabras, el crítico debe establecer una continuidad entre su mirada y la obra estudiada, pues sólo entonces se cancelarán las profusiones de subjetividad o de objetividad y se alcanzará, aunque sea por un instante, una coincidencia adecuada entre la visión del crítico y la creación literaria. Como en el caso de la obra propiamente dicha, Sucre piensa que la crítica literaria debe presentar una coincidencia total entre el sujeto (el crítico) y el objeto (la obra), y esa saturación, que por definición es momentánea, prueba la calidad del trabajo crítico. Al buscar este ideal de completitud también para la crítica, Guillermo rechaza aquellas concepciones de esta disciplina que adolecen de exceso de subjetividad o de objetividad. Ante las tendencias desmesuradas que o bien se olvidan de la obra o bien aspiran a fijar su sentido, Sucre valora aquella crítica que concilia la subjetividad del intérprete con la objetividad de la obra. Esta concepción implica que la crítica no debe ocuparse simplemente de discernir los valores de una obra sino que debe analizarlos y participar 
en ellos. Según el pensamiento de Guillermo, el crítico literario tiene que ser capaz de rescatar la experiencia ética y estética de la obra-objeto y hacerla revivir en una escritura que revele una sensibilidad y un lenguaje particulares, de manera que esa vivencia entre a formar parte de una nueva creación.

Y es a partir de esta teoría sobre la crítica que nosotros hemos leído los propios ensayos críticos de Guillermo Sucre. En ellos se aprecia, efectivamente, una doble tendencia a la participación y al análisis: por lo primero, el texto crítico tiende a reproducir la coherencia del sistema-obra $\mathrm{y}$, por lo segundo, el intérprete busca obsesivamente los límites de la obra-objeto.

Como la escritura trata de mimetizar la homogeneidad de la creación literaria, los ensayos de Sucre (y aquí me refiero sobre todo a los de La máscara, la transparencia) están gobernados por una serie de relaciones rítmicas que buscan hacer evidente la unidad de las diferentes partes (de la escritura crítica y de la obra de referencia, simultáneamente) y la del texto en su conjunto. La escritura de Guillermo tiende a controlar la proliferación incesante del lenguaje y trata de que el ensayo en su totalidad cristalice en una imagen. Para lograr esto intenta conjurar el carácter sucesivo de la expresión escrita a favor de la simultaneidad y el éxtasis, y vigila el avance del discurso para que cualquier ruptura o interrupción del mismo se resuelva en continuidad. Por eso su crítica presenta un vaivén "entre el movimiento y la fijeza" o entre "la dispersión y la tensión" que hemos observado también en la escritura de Octavio Paz.

Por otro lado, como ya hemos dicho, la crítica de Sucre trata de alcanzar la máxima coincidencia posible entre la subjetividad del exegeta y la objetividad de la obra. En base a esta idea hemos planteado que, en verdad, el tono dubitativo que se aprecia en sus ensayos no revela una voluntad dialógica o una falta de sistematicidad, 
sino que encubre justamente la actitud contraria. El recurso a la duda es, en efecto, una estrategia de la que se vale nuestro crítico para acercarse lo máximo posible a los límites de la obra-objeto y para enmascarar, al mismo tiempo, su propia posición de autoridad. En este sentido, los ensayos críticos de Guillermo dejan entrever la actitud característica del maestro hispanoamericano que González Echevarría advirtió en el Ariel (1900) de Rodó. En ese texto se adopta una apariencia dialógica pero, detrás de esa apariencia, como dice el profesor cubano, la voz del ensayista adopta una posición de magisterio. Del mismo modo, el tono vacilante que recorre los escritos de Sucre no revela una merma de autoridad sino que, al contrario, es un mecanismo que pretende encubrir las estrategias textuales mediante las cuales ella se reafirma.

Asimismo, a pesar de que al principio de La máscara, la transparencia Sucre afirma que su libro no pretende ser ni sistemático ni riguroso, hemos observado que en realidad define una concepción concreta sobre la cultura hispanoamericana. Los cambios derivados del triunfo de la Revolución cubana (1959) y el cuestionamiento posmoderno del concepto de identidad cultural dieron lugar a que el yo crítico se alejase de los discursos totalizadores y del didactismo mesiánico compartido por los ensayistas de generaciones anteriores. Sin embargo, estos cambios no implicaron que se abandonase el proceso de instauración cultural que había estado presente en la crítica y el ensayo hispanoamericanos desde la Independencia. En los ensayos de Guillermo Sucre se aprecia, en efecto, una crítica radical a la noción de identidad cultural vinculada a la "teoría de la originalidad americana", pero la impugnación de esta teoría solo tiene sentido porque defiende la fundación de la literatura (y, por tanto, de la identidad) continental sobre unos principios éticos y estéticos diametralmente opuestos. Como hemos podido apreciar al estudiar la figura del lector modelo en sus ensayos, Sucre no se dirige al pueblo como si este fuera una entidad idealmente coherente y 
homogénea, sino a una comunidad transnacional con unos mismos valores artísticos y políticos.

A lo largo de este trabajo hemos tratado de apreciar, además, las implicaciones políticas del pensamiento literario de Guillermo Sucre, para lo que nos hemos servido de la teoría de Jacques Ranciére. Este filósofo francés ha establecido que toda estética, en tanto que estética, implica un reparto de lo sensible, es decir, una determinada ordenación del mundo que habitamos. A este respecto, el pensamiento de nuestro autor muestra una gran coherencia, pues en efecto desde el principio hasta el final de su obra plantea que las obras literarias deben guiarse por un ideal de saturación entre el sujeto y el objeto que no deje lugar al suplemento. En oposición, primero, a ciertos escritores venezolanos que, abandonados a la pasión desbocada, convertían a la obra en un repositorio de cosas y de palabras y, después, a aquellos creadores afectos a la "teoría de la originalidad" que caían en el anecdotismo y en el esteticismo, Sucre piensa que las grandes obras literarias presentan una coincidencia precisa entre lo dicho y la manera de decirlo. Cuando esta unidad se alcanza no hay profusiones ni desmesuras y, entonces, la escritura encuentra el ethos esencial de la realidad y del hombre.

Hemos comprobado, de este modo, que la búsqueda de la máxima conciliación entre los cuerpos y las significaciones que nuestro autor quiere para la poesía supone la construcción de un orden político clásico y consensual donde no hay elementos sobrenumerarios que amenacen la estabilidad del sistema. En la visión de Guillermo, cuando la literatura es adecuada y carece de profusiones de cosas y de palabras encarna el orden esencial que rige en la realidad y que debe ser un modelo para la organización de la comunidad. Ese mundo primordial que la poesía encarna es inmanente e igualitario y cancela las jerarquías y las divisiones impuestas por el poder en lo sensible. Por lo tanto, el hallazgo de los límites estéticos y políticos originales supone también el encuentro de 
un universo pleno y justo que se opone radicalmente al reparto de lo sensible defendido a un tiempo por el poder autoritario y caudillista del continente y por la "teoría de la originalidad americana" y sus derivados posteriores.

Asimismo hemos advertido que Sucre identifica este paradigma
simultáneamente poético y político con lo que él llama "la sensibilidad
hispanoamericana”. En el giro que ofrece del discurso culturalista que había estado presente en el ensayo y en la crítica literaria de América Latina desde la Independencia, nuestro autor propone que el verdadero carácter del continente no es el resultado de esas creaciones que establecen una separación perniciosa entre las palabras y las cosas, sino de esas otras que se amparan en la conciencia del lenguaje y logran una continuidad apropiada entre la poesía y la vida. Al alcanzar la conciliación entre el sujeto y el objeto o entre el nombre y la realidad, los mejores poetas hispanoamericanos (esos que constituyen un verdadero "linaje") descubren, desde su propia perspectiva, la verdad esencial del mundo y del hombre, y ese orden armónico constituye el modelo para la ordenación estética y política del continente. 


\section{BIBLIOGRAFÍA (OBRAS CITADAS)}

\section{1.- BIBLIOGRAFÍA DE GUILLERMO SUCRE}

a) Monografías

Sucre, Guillermo: Borges, el poeta, México, UNAM, 1ª ed., 1967.

: Borges, el poeta, Caracas, Monte Ávila, 2a ed., 1974.

: La máscara, la transparencia. Ensayos sobre poesía hispanoamericana, Caracas, Monte Ávila, 1a ed., 1975.

: La máscara, la transparencia. Ensayos sobre poesía hispanoamericana, México, FCE, 2a ed., 1985.

b) Artículos

Sucre, Guillermo: “Testimonio”, en Sardio, Caracas, núm. 1, mayo-junio 1958, pp. 1-3.

: "Guerra del tiempo, de Alejo Carpentier", en El Papel Literario de El Nacional, Caracas, 31-07-58.

: "Huellas del silencio", en El Papel Literario de El Nacional, Caracas, 07-08-1958.

: "Nuestra novela no ha culminado", respuesta a la encuesta de Carlos

Dorante: "La novelística en manos de una juventud desinteresada", El Papel Literario de El Nacional, Caracas, 14-08-58.

: "El Reino de Ramón Palomares", en El Papel Literario de El Nacional, Caracas, 21-08-58.

: "Sobre Pablo Neruda", en Sardio, Caracas, núm. 3-4, sept.-dic. 58, pp. 254-256.

: "Vicente Gerbasi: Por arte de sol", en Sardio, Caracas, núm. 3-4, sep.-dic. 1958, pp. 257-258.

[Guillermo Sucre] s/f: "La liberación de Cuba", en Sardio, Caracas, núm. 3-4, sep.-dic. 1958, p. 274.

[Guillermo Sucre] s/f: “¿Una posible conjura contra la constitucionalidad?, en Sardio, Caracas, núm. 3-4, sept.-dic. 1958, pp. 275-276. 
: "Testimonio: Las constantes de nuestra generación", en Sardio, Caracas, núm. 3-4, sep.-dic. 1958, pp. 277-282.

: "Moneda del forastero", en El Papel Literario de El Nacional, Caracas, 18-09-58.

: “Casandra de Díaz Sánchez", en El Papel Literario de El Nacional, Caracas, 25-09-58.

: "Balance de una encuesta. Sobre novela venezolana", en El Papel Literario de El Nacional, 09-10-58.

: "La "violenta estación" de Octavio Paz", en El Papel Literario de El Nacional, Caracas, 16-10-58.

: “Los inmortales", en "El Papel Literario" de El Nacional, 30-10-58.

: "Pido la paz y la palabra", en El Papel Literario de El Nacional, Caracas, 06-11-58.

: "Obras selectas de V. Huidobro", en El Papel Literario de El Nacional, Caracas, 13-11-58.

: "Juan Sánchez Peláez: Animal de costumbre", en Sardio, Caracas, núm. 5-6, ene.-abr. 59, pp. 411-412.

22-01-59.

: "Los herbarios rojos", en El Papel Literario de El Nacional, Caracas,

: "La resaca de Juan Goytisolo", en El Papel Literario de El Nacional, Caracas, 21-05-59.

: "Testimonio. El intelectual de izquierda y cierta estética revolucionaria", en Sardio, Caracas, núm. 7, abril-mayo de 1959, pp. 429-434.

: "Les lettres nouvelles: Nouveaux Ecrivains de l'Amerique Latine", en Revista Nacional de Cultura, Caracas, núm. 148-149, sep.-dic. 61, pp. 254-256.

: "Uslar Pietri: Un retrato en la geografía", en La República, Caracas, 22-07-62, p. 7.

: "Oswaldo Trejo: También los hombres son ciudades", en La República, Caracas, 05-08-62, p. 7.

: "Tres cuentos del concurso de «El Nacional»" (La República, Caracas, 19-08-62, p. 7.

: "La poesía de Sedar Senghor", en La República, Caracas, 02-09-62, p. 7. 
: "Cuando la literatura pierde autenticidad", en La República, Caracas, 16-09-62, p.7.

: “La poesía de Antonio Arráiz", en La República, Caracas, 23-09-62, p. 7.

: "En Síntesis”, en La República, Caracas, 23-9-62, p. 7.

: "Guillermo Meneses: La Misa de Arlequín", en La República, Caracas, 14-10-62, p. 7.

: "Paul Éluard”, en La República, Caracas, 18-11-62, p. 7.

: "Revérdy y Huidobro", en La República, Caracas, 02-12-62, p. 7.

: "La crítica literaria”, en La República, Caracas, 09-12-62, p. 7.

: "Enriqueta Arvelo Larriva", en La República, Caracas, 16-12-62, p. 7.

: "Juan Calzadilla: Dictado por la jauría" y "Pascual Venegas Filardo: Los cantos fluviales", en La República, Caracas, 20-01-63, p. 7.

: "La poesía de Gonzalo Rojas", en La República, Caracas, 10-02-63, p. 7.

: "La venganza contra la poesía", en La República, Caracas, 17-03-63, p. 7.

: “Octavio Paz: Salamandra”, en La República, Caracas, 07-04-63, p. 7.

: "Situación actual de la poesía de Vallejo", en La República, Caracas, 14-04-63, p. 7.

: "Un poeta elemental y reflexivo", en Sur, Buenos Aires, núm. 283, jul-ago. 63, p. 35 .

: "Perspectivas sobre la novela", en La República, Caracas, 28-07-63, p.

7.

: "Sobre poesía venezolana", en Revista Nacional de Cultura, Caracas, núm. 161, nov.-dic. 63, pp. 225-246.

: "Manuel Pedro González: Ensayos críticos", en La República, Caracas, 03-11-63, p. 7.

: “Alain Fournier: Una pasión de absoluto", en La República, Caracas, 24-11-63, p. 7. 
: "La muerte de Honorio. Un buen testimonio, no una novela", en La República, Caracas, 12-01-64, p. 7.

: "La novela del exilio", en La República, Caracas, 16-02-64, p. 7.

: "Las buenas y las malas razones de Sartre", en Zona Franca, Caracas, año I, núm. 4, 15/30 oct. 1964, p. 4.

: "Entrevista con Lucien Goldmann", en Zona Franca, Caracas, año I, núm. 5, 1/15 nov. 1964, pp. 6-7.

: "Introducción" a Jacinto Fombona: Poesías, Caracas, Dirección de Cultura de la Universidad Central de Venezuela, 1964.

: "Una poesía sin mitos", en Zona Franca, Caracas, núm. 12, 15/28 feb. 65 , pp. $12-13$.

: "Las influencias literarias", en Zona Franca, Caracas, núm. 13-14, mar. 65, pp. 25-26.

: “Álgebra y fuego”, en Zona Franca, Caracas, núm. 15-16, abr. 65, p.

3.

: "El viajero vestido de ardor silencioso", en Zona Franca, Caracas, núm. 26 , oct. 65 , pp. 8-9.

: "En el resplandor de la infancia", en Zona Franca, Caracas, núm. 28, dic. 65 , pp. $38-39$.

: "En la magia del lenguaje”, en Zona Franca, Caracas, año II, núm. 30, feb. 1966, pp. 16-18.

: "El diálogo con el mundo", en Zona Franca, Caracas, núm. 33, may. 66, pp. 12-17.

: "Nuestra joven poesía", en Zona Franca, Caracas, núm. 33, may. 66, pp. 36-37.

: "El poder de la literatura", en Zona Franca, Caracas, año II, núm. 34, jun. 66, pp. 2-3.

: “Mutaciones”, en Mundo Nuevo, París, núm. 5, nov. 1966. [Poemas]

: "Reconciliar el universo", en Zona Franca, Caracas, núm. 39, nov. 66, pp. 2-3.

: "Presentación. Nuestro propósito", en Imagen, Caracas, núm. 1, 15/30 mayo 67, p. 2. 
: s/t (editorial del núm. 3), en Imagen, Caracas, núm. 3, 15/30 jun. 67, p.

2.

: s/t (editorial del núm. 5), en Imagen, Caracas, núm. 5, 15/30 jun. 67, p.

2.

: "Presencia de la crítica", en Imagen, Caracas, núm. 7, 15/31 de agosto de 1967, p. 2.

: "La prueba de fuego", en Imagen, Caracas, editorial núm. 8, 1/15 de septiembre de 1967, p. 2.

: "La opción de la literatura", en Imagen, Caracas, editorial núm. 9, 15/30 sep. 67 , p. 2.

: “¿Ha muerto el arte?” en Imagen, Caracas, editorial núm. 10, 1/15 oct.

67, p. 2.

: "Rosa de espadas", en Imagen, Caracas, núm 10, 1/15 oct. 67, p. 22.

: "Neruda y el tiempo recobrado", en Imagen, Caracas, núm. 12, 1/15 de noviembre de 1967, pp. 4-5.

: "El intelectual y nuestro tiempo", en Imagen, Caracas, núm. 13, 15/30 nov. 1967, p. 2.

: "La desmistificación por el humor", en Imagen, Caracas, Supl. núm. $13,15 / 30$ nov. $67, \mathrm{~s} / \mathrm{p}$.

: "Una política cultural", en Imagen, Caracas, núm. 14-15, 15/30 dic. 1967, p. 2.

: "La lucidez crítica", en Imagen, Caracas, editorial núm. 16, 15/30 ene. 68, p. 2.

: "Honrar al mundo con la escritura", en Imagen, Caracas, Supl. 17, 15/30 ene. 68 , pp. 9-16.

: "Contra la parcelación de la cultura", en Imagen, Caracas, editorial núm. 18, 1/15 feb. 68, p. 2.

: “Nuevos poetas venezolanos", en Mundo Nuevo, París, ene. 1968, pp.

$21-23$

: "El destino del libro en América Latina", en Imagen, Caracas, núm. 19, 15/29 feb. 68, p. 2. 
: "Baudelaire. Soñar y saber soñar", en Imagen, Caracas, Supl. 19, $15 / 29$ feb. $68, \mathrm{~s} / \mathrm{p}$.

: "En el umbral de una nueva literatura", en Imagen, Caracas, núm. 20, 1/15 de marzo de 1968, p. 2.

[Sucre, Guillermo] Rodrigo Antúnez: "Una revista en la tradición moderna. Revista Nacional de Cultura”, en Imagen, Caracas, núm. 20, 1/15 mar. 68, p. 22

Sucre, Guillermo: "Sarduy: los plenos poderes de la retórica", en Imagen, Caracas, núm. 20, 1/15 de marzo de 1968, p. 24. 1968, p. 2.

: "El arte y la realidad", en Imagen, Caracas, núm. 21, 15/30 marzo de

[Sucre, Guillermo] Rodrigo Antúnez: "Mariño Palacio: la inmadurez creadora" en Imagen, Caracas, núm. 21, 15/30 mar. 68, p. 4.

Sucre, Guillermo: "La trayectoria poética de Vallejo", en Imagen, Caracas, núm. 21, $15 / 30$ mar. 68 , p. 5.

[Sucre, Guillermo] Rodrigo Antúnez: “Hacia dónde van las artes plásticas?” en Imagen, Caracas, núm. 21, 15/30 mar. 68, p. 22.

Sucre, Guillermo: "Relectura de Darío", en Revista de Occidente, Madrid, año VI, 2a época, núm. 61, abr. 68, pp. 46-68.

[Sucre, Guillermo] Rodrigo Antúnez: "La poesía de los muros”, en Imagen, Caracas, núm. 22, 1/15 abr. 68, p. 22.

Sucre, Guillermo: "Vallejo: la nostalgia de la inocencia", en Imagen, Caracas, Supl. núm. 23, 15/30 abril 68, s/p.

: "Primer aniversario", Imagen, Caracas, editorial núm. 24, 1/15 mayo 68, pp. 2-3.

[Sucre, Guillermo] Rodrigo Antúnez: "Literatura y sociedad: una relación problemática”, en Imagen, Caracas, núm. 24, 1/15 may. 68, p. 6.

Sucre, Guillermo: "En la línea más cercana", Imagen, Caracas, núm. 24, 1/15 mayo 1968, p. 9. 68, p. 2.

: "El arte y la moda", Imagen, Caracas, editorial núm. 25, 15/30 mayo

[Sucre, Guillermo] s/f: "Nota introductoria al Supl. núm. 25”, en Imagen, Caracas, núm. $25,15 / 30$ mayo $1968, \mathrm{~s} / \mathrm{p}$. 
Sucre, Guillermo: "La discreta pasión de un bibliógrafo", Imagen, Caracas, editorial núm. $25,15 / 30$ may. $68, \mathrm{~s} / \mathrm{p}$.

: "Un comité contra la censura", editorial núm. 26, 1/15 de junio 1968, p. 2.

: "La nueva literatura", en Imagen, Caracas, núm. 27, 15/30 junio de 1968, p. 2.

[Sucre, Guillermo] Rodrigo Antúnez: "Literatura crítica”, en Imagen, Caracas, núm. 27, $15 / 30$ jun. 68 , p. 3.

Sucre, Guillermo: "Lo precario de nuestra crítica", en Imagen, Caracas, editorial núm. $28,1 / 15$ jul. 68 , p. 2.

: "La poesía como reconocimiento", en Imagen, Caracas, núm. 28, 1/15 de julio de 1968, p. 24.

: “Con la misma adhesión”, en Imagen, Caracas, núm. 29, 15/30 jul. 68, p. 2.

: "Tendencias de la crítica borgiana", en Revista Iberoamericana, Pittsburgh, vol. XXXV, núm. 68, may.-ago. 1969, pp. 365-369.

: "Poesía Crítica: Lenguaje y silencio", en Revista Iberoamericana, Pittsburgh, vol. XXXVII, núm. 76-77, jul.-dic. 1971, pp. 575-597.

: "Borges, una poética de la desposesión", en Revista Iberoamericana, Pittsburgh, vol. XXXVIII, núm. 79, abr.-jul. 1972, pp. 187-198.

: "La nueva crítica", en César Fernández Moreno (coord.): América Latina en su literatura, París y México, UNESCO y Siglo XXI, 1972, pp. 259275.

: "La poética de Georges Braque”, en Plural, México, núm. 38, nov. 74, Supl.

: "La cerebración de la celebración", en Plural, México, núm. 42, mar. 75 , pp. 68-72.

$70-73$.

: "La metáfora incompleta", en Plural, México, núm. 46, jul. 75, pp.

: "La nueva profundidad: superficies nítidas", en Plural, México (V-2), nov. 75 , pp. $78-81$.

: "Entretextos", en En el verano cada palabra respira en el verano, Buenos Aires, Alfa, 1976. [Poemas] 
: "Entretextos”, en Vuelta, México, may. 77, pp. 9-11.

: “Memorial, de Rafael Cadenas", en Vuelta, México, nov. 1978, pp.

$40-41$.

: "Poesía hispanoamericana y conciencia del lenguaje", en Eco, Bogotá, núm. 200, 1978, pp. 608-633.

: "Ramos Sucre: Anacronismo y/o renovación", en Revista Iberoamericana, Pittsburgh, vol. XLV, núm. 106-107, ene.-jun. 1979, pp. 77-84.

: "Contraportada" a Eduardo Mitre: Mirabilia, La Paz, Hipótesis, 1979.

: “Imitar una imagen o fundar una experiencia?”, en Guillermo Sucre (coord.): Perspectivas sobre la literatura latinoamericana, Caracas, EquinoccioUniversidad Simón Bolívar, 1980, pp. 53-68.

pp. 39-41.

: "Inscripciones, de Francisco Rivera", en Vuelta, México, feb. 1982,

: "La errancia sin fin, de Juan García Ponce", en Vuelta, México, mar. 1982, pp. 36-38.

: "Rosenblat: la generosidad del lenguaje", en "El Papel Literario" de $E l$ Nacional, Caracas, 5 y 9 de diciembre de 1982.

: "Prólogo" a Mariano Picón Salas: Viejos y nuevos mundos, Caracas, Biblioteca Ayacucho, núm. 101, 1983, pp. IX-XLI.

: "Recuerdo de Raimundo Lida" en Raimundo Lida: Rubén Darío. Modernismo, Caracas, Monte Ávila, 1984, pp. 9-17.

: “La virtud antropófaga”, en Vuelta, México, núm. 166, sep. 1990, pp.

49-51.

: "De la elegancia y otros anacronismos", en Vuelta, México, núm. 167, oct. 1990, pp. 41-42.

: “Octavio Paz: La otra voz”, en Vuelta, México, núm. 175, jun. 91, pp. 24-28.

: "Los cuadernos de la cordura", en Vuelta, México, núm. 197, abr. 93, pp. 16-18.

: "Los cuadernos de la cordura. La indefensión de las palabras", en Vuelta, México, núm. 199, jun. 1993, pp. 57-58.

: "Los cuadernos de la cordura. La polvareda y la falacia", en Vuelta, México, núm. 202, sep. 93, pp. 54-55. 
: "Introducción", a la Primera Parte de la Antología de la poesía hispanoamericana moderna, Vol. I, Caracas, Equinoccio y Monte Ávila, 1993, pp. 19-28.

: "Introducción" a la Segunda Parte de la Antología de la poesía hispanoamericana moderna, Vol. I, Caracas, Equinoccio y Monte Ávila, 1993, pp. 297-306.

: "Introducción" a la Tercera Parte de la Antología de la poesía hispanoamericana moderna, Vol. II, Caracas, Equinoccio y Monte Ávila, 1993, pp. 11-20.

(coord.): Antología de la poesía hispanoamericana moderna, Caracas, Monte Ávila y Editorial Equinoccio, Vols. I y II, 1993.

: "Mi itinerario con Octavio Paz", en Vuelta, México, núm. 259, jun. 98 , pp. 24-25.

: "Ramos Sucre. La pasión por los orígenes", en José Antonio Ramos Sucre: Obra poética completa, México, FCE, 1999, pp. 9-38.

: “Ángel Rosenblat: la palabra y la ilusión”, en Principia, Revista de Cultura de la Universidad Centrooccidental Lisandro Alvarado, Barquisimeto, enero de 2005, núm. 24, pp. 54-64.

: "Ahora reposa en Greenwood", en "El papel literario" de El Nacional, Caracas, 10 de diciembre de 2005, p. 1.

: "Recuerdos personales", en Letras libres, México, núm. 130, oct. 2009, pp. 44-48.

: "Democratura", en Letras Libres, México, núm. 165, sep. 2012, pp. $14-17$.

: “Consalvi, la diplomacia inteligente", en Letras Libres, México, núm. 175, jul. 2013, pp. 38-40.

c) Traducciones de Guillermo Sucre

Aczél, Tamás y Méray, Tibor: "Un comunista aristócrata", I y II, en La República, Caracas, 13-10-63 y 20-10-63, p. 7.

Blanchot, Maurice: "Sobre la crítica literaria", en La República, Caracas, 5 de enero de 1964, p. 7. 
Etiemble, René: "La vida intelectual en Budapest", en La República, Caracas, 16-12-62 y 23-12-62, p. 7.

Girard, René: Mentira romántica y verdad novelesca, Caracas, Ediciones de la Biblioteca de la UCV, 1963 [1961].

Goldmann, Lucien: El teatro de Jean Genet. Ensayo de estudio sociológico, Caracas, Monte Ávila, 1968.

Perse, Saint-John: Estrechos son los navios (fragmentos), Caracas, Ediciones Sardio, 1957.

Perse, Saint-John: Los pájaros, Caracas, Fundarte, 1977.

Stevens, Wallace: Adagia, Caracas, Fundarte, 1977, p. 16.

Williams, William Carlos: La primavera y todo, Caracas, Monte Ávila, 1980.

\section{2.- BIBLIOGRAFÍA SOBRE GUILLERMO SUCRE}

Anónimo: "Guillermo Sucre. Profesor titular de Cambridge", en El Nacional, Caracas, 13-06-1997, p. C-14.

Barrera Linares, Luis: "El regreso del Mariscal Sucre" en El Nacional, Caracas, 8 de julio de 1993, p. A-5.

Balza, José: "Márgenes en la locura", en Revista Criterion, Caracas, núm. 7, agosto de 1993, pp. 11-13.

: "Guillermo Sucre: la felicidad y el árbol de la tormenta", publicado en Obras selectas. Ensayos. Fulgor de Venezuela, Caracas, Fondo Editorial de Humanidades y Educación, Departamento de Publicaciones de la UCV, 2001, pp. 333-354.

Borzacchini, Chefi: "Juan Liscano por Juan Liscano", en El Nacional, Caracas, 18 de julio de 1993, p. C-2. [Entrevista a Juan Liscano centrada en la polémica suscitada por los artículos de Sucre]

Castañón, Adolfo: "Guillermo Sucre: silencio, historia y persona en la poesía hispanoamericana", en Venezuela entrevista. Crónicas, ensayos, narraciones, Mérida, El otro, el mismo, 2009, pp. 114-122. [El artículo se publicó por primera vez en la revista Siempre, México, 1976]

Chacón, Alfredo: "Guillermo Sucre en la vastedad", en Cuadernos Hispanoamericanos, Madrid, núm. 528, junio 1998, pp. 111-114.

Colmenares, Hugo: "La lucha es entre cogollos culturales", en El Nacional, Caracas, 8 de julio de 1993, p. C-14. [Participan en esta encuesta colectiva Óscar Rodríguez Ortiz, Eduardo Liendo, Manuel Bermúdez, Earle Herrera, Tarek Williams Saab] 
Equipo de Arte de El Nacional: "Toda generalización es arbitraria y hay que evitar el personalismo", en El Nacional, 3 de julio de 1993, p. C-12. [Participan Salvador Garmendia, Denzil Romero, Eduardo Casanova, Armando José Sequera, Rafael Arráiz Lucca]

Liscano, Juan: “Cinco poetas jóvenes venezolanos”, en Sur, Buenos Aires, núm. 293, mar.-abr. 65, pp. 79-91.

: "De escritores" en El Nacional, Caracas, sección Cartas a El Nacional, 27 de junio de 1993, p. A-5. pp. 53-55.

: "Polémica venezolana en México", Vuelta, México, núm. 203, oct. 1993,

Medina Portillo, David: "Antología de la poesía hispanoamericana moderna", en Vuelta, México, núm. 214, sep. 1994, pp. 36-38.

Muñoz, Boris: "Saludo mínimo a Guillermo Sucre", en El Papel Literario de El Nacional, Caracas, 20-04-1997, p. G-1.

Nuño, Juan: "Poetas a la greña”, en El Nacional, Caracas, 10 de julio de 1993, p. C-16.

: "Mala mezcla y peor puntería", en Revista Criterion, Caracas, núm. 7, agosto de 1993, pp. 8-10. 57.

: “Qué pasa en Venezuela?, en Vuelta, México, núm. 203, oct. 1993, pp. 55-

Palacios, María Fernanda y Balza, José: “Conversación con Guillermo Sucre”, en Falso Cuaderno (Literatura, arte, crítica, ciencia y otras cosas), Caracas, núm. 2, octubre de 1976, pp. 3-5 y 28-29.

Rivera, Francisco: "Guillermo Sucre y la poesía latinoamericana”, en Inscripciones, Caracas, Fundarte, 1981, pp. 11-33.

Rodríguez Gómez, Alexis: “Guillermo Sucre: ¿un metaintelectual?”, en El Nacional, Caracas, sección Cartas a El Nacional, 18 de julio de 1993, p. A-5.

Rodríguez Monegal, Emir: "Un lector de poesía”, en Plural, México, núm. 54, vol. V, $n^{\text {o }}$, marzo de 1976, pp. 58-59.

Santaella, Juan Carlos: "Dentro del cristal", en El Nacional, Caracas, 8 de julio de 1993, p. C-14.

Valle, Gustavo: "Guillermo Sucre: la libertad y la cordura", en El Papel Literario de El Nacional, Caracas, 13-06-2009, pp. 7-8. [El artículo está editado también en Cuadernos Hispanoamericanos, Madrid, núm. 713, nov. 2009, pp. 39-44]

Xirau, Ramón: “En el verano cada palabra respira en el verano, de Guillermo Sucre”, en Vuelta, México, ene. 1977, pp. 40-41. 
Yagüe Jarque, Eloi: "Muchos de nuestros intelectuales son comadronas de la conspiración militar", y "Disparos contra el Innombrable", en El Nacional, Caracas, 2 de julio de 1993, p. C-18.

\section{3.- BIBLIOGRAFÍA SOBRE EL CONTEXTO HISTÓRICO Y CULTURAL}

Abril, Xavier: Vallejo: ensayo de aproximación crítica, Buenos Aires, Front, 1958.

Achugar, Hugo: "Notas para un debate sobre la crítica literaria latinoamericana", en Casa de las Américas, La Habana, núm. 110, sep.-oct. 1978, p. 3-18.

Acosta Bello, Arnaldo: "La táctica literaria y la estrategia política", en Tabla redonda, Caracas, núm. 7, mar.-abr. 1961, p. 7.

Aguilar, Gonzalo: "Los intelectuales de la literatura: cambio social y narrativas de identidad”, en Carlos Altamirano (dir.): Historia de los intelectuales en América Latina, Vol. II. Los avatares de la ciudad letrada en el siglo XX, Madrid y Buenos Aires, Katz Editores, 2010, pp. 685-711.

Arráiz Lucca, Rafael: "Las tareas de la imaginación. (La cultura en el siglo XX venezolano)", en Carrera Damas, Germán et al.: Comprensión de nuestra democracia, Caracas, Fondo Editorial 60 años de la Contraloría General de la República, 1998, pp. 165-202.

: Juan Liscano, Caracas, El Nacional, Biblioteca biográfica venezolana, núm. 74, 2008.

Barrenechea, Ana María: La expresión de la irrealidad en la obra de Borges, Buenos Aires, Centro Editor de América Latina, 1984.

Bautista Urbaneja, Diego: "La nación, Estado, petróleo y democracia en la historia de Venezuela", en Carrera Damas, Germán et al:: Comprensión de nuestra democracia, Caracas, Fondo Editorial 60 años de la Contraloría General de la República, 1998, pp. 135-162.

: La política venezolana desde 1958 hasta nuestros días, Caracas, Fundación Centro Gumilla, Universidad Católica Andrés Bello, 2007.

Béguin, Albert: El alma romántica y el sueño, México, FCE, 1954.

Bell, Daniel: El advenimiento de la sociedad post-industrial, Madrid, Alianza, 1991 [1973].

Bravo, Víctor: "Transición y expectativas del medio siglo", en Carlos Pacheco et al. (coord.): Nación y literatura. Itinerarios de la palabra escrita en la cultura 
venezolana, Caracas, Fundación Bigott y Editorial Equinoccio, 2006, pp. 583590.

Brioso Santos, Héctor: Estridencia e ironía. El Techo de la Ballena. Un grupo de vanguardia venezolano (1961-1969), Sevilla, Universidad de Sevilla, 2002.

Cândido, Antonio: "Literatura y subdesarrollo" en César Fernández Moreno (coord.): América Latina en su literatura, París y México, UNESCO y Siglo XXI, 1972, pp. 335-353.

Carrera Damas, Germán: Una nación llamada Venezuela, Caracas, Monte Ávila, 1980.

Carrillo, Carmen Virginia: De la belleza y el furor. Propuestas poéticas renovadoras en la década de los sesenta en Venezuela, Mérida, El otro el mismo, 2007.

Chacón, Alfredo: "Trayectoria ideológica de la izquierda cultural venezolana 19581968", "Prólogo" a La izquierda cultural venezolana 1958-1968, Caracas, Editorial Domingo Fuentes, 1970, pp. 9-57.

Consalvi, Simón Alberto: "Un premio inobjetable", discurso de concesión del Premio Rómulo Gallegos, en Mundo Nuevo, París, núm. 17, nov. 1967, pp. 92-93.

Coronil, Fernando: The Magical State: Nature, Money, and Modernity in Venezuela, Chicago \& London, The University of Chicago Press, 1997.

Degler, Carl N. et. al.: Historia de los EEUU, México, Noriega, 1998.

Delprat, François: "Un magazine de grande diffusion Imagen", en VVAA: Le discours culturel dans les revues latino-américaines de 1970 à 1990, Cahiers du CRICCAL, 3ème Série, París, Presses de la Sorbonne Nouvelle, s/a., pp. 248257.

Gomes, Miguel: Poéticas del ensayo venezolano del siglo XX, Maracaibo, Universidad Católica Cecilio Acosta y Universidad del Zulia, 2007.

: La realidad y el valor estético. Configuraciones del poder en el ensayo hispanoamericano, Caracas, Equinoccio, 2009.

González, Aníbal: "La crítica literaria en Hispanoamérica", en Roberto González Echevarría y Enrique Pupo-Walker (eds.): Historia de la literatura hispanoamericana, Vol. II, Madrid, Gredos, 2006 [1996], pp. 429-459.

Earle, Peter G.: "El ensayo hispanoamericano como experiencia literaria”, Kurt. L. Lévy y Keith Ellis: El ensayo y la crítica en Iberoamérica, Actas del XIV Congreso del Instituto Internacional de Literatura Iberoamericana, Toronto, Toronto University, 1970, pp. 23-31. 
Fombona, Julieta: "Teresa de la Parra: las voces de la palabra", en Teresa de la Parra: Obra. Narrativa, ensayos, cartas, Caracas, Biblioteca Ayacucho, núm. 95, 1983, pp. IX-XXVI.

González Echeverría, Roberto: La voz de los maestros, Madrid, Verbum, 2001.

: "Doña Bárbara escribe la ley del llano", en La voz de los maestros, Madrid, Verbum, 2001, pp. 71-109.

González Silva, Pausides: "De La Alborada a Cantaclaro: literatura y compromiso en cinco revistas", en Carlos Pacheco et al. (coord.): Nación y literatura. Itinerarios de la palabra escrita en la cultura venezolana, Caracas, Fundación Bigott y Editorial Equinoccio, 2006, pp. 415-430.

Guerrero, Gustavo (ed.): Conversación con la intemperie. Seis poetas venezolanos, Barcelona, Galaxia Gutenberg, 2008.

Halperin Donghi, Tulio: Historia contemporánea de América Latina, Madrid, Alianza, 1994.

Infante, Ángel Gustavo: "Estética de la rebelión: los manifiestos literarios", en Carlos Pacheco et al. (coord.): Nación y literatura. Itinerarios de la palabra escrita en la cultura venezolana, Caracas, Fundación Bigott y Editorial Equinoccio, 2006, pp. 407-413.

Isava, Luis Miguel: "Los sesenta: seis poetas hacia la conciencia de las palabras", en Carlos Pacheco et al. (coord.): Nación y literatura. Itinerarios de la palabra escrita en la cultura venezolana, Caracas, Fundación Bigott y Editorial Equinoccio, 2006, pp. 641-652.

Krauze, Enrique: El poder y el delirio, Caracas, Alfa, 2008.

Lasarte Valcárcel, Javier: "Picón Salas: pensamiento crítico y democracia social", en $\mathrm{Al}$ filo de la lectura, Caracas, Universidad Católica Cecilio Acosta, Editorial Equinoccio, Universidad Simón Bolívar, 2005, pp. 131-144.

Mariátegui, José Carlos: "César Vallejo", en 7 ensayos de interpretación de la realidad peruana, Caracas, Biblioteca Ayacucho, núm. 69, 2007, pp. 259-266.

Márquez Rodríguez, Alexis: "La revista Zona Franca (1964-1984)", en VVAA: Le discours culturel dans les revues latino-américaines de 1970 à 1990, Cahiers du CRICCAL, 3ème Série, París, Presses de la Sorbonne Nouvelle, s/a, pp. 237245.

Martínez, Tomás Eloy: "Un hombre nunca se despierta de la misma manera”, en El Papel Literario de El Nacional, Caracas, 4 de abril de 1976. [Entrevista a Juan Liscano] 
Medina, Rubén: "El poder de la escritura y la escritura del poder: los ensayos de Octavio Paz", en Héctor Jaimes (coord.): Octavio Paz: la dimensión estética del ensayo, México, Siglo XXI, 2004, pp. 101-130.

Miranda, Julio: "Lucha armada, lucha escrita: Zona Franca e Imagen en la Venezuela de los '60" en Saúl Sosnowski et al.: La cultura de un siglo: América Latina en sus revistas, Buenos Aires, Alianza, 1999, pp. 409-419.

Rodríguez Monegal, Emir: "La nueva literatura nacional”, en Obra selecta, Caracas, Biblioteca Ayacucho, 2003, pp. 25-35. [El artículo se publicó originalmente en Marcha, Montevideo, núm. 653, 26 de diciembre de 1952, pp. 25-27]

: "Diario de Caracas", en Obra selecta, Caracas, Biblioteca Ayacucho, 2003, pp. 241-276. [El artículo se publicó originalmente en Mundo Nuevo, París, núm. 17, nov. 1967, pp. 4-24]

: “Diario del P.E.N.”, en Mundo Nuevo, París, núm. 4, oct. 66.

: "El ensayo y la crítica en la América Hispánica" en Obra selecta, Caracas, Biblioteca Ayacucho, 2003, pp. 359-364. [Este texto se editó por vez primera en Kurt. L. Lévy y Keith Ellis: El ensayo y la crítica en Iberoamérica, Actas del XIV Congreso del Instituto Internacional de Literatura Iberoamericana, Toronto, Toronto University, 1970, pp. 221-227]

: "Tradición y renovación", en César Fernández Moreno (coord.): América Latina en su literatura, París y México, UNESCO y Siglo XXI, 1972, pp. 139-166.

Mudrovcic, María Eugenia: Mundo Nuevo. Cultura y Guerra Fría en la década del 60, Rosario, Beatriz Viterbo Editora, 1997.

Oviedo, José Miguel: "Una discusión permanente" en César Fernández Moreno (coord.): América Latina en su literatura, París y México, UNESCO y Siglo XXI, 1972, pp. 424-440.

Palacios, María Fernanda: "Miserias y fulgores del ensayo en la Venezuela de hoy", en Sabor y saber de la lengua, Caracas, Monte Ávila, 1985, pp. 109-117.

Porras, María del Carmen: "Tres revistas literarias de los años sesenta y el problema de la cultura nacional", en Carlos Pacheco et al. (coord.): Nación y literatura. Itinerarios de la palabra escrita en la cultura venezolana, Caracas, Fundación Bigott y Editorial Equinoccio, 2006, pp. 625-639.

Prieto, Adolfo: "Conflictos de generaciones", en César Fernández Moreno (coord.): América Latina en su literatura, París y México, UNESCO y Siglo XXI, 1972, pp. 406-423.

Rama, Ángel: “Tímidas sospechas”, en Marcha, Montevideo, 6 de mayo de 1966, p. 29. 
: "Los intelectuales en la época desarrollista", en Marcha, Montevideo, 27 de mayo de 1966, p. 31.

: "Miguel Otero Silva de una a otra Venezuela", en Ensayos sobre literatura venezolana, Caracas, Monte Ávila, 1991, pp. 83-91.

:"Salvador Garmendia y la narrativa informalista", en Ensayos sobre literatura, Caracas, Monte Ávila, 1991, pp. 123-124.

: "La modernización literaria latinoamericana (1870-1910)", en La crítica de la cultura en América Latina, Caracas, Biblioteca Ayacucho, № 119, 1985.

Rodríguez Ortiz, Óscar: Paisaje del ensayo venezolano, Maracaibo, Universidad Cecilio Acosta, 1999.

Romero León, Jorge: La critique littéraire vénézuélienne des années 1960-1970, Paris, Université de la Sorbonne Nouvelle, Paris III, Institut d'études Ibéroaméricaines, 2. vols., 1988.

Rostow, W. W.: The Stages of Economic Growth: A Non-Communist Manifesto, Cambridge, Cambridge University Press, 1960.

Sánchez, Luis Alberto: Escritores representativos de América, Madrid, Gredos, Primera serie, 1971.

Suárez Figueroa, Naudy: "Pensar, plantar, curar la democracia en Rómulo Betancourt", prólogo a Rómulo Betancourt: Selección de escritos políticos (1929-1981), Caracas, Fundación Rómulo Betancourt, 2006.

Uslar Pietri, Arturo: De una a otra Venezuela, Caracas, Monte Avila Editores, 1973.

Velásquez, Ramón J.: "Aspectos de la evolución política de Venezuela en el último medio siglo", en VVAA: Venezuela moderna (1926-1976), Medio siglo de historia, Caracas, Fundación Eugenio Mendoza y Ariel, 2a ed., 1979, pp. 13-433.

4.- ARtículos o poemas de otros autores publicados EN LAS REVISTAS DE GUILLERMO SUCRE O EN MUNDO NUEVO.

s/a: "Testimonio sobre Cuba", en Sardio, Caracas, núm. 8, 1961, pp. 3-19.

s/a: "Un día con Solzhenitsin", en Imagen, Caracas, núm. 10, 1/15 oct. 67, p. 3.

s/a: "Carlos Fuentes y la censura española", en Imagen, núm. 11, 15/30 octubre de 1967, p. 21.

s/a: "Lam, Matta, Penalba, en el Museo de Arte Moderno de París", en Imagen, Caracas, núm. 27. 
Aridjis, Homero: “Antes del reino”, en Zona Franca, Caracas, núm. 34, junio de 1966.

Balza, José: "La operación estructuralista en Roland Barthes", en Imagen, Caracas, núm. 23, 15/30 abr. 68, pp. 6-7.

Castellet, José María: “Tiempo de destrucción para la literatura española”, en Imagen, Caracas, Supl. núm. 28, 1/15 jul. 1968, s/p.

Carricart, Héctor A.: "Puig y Sánchez en el boom literario", Imagen, Caracas, núm. 8, 1/15 sep. 1967, p. 4.

Cerda, Martín: s/t, en la sección "Las literaturas. Los libros. Los autores", La República, Caracas, 7 de abril de 1963, p. 7.

Cerda, Martín: s/t, en la sección "Las literaturas. Los libros. Los autores", en La República, Caracas, 7-4-63, p. 7.

Cerda, Martín: s/t, en la sección "Las literaturas. Los libros. Los autores", en La República, Caracas, 13-10-63, p. 7.

Cerda, Martín: s/t, en "Las literaturas. Los libros. Los autores", en La República, Caracas, el 12-1-64, p. 7.

Dubuffet, Jean: “Cultura y subversión”, en Imagen, Caracas, núm. 29, 15/30 de julio de 1968, p. 24.

Fuentes, Carlos: “Aprender una nueva rebelión”, en Imagen, Caracas, núm. 25, 15/30 mayo de 1968, p. 24.

García Morales, Luis: “El Fondo y la Forma” en La República, Caracas, 02-09-1962, p. 7. : "Kruschev y la libertad de creación", en La República, Caracas, 17-03-1963, p. 7.

Hennault, Gilles: "Modernidad y tecnología", en Imagen, Caracas, Supl. 19, 15/29 de febrero de 1968.

Izaguirre, Rodolfo: “Guimaraes Rosa: Gran sertón: Veredas" en Imagen, Caracas, núm. 5, 15/30 ago. 67, supl. pp. 10-11.

: "La censura en el cine", en Imagen, Caracas, núm. 26, 1/15 jun. 68, p. 2.

Labedz, Leopold: "El proceso de Moscú", en Mundo Nuevo, núm. 1, sección "Documentos". 
[Liscano, Juan] S/f: "Nuestra posición”, en Zona Franca, Caracas, año I, núm. 1, 1/15 sep. 1964, portada.

[Liscano, Juan] S/f: "Segundo aniversario", en Zona Franca, Caracas, año II, núm. 36, ago. 1966, p. 2.

López Sanz, Jaime: "Carlos Fuentes: Zona Sagrada", en Imagen, Caracas, núm. 9, 15/30 sep. 67, supl., s/p.

Mosquera, Marta: "Dos novelas de José Donoso", en Imagen, Caracas, núm. 8, 1/15 de sep. 1967, p. 24.

Papastamatíu, Basilia: "Severo Sarduy: una nueva interpretación del Barroco", en Imagen, Caracas, núms. 14-15, p. 3.

Parra, Edras: "Cabrera Infante. Tres tristes tigres", en Imagen, Caracas, núm. 5, 15/30 de jul. 67, p. 14.

: "Un paraíso perdido: la adolescencia", en Imagen, Caracas, núm. 14-15, 15/30 dic. 67, p. 4.

: "Fuentes y la pasión por la palabra", en Imagen, Caracas, núm. 19, 15/28 feb. 1968 , p. 24.

Pasquali, Antonio: "Marshall McLuhan o la ideología represiva", en Imagen, Caracas, núm. 27, 15/30 jun. 68, p. 8.

: "Por Marcuse y por la utopía", en Imagen, Caracas, núm. 29, 15/31 jul. 69, pp. 6-7.

Paz, Octavio: “Un día en Udaipur”, en La República, Caracas, 08-12-63, p. 7.

Riu, Federico: “Sartre escritor”, en Imagen, Caracas, Supl. núm. 10, 1/15 oct. 67.

: "Actualidad de Althusser", en Imagen, Caracas, núm. 20, 1/15 mar. 1968, p. 4.

Rodríguez Monegal, Emir y Vargas Llosa, Mario: "Paradiso", en Imagen, Caracas, núm. $11,15 / 30$ oct. 67 , p. 21.

Rodríguez Monegal, Emir: "Borges: el tiempo y el yo individual”, en Imagen, Caracas, núm. 12, 1/15 nov. 1967.

: "El mundo mágico de Carlos Fuentes", en Imagen, Caracas, núm. 16, 1/15 de enero de 1968.

: "Horacio Quiroga, el horror de París", en Imagen, Caracas, núm. 22, 1/15 abril de 1968 . 
: "Paradiso en su contexto", en Imagen, Caracas, núm. 25, 15/30 mayo de 1968, pp. 4-5.

Santos Pérez, Otoniel: “Guimaraes Rosa visto por terceros”, en Imagen, Caracas, núm. $13,15 / 30$ nov. 67 , pp. 8 y 17.

Sarduy, Severo: "Máquinas”, en Imagen, Caracas, núm. 26, 1/ 15 de junio de 1968, p. 19.

Segovia, Tomás: “Una red de agujeros”, en Mundo Nuevo, París, núm. 4, oct. 1966, pp. 88-89.

Starobinski, Jean: "Baudelaire, de la crítica a la poesía”, en Imagen, Caracas, Supl. 19, 15/29 de febrero de 1968.

Vargas Llosa, Mario: “Un hechicero maya en Londres”, en Imagen, Caracas, núm. 3, p. 3.

: "La literatura es fuego", en Imagen, Caracas, Supl. núm. 7, 15/31 ago. 67.

: “Carlos Fuentes en Londres”, en Imagen, Caracas, núm. 12, 1/15 de nov. 1967, p. 3.

: "7 relatos de cataclismo y poesía”, en Imagen, Caracas, núms. 14-15, 15/30 de dic. 1967, p. 32.

Vázquez, Eduardo: “La filosofía como subversión”, en Imagen, Caracas, núm. 9, 15/30 sep. 67 , p. 24.

: "4 ensayos de Herbert Marcuse", en Imagen, Caracas, núm. 17, 15/30 ene. 68 , pp. 6-7.

\section{5.- TEXTOS TEÓRICOS Y DE OTROS ESCRITORES}

Badiou, Alain: "El deseo de filosofía y el mundo contemporáneo", en La filosofía, otra vez, Buenos Aires, Errata Naturae, 2010.

Barthes Roland: El grado cero de la escritura, Madrid, Siglo XXI, 2005.

: "La literatura hoy", en Ensayos críticos, Buenos Aires, Seix Barral, 2003, pp. 213-228.

: "La imaginación del signo", en Ensayos críticos, Buenos Aires, Seix Barral, 2003, pp. 285-292. 
: "Las dos críticas", en Ensayos críticos, Buenos Aires, Seix Barral, 2003, pp. 337-344.

: “Qué es la crítica?”, en Ensayos críticos, Buenos Aires, Seix Barral, 2003, pp. 345-352.

: "Literatura y significación", en Ensayos críticos, Buenos Aires, Seix Barral, 2003, pp. 353-376.

: Crítica y verdad, Buenos Aires, Siglo XXI, 1972, [1966].

: Roland Barthes por Roland Barthes, Barcelona, Paidós Ibérica, 2004.

Baudelaire, Charles: “¿Para qué la crítica?” en Curiosidades estéticas, en Obras, México, Aguilar, 2a ed., 1963, pp. 477-479.

: "Exposición universal de 1855 (Bellas artes)", en Curiosidades estéticas, en Obras, México, Aguilar, 2ª ed., 1963, pp. 532-546.

: "Salón de 1859", en Curiosidades estéticas, en Obras, México, Aguilar, $2^{\mathrm{a}}$ ed., 1963, pp. 546-595.

: "La obra y la vida de Eugène Delacroix", en El arte romántico, en Obras, México, Aguilar, $2^{\mathrm{a}}$ ed., 1963, pp. 650-668.

: "El arte filosófico", en El arte romántico, en Obras México, Aguilar, $2^{a}$ ed., 1963, pp. 700-705

: “Théophile Gautier", en El arte romántico, en Obras, México, Aguilar, $2^{\text {a }}$ ed., 1963, pp. 710-727.

: "Madame Bovary de Gustave Flaubert" en El arte romántico, en Obras, México, Aguilar, $2^{\mathrm{a}}$ ed., 1963, pp. 814-820.

: "Nuevas notas sobre Edgar Poe", en VVAA: Matemática tiniebla. Genealogía de la poesía moderna, Barcelona, Galaxia Gutenberg, 2011, pp. 135-154.

Borges, Jorge Luis: "Jactancia de quietud", citado por Guillermo Sucre en "Borges, una poética de la desposesión", en Revista Iberoamericana, Pittsburgh, vol. XXXVIII, núm. 79, abr.-jul. 1972, p. 197.

: "Prólogo" a Luna de enfrente, en OOCC, Vol. I, Barcelona, RBA, 2005, p. 55.

: "La supersticiosa ética del lector", en Discusión, en OOCC, Vol. I, Barcelona, RBA, 2005, pp. 202-205. 
: "El escritor argentino y la tradición", en Discusión, en OOCC, Vol. I, Barcelona, RBA, 2005, pp. 267-274.

: "Flaubert y su destino ejemplar" en Discusión, en OOCC, Vol. I, Barcelona, RBA, pp. 263-266.

: "La metáfora", en Historia de la eternidad, en OOCC, Vol. I, Barcelona, RBA, 2005, pp. 382-384.

: "Pierre Menard, autor del Quijote", en Ficciones, OOCC, Vol. I, Barcelona, RBA, 2005, pp. 444-450.

: "La escritura del Dios", en OOCC, Vol. I, Barcelona, RBA, 2005, pp. 596-599.

: "El Aleph”, en El Aleph, OOCC, Vol. I, Barcelona, RBA, 2005, pp.

$617-628$.

: "La esfera de Pascal", en Otras inquisiciones, en OOCC, Vol. I, Barcelona, RBA, 2005, pp. 636-638.

: "La flor de Coleridge", en Otras inquisiciones, en OOCC, Vol. I, Barcelona, RBA, 2005, pp. 639-641.

: "Kafka y sus precursores", en Otras inquisiciones, OOCC, Vol. I, Barcelona, RBA, 2005, pp. 710-712.

: "Nueva refutación del tiempo", en Otras inquisiciones, OOCC, Vol. I, Barcelona, RBA, 2005, pp. 757-758.

: “Arte poética", en El hacedor, en OOCC, Vol. I, Barcelona, RBA, 2005, p. 843.

: "Mateo, 25, 30", en El otro, el mismo, OOCC, Vol. I, Barcelona, RBA, 2005, p. 874.

: “Tú", en El oro de los tigres, en OOCC, Vol. I, Barcelona, RBA, 2005, p. 1111.

Cage John: "Composition as process", en Silence, Hanover, Wesleyan University Press, 1961.

Camus, Albert: El hombre rebelde, en Obras 3, Madrid, Alianza Tres, 1996.

: "Discurso de Suecia", en Obras 5, Madrid, Alianza Tres, 1996, pp. 163-192. 
Eliot, T. S.: "La tradición y el talento individual", en VVAA: Matemática tiniebla. Genealogía de la poesía moderna, Barcelona, Galaxia Gutenberg, 2011, pp. 390-399.

Emerson, Ralph Waldo: "The Poet", en Essays: Second Series, Boston, Phillips, Samson and Company, $3^{\text {rd }}$ edition, 1857, pp. 9-45.

Foucault, Michel: “¿Qué es un autor?”, en Obras esenciales, Vol. I, Barcelona, Paidós Básica, 1999, pp. 333-356.

1981.

: Esto no es una pipa. Ensayo sobre Magritte, Barcelona, Anagrama,

Heidegger, Martin: "La época de la imagen del mundo", en Caminos de bosque, Madrid, Alianza, 1998, pp. 63-90.

: "El origen de la obra de arte", en Arte y poesía, México, FCE, 2a ed., 2006, pp. 29-91.

Huidobro, Vicente: "Balada de lo que no vuelve", en Guillermo Sucre (coord.): Antología de la poesía hispanoamericana moderna, Vol. I., Caracas, Equinoccio y Monte Ávila, 1994, p. 362.

Lezama Lima, José: “Coloquio con Juan Ramón Jiménez”, en Analecta del reloj, en Obras completas, Vol. II, México, Aguilar, 1977, pp. 44-62. [1938]

: La expresión americana, en Obras completas, Vol. II, México, Aguilar, 1977, pp. 279-390. [1957]

: "Máscaras de Portocarrero", en Tratados en La Habana, en Obras completas, Vol. II, México, Aguilar, 1977, pp. 483-486. [1958]

: "Nuevo Mallarmé I", en Tratados en La Habana, en Obras completas, Vol. II, México, Aguilar, 1977, pp. 520-524. [1958]

: "Pascal y la poesía", en Tratados en La Habana, en Obras completas, Vol. II, México, Aguilar, 1977, pp. 563-565. [1958]

: "A partir de la poesía", en La cantidad hechizada, en Obras completas, Vol. II, México, Aguilar, 1977, pp. 821-842.

: "Confluencias", en La cantidad hechizada, en Obras completas, Vol. II, México, Aguilar, 1977, pp.1208-1228.

Marcuse, Herbert: Eros y civilización, Barcelona, Seix Barral, 1969.

: El hombre unidimensional. Ensayo sobre la ideología de la sociedad industrial avanzada, Barcelona, Ariel, 1987.

Montaigne, Michel de: Ensayos escogidos, México, UNAM, 1997. 
Paz, Octavio: "Trabajos del poeta”, fragmento X, de ¿Águila o sol?, en Guillermo Sucre (coord.): Antología de la poesía hispanoamericana moderna, Vol. II, Caracas, Equinoccio y Monte Ávila, 1994, p. 152.

: Los hijos del limo. Del romanticismo a la vanguardia, Barcelona, Seix Barral, $1^{\text {a }}$ ed., 1974.

: El arco y la lira, en OOCC, Vol. I, La casa de la presencia. Poesía e historia, Barcelona, Galaxia Gutenberg, $2^{\mathrm{a}}$ ed., 1999, pp. 35-361.

: "Los signos en rotación", en OOCC, Vol. I, La casa de la presencia. Poesía e historia, Barcelona, Galaxia Gutenberg, 2a ed., 1999, pp. 307-344.

: "La nueva analogía: poesía y tecnología", en OOCC, Vol. I, La casa de la presencia. Poesía e historia, Barcelona, Galaxia Gutenberg, 2a ed., 1999, pp. 371-395.

: "Lectura y contemplación", en Entre uno y muchos, en OOCC, Vol. I, La casa de la presencia. Poesía e historia, Barcelona, Galaxia Gutenberg, $2^{\mathrm{a}}$ ed., 1999, pp. 711-753.

: “André Breton o la búsqueda del comienzo", en OOCC, Vol. II. Excursiones/Incursiones. Dominio extranjero, Barcelona, Galaxia Gutenberg/Círculo de Lectores, $2^{\mathrm{a}}$ ed., 2000, pp. 187-200. [1966]

: “Qué nombra la poesía?”, en OOCC, Vol. II. Excursiones/Incursiones. Dominio extranjero, Barcelona, Galaxia Gutenberg/Círculo de Lectores, $2^{\mathrm{a}}$ ed., 2000, pp. 487-490. [1967]

: "Invención, subdesarrollo, modernidad", en OOCC, Vol. II. Excursiones/Incursiones. Dominio extranjero, Barcelona, Galaxia Gutenberg/Círculo de Lectores, $2^{a}$ ed., 2000, pp. 492-497. [1967]

: "Prólogo" a Fundación y disidencia. Dominio hispánico, en OOCC, Vol. II. Excursiones/Incursiones. Dominio extranjero, Barcelona, Galaxia Gutenberg/Círculo de Lectores, $2^{\text {a }}$ ed., 2000, pp. 643-654. [1991]

: "Literatura de fundación", en OOCC, Vol. II. Excursiones/Incursiones. Dominio extranjero, Barcelona, Galaxia Gutenberg/Círculo de Lectores, $2^{\mathrm{a}}$ ed., 2000, pp. 672-680. [1961]

: “Jorge Guillén", en OOCC, Vol. II. Excursiones/Incursiones. Dominio extranjero, Barcelona, Galaxia Gutenberg/Círculo de Lectores, $2^{\mathrm{a}}$ ed., 2000, pp. 902-936. [1979]

: "Destiempos, de Blanca Varela", en OOCC, Vol. II. Excursiones/Incursiones. Dominio extranjero, Barcelona, Galaxia Gutenberg/Círculo de Lectores, 2a ed., 2000, p. 1128-1133. [1966] 
: "Los "Hospitales de ultramar": Álvaro Mutis", en OOCC, Vol. II. Excursiones/Incursiones. Dominio extranjero, Barcelona, Galaxia Gutenberg/Círculo de Lectores, 2ª ed., 2000, p. 1134-1139.

: "Los nuevos acólitos", en OOCC, Vol. II. Excursiones/Incursiones. Dominio extranjero, Barcelona, Galaxia Gutenberg/Círculo de Lectores, $2^{\mathrm{a}}$ ed., 2000, pp. 1142-1145. [1967]

: "El espacio del reconocimiento", en OOCC, Vol. II. Excursiones/Incursiones. Dominio extranjero, Barcelona, Galaxia Gutenberg/Círculo de Lectores, 2a ed., 2000, pp. 1146-1151.

: "Iluminación y subversión: Emilio Adolfo Westphalen", en OOCC, Vol. II. Excursiones/Incursiones. Dominio extranjero, Barcelona, Galaxia Gutenberg/Círculo de Lectores, 2a ed., 2000, pp. 1151-1156. [1979]

: La llama doble. Amor y erotismo, en OOCC, Vol. VI, Ideas y costumbres II. Usos y símbolos, Barcelona, Galaxia Gutenberg, 2a ed., 2003, pp. 859-1057. [1993]

: Claude Lévi-Strauss o el nuevo festín de Esopo, en OOCC, Vol. VI, Ideas y costumbres II. Usos y símbolos, Barcelona, Galaxia Gutenberg, 2a ed., 2003, pp. 1245-1346. [1967]

: "La persona y el principio", en OOCC, Vol. VI, Ideas y costumbres II. Usos y símbolos, Barcelona, Galaxia Gutenberg, 2a ed., 2003, pp. 1349-1355. [1967]

: "Hartazgo y náusea", en OOCC, Vol. VI, Ideas y costumbres II. Usos y símbolos, Barcelona, Galaxia Gutenberg, $2^{\mathrm{a}}$ ed., 2003, pp. 1403-1410. [1967]

: "La excepción de la regla", en OOCC, Vol. VI, Ideas y costumbres II. Usos y símbolos, Barcelona, Galaxia Gutenberg, 2a ed., 2003, pp. 1419-1424. [1967]

: "Una forma que se busca", en OOCC, Vol. VI, Ideas y costumbres II. Usos y símbolos, Barcelona, Galaxia Gutenberg, 2ª ed., 2003, pp. 1439-1446. [1967]

: "La revuelta", en OOCC, Vol. VI, Ideas y costumbres II. Usos y símbolos, Barcelona, Galaxia Gutenberg, 2a ed., 2003, pp. 1446-1459. [1967]

: El mono gramático, en OOCC VII, Obra poética (1935-1998), Barcelona, Galaxia Gutenberg, 2004, pp. 533-617. [1970]

: "Poesía en movimiento", prólogo a Poesía en movimiento, México, Siglo XXI, 2006. [1966]

Picón Salas, Mariano: "Pequeña confesión a la sordina", en Viejos y nuevos mundos, Caracas, Biblioteca Ayacucho, núm. 101, 1983, pp. 3-8. 
: "Antítesis y tesis de nuestra historia", en Viejos y nuevos mundos, Caracas, Biblioteca Ayacucho, núm. 101, 1983, pp. 49-60.

: "Proceso del pensamiento venezolano", en Viejos y nuevos mundos, Caracas, Biblioteca Ayacucho, núm. 101, 1983, pp. 60-71.

: "Notas sobre el problema de nuestra cultura", en Viejos y nuevos mundos, Caracas, Biblioteca Ayacucho, núm. 101, 1983, pp. 71-87.

: "Una voluntad nacional", en Viejos y nuevos mundos, Caracas, Biblioteca Ayacucho, núm. 101, 1983, pp. 83-87.

: "Pequeño tratado de la tradición", en Viejos y nuevos mundos, Caracas, Biblioteca Ayacucho, núm. 101, 1983, pp. 87-99.

: "Paseo por nuestra poesía (de 1880 a 1940)", en Viejos y nuevos mundos, Caracas, Biblioteca Ayacucho, núm. 101, 1983, pp. 100-116.

: "A veinte años de Doña Bárbara", en Viejos y nuevos mundos, Caracas, Biblioteca Ayacucho, núm. 101, 1983, pp. 128-133.

: "El Barroco de Indias" en Viejos y nuevos mundos, Caracas, Biblioteca Ayacucho, núm. 101, 1983, pp. 162-178.

: "Lugones, un gran argentino", en Viejos y nuevos mundos, Caracas, Biblioteca Ayacucho, núm. 101, 1983, pp. 300-309.

: "Varón humanísimo", en Viejos y nuevos mundos, Caracas, Biblioteca Ayacucho, núm. 101, 1983, pp. 312-318.

: "Alegato de Europa. Prólogo de 1946", en Viejos y nuevos mundos, Caracas, Biblioteca Ayacucho, núm. 101, 1983, pp. 327-335.

: "Preguntas a Europa. Prólogo de 1937", en Viejos y nuevos mundos, Caracas, Biblioteca Ayacucho, núm. 101, 1983, pp. 335-337.

: "Meditación francesa", en Viejos y nuevos mundos, Caracas, Biblioteca Ayacucho, núm. 101, 1983, pp. 337-346.

: "Lo hispanoamericano desde los EEUU", en Viejos y nuevos mundos, Caracas, Biblioteca Ayacucho, núm. 101, 1983, pp. 425-433.

: "Profecía de la palabra", en Viejos y nuevos mundos, Caracas, Biblioteca Ayacucho, núm. 101, 1983, pp. 453-462.

: "Literatura y sociedad", en Viejos y nuevos mundos, Caracas, Biblioteca Ayacucho, núm. 101, 1983, pp. 508-511. 
: "La lengua impura", en Viejos y nuevos mundos, Caracas, Biblioteca Ayacucho, núm. 101, 1983, pp. 517-520.

Poe, Edgar A.: "El principio poético", en VVAA: Matemática tiniebla. Genealogía de la poesía moderna, Barcelona, Galaxia Gutenberg, 2011, pp. 25-58.

Pozuelo-Yvancos, José María: "El género literario ensayo", en Vicente Cervera (ed.): El ensayo como género literario, Murcia, Universidad de Murcia, 2005, pp. 179191.

Ranciére, Jacques: "Les antinomies du modernisme”, en Malaise dans l'esthéthique, Paris, Galilée, 2004, pp. 85-142.

: "Le tournant étique de 1'ésthetique et de la politique", en Malaise dans l'esthéthique, Paris, Galilée, 2004, pp. 143-173.

: "Políticas estéticas", en Sobre políticas estéticas, Barcelona, MACBA, 2005, pp. 13-36.

: "Problemas y transformaciones del arte crítico", en Sobre políticas estéticas, Barcelona, MACBA, 2005, pp. 37-54.

: "Estado de la política, estado del arte", en Sobre políticas estéticas, Barcelona, MACBA, 2005, pp. 55-68.

: "Diez tesis sobre la política", en Política, policía, democracia, Santiago, LOM, 2006, pp. 59-79.

: "Politique de la littérature", en Politique de la littérature, Paris, Galilée, 2007, pp. 11-40.

: "Le malentendu littéraire", en Politique de la littérature, Paris, Galilée, 2007, pp. 41-55.

: "Borges et le mal français", en Politique de la littérature, Paris, Galilée, 2007, pp. 145-166.

: El reparto de lo sensible. Estética y política, Santiago, LOM, 2009.

: "Si es necesario concluir que la historia es ficción. De los modos de la ficción", en El reparto de lo sensible. Estética y política, Santiago, LOM, 2009, pp. 45-54.

: La palabra muda. Ensayo sobre las contradicciones de la literatura, Buenos Aires, Eterna Cadencia, 2009.

: "Las paradojas del arte político", en El espectador emancipado, Pontevedra, Ellago ediciones, 2010, pp. 53-86. 
: El tiempo de la igualdad. Diálogos sobre política y estética, Barcelona, Herder, 2011.

Reverdy, Pierre: "Self defense", en Escritos para una poética, Caracas, Monte Ávila, 1977, pp. 29-40.

: "El cubismo, poesía plástica", en Escritos para una poética, Caracas, Monte Ávila, 1977, pp. 41-44.

Rojas, Gonzalo: Contra la muerte y otras visiones, La Habana, Casa de Las Américas, 2007.

Rosenblat, Ángel: "Sentido mágico de la palabra", en La primera visión de América y otros estudios, Caracas, Ministerio de Educación, 2a ed., 1969, pp. 65-101.

: “Amado Alonso" en La primera visión de América y otros estudios, Caracas, Ministerio de Educación, 2a ed., 1969, pp. 211-222.

Sartre, Jean Paul: "Presentation des Temps Modernes", en Situations II, París, Gallimard, 1948, pp. 9-30.

: "La nationalisation de la littérature", en Situations II, París, Gallimard, 1948, pp. 33-53.

: "Qu'est-ce que la littérature?", en Situations II, París, Gallimard, 1948, pp. 55-350.

Sontag, Susan: "Contra la interpretación", en Contra la interpretación, Madrid, Alfaguara, 1996, pp. 25-39. [1966]

: "Sobre el estilo", en Contra la interpretación, Madrid, Alfaguara, 1996, pp. 40-67. [1966]

: "La estética del silencio", en Estilos radicales, Madrid, Taurus Bolsillo, 1985, pp. 13-56. [1969]

Stein, Gertrude: "Portraits and Repetition", en Writings 1932-1946, New York, The Library of America, 1998.

: "What Are Master-pieces and Why Are There So Few of Them", en Writings 1932-1946, New York, The Library of America, 1998.

: Picasso, Madrid, La esfera de los libros, 2002. [1938]

Steiner, George: "El abandono de la palabra", en Lenguaje y silencio, Barcelona, Gedisa, 2003, pp. 29-51. [1967]

: "El lenguaje animal", en Extraterritorial. Ensayos sobre literatura y la revolución lingüística, Barcelona, Barral editores, 1973, pp. 79-128. [1971] 
Stevens, Wallace: "The Figure of the Youth as Virile Poet", en Collected Poetry and Prose, New York, The Library of America, 1997.

Valéry, Paul: "Las ideas de Edgar Poe”, en VVAA: Matemática tiniebla. Genealogía de la poesía moderna, Barcelona, Galaxia Gutenberg, 2011, pp. 225-245.

: "Situación de Baudelaire", en VVAA: Matemática tiniebla. Genealogía de la poesía moderna, Barcelona, Galaxia Gutenberg, 2011, pp. 260-276.

: "Existencia del simbolismo", en VVAA: Matemática tiniebla Genealogía de la poesía moderna, Barcelona, Galaxia Gutenberg, 2011, pp. 277-297.

: "[Carta sobre Mallarmé a Jean Royère]", en VVAA: Matemática tiniebla. Genealogía de la poesía moderna, Barcelona, Galaxia Gutenberg, 2011, pp. 298-309.

: "Le decía yo a veces a Stéphane Mallarmé", en VVAA: Matemática tiniebla Genealogía de la poesía moderna, Barcelona, Galaxia Gutenberg, 2011, pp. 310-327.

: "Stéphane Mallarmé", en VVAA: Matemática tiniebla. Genealogía de la poesía moderna, Barcelona, Galaxia Gutenberg, 2011, pp. 328-330.

: "Mallarmé", en VVAA: Matemática tiniebla. Genealogía de la poesía moderna, Barcelona, Galaxia Gutenberg, 2011, pp. 331-336.

Vallejo, César: “Contra el secreto profesional”, en Variedades, Lima, 1927, n 1001, p. 204.

: "Ejecutoria del arte socialista", en El arte y la revolución, en Obras completas vol. 4, Barcelona, Laia, 1978, pp. 27-28.

: “Existe el arte socialista?”, en El arte y la revolución, en Obras completas vol. 4, Barcelona, Laia, 1978, pp. 39-43.

: "Manía de grandeza, enfermedad burguesa", en El arte y la revolución, en Obras completas vol. 4, Barcelona, Laia, 1978, p. 53.

: “Acerca del concepto de cultura", en El arte y la revolución, en Obras completas vol. 4, Barcelona, Laia, 1978, pp. 97-99.

: "El duelo entre dos literaturas", en El arte y la revolución, en Obras completas vol. 4, Barcelona, Laia, 1978, pp. 107-111.

: "Poesía nueva" en El arte y la revolución, en Obras completas vol. 4, Barcelona, Laia, 1978, pp. 113-114.

: "El caso Maiakovski”, en El arte y la revolución, en Obras completas vol. 4, Barcelona, Laia, 1978, pp. 117-122. 
Vattimo, Gianni: “Posmodernidad: ¿una sociedad transparente?”, en Gianni Vattimo y otros: En torno a la posmodernidad, Barcelona, Anthropos, 2003, pp. 9-19. 


\section{APÉNDICE I \\ ENTREVISTAS Y CARTAS}




\section{1.- ENTREVISTA ORAL, OCTUBRE DE 2011}

PREGUNTA.- Entonces estuvo preso primero en el año 52, me parece.

RESPUESTA.- La verdad que yo estuve preso el año 49, cuando estudiaba en el Liceo Andrés Bello. Vinieron los poetas franquistas, yo era muy amigo de unos españoles anarquistas y bueno, allí nos metimos en el [Centro] Venezolano-Americano y cuando comenzó el recital del Conde de Foxá, que fue el primero que leyó un poema que decía... Vinieron el Conde de Foxá, Panero, Rosales no vino.

\section{P.- Leopoldo Panero el padre, ¿no?}

R.- Sí, padre, por supuesto; un bárbaro. Ahí estuvimos [presos] solamente quince días; yo estudiaba en el Liceo Andrés Bello y me pusieron en libertad porque en esa época todavía estaba vivo Delgado Chalbaud, el Presidente de la Junta de Gobierno. Y después nos pusieron presos en la Universidad Central, que quedaba en San Francisco, lo que es ahora las Academias, frente al Congreso. Y ahí estaba la Universidad. Entonces nos pusieron presos porque habían quitado la autonomía universitaria. Eso fue en el comienzo del 52; y en julio nos expulsaron [del país]. Yo me fui a Chile, otros se fueron a Francia, Rafael Cadenas se fue a Trinidad.

\section{P.- ¿Por qué eligió irse a Chile y no a otro lugar?}

R.- [En el 52, cuando llega a Chile] Picón Salas todavía no había regresado [a Venezuela]. El año 52 él todavía estaba en los EEUU, en Columbia. De modo que yo conocí a Picón-Salas cuando regresé de Chile y de París. Yo era muy amigo de la hija de Picón-Salas, Delia Picón-Salas, que la llamaban Pascualita. Y de Isabel Gento, la mujer de Picón-Salas, de la cual se divorció. Y yo conocí a Picón-Salas mucho más en París, después que fue embajador en Brasil y entonces fue embajador en la UNESCO y en esa época Octavio Paz había llegado a París.

\section{P.- Esto fue entre el 59 y el 62.}

R.- Sí, sí. [Ahora habla sobre Paz:] Yo recuerdo que [OP] una vez nos invitó a su casa, él estaba divorciado ya. Nos invitó a su casa, que era un apartamento de Paul Eluárd (risas) y entonces fuimos, y después nos vimos otra vez en su casa ya cuando se iba para la India y en casa de Picón-Salas y en la Embajada de México [en París]. Pero 
después nos hicimos mucho más amigos en Pittsburgh, en Washington, en París y en Madrid.

P.- ¿Por qué motivo viajó a Madrid, por qué estuvo allí?

R.- Bueno, yo estuve en Madrid, fue cuando regresó Paz y le dieron el Premio Cervantes. Yo estuve en Madrid trabajando en la Biblioteca Nacional. Estaba recién caído Franco. Ahí hice el libro sobre Picón-Salas que formó parte de la Biblioteca Ayacucho y escribí un largo ensayo sobre [Ángel] Rosenblat. Y escribí sobre Raimundo Lida. Yo creo que Lida nació en la Argentina. Lida era judío y su familia había viajado a la Argentina y se formó junto con Rosenblat, con Amado Alonso. Después Lida se fue a México, al Colegio de México, y del Colegio de México pasó a Harvard donde fue profesor de Historia de la literatura española. Nos hicimos muy amigos tanto en Pittsburgh como en Harvard.

P.- El mandato de Pérez Jiménez se caracterizó por un nacionalismo cultural, que iba de la mano de una marcada dependencia económica e institucional. Veo en su proyecto crítico la antitesis de esto, porque usted critica los nacionalismos estrechos y defiende una cultura propia que a la vez participe de la cultura universal.

R.- Yo no creo que Pérez Jiménez tuviera ninguna concepción cultural importante y además eran muy pocos los intelectuales venezolanos que apoyaron a Pérez Jiménez. Ramón Díaz Sánchez, gente así. Pero eran como perezjimenistas vergonzantes (risas). Porque toda esa gente formaba parte del gobierno de Medina que fue derrocado el 45 por los militares y Acción Democrática con Rómulo Betancourt.

Pocaterra, que escribió Memorias de un venezolano de la decadencia, fue preso en La Rotunda, cuando Gómez. Pocaterra después fue expulsado y se fue al Canadá. Y Pocaterra entró a Venezuela con la expedición El Falke en 1928-29, con Delgado Chalbaud padre, que murió [en la expedición]. Entraron por Carúpano, Cumaná. Y murió un tío de Julieta Fombona que era Zuloaga, Armando Zuloaga Blanco.

Este joven novelista, Federico Vegas, escribió El Falke, sobre ese episodio.

Yo no conocí personalmente a Pérez Jiménez o a ninguno de los perezjimenistas, pero no creo que fuera muy inteligente, ¿no? Yo le decía a $[. .$.$] antes de ponerme preso$ [por tercera vez, siete meses antes de la caída de la dictadura, salió finalmente el 23-158] que íbamos a hacer una carta y que $\mathrm{AD}$ me enviaba a pedirle su firma. Eso fue como en junio o en julio de 1957 y la carta la iniciaba López Contreras, que todavía estaba 
vivo, Picón-Salas de segundo y otros abogados...Y Picón-Salas me decía "pero Guillermo yo creo que es muy temprano todavía, vamos a esperar que Pérez Jiménez se decida a hacer el plebiscito"; es decir, que Pérez Jiménez desconoció la Constitución y entonces hizo un plebiscito para reelegirse. Pero no hubo elecciones directas y secretas, sino que dejaron votar a los inmigrantes, y los inmigrantes cualquiera votaba, y por miedo votaban por [PJ]. Pero la verdad es que nadie votó y el ejército se dio cuenta. Y entonces [Wolfgang] Larrazábal, que era contralmirante... Yo estaba preso en Ciudad Bolívar, entre otros personajes, con Ramón Velásquez, que fue secretario de Betancourt y después cuando juzgaron a Carlos Andrés Pérez, él fue el Presidente de la transición que fue cuando ganó Rafael Caldera. Caldera era una especie de De Gaulle pero un De Gaulle que no pasaba del 33\% de los votos (risas), y fue un desastre. Entonces ellos Uslar Pietri, Juan Liscano, Mayz Vallenilla, ex-rector de la Universidad Simón Bolívarapoyaron a Chávez. Uslar Pietri escribió un artículo en Le monde diplomatique sobre elección de Chávez. Claro, Uslar Pietri de joven fue gomecista, después lópezcontrerista, después fue el secretario general de Medina, del PDV, y por supuesto fue derrocado cuando [el golpe del 45 con] Rómulo Betancourt.

P.- María Fernanda Palacios ve en su obra una identidad con la de Camus, más que con ninguna otra. Sin negar su punto de vista, ¿no le parece que en su obra hay afinidades mucho más evidentes con la obra de Borges, o con la obra de Paz?

R.- No, sin duda. Lo que pasa es que yo admiraba mucho a Camus y, bueno, hay ciertas cosas que me relacionan con Camus; pero, claro, yo siento más deuda con Octavio Paz y con Borges.

P.- Para mí, en la cultura hispanoamericana, usted juega el papel de un unificador de la crítica de los fundadores a la primera vanguardia. El rechazo de Borges a la experimentación por la experimentación, el de Vallejo al americanismo inauténtico y el de Huidobro al poema como copia de la realidad. Me parece que son rutas abiertas en busca de la autenticidad latinoamericana, que de alguna manera usted unifica, actualiza y prolonga. Como que usted es un centro que prolonga la crítica de los fundadores en una época distinta ya.

R.- Sí, es verdad. Por lo menos en Chile, yo fui muy amigo de Jorge Teiller, que murió ya. Era compañero de generación, apenas me lleva un año. Y Jorge escribió una poesía magnífica. Y [también fui amigo] de Nicanor Parra. Pero el problema con 
Neruda se agudizó, porque Neruda era stalinista de esos terribles y esa época fue la más stalinista de Neruda. En 1953 muere Stalin, yo estaba en Chile, y Neruda le escribió aquella Oda a Stalin, que Borges por malignidad decía que era de sus mejores versos, de sus mejores poemas. ¡Y en verdad era bueno, dentro del género!

Huidobro fue... Bueno, una parte de Huidobro. Porque la primera parte de Huidobro -Ecuatorial, Poemas árticos- me gusta. Pero los primeros poemas de Huidobro eran un simbolismo allí, bueno, un poco anticuado, envejecido; y después de Altazor... Bueno, Altazor tiene sus cosas buenas, pero Ciudadano del olvido y Poemas póstumos son quizás mucho mejores. Y Huidobro representaba... no sé, una cierta claridad en la poesía y no era un partisano como Neruda, aunque Huidobro era de izquierdas también. Pero Neruda tenía una fijación con Huidobro; en sus memorias, Confieso que he vivido, habla muy mal de Huidobro, y como Paz estaba en España, se dio cuenta de que eso era falso, lo que decía Neruda de Huidobro. Pero fue un modo de despreciar a Huidobro, de descalificarlo.

P.- ¿Pero usted siente que toda esa crítica de Vallejo, de Borges y de Huidobro, de alguna manera confluye en su obra?

R.- Yo creo que sí. Yo admiraba mucho la poesía de Reverdy, y Huidobro en sus primeros libros tiene mucho de Reverdy. Sobre todo la imagen, ¿no?, eso de que la imagen no era producto de una comparación o de una analogía, sino de algo mucho más... de una homología.

Huidobro no es como Neruda. A mí no me gusta por ejemplo el Canto general. Hablan mucho de "Alturas de Macchu Picchu", pero "Alturas de Macchu Picchu" tiene una parte importante, pero después cuando se pone a hablar de Macchu Picchu, de los indios, cae en una cosa convencional y una poesía como construida. Ahora, Neruda, lo que sí es verdad, era que tenía un gran dominio del verso, del endecasílabo, del octosílabo. Y Huidobro era en eso mucho más libre.

\section{P.- Y las Residencias de Neruda ¿tampoco le gustan?}

R.- Ah no, Las Residencias sí [me gustan]. Sobre todo la primera y la segunda. La tercera ya... España en el corazón, que a mí no me gustaba del todo. A mí me gustaba más Vallejo, España aparta de mí este cáliz. En Vallejo había un aspecto como más religioso, más sagrado de la causa republicana, y Neruda era casi un agente de Moscú. Y es verdad. Neruda en España se hizo más comunista o se hizo de verdad 
comunista. En cambio, Vallejo era comunista antes. Sin embargo, Vallejo escribió unos ensayos sobre Rusia porque él estuvo en Rusia en el año 1930 y habla de Trotsky, habla de Pasternak, como el gran poeta ruso. No Maiakovsky; él decía que Maiakovsky era un poeta de propaganda.

P.- Sorprende que su crítica al exotismo latinoamericano no incluya a Carpentier y su teoría de lo real maravilloso.

R.- Yo de Carpentier fui muy amigo, Carpentier vivía cerca de aquí.

P.- Pero llama la atención que se rechace tanto a Neruda, y que a Carpentier que defiende una poética parecida...

R.- Se dice que Carpentier era comunista, pero aquí en Venezuela [durante los años 1940-1950, durante la dictadura de Batista en Cuba] era el hombre más apolítico... Incluso Neruda en Confieso que he vivido habla mal de Carpentier.

A mí no me gusta la poética de lo real maravilloso. Lo real maravilloso lo escribe en El reino de este mundo, [y allí] ataca mucho a los surrealistas. Después, en una reedición de El reino de este mundo afirma que Rusia era lo real maravilloso, China... todos los países comunistas (risas). Me parecía entonces falso.

Yo escribí varios artículos sobre Carpentier, sobre El acoso, El siglo de las luces, la Guerra del tiempo. Pero Carpentier no era un buen cuentista. Carpentier volvió a Cuba con Castro, y a los castristas no les gustaba mucho Carpentier, pero fue el Che Guevara el que lo salvó un poco.

Después fue Ministro Consejero en la Embajada de Cuba en París.

P.- Y después del 59, ¿mantuvo el trato con Carpentier?

R.- Bueno, una vez lo llamé en París en el año 67, pero no nos vimos, solamente un saludo para Lilia, su mujer, porque había muerto la madre de Lilia y nada más; porque Carpentier guardaba cierta distancia; era muy temeroso, Carpentier. Eso lo decían cuando la guerra civil española, que Carpentier cuando había un bombardeo se iba para Segovia... Eso también lo dice Neruda.

P.- En una entrevista que le hicieron Palacios y Balza en el año 76, señalaba que los paréntesis, las frases interrogativas, las analogías fonéticas no eran un simple juego. A mí me parece que en esos rasgos de su escritura es donde se filtra esa postura 
ética que para usted debe darse en todo verdadero escritor. Ellos citaban, por ejemplo: “Borges finge inventándola, a veces, una precisa y preciosa erudición”. Me parece que estas analogías fonéticas, al revelar la relatividad del lenguaje, de alguna manera son complementarias de esa ética de la desposesión tan importante en Borges y en su propia obra.

R.- Bueno, sí. El problema con ciertos escritores, ¿verdad?, era que estaban muy politizados. Borges era anti-peronista, pero Borges no hizo una poesía anti-peronista. En El hacedor aparecen dos o tres poemas [con referencias al peronismo], pero que son muy simbólicos y muy complejos. Y Borges le criticaba a Neruda que en el Canto general no habla nunca de Perón ni tampoco de Pérez Jiménez, porque [Neruda] en El Nacional [Caracas] publicaba siempre las Odas. Neruda era muy amigo de Miguel Otero Silva, porque una hermana de Miguel Otero Silva, Clara Rosa, vivía en Chile, yo la conocí. Después se casó con un chileno, el Dr. Calvo, que le hizo mucho daño a Allende. Calvo era un abogado de las compañías extranjeras y después cuando Allende se convirtió en un izquierdista de esos radicales. Y claro Allende necesitaba, como decía Jorge Edwards, y el propio Neruda, cierta moderación. Y después del viaje de Castro que pasó casi dos meses en Chile - bueno, yo no estaba en Chile ya- fue un desastre porque el ejército se le volteó a Allende. Pero si Allende había nombrado a Pinochet Comandante en Jefe de Ejército cuando comenzó el levantamiento y comienzan las bombas en La Moneda, Allende preguntaba, ¿dónde está Augusto?

Yo conocí a Allende cuando estuvimos en Chile, era muy amigo de [Rómulo] Betancourt. Yo conocí a Betancourt en Chile en el año 53, y Allende nos invitó una vez al Senado porque él iba a decir un discurso sobre la Conferencia Panamericana en Caracas, pidiendo que Chile no asistiera a esa Conferencia. Y yo participaba en todas las manifestaciones de Allende. Allende, cuando yo llegué a Chile en el 52, quedó en último lugar, sacó sesenta mil votos.

[Allende] Era joven, tenía más o menos la misma edad que Betancourt. [En esas elecciones] Ganó un coronel que había sido derrocado el año 30, que lo llamaban el Caballo Ibáñez, que no era un hombre muy líder. Pero Allende organizó al Partido Socialista en esa época. Fueron Allende y Eduardo Frei padre. Había manifestaciones por ejemplo cuando Guatemala [se refiere a la intervención de la CIA en el golpe a Arbenz en 1954], que la encabezaban Allende y Eduardo Frei. 


\section{P.- Y usted estaba allí}

R.- Sí, yo iba. Y la Embajada Norteamericana, bueno. Yo no quemé la bandera americana, porque yo no puedo hacer eso. Pero me acusaban de haber quemado la bandera americana, y no me daban visa para los Estados Unidos.

P.- Para muchos es usted el crítico de poesía más importante del siglo XX, al menos en Latinoamérica.

R.- Eso me da risas (risas).

P.- ¿Cómo interpreta el silencio que hay en relación a su obra en Venezuela?

R.- Bueno, no hay mucho silencio.

El Nacional, que al comienzo era chavista,... Chávez vivió hasta en la casa de Miguel Henrique Otero, aquí en Sebucán, y se bañaba en la piscina y todo; y María Teresa Castillo y Luis Miquelena lo protegían, pero pasó un año y pasaron a la oposición.

Pero es lo que me parece criticable ¿verdad? Muchas veces el intelectual venezolano no ha sido consecuente con sus principios. De mi generación, por ejemplo, el único que es chavista es Díaz Rangel, director de Últimas noticias, pero todos los demás somos antichavistas, y lo fuimos desde el comienzo.

P.- Pero antes del chavismo su obra tampoco generaba la repercusión que debería haber generado.

R.- Bueno, porque yo en verdad no era un escritor político. Muy pocas veces escribí sobre política. Yo escribí cuando el golpe de Chávez contra Carlos Andrés Pérez [en el 92], que no era especialmente de mi admiración, pero yo creía que derrocar a Carlos Andrés Pérez iba a traer muchas consecuencias, y por eso me opuse.

Sin embargo, Caldera siempre se equivocó políticamente. No siempre, pero Caldera al comienzo, cuando derrocaron a Gallegos [en el año 48], estaba con los militares. Caldera estaba con Pérez Jiménez y él decía "yo prefiero a los militares, antes de que vengan los adecos con su odio". Sin embargo, Caldera colaboró en la Junta Militar de Betancourt [en el año 45], era Procurador de las Naciones, y fue cuando fundó COPEI. 
P.- En su poesía se aprecia un cambio pronunciado entre lo que se publica antes de La mirada y lo que se publica después de En el verano cada palabra respira en el verano. En la primera época parece defender (también en su crítica literaria de esa época) que la poesía es elevación de lo individual a lo universal o arquetípico, mientras que en la segunda época parece concebir la poesía como un ejercicio crítico.

R.- Sí, es verdad. Estoy de acuerdo. Yo creo que salvaría muy pocos poemas de los primeros libros. En cambio, que a partir de En el verano..., yo creo que mi poesía cambió, y después de La vastedad, también cambió. La segunda versión es más diferente, más despojada, más concentrada.

P.- ¿A qué se debió este cambio de poética tan pronunciado? Es la época en que se encuentra en los EEUU, quizás el trabajo crítico tiene que ver en ese cambio, ¿no?

R.- Claro. La mirada es un libro que yo había comenzado aquí [en Venezuela] y continué en los EEUU, pero no tiene la unidad que tiene En el verano..., donde hay más individualidad, más originalidad, se puede decir.

P.- ¿Por qué no ha reeditado su poesía?

R.- No bueno, porque no me lo han propuesto. Bueno, Gustavo Guerrero ha querido publicar en Pre-textos. Pero la verdad es que en Venezuela actualmente la publicación de poemas o de libros ha decaído.

P.- ¿Dónde va a publicar lo que está escribiendo? ¿Fuera de Venezuela?

R.- Bueno, posiblemente. Hay una colección para la cual yo he prometido Los regresos (poemas) que se va a publicar en el próximo año [2012]. Es una colección que dirige Lisbet Salas, con un tipógrafo que lo patrocina Banesco, eso es lo que no me gusta, que se llama Sotillo, que ha editado libros que han ganado premios; quizás a ella le daré la edición.

P.- ¿Los ensayos que va a publicar de qué tratan?

R.- Los ensayos son una colección que se llama, uno El lenguaje del alma. Son varios ensayos que yo escribí muy joven, pero que me parece que tienen cierta unidad.

P.- ¿Es sobre diferentes autores? 
R.- Es siempre sobre literatura. Es sobre el tema de las persona poética, es sobre el tema de... Y el otro [libro de ensayos] es Poesía y ensayo, que es sobre Ramos Sucre y Picón-Salas, que saldrá el próximo año, bueno, si es posible... (risas) 


\section{2.- ENTREVISTA POR ESCRITO, OCTUBRE DE 2011}

P.- En los años 60 usted accede al campo literario y ocupa cargos de importancia en la cultura nacional. En esa década se produce una intensa polarización cultural en todo el continente. ¿Puede hablarme de cómo vivió esa década convulsa y cómo fue su relación con otras figuras con las que de alguna manera "compartió" posición como Paz o Monegal?

R.- Primero salí de la cárcel el 23 de enero de 1958. Apoyé la candidatura de Rómulo Betancourt, quien fue electo Presidente ese mismo año. Terminé mis estudios de Letras en la UCV. Me casé con Julieta Fombona y viajamos a Francia, becados por la UCV y por la Embajada de Francia. Cuando regresé, a comienzos de 1962, el país no sólo estaba polarizado políticamente sino enguerrillado: los jóvenes de Acción Democrática y todo el Partido Comunista - muchos de ellos compañeros de cárcelhabían creado un maquis y un terrorismo en ciertas ciudades. Eso después de dos intentos de insurrección militar en Carúpano y en Puerto Cabello. Y, además contaban con el apoyo de Fidel Castro. Nunca apoyé estos movimientos y, personalmente, se lo decía a muchos de sus activistas. Por cierto, en esos años - hasta 1960- fui amigo de Alejo Carpentier, quien vivió en nuestro país desde 1947, cuando fue electo Presidente Rómulo Gallegos, derrocado en noviembre de 1948. Desde este año empezó mi actividad política, en el Liceo y en la Universidad, lo que me costó dos cárceles y la expulsión el país en 1952. Por cierto, Carpentier era la persona más apolítica que he conocido, pero también se contagió de la "castroenteritis" (para emplear un término de Cabrera Infante).

En París conocí a Octavio Paz el año 1959, a quien, sin embargo, no frecuenté mucho. Una o dos veces nos reunimos en su casa o en la Embajada de México, y en casa de Mariano Picón-Salas, Embajador de Venezuela en la UNESCO y antiguo profesor mío. Para mí era, además, uno de los mejores escritores venezolanos cuya obra conocía desde joven (14 ó 15 años). En 1962, Paz y yo nos despedimos: él se iba para la India como embajador y yo regresaba a Venezuela. Paz no era castrista, sobre todo por el apoyo soviético, pero tampoco lo atacaba hasta la crisis de los misiles y posteriormente el lamentable "caso" Padilla. Nuestra amistad se profundizó más en Pittsburgh, en Washington, otra vez París y en Madrid. Fui continuo colaborador de las dos revistas que fundó: Plural y Vuelta. Cuando la insurrección fallida del actual 
Comandante-Presidente [Chávez] en 1992, publiqué dos o tres artículos en Vuelta. Sin nombrarlos, aludía a ciertos intelectuales que luego apoyaron al Comandante cuando ganó las elecciones en 1998. Eso me parecía un bochorno. Gente amiga, que yo apreciaba y creo que aún aprecio, que fueron intelectuales civilistas y hasta rectores de Universidades, se sumaron a esta desgracia. Y también ataqué al periódico El Nacional, chavista desde el comienzo y hoy decepcionados. Pero todo esto me reveló la crisis moral de nuestro país. La muerte de Paz, la de mis hermanos mayores, la de mi esposa aunque ya nos habíamos divorciado- fue todavía un motivo de crisis personal. De Emir Rodríguez Monegal fui también muy amigo; era generoso y lúcido como Paz. Recuerdo que me invitó a Yale a un coloquio sobre Lezama Lima. Y su muerte la sentí como algo muy íntimo.

Pero los años 60 no terminan aquí. Quiero aclarar que nunca ocupé un puesto relevante en la cultura oficial. Fui director de la revista-quincenal Imagen, entre 19671968, que editaba el Instituto Nacional de Cultura, fundado por Mariano Picón-Salas y, luego de su muerte, regido por mi amigo Simón Alberto Consalvi; también colaboré con Consalvi en la fundación de Monte Ávila Editores. Entre 1964-1967 formé parte del consejo de redacción de la revista Zona Franca, de la que me retiré por desavenencias intelectuales con su director, Juan Liscano, quien después de ser amigo de Betancourt y "habitué" de Carlos Andrés Pérez, se convirtió en uno de los llamados "notables" (como Uslar Pietri) que alentaron el golpe militar y luego el chavismo triunfante.

P.- En su Antología de la poesía hispanoamericana moderna habla de la intemperie como del sentimiento fundamental que comparten los poetas de su generación. Contra lo que cabría esperar, esta intemperie adquiere un sentido positivo. ¿A qué se refiere con esta intemperie? ¿De qué manera ella interviene en su obra?

R.- Sí, creo que es un signo de mi generación, aunque no sólo de ella. Uno de mis mejores amigos tituló así uno de sus libros en 1976, creo. Me refiero a Rafael Cadenas. Hace poco, Gustavo Guerrero publicó una antología de 6 poetas venezolanos titulada Una conversación con la intemperie, que es un verso de un libro mío escrito también en los setenta y el poema está dedicado a Ramos Sucre. Ese poema, creo, tiene un sentido histórico pero también biográfico y poético. Esos tres sentidos -me parecetiene la intemperie en los otros libros en que hablo mucho de ella. Y comenzando por lo personal. Pero ya esto me llevaría a extenderme. Gustavo Guerrero dice haber escrito un 
ensayo sobre la intemperie en la poesía venezolana. No lo conozco; seguramente coincido con él.

P.- Otro concepto fundamental en su obra es el de la transparencia, que es definido en varias ocasiones a lo largo de la misma. En la formulación que aparece en su ensayo "Poetics of Vivacity" se acerca a eso que Blanchot llamaba "lo neutro". Sin embargo, en otras ocasiones parece acercarse a la epojé fenomenológica. ¿Puede aclarar (una vez más) lo que significa la transparencia para usted y de qué manera es importante en su obra? ¿Tiene algo que ver con el sentimiento de la intemperie por el que le acabo de preguntar?

R.- En cuanto al término "transparencia" tiene, entre otros sentidos, el de impersonalidad, que quizá es la mejor manera de ser personal. Aunque el epígrafe de mi libro lo tomo de un ensayo de Lezama Lima, creo que la transparencia le debe mucho a Octavio Paz. "Sólo nos queda la transparencia", dice Paz en algunos de sus últimos poemas. Es lo que nos queda cuando ya no nos queda nada, sino una suerte de iluminación de lo vivido o de los que nos han hecho vivir. Es posible que tenga algo que ver con la intemperie y con la memoria.

P.- a) Su poesía entronca con la tradición crítica de la modernidad y es eso, me parece, lo que en ciertos momentos (como en Serpiente breve por ejemplo) la vuelve intensamente irónica. Además la ironía goza de una valoración positiva a lo largo de su obra. ¿Es para usted el non plus ultra de la crítica? ¿En qué sentido se puede relacionar con la pasión y con la inteligencia, tan determinantes en su obra? (b) En algún fragmento de su Diario literario, Alejandro Oliveros refiere cómo en una carta usted le recomienda vivir con intensidad esos años en el extranjero porque después los recordará como un paraíso perdido. Un verso de La vastedad señala: "la memoria desata el juego de nunca acabar". No sólo por esto me parece que la memoria cumple una función determinante en su poesía, pues da la sensación de ser el impulso que la origina, la fuerza que le permite (re)crear una realidad mítica que conforma el poema. ¿Qué relación guarda su creación poética con el pasado, con la memoria? ¿En qué sentido son el pasado y la memoria determinantes para la misma? (c) En última instancia me parece que lo que está en juego en su crítica es la naturaleza ética de una obra determinada. Lo que su crítica busca, me parece, es la raíz de una postura ética en toda su extensión, lo que incluye por supuesto al lenguaje. Por eso-porque ética y 
estética son inseparables- adquiere tanta importancia la "autenticidad" del escritor y la "verdad" de la escritura. Creo además que esto tiene que ver con el valor que en su obra le asigna a la mirada y a la pasión. ¿Podría ahondar en esto un poco más?

R.- Voy a tratar de contestar, en uno solo, los tres temas siguientes (a, b, c). Comienzo por la ironía. En uno de los primeros escritos de A. Camus se dice: "Es usted irónico, eso prueba que usted es malo". Hay mucha gente que piensa que la ironía es una maldad (lo que no es descartable del todo). Pienso, sin embargo, que la ironía es una manera de no ser aseverativo (ni totalitario). Tampoco es un juego, sino una última sagesse. Es una pasión en la medida en que no nace de un cálculo. Y quizá surja de una experiencia: la de tantos paraísos perdidos. En mi caso, la muerte de mi padre cuando apenas era un infante o la de mi madre cuando era un adolescente impúber. Un amigo solía decir: es que Guillermo no ha tenido infancia. Es y no es cierto. Conservo un amor por el amor o por la felicidad que sólo se tiene en la infancia. Y, claro, por eso el pasado y la memoria son tan intensos en mí. Y al juzgar u opinar sobre una obra pongo más el acento en su autenticidad que en su "grandeza". De esta última, se encargará el tiempo, decía T. S. Eliot.

P.- A partir de la segunda edición de La máscara, la transparencia y de La vastedad deja de producir con la intensidad con que lo habia hecho hasta ese momento. Cuando no adviene el silencio, la escritura pierde sensorialidad, se vuelve melancólica. Este cambio coincide con el auge de lo que la crítica ha llamado la cultura posmoderna y con el advenimiento de teorías literarias como la semiótica, la deconstrucción y los estudios culturales. En este nuevo panorama ¿cree que todavía puede tener lugar la crítica tal como usted la entiende? ¿Cree que es posible Resistir, como propone Eduardo Milán? ¿Cómo ve el futuro de la crítica y de la poesía?

R.- He dejado de publicar pero no de escribir. He publicado en la última década: La segunda versión (poemas) y ensayos en revistas. Tengo otro libro "in progress" El Regreso (poemas) y dos de ensayos. Pero confieso que paso por largos períodos de depresión personal y literaria. Eduardo Milán es un escritor con resistencia; y una manera de resistir es insistir. Pero sin exagerar: conozco autores cuya bibliografía ya casi sobrepasa a la de Balzac.

P.- Borges afirmó, como usted cita en varios lugares, "que otros se jacten de los libros que han escrito, yo me jacto de aquellos que he leído”. ¿Qué libros se jacta de 
haber de leído? ¿A qué libros o autores le concede a día de hoy una importancia mayor?

R.- Sólo Borges podía decir una frase como ésta, que, además, la dice sin jactancia, pero con orgullo. Conozco otros escritores (post-borgianos, no Neruda, no) que decían lo mismo, pero la jactancia era visible. "Somos los últimos grandes lectores", le oí decir a uno (y creo que era cierto en él). A él y a Borges, los incluyo en mi biblioteca. Como decía Montaigne no hago nada, no leo libros sin cierta "joie". A Montaigne y a Cervantes los incluyo en mi biblioteca personal. Así como a Antonio Machado, Proust, Eliot, y al Joyce de "Un retrato del artista adolescente" y de "Stephen Dedalus", y a W. C. Williams, Ramos Sucre y M. Picón-Salas. 


\section{3.- CARTA I, OCTUBRE DE 2012}

P.- Durante su estancia en Madrid tengo entendido que escribió un texto sobre Ángel Rosenblat. Me interesa conocer el vínculo (personal y profesional) que mantuvo con Rosenblat, que me parece que marcó en buena medida su concepción del lenguaje. No he podido conseguir ese texto, por lo que me gustaría saber dónde se publicó.

R.- Viví en Madrid entre fines de 1981 y principios de 1983. En 1982, Ángel Rosenblat cumplía 80 años -había nacido el 9 de diciembre de 1982 en Wengrow, una aldea de Polonia- y me propuse hacerle un homenaje. Entonces escribí un largo artículo que apareció en el Papel Literario de El Nacional en dos sucesivas entregas, 5 y 9 de diciembre de 1982, titulado "Rosenblat: la generosidad del lenguaje". Yo había escrito antes sobre Rosenblat, al reseñar la aparición en 1965 de su libro "La primera visión de América y otros estudios”. Esa reseña estaba publicada en Zona Franca. Luego en 2003, la Escuela de Letras le hizo un homenaje para conmemorar el Centenario de su nacimiento. Yo participé leyendo unas notas sobre lo que me parecía la poética de un filólogo, que titulé “Ángel Rosenblat: la palabra como ilusión” que luego publiqué en Prinicipia. (Revista de Cultura de la Universidad Centroocidental Lisandro Alvarado. Enero 2005, $\left.\mathrm{n}^{\mathrm{o}} 24\right)$.

Me unió al profesor Rosenblat una larga amistad, desde cuando regresé al país en 1956. Estudié con él las dos materias de Filología que me faltaban cursar y Literatura Española. En 1957, recién presentado mis exámenes finales con él, caí preso, junto con mi hermano Quico, y estuve fuera de circulación hasta Enero de 1958, cuando fue derrocada la dictadura de Pérez Jiménez. Al año siguiente me recibí de Licenciado en Letras y el Profesor Rosenblat firmó mi diploma. Me casé y con mi mujer Julieta Fombona me fui a París con una beca de la Universidad Central de Venezuela y de la Embajada de Francia. A mi regreso reanudé mis relaciones con Rosenblat y su familia: había ingresado en la Escuela de Letras y viví en la Urbanización El Paraíso (Calle Machado núm. 28) muy cerca de donde vivía Rosenblat. Algunos sábados nos invitaba (mi mujer y mis tres hijos) al Club Playa Grande en el Litoral. Rosenblat era un gran nadador.

Abro un paréntesis que tiene sentido. En 1956 también estudié en la Escuela de Letras la otra parte de la Literatura Hispanoamericana que me faltaba. Me hice muy amigo de él. Al terminar las clases, a eso de las 7 de la noche, nos íbamos caminando 
juntos hacia Sabana Grande, donde ambos vivíamos. Aproveché esas ocasiones para hablar con él de la situación política del país y finalmente le llevé un mensaje del Partido Acción Democrática pidiéndole su firma para un documento que él contribuiría a redactar, dirigido a la Nación y al Congreso (perezjimenista) pidiendo que se celebraran elecciones libres para elegir un nuevo Presidente de la República. Ese documento iba a ser firmado por el ex-Presidente, General López Contreras, en primer lugar, y luego por él (el Dr. Uslar Pietri escurrió el bulto) y por un grupo importante de intelectuales, científicos, profesores universitarios, profesionales y empresarios liberales, etc. Me contestó que, por supuesto, él firmaría tal documento, pero que en el momento en que le hablé de ello (junio de 1957) le parecía un poco prematuro y que era mejor esperar la "rentrée" de septiembre. Fue entonces cuando caí preso. Pero se cumplió lo que habíamos previsto. Pérez Jiménez convocó un Plebiscito para prolongar su periodo presidencial, violando así su propia constitución. Lo que fue el principio del fin, comenzando por la protesta pública de los estudiantes en la Ciudad universitaria, continuando con las pastorales de la Iglesia, las huelgas, los manifiestos de los intelectuales, profesionales, gremios y sindicatos, hasta la final intervención del Ejército, y el 23 de enero de 1958 Pérez Jiménez tuvo que huir del país. Al salir de la cárcel, regresar a mi casa y volver a la Universidad me encontré con Don Mariano, cuyo primer saludo fue: "No le había dicho que a este gobierno lo tumbábamos con papelitos". Lo que era verdad, pero esos "papelitos" habían costado años de "sangre, sudor y lágrimas". Picón-Salas fue nombrado Embajador primero en Brasil y luego en la UNESCO, París. Así que cuando viajé a Francia en 1959 lo encontré, así como a su hija Delia (Pasqualita), a quien había conocido en Santiago de Chile. Desde estos años mi vida se cruzó, de alguna manera, con la de Picón-Salas y la de Ángel Rosenblat.

Regresé de París en 1962 y él en 1963, designado Secretario de la Presidencia con Rómulo Betancourt. Yo ingresé [como profesor] en la Escuela de Letras y a él le tocó un período político difícil por las conspiraciones militares y la guerrilla alentada por Castro desde Cuba. Sin embargo, contribuyó a la realización de unas elecciones pacíficas en las que por primera vez en nuestra historia había una sucesión presidencial democrática, y así sucesivamente hasta 1993. Picón-Salas murió el 1 de enero de 1965. El año anterior, encargado por el presidente electo Raúl Leoni, preparó lo que iba a ser el Instituto de Cultura y Bellas Artes (INCIBA), que se iba a instalar el 18 de enero de 1965. Poco antes de morir, había escrito "Prólogo del Instituto Nacional de Cultura", discurso inaugural que como el que había pronunciado 30 años antes al inaugurar las 
actividades de la Facultad de Filosofía y Letras, constituyen la verdadera doctrina del pensamiento democrático frente a la cultura. En ninguna otra época se ha hablado de la relación Estado y Cultura con tanta inteligencia, ecuanimidad, y sin ningún paternalismo. La cultura venezolana ha tenido otros logros después, pero no ha superado ese momento como de cotidiano dominio y de generosa empresa colectiva que iba a tener con Picón Salas. Un mes después de su muerte, un grupo de profesores de la Facultad de Humanidades y Educación, la antigua facultad de Filosofía y Letras que él había fundado en 1946, propuso que la Universidad le rindiera un homenaje público. Lo que fue aceptado por el Decano de entonces y el Consejo de Facultad, pero el acto de homenaje no pudo efectuarse porque una nutrida barra de estudiantes de "izquierda" lo saboteó al momento en que iba a hablar el Dr. Arturo Uslar Pietri, ex-candidato a la Presidencia de la República en 1963 y cuyo partido formaba parte de la coalición que apoyaba al gobierno de Leoni. En ese momento la tensión política era muy grande, la guerrilla -aunque en menor escala- continuaba y la Ciudad Universitaria le servía de "escondite". Como el homenaje [a Picón-Salas] no pudo realizarse en el recinto universitario se decidió celebrarlo en el auditorio del Colegio de Ingenieros; como el Dr. USLAR NO QUISO ESTA VEZ PARTICIPAR aduciendo que el acto se había politizado (y, claro, él no era político, lo mismo había dicho en 1957 cuando se le propuso firmar el documento que sí firmó Picón-Salas), Rosenblat me pidió que yo participara. Lo hice con el segundo texto que escribí después de su muerte. La pieza central de ese acto fue lo que leyó Rosenblat sobre el Estilo de Picón-Salas. Siento que he tratado de guiarme por la obra de Picón-Salas y la de Rosenblat, sobre todo en lo relativo al lenguaje. Leía a Picón-Salas desde mi adolescencia y aún conservo las ediciones que compraba cuando estudiaba bachillerato y en la Universidad. Vg. EuropaAmérica (Cuadernos Americanos, México, 1927), De la Conquista a la Independencia, Viaje al amanecer, Regreso de tres mundos. También leí muy joven a Rosenblat. Antes de publicarlas en libro, yo leía en la "Página Literaria" de El Nacional, que dirigía justamente Picón-Salas, sus Buenas y malas palabras. Cuando, siendo ya profesor de la Escuela de Letras me tocó presentar, como trabajo de ascenso a la categoría de Profesor Asistente, mi librito sobre Borges, el poeta, Rosenblat estuvo en el Jurado que lo leyó y aprobó. Luego, individualmente, me hizo muchas observaciones y me propuso correcciones. Con frecuencia, yo metía la pata en mis opiniones y en mi estilo; Rosenblat me sugería soluciones. 
P.- Me ha llamado la atención que en un texto suyo titulado "Sobre poesía venezolana”, publicado en la Revista Nacional de Cultura en 1963, no haya menciones significativas a la obra de Ramos Sucre. ¿De cuándo data su conocimiento de la poesía de Ramos Sucre? Querría saber también si les une algún vínculo familiar.

R.- "Sobre Poesía Venezolana", que publiqué en 1963 en la Revista Nacional de Cultura, a pedido de su Director, tenía que limitarme a un panorama de nuestra poesía en los últimos 25 años que cumplía la revista en 1963. Así que no podía referirme a Ramos Sucre. Es posible que mi panorama no fuera tan feliz y, con los años, me di cuenta de que era un poco errático. A Ramos Sucre ya lo conocía; en Chile había comprado las ediciones originales de Las Formas del Fuego y Cielo de Esmalte (1929). Había leído la edición de toda su obra en el volumen Obras, que publicó la Dirección de Publicaciones del Ministerio de Educación en 1956, una edición, por cierto, poco recomendable, pues no incluía el contenido de cada libro y los poemas eran presentados tipográficamente como si fueran prosa. Pero vine a leer más detenidamente a Ramos Sucre en 1972-1973 cuando viví en Washington y estaba escribiendo La máscara, la transparencia. Hoy estoy escribiendo un pequeño libro titulado Poesía y Ensayo: un estudio sobre Ramos Sucre y Picón-Salas.

El apellido Sucre en Venezuela es un solo tronco y viene desde la época de la Colonia y de la Capitanía General de Venezuela. Ramos Sucre desciende del primer matrimonio del padre del Mariscal Sucre, es decir, de los Sucre Alcalá; mi abuelo paterno era descendiente del segundo matrimonio del padre del Mariscal, es decir, de los Sucre Márquez, uno de los cuales Juan Manuel Sucre Márquez se estableció en Angostura (Ciudad Bolívar) después de las guerras de Independencia. En pocas palabras, Ramos Sucre era sobrino bisnieto del Mariscal, lo mismo que mi abuelo Juan Manuel Sucre Samarra. C'est tout.

P.- Durante su estancia en Chile conoció a Jorge Teiller y a Nicanor Parra, ¿conoció también a otros poetas de su misma generación? ¿En qué manera cree que la poesía lárica de Teiller (y la importancia que él le concede al pasado) marcó de alguna manera su primera poesía? Quisiera saber también si en Chile tuvo ocasión de publicar en alguna revista literaria.

R.- Viví en Santiago de Chile entre 1952 y 1955. Estudié Castellano y Literatura en el Instituto Pedagógico. Uno de mis profesores era Ricardo Latcham, amigo de 
Picón-Salas, quien, al saber que yo era venezolano, me distinguió con su protección y amistad. En el Pedagógico conocí a Jorge Teiller, estudiante de Historia y Geografía. Mis otros amigos estudiaban lo mismo que yo, Jaime Valdivieso, Antonio Avalón, Mónica Imbert y otras musas. Entre ellas una muchacha muy bella, estudiante de geografía como Jorge, Ángel Jiménez, a la que conocí tomando el troleybus en Vicuña Macquena, que nos dejaba a varias cuadras del Instituto al que llegábamos caminando. El Instituto era un conjunto de hermosos y sencillos edificios cubiertos de hiedra, y con un inmenso jardín (campus) sembrado de álamos. En el trayecto hablaba mucho con Ángela y casi iniciamos un romance. Dejé de verla por un tiempo y cuando la encontré de nuevo en el centro de Santiago me presentó a un profesor de matemáticas, con el que iba a casarse. Disimulé mi indignación y no nos volvimos a ver. Sin embargo, le dedico un breve poema de mi tercer libro, al cual añado unos versos de Neruda, titulado “Ángela Adónica”, que con frecuencia le memorizaba a ella, y era como nuestra contraseña. En el Pedagógico formamos una tertulia literaria y nos reuníamos allí un día a la semana, leíamos y comentábamos nuestros poemas, ensayos y relatos. En una ocasión, el Pedagógico publicó una Antología de Poetas Universitarios, con colaboraciones nuestras. Jorge Teiller era ya un poeta con mucho dominio expresivo y originalidad, lo que se nota en su primer libro Para ángeles y gorriones (1956). Jorge, hacia esta fecha, estaba por casarse con una muchacha preciosa, que era muy amiga de todos nosotros Matilde Guevara. Cuando yo vivía en Caracas, me enviaba sus libros que yo reseñaba en Zona Franca. Cuando elaboramos la Antología de la USB incluí a Jorge y creo que fue uno de los éxitos de esta Antología, al menos le abrió un público lector venezolano. Creo que el tono nostálgico de su poesía, su sentido de lo irreparable y el sentido misterioso de la Frontera (del Sur), la fascinación por la aventura como el Grand Meaulnes de Fournier o el Rimbaud de las Iluminaciones, son rasgos notables de su poesía. Y nadie más inocente que él. En un capitulo que ideo para La máscara-El Reino- le reservo un buen espacio.

También conocí a Nicanor Parra, así como Braulio Arenas y a Gonzalo Rojas. A Nicanor me lo presentaron en la Biblioteca y cuando supo que yo era venezolano inmediatamente me preguntó por su amigo Juan Sánchez Peláez, quien había vivido años antes en Santiago. Éramos más o menos vecinos (él vivía en La Alameda y yo en Vicuña Macquena) y con frecuencia me invitaba a ver las piezas que montaba el Teatro Universitario en la Plaza de la Moneda. A veces él no iba y me acompañaba su hija. Yo admiraba a Nicanor por su poesía (era la época de Poemas y anti-poemas) y por su 
ingenio un poco mordaz. En los veranos nos encontrábamos en el Sur, ya fuese en Valdivia, ya fuese en Concepción. Años después, en 1967, vino a Caracas, invitado a un Encuentro de Escritores norteamericanos y latinoamericanos, que celebró sus reuniones en un Club del Litoral, y al cual yo también asistí. Recuerdo una sesión nocturna que fue de diálogo abierto y en la que Robert Lowell y Nicanor leyeron sus poemas y, además, Lowell leyó un poema de Nicanor, y éste un poema de Lowell traducido por él. En ese Encuentro Nicanor me decía: "en estas reuniones no hay que hablar mucho porque después no nos invitan más”. Terminado el Encuentro, nos vinimos a Caracas, y fui un poco su cicerone en la ciudad, junto con Sánchez Peláez. Lo llevé a la Ciudad Universitaria y cuando le mostré el Aula Magna, le dije: “aquí Neruda en 1959 leyó sus poemas". Noté que a Nicanor no le cayó muy bien la noticia. Poco después me preguntó por qué a él no lo invitaban al Aula Magna en vez de la pequeña sala del Ateneo de Caracas. Al día siguiente había tomado el avión y sin avisar se marchó; apenas me dejó una esquela con el adiós. Por suerte, le había pedido permiso para publicar en Imagen los "Artefactos" que había leído en las reuniones del Litoral, a lo cual accedió no sin antes protestar por los honorarios. Así era Nicanor, siempre inconforme. Imagen era una revista tamaño tabloide, quinquenal, que se vendía en los kioscos, recién creada por el INCIBA y la cual yo dirigí hasta 1968. Para una futura edición de La máscara, pienso dedicarle a Nicanor un espacio más amplio.

P.- ¿De qué manera cree que su estancia en los EEUU modificó su obra? ¿Cómo eran los estudios literarios en los EEUU durante el período que usted residió alli? ¿Qué motivó su vuelta a Venezuela? Al volver trabajó como Director literario de Monte Ávila, ¿cómo fue su trabajo de editor?

R.- Mi estancia en los States fue muy estimulante en lo personal y en lo intelectual, a pesar de los malos ratos que se pasaban en esos departamentos hispánicos. Como tuve que concentrarme en el campo hispanoamericano, esos años me sirvieron para ampliar mis lecturas y para tener una visión más amplia de nuestra literatura. Conocí en Pittsburgh al profesor Raimundo Lida que iba a dirigir la cátedra Mellon en Literatura Española. Lida era de la misma generación que Rosenblat, amigo de él y lector de sus libros; ya me conocía de nombre, pues había leído mi libro sobre Borges, y por él supe que a Borges le había gustado mucho también y se lo dijo cuando había dado clases en Harvard. Cuando regresé a Caracas, en 1975, recibí una carta de él proponiéndome, autorizado por los demás profesores del Departamento Hispánico, la 
Cátedra de Literatura Hispanoamericana en reemplazo de Anderson Imbert, quien se iba a jubilar. Pero -¡hélas!- no podía aceptar por muchas razones. Las personales: tanto Julieta como yo creíamos que nuestros hijos debían terminar su formación en nuestro país; lo que en ese momento fue acertado pero a la larga un error: mis hijos, aun en Caracas, tuvieron una educación más norteamericana que hispánica; actualmente los tres viven y trabajan en Nueva York, y Julieta misma - para quien los States era su segunda patria-, murió en NY, Brooklyn, en 2005. Luego, porque yo mismo pensaba que tenía y tengo un espíritu poco académico y una formación intelectual nada apta para pasar mi vida en una Universidad tan exigente como Harvard.

Al volver a Caracas en 1975, volví a trabajar en Monte Ávila y retomé mi puesto de Director Literario, además de mis clases en el Postgrado de Literatura Hispanoamericana en el Pedagógico. En verdad, en 1967, junto con Simón Alberto Consalvi y Benito Milla fui uno de los fundadores de Monte Ávila. A mí me había gustado mucho trabajar en Monte Ávila, en los años iniciales. Pero había cambiado enormemente. Curioso: la Editorial, como tal, se había consolidado y tenía cierto prestigio, pero humanamente no era la misma. El Sr. Juan Liscano, íntimo amigo del nuevo Presidente de la República, Carlos Andrés Pérez, se hizo nombrar VicePresidente de la empresa, ya había introducido en ella "l'ére du soupçon", estimulando en empleados subalternos y hasta en el propio Don Benito Milla un espíritu de intriga y de recelos. Lentamente se había ido apoderando de Monte Ávila y se había vuelto medio "argentino" (y tan pedante como ellos): vivía con una escritora argentina, a la cual publicaba sus libros, así como todos los de él. Lo decisivo para mí fue un sr. ególatra, que hacía su politiquería literaria, había puesto a Monte Ávila a su servicio y obstaculizaba mi trabajo. Así que no me quedó otro camino que renunciar. Fui contratado como profesor en la Universidad Simón Bolívar, donde organicé y fundé la Maestría en Literatura Hispanoamericana, en donde se han graduado brillantes alumnos que hoy son jóvenes maestros, y donde dirigí un equipo que elaboró la Antología de la Poesía Hispanoamericana Moderna, en dos tomos. En 1981 viajé a España, regresé, preparé las Bibliotecas de Mariano Picón-Salas y agilicé la de Ángel Rosenblat, continué de profesor en la USB hasta 1985, año que me separo de Julieta, entro a mi verdadera casa, la Escuela de Letras de la Facultad de Humanidades, UCV.

P.- Me parece que su pensamiento se enmarca en la crítica al logocentrismo que caracteriza a la filosofia occidental de la segunda mitad del siglo XX. Aparte de que 
Borges y Paz en buena medida coinciden con esta crítica. ¿Cuáles fueron sus fuentes en este sentido? ¿Heidegger? ¿el postestructuralismo francés?

R.- ¿Contra el "logocentrismo" de la Filosofía Occidental? Es posible. Mis lecturas en un tiempo fueron, sobre todo, Eliot, Barthes, Foucault; después, Borges, Paz. De Heidegger había leído, en mis estudios de Letras, sus ensayos "Hölderlin o la esencia de la Poesía", "Orígenes de la obra de arte", "Senderos en el bosque". Un año antes de terminar mis estudios de Letras, hice un seminario de Estética con el profesor español-venezolano Federico Riu, que versó sobre Heidegger. En los últimos años, leo o soy asiduo lector de Georges Steiner.

P.- ¿Escribió usted los Testimonios de la revista Sardio? ¿Cuáles fueron las “desavenencias ideológicas" que motivaron su distanciamiento de Zona Franca?

R.- Sí, muchos de los Testimonios de Sardio son míos. La cárcel y las primeras Situations de Sartre influyeron quizá en mí. Pero luego no me reconocí en ellos. Sartre se volvió más dogmático y stalinista que Neruda, lo que ya es mucho decir. Por otra parte, fuera del entusiasmo juvenil y ciertas amistades, tampoco Sardio representó mucho para mí, quizá porque no estuve a la altura de ella. Así que puedo hablar, como Borges de la secta ultraísta, de la equivocada secta sardiana. Lo mismo puedo decir de Zona Franca.

P.- Me gustaría saber si tuvo la oportunidad de conocer a Borges y si él leyó el libro que usted escribió sobre su poesía.

R.- No conocí personalmente a Borges. Como le decía en mi respuesta al tema cuarto, fue en los States, a través del profesor Raimundo Lida, cuando supe la opinión de Borges sobre el libro que escribí de él.

P.- A lo largo de los años 60, usted vivió de manera esperanzada el renacer de la democracia en Venezuela. Me gustaría saber cómo vivió en los años 80 el desgaste del sistema democrático y eventos como "el Caracazo", que marcaban un punto y aparte en el funcionamiento de ese sistema.

R.- A lo largo de la llamada IV República (1958-1998) viví momentos de mucha tensión emocional e intelectual. A poco de instalarse el gobierno de Rómulo Betancourt, que yo apoyaba, se produjo la división de su partido Acción Democrática y la formación 
del Movimiento de Izquierda Revolucionaria con la mayoría de la juventud adeca y se iniciaron los escarceos personales y verbales en las Universidades. El MIR junto con el PCV se lanzó a la lucha armada, a las guerrillas, que si no fuera por sus consecuencias dramáticas, diría que eran risibles. Por más ayuda de Fidel Castro que tuvieran, era imposible que lograran vencer y, mucho menos, convencer. Ya en los años 60 el Castrismo se había desprestigiado, mucho antes la izquierda guerrillera había sido derrotada. En Venezuela, el MIR perdió fuerza en la juventud que tenía incluso algunos de sus altos dirigentes como Gumersindo Rodríguez (y hasta jóvenes comunistas) se habían plegado al gobierno de Carlos Andrés Pérez en 1973. En medio de la proverbial confusión ideológica, lo único más o menos claro fue la división del Partido Comunista y la formación de MAS (Movimiento hacia el socialismo) que lideraron Pompeyo Márquez y Teodoro Petkoff. En el primer gobierno de Carlos Andrés Pérez el clima político que, en verdad, era plural y vigoroso, comenzó a enturbiarse. A pesar de que $\mathrm{AD}$ se había dividido en tres ocasiones durante los gobiernos de Betancourt y de Leoni, en 1973 volvió a recuperar su fuerza anterior y aun aumentarla; y esto se había logrado con un líder como Carlos Andrés Pérez, lo cual no era visto muy bien ni por la derecha, ni por los socialcristianos (ya más de izquierda que nadie, como los curas jesuitas) ni por la izquierda menos resentida y menos dogmática, esto, es el MAS. Dos décadas después vuelve CARLOS ANDRES PÉREZ a triunfar en las elecciones presidenciales, quizá con una mayoría más alta. COPEY (social cristianos) no se había debilitado, pero estaba a punto de que su propio fundador, Rafael Caldera, lo desconociera y se lanzara como candidato presidencial contra Álvarez Paz, el candidato legítimo, y después de alentar consciente o inconscientemente al militarismo chavista insurgente en 1992 lo cual contribuyó a la destitución del Presidente Pérez. Un partido como el MAS formó parte del gobierno de Caldera y le dio cierta fuerza programática y pública (el MAS había obtenido unos 600 mil votos, casi la mitad de los votos que obtuvo, por suerte, Caldera). De manera que el gobierno de Caldera en 1993 como en 1969 se apoyaba sólo en una tercera parte de la población. Fue, pues, un gobierno débil y no muy popular, que parecía garantizar estabilidad debido al apoyo o no intervención de las Fuerzas Armadas. La crisis política se había acentuado con el "caracazo" en 1989, luego los intentos fallidos de Chávez. ¿Cómo reaccionó Caldera? Ante el "caracazo" dijo en el Congreso, era Senador Vitalicio: "es que Democracia con hambre no dura" -como acusando de manera infeliz al gobierno de CAP. Y, ¿cómo reaccionó ante el golpe fallido de Chávez? Con otro discurso infeliz en el Senado defendiendo a los alzados de 
sus intenciones honestas y no criminales, como los acusaba el Presidente Pérez. No son ningunos asesinos, Presidentes. Total que Caldera se valió de Chávez para acabar con Pérez, y Chávez aprovechó a Caldera para terminar de defenestrar a Pérez.

En ese momento el país político sufrió una gran crisis. Un partido como el MAS, de Pompeyo Márquez y Petkoff, se dividió o, mejor, se fue todo con Chávez. Los social cristianos de COPEY querían apoyar a la entonces alcaldesa de Chacao, Irene Sáez. Caldera había abandonado su propio partido y el que había fundado, Convergencia, no tuvo ninguna influencia. Inexplicablemente, el Partido Acción Democrática, que en las elecciones de 1993 había quedado en segundo lugar y su candidato Claudio Fermín había obtenido 1.200 .000 votos, ahora en las elecciones de 1998 ya no tenía la misma influencia, y se había desligado de Carlos Andrés Pérez. De modo que Chávez ganó fácilmente las elecciones con una alta votación, y el candidato Independiente, Salas Romer, apoyado por los demás partidos democráticos, así como por el MAS, obtuvo una tercera parte de los votos. Era la hora del anti-partidismo. Los llamados Notables que abiertamente habían apoyado y alentado los golpes de Chávez- hablaban del fin de la partidocracia. Uslar Pietri escribió un artículo para Le Monde Diplomatique en la que anunciaba el nacimiento de una nueva era democrática. Creo que Liscano publicó un libro donde exponía las fallas de nuestra Democracia y sus correctivos, que bautizó en presencia del Sr. Luis Miquelena, el tutor político de Chávez, que antes del 2002 se separa de él y lo critica abiertamente; en la huelga general del 2002 lo acusa de tener manchadas las manos de sangre. El ex-rector de la USB [Universidad Simón Bolívar], Mayz Vallenilla, pone al servicio de Chávez todos su cacumen de filósofo-legislador y después que Chávez ganó las elecciones, se entrevistaba con él en la Casa Presidencial y dijo: "Nos pusimos las botas". Sólo que Chávez, al parecer, no dejó que se las pusiera del todo y lo fue apartando, o no le dio los privilegios políticos e intelectuales a los que él aspiraba. Ya en 2002 el engañado ex-rector también se decidió a sumarse a la oposición. El dirigente de COPEY y candidato a la Presidencia en 1993, Álvarez Paz, que también había sido seducido por el caudillito, luego rompió con él y hasta estuvo preso por unas semanas. Aun suponiendo que todos hayan actuado con honestidad en estos hechos y después en su reacción en contra, dimos una pobre imagen de nuestra Democracia y de sus líderes. Todos se equivocaron inocentemente y sólo Chávez no se equivocó y se valió de ellos. Hasta 2002 y 2004 -huelga general, prisión momentánea de Chávez y Referendo Revocatorio-, la oposición democrática tuvo un alto espíritu combativo, quizá, entre otras cosas, porque creía que era fácil salir de Chávez. Después 
del Revocatorio (2004) y de las elecciones de 2006, Chávez se reafirmó en el poder y ya había buscado apoyo humano en Cuba a cambio de nuestro petróleo y otras riquezas. La oposición tuvo que replegarse. Pero a partir del 2007, con el triunfo del NO a la reforma constitucional que buscaba Chávez, la oposición crea la MESA DE LA UNIDAD DEMOCRÁTICA con un Secretario Ejecutivo elegido por los propios partidos que la integran. De este modo se ha avanzado mucho en la unidad democrática y desde esa fecha el contendor de Chávez tiene mayor fuerza y eficacia. De esta política y estrategia se deriva la candidatura de Henrique Capriles Radonski y la gran campaña electoral que terminará este domingo próximo 7 de octubre [de 2012], esperamos que con la victoria de quienes lo merecen.

Guillermo Sucre, Los Caobos, viernes 5 de octubre de 2012. 


\section{4.- CARTA II, ABRIL DE 2013}

P.- En sus primeras críticas usted insiste mucho en el concepto de autenticidady establece un vínculo entre la ética y la estética (o, lo que es lo mismo, entre la actitud vital del escritor y su actitud ante el lenguaje). ¿Se debe esta concepción a sus lecturas de Baudelaire y de Valéry? ¿Puede ser que César Vallejo tuviera también un peso importante en el concepto de autenticidad que usted emplea?

R.- Cada vez tengo más cuidado en el empleo de vocablos como autenticidad y auténtico. Desde cualquier punto de vista resultan vocablos muy inasibles y con frecuencia se emplean de manera contradictoria. Los escritores que he admirado desde Eliot a Vallejo, pasando por Borges y Picón-Salas, me han enseñado que la autenticidad se siente, sin necesidad de definirla, que no es sólo cuestión de lenguaje sino también de sentimientos. Exagerar el lenguaje o los sentimientos pone en peligro la autenticidad, pues se nota el esfuerzo por lograrla. El realismo-socialista (cierto Neruda) y el realismo-mágico (Carpentier, García Márquez) se nutren de esta exageración: el culto a la Historia, al Pueblo, a la Naturaleza mágica, paradisíaca, que concluye en el culto al autor. Si Baudelaire me parece más auténtico o me gusta más que Vicente Huidobro no es porque me parezca poéticamente superior, sino porque el vínculo entre poesía y vida no se convierte en apoteosis o teatralidad del yo. Al parecer, a la autenticidad le gusta revestirse de cierta impersonalidad, para que surja del texto mismo y no de los énfasis y las decisiones previas del autor. Aunque parezca un escándalo decirlo, con frecuencia nos atrae más un escritor considerado menor pero que sentimos como auténtico que un escritor mayor (o tenido como tal) pero al que sentimos inauténtico. Pienso en la novela Viaje al amanecer (1943) de Picón Salas y El reino de este mundo (1948) de Alejo Carpentier. Pero en todo esto quien tendrá la última palabra es el tiempo. "Sé el hijo de tu tiempo pero no su favorito", decía Schiller. Hay escritores que siempre prefieren ser "el favorito" -son los imprescindibles, los únicos merecedores del mañana, diría Borges.

P.- Esta relación que usted establece entre ética y estética en su crítica literaria implica un gusto por la mesura en la literatura y, por consiguiente, en el hombre. ¿De quién toma esta noción de la mesura? ¿De Picón-Salas? ¿De los ensayos iniciales de Camus (Noces sobre todo)? 
R.- Es posible que la autenticidad conduzca a la mesura (aunque no siempre), porque la desmesura (aunque no siempre) es hija de la megalomanía. Y la mesura no es sólo del yo sino también del lenguaje. El lenguaje es creación del hombre pero simultáneamente crea al hombre. Yo he hecho mi libro tanto como él me ha hecho a mí, decía Montaigne, a quien no le interesaba otro valor que esa doble conjunción. Borges parece decir lo mismo en el epílogo de El hacedor.

No sabría decir de quien tomo el gusto por la mesura, si es que la tomo de alguien, si es de Picón-Salas o de Camus, entre quienes he buscado un guía. Seguramente lo tomo de la literatura misma.

P.- En su carta anterior hace referencia a sus lecturas de T. S. Eliot. ¿Qué fue lo que más le interesó del poeta anglosajón?

R.- Lo primero que me interesó de Eliot fue su poesía. Muy joven leí un librito titulado Tierra baldía y otros poemas (1954), con buenas traducciones de Ángel Flores, León Felipe, J. R. Jiménez y Ortiz de Montellano. Esa primera lectura se continuó con la poesía completa en el original -aún tengo el disco con grabaciones de Eliot, quien es un magnífico lector de su poesía (al igual que Borges de la suya). Aun he leído sus divertidos poemas sobre los gatos, y otros animales. Algo que siempre me impresiona de Eliot es su ironía, su dramaticidad, la emoción que subyace en estructuras poéticas tan concertadas. Cuando leí la biografía que le dedicó Peter Ackroyd (1992) fui descubriendo todo lo que hay de experiencia vivida en su poesía. Al final, él mismo confesaba que se había desgastado mucho escribiendo sus poemas -desgaste físico, psíquico. Como en todos los poemas que he admirado, Eliot ha sido para mí un ensayista inigualable y un crítico que me ha enriquecido en el momento de leer poesía. La interrelación entre el escritor y la tradición, su idea de la impersonalidad poética, o del correlato objetivo, o las diferentes voces que pueden coexistir en un poema, o los diferentes textos en un texto, ese espléndido que a veces son sus poemas, todo eso que asociamos con él nos revela que es uno de los poetas contemporáneos más singulares y, a la vez, más antiguos. Creo que su poesía tiene esa otra virtud de crearnos a un personaje que ya no es él tan sólo, sino una época, quizá una cultura que desaparece. En el fondo Neruda tenía razón cuando en uno de sus libros lo toma como mofa, signo de la decadencia (algo así como "y el poeta Eliot, con su viejo frac, leyendo sus poemas a los 
gusanos”, qué delicadeza, qué vulgaridad, ¿no?) ¿Y el teatro de Eliot? Casi no lo he leído, pero sí he visto algunas de sus piezas en versiones al español y al francés.

P.- He consultado la revista Imagen durante el tiempo que usted la dirigió y, aparte de que la he encontrado excepcional y completamente coherente con su pensamiento sobre la literatura, he advertido en ella un vínculo estrecho con Mundo Nuevo, la publicación de Emir Rodríguez Monegal. ¿Puede ahondar un poco en la relación que unió a ambas revistas y también en lo que aprendió de Rodríguez Monegal (que tuvo que ver-según creo-sobre todo con su concepción del lenguaje)?

R.- Cuando apareció Imagen en 1967, Rodríguez Monegal empezó a venir con frecuencia a Caracas. Ya era director de Mundo Nuevo, revista en la que yo colaboraba, pero ya estaba a punto de renunciar e irse a las Universidades norteamericanas. En 1967 vino a un Congreso de Literatura Hispanoamericana y fue cuando lo conoció Simón Alberto Consalvi, Presidente del INCIBA, que lo invitó a dar un curso que duró dos meses, tiempo en el cual nos hicimos buenos amigos (mucho después, a mediados de los setenta, me invitó a Yale a un Coloquio sobre Lezama Lima). Admiraba a Emir por su inteligencia, por su amplia formación y por su honestidad crítica. Me gustaba más lo que escribía sobre Borges que lo que escribía sobre Neruda, aunque finalmente escribí sobre El viajero inmóvil, el libro que le dedicó a Neruda, una cuerda muy tensa entre la amistad y las convicciones. Creo que lo más perdurable de Emir es Ficcionario, una antología de textos de Borges, organizados y comentados por él- en ese libro logra dar una visión caleidoscópica de Borges.

P.- En su carta anterior habla de la "equivocada secta sardiana". ¿A qué se refiere exactamente? En verdad, yo veo que el proyecto cultural de Sardio es bastante coherente con las demás publicaciones en las que participó en los años 60 (de las cuales la más anómala es quizás Zona Franca) ¿Tiene que ver esta opinión negativa de Sardio con la posterior deriva vanguardista de parte de los integrantes del grupo?

R.- "La equivocada secta de Sardio". En verdad, quien estaba equivocado era yo y los verdaderos sardianos - cuando nos separamos amistosamente -fundaron El techo de la ballena, una revista radicalmente herética y provocadora; el escándalo de su época, un síntoma más de la epidemia de "castroenteritis". 
P.- En un artículo sobre Braque, usted destacaba la importancia del cubismo en algunos escritores de su predilección (Huidobro, Stein, Paz, etc.) En otro lugar, señalaba la importancia que tuvo para usted Pierre Reverdy. ¿Puede ahondar un poco en su relación con este poeta francés?

R.- Desde que en 1955 vi en El Louvre la primera Retrospectiva de su obra, siempre me gustó Braque. Me seducía también el hecho de que fuese un pintor que pensaba y escribía muy bien. Al menos yo me identificaba con sus ideas. En 1973 traduje para Plural sus "Cahiers", acompañados de un breve comentario. Antes, había publicado en Imagen "Pájaros", el poema de Saint-John Perse, cuyo tema visible son los cuadros de Braque y que es también como una reflexión sobre los nexos de la realidad (la naturaleza) y el arte, y la celebración de otro nacimiento. Por supuesto, esto me llevó a interesarme por la relación entre el Cubismo y la poesía que escribían Reverdy, Huidobro, Gertrude Stein y Octavio Paz. Sobre Reverdy y Huidobro di un curso en la Maestría de Literatura Hispanoamericana de la USB, y de él traduje varios de sus textos teóricos para un libro que publicó Monte Ávila en 1977, titulado Escritos para una poética. Años después, la misma Monte Ávila publicó una Antología poética de Reverdy, en traducción de Alfredo Simpatía Estrada, un magnífico poeta venezolano. Igualmente traduje de Reverdy otro texto, notas sobre la poesía, de 1942, que reprodujo en 1974 una revista francesa de poca duración, Argile, que aglutinaba a poetas jóvenes importantes. Publiqué mi traducción y un breve ensayo sobre Reverdy en la revista Poesía de la Universidad de Carabobo, Venezuela. Reverdy me atrajo por la limpidez de su poesía y su imaginación homológica, así como por su nueva visión de la imagen y la lucidez crítica en general.

P.- A partir de los años 70 crece enormemente su interés por Lezama Lima que, en apariencia, es un escritor de una sensibilidad muy diferente de la suya. ¿Puede comentarme un poco cómo llegó a él y qué es lo que más le interesó de su obra?

R.- Mi conocimiento de Lezama Lima se remonta al año 1957 cuando Alejo Carpentier me regaló un ejemplar de la primera edición de La expresión americana que contenía cinco conferencias dictadas en el Centro de Altos Estudios, La Habana, durante las cinco semanas de enero de 1957. Este libro me impresionó mucho por sus ideas y su lenguaje y sentí que estaba frente a un escritor considerable, distinto, por ejemplo, al propio Carpentier. En efecto, pequeño tratado sobre la expresión americana, el nacimiento de la expresión criolla, nuestro barroco, nuestro romanticismo (en el que 
estudia tres figuras venezolanas tan admirables como Simón Rodríguez, Miranda, Bolívar), nuestras sumas críticas (el paisaje como un espacio gnóstico, el complejo americano de creer que su expresión no es forma alcanzable sino cosa por resolver, por ejemplo), este libro de Lezama es, en sí mismo, una muestra de una expresión lograda que puede hablar de lo americano sin complejos de inferioridad o de superioridad, y que tenía "ganancias" deslumbrantes en textos como "Sucesiva o las coordenadas habaneras" (sept. de 1949 y carnaval de 1950), que leí posteriormente. Luego fui leyendo su sorprendente poesía, tan desmesurada, extraña, pero igualmente familiar e íntima. La oscuridad transparente o la transparencia oscura. Sigo leyéndola y cuando leí el último libro de Lezama, Fragmentos a su imán (póstumo, 1978), pude comprobar que su fuerza creadora estaba intacta y que ese pequeño libro era como el "tour de forcé" de un rasgo que parece imposible lograr con tanta soltura: que el tema y la experiencia del poema nacen del momento mismo de escribir el poema, que una imagen desencadena una constelación de imágenes, que todas las alusiones exóticas (de clima, de ciudad, de cultura) son vividas por un personaje que vive en una ciudad que es La Habana y no lo es, una ciudad cotidiana y soñada, un personaje refinado y a la vez candoroso, que, como se dice en el último poema, lo vive todo "para morir, para la primavera", y va abriendo el tokonoma en la pared, un pequeño vacío en donde se va reduciendo "para reaparecer de nuevo". Hay, sin duda, poetas más grandes que Lezama, más buena compañía, pero pocos tan sacerdotales y dionisíacos como él. La edición que ha hecho Alianza Editorial de su Poesía Completa es digna de él. ¿Y Paradiso? Creo que no hay una novela sobre la vida del artista, su juventud, como ésta de Lezama, tan rica e inagotablemente mítica. Me refiero, claro, a la literatura en español. Lezama parece demasiado grandioso, desproporcionado, pero es un mago de esa desmesura y llega a ser un Parménides del Logos de la imaginación. Si alguna parte de La máscara, la transparencia me sigue gustando es la que dediqué a Lezama. En una futura (?) edición creo que tendré ánimo para ampliarla. También he ideado un nuevo capítulo que se titularía El Reino en el que incluiré a un poeta cubano como Eliseo Diego.

Guillermo Sucre, 11 de abril de 2013. 


\section{APÉNDICE II CONTRIBUCIÓN PARA UNA BIBLIOGRAFÍA DE GUILLERMO SUCRE}




\section{BIBLIOGRAFÍA DE GUILLERMO SUCRE}

\section{1.- POESÍA}

\section{a) Libros de poesía}

Mientras suceden los días, Caracas, Editorial Cordillera, 1961.

La mirada, Caracas, Editorial Tiempo Nuevo, 1970.

En el verano cada palabra respira en el verano, Buenos Aires, Editorial Alfa, 1976.

Serpiente breve, París, Colección Imaginaria, 1977.

La vastedad, México, Editorial Vuelta, colección La Imaginación, 1988.

La segunda versión, Sevilla, Palimpsesto, 1992.

\section{b) Poemas aparecidos en revistas o volúmenes colectivos}

Aparece su primer poema en el único número de la revista Cantaclaro, 1950. [Comprobar dato]

"El mar de cada día”, en Revista Nacional de Cultura, Caracas, núm. 120, enerofebrero de 1957, pp. 88-91.

"De los viajes y el regreso (fragmentos)", en Sardio, Caracas, núm. 1, mayo-junio de 1958, pp. 41-44.

"Donde el viento no ha podido vencer" (fragmento del poema homónimo), en El papel literario de El Nacional, Caracas, 14 de agosto de 1958, p. 6.

“Los adioses”, en Sardio, Caracas, núm. 7, abril-mayo de 1959, pp. 476-479.

"Los sepulcrales", aparecido por primera vez en Medina, José Ramón (ed.): La nueva poesía venezolana (antología), Caracas, Cuadernos literarios de la Asociación de Escritores Venezolanos, 1959, pp. 183-190. Reproducido después en Paredes, Pedro Pablo (ed.): Antología de la poesía venezolana contemporánea, Caracas, Asociación de Escritores de Venezuela, 1981, pp. 75-80.

"En la profundidad del verano" (poemas), en La República, Caracas, 11 de noviembre de 1962 , p. 7.

“Después de tanto orgullo", en La República, Caracas, 12 de mayo de 1963, p. 7. [Poema inédito de Guillermo Sucre]

"Después de tanto orgullo", en Sur, Buenos Aires, núm. 293, marzo y abril de 1965, pp. 81-84. [introducido y seleccionado junto a otros poemas venezolanos por Juan Liscano] 
"Sino gestos", en Revista Nacional de Cultura, Caracas, núms. 158-159, may.-ago. 1963, pp. 12-15.

"Poemas" en Zona Franca, Caracas, Año 2. núm. 26, octubre de 1965, pp. 10-13. [Poemas de La mirada]

"Poemas", en Zona Franca, Caracas, núm. 36, ago. 1966, pp. 16-17. [Se publican los poemas "Arboledas", "Telémaco" y "Conocimiento", los dos primeros aparecen en La mirada]

“Sino gestos”, en Poesía de Venezuela, Caracas, núm. 44, jul.-ago. 1970, p. 1.

"Elegía por el combatiente que no muere", en VVAA: Poesía de la resistencia, Caracas, Ediciones Centauro, 1971, pp. 111-119. [Escrito en 1952]

"Frases y poemas" en Plural, México, núm. 2, nov. 1971, p. 7. [Incluye poemas de Serpiente breve y otros]

“Poemas” en Plural, México, núm. 17, feb. 1973, p. 9.

“La felicidad”, en Plural, México, núm. 35, ago. 1974.

“Poemas" en Plural, México, núm. 52, (V-4), enero de 1976, pp. 47-48.

"La vastedad" en El Papel literario de El Nacional, Caracas, 3 de diciembre de 1978, p. 3.

"La vastedad", Vuelta, México, febrero 1980, p. 14. [Dos poemas ("Escribo con palabras..." y "La memoria no perfecciona..."), que luego aparecen en la versión publicada del libro homónimo en 1988, con algunas variaciones significativas]

"Transparencias", en Vuelta, México, diciembre 1982, pp. 31-32. [Incluye textos que luego aparecen en el apartado homónimo de La vastedad; aunque con algunos cambios.]

"El último dominio", en Vuelta, México, núm. 141, agosto 1988, pp. 10-12. [Poema igual al que aparece después publicado en La segunda versión]

"La segunda versión”, en Vuelta, México, núm. 150, mayo 1989, pp. 24-25. [Poemas titulados "La segunda versión", "El encuentro", "Av. Buenos Aires, Los Caobos", y "El otro destino", sin modificaciones aparecen en La segunda versión, aunque en otro orden: "Av. Buenos Aires..." abre el libro.]

“Tres poemas”, en Vuelta, México, núm. 165, ago. 1990, pp. 16-17. [Poemas "La corza blanca", "La penumbra" y "Sábado de gloria", aparecen sin cambios en La segunda versión, aunque en otro orden: "Sábado de gloria" primero, "La corza blanca" segundo y "La penumbra" tercero.]

“Dos poemas”, en Vuelta, México, núm. 180, nov. 1991, p. 32. [Se trata de los poemas "La muerte que no supe" y "Tierra secreta"] 
“La segunda versión”, en Vuelta, México, núm. 186, mayo 1992, pp. 8-9. [Incluye los poemas titulados "El extravío", "Retrato en 1987", "Amamos", "Monte Amante (I)". Aparecen igual que en el libro La segunda versión.]

“La cifra”, en Vuelta, México, núm. 261, ago.-sep. 1998, pp. 100-103.

“Oval”, en Vuelta, México, núm. 261, ago.-sep. 1998, pp. 89-90. [Incluye el poema "Oval" de La vastedad, que en la edición original aparece dividido en dos partes y aquí las dos partes se unen. El original está fechado en 1977 y abarca las pp. 43-46]

"La Felicidad I", en Doce, Jordi y Sánchez Robayna, Andrés: Poesía hispánica contemporánea: ensayos y poemas, Barcelona, Círculo de Lectores, 2005, pp. 164-165.

"La vastedad VIII", en Doce, Jordi y Sánchez Robayna, Andrés: Poesía hispánica contemporánea: ensayos y poemas, Barcelona, Círculo de Lectores, 2005, pp. 165-166.

"Cualquier tierra V", en Doce, Jordi y Sánchez Robayna, Andrés: Poesía hispánica contemporánea: ensayos y poemas, Barcelona, Círculo de Lectores, 2005, pp. 166-167.

"La corza blanca", en Doce, Jordi y Sánchez Robayna, Andrés: Poesía hispánica contemporánea: ensayos y poemas, Barcelona, Círculo de Lectores, 2005, pp. 168.

"Un jardín, un monte”, en Doce, Jordi y Sánchez Robayna, Andrés: Poesía hispánica contemporánea: ensayos y poemas, Barcelona, Círculo de Lectores, 2005, p. 169.

\section{2.- MONOGRAFÍAS}

Borges, el poeta, México, UNAM, 1ª ed., 1967.

Borges, el poeta, Caracas, Monte Ávila, (reedición), 1968.

Borges, el poeta, Caracas, Monte Ávila, 2a ed. corregida y aumentada, 1974.

La máscara, la transparencia. Ensayos sobre poesia hispanoamericana, Caracas, Monte Ávila, $1^{\mathrm{a}}$ ed., 1975.

La máscara, la transparencia. Ensayos sobre poesía hispanoamericana. México, Fondo de Cultura Económica, 2a ed. corregida y aumentada, 1985. 


\section{3.- ARTÍCULOS EN PERIÓDICOS Y REVISTAS}

\section{a) Sardio (Caracas)}

“Testimonio”, en Sardio, Caracas, núm. 1, mayo-junio 1958, p. 2.

“Alejo Carpentier: Guerra del tiempo", en Sardio, Caracas, núm. 2, julio-agosto de 1958, pp. 164-166.

“Sobre Pablo Neruda”, en Sardio, Caracas, núms. 3-4, sept.-dic. 1958, pp. 254-256.

"Vicente Gerbasi: por arte de sol" en Sardio, Caracas, núms. 3-4, sept.-dic. 1958, pp. 257-258.

[Guillermo Sucre] s/f: "La liberación de Cuba”, en Sardio, Caracas, núm. 3-4, sep.-dic. 1958, p. 274.

[Guillermo Sucre] s/f: “¿Una posible conjura contra la constitucionalidad?, en Sardio, Caracas, núm. 3-4, sept.-dic. 1958, p. 276.

“Testimonio. Las constantes de nuestra generación”, en Sardio, Caracas, núm. 5-6, enero-abril de 1959, pp. 277-282.

“Juan Sánchez Peláez: Animal de costumbre”, en Sardio, Caracas, núm. 5-6, ene.-abr. de 1959, pp. 411-412.

“Testimonio. El intelectual de izquierda y cierta estética revolucionaria", en Sardio, Caracas, núm. 7, abr.-may. 1959, pp. 429-434.

\section{b) "El Papel Literario" de El Nacional (Caracas)}

"Guerra del tiempo de Alejo Carpentier", en "El Papel Literario" de El Nacional, Caracas, 31 de julio de 1958, s/p. [sección "Vigía de libros"]

"Huellas del silencio", en "El Papel Literario" de El Nacional, Caracas, 7 de agosto de 1958, p. 6.

Dorante, Carlos: "La novelística en manos de una juventud desinteresada", en "El Papel Literario" de El Nacional, Caracas, 7 de agosto de 1958, pp. 4-5. [En esta encuesta participa Guillermo Sucre]

“El reino de Ramón Palomares", en "El Papel Literario" de El Nacional, Caracas, 21 de agosto de 1958, p. 8.

"Moneda del forastero", en "El Papel Literario" de El Nacional, Caracas, 18 de septiembre de 1958, p. 2.

“Casandra de Ramón Díaz Sánchez”, en "El Papel Literario” de El Nacional, Caracas, 25 de septiembre de 1958, p. 8. 
"Sobre novela venezolana", en "El Papel Literario" de El Nacional, Caracas, 9 de octubre de 1958, [s/p]

"La "violenta estación” de Octavio Paz", en "El Papel Literario" de El Nacional, Caracas, 16 de octubre de 1958, [s/p]

"Diálogo de los seres profundos", en "El Papel Literario" de El Nacional, Caracas, 23 de octubre de 1958, p. 2. [Sección "Libros"]

"Los inmortales", en "El Papel Literario" de El Nacional, Caracas, 30 de octubre de 1958, p. 3.

"Pido la paz y la palabra", en "El Papel Literario" de El Nacional, Caracas, 6 de noviembre de 1958, p. 3.

"Obras selectas de Vicente Huidobro" en "El Papel Literario" de El Nacional, Caracas, 13 de noviembre de 1958, p. 6.

"Brújula en vigilia", en "El Papel Literario" de El Nacional, Caracas, 20 de noviembre de 1958 , p. 2.

"Los herbarios rojos", en "El Papel Literario" de El Nacional, Caracas, 22 de enero de 1959, p. 3.

"La resaca de Juan Goytisolo", en "El Papel Literario" de El Nacional, Caracas, 21 de mayo de 1959, pp. 6 y 8.

"Sobre Tabla redonda", en "El Papel Literario" de El Nacional, Caracas, 4 de junio de 1959, p. 3.

"La poesía de Aimé Cesaire", en "El Papel Literario" de El Nacional, Caracas, 26 de marzo de 1960, p. 6. [No consultado]

"El proceso creador en César Vallejo", en "El Papel Literario" de El Nacional, Caracas, 28 de abril de 1960, pp. 1-6. [No consultado]

"Ionesco: un teatro contra la alienación", en "El Papel Literario" de El Nacional, Caracas, 17 de marzo de 1960, p. 6. [No consultado]

"Un fariseo honorable", dentro del cuestionario múltiple "Diez inquietudes sobre El inquieto Anacobero", en "El Papel Literario" de El Nacional, 29 de febrero de 1976, p. encartada.

"Rosenblat: la generosidad del lenguaje", en "El Papel Literario" de El Nacional, Caracas, 5 y 9 de diciembre de 1982.

"Picón Salas: el punto de vista de un latinoamericano", en "El Papel Literario" de El Nacional, Caracas, 20 de febrero de 1983, p. 7. [Es un resumen del "Prólogo" a Picón-Salas: Viejos y nuevos mundos, Caracas, Biblioteca Ayacucho] 
"Poética de la muerte y de la historia", en "El Papel Literario" de El Nacional, Caracas, 9 de mayo de 1999, p. 1. [Es un fragmento del prólogo a la Obra completa de Ramos Sucre editada por el FCE]

"Ahora reposa en Greenwood", en "El Papel Literario" de El Nacional, Caracas, 10 de diciembre de 2005, p. 1. [Sobre la muerte de Julieta Fombona]

\section{c) Revista Nacional de Cultura (Venezuela)}

"Les lettres nouvelles: Nouveaux Ecrivains de l'Amerique Latine", en Revista Nacional de Cultura, Caracas, núm. 148-149, sept-dic. 1961, pp. 254-256.

"La obra de Bruno Schulz" en Revista Nacional de Cultura, Caracas, núm. 150, enerofebrero 1962, pp. 150-157.

"Ricardo Paysero: Árbol de ruinas", en Revista Nacional de Cultura, Caracas, núm. 150, enero-febrero 1962, pp. 208-210.

"Rafael Alberti: Poemas escénicos", en Revista Nacional de Cultura, Caracas, núms. 158-159, may.-ago. 1962, pp. 173-174.

"Olga Orozco: Los juegos peligrosos" en Revista Nacional de Cultura, Caracas, núms. 158-159, may.-ago. 1962, pp. 174-176.

"Sobre poesía venezolana", en Revista Nacional de Cultura, Caracas, núm. 161, nov.dic. 1963, pp. 225-246.

"Hesnor Rivera: En la red de los éxodos", en Revista Nacional de Cultura, Caracas, núm. 164, may.-jun. 1964, pp. 123-124.

"Argenis Daza Guevara: Actos de magia" en Revista Nacional de Cultura, Caracas, núm. 164, may.-jun. 1964, pp. 124-125.

"Efraín Hurtado: Papeles de condenado", en Revista Nacional de Cultura, Caracas, núm. 165, jul.-sep. 1964, pp. 177-178.

"Dardo Cuneo: Aventura y letra de América Latina", en Revista Nacional de Cultura, Caracas, núm. 165, jul.-sep. 1964, pp. 178-179.

"Lucien Goldmann: Pour une sociologie du roman" en Revista Nacional de Cultura, Caracas, núm. 166, oct.-dic. 1964, pp. 138-140.

Presentación y selección de poemas de Héctor Vera, en Revista Nacional de Cultura, Caracas, núm. 180, abr.-jun. 1967, pp. 49-55.

“Alejo Carpentier: El siglo de las luces" en Revista Nacional de Cultura, Caracas, núm. 180, abr.-jun. 1967, pp. 84-87. [Se publica posteriormente en Imagen, Caracas, núm. 4, 1/15 de julio de 1967, Supl. pp. 10-11] 
"La metáfora del silencio" en Revista Nacional de Cultura, Caracas, núm. 216, sep.-oct. 1974, pp. 47-57. [Fragmento de La máscara, la transparencia]

\section{d) "Letras y Artes", página literaria de La República (Caracas)}

“Uslar Pietri. Un retrato en la geografía”, en La República, Caracas, 22 de julio de 1962, p. 7.

"Oswaldo Trejo: También los hombres son ciudades", en La República, Caracas, 5 de agosto de 1962, p. 7.

"Tres cuentos del concurso de El Nacional", en La República, Caracas, 19 de agosto de 1962, p. 7.

“Antonio Stempel Paris: Los habituados", en La República, Caracas, 26 de agosto de 1962 , p. 7.

“Octavio Paz”, en La República, Caracas, 12 de agosto de 1962, p. 7.

“La poesía de Sedar Senghor”, en La República, Caracas, 2 de septiembre de 1962, p. 7.

“La actual poesía soviética”, en La República, Caracas, 9 de septiembre de 1962, p. 7.

"Cuando la literatura pierde autenticidad", en La República, Caracas, 16 de septiembre de 1962 , p. 7.

“La poesía de Antonio Arráiz”, en La República, Caracas, 23 de septiembre de 1962, p. 7.

“Jorge Gaitán Durán: Si mañana despierto", en La República, Caracas, 30 de septiembre de 1962, p. 7.

“Guillermo Meneses: La misa de Arlequín”, en La República, Caracas, 14 de octubre de 1962 , p. 7.

"W. Gombrowich: La pornografia", en La República, Caracas, 28 de octubre de 1962, p. 7.

“Lawrence Durrell: poemas”, en La República, Caracas, 4 de noviembre de 1962, p. 7.

“Paul Eluard”, en La República, Caracas, 18 de noviembre de 1962, p. 7.

“Reverdy y Huidobro", en La República, Caracas, 2 de diciembre de 1962, p. 7.

“La crítica literaria”, en La República, Caracas, 9 de diciembre de 1962, p. 7.

“Enriqueta Arvelo Larriva”, en La República, Caracas, 16 de diciembre de 1962, p. 7.

“Anna Langfus: Les bagages de sable”, en La República, Caracas, 6 de enero de 1963, p. 7. 
“Dos poetas de la "Beat Generation", en La República, Caracas, 13 de enero de 1963, p. 7.

"Juan Calzadilla: Dictado por la jauría; Pascual Venegas Filardo: Los cantos fluviales", en La República, Caracas, 20 de enero de 1963, p. 7.

"El Instituto de Cultura", en La República, Caracas, 3 de febrero de 1963, p. 7.

“La poesía de Gonzalo Rojas”, en La República, Caracas, 20 de febrero de 1963, p. 7.

"La venganza contra la poesía" en La República, Caracas, 17 de marzo de 1963, p. 7. [Sobre Vicente Gerbasi]

"La poesía de Jorge Luis Borges", en La República, Caracas, 24 de marzo de 1963, p. 7. [Es su primer texto sobre Borges]

“Octavio Paz: Salamandra”, en La República, Caracas, 7 de abril de 1963, p. 7.

"Situación actual de la poesía de Vallejo", en La República, Caracas, 14 de abril de 1963, p. 7.

"Vicente Aleixandre", en La República, Caracas, 21 de julio de 1963, p. 7.

"Perspectivas sobre la novela", en La República, Caracas, 28 de julio de 1963, p. 7.

"Reencuentro con Juan Sánchez Peláez", en La República, Caracas, 4 de agosto de 1963 , p. 7.

“La poesía de Alarico Gómez”, en La República, Caracas, 8 de septiembre de 1963, p. 7.

"Los premios nacionales de música", en La República, Caracas, 15 de septiembre de 1963 , p. 7.

"La cuentística de Arturo Uslar Pietri”, en La República, Caracas, 15 de septiembre de 1963, p. 7.

“Jesús Soto” en La República, Caracas, 6 de octubre de 1963, p. 7.

"De nuevo sobre "Los animales feroces"”, en La República, Caracas, 6 de octubre de 1963 , p. 7.

“Claudio Giacone” en La República, Caracas, 27 de octubre de 1963, p. 7.

"Manuel Pedro González: Ensayos críticos", en La República, Caracas, 3 de noviembre de 1963 , p. 7.

“Alain Fournier: Una pasión de absoluto", en La República, Caracas, 24 de noviembre de 1963, p. 7.

“En síntesis”, en La República, Caracas, 8 de diciembre de 1963, p. 7.

“En síntesis”, en La República, Caracas, 15 de diciembre de 1963, p. 7. 
"La muerte de Honorio: un buen testimonio, no una novela", en La República, Caracas, 12 de enero de 1964, p. 7.

“Libros a la vista”, en La República, Caracas, 26 de enero de 1964, p. 7.

"Homenaje a Fombona Pachano. Un hombre, una poesía, un destino", en La República, Caracas, 9 de febrero de 1964, p. 7.

"Una novela del exilio", La República, Caracas, 16 de febrero de 1964, p. 7. [Sobre Serrano Poncela: Habitación para hombre solo]

\section{e) Zona Franca (Caracas)}

"Una poesía humanizada por los dioses", en Zona Franca, Caracas, año I, núm. 1, 1/15 sep. 1964, pp. 10-11.

"Entre el sufrimiento y el humor cruel", en Zona Franca, Caracas, año I, núm. 1, 1/15 sep. 1964, p. 13.

"En la desolación de la violencia”, Zona Franca, Caracas, año I, núm. 2, 15/30 sep. 1964, p. 10.

"El Pocaterra de las nuevas generaciones", en Zona Franca, Caracas, año I, núm. 2, 15/30 sep. 1964, p. 10.

"Las buenas y las malas razones de Sartre", en Zona Franca, Caracas, año I, núm. 4, 15/30 oct. 1964, p. 4.

"El escritor más allá de la letra", en Zona Franca, Caracas, año I, núm. 4, 15/30 oct. 1964, p. 16. [Sobre Enrique Bernardo Núñez]

"Entrevista con Lucien Goldmann", en Zona Franca, Caracas, año I, núm. 5, 1/15 nov. 1964, pp. 6-7. [En colaboración con Julieta Fombona de Sucre]

“Los libros en 1964”, en Zona Franca, Caracas, año I, núms. 7-8, dic. 1964, pp. 4-5.

“Al encuentro con su destino", Zona Franca, Caracas, año I, núms. 9-10, enero 1965, pp. 4-5. [Sobre Picón-Salas]

“Una poesía sin mitos”, en Zona Franca, Caracas, año I, núm. 12, 15/28 febrero 1965, pp. 12-13. [Sobre Gonzalo Rojas]

"Las influencias literarias", en Zona Franca, Caracas, año I, núms. 13-14, marzo de 1965, pp. 25-26.

“Álgebra y fuego”, Zona Franca, Caracas, año I, núms. 15-16, abril 1965, p. 3.

"En el delirio, en la serenidad", en Zona Franca, Caracas, año I, núms. 19-20, junio 1965 , p. 22. 
“Alejandra Pizarnik: La ceremonia poética pura”, en Zona Franca, Caracas, año I, núms. 23-24, ago. 1965, p. 29. [Este artículo vuelve a aparecer con el mismo título en un número especial de Zona Franca en homenaje a Pizarnik, $2^{\mathrm{a}}$ época, año II, dic. 1972, p. 31.]

"El viajero vestido de ardor silencioso" en Zona Franca, Caracas, año II. No. 26, octubre de 1965, pp. 8-9. [Sobre la muerte de Rosamel del Valle]

"La palabra del universo", en Zona Franca, Caracas, año II, núm. 27, nov. 1965, pp. 29. [Capítulo del libro Borges, el poeta]

“En el espejo de la percepción poética”, en Zona Franca, Caracas, núm. 27, nov. 1965, pp. 52-55.

"En el resplandor de la infancia", en Zona Franca, Caracas, año II, núm. 28, diciembre de 1965, pp. 38-39. [Sobre el libro de Elizabeth Schön: El abuelo, la cesta y el mar]

"En la magia del lenguaje", en Zona Franca, Caracas, año II, núm. 30, febrero de 1966, pp. 16-18. [Sobre Rosenblat: Primera visión de América]

"El dialogo con el mundo" en Zona Franca, Caracas, año II. núm. 33, mayo de 1966, pp. 12-17. [Sobre Octavio Paz]

"Nuestra joven poesía" en Zona Franca, Caracas, año II, núm. 33, mayo de 1966, pp. 36-37.

“El poder de la literatura", en Zona Franca, Caracas, año II, núm. 34, junio de 1966, pp. 2-3.

“Reconciliar el universo", en Zona Franca, Caracas, año III, núm. 39, nov. 1966, pp. 23. [Sobre la poesía de André Breton]

“Girri: la negación creadora", en Zona Franca, Caracas, $3^{a}$ época, núm. 7, mayo-junio 1978, pp. 26-27. [fragmento de La máscara, la transparencia]

\section{f) Imagen (Caracas)}

[Los editoriales no firmados se los atribuyo a Guillermo Sucre por ser el director de la revista. Se incluyen además los artículos de nuestro autor firmados bajo el pseudónimo de Sucre: Rodrigo Antúnez]

“Presentación. Nuestro propósito”, en Imagen, Caracas, núm 1, 15/30 de mayo de 1967, p. 2. [Sin firma]

[Editorial sin título, sobre el pintor Alirio Palacios], en Imagen, Caracas, núm. 2, 1/15 de junio de 1967, p. 2. [Sin firma]

“E1 Borges nuestro”, en Imagen, Caracas, núm. 2, 1/15 de junio de 1967, Supl. pp. 9-16. 
[Editorial sin título], en Imagen, Caracas, núm. 3, 15/30 de junio de 1967, p. 2. [Sin firma]

"Alejo Carpentier: El siglo de las luces", en Imagen, Caracas, núm. 4, 1/15 de julio de 1967, Supl. pp. 10-11.

[Editorial sin título], en Imagen, Caracas, núm. 5, 15/30 de julio de 1967, p. 2. [Sin firma]

[Editorial sin título] en Imagen, Caracas, núm. 6, 1/15 de agosto de 1967, p. 2. [Sin firma]

"Presencia de la crítica" (Editorial), en Imagen, Caracas, núm. 7, 15/31 de agosto de 1967, p. 2.

"La prueba de fuego" (Editorial), en Imagen, Caracas, núm. 8, 1/15 de septiembre de 1967, p. 2. [Sin firma. En este número aparece por primera vez Guillermo Sucre como responsable de la dirección de la revista]

"La opción de la literatura" (Editorial), en Imagen, Caracas, núm. 9, 15/30 de septiembre de 1967, p. 2. [Sin firma]

“¿Ha muerto el arte?” (Editorial), en Imagen, Caracas, núm. 10, 1/15 de octubre de 1967, p. 2. [Sin firma]

"Rosa de espadas" (Sobre un libro de Alfredo Coronil Hartmann), en Imagen, Caracas, núm. 10, 1/15 oct. 1967, p. 23.

"Un aprendizaje argentino del mundo", en Imagen, Caracas, núm. 10, p. 24. [Sobre el libro de Fernández Moreno: Argentino hasta la muerte]

"Comunicación de masas" (Editorial) en Imagen, Caracas, núm. 11, 15/30 de octubre de 1967, p. 2. [Sin firma]

“La alienación, Marx y Heidegger", en Imagen, Caracas, núm. 11, 15/30 de octubre de 1967, p. 23. [Firmado G.S.]

"Neruda y el tiempo recobrado", en Imagen, Caracas, núm. 12, 1/15 de noviembre de 1967, pp. 4-5. [Sobre el libro de Monegal: El viajero inmóvil]

"El intelectual y nuestro tiempo" (Editorial) en Imagen, Caracas, núm. 13, 15/30 de noviembre de 1967, p. 2. [Sin firma]

"La desmistificación por el humor", en Imagen, Caracas, núm. 13, 15/30 de noviembre de 1967, suplemento, s/p. [Sobre los "Artefactos" de Nicanor Parra]

"Una política cultural" (Editorial), en Imagen, Caracas, núms. 14-15, 15/30 de diciembre de 1967, p. 2. [Sin firma]

"La lucidez crítica" (Editorial) en Imagen, Caracas, núm. 16, 1/15 de enero de 1968, p. 2. [Sin firma] 
"Honrar al mundo con la escritura", en Imagen, Caracas, núm. 17, 15/30 de enero de 1968, p. 9. [Introducción a los poemas "Pájaros" de Saint-John Perse, traducidos por el propio Sucre]

"Contra la parcelación de la cultura" (Editorial), en Imagen, Caracas, núm. 18, 1/15 de febrero de 1968, p. 2. [Sin firma]

"El destino del libro en América Latina" (Editorial), en Imagen, Caracas, núm. 19, $15 / 29$ de febrero de 1968 , p. 2. [Sin firma]

“Baudelaire: soñar y saber soñar”, en Imagen, Caracas, núm. 19, Supl., pp. 9-10.

"En el umbral de una nueva literatura" (Editorial), en Imagen, Caracas, núm. 20, 1/15 de marzo de 1968, p. 2. [Sin firma]

Rodrigo Antúnez: "Una revista en la tradición moderna. Revista Nacional de Cultura", en Imagen, Caracas, núm. 20, 1/15 mar. 68, p. 22.

"Una figura y su memoria persisten”, en Imagen, Caracas, núm. 20, 1/15 de marzo de 1968, p. 22.

"Sarduy: los plenos poderes de la retórica", en Imagen, Caracas, núm. 20, 1/15 de marzo de 1968, p. 24.

"El arte y la realidad" (Editorial), en Imagen, Caracas, núm. 21, 15/30 de marzo de 1968, p. 2. [Sin firma]

Rodrigo Antúnez: "Mariño Palacio: la inmadurez creadora" en Imagen, Caracas, núm. $21,15 / 30$ mar. 68 , p. 4.

"La trayectoria poética de Vallejo", en Imagen, Caracas, núm. 21, 15/30 de marzo de 1968, p. 5. [Sobre el libro de Américo Ferrari y Georgette Vallejo: César Vallejo]

Rodrigo Antúnez: “¿Hacia dónde van las artes plásticas?” en Imagen, Caracas, núm. 21, 15/30 mar. 68, p. 22.

Rodrigo Antúnez: "La poesía de los muros”, en Imagen, Caracas, núm. 22, 1/15 abr. 68, p. 22.

"César Vallejo" (Editorial), en Imagen, Caracas, núm. 23, 15/30 de abril de 1968, p. 2. [Sin firma]

"Vallejo: la nostalgia de la inocencia", en Imagen, Caracas, núm. 23, 15/30 de abril de 1968, Supl., s/p.

"Primer aniversario" (Editorial), en Imagen, Caracas, núm. 24, 1/15 de mayo de 1968, pp. 2-3. [Sin firma]

Rodrigo Antúnez: "Literatura y sociedad: una relación problemática", en Imagen, Caracas, núm. 24, 1/15 may. 68, p. 6. 
"Nota introductoria: en la línea más cercana", en Imagen, Caracas, núm. 24, 1/15 de mayo de 1968, Supl. p. 9.

"El poema: un archipiélago de signos", en Imagen, Caracas, núm. 24, 1/15 de mayo de 1968, p. 24. [Sobre Blanco de Octavio Paz] [El mismo artículo se edita bajo el nombre "Blanco: un archipiélago de signos", en Siempre, México, núm. 790, 4 de agosto de 1968, p. VII]

“El arte y la moda" (Editorial), en Imagen, Caracas, núm. 25, 15/30 de mayo de 1968, p. 2. [Sin firma]

"La discreta pasión de un bibliógrafo", en Imagen, Caracas, núm. 25, 15/30 de mayo de 1968, s/p. [Sobre Pedro Grases]

"Un comité contra la censura" (Editorial), en Imagen, Caracas, núm. 26, 1/15 de junio de 1968, p. 2. [Sin firma]

"La nueva literatura" (Editorial) en Imagen, Caracas, núm. 27, 15/30 de junio de 1968, p. 2. [Sin firma]

"Lo precario de nuestra crítica" (Editorial), en Imagen, Caracas, núm. 28, 1/15 de julio de 1968 , p. 2. [Sin firma]

Rodrigo Antúnez: "Literatura crítica", en Imagen, Caracas, núm. 27, 15/30 jun. 68, p. 3.

"La poesía como reconocimiento", en Imagen, Caracas, núm. 28, 1/15 de julio de 1968, p. 24. [Sobre Anagnórisis de Tomás Segovia]

"Con la misma adhesión" (Editorial), en Imagen, Caracas, núm. 29, 15/30 de julio de 1968, p. 2. [En este editorial se despide de la dirección de la revista]

"Huidobro: la poesía del espacio", en Imagen, Caracas, núm. 43, 1/15 febrero de 1969, pp. 6-7.

"Poesía y crítica en movimiento", en Imagen, Caracas, núm. 45, 15/31 de marzo de 1969, pp. 4-5. [Sobre las obras de Octavio Paz tituladas Discos visuales y Marcel Duchamp]

\section{g) Revista Sur (Buenos Aires)}

"Un poeta elemental y reflexivo", en Sur, Buenos Aires, núm. 283, julio y agosto de 1963, p. 35. [Sobre Juan Liscano. Incluye selección de poemas de Liscano]

"Pierre de Place: la poesía de la conciencia", en Sur, Buenos Aires, núm. 301, julio y agosto de 1966, pp. 32-33. [Incluye una selección de poemas traducidos por Sucre en pp. 34-45]

"Vallejo, la nostalgia de la inocencia", en Sur, Buenos Aires, núm. 312, mayo-junio de 1968, pp. 1-16. 


\section{h) Revista Iberoamericana (Pittsburgh)}

"Tendencias de la crítica borgiana", en Revista Iberoamericana, Pittsburgh, vol. XXXV, núm. 68, may.-ago. 1969, pp. 365-369.

"Andrés Bello en su aventura creadora", en Revista Iberoamericana, Pittsburgh, vol. XXXVI, núm. 70, ene.-mar. 1970, pp. 95-100. [Sobre el libro de E. R. Monegal: El otro Andrés Bello]

"Borges: el elogio de la sombra", en Revista Iberoamericana, Pittsburgh, vol. XXXVI, núm. 70, ene.-mar. 1970, pp. 371-388.

"La fijeza y el vértigo" en Revista Iberoamericana, Pittsburgh, vol. XXXVII, núm. 74, ene-mar. 1971, pp. 47-72. [Este artículo se publicó también en Sucre, Guillermo et al. (comp.): Acerca de Octavio Paz, Montevideo, 1974, p. 7 y ss.]

"Poesía Crítica: Lenguaje y silencio", en Revista Iberoamericana, Pittsburgh, vol. XXXVII, núm. 76-77, jul.-dic. 1971, pp. 575-597.

"Borges, una poética de la desposesión", en Revista Iberoamericana, Pittsburgh, vol. XXXVIII, núm. 79, abr.-jul. 1972, pp. 187-198.

"Lezama Lima: el logos de la imaginación", en Revista Iberoamericana, Pittsburgh, vol. XLI, núm. 92-93, jul.-dic. 1975, pp. 493-508. [Es el capítulo de La máscara, la transparencia]

"Ramos Sucre: anacronismo y/o renovación" en Revista Iberoamericana, Pittsburgh, vol. XLV, núm. 106-107, ene.-jun. 1979, pp. 77-84. [Se publica también en Tiempo Real. Revista de la Universidad Simón Bolivar, Caracas, núm. 8, nov. 1978]

\section{i) Revistas Plural, Vuelta y Letras Libres (México)}

“Roberto Juarroz: Sino/ Si no”, en Plural, México, núm. 27, dic. 1973, pp. 48-51.

"La poética de Georges Braque" en Plural, México, núm. 38, nov. 1974, suplemento, pp. 47-58.

“La celebración de la celebración” en Plural, México, núm. 42, marzo 1975, p. 68-72. [Sobre John Cage]

"Álvaro Mutis: El poema: una fértil miseria”, en Plural, México, vol. IV, núm. 7, abril de 1975, pp. 17-22.

"La metáfora incompleta" en Plural, México, núm. 46, julio 1975, pp. 70-73. [Sobre Roberto Juarroz: Quinta poesía vertical] 
"La nueva profundidad: superficies nítidas" en Plural, México, núm. 50, (V-2), nov. 1975, pp. 17-22. [Sobre Homero Aridjis y Eduardo Mitre]

“La poesía del personaje”, en Plural, México, núm. 56, (V-8), mayo 1976, pp. 66-68. [Sobre Jaime Gil de Biedma: Las personas del verbo]

“The unending rose”, en Plural, México, núm. 57, (V-9), junio 1976, pp. 57-59.

“Entretextos”, Vuelta, México, mayo 1977, pp. 9-11.

“Memorial de Rafael Cadenas”, en Vuelta, México, noviembre 1978, pp. 40-41.

“Inscripciones de Francisco Rivera”, en Vuelta, México, núm. 63, febrero 1982, pp. 3941.

"La errancia sin fin: Musil, Borges, Klossowski, de Juan García Ponce", en Vuelta, México, núm. 64, marzo 1982, pp. 36-38.

“La cifra de Jorge Luis Borges”, en Vuelta, México, núm. 65, abril de 1982, pp. 38-40.

"Los cuadernos de la cordura: La virtud antropófaga", en Vuelta, México, núm. 166, sept. 1990, pp. 49-51. [Con este artículo inicia la serie en Vuelta titulada "Los cuadernos de la cordura". Por tanto, deben faltar artículos de esta serie.]

"Los cuadernos de la cordura: De la elegancia y otros anacronismos", en Vuelta, México, núm. 167, oct. 1990, pp. 41-42. [El mismo artículo aparece en El Universal, Caracas, el 12 de agosto de 1990, p. 4-1, y en la revista Criterion, Caracas, jul-sep., 1991]

“Octavio Paz: La otra voz” en Vuelta, México, núm. 175, junio 1991, pp. 24-28.

"Los cuadernos de la cordura. Homenaje a Martín Cerda", en Vuelta, México, núm. 182, enero 1992, pp. 56-57.

“Los cuadernos de la cordura”, en Vuelta, México, núm. 197, abril 1993, pp. 16-18.

"Los cuadernos de la cordura. La indefensión de las palabras", en Vuelta México, núm. 199, junio 1993, pp. 57-58.

"Los cuadernos de la cordura. La polvareda y la falacia", en Vuelta, México, núm. 202, septiembre 1993, pp. 54-55.

“Mi itinerario con Octavio Paz”, en Vuelta, México, núm. 259, junio 1998, pp. 24-25.

“Recuerdos personales”, en Letras libres, México, núm. 130, oct. 2009, pp. 44-48.

“Democratura”, en Letras Libres, México, núm. 165, sep. 2012, pp. 14-17.

“Consalvi, la diplomacia inteligente”, en Letras Libres, México, núm. 175, jul. 2013, pp. 38-40. 


\section{j) Revista Criterion (Caracas)}

"De la elegancia y otros anacronismos", en Revista Criterion, Caracas, s/n, jul.-sep. De 1991, p. 18. [Se trata del mismo artículo que aparece en Vuelta, México]

"Los cuadernos de la cordura", en Revista Criterion, Caracas, núm. 7, agosto de 1993, pp. 4-7. [Incluye lo que en Vuelta, México se publicó en dos artículos distintos: uno sin título y otro titulado "La indefensión de las palabras"]

\section{k) Artículos de Sucre aparecidos en otras revistas o libros recopilatorios}

“Lo que se piensa en el extranjero de la poesía de Octavio Paz", U. de M. [Universidad de Medellín], núm. 3, nov. 1958, pp. 28-29. [Es reproducción del artículo "La "violenta estación" de Octavio Paz", aparecido en "El Papel Literario" de El Nacional, Caracas, 16 de octubre de 1958, s/p]

“Introducción a «Nuevos Poetas Venezolanos»", en Mundo Nuevo, París, núm. 19, enero de 1968, pp. 21-54.

“Relectura de Darío", en Revista de Occidente, Madrid, año VI, $2^{\mathrm{a}}$ época, núm. 61, abr. 68 , pp. 46-68.

"La última poesía de Gonzalo Rojas", en Suplemento de libros de Monte Ávila, Caracas. [Faltan datos]

"La nueva crítica", en César Fernández Moreno (coord.): América Latina en su literatura, París y México, UNESCO y Siglo XXI, 1972, pp. 259-275.

"The Body of the Language and the Language of the Body", en Review, New York, Fall 1972, pp. 11-14.

“Octavio Paz: Poetics of Vivacity", en Ivask, Ivar: The Perpetual Present: The Poetry and Prose of Octavio Paz, Norman, University of Oklahoma Press, 1973, pp. 321.

Guillermo Sucre et al. (comp.): Acerca de Octavio Paz, Montevideo: Fundación de Cultura Universitaria, 1974.

“La alusión o mención”, en Tejera, María Josefina: Homenaje a Ángel Rosenblat en sus 70 años, Estudios filológicos y lingüísticos, Caracas, Instituto Pedagógico, 1974, pp. 479-486. [Es fragmento de La máscara, la transparencia]

“Blanco: Un archipiélago de signos", en Flores, Ángel: Aproximaciones a Octavio Paz, México, Joaquín Mortiz, 1974, pp. 232-236.

“Poesía hispanoamericana y conciencia del lenguaje”, en Eco, Bogotá, núm. 200, 1978, pp. 608-633. 
"¿Imitar una imagen o fundar una experiencia?”, en Guillermo Sucre (coord.): Simposia. Perspectivas sobre la literatura latinoamericana, Editorial Equinoccio, Caracas, 1980, pp. 53-68.

"The New Criticism", en Fernández Moreno, César et al.: Latin America in its Literature, New York: Holmes \& Meier, 1980, pp. 201-218.

"Introduction to Juan Sánchez Peláez", en Review: Latin American Literature and Arts, New York, (29), May-Aug 1981, pp. 42-46.

"Jactancia de quietud", en Flores, Ángel (ed.): Expliquémonos a Borges como poeta, México, Siglo XXI, 1984, pp. 174-182.

"El pensamiento poético: Dentro del cristal", en Hora de Poesía, Barcelona, (83-84), sep.-dic. 1992, pp. 139-142. [Fragmento de La máscara, la trasparencia]

"Una sola gran tradición" en Doce, Jordi y Sánchez Robayna, Andrés: Poesía hispánica contemporánea: ensayos y poemas, Barcelona, Círculo de Lectores, 2005, pp. 161-170.

"Ángel Rosenblat: la palabra y la ilusión", Principia, Revista de Cultura de la Universidad Centrooccidental Lisandro Alvarado, Barquisimeto, enero de 2005, núm. 24, pp. 54-64.

\section{4.- PRÓLOGOS Y EPÍLOGOS}

"Introducción" a Fombona Pachano, Jacinto: Poesías, Caracas, Imprenta Universitaria de Caracas, pp. 7-59, 1964.

"Prólogo" a Enrique Bernardo Núñez: La ciudad de los techos rojos, Caracas, Universidad Central de Venezuela, 1966.

"Prólogo" a Picón Salas, Mariano: Comprensión de Venezuela, Caracas, Monte Ávila Editores, 1976, pp. 5-21.

"Contraportada" a Eduardo Mitre: Mirabilia, La Paz, Hipótesis, 1979.

"Prólogo" a Picón Salas, Mariano: Viejos y nuevos mundos, Caracas, Biblioteca Ayacucho, núm. 101, 1983.

"Recuerdo de Raimundo Lida" en Lida, Raimundo: Rubén Darío: Modernismo, Caracas, Monte Ávila Editores, 1984, pp. 9-17.

"Epílogo" en González, Juan Vicente: Páginas escogidas, Caracas, Monte Ávila Editores, 1985, pp. 245-249.

"Introducción" a Picón Salas: Autobiografias, Biblioteca Mariano Picón Salas, vol. I, Caracas, Monte Ávila, 1987, pp. VII-XIX. [La edición de esta Biblioteca es suya en colaboración con Cristián Álvarez] [El mismo artículo aparece en Imagen, Caracas, núm. 100, 24 de noviembre de 1986, pp. 6-8] 
"Introducción" a Picón-Salas, Mariano: Suma de Venezuela, vol. II de la Biblioteca Mariano Picón-Salas, Caracas, Monte Ávila Editores, 1987, pp. VII-X.

"Introducción" a Picón-Salas, Mariano: "De la Conquista a la Independencia", vol. III de la Biblioteca Mariano Picón-Salas, Caracas, Monte Ávila Editores, 1990, pp. VII-XII.

"Ramos Sucre: la pasión por los orígenes" en Ramos Sucre, José Antonio: Obra poética completa, México, FCE, 1999, pp. 9-38.

\section{5.- TRADUCCIONES}

Perse, Saint-John: “Crónica”, en Revista Nacional de Cultura, Caracas, núm. 144, ene.feb. 1961, pp. 49-59.

Perse, Saint-John: Estrechos son los navios (fragmentos), Caracas, Ediciones Sardio, 1957.

"Tres relatos" de Bruno Schulz, en Revista Nacional de Cultura, Caracas, núm. 150, enero-febrero 1962, pp. 159-173.

"Francis Ponge", introducción y traducción de poemas de Guillermo Sucre, en La República, Caracas, 29 de julio de 1962, p. 7.

Etiemble, René: “La vida intelectual en Budapest I y II", en La República, Caracas, 16 y 23 de diciembre de 1962, p. 7.

Girard, René: Mentira romántica y verdad novelesca, versión de Guillermo Sucre, Caracas, Universidad Central de Venezuela, 1963.

Blanchot, Maurice: "Sobre la crítica literaria", introducido y traducido (aparentemente) por Guillermo Sucre, en La República, Caracas, 5 de enero de 1964, p. 7. [1a traducción no está firmada]

Perse, Saint-John: "Pájaros”, en La República, Caracas, 26 de enero de 1964, p. 7.

"Norte-Sur", Zona Franca, Caracas, año I, núm. 17, 1/15 mayo 1965, p. 11. [Traducción de poemas de Pierre de Place]

"La poesía de Pierre de Place”, en Sur, Buenos Aires, núm. 301, julio y agosto de 1966, pp. 32-33. [Incluye selección de poemas traducidos por Sucre en pp. 34-45]

Perse, Saint-John: "Pájaros", en Imagen, Caracas, núm. 17, 15/30 de enero de 1968, Supl.17, pp. 9-16.

Goldmann, Lucien: El teatro de Jean Genet. Ensayo de estudio sociológico, Caracas, Monte Ávila, 1968.

Stevens, Wallace: Adagia, Caracas, Fundarte y Dirección de Cultura de la G.D.F., Colección "Breves” núm. 6, Caracas, 1977. 
Cuadernos de Georges Braque, prólogo y traducción de Guillermo Sucre, Fundarte y Dirección de Cultura de la G.D.F., Colección "Breves” núm. 8, Caracas, 1977.

Perse, Saint-John: Los pájaros, Caracas, Fundarte y Dirección de Cultura de la G.D.F., Colección "Breves” núm. 10, 1977.

Williams, William Carlos: La primavera y todo, Caracas, Monte Ávila, 1980. [En colaboración con Julieta Sucre]

[En "Letras y artes", la página literaria de La República (Caracas) aparecieron también traducciones suyas de Pierre Reverdy y Anne Langfus]

\section{6.- ANTOLOGÍAS ELABORADAS POR SUCRE}

Las mejores poesías venezolanas, Caracas, Primer Festival del Libro Popular Venezolano. Biblioteca Básica de Cultura Venezolana, Organización continental de los festivales del libro, División venezolana, 1958.

Antología de la poesía hispanoamericana moderna, Vol. I y II, Caracas, Editorial Equinoccio y Monte Ávila, 1993.

\section{7.- ANTOLOGÍAS QUE RECOGEN PARTE DE SU OBRA}

Medina, José Ramón (ed.): La nueva poesía venezolana (antología), Caracas, Cuadernos literarios de la Asociación de Escritores Venezolanos, 1959, pp. 183190. [Aquí aparece un poema que creo inédito titulado "Los sepulcrales"]

Escalona-Escalona, José Antonio (ed.): Antología de la actual poesía venezolana (19501980), 2 tomos, Caracas-Madrid, Edime, 1981. [Los poemas de Sucre aparecen en el tomo II, pp. 149-152]

Paredes, Pedro Pablo (ed.): Antología de la poesía venezolana contemporánea, Caracas, Asociación de Escritores de Venezuela, 1981, pp. 75-80. [Paredes, basándose en la antología anterior de Medina incluye el poema "Los sepulcrales" que creo que sólo aparece en esa Antología anterior]

Palma, Douglas (ed.): Poesía venezolana. Antología, Caracas, Editorial Panapo, 1988, pp. 156-157.

Salas, Alejandro (ed.): Antología comentada de la poesía venezolana, Caracas, Alfadil, 1989, pp. 211-213.

Jiménez Emán, Gabriel (ed.): El ensayo literario en Venezuela, 6 tomos, Caracas, Ediciones La Casa de Bello, 1988. [El texto de Sucre aparece en el vol. II, pp. 331-361. Está tomado de La máscara, la transparencia y se titula "Un sistema crítico"] 
Rodríguez Ortiz, Oscar (ed.): Ensayistas venezolanos del siglo XX. Una antología, 2 tomos, Caracas, Colección Medio Siglo de la Contraloría General de la República, 1989. [Los textos seleccionados de Guillermo Sucre se encuentran en el tomo II, pp. 163-174. Los ensayos que de él aparecen se extraen de la $1^{\mathrm{a}}$ edición de La máscara, la transparencia y se titulan "Dentro del cristal" y "Del autor al texto"]

Leal, Néstor (ed.): Cuerpos desnudos, hechos ardientes, Barcelona, Grijalbo, 1997.

Arráiz Lucca, Rafael (ed.): Antología de la poesía venezolana, 2 vols. Caracas, Editorial Panapo, 1997.

Arráiz Lucca, Rafael (ed.): Veinte poetas venezolanos del siglo XX (antología), Caracas, Fondo Editorial 60 años de la Contraloría General de la República, 1998, pp. 157-168.

Miranda, Julio (ed.): Antología venezolana del poema en prosa, Mérida, Ediciones Mucuglifo, CONAC, 1999.

Lichy, Diana (ed.): Poésie vénèzuélienne du XXe siècle, Genève, Editions Patiño, 2002, pp. 212-217.

Marta Sosa, Joaquín (ed.): Poetas y poéticas de Venezuela (antología 1876-2002), Barcelona, Bartleby Editores, 2003.

Arráiz, Lucca, Rafael (ed.): Antología. La poesía del siglo XX en Venezuela, Madrid, Colección Visor de Poesía-La Estafeta del Viento, 2005, pp. 171-183.

Guerrero, Gustavo (ed.): Conversación con la intemperie, Barcelona, Galaxia Gutenberg, 2008, pp. 406-505.

\section{8.- ENTREVISTAS REALIZADAS A GUILLERMO SUCRE}

Palacios, María Fernanda y Balza, José: “Conversación con Guillermo Sucre”, en Falso Cuaderno (Literatura, arte, crítica, ciencia y otras cosas), Caracas, núm. 2, octubre de 1976, pp. 3-5 y 28-29.

Arráiz Lucca, Rafael: "Seguimos siendo objetos y no sujetos de la historia. Conversación con Guillermo Sucre", en Imagen, Caracas, núm. 100, 24 de nov. 1986, pp. 3-5. [La misma entrevista aparece en Arráiz Lucca, Rafael y Uslar Pietri, Arturo: Venezuela en terapia intensiva, Caracas, Alfa Grupo Editorial, 2003, pp. 145-154]

Krauze, Enrique: El poder y el delirio, Caracas, Editorial Alfa, 2008. [Una paráfrasis de la entrevista a Sucre y Palacios se encuentra en pp. 118-121] 


\section{BIBLIOGRAFÍA SOBRE GUILLERMO SUCRE}

Acosta Bello, Arnaldo: “Acerca de Neruda" en Tabla redonda, Caracas, núm. 1, mayo de 1959, p. 2. [Respuesta al artículo de Sucre "Sobre Pablo Neruda", aparecido en Sardio, Caracas, núm. 3-4]

Sanoja Hernández, Jesús: "Notas para la «burguesía intelectual»”, en Tabla redonda, Caracas, núm. 2, junio de 1959, pp. 1-2.

Caballero, Manuel: "Sobre la rebelión moral y el diálogo", en Tabla redonda, Caracas, núm. 2, junio de 1959, pp. 2 y 10. [Aquí no sé si hace claramente alusión a Sucre, parece que la alusión si existe es velada o implícita]

Acosta Bello, Arnaldo: "Tres o cuatro castañas" en Tabla redonda, Caracas, núm. 2, junio de 1959, p. 2. [Respuesta al artículo de Sucre "Sobre Pablo Neruda", aparecido en Sardio, Caracas, núm. 3-4]

Chacón, Alfredo: "Dos antologías", en Señal, Revista de venezolanos de París, ParísCaracas, núm. 1, jun.-jul. 1959. [Se reedita en Chacón, Alfredo: La pasión literaria, Caracas, El libro menor de la Academia Nacional de la Historia, 1988, pp. 27-30. Trata sobre dos antologías, una de ellas es la antología de Guillermo Sucre: Las mejores poesías venezolanas, de 1958]

Alonso, María Rosa: "Mientras suceden los días", en La República, Caracas, 24 de mayo de 1964, p. 7.

Juan Liscano: "Cinco poetas jóvenes venezolanos", en Sur, Buenos Aires, no 293, mar.abr. 1965, pp. 79-91. [Las páginas dedicadas a Sucre son las pp. 81-84]

Pérez Perdomo, Francisco: "Borges, el poeta. Un libro de Guillermo Sucre", en Imagen, Caracas, núm. 7, 15/31 de agosto de 1967, pp. 20-21.

Insausti, Rafael Ángel: "Las influencias literarias", en Zona Franca, Caracas, año I, núm. 17, 1/15 mayo 1965, p. 12. [Respuesta al artículo de Guillermo Sucre "Las influencias literarias", Zona Franca, Caracas, año I, núms. 13-14, marzo de 1965, pp. 25-26.]

Zarcos, Gabriel: “Guillermo Sucre” en "El Papel Literario" de El Nacional, Caracas, 23 de agosto de 1970, p. 3.

Liscano, Juan: "Exigencia de una poética.” En Zona Franca, Caracas, $2^{\text {a }}$ etapa, núm. 3, sept.-oct. 1970, pp. 123-124. [Sobre el poemario de Guillermo Sucre: La mirada ]

Liscano, Juan: Panorama de la literatura venezolana actual, Caracas, Publicaciones españolas, 1973, pp. 292-295 [Sobre su poesía] y 381-382 [Sobre su labor crítica].

Plaza, Galvarino: “Guillermo Sucre: Borges, el poeta", en Cuadernos hispanoamericanos, Madrid, núm. 300, junio 1975, pp. 746-747. 
Sanoja Hernández, Jesús: "Guillermo Sucre, la poesía como diálogo", en El papel literario de El Nacional, Caracas, 14 de diciembre de 1975, p. 1.

Palacios, María Fernanda: "Miserias y fulgores del ensayo en la Venezuela de hoy", en Sabor y saber de la lengua, Caracas, Monte Ávila, 1985, pp. 109-117.

: "Guillermo Sucre: La palabra, la pasión, el esplendor" en Sabor y saber de la lengua, Caracas, Monte Ávila Editores, 1976, pp. 133-170.

Rodríguez Monegal, Emir: "Un lector de poesía", en Plural, México, núm. 54, (V-6), marzo de 1976, pp. 58-59.

Xirau, Ramón: "En el verano cada palabra respira en el verano, de Guillermo Sucre", en Vuelta, México, enero 1977, pp. 40-41.

Liscano, Juan: "Guillermo Sucre: En el verano cada palabra respira en el verano", en Zona Franca, Caracas, $3^{a}$ etapa, núm. 1, may.-jun. 1977, pp. 58-59.

Balza, José: "Sobre Guillermo Sucre”, en Suplemento Cultural de Últimas noticias, Caracas, 21 de junio de 1981, pp. 1-3. [Este artículo también aparece en Balza, José: Transfigurable, Caracas, Dirección de Cultura de la Universidad Central de Venezuela, 1983, pp. 57-70.]

Rivera, Francisco: "Guillermo Sucre y la poesía latinoamericana", en Inscripciones, Caracas, Monte Ávila, 1981, pp. 11-33. [Este artículo se reproduce con el mismo título en Rivera, Francisco: Entre el silencio y la palabra, Caracas, Monte Ávila Editores, 1986, pp. 13-29]

Romero-León, Jorge: Algunos problemas de la crítica literaria actual en América Latina, Caracas, UCV, 1982. [Trabajo de Grado dirigido por Hugo Achugar] [Habla sobre la crítica literaria de Guillermo Sucre en las pp. 150-152]

Castillo Castellanos, Freddy: "La mira(da) crítica de Guillermo Sucre”, en Imagen, Caracas, núm. 100, 27 de febrero de 1987, pp. 6-7.

Romero-León, Jorge: La critique litteraire vénèzuélienne des années 1960-1970, 2 vols., París, Université Paris III, 1988. [Tesis Doctoral] [El estudio de la crítica se Sucre se encuentra en las pp. 437-460 y 466-477]

Milán, Eduardo: "Solapa de presentación” a Sucre, Guillermo: La vastedad, México, Vuelta, colección La Imaginación, 1988.

Liscano, Juan: "De escritores" en El Nacional, Caracas, sección Cartas a El Nacional, 27 de junio de 1993, p. A-5.

Yagüe Jarque, Eloi: "Muchos de nuestros intelectuales son comadronas de la conspiración militar", y "Disparos contra el Innombrable", en El Nacional, Caracas, 2 de julio de 1993, p. C-18. [Paráfrasis intencionadamente polémica de los artículos de Sucre]

Equipo de Arte de El Nacional: "Toda generalización es arbitraria y hay que evitar el personalismo", en El Nacional, 3 de julio de 1993, p. C-12. [Participan Salvador 
Garmendia, Denzil Romero, Eduardo Casanova, Armando José Sequera, Rafael Arráiz Lucca]

Barrera Linares, Luis: "El regreso del Mariscal Sucre" en El Nacional, Caracas, 8 de julio de 1993, p. A-5.

Colmenares, Hugo: "La lucha es entre cogollos culturales", en El Nacional, Caracas, 8 de julio de 1993, p. C-14. [Participan en esta encuesta colectiva Óscar Rodríguez Ortiz, Eduardo Liendo, Manuel Bermúdez, Earle Herrera, Tarek Williams Saab]

Santaella, Juan Carlos: "Dentro del cristal", en El Nacional, Caracas, 8 de julio de 1993, p. C-14.

Nuño, Juan: "Poetas a la greña", en El Nacional, Caracas, 10 de julio de 1993, p. C-16.

Borzacchini, Chefi: "Juan Liscano por Juan Liscano", en El Nacional, Caracas, 18 de julio de 1993, p. C-2. [Entrevista a Juan Liscano centrada en la polémica suscitada por los artículos de Sucre]

Rodríguez Gómez, Alexis: “Guillermo Sucre: ¿un metaintelectual?”, en El Nacional, Caracas, sección Cartas a El Nacional, 18 de julio de 1993, p. A-5. [se trata de un lector anónimo]

Nuño, Juan: "Mala mezcla y peor puntería", en Revista Criterion, Caracas, núm. 7, agosto de 1993, pp. 8-10.

Balza, José: "Márgenes en la locura", en Revista Criterion, Caracas, núm. 7, agosto de 1993, pp. 11-13.

Liscano, Juan: "Polémica venezolana en México", Vuelta, México, núm. 203, oct. 1993, pp. 53-55.

Nuño, Juan: “¿Qué pasa en Venezuela?, en Vuelta, México, núm. 203, oct. 1993, pp. $55-57$.

Chacón, Alfredo: "Guillermo Sucre en la vastedad", en Cuadernos Hispanoamericanos, Madrid, núm. 528, junio 1994, pp. 111-114. [Este artículo se vuelve a publicar con el mismo título en Chacón, Alfredo: La voz y la palabra (lecturas de poesía venezolana: 1986/1998), Maracaibo, Univ. Cecilio Acosta, 1999, pp. 33-34.]

Medina Portillo, David: “Antología de la poesía hispanoamericana moderna”, en Vuelta, México, núm. 214, sept. 1994, pp. 36-38.

Macht de Vera, Elvira: “Aproximación semiótica al «Prólogo» introductorio del libro de Mariano Picón Salas Comprensión de Venezuela por Guillermo Sucre", en El ensayo contemporáneo en Venezuela, Caracas, Monte Ávila, 1994, pp. 162-166.

Gomes, Miguel: Poéticas del ensayo venezolano en el siglo XX: la forma de lo diverso, Providence, INTI, 1996, pp. 201-205.

León, Eleazar: “Guillermo Sucre: Ceremonia y celebración”, en El papel literario de $E l$ Nacional, Caracas, 15-01-1997, p. 2. [Sobre La segunda versión] 
Carrera, Hernán: "Verticalidad, rara palabra", en El papel literario de El Nacional, Caracas, 13-04-1997, p. 1.

Muñoz, Boris: "Saludo mínimo a Guillermo Sucre", en El papel literario de El Nacional, Caracas, 20-04-1997, p. 1.

Anónimo: "Guillermo Sucre, profesor titular de Cambridge", en El Nacional, Caracas, 13-06-1997, p. C-14.

García, Beatriz Alicia: “Guillermo Sucre: poeta solar”, en El Universal, Caracas, 31 de enero de 1999, p. 4-21.

Anónimo: "Nueva antología de la obra poética de Ramos Sucre", en El Universal, Caracas, 28 de julio de 1999, p. 3-12. [Aparece un fragmento del prólogo de Guillermo Sucre a la Obra poética de Ramos Sucre publicada por el FCE en 1999]

Álvarez, Cristian: "Guillermo Sucre. Poesía y Ensayo: la misma realidad del lenguaje", en Salir a la realidad: un legado quijotesco, Caracas, Monte Ávila Editores Latinoamericana y Equinoccio, Ediciones de la Universidad Simón Bolívar, Colección Estudios, 1999, pp. 147-161.

Balza, José: "Guillermo Sucre: La felicidad y el árbol de la tormenta", en Obras selectas. Vol. II. Ensayos. Fulgor de Venezuela, Fondo Editorial de Humanidades y Educación, Universidad Central de Venezuela, 2001, pp. 333354.

Arráiz Lucca, Rafael: El coro de las voces solitarias. Una historia de la poesía venezolana, Caracas, Grupo Editorial Clepsidra, 2003. [Trata sobre la poesía de Sucre en las pp. 221-227]

Rodríguez Ortiz, Oscar: "Para una lectura de nuestro ensayo contemporáneo", en Pacheco, Carlos et al.: Nación y literatura. Itinerarios de la palabra escrita en la cultura venezolana, Caracas, 2006, pp. 653-668. [El fragmento dedicado a La máscara, la transparencia se encuentra en pp. 657-659] [Este artículo es una versión revisada de un fragmento de su obra Paisaje del ensayo venezolano, Maracaibo, Universidad Católica Cecilio Acosta, 1999, pp. 93-118]

Cuartín, Pedro: "Aire que surgía del mar en algunos textos de Guillermo Sucre", en Memoria del XXV Simposio de Docentes e Investigadores de la literatura venezolana, Venezuela, Universidad Nacional Abierta (UNA), 2000, pp. 355359.

Isava, Luis Miguel: "Guillermo Sucre", en "Los sesenta: seis poetas hacia la conciencia de las palabras", en Pacheco, Carlos et al.: Nación y literatura. Itinerarios de la palabra escrita en la cultura venezolana, Caracas, 2006, pp. 649-650.

Guerrero, Gustavo: "La flor y el abismo: tradición de la poesía venezolana", en Pacheco, Carlos et al.: Nación y literatura. Itinerarios de la palabra escrita en la cultura venezolana, Caracas, 2006, pp. 699-709. [La parte dedicada a la poesía de Sucre se encuentra en las pp. 705-706]. [Este ensayo se publicó también $L a$ religión del vacio y otros ensayos, México, FCE, 2002, pp. 104-121] 
: "Introducción" a Conversación con la intemperie, Barcelona, Galaxia Gutenberg, 2006. [El fragmento dedicado a la poesía de Sucre se encuentra en las pp. 23-25]

Martínez Bachrich, Roberto: "Conciencia de los sentidos", en El Salmón. Revista de Poesía, Caracas, año 1, núm. 2, mayo-ago. 2008, pp. 2-5.

Roche, Michelle: "Maestros del asombro serán hechos prosa lírica", en El Nacional, Caracas, 27-02-2009, p. C-4. [Sobre una lectura de poemas de Guillermo Sucre y de María Antonieta Palacios]

Roosen, Erika: "El honor de admirar", en "El Papel Literario" de El Nacional, Caracas, 13-06-2009. [Sobre la concesión del Doctorado Honoris Causa en la UCV a Guillermo Sucre, Ma Fernanda Palacios, Adriano González León y LópezPedraza]

Castañón, Adolfo: "Guillermo Sucre: silencio, historia y persona en la poesía hispanoamericana", en Venezuela entrevista. Crónicas, ensayos, narraciones, Mérida, El otro el mismo, 2009, pp. 113-122.

Valle, Gustavo: "Guillermo Sucre: la libertad y la cordura", en Cuadernos Hispanoamericanos, Madrid, núm. 713, nov. 2009, pp. 39-44. [Este texto aparece publicado anteriormente (con motivo del Doctorado Honoris Causa concedido a Guillermo Sucre) en "El Papel Literario" de El Nacional, Caracas, 13-06-2009, pp.7-8]

Yepes Boscán, Guillermo: La poesía de Guillermo Sucre: pasión, conciencia crítica, e ironía ante el lenguaje, Caracas, Fundación para la Cultura Urbana, 2010. [Sin publicar]

Balderston, Daniel y González, Mike: The Encyclopedia of Twentieth-Century Latin American and Caribbean Literature 1900-2003, London \& NY, Routledge, 2004, pp. 553-554.

Para completar esta bibliografía faltan (al menos) los artículos publicados por Sucre en las páginas culturales de El Universal (Caracas) cuando este periódico estuvo bajo la dirección de Patricia Guzmán al principio de los años 90, y los editados en "El Papel Literario" de El Nacional (Caracas) de comienzos de los años 80. 


\section{THE LAST CLARITY. THE LITERARY THOUGHT OF GUILLERMO SUCRE}

\section{SUMMARY \& CONCLUSIONS IN ENGLISH}




\section{SUMMARY}

\section{THE INVOLVEMENT OF GUILLERMO SUCRE IN THE VENEZUELAN LITERARY FIELD}

(1958-1968)

Even though Guillermo Sucre took part in the only number of Cantaclaro magazine in 1950, his involvement in the Venezuelan literary field gained relevance from 1958 on. During the years between these two dates, the young Sucre resisted Marcos Pérez Jiménez's dictatorship and suffered prison and exile due to political reasons. When he was released from prison on the $23^{\text {rd }}$ of January 1958 , our author supported the transition towards democracy and began to intervene actively in national culture. When he entered into the Venezuelan literary field, Guillermo, together with other youngsters of his generation, perceived that there was no relation between the social and political change that was underway and the literary production. In fiction still prevailed the realist and telluric model that was involved in the construction of the nation and, in what informs poetry, the most different aesthetic movements coexisted without major problems. This plurality of aesthetic tendencies and the persistence of movements that in other parts of the continent were considered obsolete was a result of the complete absence of literary criticism. Most intellectuals in Venezuela did not have any well defined aesthetic program and this led them to misjudge literary works. In Sucre's opinion, this aesthetic and intellectual situation was unsustainable. That is why he attempted, in the following years, to modernize Venezuelan culture following the patterns that he observed in other parts of the West. In doing so, Guillermo was not only trying to introduce in national literature the same aesthetic principles that he observed in the great works of the Western tradition but he was also establishing the basis of an "art institution" structurally equivalent to the rising Venezuelan democracy. 
The involvement of our author in Venezuelan culture covered all the 1958-1968 decade, and the continuity of the same artistic project can be seen in the magazines in which he played an important role: Sardio, "Letras y Artes", Zona Franca and Imagen. The same conception of literature persists, with slight changes, in all these periodicals, which constitute the core of the aesthetic and cultural ambitions of the "progovernment" intelligentsia, that is to say, of those moderate writers fond of a modernist aesthetic that supported and were supported by the cultural apparatus of the new democratic State. The opposite side of the Venezuelan literary field was occupied by those artists keen to the rebellious artistic movements such as "El Techo de la Ballena" (1961-1968), that appeared from 1961 on as a consequence of the political radicalization of the left.

The first relevant project in which Guillermo Sucre took part was Sardio magazine, of which he was a founding member. This periodical, in which our author wrote between 1958 and the summer of 1959, tried to introduce in Venezuela a modernist aesthetic. This aim implied the rejection of those dishonest intellectuals that judged literary works attending exclusively to their personal interests and not to literary criteria. Faced with this situation, that could be seen in many critics of previous generations, the young intellectuals gathered around the magazine adopted more professional attitudes and established firm principles to judge conveniently the literary works. Apart from introducing a new intellectual consciousness, the magazine tried to acquaint Venezuelan readers with the great authors and movements of European and North American literature.

In July 1962 Sucre founded, together with Martin Cerda and Luis García Morales, the Sunday's literary broadsheet "Letras y Artes", that was published in the pro-government diary La República until 1964. This sheet took into account the 
information of the major liberal magazines edited in France, with which Guillermo had come into contact during a recent three year stay in Paris between 1959 and 1962. The section "Las literaturas. Los libros. Los autores", signed by Martin Cerda, was an open window to the latest news of French publishing houses and of those from other European and Latin American countries, and its aim was to familiarize the Venezuelan reader with the works and authors that defined the modernist canon that the page wanted to encourage. On the section "Crónica literaria", Guillermo Sucre judged national literary works with the criteria of the modernist aesthetic that "Letras y Artes" proposed as a model for the development of Venezuelan literature. Apart from these two parts, the broadsheet reserved the central space to familiarize the reader with the works of those authors that were proposed as models, such as Paul Eluard, Vicente Huidobro, Octavio Paz, Pierre Reverdy, Cesare Pavese, César Vallejo, Fernando Pessoa, Jorge Luis Borges, Saint-John Perse, etc. Furthermore, the editors of the sheet based on the value of authenticity to judge the literary works and, as it was the norm in the European liberal press, they established a dichotomy between the communist countries where intellectuals were repressed and the "free world" that granted freedom of expression.

In September 1964, just some months after the project of "Letras y Artes" was over, Guillermo began to collaborate on the magazine Zona Franca, where he was subeditor under the supervision of Juan Liscano. Even though this publication was not funded by the Government, it has been considered one of the main cultural enterprises of the pro-government intelligentsia. In fact, this magazine was created by liberal intellectuals in order to exert an influence on Venezuelan cultural circles, which at the moment were controlled by leftist writers. In line with the proposals of the Western liberal press, during these years Zona Franca set out on the need of a pacific coexistence among intellectuals and tried to promote a dialogue beyond ideological 
differences. These ideas matched up well with the essentialist and humanist model of culture and with the modernist aesthetic that the magazine encouraged. In both senses, Liscano's magazine was following the strategies of the cultural institutions (such as the ILARI, Latin American Institute for International Relations, succeeding the Congress for Cultural Freedom) that had been founded by the CIA to exert an influence among intellectuals. The relation of Zona Franca with these institutions is obvious because in it there can be seen advertisements of other magazines financed by them, and because it took part in the borrowing of information that was established between these periodicals. The political and cultural line of Liscano's magazine followed in part the project that Sucre had promoted in Sardio and "Letras y Artes". And I say "in part" because, on this occasion, our author could not develop thoroughly his own conception of culture and literature. Instead of focusing exclusively on aspects related to artistic creation (the ones that interested Sucre), Zona Franca gave room to religious and esoteric issues that were keen to Juan Liscano. Moreover, the editor rejected to include in his magazine the boom of Latin American literature that was emerging in these years. Then, Zona Franca grew apart from the cultural internationalism and the aesthetic avant-gardism that were basic aspects of the program that Sucre wanted to implement in Venezuela. Due to these disagreements, Sucre gave up the magazine in November 1966 to lead a new cultural project where he could fully promote his own conception of art and culture.

This new project was Imagen, a magazine that Sucre founded in May 1967 and that was directly funded by the Instituto Nacional de Cultura y Bellas Artes of Venezuela (INCIBA). As in "Letras y Artes", Sucre's aim was to introduce Venezuelan artistic creation into the modernist aesthetic, which was based on the two basic notions of autonomy and internationalism. This artistic conception was enriched in this moment 
by two other ideas: the vindication of criticism as an essential activity and the belief that literature is above all language and that this autonomy grants it a critical character. This implied a rejection of all those works that tried naïvely to represent the empirical world or to put creation at the service of purposes that exceeded the purely aesthetic ones. In this theoretical improvement that can be observed in relation to Sardio and "Letras y Artes", the tie that Imagen established with Mundo Nuevo, the Parisian magazine edited by Rodríguez Monegal, was certainly defining. The link between Imagen and Mundo Nuevo was created once the funding of Mundo Nuevo by the CIA had been revealed. Therefore, in choosing it as a model for his own magazine, Guillermo was taking sides in that ideological war that were the $60^{\prime}$ s. The periodical edited by Sucre followed the canon established by Monegal's magazine and copied certain political issues that had to do with the repudiation of censorship and with the State intervention in culture. Nevertheless, the relationship that Imagen established with Mundo Nuevo and with other liberal magazines edited in France does not exhaust the dimension of Sucre's review. At least during the period that Guillermo was on head of it, the magazine accomplished its initial aim of establishing bridges between Venezuelan culture and the great works of the West. This goal was achieved in part thanks to the supplements of the periodical that studied in depth a particular author or subject, but also thanks to the publication of articles about European and Latin American writers, artists and thinkers. In dealing with works of any latitude, the magazine made clear its internationalist conception of culture and assumed an equal position with the greater works and artists of the West. 


\section{THE LITERARY THOUGHT OF GUILLERMO SUCRE (1958-1968)}

When Guillermo Sucre began to intervene in the Venezuelan literary field after the fall of Dictator Marcos Pérez Jiménez (1958) he noticed that the complete absence of aesthetic values prevented the development of national literature. This absence was the result of a dishonest intelligentsia that judged literary works attending only to their personal interests and not to artistic quality. This lack of sincerity had had at least two consequences in the development of Venezuelan literature. On the first place, it had prevented the definition of a literary tradition, that is to say, of a group of works linked by common factors. On the second place, it had prevented national literature to connect with the Western tradition and this situation had led on to the isolation of Venezuelan literature. Faced with this dismal outlook, Guillermo Sucre imposed himself the task of modernizing and professionalizing national literature. His goal was to put an end to the complacency that he observed in Venezuelan literary circles. With this aim, he tried to promote new intellectual attitudes and to introduce a new aesthetic consciousness based on objective criteria. To finish with the profusions that he perceived in Venezuelan literature, Guillermo used the concept of authenticity. This notion implied the establishment of an unavoidable link between the experiences of the writers and their literary expression that would allow national literature to overcome the pernicious excesses of realism and of formalism. In demanding an agreement between the expression and the expressed, or, in other words, between the author, the world and his writing, Sucre was rejecting expressive profusions and trying to transform literature into an harmonious and well-balance body without any waste or excess. Our author learned this ideal of order and completeness from the French symbolist poets and from the Venezuelan essayist Mariano Picón Salas (1901-1965). The first had emphatically opposed the carelessness of certain romantic poets. As a result of a colossal confidence 
in their own possibilities, these poets had given room in their literary works to profusions of things and words or of objectivity and subjectivity. Contrary to these excesses of content and expression, and with the aim to achieve a whole and perfect expression, the symbolist poets became extremely calculating and sought the synthesis of subject and object, passion and intelligence, form and meaning. Picón Salas, for his part, tried in his essays to organize Venezuelan culture according to the model that he observed in the older European civilizations. For him, ideas should put down roots on the land, and no distance should break up the agreement of the cultural expression and the environment. Only when that unity is achieved, Venezuelan culture would solve the cultural (nationalism-cosmopolitanism) and aesthetic (realism-formalism) excesses between which it had historically swung and express, from its own point of view, the common values of Western culture.

In vindicating the principle of authenticity, Guillermo disdained those works that indulged in profusions of description or of formalism. In his opinion, the realist works presented a descriptive excess and implied a pleasure on the local color that he rejected. Formalist literature, for its part, implied the recourse to formal moulds that were not imposed by an internal need of the author or of the work, and this attitude led the works to the fault of cosmopolitanism. Therefore, it can be perceived that in rejecting the expressive profusions (realism-aestheticism), Sucre disdained at the same time the distance between the writer and his situation (nationalism-cosmopolitanism). Faced with these disproportionate attitudes, Guillermo tried to introduce Venezuelan literature into the harmonious aesthetic of the modern Western tradition. As Picón Salas had already stated, in transcending these cultural and aesthetic faults, Venezuelan literature would be able to raise the particular to the universal and to attain, consequently, an impact beyond national borders. 
In the period 1964-1968, our author still encouraged Venezuelan writers to achieve the same ideal of aesthetic completeness, but now he suggested that his ideal was the result of the correlation between passion and intelligence, that is, of the contraries between which man struggles. In line with the symbolist thought and with Picón Salas, Guillermo rejected natural or instinctive poetry that turned to inspiration and required instead that literary creation should be tempered by rigor and lucidity. When poetry is the consequence of primary impulse the poet loses control over it and the work of art is filled with expressive profusions that prevent its connection with the true intellectual tradition and with the universal values of man. Instead, when literary creation results from the joining of rigor and inspiration, it attracts the opposites and restores the Absolute that was dissolved with the arrival of modernity.

Sucre perceived this ability to reconcile vision and writing in those poets who had built a magnificent world through their works. Among them a special place was reserved for those poets (such as César Vallejo, Jacinto Fombona o Elizabeth Schön) that had embodied in their writing the original and innocent world of childhood. In recovering the absolute of infancy through imagination, these writers created a symbolic space that integrates the opposites between which man struggles, allowing, in this way, his access to a domain of splendor. To reveal the original and pure world of childhood, these poets had to achieve unity between their vision and their writing, unity which implied the cancellation of any ethical and aesthetical excesses. In cancelling all distance between the expression and the expressed, these writers created a mythical space where only the poetic vision unfolded and, thus, they found the original truth of man and of the world through their writing.

In addition, when Sucre assumed the editorship of magazine Imagen in May 1967, he began to defend a modernist aesthetic according to which literature is 
characterized by a progressive deepening into its own materiality. This perspective on literature implies an unrealistic conception of language, that is to say, the awareness that words do not reflect reality but only allude to it. Following the ideas of Borges and Barthes, Sucre believes that any writer must be aware of the distance that separates language from the world, and of the fact that he does not work with reality but with words. For Guillermo words do not explain or describe a pre-existing reality but embody, instead, the meaning in their own form and have the ability to found the real world. This explains why our author criticized those writers who believed they could express faithfully the real world or that used the literary work of art as a means to achieve political or ideological goals. Furthermore, Sucre thinks that the autonomy of literature is linked to a critical dimension that is essential to it and that is performed in a double plane: in deepening into its own material aspect and avoiding any external involvements, literary creation questions itself and, at the same time, questions social reality.

The aesthetic that Guillermo Sucre set out on in this period 1958-1968 has political implications. In order to appreciate this aspect of Sucre's thought, I follow the ideas of Jacques Ranciére. This French thinker has established that both politics and aesthetics imply a "distribution of the sensitive", that is to say, a certain arrangement of the objects that are part of our common experience. In the case of our author, the establishment of this order can be seen in the fact that he wants to suppress the excesses of realism and formalism in Venezuelan literature. Faced with these disproportions, Sucre suggests that literary works should be a model of completeness in which the expression and the expressed are one and the same. In encouraging this aesthetic ideal, Guillermo wanted national literary works to connect with the model of order that he observed in the master-pieces of Western tradition, which embodied, from his point of 
view, the human, aesthetic and political essential values. In Sucre's conception, when the writer attains the unity of his vision and his writing, his work reveals an ethical world where the opposites fit and where the essence of man and of the world is revealed. It is in this sense that Guillermo establishes a "distribution of the sensitive" through his aesthetic thought. His conception of literature implies an ideal of expressive whole that is linked to an aesthetic and political order which he believes to be essential.

Moreover, Sucre's political aesthetic establishes a symmetric relationship with the aesthetical politics that the democratic Venezuelan governments had set out on after recovering power in 1958. In searching the widest consensus possible, the democratic parties tried to create an ideal State in which the excess of bodies and/or words would not have place. With this aim, the political radicalisms of left and right were banned and democracy defined itself as the representative of moderation before extremist threats. Then, the aesthetic principles on which Sucre based his own literary criticism implied a certain "distribution of the sensitive" that was linked to a political ideal. In setting out a model of expressive whole, the aesthetic of Sucre was structurally related to the political changes that the Venezuelan democracy was accomplishing at the same time. Just like the political system wanted to establish a utopian and apolitical order with no extra bodies or words, Guillermo Sucre established through his aesthetic thought a necessary link between vision and writing that left no place for surplus elements. Literary works should be harmonious bodies without profusions of things or words, models of completeness in which the subject and the object, passion and intelligence, the particular and the universal would finally agree. Once attained this ideal, literature would reveal the true essence of man and of the world.

In this search for an ethical and aesthetical order, Sucre was following at least three authors he had read in this period: Mariano Picón Salas, Ángel Rosenblat and 
César Vallejo. In his essays, Picón Salas defended a model of order and completeness that was related to the political ideal he longed for his country (Venezuela) and for the continent (Latin America). This writer thought that human and artistic values were universal and believed, in consequence, that national culture should agree with them. In his opinion, universal values were the result of moderation and Venezuelan culture would find them when it could establish a harmonious synthesis of the excesses between which it struggled. Ángel Rosenblat, for his part, set out on a similar "distribution of the sensitive" but in his case from his conception of language. For this philologist, the magical function of words was linked to a political and social ideal. In recalling the ability of words to embody their referent, Rosenblat was also defending the restoration of a precise bond between the bodies and the meanings and, therefore, a conservative order in which every element would occupy the place it deserved by nature. Vallejo, for his part, wanted to reestablish a precise tie between the bodies and the meanings that the capitalist system had broken. In the case of the Peruvian poet this ideal of aesthetic, linguistic and political order would take place in the socialist society, where the interest of all men would be the same, and where consensus would be possible at last.

\section{THE LITERARY THOUGHT OF GUILLERMO SUCRE FROM 1969 ONWARDS}

In the summer of 1968, Guillermo Sucre left the editorship of Imagen magazine and departed for the United States, where he will live until 1975. The stay of our author in the US brought along defining changes in his intellectual perspective and in his aesthetical conception that can be summed up in three basic points. In the first place, the new context led to changes in the nature of his writings. If before 1968 Guillermo had tried to determine the course of Venezuelan literature, his arrival to the States released 
him from this involvement, and this freedom led him to an exclusive interest on authors whose aesthetic was similar to the one he defended. Moreover, in setting aside his immediate involvement in national literature, Guillermo's critical essays attained a real aesthetic value. Secondly, the change of context determined a change of perspective. Both the new academic environment and the magazines in which he began to publish in the late 60's, such as Revista Iberoamericana (Pittsburgh), Plural (México) or Review (New York), were aimed at readers from all over Latin America. This fact forced our author to focus on the study of continental poetry and led him to develop a coherent reading of it, the most visible result of which is La máscara, la transparencia (1975). Thirdly, Sucre's stay in North America imposed certain changes on the aesthetic thought he had encouraged up to that moment. These were the result of his entry into a new social and political atmosphere and of his approach to some authors of the AngloSaxon literary tradition, such as John Cage, Susan Sontag, Gertrude Stein or Wallace Stevens.

After 1969, Guillermo writes from a philosophical context where the metaphysics of truth are no longer possible and where language has become a crucial issue because is in it where the question of the sense is at stake. Contrary to the logocentric tradition, according to which reality had an objective sense that was possible to communicate through language, Sucre thinks that words are directly implied in the creation of meaning and knowledge. For him words are not a simple tool to express a preexisting knowledge but the space where this knowledge is produced. Therefore, language is no longer, as the logocentric thought stated, a mere reflection of the world or an instrument at its service, but the space where reality is constituted. Guillermo refers to the idea that the meaning is inseparable from the word with the expression 
"consciousness of language", which is the basic mainstay of his aesthetics and an important value in all the authors he admires.

The "consciousness of language" implies that man and reality are not established and self-sufficient entities that in a given moment take part in the work of art. Instead, both are absorbed by literary creation and only exist through words. This means that literature does not copy a pre-established idea of the world (or of the writer) but rather invents it and becomes in this way a new born. Therefore, literature becomes an invention of the identity of the writer and of reality itself, and this invention is not arbitrary as it restores to man and to the world their true presence. Our author believes in the existence of an essential reality where the divisions and hierarchies imposed by power on the empirical world no longer exist. The function of poetry is to invent and reveal at the same time the pure world that has been concealed by metaphysics and history but that is the very same reality where we live every day.

In Sucre's thought, literature invents and reveals true reality when it is capable of establishing a perfect unity between the name and the named or, in other words, when the subject and the object, the imaginary and the real or the language and the universe are no longer perceived as opposites. Therefore, the literary work of art creates and discovers true reality when it achieves an expressive whole and cancels the excesses of description or formalism. Guillermo refers to the correlation between the vision and the viewed that takes place in great masterpieces as "transparency". The term "transparency" implies the imaginary survival of the real, that is, the union of the subject and the object, and allows in this way the restoration of the true and essential reality that was disintegrated by the action of power and modernity. In effect, when the work reaches the highest degree of completeness and achieves a perfect correlation between the subject and the object and between words and things, it reveals an essential 
reality where the hierarchies and dualities established by centuries of metaphysics are cancelled and where a pure and essential universe is restored. Thus, the literary utopia is at the same time a political utopia, because the cancellation of the expressive profusions (realism-formalism) implies the discovery of an original and fair world that is emphatically opposed to the one that power and its ideological instruments have established in the empirical world. Indeed, Sucre thinks that instead of accepting the world as it is, power introduces in it a secret background that legitimizes its own privileged position. Moreover, in Sucre's opinion, power is responsible for the establishment of false dualities in the real world and for having placed the soul before the body, the spiritual before the material and the future before the present. Contrary to the opacities and arbitrary hierarchies that power has introduced in the empirical world, Guillermo defends an essential reality that exists beyond any value and that presents two basic aspects: immanence and equality.

For Sucre, all things that exist are marvelous in their concrete appearance, without the need to refer them to any transcendent dimension. That is why, instead of establishing hierarchies and placing the soul before the body, Guillermo thinks that every element depends only on its condition of possibility. Our author also defends the value of what is merely visible and disdains, in consequence, the depths and the symbolism that characterizes metaphysical thought. This defense of immanence implies that the world is a locus of radical equality. Sucre thinks that if reality could be seen beyond power relations, it will appear as a group of equal links, without hierarchies of any kind. Once accepted the complete equality of the apparent world, everything becomes thoroughly visible, the categories and divisions imposed by power are cancelled, the instant is preferred to history, and the spatial relations prevail over the chronological or causal ones. 
To achieve the unity of the subject and the object, Sucre believes it is necessary that the poetic language is equivalent to reality, that is to say, that words agree with the entities they refer to. That is why our author thinks that literature has to find a pristine language, the First Word that embodies the harmony between man and the universe. Sucre considers that the finding of this absolute writing has been the aim of the great modern poets and that this search has led to a double attitude of passion and criticism towards language and towards poetry: on the one hand, modern writers have praised the power of words and have tried to achieve the height of expressivity; on the other hand, their experience has forced them to recognize that their search for the absolute through language was impossible to achieve.

In our critic's conception, the impossibility to restore the essential unity through writing is due to two "fatalities" present in language. The "constitutive fatality" is the acknowledgement of the impassable distance that separate words from reality. Indeed, as Paz has stated, language is a bridge that simultaneously joins us and divides us from the world. The other fatality, which Sucre calls "the social character fatality", is the result of the degradation of language by power and custom. Politicians employ language to achieve their personal goals: that is why words have acquired a semantic density that is strange to them and that compels them to say different things from the ones they say or should say. In using language with the purpose of falsifying facts and manipulating people, power has made words lose their ability to show the reference. To recover the essential reality through poetry, language has to overcome these fatalities and revive its ability to show the reference. For this reason, Guillermo admires authors such as Homero Aridjis, Rafael Cadenas or Roberto Juarroz who manage to restore to words the clarity and precision they have lost, and who write, consequently, with a clear language capable of revealing the referent. 
In line with his notion of reality, Sucre thinks that the poem should be a transparent body with no excesses or opacities and where everything is thoroughly visible. What is important for Sucre is writing itself, that is to say, the body or the surface of language, and not a deep semantic dimension that would legitimize the meaning. This perspective implies that our author rejects all those rhetoric figures that separate the meaning from the signifier and that make the former depend on an interpretative key that is not available to everybody. That is why Guillermo is against the use of symbolism and allegory, figures that refer what is merely visible to a hermeneutic pattern. For Sucre, literature is in itself an experience that need not be explained, because in it the meaning takes form and becomes thoroughly visible. In consequence, he gives great importance to the material appearance of words and to the poetic image, aspects which do not refer the meaning to a deeper or secret dimension but, instead, transform writing into a clear glass.

Contrary to the arbitrary interpretation that power has imposed on reality, Guillermo thinks that literature must invent and reveal the essential world. To achieve this is necessary to write without excesses of realism or formalism. When the work of art attains a correlation between the internal and the external or between words and things, the independent existence of the subject and the object is cancelled and true reality is revealed. When this ideal is achieved, the being of the author (that is, the imaginary entity created in and by the work itself) is one with the essential being of the world, and this implies that the text becomes universal and depersonalized. Sucre defends that literature reveals the fundamental ethos of the man and the world, then, it is obvious that he has a classical conception of it. In his opinion, great literature presents the same values throughout history, and that makes of it a universal discourse. This implies that literature has nothing to do with a sectarian spirit but, instead, with an 
aristocratic ideal. It does not imply the mere search for novelty (only the works that indulge in expressive excesses can be original or new) but the discovery of an essential ethical and aesthetical attitude.

\section{1. Guillermo SuCRE AND LATin AMERICAN Literature}

The aesthetic thought of our author during this period can be better understood if it is applied to the concrete problems he observed in continental literature. In Sucre's conception, the main problem of Latin American literature is what he calls the "theory of American originality", that was a consequence of the Independence process. Indeed, as a result of political emancipation, some Latin American intellectuals (among whom the most important is perhaps Andrés Bello) wanted to achieve as well the intellectual, cultural and aesthetical autonomy. To create a purely Latin American art, these intellectuals supposed that it was enough to describe the nature and customs of the continent. In establishing a prori what Latin American literature should be, this conception led to the representative and logocentric character of the continent's literary production and linked it to a pre-established idea that was arbitrary and exotic. The belief that the originality of Latin American culture was already in the human or geographic referent and that the writer had only to describe this referent to give birth to an autonomous aesthetic made Latin American literature a matter of content. In consequence, language adopted an ancillary function and a huge distance between the name and the named was established. Moreover, in transforming the idea of Latin America into an official slogan, the ideologues of identity were in fact reducing the plurality of the continental experience into a partial image that they wanted to pass as the essential and objective definition of it. What Sucre considered unacceptable was that this interpretation of the continent to which the literary works must unambiguously 
apply was the consequence of a colonial point of view that Latin American writers cast on themselves. The idea that there were American subjects whose simple expression would have as a result the creation of genuine works was the evidence of the writers' submission to a European gaze. Furthermore, Guillermo questioned the fact that the writers fond of the "theory of originality" considered themselves capable of representing the telluric and social particularity of the continent, because this attitude implied they had excessive confidence in their own possibilities. That is why Sucre thought that the "theory of originality" was responsible for another great fault he perceived in Latin American literature: the messianic attitude of certain writers. The obsessive search for originality and the egomania linked to it not only deprived literature from its creativity, but also prevented continental literature from establishing an equal relation with the rest of Western literature.

Guillermo established his idea of Latin American literature in opposition to the "theory of originality" and the faults it implied. In Sucre's conception, the literary work of art is first of all a linguistic creation and, as such, is not a matter of content and cannot be reduced to the expression of previously established knowledge. In being built with words, the work of art has an intrinsic potential: its function, therefore, is not only to copy a pre-established idea or identity, but to create them. For this reason, Guillermo thought -following what Octavio Paz had stated in his essay "Literature of foundation" (1961)- that if there is such thing as an "essence" of Latin America, this essence will result from the works of literature, and will not be merely its cause. For Sucre, this essence cannot be found in an assumed originality of the referent buy only in a particular sensibility, that is to say, in a certain way of looking and of writing. Our author's belief is that whenever Latin American writers have avoided the "theory of originality" and have communicated their own experience without any mediation, they 
have revealed, without intending to, an authentic continental sensibility. In line with these ideas, Guillermo esteemed those authors who questioned the "theory of originality" and who, instead of basing on an established idea of the continent and projecting a European gaze, managed to create from their immediate experience and from their own sensibility. This group of works (among which Sucre includes those of Darío, Huidobro, Vallejo, Borges, Reyes, Lezama Lima, Picón Salas or Paz) that has been created from a Latin American sensibility without previous mediations has allowed continental literature to attain a universal dimension and to establish an equal relation with the great works of Western tradition.

\section{2. GUILLERMO SUCRE AND LITERARY CRITICISM}

Sucre's conception of literary criticism is closely linked to his aesthetic thought. As it has been already said, for him the most important aspect of literary creation is not the subject of the work of art nor the ideas it contains but the experience of the world and of the language in writing. That is why his literary criticism tries to explain the imaginary and verbal experience that takes form in a literary work. In focusing on the experience of reality shown by words, what really captures Guillermo's attention is not the text in itself but the vision and the linguistic attitude of an author, figure that is not the real writer but the imaginary entity created in and by the literary work. To focus on the imaginary and verbal experience of an author brings along many consequences to its conception of literary criticism. To begin with, this entity imposes homogeneity on the different texts written by it and its entire work becomes a coherent system where the various parts establish a number of relations. In conceiving literary works as structures that show the persistence of the same vision and of the same attitude towards language, Sucre's criticism tends to smooth the differences that could exist between two parts of 
the same work and to control the potential difference of meanings that could appear between them. Moreover, this notion of the literary work implies that the critic looks for its most fathomable aspect of it to undertake the study of the whole work. If all the works of a given author constitute a structure of relations, Guillermo tries to find its most significant aspect to develop a coherent vision of all the author's writings. In Sucre's conception, not only the work of a given author but also literary history as a whole is the result of a number of relations. That is why also in it continuity is preferred to interruption. As it has been pointed out before, Guillermo believes that literature should agree with the essential being of man and of the world. Therefore, literary history cannot show big interruptions or changes, but the persistence of the same attitude. In spite of the circumstantial differences of style and/or context, all the appropriate literary works are part of the system of literature and establish in it a dialogue of affinities and oppositions. In conceiving literary history as a group of relations, Sucre considers that it is essential for the critic to place the work being studied in relation to other works. This dialogue, of course, transcends the mere chronological order of traditional historiography because in our author's vision any new creation that enters the system of literature can determine the works of the past in the same way that these modify future creations.

Additionally, Sucre's conception of the literary work has consequences in his way of thinking criticism. As I said before, Guillermo considers that literary creation should attract the subject and the object. To attain this correlation, the writer has to find a clear language that, free from any semantic depth, is able to show the referent. When this aesthetic ideal is achieved, the work cancels the distance between the word and reality and becomes a diaphanous space where an imaginary experience takes form and where nothing refers to a veiled or secret sense. If literary creation is conceived as a 
diaphanous experience of the world that takes form in a superficial language, it is obvious that literary criticism would have nothing to do with the hermeneutic theories that refer the meaning to a transcendent dimension. That is why Guillermo rejects deterministic readings that see the work as an excuse to look into history, society or the author's psychology. Sucre believes that art cannot be limited to copy an idea of the world previously established: instead, it has to found this idea. If the work is a new born, deterministic interpretation (be it positivist, psychoanalytic or Marxist) have no value. In this rejection of interpretation, Sucre was taking up the thoughts exposed by Susan Sontag in "Against Interpretation" that, in turn, referred to ideas of other thinkers admitted by Sucre, such as Roland Barthes and Gertrude Stein.

In addition, Guillermo's conception on literary criticism also depends on the way he thinks writing itself. Along with Barthes, our author considers that there is no essential difference between the work of the writer and that of the critic, because both work with language. That is why, for him, the relation that the writer establishes with the world is symmetrical to the one the critic establishes with the literary work. From Sucre's perspective, both the universe and the literary work are systems of relations that lack a final signification. Its meaning only exists momentarily and depends on the agreement between the subject (the critic) and the object (the literary creation). Sucre thinks that the writer has to join subjectivity and objectivity to achieve a whole expression free of excesses of realism and of formalism. In the same way, he considers that the critic has to establish a correlation between his vision and the work being studied, as only then profusions of subjectivity and objectivity will be cancelled and the critic will attain, albeit for an instant, an appropriate coinciding (that will be absolute and relative at the same time) between his vision and the literary creation. Just as literature itself, literary criticism has to show a total unity between the subject (the 
critic) and the object (the work), and this completeness, that is momentary by definition, is evidence of the quality of the critical essay. In proposing this ideal for criticism, Guillermo is rejecting those conceptions that have excesses of subjectivity or of objectivity. Faced with these disproportionate tendencies that either forget the given literary work or try to establish its meaning forever, Sucre esteems that criticism which joins the subjectivity of the critic with the objectivity of the literary work. This conception implies that literary criticism must not simple discern the values of a given work but it must also analyze them and participate in them. In our author's thought, the literary critic has to restore the ethical and aesthetical experience of the work of art and revive it in a new writing that will reveal a particular sensibility and a particular attitude towards language. In this way, the experience of the literary work will be subject to a new creation: the critical essay.

\section{3. THE CRITICAL WRITING OF GUILLERMO SUCRE}

In Sucre's critical essays the experience of the literary work being studied takes form in a new writing in which it is impossible to distinguish the subject from the object. Our author conceives a literary work is a coherent system and he thinks that the critical text has to reproduce that coherence. That is why his critical essays are governed by a series of rhythmic relations that want to make evident the unity of the different parts (of the critical essay and of the work being studied, simultaneously) and that of the text as a whole. Sucre wants his essays to be crystallized in a consistent image, and his writing tends to limit the unceasing proliferation of language. To achieve this, he tries to control the continuous character of written expression in favor of simultaneity and ecstasy. That is why his critical writing swings between "movement and fixity" or between "dispersal and tension", swinging that can also be observed in Octavio Paz's 
essays. In Sucre's writing the reader watches a thought in motion. In it, every conclusion leads to another critical insight and every new point of view arises from the former: that is why the continuity of the discourse is preferred to its interruption. In addition, Guillermo gives coherence to his essays as a whole through various textual strategies such as the disposition of verbal "milestones" or the circular structuring of the texts.

Despite the fact that certain critics, such as María Fernanda Palacios and Miguel Gomes, have considered that the dubious tone of Sucre's writings shows a dialogic will, I think that the undecided and conversed style of his essays hides, in fact, the opposite attitude. As it was said before, Guillermo believes that literary criticism has to attain the utmost correlation between the critic's subjectivity and the literary work. That is why I consider that the dubious tone is a strategy that our author uses to approach the limits of the literary work being studied and to mask, at the same time, his own position of authority. From our point of view, the uncertain tone of Sucre's essays reveals that the critic seeks obsessively the limits of his object of study and that he wants to seem asystematic precisely because he is not. In this sense, Guillermo's critical essays show the characteristic attitude of the Latin American master that Roberto González Echevarría discovered in Rodó's Ariel (1900). In this text, the author adopts a dialogic appearance but, behind this appearance, the voice of the essayist is that of a master. In the same way, the hesitant tone that can be perceived in Sucre's writings does not reveal a weakening of authority but, on the contrary, it is a strategy that masks the textual procedures by means of which this authority is reinforced.

In addition, Sucre's essays are framed in a context that does not share the assumptions of the essayists of the first half of the XXth Century. In his texts, the author is far from the messianic pedagogy that was a common feature of "mundonovistas" 
essayists such as Picón Salas, Uslar Pietri or Briceño Iragorry. Our author is no longer a guide who embodies collective knowledge, nor a teacher with a pedagogic vocation. His new attitude leads him to state at the beginning of La mascara, la transparencia that his book should not be systematic or rigorous. Nevertheless, this statement does not mean that Guillermo refuses to impose his own conception of Latin American culture. What has happened is simply that the formulation of this project has had to adapt to a new epistemological context. The situation where Sucre writes is determined by two facts that have frequently been linked by researchers: the triumph of the Cuban Revolution (1959) and the postmodern questioning of the concept of cultural identity. As a result of the first event, Latin American intelligentsia (literary critics included) was ideologically polarised. As a consequence of the second point, the notions of culture and identity, that up to now had been obsessive subjects for generations of Latin American writers, began to be emphatically questioned. In Guillermo's critical essays a radical questioning of the concept of cultural identity linked to the "theory of American originality" can be perceived. But the questioning of this notion and our author's insistence in seeming asystematic must not be interpreted as a will to abandon the process of cultural foundation that had been present in Latin American essays and literary criticism since Independence, quite the opposite. If Sucre rejects the "theory of American originality" and all its consequences is because he defends the establishment of continental literature (and, therefore, of continental cultural identity) on other ethical and aesthetical values. In the twist offered by Sucre, the project he wants for the continent is brought forth by an author that speaks from a clear aesthetic and political position and that has to mask his intentions. Therefore, in Sucre's essays there is a will to break with the prophetic discourse of the essayists of previous generations, but this break up does not prevent our author from proposing a certain idea about Latin American literature and identity. In 
Sucre's essays, the author does not address the people as a coherent or homogeneous entity but as a transnational community with the same aesthetic and political values. The master is still present, but his perspective is no longer humanist and ecumenical, but political and exclusive.

\section{4. SUCRE'S POLITICAL AESTHETICS FROM 1969 ONWARDS}

In what informs the link between aesthetics and politics in Sucre's thought after 1969 , it has been noticed that it is contrary to a political and aesthetic order, represented on the one hand by the authoritarian and militaristic power of the continent and, on the other, by the "theory of originality" that was invented in the years after Independence. When Guillermo began to intervene in the continental literary field from 1969 onwards, he found many problems that were the consequence of the "theory of Latin American originality", that had emerged at the beginning of the XIXth Century. In Sucre's opinion, this theory was responsible for the main faults in which certain literary works of the continent indulged: realism and aestheticism or, what is the same, excesses of things and of words. Continental literature had focused on the content and, as a necessary complement, had tried to name this content with a "precious" or "beautiful" style. The profusions of things and of words that Sucre observed in those authors related to this aesthetic tendency implied a logocentric conception of language that led to a more serious mistake: the disproportions of subjectivity and objectivity. In effect, the excesses of content or of expression implied that the writer possessed the ultimate sense of reality and that words were just means to convey a previously established signification. These profusions of anecdote or of style (of objectivity and of subjectivity) meant a distance between poetry and life that led certain Latin American writers to project a European gaze. Sucre believes that in separating the word from its 
referent, the "representative" authors had referred to the continent from outside and had cast a false vision on themselves. It is clear, then, that our author rejects that continental literature that had indulged in excesses of things or words and that, having established a distance between life and poetry, had been incapable of conveying an immediate experience. These faults that Guillermo considered, in a certain way, to be "chronic" of Latin American literature were in fact, according to Ranciére, the display of the revolution that took place at the beginning of the XIXth Century and that is known as "literature". This thinker has established that the rejection of the realist excess of things and of the formalist superstition of words is in fact a reaction against those antagonistic principles (the principle of indifference and the principle of poeticism) that appeared when the old building of the classicist poetics collapsed. In effect, the profusion in writing of vain and unsubstantial details is the result of the principle of indifference, according to which any person can write about any subject. And the formalist fault is the consequence of the fact that in the new poetics (that is, in literature) the material aspect of words is opposed to the intellectual strength of ideas. It is obvious, then, that in facing the excesses he found on works stemming from the theory of originality, Sucre was in fact trying to rule the antagonistic principles that constitute literature.

To solve the faults that he observed in continental literature, Guillermo searched for the unity between the subject and the object, that is, for a perfect agreement between the language and the referent that would leave no room for any supplementation. Through the "consciousness of language", or even through the reversal of the relation between poetry and reality, Sucre tried to transform the literary work of art into a model of completeness where no words or things were in excess. This ideal of order implied a correlation between language and the world that cancelled any distance between the writer and his world and that allowed the literary texts to create and discover the 
essential truth of man and of the universe. If true reality is configured in the work of art, the patterns followed by literary creation imply a definition of the original world that poetry reveals and invents. Then, the search for the utmost unity between bodies and meanings that our author wanted for poetry implied the construction of a classical political order where no surplus elements threatened the stability of the system. In Guillermo's opinion, when literature is appropriate and lacks profusions of things or words, it embodies the essential order that rules over reality and that should be a model for social order. In the original world that the work creates and discovers, things lack any transcendent dimension and are marvellous on their own materiality. In this pure reality the divisions that Western metaphysics had established between the soul and the body or between the future and the present are rejected and that the contraries imply each other. This original universe is a locus of radical equality, that is, a system of relations in which no element (and, of course, no person) is more important than the rest. According to this order, each element occupies its place inside the whole and establishes with the rest of the elements an equal relation. Therefore, the finding of the aesthetic and political original limits means the discovery of an original and fair universe that is emphatically opposed to the "distribution of the sensitive" defended at the same time by the authoritarian and militaristic power of the continent and by the authors fond of the "theory of American originality".

At the end of La máscara, la transparencia's second edition (1985), Sucre states that his poetical and political program reveals what he calls "the Latin American sensibility". Sucre says there that this sensibility is the result of certain literary works. In this way, he establishes a relation between the "distribution of the sensitive" that his aesthetics imply and the continental character. Therefore, as it has been said, Sucre does not end up with the cultural discourse that had been linked to the Latin American 
literary tradition. Instead, he offers a twist to this discourse from his own perspective. The other tradition, that is, the "sect" of identity, related to authoritarian politics, imposed a distance between creation and experience that led to ethical and aesthetical excesses and to other faults. Sucre proposes, for his part, that the real Latin American character is not the result of those representative and logocentric literary works that established a pernicious distance between words and things but of those other works that had "consciousness of language" and that achieved a correlation between poetry and life. When Latin American literary creations attain the unity between the subject and the object or between language and reality, they discover the true essence of man and of the world, a harmonious order that in Sucre's vision also reveals the true continental sensibility. 


\section{CONCLUSIONS}

Throughout this research, the literary thought of Guillermo Sucre has been studied diachronically. Thus, it has been possible to appreciate the formative process of his ideas and the changes that took place in his aesthetics over the years. To achieve this goal, Sucre's critical writings have been divided into two periods: first, I have addressed his "Venezuelan" phase, which covers from 1958 to 1968, and then his mature phase, from his arrival in the States (summer of 1968) onwards. This division is appropriate because the different situations meant decisive changes in Sucre's intellectual perspective and, therefore, in his literary thought.

In the first part of this dissertation, Sucre's intervention in the Venezuelan literary field throughout the tumultuous period of the 1960's was covered. After getting out of prison in 1958, and up to his departure for the US in the summer of 1968, our author edited or played a prominent role in various magazines such as Sardio (19581959), "Letras y Artes" (1962-1964), Zona Franca (1964-1966) and Imagen (19671968). In all these periodicals, the continuity of the same aesthetical project can be seen and so, in consequence, I propose that Sucre's work constitutes the core of the "progovernment" intelligentsia in Venezuelan literary circles of the 1960's. In effect, in all these magazines (with the exception of Zona Franca, where our author's project had to coexist with that of Liscano) Sucre promoted a modernist aesthetic, based on the principles of autonomy and internationalism, and tried to familiarize Venezuelan readers with the central canon of Western tradition. In this sense, Guillermo's aesthetic preferences matched up with the cultural conception that the new democratic Venezuelan state tried to encourage: an art clearly separated from the other spheres of life and whose critical value depended on this same separation. In defending this cultural model, the discursive strategy of the publications in which Sucre collaborated 
found a model in the European and Latin American liberal press that was being supported by North American institutions such as the Congress for Cultural Freedom (and later the ILARI) that tried to gain followers in the ideological struggle that was the Cold War. The magazines edited by our author during the 1960's used the same ideas as the major liberal reviews and reproduced their aesthetic preferences. In this regard, the tie that Imagen established with Mundo Nuevo, the Parisian review edited by Rodríguez Monegal which was directly funded by the US to exert an influence on Latin American intellectuals, is paradigmatic. Imagen vindicated the same writers that were being promoted by Monegal's magazine -such as Vargas Llosa and Carlos Fuentes, the “novísimos” Puig or Sáinz, and some Cuban authors such as Sarduy or Cabrera Infanteand copied the interpretative patterns legitimized by the Uruguayan critic.

Apart from analyzing his work as a cultural promoter, in the first part of this investigation the main points of Guillermo Sucre's literary thought during the period 1958-1968 have been ordered in two phases, the first covering from 1958 to 1963 and the second from 1964 to 1968 . In the years between his release from prison and the end of the literary broadsheet "Letras y Artes" (1958-1963), Guillermo tries to impose limits on the complacency and the social climbing in the Venezuelan literary field. The dishonesty of the intelligentsia and the consequent lack of critical criteria have had at least two consequences on the development of Venezuelan literature. In the first place, it prevented the creation of a national literature, that is, of a group of works linked by common factors. In the second place, it had stopped the connection of Venezuelan literature with the modern tradition and this situation had led to the isolation of Venezuelan literature. Faced with this dismal outlook, Guillermo Sucre tried to modernize and professionalize national literature. With this aim, he promoted new intellectual attitudes and tried to introduce a new aesthetic consciousness based on 
objective criteria. To elaborate this solid aesthetic that would guide Venezuelan writers, our author used the concept of authenticity. This notion implied the establishment of an unavoidable link between the experiences of the writers and their literary expression that would allow national literature to overcome the pernicious excesses of things and of verbosity. In demanding a correlation between the expression and the expressed, Sucre disdained those inharmonious aesthetic tendencies that led to realism or aestheticism, and thus he was trying to transform literature into an entire and well-balanced body without any waste or excess. Furthermore, in rejecting those expressive profusions (realism and formalism), our author was also dismissing the distance between the writer and his situation (distance that led to the faults of nationalism and cosmopolitanism). In his opinion, these cultural and aesthetic attitudes were disproportionate and estranged Venezuelan literary creations from the ethos that he considered typical of the universal literary tradition.

In the critiques and essays that Guillermo wrote during his collaboration in Zona Franca and Imagen (1964-1968), he continued to demand an ideal of expressive completeness from the Venezuelan writers. The only difference with the previous period is that now Sucre considered that this ideal was the result of the correlation between passion and intelligence. In line with the symbolist tradition and with Mariano Picón Salas, Guillermo rejected instinctive or natural poetry that was the result of pure inspiration and demanded instead that literary creation should be tempered by intelligence and lucidity. When poetry comes only from primary impulse, the poet loses control over it and fills the works of art with expressive profusions that prevent its connection to the true intellectual tradition and to the universal values of the human spirit. By contrast, when the poet combines adequately impulse and rigor, the work attracts the opposites and recovers the reality of the world, that is to say, the Absolute 
that was dissolved with the arrival of modernity. It has also been observed that, from the moment that Sucre assumed the editorship of Imagen, with structuralism at its height, he began to suggest that the typical feature of literature is deepening into its own materiality, a deepening that implies a critical component which literary creation cannot renounce.

In the second part of this study, Sucre's thought from his arrival to the United States in 1969 on has been analyzed. The change of context modified his intellectual career in three different ways. In the first place, the stay in North America made him set aside the involvement with Venezuelan culture that he had adopted in the previous years. In the second place, the Latin Americanism of the new academic environment made him focus on the study of continental poetry, the most visible result of which is $L a$ máscara, la transparencia (1975). And, in the third place, his entry into a new political and social situation and his approach to certain authors of the Anglo-Saxon literary tradition imposed certain changes on his aesthetics. However, the writings of Sucre after 1969 show the persistence, with slight modifications, of the aesthetical and cultural project he had set out on in the previous period.

It is perceived that Sucre's literary thought after 1969 settles on what he calls "the consciousness of language". This notion means that man and reality are not fixed entities that at a certain moment take part in the literary work of art. Instead, both are absorbed by the literary work and only exist after taking form in words. According to this consciousness, and contrary to the logocentric tradition, literary creation does not copy a pre-established sense of the world or of the writer: it invents this sense and becomes, in consequence, a new birth. Following what Paz and other authors had stated, Sucre conceives that the literary work of art is an invention of the identity of the author and of reality itself. But this invention is, at the same time, a revelation as it restores 
man and the world their true presence. In Guillermo's conception, the work creates and discovers the essential reality when it attains expressive completeness and cancels the excesses of things and of verbosity or of objectivity and subjectivity. Our author refers to this perfect union between the name and the named as "transparency", which is the form that reality adopts in being apprehended by the writer and incarnated in writing. When the literary work of art attains its utmost expressive completeness and achieves a precise correlation between the subject and the object and between things and words, it reveals an essential world where the hierarchies and opacities that power has introduced into the empirical world have been cancelled. Therefore, it can be seen that for Sucre the literary utopia is at the same time a political utopia because the cancellation of the expressive profusions implies the discovery of an original world detached from power relations. In addition, this means that for our author literature is inseparable from a basic ethos, inherent to man and to the world. In effect, Guillermo thinks that great literature presents the same ethical and aesthetical values through the ages and that it constitutes a universal discourse. Consequently, it has nothing to do with a sectarian spirit but with an aristocratic ideal, that is to say, it does not imply a mere search for novelty but the discovery of an essential ethical and aesthetical attitude.

In order to reconcile conveniently the subject and the object, our author thinks that the poetic language should be equivalent to reality, that is, that the words should coincide with the objects which they refer to. If Guillermo knows perfectly well that is impossible for the writer to achieve an absolute writing, he suggests that modern literature always goes after this aim. In his opinion, the impossibility to restore the primordial unity through writing is the consequence of two "fatalities" present in language. On the one hand, the constitutive fatality is the acknowledgment of the impassable distance that separates words from reality. On the other hand, there is what 
Sucre calls the "social character fatality", which is the degradation of language by power and custom. In order to revive the essential reality through poetry it is necessary that the language overcomes these fatalities and recovers its ability to show the reference. That is why Guillermo esteems those authors like Homero Aridjis, Rafael Cadenas or Roberto Juarroz who manage to restore to words the precision and clarity they have lost and who write with clear language, capable of revealing the thing in itself. Therefore, it has been observed that for our author the poem must be a translucent body without excesses or opacities, and where everything becomes thoroughly visible. What is important for Sucre is writing itself, that is to say, the body or the surface of language and not a deep semantic dimension that would legitimize the meaning. This is why he rejects symbolism and allegory and prefers instead to focus on the materiality of the word and on the poetic image.

In what informs Sucre's conception on Latin American literature it has been noticed that he opposes emphatically what he calls the "theory of American originality" and all it consequences. This theory was established by certain Latin American intellectuals that in the years after Independence thought that it was possible to found an autonomous aesthetic by just describing the autochthonous nature and customs. They considered that originality was a condition of the human or geographic referent, and that the writer simply had to describe that referent to create a genuine aesthetic. In consequence, literature became a matter of contents and an enormous distance between the expression and the expressed was established. In addition, the idea of the continent to which the literary works must respond was the result of a colonial gaze that Latin American writers projected on themselves, that is to say, a case of what is known as internal orientalism. The belief that existed "American" topics there whose simple expression would have, as a result, the creation of genuine works was in fact the 
evidence that Latin American writers had a European point of view. Apart from that, Guillermo questioned the fact that the writers linked to the "theory of originality" considered themselves capable of representing the telluric or social originality of the continent, because that attitude implied they had excessive confidence in their own possibilities. In fact, the theory of American originality is responsible for other faults that Sucre perceived in continental literature: the messianism of certain writers. The obsessive search for originality and the egomania that it implied not only deprived the literary works from the creative potential that is proper to them, but it also stopped Latin American literature from establishing an equal relation with the rest of Western literature.

Our author's conception of Latin American literature was established in opposition to the theory of originality and to the faults it implied. From his point of view, the literary work of art is, above all, a verbal creation and, as such, it is not a matter of content nor can it be reduced to the expression of previously established knowledge. The literary work of art has an intrinsic creative potential and, therefore, its function is not to copy a pre-established sense or identity but to create them. Guillermo thought -following what Octavio Paz had stated in his essay "Literature of foundation" (1961)- that if there is such thing as an "essence" of Latin America, this essence will result from the works of art and will not be merely its cause. Having said that, Sucre believes that this essence cannot be found in an assumed originality of the referent but only in a particular sensibility, that is to say, in a way of looking and of writing. Guillermo thinks that whenever Latin American writers have avoided the theory of originality and have communicated an immediate experience, they have managed to reveal, even without intending to, a characteristic Latin American sensibility. In line with this ideas, our author values those authors that questioned the "essentialist theory" 
of the continent and that, instead of basing themselves on a fixed sense of the continent and projecting a European gaze, managed to create from their immediate experience and from their own sensibility. The group of works (among which we find those of Darío, Huidobro, Vallejo, Borges, Reyes, Lezama Lima, Picón Salas or Paz) that has been created from a Latin American sensibility, without previous mediations, has allowed continental literature to attain a universal dimension and to establish an equal relation with the great works of Western tradition.

In this research, it has also been addressed how Sucre conceives literary criticism. For him, the most important aspect of literary creation is not the subject of the work or the ideas it contains but the experience of the world and of the language in writing. This explains why his literary criticism tries to explain the imaginary and verbal experience that takes form in a given creation. In focusing on the experience of the world shown by words, what really captures the attention of our critic is not the text in itself but the vision and behavior of an author -that is, not the real writer but the imaginary entity created in and by the literary work. As he conceives the literary work as a system controlled by the persistence in it of the vision of an author and of an attitude towards language, Sucre's criticism tends to smooth the differences between various parts of the same work and to control the potential disparity of meanings that could exist in it. It has been said, in addition, that this structural conception of the work of art is duplicated in his notion of literary history. In considering that this history is the result of a number of relationships, Sucre believes it is essential for the critic to place the work he studies in relation to the group of works with which it establishes a dialogue of affinities and oppositions. This dialogue transcends the mere chronological disposition of traditional historiography because in Sucre's vision any new creation that 
enters the system of literature determines the works of the past in the same way that these modify future creations.

On the other hand, it has been said that Guillermo's notion of the literary work of art has consequences in the way he conceives criticism. If literary creation embodies a diaphanous experience of the world in a language that lacks any depth or density, it is evident that literary criticism has nothing to do with those interpretative theories that consider that the meaning is the result of a transcendent dimension. From Sucre's point of view, art is not the copy of a pre-established knowledge of the world. Instead, it is the place where this is founded: the work of art is a new born and, therefore, deterministic interpretations (be it positivist, psychoanalytic or Marxist) have no value.

It has also been pointed out that our author's conception of literary criticism depends on the way he thinks about writing itself. Along with Barthes, Guillermo considers that there is no essential difference between the work of the writer and that of the critic, because both work with language. Therefore, in the same way that the writer has to reconcile subjectivity and objectivity to attain a complete expression without any excesses, the critic has to establish a correlation between his vision and the literary work being studied. Only then the profusions of subjectivity and objectivity will be cancelled and the critic will achieve, albeit for an instant, an appropriate coinciding of his vision and the literary creation. Sucre believes that literary criticism must attain a total unity between the subject (the critic) and the object (the work of art), and that this completeness, that is momentary by definition, is evidence of the quality of a critical essay. In proposing this ideal of completeness for literary criticism, Guillermo is rejecting those conceptions that show excesses of subjectivity or objectivity. Faced with these disproportionate tendencies that either forget the given work or try to establish its meaning, Sucre admires that criticism which reconciles the subjectivity of the critic with 
the objectivity of the literary work. This conception implies that criticism must not simply discern the values of a given work but that it must analyze them and participate in them. In Sucre's thought, the literary critic has to recover the ethical and aesthetical experience of the work of art and to revive it in a new writing that would reveal a particular sensibility and a particular attitude towards language. In this way, the experience of the work of art will be subject to a new creation: the critical essay.

Sucre's critical essays have been read from the perspective of his own theory. Indeed, in his writings there is a double tendency to participation and analysis: the critical text tends to reproduce the coherence of the work it studies, and the reader searches obsessively the limits of the work of art.

As his critical writing tends to copy the coherence of the literary creation, Sucre's essays (and here I refer, above all, to the ones included in La máscara, la transparencia) are governed by a series of rhythmic relations that want to make evident the unity of the different parts (of the critical essay and of the work of reference, simultaneously) and that of the text as a whole. Guillermo's writing tends to control the unceasing proliferation of language and he wants his essays to be crystallized in a consistent image. To achieve this, he tries to control the successive character of written expression in favor of simultaneity and ecstasy. That is why his literary criticism swings between "movement and fixity" or between "dispersion and firmness", swinging that can be seen as well in Octavio Paz's writings.

In contrast, as it has been said, Sucre's criticism tries to attain the utmost unity between the reader's subjectivity and the work's objectivity. Based on this idea, I have suggested that the dubious tone that appears in his essays does not reveal (as some critics have said) a dialogic will or a lack of organization. In fact, the recourse to uncertainty is a strategy that our critic uses to approach the limits of the given literary 
work and to mask, at the same time, his own position of authority. In this sense, Guillermo's critical essays show the characteristic attitude of the Latin American master that González Echevarría discovered in Rodo's Ariel (1900). In this text, the author adopts a dialogic appearance but, behind this appearance, the voice of the essayist is that of a master. In the same way, the hesitant tone that can be seen in Sucre's writings does not reveal a weakening of authority but, on the contrary, it is a mechanism that tries to mask the textual strategies, by means of which, his authority is reinforced.

In addition, even if at the beginning of La máscara, la transparencia Sucre states that his book should not be systematic or rigorous, it has been observed that he does not avoid imposing a certain conception of Latin American culture. The epistemological transformations resulting from the victory of the Cuban Revolution (1959) and from the postmodern questioning of the concept of cultural identity made the writers move away from the messianic pedagogy that was a common feature of the essayists of previous generations. But this change does not mean that Latin American writers gave up the attempt at cultural founding through writing that had been present in the continental essayistic tradition since Independence. In Sucre's essays there is, indeed, a radical critique of the notion of cultural identity linked to the "theory of American originality", but the rejection of this concept only has sense because he defends the founding of continental literature (and, thus, of cultural identity) on other ethical and aesthetical principles. As it has been noticed in studying the figure of the model reader, in Sucre's essays the writer does not address the people as a coherent or homogenous entity but as a transnational community with the same artistic and political values.

In addition, throughout this research the political implications of Guillermo Sucre's literary thought have been studied following the theory of Jacques Ranciére. 
This French philosopher has stated that aesthetics imply a certain "partage du sensible", that is to say, a certain organization of the world we live in. In this regard, our author's thought shows great coherence because, throughout his work, he suggests that literary works should follow a model of correlation between the subject and the object that leaves no room for any supplementation. In opposition, first, to certain Venezuelan writers that abandoned themselves to wild passion and made of the work of art a repository of things and words and, later, to those Latin American writers fond of the "theory of originality", who indulged in descriptive or aestheticist profusions, Sucre believed that great literary works present a precise correlation between what they say and the way in which they say it. When the works attain this target, excesses or disproportions disappear and the writing finds the essential ethos of the man and of the world.

In this way, the search for the utmost coincidence between the bodies and the meanings that our author wants for poetry implies the construction of a classic political order where no supplementary elements threaten the stability of the system. From Sucre's point of view, when literature is appropriate and lacks profusions of things or words it embodies the essential order that rules over reality and that should be a model for social order. The primordial world that poetry incarnates is immanent and egalitarian and cancels the hierarchies and the divisions imposed by power on the empirical world. Therefore, the discovery of the original aesthetical and political limits imply the finding of a pure, fair universe that is radically opposed to the "distribution of the sensitive" imposed at the same time by the authoritarian and militaristic power of the continent and by the "theory of American originality" and its subsequent consequences.

It has also been said that Sucre identifies this poetical and political model with what he calls the "Latin American sensibility". In the twist that he offers to the cultural 
discourse that had been present in the Latin American essayist tradition since Independence, our author suggests that the real character of the continent is not the consequence of those works that establish a pernicious distance between words and things, but instead of those that show "consciousness of language" and achieve an appropriate correlation between poetry and life. In achieving the unity between the subject and the object or between the name and reality, the best Latin American poets (those that constitute a true "lineage") discover, from their own perspective, the essential truth of man and of the world, and this harmonious order constitutes an aesthetic and political model for the continent. 


\section{RELACIÓN DE IMÁGENES}

Imágenes 1 y 2. Mariano Picón Salas (1901-1965) y Ángel Rosenblat (1902-1984) (p. 16)

Imágenes 3 y 4. El escudo de Acción Democrática y su líder Rómulo Betancourt (19081981). (p. 19)

Imagen 5. Guillermo Sucre (izq.) con Julieta Fombona y Lucien Goldmann en la Ciudad Universitaria de Caracas. (La foto acompañaba al artículo de Sucre titulado "Entrevista con Lucien Goldmann", en Zona Franca, Caracas, año I, núm. 5, 1/15 nov. 1964, pp. 6-7) (p. 27)

Imágenes 6 y 7. Primera y segunda ediciones de la obra de Sucre Borges, el poeta (1967; 1975). (p. 30)

Imágenes 8 y 9. Primera y segunda ediciones de La máscara, la transparencia (1975; 1985). (p. 33)

Imagen 10. Guillermo Sucre en su despacho. (p. 40)

Imagen 11. Portada fotocopiada del primer número de la revista Sardio. (p. 54)

Imagen 12. Primer manifiesto-revista de "El Techo de la Ballena". (p. 59)

Imagen 13. Simón Alberto Consalvi (1927-2013), director del INCIBA durante este periodo. (p. 74)

Imágenes 14 y 15. Dos números de la página literaria "Letras y Artes". (p. 79)

Imágenes 16 y 17. El primer número de Zona Franca y Juan Liscano (1915-2001), director de la publicación. (p. 89)

Imágenes 18 y 19. Propaganda de otras publicaciones del ILARI aparecida en Zona Franca y número de la revista Encounter, financiada por el Congreso por la Libertad de la Cultura. (p. 95)

Imágenes 20 y 21. Dos números de la revista Imagen editados durante la dirección de Guillermo Sucre. (p. 96)

Imágenes 22 y 23. Ejemplar de Mundo Nuevo y fotografía de su director, Emir Rodríguez Monegal (1921-1985). (p. 100)

Imágenes 24 y 25. Manuel Puig (1932-1990) y Gustavo Sáinz (1940), dos de los "novísimos" que fueron impulsados por la publicación Mundo Nuevo. (p. 102)

Imágenes 26 y 27. José Lezama Lima (1910-1976) y Severo Sarduy (1937-1993). (p. 103)

Imagen 28. Suplemento núm. 7 de la revista Imagen, dedicado a la entrega del Premio Internacional de Novela "Rómulo Gallegos". En la portada se aprecia a Vargas Llosa saludando al mismo R. Gallegos. (p. 109) 
Imágenes 29 y 30. Charles Baudelaire (1821-1867) y Paul Valéry (1871-1945), dos de los grandes poetas simbolistas. (p. 120)

Imágenes 31 y 32. César Vallejo (1892-1938) y Octavio Paz (1914-1998). (p. 129)

Imágenes 33 y 34. Herbert Marcuse (1898-1979) y Roland Barthes (1915-1980), teóricos influyentes en esta época. (p. 179)

Imágenes 35 y 36. Números de la Revista Iberoamericana (Pittsburgh) y de Plural (México) (p. 224)

Imagen 37. Martin Luther King (1929-1968), estuvo al frente del Movimiento por los derechos civiles para los afroamericanos durante esta época. (p. 227)

Imágenes 38 y 39. Protestas en contra de la guerra de Vietnam. (p. 229)

Imagen 40. Martin Heidegger (1889-1976) (p. 245)

Imagen 41. El pintor Georges Braque (1882-1963) (p. 260)

Imagen 42. El cuadro de Braque "Puerto en Normandía" (1909) (p. 262)

Imagen 43. Gertrude Stein (1874-1946), retratada por Pablo Picasso (1905-1906) (p. 264)

Imágenes 44, 45 y 46. Los poetas Homero Aridjis (1940), Roberto Juarroz (1925-1995) y Rafael Cadenas (1930). (p. 275)

Imágenes 47 y 48. Pierre Reverdy (1889-1960) y Vicente Huidobro (1893-1948) (p. 284)

Imagen 49. Jorge Luis Borges (1899-1986) (p. 301)

Imagen 50. Andrés Bello (1781-1865) (p. 308)

Imágenes 51 y 52. José Santos Chocano (1875-1934) y Pablo Neruda (1904-1973), vates a los que Sucre vincula con la poética mesiánica y representativa del continente. (p. 312)

Imágenes 53 y 54. José Martí (1853-1895) y Rubén Darío (1867-1916), poetas fundamentales del modernismo hispanoamericano. (p. 327)

Imágenes 55 y 56. Los poetas José Antonio Ramos Sucre (1890-1930) y Alejandra Pizarnik (1936-1972) (p. 340)

Imagen 57. Susan Sontag (1933-2004) (p. 342)

Imagen 58. Guillermo Sucre (p. 410) 